

$A-2$ 


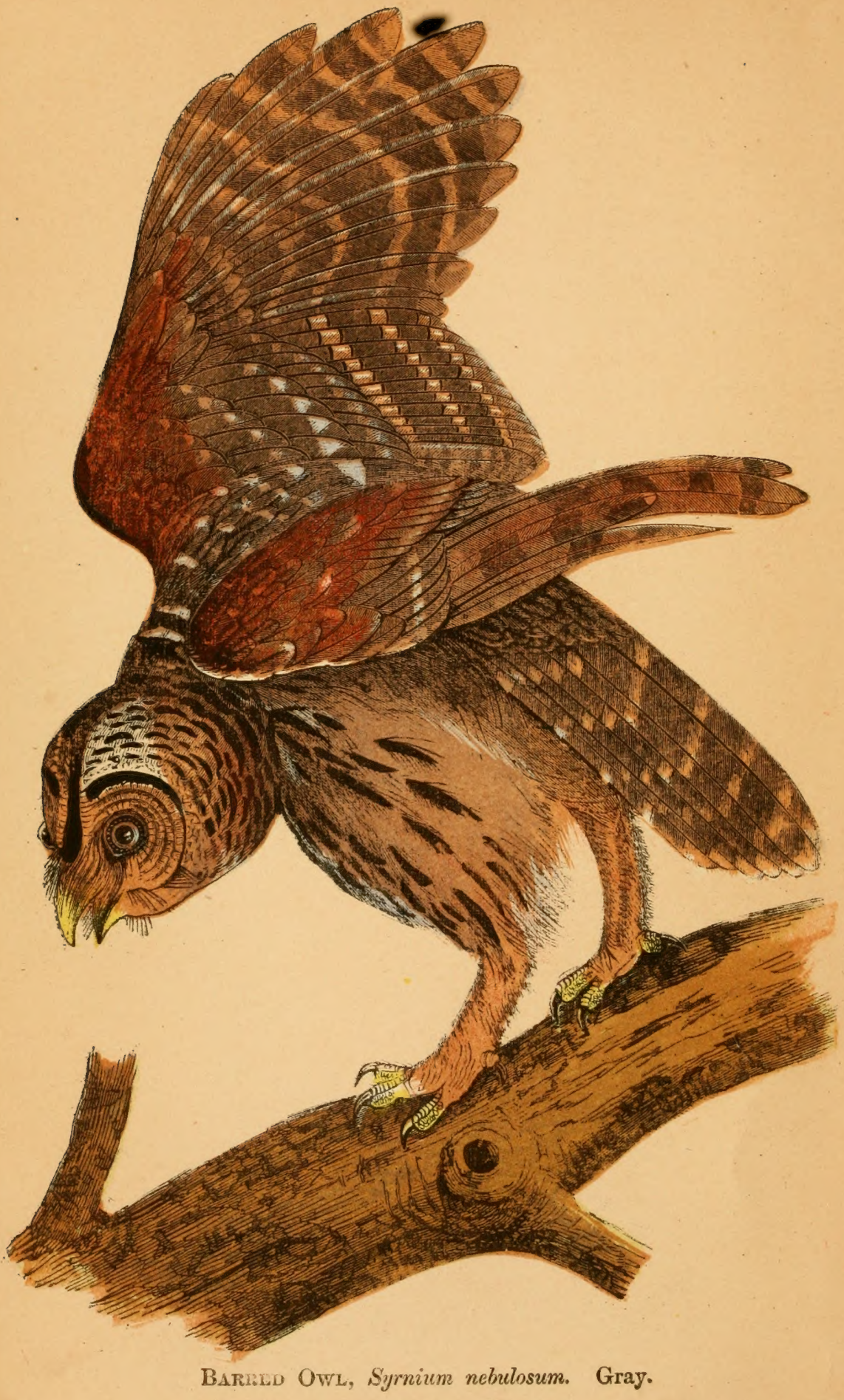




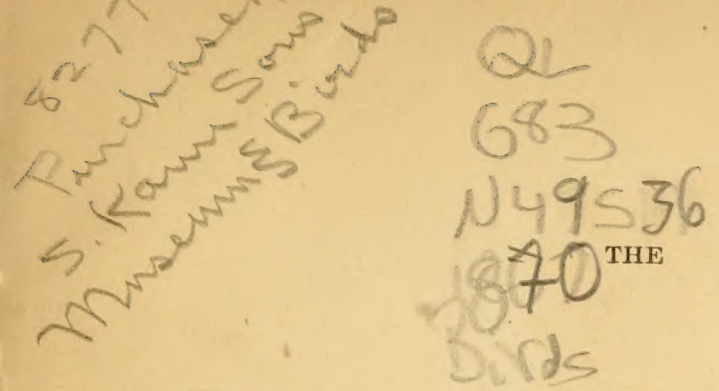

\section{BIRDs OF NEW ENGLAND}

AND

\section{ADJACENT STATES:}

CONTAINING DESCRIPTIONS OF THE BIRDS OF NEW ENGLAND, AND ADJOINING STATES AND PROVINCES, ARRANGED BY A LONG-APPROVED CLASSIFICATION AND NOMENCLATURE;

TOGETHER WITH

A HISTORY OF THEIR HABITS, TIMES OF ARRIVAL AND DEPARTURE, THEIR DISTRIBUTION, FOOD, SONG, TIME OF BREEDING, AND A CAREFUL AND ACCURATE DESCRIPTION OF THEIR NESTS AND EGGS;

WITH

Fllustrations of mant Speries of the Birøs, and accurate frigures of thrir 琵gs.

BY EDWARD A. SAMUELS, OURATOR OF ZOOLOGY IN THE MASBACHUSETTS STATE OABINET.

WITH AN APPENDIX CONTAINING SUPPLEMENTึARY NOTES.

FIFTH EDITION, REVISED AND ENLARGED.

B O S T ON:

NOYES, HOLMES, AND COMPANY,

117, WASHiNGTon STREet.

1870.

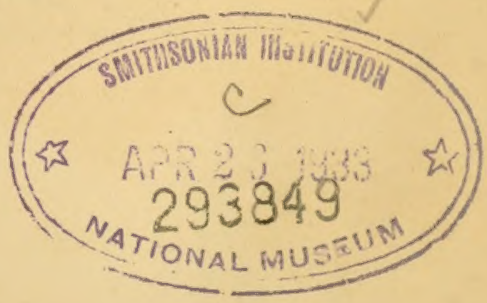


Entered according to Act of Congress, in the year 1867, by Edward A. Samuels,

in the Clerk's Office of the District Court of the District of Massachusetts.

CAMBRIDGE :

STEREOTYPED AND PRINTED BY JOHN WILSON AND SON 


\section{P R E F A CE.}

IN presenting this volume to the public, I would say that my chief aim in its preparation has been to supply the great demand for some work that might be accessible to all, both in consequence of its moderate price and its plain, untechnical language.

The want of such a volume is keenly appreciated by our students in this interesting branch of natural history; and, as all the editions of the valuable and popular works of Wilson and Nuttall are out of print, it has long been almost entirely unsupplied.

I have been able, from my own observations, to correct some important errors that have been published as to the breeding habits of different species, and have added, probably, a few new facts to our knowledge respecting those of others; but I must apologize for being obliged, in a great many cases, to use the observations of others for facts which I have had no opportunity of ascertaining myself.

I am greatly indebted to Professor Spencer F. Baird, of Washington, for his generous permission to use the descriptions of the birds given by him in the ninth volume :of 
the Pacific Railroad Reports, and for some valuable speci mens with which he furnished me for descriptions and figures. I also take this occasion to return my thanks to Hon. James S. Grennell, of Washington, and J. P. Norris, of Philadelphia, for the use of many valuable cuts of birds ; and to George A. Boardman, Esq., of Milltown, Me., John Krider, of Philadelphia, Thure Kumlien, of Albion, Wis., J. A. Allen, of Springfield, Mass., William Couper, of Quebec, Lower Canada, Henry A. Purdie, of Boston, and J. G. Rich, of Upton, Me., for many interesting specimens, and much valuable information.

Great credit is due Messrs. M. M. Tidd and Nathan Brown, of Boston, for the careful and accurate manner in which they have illustrated the eggs; subjects, as is well known, exceedingly difficult to figure, particularly on wood.

To Messrs. John Wilson \& Son, of Cambridge, Mass., my grateful acknowledgments are made for their indefatigable efforts to secure an elegant and perfect typographical execution.

The imperfections and shortcomings in the present work are too apparent; but they are, in most cases, unavoidable, because of the very meagre knowledge that we have of the habits of many of our birds, and the confusion that exists in the nomenclature, in descriptions, and observations concerning them in the works of many authors.

E. A. S.

Boston, March 25, 1867. 


\section{CONTENTS.}

Characteristics of Orders . . . . . . . . . . $\frac{{ }_{4}^{4}}{4}$

ORDER I.-RAPTORES, ROBBERS.

Family Falconidæ, Falcons . . . . . . . . . . . 7

Sub-Family Falconinæ, Falcons proper . . . . . . . . 7

Accipitrinæ, Hawks c . . . . . . . . . . 22

Buteoninæ, Buzzard-Hawks . . . . . . . . . 34

Aquilinæ, Eagles . . . . . . . . . . . . 49

Family Strigidæ, Owls . . . . . . . . . . . . 60

Sub-Family Buboninæ, Horned Owls . . . . . . . . . 60

Syrninæ, Gray Owls . . . . . . . . 71

Nycteininæ, Day Owls . . . . . . . . . 77

ORDER II.-SCANSORES, CLIMBERS.

Family Cuculidæ, Cuckoos . . . . . . . . . . . 83

Picidæ, Woodpeckers . . . . . . . . 87

\section{. ORDER III. - INSESSORES, PERCHERS.}

Sub-Order Strisores . . . . . . . . . . . . 110

Family Trochilidæ, Humming-Birds . . . . . . . . . 110

Cypselidæ, Swifts . . . . . . . . . . . 116

Caprimulgidæ, Goat-Suckers . . . . . . . . . 119

Sub-Order Clamatores, Screamers . . . . . . . . . 125

Family Alcedinidæ, Kingfishers . . . . . . . . . . . . 125

Colopteridæ, Flycatchers . . . . . . . . 1:8

Sub-Family Tyranninæ, Tyrant Flycatchers . . . . . . . 128

Sub-Order Oscines, Singers . . . . . . . . . . . .

Family Turdida, Thrushes . . . . . . . . . . . 145

Sub-Family Miminæ, Mocking-Birds . . . . . . . . . . 163

Family Saxicolidæ, Rock-Inhabiters . . . . . . . . 175 
Family Sylviidæ, Wood-Inhabiters . . . . . . . . 178

Paride, Titmice . . . . . . . . . . . 182

Sub-Family Sittinæ, Nuthatches . . . . . . . . 186

Family Certhiadæ, Creepers . . . . . . . . . . 190

Troglodytidx, Wrens . . . . . . . . . 192

Sylvicolidæ, Warblers . . . . . . . . . . . 199

Sub-Family Motacillinæ, Wagtails . . . . . . . . . . 199

Sylvicolinæ, Wood-Warblers . . . . . . 201

Tanagrinæ, Tanagers . . . . . . . . 250

Family Hirundinidæ, Swallows . . . . . . . . . 254

Bombycillidæ, Chatterers . . . . . . . . . 264

Laniidæ, Shrikes . . . . . . . . . . . 268

Sub-Family Laniinæ, Shrikes proper . . . . . . . . 268

Vireoninæ, Vireos . . . . . . . . . 270

Family Alaudidæ, Skylarks . . . . . . . . . . 280

Fringillidæ, Seed-Eaters . . . . . . . . . 288

Sub-Family Coccothraustinæ, Finches . . . . . . . . 283

Spizellinæ, Sparrows . . . . . . . . 301

Passerellinæ, Buntings . . . . . . . . . 325

Family Icteridæ . . . . . . . . . . . . . . . . 335

Sub-Family Agelaeinæ, Starlings . . . . . . . . . . 335

Icterinæ, Orioles . . . . . . . . . . 346

Quiscalinæ, Blackbirds . . . . . . . . 350

Family Corvidæ, Crows . . . . . . . . . . . 355

Sub-Family Corvinæ, Crows proper . . . . . . . . 355

Garrulinæ, Jays . . . . . . . . . . 364

\section{ORDER IV.-RASORES, SCRATCHERS.}

Sub-Order Columbæ . . . . . . . . . . . . 573

Family Columbidæ, Doves . . . . . . . . . . 373

Sub-Order Gallinæ, Game-Birds . . . . . . . . 378

Family Tetraonidæ, Grouse . . . . . . . . . . 378

Perdicidæ, Partridges . . . . . . . . . . 393

ORDER V.-GRALLA'TORES, WADERS.

Sub-Order Herodiones . . . . . . . . . . . . 398

Family Ardeidæ, Herons . . . . . . . . . . . . 398

Sub-Order Grallæ, Shore-Birds . . . . . . . . . . 412

Family Charadridæ, Plovers . . . . . . . . . . . 413

Hæmatopodidæ, Oyster-Catchers . . . . . . . 424

Recurvirostridx, Avosets . . . . . . . . . . 428 


\section{CONTENTS.}

Family Phalaropodidx, Phalaropes . . . . . . . . 430

Scolopacidx, Snipes . . . . . . . . . . . 432

Sub-family Tringinæ, Sandpipers . . . . . . . . 440

Sub-Family Totaninæ, Stilts . . . . . . . . . . 451

Family Paludicolæ. Swamp Inhabiters . . . . . . . 470

Sub-Family Rallinæ, Rails . . . . . . . . . . . 470

\section{ORDER VI. - NATATORES, SWIMMFERS.}

Sub-Order Anseres . . . . . . . . . . . . . 480

Family Anatidæ . . . . . . . . . . . . 480

Sub-Family Cygninæ, Swans. . . . . . . . . 480

Anserinæ, Geese . . . . . . . . . . 481

Anatinæ, River-Ducks . . . . . . . . . . 487

Fuligulinæ, Sea-Ducks . . . . . . . 503

Merginæ, Sheldrakes . . . . . . . . 525

Family Sulidæ, Gannets . . . . . . . . . . . 532

Graculidæ, Cormorants . . . . . . . . . 534

Laridæ, Gulls . . . . . . . . . . . 537

Sub-Family Lestridinæ, Skua-Gulls . . . . . . . 537

Larinæ, Gulls proper . . . . . . . . . 539

Sterninæ, Terns . . . . . . . . . 545

Sub-Order Gaviæ . . . . . . . . . . 532

Family Procellaridæ, Petrels . . . . . . . . . 552

Colymbidæ, Divers . . . . . . . . . . 555

Süb-Family Colymbinæ, Loons . . . . . . . . . . 555

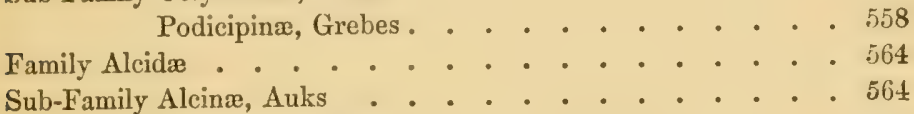

Urinæ, Guillemots . . . . . . . . . $\$ 67$

APPENDIX . . . . . . . . . . . . . 575

Index of Common Names . . . . . . . . . . 585

Index of Scientific Names. . . . . . . . . . 589 



\title{
ORNITHOLOGY AND 0ÖLOGY.
}

\section{INTRODUCTION.}

\begin{abstract}
A S I have generally adopted, in the present volume, the A system of classification, and the nomenclature, \&c., presented by Professor Baird in his report on the Birds of North America, I will state here, that I have given, so far as possible, his own remarks in the explanations of the characteristics of the different orders, families, genera, \&c., because they are expressed in the most concise and comprehensive language possible. I have also given the same descriptions of the species as those contained in the abovementioned report, because, being made from a much greater number of specimens than I could possibly have access to, they are certainly better than I could present from my own observations. The descriptions of the characteristics of the Raptores, the Gralloe, and the Alcidoe, are by John Cassin, of Philadelphia; those of the Longipennes Totipalmes and Colymbidee were written by Mr. George N. Lawrence, of New York; those of the other birds were prepared by Professor Spencer F. Baird, of the Smithsonian Institute.
\end{abstract}

In order that the descriptions of the birds in the follow- 
ing pages may be perfectly understood, I give the subjoined cuts, illustrating and explaining them:-

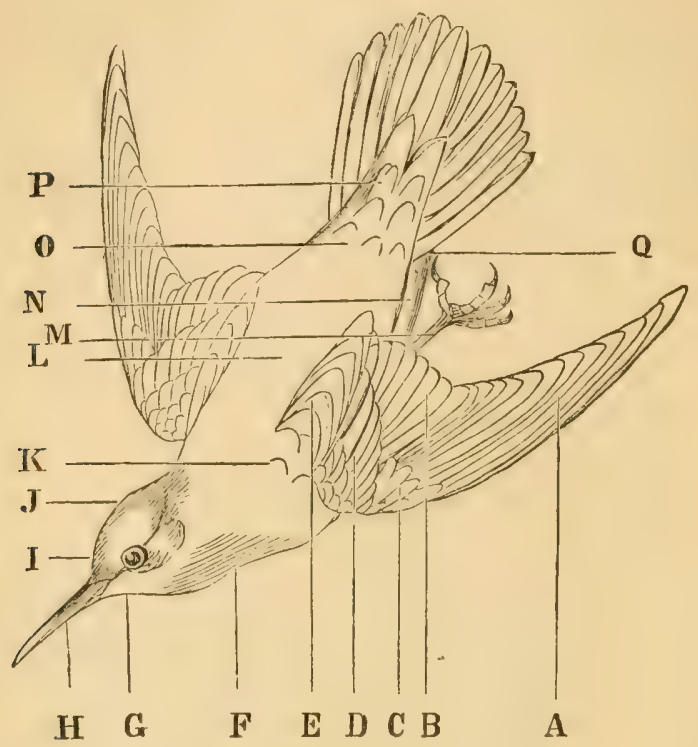

A represents the primary quills, usually called primaries.

$B$ represents the secondary quills, usually called secondaries.

C spurious wing.

D wing coverts.

E tertiary quills, usually called tertiaries.

$\mathrm{F}$. represents the throat.

$\mathrm{G}$ is the upper part of the throat, called the jugulum.

$\mathbf{H}$ is the bill or beak: this is divided into two parts, called the upper and lower mandibles.

I is the frons, or forehead: feathers at this point are called frontal feathers.

$J$ is the crown : feathers here are called coronal feathers, and occipital.

$\mathrm{K}$ represents the scapular feathers.

$\mathrm{L}$ is the back: feathers here are sometimes called interscapular.

M represents the tarsus: called shank or leg sometimes.

$\mathrm{N}$ is the abdomen.

$O$ is the rump.

$\mathrm{P}$ shows the upper tail coverts.

$\mathrm{Q}$ indicates the position of the lower tail coverts. 
$\mathrm{R}$ shows on the bill the culmen, or crown, of the upper mandible.

$S$ is the naked skin at the base of the bill, called the cere.

$\mathrm{T}$ shows the position of the lores between the eye and bill.

$\mathrm{U}$ indicates the gape, the angle at the junction of the upper and lower mandibles: the feathers in this locality are called rictal.

$\mathrm{V}$ is the commissure, or the folding edges of the mandibles.

In addition to these parts, there are the flanks or sides of the bird; the pectus, or breast; the flexure, or bend of the wing; the iris, or irides, the colored circle which surrounds the pupil of the eye; and the toes and tibia: the former are sometimes palmated, as with the swimmers, or natatores; and the latter is that portion next above the tarsus on the leg. 


\section{SYNOPSIS}

OF THE

\section{CHARACTERISTICS OF NORTH-AMERICAN BIRDS.}

THE following synopsis of the orders of birds, taken 1 partly from Keyserling and Blasius, will serve to illustrate the cliaracteristics of the higher groups in American Ornithology:-

\section{A.- Hind Toe on the same Level with the Anterior ONES.}

a. Posterior face or the sides of the tarsus more or less reticulated, granulated, or with scales more numerous or smaller than in front; sometimes naked. Anterior face of the tarsus never in one unbroken plate. Larynx without complex vocal muscles.

Order I. RAptoRes. - Base of the upper mandible with a soft skin or cere. Upper mandible compressed; its point curving down over that of the lower, forming a strong, sharp hook. Claws generally retractile. Toes, never two behind. Birds usually of large size and of powerful frame, embracing the so-called birds of prey.

Order II. Scansores. - Toes in pairs; two in front and two behind: the outer anterior being usually directed backwards; the inner, in Trogonida. Tail-feathers eight to twelve.

Order III. Strisones. - Toes either three anterior and one behind (or lateral), or four anterior: the hinder one is, however, usually versatile, or capable of direction more or less laterally forward. Tail-feathers never more than ten. Primaries always ten; the first, long. 
Order IV. Clamatores. - Toes, three anterior and one posterior (not versatile). Primaries always ten; the first nearly as long as the second. Tail-feathers usually twelve.

b. Anterior face of the tarsus in one continuous plate, or divided transversely into large quadrate scales. Plates on either the posterior surface of the tarsus or the sides, without subdivisions, never both divided together: when divided, the divisions correspond with the anterior ones. Larynx with peculiar complex singing muscles.

Order V. Oscines. - Toes, three anterior, one posterior. Primaries, either nine only; or, if ten, the first usually short or spurious.

\section{B. - Hind 'Toe raised above the Level of the Rest.}

Order VI. RASORES. - Nostrils arched over by an incumbent thick, fleshy valve. Bill not longer than the head, obtuse anteriorly. Nails broad, obtusely rounded.

Order VII. Grallatores. - Legs lengthened, adapted for walking, naked above the knee. Nostrils naked. Thighs usually quite free from the body. Toes not connected by a membrane, or for a short distance only; sometimes with a lobed margin.

Order VIII. Natatores. - Adapted for swimming. Legs generally short. Toes united by a continuous membrane. Thighs mostly buried in the muscles of the body. 


\section{ORDER I. - RAPTORES. ROBBERS.}

The peculiarities already given of the order Raptores are sufficient to define it among the others mentioned, although many additional features might be named. . The order embraces three families, which are characterized by Keyserling and Blasius as follows:-

\section{A. - Diurnal Birds of Prey.}

Eyes lateral, with lashes, surrounded by a naked or woolly orbital circle; the feathers above, below, and behind the eyes directed backwards, as on the rest of the head; anterior to the eye, the lore imperfectly clothed with a radiating star of bristles, or with scalelike feathers. The inner toe without the nail, shorter, or as long as the outer. Nostrils opening in the cere.

VULTURIDE. - Bill contracted or indented on the anterior border of the cere, so that the culmen is bow-shaped, or ascending anterior to it. Eyes lying on a level with the sides of the head. Head sparsely covered with downy feathers only, or partially naked. Claws weak, rather slender, and only moderately curved; the tarsi and bases of the toes reticulated.

FaLCONIDE. - The bill not contracted, nor the culmen ascending anterior to the cere. Eyes sunken. The head completely covered with compact, perfect feathers. Claws strong.

\section{B. - Nocturnal Birds of Prey.}

STRIGIDæ. - Eyes directed forwards; more or less completely surrounded by a crown of radiating bristly feathers. Lores and base of bill densely covered with bristly feathers directed forwards. The nostrils opening on the anterior edge of the cere. The inner toe without its claw longer than the outer, which is versatile. A crown of peculiarly formed feathers on the side of the head and above the throat. Head fully feathered. Plumage very soft and downy. 


\title{
FAMILY FALCONID
}

\section{Sub-Family Falconinde. The Falcons.}

\author{
FALCO, Linkeus.
}

Falco, Linn eus, Syst. Nat. I. 124 (1766).

General form robust and compact. Bill short, curved strongly from the base to the point, which is very sharp, and near which is a distinct and generally prominent tooth; nostrils circular, with a central tubercle; wings long, pointed, formed for vigorous, rapid, and long-continued flight; tail rather long and wide; tarsi short, robust, covered with circular or hexagonal scales; middle toe long; claws large, strong, curved, and very sharp.

\section{FALCO ANATUM, - Bonaparte.}

The Duck Hawk; Great-Footed Hawk.

Falco anatum, Bonap. Comp. List, p. 4 (1838).

"Falco peregrinus," Wilson, Audubon, and other authors.

\section{Description.}

Adult. - Frontal band white; entire upper parts bluish-cinereous, with transverse bands of brownish-black, lighter on the rump; under parts yellowish-white, with cordate and circular spots of black on the breast and abdomen, and transverse bands of black on the sides, under tail coverts, and tibiæ; quills and tail brownishblack, the latter with transverse bars of pale cinereous; cheeks with a patch of black; bill light-blue; tarsi and toes yellow Sexes alike.

Younger. - Entire upper parts brownish-black; frontal spot obscure; large space on the cheeks black; under parts dull yellowish-white, darker than in adult, and with longitudinal stripes of brownish-black; tarsi and toes bluish-lead color, iris hazel.

Total length, eighteen to twenty inches; wing, fourteen to fifteen; tail, seven to eight inches. 1

The Duck Hawk, which by the name of Peregine Falcon is known to my readers as one of the most rapacious of our birds of prey, is not uncommon in many portions of New England. It is nearly identical with the European species, and its habits and destructiveness are equally great with that bird. In its habitat, it is oftener found in the neighborhood of the sea-coast than in the interior. It is a powerful bird, of rapid flight and great boldness and cour-

1 See Introduction. 
age, and is the terror of the water-fowl, which constitute the greater portion of its prey. The breeding season of this species is very early. It commences building the nest usually on an inaccessible cliff, by the first of April. This is constructed of twigs, grasses, and sometimes seaweeds. The eggs are from two to four in number: their form is almost spherical, and their color is of a reddish-brown, covered with numerous minute spots and blotches of a darker shade. The dimensions of the only two specimens accessible to me at present are 1.90 inch in length by 1.75 in breadth, and 1.85 inch in length by 1.72 inch in breadth.

The following extracts from the writings of different authors comprise the most interesting observations made of this species:-

"The flight of this bird is of astonishing rapidity. It is scarcely ever seen sailing, unless after being disappointed in its attempt to secure the prey which it had been pursuing; and even at such times it merely rises, with a broad spiral circuit, to attain a sufficient elevation to enable it to reconnoitre a certain space below. It then emits a cry much resembling that of the sparrow-harvk, but greatly louder, like that of the European kestrel, and flies off swiftly in quest of plunder. The search is often performed with a flight resembling that of the tame pigeon, until, perceiving an object, it redoubles its flappings, and pursues the fugitive with a rapidity scarcely to be conceived. Its turnings, windings, and cuttings through the air, are now surprising. It follows and nears the timorous quarry at every turn and back-cutting which the latter attempts. Arrived within a few feet of the prey, the Falcon is seen protruding his powerful legs and talons to their full stretch. His wings are, for a moment, almost closed; the next instant, he grapples the prize, which, if too weighty to be carried off directly, he forces obliquely toward the ground, sometimes a hundred yards from where it was seized, to kill it, and devour it on the spot. Should this happen over a large extent of water, the Falcon drops his prey, and sets off in quest of another. On the contrary, should it not prove too heavy, the exulting bird carries it off to a sequestered and secure place. He pursues the smaller ducks, water-hens, 
and other swimming birds; and, if they are not quick in diving, seizes them, and rises with them from the water. I have seen this hawk come at the report of a gun, and carry off a teal, not thirty steps distant from the sportsman who had killed it, with a daring assurance as surprising as unexpected. This conduct has been observed by many individuals, and is a characteristic trait of the species. The largest bird that $\mathbf{I}$ have seen this hawk attack and grapple with on the wing is the Mallard.

"The Great-footed Hawk does not, however, content himself with waterfowl. He is generally seen following the flocks of pigeons, and even blackbirds, causing great terror in their ranks, and forcing them to perform aërial evolutions to escape the grasp of his dreaded talons. For several days, I watched one of them that had taken a particular fancy to some tame pigeons, to secure which it went so far as to enter their house at one of the holes, seize a bird, and issue by another hole in an instant, causing such terror among the rest as to render me fearful that they would abandon the place. However, I fortunately shot the depredator.

"They occasionally feed on dead fish, that have floated to the shores or sand-bars. I saw several of them thus occupied, while descending the Mississippi on a journey undertaken expressly for the purpose of observing and procuring different specimens of birds, and which lasted four months, as I followed the windings of that great river, floating down it only a few miles daily. During that period, I and my companion counted upwards of fifty of these hawks, and killed several; one of which was found to contain in its stomach bones of birds, a few downy feathers, the gizzard of a teal, and the eyes and many scales of a fish.

"Whilst in quest of food, the Great-footed Hawk will frequently alight on the highest dead branch of a tree, in the immediate neighborhood of such wet or marshy ground as the common snipe resorts to by preference. His head is seen moving in short starts, as if he were counting every little space below; and, while so engaged, the moment he espies a snipe; down he darts like an arrow, making a rustling noise with his wings, that may be heard several hundred yards off, seizes the snipe, and flies away to some near wood to Jevour it.

"It is a cleanly bird, in respect to feeding. No sooner is the prey dead, than the Falcon turns it belly upwards, and begins to 
pluck it with his bill, which he does very expertly, holding it meantime quite fast in his talons; and, as soon as a portion is cleared of feathers, tears the flesh in large pieces, and swallows it with great avidity.

"If it is a large bird, he leaves the refuse parts; but, if small, swallows the whole in pieces. Should he be approached by an enemy, he rises with it, and flies off into the interior of the woods; or, if he happens to be in a meadow, to some considerable distance, he being more wary at such times than when he has alighted on a tree." - AUduron.

The following very complete description of the breeding habits of the Great-footed Hawk is from the pen of J.A. Allen, of Springfield, Mass., one of our most enthusiastic students, published in the "Proceedings of the Essex Institute," vol. IV.:-

"All accounts agree that the nest is placed on almost inaccessible cliffs; and often it can only be approached by a person being let down by a rope from above. The old birds are represented as bold in the defence of their nest, approaching so near as generally to be easily shot. They arrive early at their nesting-place; and, though they often bestow no labor in the construction of a nest, beyond the scraping of a slight hollow in the ground, they. defend their chosen eyrie for weeks before the eggs are laid, and are known to return for several years to the same site. Incubation commences very early, the young having been found in the nest at Mount Tom, May 30, nearly fledged, ${ }^{1}$ and on Talcott Mountain, in the same condition, June 1; so that the laying of the eggs must occur by the last of March, or very early in April. The number of eggs has been known in several instances to be four.

"Mountains Tom and Holyoke, in Massachusetts, afford several localities favorable for the nidification of the Duck Hawk; and sometimes several pairs, and probably usually more than one, breed about these mountains. ${ }^{2}$ About the last of May, 1863, Mr. Bennett

I According to R. B. Hildreth, Esq., of Springfield, who visited this nest May 30,1861 , and noted the fact. The nest on Talcott Mountain, Conn., was found the same season, and first visited only a few days later, - about June 1, 1861.

2 Since the above was written, I have been informed by Mr. Bennett, that a pair of these hawks actually raised their young on Mount Tom in the summer of 1864, notwithstanding one pair was broken up the same season. 
saw five adult birds of this species about Mount Tom. Dr. W. Wood, of East-Windsor Hill, Conn., informs me, that two pairs of Duck Hawks were evidently breeding on Talcott Mountain in the summer of 1863 .

"Discovery of the Eggs on Mount Tom. - Although the Duck Hawk has been long known to breed at the localities in Massachusetts mentioned above, those conversant with the fact were not aware that any special interest was attached to it, or that its eggs and breeding habits were but very little known to ornithologists; and so, until very recently, no particular efforts have been made to obtain the eggs. Mr. Bennett, becoming aware of this, resolved to procure the eggs. He accordingly visited Mount Tom for this purpose, April 7, of the present year, when he searched the whole ridge of the mountain, discovered the old birds, and the particular part they most frequented, and also the site of a nest where young had been raised. The old birds were continually near this spot, and manifested much solicitude when it was approached, often flying within six or eight rods; and once the female came within three, screaming and thrusting out her talons with an expression of great rage and fierceness. The birds did not appear at all shy, being easily approached quite near to ; though, in walking, the cracking of sticks and the clinking of the splinters of trap-rock made no little noise. One of the birds appeared to keep close to the eyrie; and both would approach whenever it was visited, screaming at and menacing the intruder, notwithstanding that at that time there, were no eggs, as was afterwards proved. Mr. Bennett, suspecting that incubation had already commenced, visited the locality again on the 9 th, but only saw the old nest; the birds behaving as before. On April 19, ten days later, he made another visit; and creeping carefully to the summit of the cliff, at a point near the eyrie already spoken of, he saw the female, on looking over the cliff, sitting on the nest, and but five or six yards distant. She eyed him fiercely for an instant, and then, scrambling from the nest to the edge of the narrow shelf supporting it, launched into the air : in a twinkling, Mr. Bennett's unerring aim sent her tumbling dead at the foot of the precipice, several hundred feet below. The nest contained four eggs, which were soon safely secured, and the body of the female was obtained from the foot of the cliff. The male, soon coming about, was shot at; but he was too shy to come within 
range, except once, while the gun was being reloaded. The eggs were all laid after Mr. Bennett's visit, April 9 ; and their contents showed, April 19, that they had been incubated but a day or two. Incubation seems, in this case, to have commenced several weeks later than usual, which may be owing to the late snows and unusual coldness of the weather this year, during the first half of April.

"Location and Description of the Eyrie. - The situation of the eyrie was near the highest part of the mountain, about one-third of the length of the mountain from the south end, on a narrow shelf in the rock, eight or ten feet from the top of a nearly perpendicular cliff, one hundred and fifty or two hundred feet in height, and was inaccessible except to a bold climber, and at one particular point. The nest was merely a slight excavation, sufficient to contain the eggs: no accessory material had been added. The site had been previously occupied, and probably for several years ; and, for weeks before the eggs were laid, was carefully guarded by the bold and watchful birds.

"Description of the Eggs. - The eggs, four in number, as already stated, differ greatly both in shape and coloring; the extremes in either being widely diverse. They are described in detail, and probably in the same order as laid.

"No. 1. Longer diameter, 2.18 inches; shorter diameter, 1.71 inches: the shorter diameter is .885 the longer. The form is somewhat ovoid, one end being slightly larger than the other; but neither end is very pointed: the point of greatest transverse diameter is .645 the length of the egg from the smallest end. In form, this egg is very nearly like the egg from Greenland, figured by Dr. Brewer in the 'North-American Oology' (pt. I. plate II. fig. 11). The general color is chocolate-brown, darker and more dense and uniform about the ends, the part about the middle being lighter, varied with small irregular blotches and specks of a darker tint than the ground-color. The color of the smaller end is nearly a uniform dull-red ochre. There is also an irregular belt of scattered and apparently very superficial blotches of very dark brown, or nearly black. Something similar is often noticed on the eggs of many birds that lay brown or speckled eggs.

"No. 2. Longer diameter, 2.21 inches; shorter diameter, 1.67 inches: shorter diameter, .755 the longer. Form, nearly an ellipsoid, the point of greatest transverse diameter being scarcely to 
one side of the middle (.54 the length of the egg from the smaller end); ends very nearly equal, and not very pointed. The distribution of the color in this is nearest of any of the four eggs before me to that figured by Dr. Brewer, and only differs from it in tint. One end (the smaller?) is very light reddish, or reddishwhite, becoming lighter from the middle towards this end, about which it is the lightest, and thinly marked with irregular mottlings of dark reddish chocolate, which present a very superficial grayish tinge that is very characteristic; the other end (the larger?) is of a uniform dark ferruginous-brown or dull-red ochre, varied towards the middle by the appearance of the light ground-color between the there scarcely confluent blotches of dark-brown that give the uniform deep tint towards and about this end.

"No. 3. Longer diameter, 2.32 inches; shorter diameter, 1.70 inches: shorter diameter, .733 the longer. Form ovoid, the smaller end elongated and much pointed. This egg is the longest, and much larger in proportion to its diameter than either of the others. The point of greatest diameter is .656 the length of the egg from the smaller end. In this specimen, the contrast between the ground-color and the markings becomes very strong: the ground-color, which is seen chiefly in a broad band about the middle of the egg, being white or reddish-white; and the markings very dark reddish-brown, nearly approaching purple, and are quite uniformly distributed in blotches of various sizes, the largest being near the larger end of the egg : the sub-markings are of a lighter reddish-brown, and are more blended.

"No. 4. Longer diameter, 2.16 inches; shorter diameter, 1.65 inches: shorter diameter, .765 the longer. Form regular ovoid, the smaller end rather more pointed than the same in No. 1 ; point of greatest transverse diameter .60 the length of the egg from the smaller end. In this specimen, the contrast of the ground-color with the markings is very striking, especially when compared with specimens No. 1 and No. 2 ; and the most peculiar part is, that the greater end of the egg, which in the eggs of most birds is the end usually most subject to markings and to the greatest depth of color, is white, sprinkled sparingly with reddish specks, while the smaller end is deep, bright brick-red, here and there reliered by small specks and patches of white ground-color. About the middle of the egg; the colors are in more equal proportions; the white patches 
becoming larger on the smaller end towards the middle, and the red patches on the larger end increase towards the same point, where the colors meet and become mixed in irregular patches of various sizes, from mere dots to blotches. The smaller end has a few streaks and blotches of dark-purple overlying apparently the other colors, as in specimen No. 1.

"These specimens are very interesting, as indicating the great amount of variation to which the American Peregrine's eggs are subject; and especially so since they are all the product of one pair of birds, laid in one set, and identified as such beyond question. In coloration, a transition can be traced between the extreme in the order they are numbered, which is undoubtedly the order in which they were laid, as indicated by the thickness of the shell as well as by the depth of color.

TABLE OF COMPARATIVE MEASUREMENTS.

\begin{tabular}{|c|c|c|c|c|c|c|c|c|c|c|c|c|}
\hline \multirow[b]{2}{*}{ No. 1.} & \multirow[b]{2}{*}{ - } & \multirow[b]{2}{*}{. } & \multirow[b]{2}{*}{. } & \multicolumn{2}{|r|}{ Length. } & Breadth. & $\begin{array}{l}\text { Prop. of breadth } \\
\text { to length. }\end{array}$ & \multicolumn{5}{|c|}{$\begin{array}{l}\text { Point of greatest transverse } \\
\text { diameter from small end. }\end{array}$} \\
\hline & & & & - & 2.18 in. & 1.71 in. & $0.785 \mathrm{in}$ & 0.6401 & ength & of & the & egg. \\
\hline No. 2 . & - &. & . . & - & 2.21 & $1.67 n$ & 0.756 & 0.540 & $\eta$ & $"$ & " & " \\
\hline No. 3 . & . & .. & .. & - & 2.32 & 1.70 & 0.732, & 0.656 & " & $n$ & 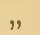 & 19 \\
\hline No. 4. & - & . & .. & - & 2.16 & 1.65 & 0.765 & 0.600 & $"$ & , & " & $"$ \\
\hline Average & - & . & . & - & 2.22, & $1.68 n$ & 0.759 & 0.609 & $n$ & " & , & १ \\
\hline Greater & ext & reme & . . & - & 2.32 & 1.71 & 0.785 & 0.656 & g & $9^{\circ}$ & , & y \\
\hline Lesser ex & xtre & eme & . & - & 2.16 & 1.65, & 0.732, & 0.540 & $"$ & 99 & $n$ & 9 \\
\hline Amount & & varia & tion & 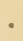 & 0.16 & 0.06, & $0.053 "$ & 0.116 & $n$ & $n$ & $n$ & " \\
\hline Dr. Brew & wer? & s spe & cimen & . & 2.00 & 1.56 & 0.780 & & & & & \\
\hline
\end{tabular}

"From the above table, it will be seen that the range of variation in the four specimens in length is .16 of an inch, or nearly seven and a half per cent of the average length; in breadth, .06 of an inch, or about three and a half per cent of the average breadth: in the proportion of breadth to length, about fifteen per cent of the length, or nearly twenty per cent of the average proportion. The variation in the position of the point of greatest transverse diameter is about eleven and a half per cent of the whole length of the egg; the form of the eggs varying from an ellipsoid in No. 2 to an ovoid, which, in No. 3, has the smaller end considerably elongated. It will be observed that the egg measured by Dr. Brewer is considerably smaller than my smallest specimen, and that the proportion of breadth to length scarcely differs from the same proportion in No. 1. 
"In comparing the eggs of the American and the European Peregrine Falcons, Dr. Brewer observes: 'It [the American] closely resembles a variety of the eggs of the European species, but seems to present differences sufficiently well marked to be regarded as specific. ... The ground-colors of both American and European are a reddish-yellow; and both are thickly covered with fine dottings of chocolate and ferruginous brown, diffused over the whole egg in nearly equal degree, and to such an extent as nearly to conceal the ground. The length of the American egg is slightly less; but it is of equal or greater capacity, and varies in its markings from all the European specimens that I have ever met with. These variations, though readily traceable by the eye, are not so easily described. The shades of coloring in both are closely alike: the variation consists more in the distribution of these markings. In the European specimens, the fine markings of chocolate are distributed with nearly exact uniformity. In the American, the secondary colorings are now more thickly and now more thinly diffused, - here leaving the ground-color nearly unchanged; there becoming confluent, and blending into waving lines, blotches, and bold dashes. The egg, in consequence, presents a more varied appearance. These markings are also in greater proportion around the larger end of the egg, and the blotches are of a deeper shade; so there is a variation in the shading between the smaller and larger extremities not noticeable in any European egg that I have met with.'

"The amount of variation presented by the eggs of the Duck Hawk, described above, shows that but little dependence can be placed on the eggs in deciding specific differences. The eggs mentioned by Dr. Brewer are not much different from those of the true European Peregrine. One or two of the specimens before me considerably resemble Dr. Brewer's, and likewise eggs of the European species, as figured and described by authors, while the others are very different, one being remarkably so.

"The eggs of the different species of this group of Falcons seem to resemble each other greatly, and to be subject to considerable variation in the same species. In the manner of laying the eggs, there is also a similarity, as might be expected among closely allied species; the same species sometimes laying them on the bare rocks, and again in a bulky nest of sticks and other coarse materials. The nest of this species visited on Talcott Mountain, Conn., 
was of the latter kind; while on Mount Holyoke the eggs were laid on the bare earth.

"Audubon thus describes the nest and eggs of the Duck Hawk, as observed by him at Labrador:-

"I have nowhere seen it so abundant as along the high, rocky shores of Labrador and Newfoundland, where I procured several adult individuals of both sexes, as well as some eggs and young. The nests were placed on the shelves of rocks, a few feet from the top, and were flat, and rudely constructed of sticks and moss. In some were found four eggs, in others only two, and in one five. In one nest only a single young bird was found. The eggs vary considerably in color and size, which, I think, is owing to a difference of age in the females; the eggs of young birds being smaller. The average length of four was two inches, their breadth one and five-eighths. They are somewhat rounded, though larger at one end than the other; their general and most common color is a reddish or rusty yellowish-brown, spotted and confusedly marked with darker tints of the same, here and there intermixed with lighter. The young are at first thickly covered with soft white down. ... In several instances, we found these falcons breeding on the same ledge with cormorants, Phalacrocorax carbo." "1

"Audubon adds that he is perfectly convinced that the Greatfooted Falcon, or Duck Hawk of the later ornithologists, is not different from the Peregrine Falcon of Europe. 'Since my first acquaintance with this species,' he says, ' $I$ have observed nothing in its habits, form, or marking on one continent that is different from what is found on the other.' Since the difference in breeding habits supposed to exist when Bonaparte separated them in 1838, and which influenced his judgment in the matter, has been found to be not real, there seems to be nothing whatever in the breeding habits or in the appearance of the eggs to indicate specific difference between the American and European birds."

\section{HYPOTRIORCHIS COLUMBARIUS. - Gray.}

The Pigeon Hawk.

Falco columbarius, Linnæus. Syst. Nat., I. 128 (1766).

Falco intermixtus, Daudin. Traite d'Orn., II. 141 (1800).

Falco temerarius, Audubon. Orn. Biog., I. 381 (1831).

Falco Auduboni. Blackwall, Researches, Zoöl., 1834.

\section{Description.}

Adult Male. - Entire upper parts bluish-slate color, every feather with a black longitudinal line; forehead and throat white; other under parts pale yellowish or

1 Orn. Biog., vol. V. p. 366. 
reddish white; every feather with a longitudinal line of brownish-black; tibix light ferruginous, with lines of black; quills black, tipped with ashy white; tail light-bluish ashy, tipped with white and with a wide subterminal band of black, and with several other transverse narrower bands of black; inner webs nearly white; cere and legs yellow; bill blue.

Younger. - Entire upper plumage dusky-brown, quite light in some specimens, and with a tinge of ashy; head above, with narrow stripes of dark brown and ferruginous, and in some specimens many irregular spots and edgings of the latter color on the other upper parts; forehead and entire under parts dull-white, the latter with longitudinal stripes of light-brown; sides and flanks light-brown, with pairs of circular spots of white; tibix dull white, with dashes of brown; tail pale-brown, with about six transverse bands of white; cere and legs greenish-yellow.

Young. - Upper plumage brownish-black, white of the forehead and under parts more deeply tinged with reddish-yellow; dark stripes wider than the preceding; sides and flanks with wide transverse bands of brownish-black, and with circular spots of yellowish-white; quills black; tail brownish-black, tipped with white, and with about four bands of white; cere and feet greenish-yellow; iris dark-hazel.

Total length, female twelve to fourteen inches; wing, eight to nine inches; tail, five to five and a half inches. Male, total length, ten to eleven inches; wing, seven and a half to eight inches; tail, five inches.

This species is a pretty common spring and fall visitor in all the New-England States, and is sometimes a resident in the southern sections of these States through the winter; specimens being occasionally taken as late as January, in mild seasons. This bird is one of the most destructive of our rapacia: he kills all the smaller birds, robins, blackbirds, sparrows in great numbers, and even attacks the wild pigeon and dove, which he is almost always able to overtake and capture, as he is possessed of very great rapidity of flight. I have seen one of these hawks make a pounce at a sparrow that was singing on a low bush; and the bird happily eluding his clutch, as quick as a flash of light, he turned, and pursued and captured a robin that had taken flight at his first appearance, and was already quite a considerable distance off: as the robin is well known to have great speed of flight, this circumstance well illustrates the velocity of this hawk.

The flight of the bird consists of a series of flaps of the wings, with but a very few intervals of soaring: in pursuing the wild pigeon, the strokes of the wings of the two birds are nearly simultaneous. As he strikes his prey, he almost 
always, instead of clutching it as it falls, alights after it has fallen, in the same manner as the Great-footed Hawk. I have noticed the same fact with the Red-tailed Hawk; the victim seems to fall dead, or, at any rate, perfectly incapable of motion: whether this is the result of a kind of mesmerism, as it were, similar to the influence of the cats on their prey, or the hawk transfixes his quarry through the vitals, I am unable to say.

The Pigeon Hawk, in alighting on a branch or other object, always descends below the level of it, and rises up; and usually turns abruptly about, and faces the direction from which it came, as soon as it has struck its perch. This habit is observable in many of the other hawks.

While perching, the tail is often flirted up and down, and the wings are partially opened and shut in a nervous manner, as if the bird were anxious to be off again in the pursuit of game.

It is not improbable that it breeds in New England, although I do not remember of an authenticated instance. I have no egg of this bird in my collection, and have never met with its nest. There seems considerable confusion regarding this species, both as to its nesting-place and its eggs. Mr. Hutchins says ("Fauna Boreali Americana," II. 36) it "makes its nest on rocks and in hollow trees, of sticks and grass, lined with feathers; laying from two to four white eggs, marked with red spots." Audubon, in describing the eggs, says ("Birds of America"): "Mr. Hutchins's description of the eggs of this bird is greatly at variance with my own observations. The eggs, in three instances which occurred at Labrador, were five; they measured an inch and three-quarters in length, an inch and a quarter in breadth, and were rather elongated; their ground-color a dull yellowish-brown, thickly clouded with irregular blotches of dull, dark reddish-brown." Dr. Brewer says ("Synopsis of Birds of North America," as an appendix to Wilson's "Ornithology") it "nests in low 


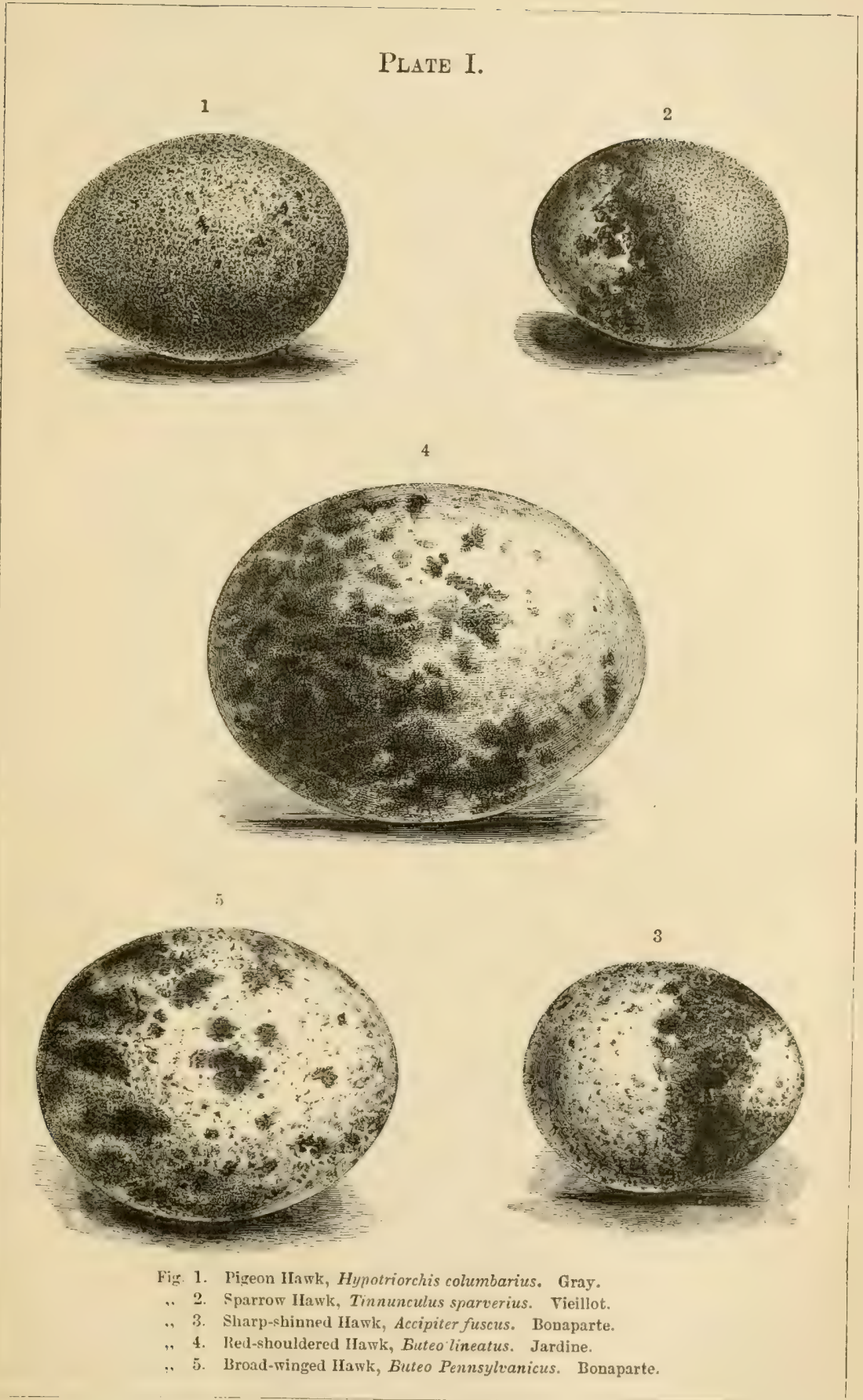



fir-trees, twelve feet from the ground; eggs three, dull yellowish-brown, with dark reddish-brown blotches."

A single egg before me, kindly loaned for descriptions and figure by George A. Boardman of Milltown, Me., is of the above color. It is admirably figured, fig. 1, plate I., in this volume. It is a trifle more pointed than the eggs of rapacious birds usually are, and measures 1.50 inch in length, and 1.14 inch at its greatest breadth.

\section{TINNUNCULUS SPARVERIUS.-Vieillot.}

\section{The Sparrow Hawk.}

Falco sparverius, Linnæus. Syst. Nat., I. 128 (1766).

Falco dominicenses, Gm. Syst. Nat., I. 285 (1788).

Falco gracilis, cinnamoninus, and isabellinus. Sw. Cab. Cy., p. 281 (1838).

\section{DESCRIPTION.}

Adult. - Frontal band and space, including the eyes and throat, white; spot on the neck behind, two others on each side of the neck, and line running downwards from before the eye, black; spot on the top of the head, the neck behind, back, rump and tail, light rufous or cinnamon color; under parts generally a paler shade of the same rufous as the back, frequently nearly white, but sometimes as dark as the upper parts, and always with more or less numerous circular or oblong spots of black; quills brownish-black, with white bars on their inner webs; tail tipped with white, frequently tinged with rufous, and with a broad subterminal band of black, outer frequently white, tinged with ashy, and barred with black; bill light-blue; legs yellow; back generally with transverse stripes of black, but frequently with very few, or entirely without; rufous spot on the head, variable in size, and sometimes wanting.

Younger Afale. - Upper parts as above; wing coverts and tail ferruginous red, with numerous transverse bands of brownish-black; under parts with numerous longitudinal stripes, and on the sides with transverse bands of brownish-black; external feathers of the tail palest; broad subterminal band on the tail, obscure or wanting.

Young. - All the rufous parts of the plumage with wider transverse bands of brownish-black; wing coverts, dark bluish-cinereons, with large circular spots of black; under parts with longitudinal stripes, and large circular spots of black; iris very dark hazel.

Total length, eleven to twelve inches; wing, seven to seven and a half; tail, five to five and a half inches.

This beautiful little hawk is a summer inhabitant of all the New-England States, and, in the more southern districts, a resident throughout the year. It is not a very common species in any but the most northern sections of these 
states, but in those localities it is the most abundant of the birds of prey. I can add but little to Wilson's description that will be of interest: it is as follows :-

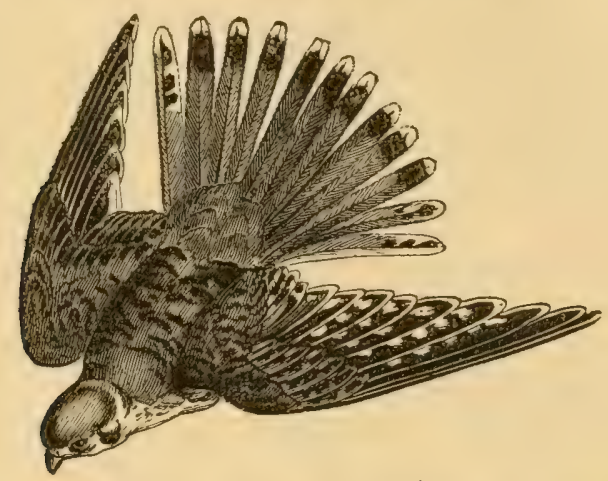

"The habits and manners of this bird are well known. It flies rather irregularly, occasionally suspending itself in the air, hovering over a particular spot for a minute or two, and then shooting off in another direction. It perches on the top of a dead tree or pole, in the middle of a field or meadow, and, as it alights, shuts its long wings so suddenly that they seem instantly to disappear: it sits here in an almost perpendicular position, sometimes for an hour at a time, frequently jerking its tail, and reconnoitring the ground below, in every direction, for mice, lizards, \&c. It approaches the farmhouse, particularly in the morning, skulking about the barnyard for mice or young chickens. It frequently plunges into a thicket after small birds, as if by random, but always with a particular, and generally a fatal aim. One day I observed a bird of this species perched on the highest top of a large poplar, on the skirts of the wood, and was in the act of raising the gun to my eye, when he swept down, with the rapidity of an arrow, into a thicket of briers, about thirty yards off, where I shot him dead, and, on coming up, found a small field-sparrow quivering in his grasp. Both our aims had been taken in the same instant; and, unfortunately for him, both were fatal. It is particularly fond of watching along hedge-rows and in orchards, where small birds usually resort. When grasshoppers are plenty, they form a considerable part of its food. 
"Though small snakes, mice, lizards, \&c., are favorite morsels with this active bird, yet we are not to suppose it altogether destitute of delicacy in feeding. It will seldom or never eat of any thing that it has not itself killed; and even that, if not (as epicures would term it) in good eating order, is sometimes rejected. A very respectable friend, through the medium of $\mathrm{Mr}$. Bartram, informs me, that one morning he observed one of these hawks dart down on the ground, and seize a mouse, which he carried to a fence-post, where, after examining it for some time, he left it, and, a little while after, pounced upon another mouse, which he instantly carried off to his nest in the hollow of a tree hard by. The gentleman, anxious to know why the hawk had rejected the first mouse, went up to it, and found it to be almost covered with lice, and greatly emaciated. Here was not only delicacy of taste, but sound and prudent reasoning: "If I carry this to my nest," thought he, "it will fill it with vermin, and hardly be worth eating."

"The Blue Jays have a particular antipathy to this bird, and frequently insult it by following and imitating its notes so exactly as to deceive even those well acquainted with both. In return for all this abuse, the Hawk contents himself with now and then feasting on the plumpest of his persecutors, who are, therefore, in perpetual dread of him; and yet, through some strange infatuation, or from fear that, if they lose sight of him, he may attack them unawares, the Sparrow Hawk no sooner appears than the alarm is given, and the whole posse of jays follow."

Although I have had quite a number of the eggs of this bird, I have been able to meet with but one nest, notwithstanding I have repeatedly searched for it in many localities. This was built in a crow's nest of the previous year, in a hemlock-tree, about thirty feet from the ground. There had been apparently but few alterations of the old nest; these consisting principally of the addition of a fer loose sticks and twigs to the interior of the nest, making it nearly a flat platform. The locality was the valley of the Magalloway River, about twenty-five miles north of Lake Umbagog, Me. The eggs were four in number; and these, with several other specimens collected in Upton, Me., 
Calais, Me., and Williamstown, Mass., are before me. I am inclined to think, from what I can learn from collectors and others, that four is the usual number laid by this bird, probably seldom more. Their ground-color varies from a deep cream or yellowish-buff to a pale reddish-white: this is covered, more or less thickly in different specimens, with spots and confluent blotehes of reddish-brown and Vandykebrown, or chocolate. Their form is nearly spherical, being but very little pointed at either end. Their dimensions vary from 1.40 inch by 1.15 inch to 1.30 inch by 1.13 inch. This species breeds later than most of the other birds of prey, as the eggs which I found in Maine on the 11th of June, 1864, were newly laid. This species usually nests in a hollow tree or a deserted woodpecker's nest.

\section{Sub-Family Accipitrine. - The Hawks.}

Form rather long and slender; tail and legs long; wings rather short; bill short, hooked; upper mandible lobed, but not toothed. Very active and vigilant, and swift of flight; pursuing their prey, which consists of birds and small quadrupeds, into the woods and forests.

\section{ASTUR, LAC.}

Astur, LACEPEDE, Mem. Inst., III. p. 506.

The largest birds of this sub-family. General form strong, but rather long and slender; wing rather short; tail long and broad; tarsi long, covered in front with rather wide transverse scales; toes and claws moderate, the latter fully curved, sharp; bill short, curved; nostrils large, ovate, inserted in the cere. This genus contains about twelve species of all countries.

\section{ASTUR ATRICAPILLUS, - Bonaparte.}

\section{The Goshawk.}

Falco atricapillus, Wilson. Am. Orn., VI. 80 (1812).

Falco regalis, Temm. Pl. col. I. (liv. 84, about 1827 ).

Dodalion pictum, Lesson. Traite d'Orn., I. 67 (1831).

\section{DESCRIPTION.}

Adult. - Head above, neck behind, and stripe from behind the eye, black, generally more or less tinged with ashy; other upper parts dark ashy bluish or slate color, with the shafts of the feathers black, and frequently with the feathers narrowly edged with black, presenting a squamate or scale-like appearance; a con8picuous stripe over the eye, and an obscure and partially concealed occipital and 
nuchal band, white; entire under parts mottled with white and light ashy-brown; every feather with a longitudinal line of dark-brown on its shaft, and with numerous irregular and imperfect transverse lines or narrow stripes of light ashy-brown, more distinct and regular on the abdomen and tibiæ; quills brown, with bands of a deeper shade of the same color, and of ashy-white on their inner webs; tail same color as other upper parts; under surface very pale, nearly white, and having about four obscure bands of a deeper shade of ashy-brown, and narrowly tipped with white; under tail coverts white.

Young. - Entire upper parts, including head, dark-brown, with the feathers, especially on the head and neck behind, edged and spotted with light-reddish, or nearly white; tail light-ashy, with about five wide and conspicuous bands of ashybrown, and narrowly tipped with ashy-white; quills brown, with wide bars of a darker shade of the same color, and wide bands of reddish-white on their inner webs; under parts white, generally tinged with yellowish, and frequently with reddish; every feather with a longitudinal stripe terminating in an ovate spot of brown; sides and tibix frequently with circular and lanceolate spots and irregular bands of the same color, the tibix generally very conspicuously marked in this manner; under tail coverts white, with a few large lanceolate spots of brown.

"Adult.-Bill black, light-blue at the base; cere greenish-yellow; eyebrow greenish-blue; iris reddish-orange; feet yellow.

"Young. - Bill as in the adult; iris light-yellow; feet greenish-yellow." Aunubon.

Total length, female, twenty-two to twenty-four inches; wing about fourteen; tail, ten and a half to eleven inches. Male, about twenty inches; wing, twelve and a half; tail, nine and a half inches.

This handsome hawk is a not very common winter visitor in the New-England States; at least, such is my observation, which is corroborated by many others, although Mr. Verrill, in his catalogue of the birds of Maine, ${ }^{1}$ says it is common, and that it breeds there. I have never met with a nest of this species, and have no authentic specimen of its egg in my collection. In 1864, a gentleman brought me two eggs that he found in a large hawk's nest in Woburn, Mass. He described the hawk, which he killed, and which corresponded pretty closely with that of this bird. I showed him mounted specimens of the Goshark, and he thought them identical with his bird. As there was still a doubt concerning the identity of the eggs, I did not label them as of this species, and for the same reason will not figure them in this work. So far as description goes, they are almost exactly like the eggs of the Red-tailed Hawk

1 Proceedings Essex Institute, vol. III. p. 140. 
(Buteo borealis), but are a little more of a bluish-white in the ground-color.

For some reason, this species was quite abundant in the neighborhood of Boston in the winter of 1859 60: probably a dozen or fifteen specimens were sent to me in the different plumages, and I have heard of many others being shot in the same season.

I have had but few opportunities for studying the habits of this hawk, and, as my observations have been very meagre, I will give Audubon's description, which, so far as my experience goes, is very accurate; it is as follows :-

"The flight of the Goshawk is extremely rapid and protracted. He sweeps along the margins of the fields, through the woods, and by the edges of ponds and rivers, with such speed as to enable him to seize his prey by merely deviating a few yards from his course; assisting himself on such occasions by his long tail, which, like a rudder, he throws to the right or left, upwards or downwards, to check his progress, or enable him suddenly to alter his course. At times he passes like a meteor through the underwood, where he secures squirrels and hares with ease. Should a flock of wild pigeons pass him when on these predatory excursions, he immediately gives chase, soon overtakes them, and, forcing his way into the very centre of the flock, scatters them in confusion, when you may see him emerging with a bird in his talons, and diving towards the depth of the forest to feed upon his victim. When travelling, he flies high, with a constant beat of the wings, seldom moving in large circles like other hawks; and, when he does this, it is only a few times in a hurried manner, after which he continues his journey.

"Along the Atlantic Coast, this species follows the numerous flocks of ducks that are found there during the autumn and winter; and greatly aids in the destruction of mallards, teals, black ducks, and other species, in company with the Peregrine Falcon (Falco anatum). It is a restless bird, apparently more vigilant and industrious than many other hawks, and it seldom alights unless to devour its prey; nor can I recollect ever having seen one alighted for many minutes at a time, without having a bird in its talons. 
When thus engaged with its prey, it stands nearly upright; and in general, when perched, it keeps itself more erect than most species of hawks. It is extremely expert at catching snipes on the wing; and so well do these birds know their insecurity, that, on its approach, they prefer squatting to endeavoring to escape by flight.

"When the passenger pigeons are abundant in the western country, the Goshawk follows their close masses, and subsists upon them. A single hawk suffices to spread the greatest terror among their ranks; and the moment he sweeps towards a flock, the whole immediately dive into the deepest woods, where, notwithstanding their great speed, the marauder succeeds in clutching the fattest. While travelling along the Ohio, I observed several hawks of this species in the train of millions of these pigeons. Towards the evening of the same day, I saw one abandoning its course to give chase to a large flock of Crow Blackbirds (Quiscalus versicolor), then crossing the river. The hawk approached them with the swiftness of an arrow, when the blackbirds rushed together so closely that the flock looked like a dusky ball passing through the air. On reaching the mass, he, with the greatest ease, seized first one, then another and another, giving each a squeeze with his talons, and suffering it to drop upon the water. In this manner he had procured four or five, before the poor birds reached the woods, into which they instantly plunged, when he gave up the chase, swept over the water in graceful curves, and picked the fruits of his industry, carrying each bird singly to the shore. Reader, is this instinct or reasen?

"The nest of the Goshawk is placed on the branches of a tree, near the trunk or main stem. It is' of great size, and resembles that of our crow, or some species of owl; being constructed of withered twigs and coarse grass, with a lining of fibrous strips of plants resembling hemp. It is, however, much flatter than that of the crow. In one I found, in the month of April, three eggs ready to be hatched: they were of a dull bluish-white, sparingly spotted with light reddish-brown. In another, which I found placed on a pine-tree, growing on the eastern rocky bank of the Niagara River, a few miles below the great cataract, the lining was formed of withered herbaceous plants, with a few feathers: the eggs were four in number, of a white color tinged with greenish-blue, large, much rounded, and somewhat granulated. 
"In another nest were four young birds covered with buff-colored down, their legs and feet of a pale yellowish flesh-color, the bill light-blue, and the eyes pale-gray. 'They differed greatly in size, one being quite small compared with the rest. I am of opinion that few breed to the south of the State of Maine."

I once witnessed an attempt of this bird to capture a common gray squirrel, that was quite interesting to the - beholder, but certainly not to the animal. While on a collecting excursion, a few miles from Boston, as I was seated beneath a huge oak, observing the movements of some small birds, I heard the barking of a squirrel; and, while looking for his whereabouts, I suddenly heard a whistling sound as of a body falling through the air, and, as quick as thought, a Goshawk struck on the limb, on the spot where, a second before, the squirrel had been seated: luckily for the squirrel, the hawk missed his aim, the animal giving a sudden dodge beneath the limb the moment the hawk appeared. All who are acquainted with the habits of this quadruped know that it is very successful in dodging behind the limb of a tree, and hugging it closely. The hawk sat a few moments, apparently surprised at his disappointment, when, suddenly launching into the air, he espied it beneath the limb, hugging for dear life. As soon as he had moved, the squirrel turned adroitly on the limb, still keeping it between itself and its enemy. After several trials, the hawk always alighting and remaining perched on the limb a few seconds, he succeded, by a dexterous feint, in securing his prey, when, on the instant, I fired, bringing the hawk and his victim to the ground. The hawk dropped dead; but the squirrel, after lying on the ground a moment, got up, and staggered off beneath a pile of rocks, and I neither saw nor lieard any thing more of it.

\section{ACCIPITER, BRISSON.}

Accipiter, Brisson, Orn., I. 310 (1760).

General form more slender and smaller than Astur, but otherwise similar; wings short, tail long, tarsi long and slender, frequently with the scales in front nearly 
obsolete. Contains about twenty species of all countries, several of which intimately resemble each other. Colors in North-American species very similar to each other, especially in adult specimens, though they differ materially in sizo.

\section{ACCIPITER COOPERII. - Bonaparte.}

\section{The Cooper's Hawk.}

Falco Cooperii, Bonaparte. Am. Orn., II. 1 (1828).

Falco Stanleii, Audubon. Orn. Biog., I. 186 (1831).

\section{DESCRIPTION.}

Adult. - Head above brownish-black, mixed with white on the occiput, other upper parts dark ashy-brown, with the shafts of the feathers brownish-black; an obscure rufous collar on the neck behind; throat and under tail coverts white, the former with lines of dark-brown; other under parts transyersely barred with light rufous and white; quills ashy-brown, with darker bands, and white irregular markings on their inner webs; tail dark cinereous, tipped with white, and with four wide bands of brownish-black.

Young. - Head and neck behind yellowish-white, tinged with rufous, and with longitudinal stripes and oblong spots of brown; other upper parts light amberbrown, with large partially concealed spots and bars of white; upper tail coverts tipped with white; under parts white, with narrow longitudinal stripes of lightbrown; tail as in adult; bill bluish horn-color; tarsi yellow; iris in adult, reddishorange; in young, bright yellow.

Total length, male fifteen to sixteen inches; wing, nine; tail, eight inches. Female, total length, seventeen to eighteen inches; wing, nine and a half to ten: tail, nine inches.

It is a noticeable fact in the history of many of our birds, that in different periods, from some cause or other, many species have increased in number to a remarkable extent, while others have diminished in like proportion. Some have moved from sections in which they were for years common residents, to others in which they were, comparatively, strangers.

The Cooper's or Stanley Hawk of Audubon has had one of these changes; and throughout New England, where it was formerly a comparatively rare species, it is now one of the most abundant of our birds of prey.

The habits of the Cooper's Hawk are generally well known. It is the smallest of those known by the name of "Hen Hawk;" and the mischief it does among domestic poultry well earns for it this title. 
Powerful, active, and gifted with great rapidity of flight, he is able to attack and conquer birds and animals greatly his superior in size and weight. The Common Hare (Lepus Americanus) often falls a victim to his voracity. Ducks, grouse, squirrels, and small birds, are destroyed by him; and I have known of his capturing and eating snakes and other reptiles, and even grasshoppers and crickets.

In hunting for prey, he usually flies just above the trees in the forest, and quite near the earth in the open country. His flight consists of a rapid succession of beatings of the wings, with intervals of equal periods of soarings. On discovering a bird or other object that he may wish to capture, he immediately gives chase. If the bird takes to the foliage of the trees, he immediately follows, turning at every turn, doubling and twisting through the trees with wonderful speed and success; and the chase is usually but a very short one indeed before he alights to feed on the quarry that he has secured.

He is very destructive to the flocks of young ducks that breed in the wilder districts of the country. I remember an instance of one of his raids on these birds that is not without interest.

While on a hunting and collecting excursion in the wilds of Maine, up the Magalloway River, - a beautiful stream that empties into the Androscoggin, near Lake Umbagog, I wandered down the river banks, that are, for nearly the entire length of the stream, fringed with a thick growth of trees, away from the camp perhaps a mile. I was watching an old Black Duck (Anas obscura) and her brood of eight "flappers" disporting themselves in the water, and impatiently waiting for an opportunity for a shot; for, kind reader, I can assure you that a "broiled flapper," or wild duck about half grown, is a delicacy which, once enjoyed, is eagerly sought for by the frequenters of the wilderness. As I was creeping cautiously within shot of the birds, I suddenly heard a "quack" and splash, and the whole bevy was 
gone. At that instant, a Cooper's Hawk, that had evidently just made a swoop at the flock and missed it, alighted on a small tree that hung over the water, and remained perfectly motioniless. Now, when man attempts to secure any of these young ducks, the parent almost always flies off, while the young dive and swim under water to the banks of the stream or pond where they may be. When a bird of prey makes his appearance, the whole family dires beneath the surface, and swims off; the mother in one direction, the young in another. I have roticed the same fact several times, and conclude that the parent, who frequently makes her appearance above the surface, does so because she is capable of enduring submersion better than her young, and shows herself often, a little färther from her offspring every time, until she had led their pursuer away from them; giving them, in the mean time, a chance to swim off, and conceal themselves. The hawk, in this instance, was not to be deceived. He followed the parent but once, and then immediately returned to his perch. The banks of the river at this place were steep, there was no vegetation growing in the water, and the chances for obtaining a meal from one of the young ducks were decidedly in the hawk's favor.

The young ducks are very expert divers. They have the faculty of sinking beneath the surface at any alarm, and will remain there perhaps half a minute. Unfortunately for them, they cannot swim beneath the surface a great distance, and generally come up quite near the place where they went down. The hawk sat attentively inspecting the river in different places; and, as one of the young birds made its appearance, he marked it for his victim. The moment it rose to the surface, he made a swoop for it, when, of course, it dove. This was repeated several times, the young duck remaining beneath the water a shorter length of time at each dive. Soon it was manifest that the bawk would obtain his quarry, when, as he flew for 
the duck the last time, I pulled trigger on him; for we are all eminently selfish, and when one of the lower animals, as we regard them, interferes with us in our pleasures or comforts, even if they are fulfilling the dictates of their natures, we brush them from existence, as if we were the only rightful possessors of this beautiful world. Fortunately for the hawk, unfortunately for the flapper, and much to my chagrin, the cap failed to explode, and the poor duck was borne off for food for the family of the hawk.

The Cooper's Hawk breeds in all the New-England States, and is partial to no particular locality. I have found the nest in sections not a mile from the seacoast; in the deepest woods of Northern Maine; and have had the eggs sent me from different localities in Rhode Island, Comnecticut, and New Hampshire.

The nest of this species is more often found than that of any other. In my collecting trips, my experience has been that I have found certainly two nests of this to one of all others. Audubon says, "The nest is usually placed in the forks of the branch of an oak-tree, towards its extremity. In its general appearance, it resembles that of the common crow, for which I have several times mistaken it. It is composed externally of numerous crooked sticks, and has a slight lining of grasses and a few feathers." This does not agree with my observation; for, in great numbers of nests that I have examined, in which $I$ have found no great variation in character, they were almost invariably in a fork of a tall tree near the top, - in three cases out of five in the different pines. They were large, bulky affairs, constructed of twigs and sticks, some of them nearly half an inch in diameter: they were decidedly hollowed, and often lined with leaves and the loose bark of the cedar. The eggs of this species vary in number from two to four. I do not remember ever having found more than four, which number is usually laid. Their ground-color is a dirty bluish-white, with often thinly scattered spots of brown, or obscure 
blotches and markings of a shade darker than the groundcolor of the egg. A great number of specimens in my collection exhibit a variation in dimensions of from 1.82 inch to 2 inches in length, by from 1.50 inch to 1.62 in breadth. The average dimensions are about 1.78 inch by 1.52 inch. The breeding season varies considerably with this species, even in the same latitude. I have found nests with eggs as early, as the first week in May, and as late as the first week in June. Usually the eggs are laid before the 20th of May in Massachusetts. The season for the northern district of New England seems to be from one to two weeks later than this ; that of the southern district, about a week earlier.

A pair of birds that nested in Newton, Mass., in the summer of 1866, were robbed of their eggs four times in the season. They built different nests in the same grove, and laid in the four litters four, four, five, and three eggs respectively. The eggs of the last litter were very small; but little larger than the eggs of the Sharp-shimed Hawk.

ACCIPITER FUSCUS. - Gmelin.

\section{The Sharp-shinned Hawk.}

Falco fuscus et dubius, Gm. Syst. Nat., I. 280, 281 (1788). Accipiter striatus, Vieillot. Ois. d'Am. Sept., I. 42 (1807). Falco velox et Pennsyleanicus, Wilson. Am. Orn., V. 116, and VI. p. 13 (1812). Sparrius lineatus, Vieillot. Ency. Meth., III. 1266 (1823).

Nisus Malfini, Lesson. Traite d'Orn., I. 58 (1831).

\section{DESCRIPTION.}

Adult. - Small; tail rather long; legs and toes slender; entire upper parts brownish-black, tinged with ashy; occiput mixed with white; throat and under tail coverts white, the former with lines of black on the shafts of the feathers; other under parts fine light rufous, deepest on the tibiæ, and with transverse bands of white; shafts of the feathers with lines of dark-brown; tail ashy-brown tipped with white, and with about four bands of brownish-black; quills brownish-black, with bands of a darker shade, and of white on their inner webs; secondaries and tertiaries with large partially concealed spots of white.

Young. - Entire upper parts dull umber-brown, tinged with ashy; neck behind mixed with white; greater wing coverts and shorter quills with large partially concealed spots of white; under parts white, with longitudinal stripes and circular and ovate spots of reddish-brown, changing into transverse bands on the flanks 
and tibiæ; under tail coverts white; bill dark bluish horn-color; cere and tarsi yellow; iris reddish-yellow.

Total length of female, twelve to fourteen inches; wing, seven and a half to eight; tail, six and a half to seven inches. Male, ten to eleven inches; wing, six to six and a half; tail, five to five and a half inches.

This well-known little species is a general and common summer inhabitant of all the New-England States: it makes its appearance with the arrival of the earliest flight of the smaller migratory birds in spring, and remains until the latter part of autumn; and, in the southern portions of these States, even throughout the winter. The habits of the bird are so well described by Audubon, that I cannot do better than include the description here. He says :-

"While in search of prey, the Sharp-shinned Hawk passes over the country, now at a moderate height, now close over the land, in so swift a manner, that, although your eye has marked it, you feel surprised that the very next moment it has dashed off, and is far away. In fact, it is usually seen when least expected, and almost always but for a few moments, unless when it has procured some prey, and is engaged in feeding upon it. The kind of vacillation or wavering with which it moves through the air appears perfectly adapted to its wants; for it undoubtedly enables this little warrior to watch and to see at a single quick glance of its keen eyes every object, whether to the right or to the left, as it pursues its course. It advances by sudden dashes, as if impetuosity of movement were essential to its nature, and pounces upon and strikes such objects as best suit its appetite, but so very suddenly that it appears quite hopeless for any of them to try to escape. Many have been the times, reader, when watching this vigilant, active, and industrious bird, I have seen it plunge headlong among the briery patches of one of our old fields, in defiance of all thorny obstacles; and, passing through, emerge on the other side, bearing off with exultation in its sharp claws a sparrow or finch, which it had surprised when at rest. At other times, I have seen two or three of these hawks, acting in concert, fly. at a Golden-winged Woodpecker while alighted against the bark of a tree, where it thought itself secure, but was suddenly clutched by one of the hawks throwing, as it were, its long legs with the quickness of 


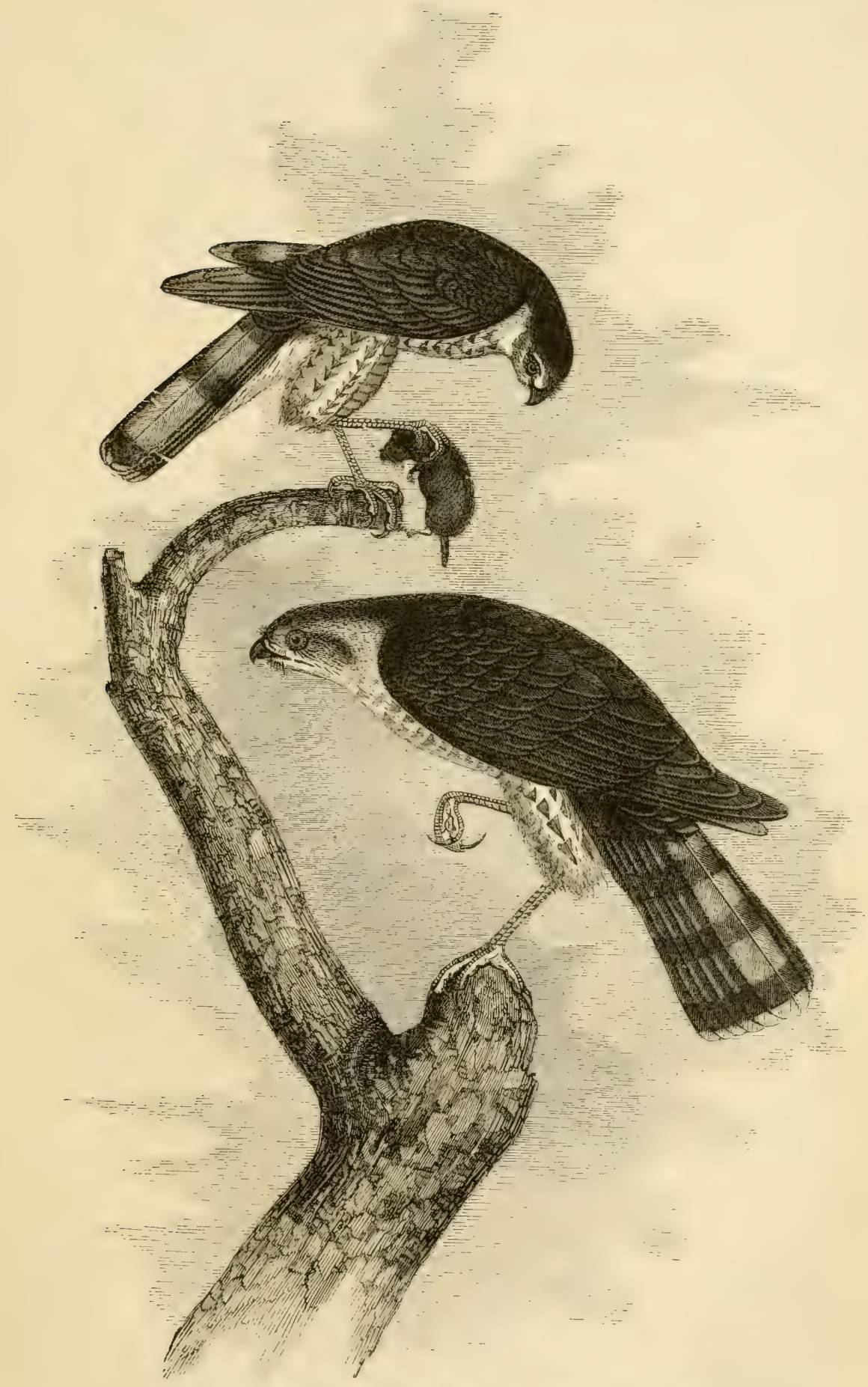

SHARP-SHINNED HaWk, Accipiter fuscus. Bouaparte. 

thought, protruding its sharp talons, and thrusting them into the back of the devoted bird, while it was endeavoring to elude the harassing attacks of another, by hopping and twisting around the tree. Then down to the ground assailants and assailed would fall, the woodpecker still offering great resistance, until a second hawk would also seize upon it, and, with claws deeply thrust into its vitals, put an end to its life, when both the marauders would at once commence their repast."

Nuttall informs us that " descending furiously and blindly upon its quarry, a young hawk of this species broke through the glass of the greenhouse at the Cambridge Botanic Garden; and, fearlessly passing through a second glass partition, he was only brought up by the third, and caught, though little stumned by the effort. His wing-feathers were much torn by the glass, and his flight in this way so impeded as to allow of his being approached."

Whilst travelling to some point at a considerable distance, the Sharp-shinned Hawk flies high, though in a desultory manner, with irregular quick flappings of its wings; and at times, as if to pause for a while and examine the objects below, moves in short and unequal circles, after which it is seen to descend rapidly, and then follow its course at the height of only a few feet from the ground, visiting, as it were, every clump of low bushes or brier patches likely to be inhabited by the smaller birds, on which it principally feeds. Again, after having satisfied its hunger, it at times rises to a great height, and indeed now and then is scarcely discernible from the ground.

Notwithstanding the comparative abundance of this species, its nest, until quite recently, has been quite rarely found. Audubon met with but three, and neither Wilson nor Nuttall ever saw one. I have been so fortunate as to find several, two of which had in each four eggs. They were built in the forks of pine-trees, about twenty-five feet from the ground: they were loosely constructed of sticks and twigs, were not much hollowed, and were lined with 
smaller twigs and a few leaves. Fourteen eggs in my collection, from different parts of New England, exhibit but slight variations; they are of a bluish-white color, and covered at the larger end with spots and blotches of chocolate-brown : in some specimens these blotches are confluent, making a ring near the large end $;^{1}$ others are covered nearly over their entire surface with these markings. The form of the egg is nearly spherical; the length,varying from.1.50 inch to $1.23 \mathrm{inch}$, and the breadth from 1.24 inch to $1.06 \mathrm{inch}$. Average dimensions about $1.40 \mathrm{inch}$ by 1.20 inch. I have found the eggs as early as the 10th of May; but usually they are not laid before the 20th, in the latitude of Massachusetts. The same nest is occupied by the parent birds for several years, and the female is a persistent layer. A case came to my knowledge in the spring of 1864, when the nest was robbed three times: fourteen eggs were removed; and, if the female had not been killed when the last eggs were taken, she would probably have laid another litter, as there were several found in her nearly formed. Both sexes, as with nearly. all the other birds of prey, incubate

\section{Sub-Family Buteonine. - The Buzzard-Hawks.}

General form heavy; flight vigorous and long continued, but not so rapid as in the preceding sub-families. Subsist mainly on small quadrupeds and reptiles.

\section{BUTEO, Cuvier.}

Buteo, Cuvier, Regne Animal, I. 323 (1817).

Bill short, wide at base; edges of upper mandible lobed; nostrils large, ovate, wings long, wide, fourth and fifth quills usually longest; tail moderate, rather wide; tarsi moderate, robust, with transverse scales before and behind, laterally with small circular and hexagonal scales; toes moderate, or rather short; claws strong. Contains about thirty species, inhabiting all countries.

1 The specimen, fig. 3 , plate $I_{\text {., }}$ is marked with a ring of confluent blotches at the smaller end, a peculiarity rarely met with. 



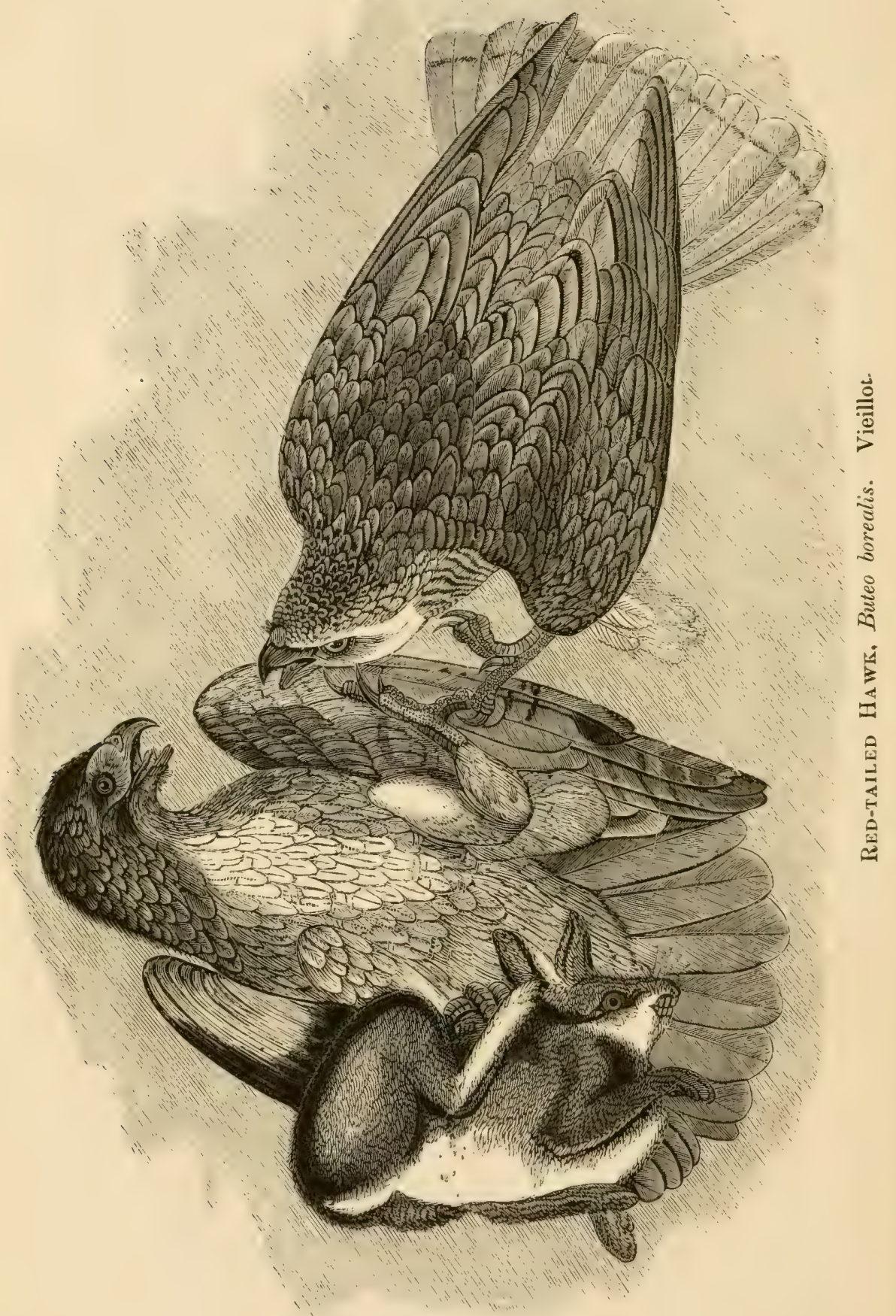




\section{BUTEO BOREALIS. - Vieillot.}

\section{The Red-tailed Hawk.}

Falco borealis, Leverianus, and Jamaicensis, Gm. Syst. Nat., I. 266 (1788). Falco aquilinus, Bartram. Trav., p. 290 (1791).

Buteo ferrugineicaudus, Vieillot. Ois. d'Am. Sept., I. 32 (1807).

Accipiter ruficaudus, Vieillot. Ois. d'Am. Sept., I. 43 (1807).

Buteo fulvous and Americanus, Vieillot. Nouv. Dict., IV. 472, 477 (1816).

\section{DESCRIPTION.}

Adult. - Tail bright rufous, narrowly tipped with white, and having a subterminal band of black; entire upper parts dark umber-brown, lighter and with fulvous edgings on the head and neck; upper tail coverts yellowish-white, with rufous and brown spots and bands; throat white, with narrow longitudinal stripes of brown; other under parts pale yellowish-white, with longitudinal lines and spots of reddishbrown, tinged with fulvous; most numerous on the breast, and forming an irregular band across the abdomen; under tail coverts and tibiæ generally clear yellowishwhite, unspotted, but the latter frequently spotted and transversely barred with light rufous; under surface of tail silvery-white.

Young. - Tail usually ashy-brown, with numerous bands of a darker shade of the same color, and narrowly tipped with white; upper tail coverts white, with bands of dark-brown; other upper parts dark umber-brown, many feathers edged with dull white and with partially concealed spots of white; entire undex parts white, sides of the breast with large ovate spots of brownish-black, and with a wide irregular band on the abdomen, composed of spots of the same color; under tail coverts and tibix with irregular transverse stripes and sagittate spots of dark-brown; bill, blue-black; cere and sides of the mouth, yellow tinged with green; legs yellow; iris pale amber.

Total length of female, about twenty-three inches; wing, fifteen to sixteen inches; tail, eight and a half inches. Male, nineteen to twenty-one inches; wing, fourteen inches; tail, seven and a half to eight inches.

The Red-tailed Hawk is a common resident of all the New-England States throughout the year. Its habits are so well known that a description here is hardly needed. Every one has noticed this hawk up in the air, at a considerable height, soaring in extended circles, and uttering the oft-repeated cry, kae, kae, kae, as he examines the earth beneath him for prey. Audubon was of the opinion, that the bird emitted this shriek for the purpose of attracting the notice of birds and animals beneath, and causing them to fly to a place of concealment, thus giving him a knowledge of their whereabouts. This supposition is not improbable; for he is often observed descending with great rapidity towards a bird that has taken flight at his outcries. 
This Hawk is very destructive among domestic poultry, and is generally regarded with dislike. I have known of instances when he has almost completely depopulated a poultry-yard before he could be captured.

It is the custom of the Hawk, when he has once had a taste of a flock of fowls, to visit it regularly every day at about the same time; sometimes in the afternoon, oftener in the morning.

The moment his cry is heard, the shrill alarm of the cock is given, when the hens run hither and thither, cackling, and adding to their own affright; the guinea-fowls rattle their discordant notes; the mother with her chickens becomes almost frantic in her efforts to protect her young from the inevitable destroyer. In the midst of this clatter, the pirate who has been its sole cause comes on eager wing, and, selecting the fattest of the flock, pounces upon it, and, with scarcely an effort, bears it off to feast his mate and young. The Ruffed Grouse (Bonasa umbellus) and Common Hare (Lepus Americanus) both fall victims; and the number he destroys is very great.

The Red-Tailed Hawk builds its nest in a lofty fork of a large tree. The nest is one of the largest of our rapacious birds, - in one case, to my knowledge, exceeding two feet in width and twenty inches in depth. It is constructed of large sticks and twigs; is but slightly hollowed; and is lined with smaller twigs, leaves, and moss. The eggs are generally three in number, seldom more: their groundcolor is a dirty yellowish-white, with blotches of a yellowish-brown, and sometimes distinct blotches of a darker brown. Their form varies from nearly spherical to ovoidal; but they are, in general, nearly as large at one end as at the other. Dimensions of specimens vary from 2.12 to 2.25 inches in length, by from 1.68 to 2 inches in breadth.

Three eggs that I took from a nest in the southern part of Ohio, early in the month of April, measure 2.18 by 1.62 ; 2.14 by 1.70 ; and 2.20 by 2 inches, - averaging a little 
smaller than specimens collected in New England. These eggs must have been laid by the 25th of March. In New England, they are seldom laid before the last week in April to the first week in May.

\section{BUTEO LINEATUS. - Jardine.}

The Red-shouldered Hawk.

Falco lineatus and hyemalis, Gm. Syst. Nat., I. 268, 274 (1788).

Falco buteoides, Nuttall. Man., I. 100 (1st edition, 1832).

\section{DESCRIPTION.}

Adult. - Wing coverts, from its flexure to the body, fine bright rufous; breast and other lower parts of the body paler orange rufous, many feathers with transverse bars and spots of white, which predominate on the abdomen and under tail coverts; entire upper parts brown; on the head mixed with rufous, and with white spots on the wing coverts and shorter quills and rump; quills brownish-black, with white spots on their outer webs, and with bars of a lighter shade of brown and of white on their inner webs; tail brownish-black, with about five transverse bands of white, and tipped with white.

Young. - Entire upper parts yellowish-white, with longitudinal stripes and oblong spots of dark-brown; throat dark-brown; upper parts lighter ashy-brown, with many partially concealed spots and bars of white; quills dark-brown, with wide transverse bars of rufous and white on both webs; tail ashy-brown, with numerous bands of pale-brownish and rufous white; tail beneath silvery-white; bill light-blue at the base, bluish-black at the tip; cere, basal margin of the bill, edges of the eyelids and the feet, bright-yellow; iris hazel.

Total length, female, twenty-one to twenty-three inches; wing, fourteen; tail, nine inches. Male, eighteen to twenty inches; wing, twelve; tail, eight inches.

This bird is a rather common resident of all New England throughout the year. Its habits are so nearly like those of the preceding, that I can add nothing to that I have already written.

The best account of the bird's habits in the breeding season, that I remember, is given by Audubon. It is as follows :-

"This bird is one of the most noisy of its genus, during spring especially, when it would be difficult to approach the skirts of woods bordering a large plantation without hearing its discordant shrill notes, - $k a-h e e, k a-h e e, \ldots$ as it is seen sailing in rapid circles at a very great elevation. Its ordinary flight is even and protracted, 
excepting when it is describing the circles just mentioned, when it often dives and gambols. It is a more general inhabitant of the woods than most of our other species, particularly during the summer, and in autumn and winter; now and then only, in early spring, showing itself in the open grounds, and about the vicinity of small lakes, for the purpoše of securing red-winged starlings and wounded ducks.

"The interior of woods seems, as I have said, the fittest haunts for the Red-shouldered Hawk. He sails through them a few yards above the ground, and suddenly alights on the low branch of a tree or the top of a dead stump, from which he silently watches, in an erect posture, for the appearance of squirrels, upon which he pounces directly, and kills in an instant, afterwards devouring them on the ground. If accidentally discovered, he essays to remove the squirrel; but, finding this difficult, he drags it, partly through the air and partly along the ground, to some short distance, until he conceives himself out of sight of the intruder, when he again commences feeding. The eating of a whole squirrel, which this bird often devours at one meal, so gorges it, that I have seen it in this state almost unable to fly, and with such an extraordinary protuberance on its breast as seemed very unnatural, and very injurious to the beauty of form which the bird usually displays. On all occasions such as I have described, when the bird is so gorged, it is approached with the greatest ease. On the contrary, when it is in want of food, it requires the greatest caution to get within shooting distance of it.

"At the approach of spring, this species begins to pair; and its flight is accompanied with many circlings and zigzag motions, during which it emits its shrill cries. The male is particularly noisy at this time. He gives chase to all other hawks, returns to the branch on which his mate has chanced to perch, and caresses her. This happens about the beginning of March. ${ }^{1}$ The spot adapted for a nest is already fixed upon, and the fabric is half finished. The top of a tall tree appears to be preferred by this hawk, as I have found its nest more commonly placed there, not far from the edges of woods bordering plantations.

"When one ascends to the nest (which, by the way, is not

1 May in New England. 
always an easy matter, as our beech-trees are not only very smooth, but frequently without any boughs to a considerable distance from the ground, as well as of rather large size), the female bird, if she happens to be sitting, flies off silently, and alights on a neighboring tree to wait the result; but should the male, who supplies her with food, and assists in incubation, be there, or make his appearance, he immediately sets up a hue and cry, and plunges toward the assailant with such violence as to astonish him.

"When, on several occasions, I have had the tree, on which the nest was placed, cut down, I have observed the same pair, a few days after, build another nest on a tree not far distant from the spot in which the first one had been.

"The mutual attachment of the male and the female continues during life. They usually hunt in pairs during the whole year' and, although they build a new nest every spring, they are fond of resorting to the same parts of the woods for that purpose. ${ }^{1}$

"The young remain in the nest until fully fledged, and are fed by the parents for several weeks after they have begun to fly; but leave them, and begin to shift for themselves, in about a month, when they disperse, and hunt separately, until the approach of the succeeding spring, at which time they pair.

"This Hawk seldom attacks any kind of poultry, and yet frequently pounces on partridges, doves, or wild pigeons, as well as red-winged blackbirds, and now and then young rabbits. On one or two occasions, I have seen them make their appearance at the report of my gun, and try to rob me of some blue-winged teals, shot in small ponds. I have never seen them chase any other small birds than those mentioned, or quadrupeds of smaller size than the Cotton Rat."

My experience has been different from the above paragraph; for I have known of this Hawk attacking poultry, and, even several times in the same flock, killing a fowl each time. The breeding habits of this and the Red-tailed Hawk are so exactly similar, that the above description well answers for both.

1 I have known of the same nest being occupied by a pair of these birds for several seasons. - E. A. S. 
I have found several nests of this species in different localities, all of which were placed in high forks of trees. They were built of twigs and sticks of different sizes, and usually were of large size. A nest that I found in Milton, Mass., was built in a fork of a large oak, against the trunk, about forty feet from the ground. It was of a bulk nearly sufficient to fill a bushel-basket: it was considerably hollowed, and lined with dry grass and leaves. The eggs, two in number, are in the cabinet of Dr. Brewer, who describes them as follows:-

"Two others belonging to this species, obtained in Milton, Mass., by Mr. E. A. Samuels, and identified by securing the parent birds, may be thus described: One measures $2 \frac{1}{16}$ by $1 \frac{1}{16}$ inch. The ground-color is a dirty-white, and is marked with large blotches, lines, and dottings of umber-brown of various shades, from quite dark to light. The other is 2 inches by $1 \frac{10}{16}$, has a bluish-white ground, and is only marked by a number of very faint blotehes of yellowish-brown and a slate-drab. Except in their shape, which is an oval spheroid, slightly pointed at one end, these bear but very slight resemblance to each other, though taken at the same time from one nest."

A number of specimens in my collection exhibit as great a variety as the above instances; and one specimen, obtained in Connecticut, which measures 2.12 by 1.65 inches, has a dirty yellowish-white ground-color, which is nearly covered with blotches of faint-purple; the appearance being as if the purple spots were laid on, and then a coating of whitewash laid over them.

\section{BUTEO PENNSTLVANICUS, - Bonaparte.}

The Broad-winged Hawk.

Falco Pennsylvanicus, Wilson. Am. Orn., VI. 92 (1812). Aud. Orn. Biog., I. 161. Falco Wilsonii, Bonaparte. Jour. Phila. Acad., III. 348 (1824).

\section{DEscription.}

Adult. - Entire upper parts umber-brown; feathers on the occiput and back of the neck white at their bases; throat white, with longitudinal lines of brown, and 
with a patch of brown on each side running from the base of the lower mandible; breast with a wide band composed of large cordate and sagittate spots and transverse bands of reddish-ferruginous tinged with ashy; other under parts white, with numerous sagittate spots of reddish on the tlanks, abdomen, and tibix. In some specimens, the ferruginous color predominates on all the under parts, except the under tail coverts, and all the feathers have large circular or ovate spots of white on both edges; under tail coverts white; quills brownish-black, widely bordered with white on their inner webs; tail dark-brown, narrowly tipped with white, and with one wide band of white and several narrower bands near the base.

Young. - Upper parts dull umber-brown, many feathers edged with fulvous anil ashy-white; upper tail coverts spotted with white; under parts white, generally tinged with yellowish, and having longitudinal stripes and oblong and lanceolate spots of brownish-black; a stripe of dark-brown on each side of the neck from the base of the under mandible; tail brown, with several bands of a darker shade of the same color, and of white on the inner webs, and narrowly tipped with white. Bill bluish-black at the tip, blue towards the base; cere and margin yellow; iris hazel; feet gamboge-yellow; claws brownish-black.

Total length, female, seventeen to eighteen inches; wing, eleven; tail, six and a half to seven inches. Male, total length, sixteen to sixteen and a half inches; wing, ten inches; tail, six to six and a half inches.

This bird, until quite recently, has been regarded as rare in all the New-England States; and even now it is by no means common, although it is much oftener found here than formerly. It occurs in these States only, as a summer visitor, arriving in the spring about the middle of April, and departing for the South in October. The flight of this Hawk is quite rapid, consisting of long intervals of soaring, with shorter periods of flappings of the wings. It seems to prefer the wilder districts to the more thickly settled ones, and is most often met with in the interior of the country. I noticed several individuals, in the course of a day's mareh in Northern Maine, soaring above the hemlock and pine forests, and uttering their shrill key, ky-ah, ky-ah-ke-ee, ke-ee, as they were searching for prey beneath them. Small birds, reptiles, squirrels, and insects constitute the principal portion of their food; and they seldom attack a bird larger than a pigeon or quail.

Once, while listening to the beautiful song of the Whitethroated Sparrow, I was startled by the sudden appearance of one of these hawks, which, flying within a yard of my head, as I sat in some bushes on the shores of Lake Umba- 
gog, pounced at a Red Squirrel (S. Hudsonius), that was chattering at me from the top of a hollow stump: the squirrel barely escaped by diving into the hollow, when the hawk, turning suddenly, rushed at my little songster, and, clutching him through the vitals, bore him off in exultation. So sudden was the attack, that I had no time to cock my gun before he was half a dozen rods off, when I fired, and brought him to the ground: the sparrow was, of course, dead. The hawk was only wing-tipped; and, throwing himself on his back, his feet extended, he awaited my approach. As I drew near him, he emitted a sort of hiss; and, as he glared at me with rage-enkindled eye, he appeared the very incarnation of wrath. On killing him, I found that he had had one of his tarsi broken before, apparently by a shot: it had healed, but had lost none of its strength; for, as I touched him with a stick, he grasped it with both feet so powerfully that all his claws were thrust deep into the wood.

The nest is rarely found. One that I visited in West Roxbury, Mass., on the 20th of May, 1864, had four eggs; it was built in a tall pine-tree, in a fork near the top; it was composed of coarse sticks and twigs, and was lined with the bark of the red cedar and a few leaves and feathers. The eggs, which are now before me, vary from 2 by 1.70 inches, to 2.15 by 1.72 inches; their color is a dirty yellowish-white, covered more or less thickly in the different specimens with spots and blotches of reddish-brown: an. other egg, obtained in Newton, Mass., in the previous season, is somewhat smaller, and the markings are fainter, and of a lighter color. Two other specimens in my collection, collected in New Hampshire, correspond to this description; but the spots are much finer and of a darker color.

\section{ARChIBUteO, Brensi.}

Archibuteo, Brehm, IsIs, 1828, p. 1269.

Tarsi densely feathered to the toes, but more or less naked behind, and then covered with scales. Wings long and wide; toes short; claws moderate; tail rather short, wide. Other characters very similar to those of Buteo 
This genus contains six or seven species, inhabiting Europe, Asia, and North America, all birds of heavy though robust organization, subsisting mainly on small quadrupeds and reptiles. The species of this genus are easily recognized by their having the tarsi feathered.

\section{ARCHIBUTEO LAGOPUS. - Gray.}

The Rough-legged Hawk.

Falco lagopus, Gm. Syst. Nat., 260 (1788). Aud. Oru. Biog., II. 377, and * Wilson.

Falco plumipes, Daudin. Traite d'Orn., II. 163.

Falco pennatus, Cuvier. Reg. An., I. 323 (1817).

Archibuteo alticeps, Brehm. Vog. Deutsch, I. 40.

\section{Description.}

Tarsus densely feathered in front to the toes, naked behind; wing long; tail rather short.

Adult. - Head above yellowish-white, with longitudinal stripes of brown tinged with reddish, especially on the occiput; back scapular, and shorter quills pale cinereous, with partially concealed transverse bands of white and dark-brown, the latter frequently predominating, and giving the color on the back; rump dark umber-brown; longer quills and wing coverts umber-brown; primaries edged externally with ashy, and with a large space on their inner webs at their base, white with a silky lustre; under parts white; throat with longitudinal stripes of dark-brown; breast with large spots and concealed stripes of reddish-brown; abdomen with numerous transverse narrow bands of brownish-black, most conspicuous on the flanks, and tinged with ashy; tibiæ and tarsi barred transversely with white and dark-brown, and tinged with reddish; under tail coverts white; upper tail coverts white at base and tipped with brownish-black; tail white at base, with a wide subterminal band of black, and about two other bands of black alternating with others of light-cinereous; cere and toes yellow; iris hazel; under wing coverts white, with spots of brownish-black, and on the longer coverts with a large space of ashy-brown.

Young. - Upper parts light umber-brown, many feathers, especially on the head and neck behind, edged with yellowish-white and pale-reddish; a wide transverse band or belt on the abdomen brownish-black; other under parts yellowish-white, with a few longitudinal lines and spots of brownish-black; quills ashy-brown, with a large basal portion of their inner webs white; tail at its base white, with a subterminal band of light umber-brown, tip white; tibiæ and tarsi pale reddish-yellow, with longitudinal stripes and spots of dark-brown; cere and toes yellow; iris hazel.

Total length, female, twenty-one to twenty-three inches; wing, sixteen to seventeen inches; tail, nine inches. Male, total length, nineteen to twenty-one inches; wing, fifteen to sixteen inches; tail, eight to eight'and a half inches.

This Hawk is rarely seen in New England, appearing only in the late fall and winter months. I have had no opportunities of studying its habits and characteristics, and will give the short description by Audubon. He says, - 
"The Rough-legged Hawk seldom goes further south along our Atlantic Coast than the eastern portions of North Carolina; nor have I ever seen it west of the Alleghanies. It is a sluggish bird, and confines itself to the meadows and low grounds bordering the rivers and salt marshes along our bays and inlets. In such places, you may see it perched on a stake, where it remains for hours at a time, unless some wounded bird comes in sight, when it sails after it, and secures it without manifesting much swiftness of flight. It feeds principally on moles, mice, and other small quadrupeds, and never attacks a duck on the wing, although now and then it pursues a wounded one. When not alarmed, it usually flies low and sedately, and does not exhibit any of the courage and vigor so conspicuous in most other hawks, suffering thousands of birds to pass without pursuing them. The greatest feat $I$ have seen it perform was scrambling at the edge of the water to secure a lethargic frog.

"They alight on trees to roost, but appear so hungry or indolent at all times, that they seldom retire to rest until after dusk. Their large eyes, indeed, seem to indicate their possession of the faculty of seeing at that late hour. I have frequently put up one that seemed watching for food at the edge of a ditch, long after sunset. Whenever an opportunity offer, they eat to excess, and, like the Turkey Buzzards and Carrion Crows, disgorge their food, to enable themselves to fly off. The species is more nocturnal in its habits than any other hawk found in the United States."

I have never met with the nest of this bird, and know but little of its breeding habits. It does not breed in New England, or, if it does, only very rarely, preferring the more northern sections of the continent. Two eggs in my collection, from Canada, are of the following description. Their ground-color is a dirty bluish-white, which is covered more or less thickly on different parts of their surface with obscure spots and blotches of different shades of brownish-ochre and faint-umber. They are broadly ovate in, form, and are 2.87 by 1.75 inch and 2.87 by 1.63 inch in dimensions. 


\section{ARCHIBUTEO SANCTI-JOHANNIS. - Gray.}

\section{The Black Hawk.}

Falco sancti-johannis, Gm. Syst. Nat, 273 (1788).

Falco nove-terroe, Gm. Syst. Nat., I. 274 (1788).

Falco niger, Wilson. Am. Orn., VI. 82 (1812).

\section{Description.}

Adult. - Entire plumage glossy black, in many specimens with a brown tinge; forehead, throat, and large partially concealed spot on occiput, white; tail with one transverse well-defined band of white, and irregularly marked towards the base with the same color; quills with their inner webs white, readily seen from below; cere and toes yellow; iris hazel; tarsi densely feathered in front, naked behind. Other specimens are entirely dark chocolate-brown, with the head more or less striped with yellowish-white and reddish-yellow; tail with several transverse bands of white, more or less imperfect and irregular.

Young. - Upper parts light umber-brown, with the feathers more or less edged with dull-white and reddish-yellow; abdomen with a broad transverse band of brownish-black; other under parts pale yellowish-white, with longitudinal stripes of brownish-black, frequently giving the predominating color on the breast and sides; wings and tail brown, tinged with cinereous, the former marked with white on their inner webs, the latter white at their base; tarsi and tibix pale reddishyellow, spotted with brown; cere, feet, and iris the same as in adult.

Total length, female, twenty-two to twenty-four inches; wing, seventeen to seventeen and a half; tail, nine inches. Male, twenty to twenty-two inches; wing, sixteen to sixteen and a half; tail, eight to eight and a half inches.

This species, ${ }^{1}$ so often confounded in the immature plumage with the preceding, but which may be separated from it by its greater size and more numerous dark spots beneath, is a rare winter visitor in New England. Like the Rough-legged Hawk, it prefers the marshes and low, swampy woods to the higher localities, and preys upon mice, wounded ducks, and small birds. I have known of it being killed while pursuing a flock of Snow Buntings (Plectrophanes nivalis), and have heard of its attacking a flock of domestic poultry. Its habits, therefore, are different from those of the A. lagopus, as given by Audubon; but it lacks the courage and vigor of most of our other rapacious birds, and is hardly worthy of the immortality it has received from the pens of some of our writers.

The distribution of this species is limited to the northern regions of the continent in summer, and is very rarely

1 See Appendix. 
found south of Massachusetts in winter. I do not remember of an instance of its being captured far inland, although J. A. Allen, before quoted, includes it in the catalogue of the birds of Springfield, Mass.

A single egg in my collection, from Northern America, is of the following dimensions: 2.17 by 1.70 inch. Its form is a perfect ovoidal. Its primary color is a dirty white; and it is marked with obscure blotches of lilac, and some obscure blotches of brown and brownish-yellow. None of the markings are decided; and, at a little distance, the egg has the appearance of being of a dirty-white color.

\section{Sub-Family Milvind. - The Kites.}

Size various, usually medium or small; general form usually rather slender, and not strong; wings and tail usually long; bill short, weak, hooked, and acute; tarsi and toes usually slender, and not strong, sometimes short. The birds of this group habitually feed on reptiles and other small animals, and are deficient in the strength and courage of the other groups of the falcons.

\section{CIRCUS, LACEPEDE.}

Circus, Lacepede, Mem. d'Inst. Paris, III. CXI. 506 (1803).

Face partially encircled by a ring or ruff of short projecting feathers, as in the otvls; head rather large; bill short, compressed, curved from the base; nostrils large; wings long, pointed; tail rather long, wide; tarsi long and slender; toes moderate; claws rather slender and weak.

\section{CIRCUS HUDSONIUS, - Vieillot.}

The Marsh-hawk; Harrier; Mouse-hawk.

I"alco II dsonius, Linnæus. Syst. Nat., I. 128 (1766).

Falco uliginosus, Gm. Syst. Nat., I. 278 (1788).

Falco uliginosus, Wilson. Am. Orn., VI. 67.

Falco cyaneus, Aububon. Orn. Biog., IV. 396.

\section{Description.}

Adult. - Form rather long and slender; tarsi iong; ruff quite distinct on the neck in front: entire upper parts, head, and breast, pale bluish-cinereous, on the back of the head mixed with dark-fulvous; upper tail coverts white; under parts white, with small cordate or hastate spots of light-ferruginous; quills brownishblack, with their outer webs tinged with ashy, and a large portion of their inner 
webs white; tail light-cinereous, nearly white on the inner webs of the feathers, and with obscure transverse bands of brown; under surface silky-white; under wing coverts white; bill blue-Black at the extremity; cere and legs yellow, the former with a tinge of green; iris hazel.

Younger. - Entire upper parts dull umber-brown, many feathers edged with dull rufous, especially on the neck; under parts dull reddish-white, with longitudinal stripes of brown, most numerous on the throat and neck before; tibire tinged with reddish; upper tail coverts white.

Young. - Entire upper parts dark umber-brown; upper tail coverts white; under parts rufous, with longitudinal stripes of brown on the breast and sides; tail reddish-brown, with about three wide bands of dark-fulvous, paler on the inner webs; tarsi, cere, and iris as in the adult.

Total length, female, nineteen to twenty-one inches; wing, fifteen and a half; tail, ten inches. Male, total length, sixteen to eighteen inches; wing, fourteen and a half; tail, eight and a half to nine inches.

This species is pretty generally diffused throughout New England as a summer visitor. It is one of the least mischievous of all the hawks, as it destroys but few of the smaller birds. It is more common in districts that are low and marshy than in others; and this fact gives it the name, in many localities, of the "Bogtrotter."

Its flight is low and rapid, consisting of long intervals of flappings, with shorter periods of soaring. I do not remember of ever hearing it ęry out in the manner that other hawks do, and think that it hunts silently. It arrives from the South from about the middle of April to the first of May. I am inclined to think that the birds are generally mated before their arrival ; for they are almost always seen in pairs from their first appearance. In choosing a situation for a nest, both birds are remarkably nervous and restless: they are almost constantly on the wing, prying into, and apparently taking into account, every thing with reference to future comfort. The following circumstances came to my observation, and, as I improved every opportunity to watch the proceedings, will serve to illustrate the breeding habits of this bird: A pair made their appearance about the middle of April, a few years since, in a large meadow in Dedham, Mass. They were apparently mated from the first; and, as the neighborhood gave promise of an abun- 
dance of food (field-mice), I concluded that this would bo selected as a breeding-place, and watched accordingly. The male was very attentive to his mate, often talking to and caressing her. If she should alight on the ground or on a fence-rail, he would alight with her, and often fly and walk around her, bowing and chattering in a ludicrous manner. After a situation (luckily where I could watch them unobserved) was fixed upon for a nest, both birds were very active in its construction. It was built on a hummock, perhaps eighteen inches above the level of the meadow. The materials used in its construction were dried grasses, which were woven together rather neatly. It was considerably hollowed,- perhaps an inch and a half,and lined with very soft grass. The external diameter of the nest was about eighteen inches; internal diameter, about eight inches. The female laid four eggs of a dirtywhite color, with'a faint tinge of blue. In one specimen there were a few faint spots of brown; but I think that generally the eggs of this species are without spots. ${ }^{1}$ I have seen a great many, and but a very few had spots, and these not at all distinct. A great number of specimens exhibit a variation of from 1.62 to 1.90 inch in length, and from 1.32 to 1.25 inch in breadth. The habits of this bird entitle it to the protection of the farmer. It subsists almost entirely upon the injurious field-mice, and the numbers of these animals which it destroys in the breeding season are incredible: from early dawn to dim twilight it may be seen busily searching for these pests, seldom molesting the small heneficial birds or poultry.

1 Dr. Brewer, in describing the eggs of this species, says: "With but a single exception, all these eggs (six) are very distinctly blotched and spotted. Their ground-color is a dirty bluish-white, which in one is nearly unspotted; the markings so faint as to be hardly perceptible, and only upon close inspection. In all the others, spots and blotches of a light shade of purplish-brown occur, in a greater or less degree, over their entire surface. In two, the blotches are large and well marked; in the others, less strongly traced, but quite distinct. This has led to a closer examination of eggs from other parts of the country, and nearly all are perceptibly spotted." 


\section{Sub-Family Aquiline. - The Eagles.}

Size large, and all parts very strongly organized; bill large, compressed, straight at base, curved and acute at tip; wings long, pointed; tail ample, generally rounded; tarsi moderate, very strong; claws curved, very sharp and strong. There are about seventy species of eagles of all countries.

\section{AQUHLA, MoEhrikg.}

Aquila, Moemring, Av. Gen., 49 (1752).

General form large and very strong, and adapted to long-continued and swift flight; bill large, strong, compressed, and hooked at the tip; wings long, pointed; tarsi rather short, very strong, feathered to the toes; claws sharp, strong, curved. This genus includes about twenty species, which are regarded as the true eagles.

\section{AQUILA CANADENSIS, - Cassin.}

The Golden Eagle; the Ring-tailed Eagle.

Falco Canadensis, Linnæus. Syst. Nat., I. 125 (1766).

Falco niger, Gm. Syst. Nat., I. 259 (1788).

Aquila nobilis, Pallas. Zoog. Ross. As., I. 338 (1811).

Falco chryscetos, Wilson. Aud., Ir. 464.

\section{DESCRIPTION.}

Adult. - Large; tarsi densely feathered to the toes; head and neck behind light brownish-fulvous, varying in shade in different specimens, frequently light orangefulvous, generally darker; tail at base white, which color frequently occupies the greater part of the tail; other terminal portion glossy black; all other parts rich purplish-brown, frequently very dark, and nearly clear black on the under parts of the body; primaries shining black; secondaries purplish-brown; tibiæ and tarsi brownish-fulvous, generally mixed with dark-ashy; cere and toes yellow: iris reddish-hazel.

Younger. - Entire plumage lighter, and mixed with dull-fulvous; under parts of the body nearly uniform with the upper parts; cere, toes, and iris like adult.

Total length, female, thirty-three to forty inches; wing, about twenty-five; tail, about fifteen inches. Male, total length, thirty to thirty-five inches; wing, twenty to twenty-three: tail, twelve to fourteen inches.

The above description is incomplete, so far as the markings of the tail are men tioned; for in the adult bird the tail is entirely black, and the young have more or less white in proportion to their age, - the youngest birds having the widest white band at the base.

This bird is so extremely rare in New England, that I have had no opportunities for studying its habits. It is occasionally found here in different seasons of the year, 
and it undoubtedly breeds in the wildest districts of these States. The following are the most interesting facts, given by. Audubon, in relation to this species :-

"The Golden Eagle, although a permanent resident in the United States, is of rare occurrence there; it being seldom that one sees more than a pair or two in the course of a year, unless he be an inhabitant of the mountains, or of the large plains spread out at their base. I have seen a few of them on the wing along the shores of the Hudson, others on the upper parts of the Mississippi, some among the Alleghanies, and a pair in the State of Maine. At Labrador, we saw an individual sailing, at the height of a few yards, over the moss-covered surface of the dreary rocks.

"Although powerful in flight, it has not the speed of many hawks, nor even of the White-headed Eagle. It cannot, like the latter, pursue and seize, on the wing, the prey it longs for ; but is obliged to glide down through the air for a certain height to insure the success of its enterprise. The keenness of its eye, however, makes up for this defect, and enables it to spy, at a great distance, the objects on which it preys; and it seldom misses its aim, as it falls with the swiftness of a meteor towards the spot on which they are concealed. When at a great height in the air, its gyrations are uncommonly beautiful, being slow and of wide circuit, and becoming the majesty of the king of birds. It often continues them for hours at a time, with apparently the greatest ease.

"The notes of this species are sharp and harsh; resembling, at times, the barking of a dog; especially about the breeding season, when the birds become extremely noisy and turbulent, flying more swiftly than at other times, alighting more frequently, and evincing a fretfulness which is not so observable after their eggs are laid.

"They are capable of remaining without food for several days at a time, and eat voraciously whenever they find an opportunity.

"Young fawns, raccoons, hares, wild turkeys, and other large birds, are their usual food; and they devour putrid flesh only when hard pressed by hunger, none alighting on carrion at any other time.

I regret that I am unable to add any thing to our knowledge of its habits and breeding peculiarities. Dr. Brewer 
says, "It breeds in the mountainous portions of Maine, New Hampshire, Vermont, and New York." The Golden Eagle usually constructs its nest on the sides of steep rocky crags, where its materials are coarsely heaped together on a projecting shelf of rock. These consist of large sticks loosely arranged. In rare instances, they are said to have been built on trees in the Western States, where rocky cliffs are not to be met with. The eggs are usually three in number; sometimes two, or only one. Mr. Audubon describes them as measuring three and a half inches in length by two and a half in breadth; the shell thick and smooth, dull-white, brushed over with undefined patches of brown, which are most numerous at the larger end.

\section{HALIETUS, SAVIGNY.}

Size large; tarsi short, naked, or feathered for a short distance below the joint of the tibia and tarsus, and with the toes covered with scales; toes rather long; claws very strong, curved, very sharp; bill large, very strong, compressed; margin of upper mandible slightly lobed; wings long, pointed; tail moderate.

\section{HALIETUS LEUCOCEPHALUS.}

The White-headed Eagle; the Bald Eagle; the Gray Eagle.

Falco leucocephalus, Linnæus. Syst. Nat., I. 124 (1766).

Falco pygargus, Daudin. Traite d'Orn., II. 62 (1800).

Falco ossifragus, Wilson. Am. Orn., VII. 16 (1813).

\section{DESCRIPTION.}

Bill large, strong, straight at the base, rather abruptly hooked; wings long; tarsi rather short.

Adult. - Head, tail, and its upper and under coverts, white; entire other plumage brownish-black, generally with the edges of the feathers paler; bill, feet, and irides, or iris, yellow.

Younger. - Entire plumage, including head and tail, dark-brown; paler on the throat; edges of the feathers paler or fulvous, especially on the under parts; tail more or less mottled with white, which color, in more advanced age, extends over a large portion of the tail, especially on the inner webs; bill brownish-black; irides brown.

Total length, female, about thirty-five to forty inches; wing, twenty-three to twenty-five inches; tail, fourteen to fifteen inches. Male, thirty to thirty-four inches: wing, twenty to twenty-two inches; tail, thirteen to fourteen inches. 
This beautiful and well-known bird is occasionally seen in different parts of New England throughout the year, most commonly near the seacoast or in the neighborhood of large

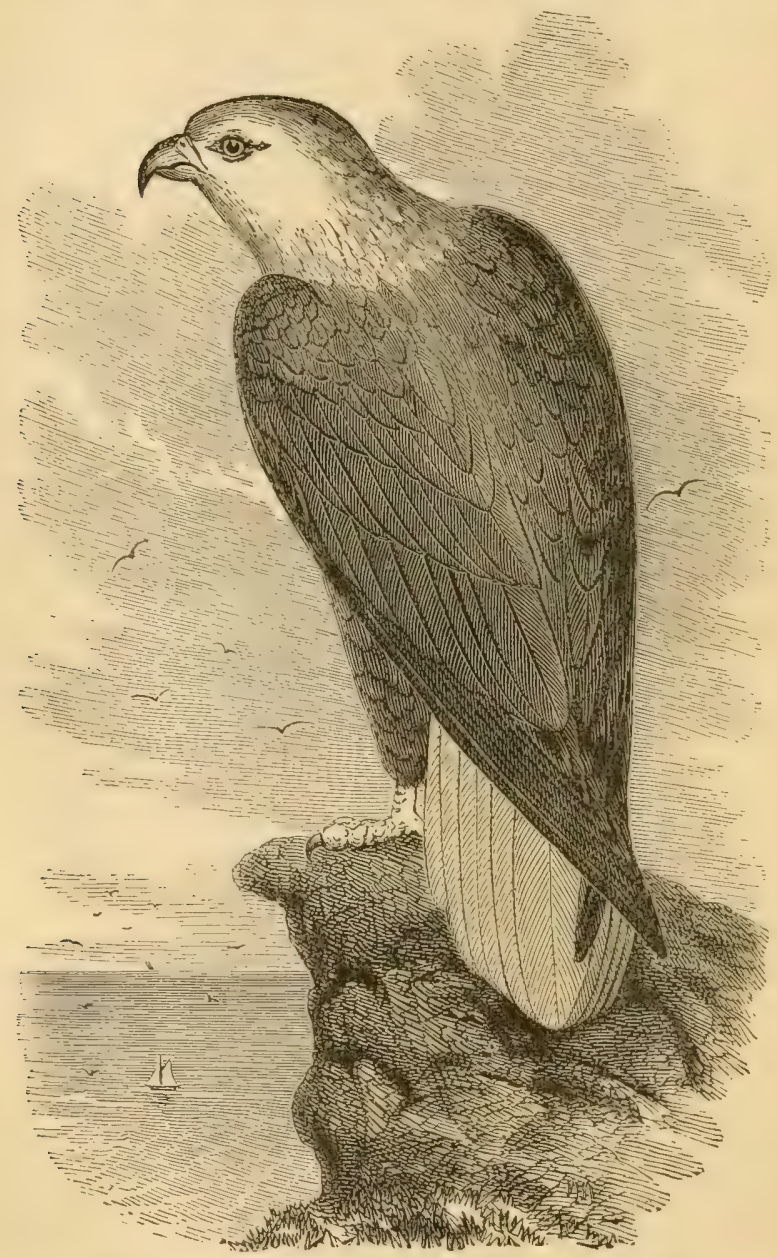

tracts of water. I have had several opportunities of observmg and studying its habits, but have discovered nothing that . has not been already presented to the public. Its flight is 
rapid and graceful, and is often prolonged for hours with apparent ease. It feeds upon wild-fowl, wild geese, and small animals, and is very partial to fish, which it robs from the Fish Hawk ( $P$. Carolinensis), and finds cast upon the shore, dead.

Wilson, in describing its attacks on the Fish Hawk, says:-

"Formed by nature for braving the severest cold; feeding equally on the produce of the sea and of the land; possessing powrers of flight capable of outstripping even the tempests themselves; unawed by any thing but man; and, from the ethereal heights to which he soars, looking abroad, at one glance, on an immeasurable expanse of forests, fields, lakes, and ocean, deep below him, - he appears indifferent to the little change of localities or seasons; as, in a few minutes, he can pass from summer to winter, from the lower to the higher regions of the atmosphere, the abode of eternal cold, and thence descend, at will, to the torrid or the arctic regions of the earth. $\mathrm{He}$ is therefore found at all seasons in the countries he inhabits, but prefers such places as have been mentioned above, from the great partiality he has for fish.

"In procuring these, he displays, in a very singular manner, the genius and energy of his character, which is fierce, contemplative, daring, and tyrannical, - attributes not exerted but on par ticular occasions, but, when put forth, overpowering all opposition. Elevated on the high dead limb of some gigantic tree that commands a wide view of the neighboring shores and ocean, he seems calmly to contemplate the motions of the various feathered tribes that pursue their busy avocations below, - the snow-white gulls slowly winnowing the air; the busy tringe coursing along the sands; trains of ducks streaming over the surface; silent and watchful cranes, intent and wading; clamorous crows; and all the winged multitudes that subsist by the bounty of this vast liquid magazine of nature. High over all these hovers one whose action instantly arrests his whole attention. By his wide curvature of wing and sudden suspension in air, he knows him to be the Fish Hawk, settling over some devoted victim of the deep. His eye kindles at the sight; and, balancing himself, with half-opened wings, 
on the branch, he watches the result. Down, rapid as an arrow from heaven, descends the distant object of his attention; the roar of its wings reaching the ear as it disappears in the deep, making the surges foam around. At this moment, the eager looks of the Eagle are all ardor; and, levelling his neck for flight, he sees the Fish-hawk once more emerge, struggling with his prey, and mounting in the air with screams of exultation. These are the signal for our hero, who, launching into the air, instantly gives chase, and soon gains on the Fish-hawk: each exerts his utmost to mount above the other, displaying in these rencontres the most elegant and sublime aërial evolutions. The unencumbered Eagle rapidly advances, and is just on the point of reaching his opponent, when, with a sudden scream, probably of despair and honest execration, the latter drops his fish : the Eagle, poising himself for a moment, as if to take a more certain aim, descends like a whirlwind, suatches it in his grasp ere it reaches the water, and bears his ill-gotten booty silently away to the woods.

"These predatory attacks and defensive manœurres of the Eagle and the Fish-hawk are matters of daily observation along the whole of our seaboard, from Georgia to New England, and frequently excite great interest in the spectators. Sympathy, however, on this as on most other occasions, generally sides with the honest and laborious sufferer, in opposition to the attacks of power, injustice, and rapacity; qualities for which our hero is so generally notorious, and which, in his superior, man, are certainly detestable. As for the feelings of the poor fish, they seem altogether out of the question.

"When driven, as he sometimes is, by the combined courage and perseverance of the fish-hawks, from their neighborhood, and forced to hunt for himself, he retires more inland, in search of young pigs, of which he destroys great numbers. In the lower parts of Virginia and North Carolina, where the inhabitants raise vast herds of those animals, complaints of this kind are very general against him. He also destroys young lambs in the early part of spring; and will sometimes attack old sickly sheep, aiming furiously at their eyes."

It generally chooses for a breeding-place a retired spot in the neighborhood of a tract of water. The nest is 
usually placed ir the fork of a large dead tree, and is occupied by the same pair of birds for successive years. I am informed, that a pair of these birds have, for a number of years past, made their eyrie on a shelf of an inaccessible cliff on the side of what is called "Diamond Mountain," a few miles south of the Umbagog lakes. Mr. J. A. Allen (Catalogue of Birds of Springfield, Mass., in "Proceedings of Essex Institute," vol. IV., No. 2) says that this species "sometimes breeds on Mount Tom, about twenty miles north of Springfield, Mass." These are probably, however, exceptional cases. The nest is constructed of large sticks, twigs, branches of seaweeds, turf, and moss : some of these sticks are nearly or quite an inch in thickness. It is a bulky affair; its diameter often being five feet, and its thickness from two to three feet. It is not much hollowed, and is nearly level across the top. Of numbers of eggs of this bird, that I have examined, I could see no material difference as to shape or color; the form being nearly spherical, and the color a dirty yellowish-white. Length of specimens varies from 2.93 to 3.07 inches; breadth, from 2.31 to 2.47 inches.

\section{PANDION, SAYigny.}

Pandion, Savigny, Hist. Nat. d'Egypt, I. 95 (1809).

Wings very long; general form heavy, and not adapted to vigorous or swift flight like the preceding eagles; bill short, curved from the base, compressed; tarsi thick and strong, and covered with small circular scales; claws large, curved, very sharp; toes beneath rough; tail moderate or rather short.

This genus contains three or four species only, nearly allied to each other, and inhabiting all temperate regions of the world.

\section{PANDION CAROLINENSIS. - Bonaparte.}

The Fish-hawk, Osprey.

Falco Carolinensis, Gm. Syst. Nat., I. 263 (1788). Aquila piscatrix, Vieillot. Ois. d'Am. Sept., I. 29 (1807). Pandion Americanus, Vieillot. Gal. Ois., I. 33 (1825).

Falco halicetus, Linnæus. Wilson, Am. Orn., V. 14.

Falco halicetus, Linnæus. Aud. Orn. Biog., I. 415. 


\section{DESCRIPTION.}

Wings long; legs, toes, and claws very robust and strong.

Adult. - Head and entire under parts white; stripe through the eye, top of the head, and upper parts of the body, wings and tail deep umber-brown, tail having about eight bands of blackish-brown; breast with numerous cordate and circular spots of pale yellowish-brown; bill and claws bluish-black; tarsi and toes greenish-yellow; iris reddish-yellow.

Young. - Similar to the adult, but with the upper plumage edged and tipped with pale-brownish, nearly white; spots on the breast more numerous and darker colored.

Total length, female, about twenty-five inches; wing, twenty-one inches; tail, ten and a half inches. Male, rather smaller.

"Soon as the sun, great ruler of the year,

Bends to our northern climes his bright career,

And from the caves of Ocean calls from sleep

The finny shoals and myriads of the deep ;

When freezing tempests back to Greenland ride,

. And day and night the equal hours divide, -

True to the season, o'er our sea-beat shore,

The sailing Osprey high is seen to soar

With broad, unmoving wing; and, circling slow,

Marks each loose straggler in the deep below,

Sweeps down like lightning, plunges with a roar,

And bears his struggling victim to the shore.

The long-housed fisherman beholds with joy

The well-known signals of his rough employ;

And, as he bears his nets and oars along,

Thus hails the welcome season with a song:-

\section{THE FISHERMAN'S HYMN.}

The Osprey sails above the sound;

The geese are gone, the gulls are flying;

The herring-shoals swarm thick around;

The nets are launched, the boats are plying.

$Y_{0}$, ho, my hearts! let's seek the deep,

Raise high the song, and cheerly wish her,

Still, as the bending net we sweep,

'God bless the Fish-hawk and the fisher!'

She brings us fish : she brings us spring,

Good times, fair weather, warmth, and plenty;

Fine store of shad, trout, herring, ling,

Sheep's-head and drum, and old-wives dainty. 
Yo, ho, my hearts! let's seek the deep,

Ply every oar, and cheerly wish her,

Still as the bending net we sweep,

'God bless the Fish-hawk and the fisher!'

She rears her young on yonder tree;

She leaves her faithful mate to mind 'em;

Like us, for fish, she sails to sea,

And, plunging, shows us where to find 'em.

Yo, ho, my hearts! let's seek the deep,

Ply every oar, and cheerly wish her,

While the slow-bending net we sweep,

'God bless the Fish-hark and the fisher!' ",

Alexander Wilson.

The common and well-known bird which furnishes the theme of the above beautiful verses is a summer inhabitant of New England along the whole coast, and in the neighborhood of large sheets of water. The males arrive from the south about the middle of April, and the females about a week later. I believe that the same pair are constant to each other for several years: those that commence their matrimonial career in the spring usually mate about the first week in May, in our latitude. The movements of the male, while paying court to the female, are interesting; and, as Audubon has described them better than I can myself, I will give his description :-

"As soon as the females make their appearance, which happens eight or ten days after the arrival of the males, the love-season commences, and, soon after, incubation takes place. The loves of these birds are conducted in a different way from those of the other falcons. The males are seen playing through the air amongst themselves, chasing each other in sport, or sailing by the side or after the female which they have selected, uttering cries of joy and exultation, alighting on the branches of the tree on which their last year's nest is yet seen remaining, and doubtless congratulating each other on finding their home again. Their caresses are mutual. They begin to augment their habitation, or to repair the injuries which it may have sustained during the winter, and are 
seen sailing together towards the shores, to collect the drifted seaweeds, with which they line the nest anew. They alight on the beach, search for the dryest and largest weeds, collect a mass of them, clench them in their talons, and fly towards their nest, with the materials dangling beneath. They both alight and labor together. In a fortnight, the nest is complete, and the female deposits her eggs."

The nest is generally placed in a large tree in the immediate vicinity of the water, either along the seashore, on the margins of the inland lakes, or by some large river. It is, however, sometimes to be seen in the interior of a wood, a mile or more from the water. I have concluded, that, in the latter case, it was on account of frequent disturbance, or attempts at destruction, that the birds had remored from their usual haunts. The nest is very large, sometimes measuring fully four feet across, and is composed of a quantity of materials sufficient to render its depth equal to its diameter. Large sticks, mixed with seaweeds, tufts of strong grass, and other materials, form its exterior, while the interior is composed of seaweeds and finer grasses. I have not observed that any particular species of tree is preferred by the Fish-hawk. It places its nest in the fork of an oak or a pine with equal pleasure. But.I have observed that the tree chosen is usually of considerable size, and not unfrequently a decayed one.

The Fish-hawk is gregarious, and often breeds in colonies of three or four nests in an area of a few acres. The males assist in incubation.

I have heard of instances of as many as a dozen nests being found in the distance of half a mile on the coast of New Jersey.

In New England, the species is not so plentiful, and seldom more than one nest can be found in one locality. The flight of the bird is strong, vigorous, and well sustained. As he flies over the ocean, at a height of perhaps fifty 
feet, his long wings, as they beat the air in quick, sharp strokes, give the bird the appearance of being much larger than he really is. When he plunges into the water, he invariably seizes the fish, his prey, in his talons, and is sometimes immersed to the depth of a foot or eighteen inches in his efforts to capture it. He is of a peaceable disposition, and never molests any of his feathered neighbors. If the nest is plundered, the parent attacks the intruder, and often inflicts ugly wounds in its defence.

Mr. Allen, in his notes on the "Rarer Birds of Massachusetts," remarks while the osprey "breeds abundantly on the New Jersey coast, on portions of Long Island, on the coast of Maine and about the large lakes in the interior, it is now, only seen in this state, (Massachusetts,) so far as I can learn, during its migrations."

During the past winter, I have had frequent conversations with hunters and others, interested in our birds, who are residents of Plymouth and Barnstable counties, and their testimony is that in the large tracts of woodland in those counties, such as the Plymouth and Sandwich woods, the osprey nests, not in communities, but so frequently that the birds and nests are often found.

The eggs are usually laid before the 10th of May: they are generally three in number. They vary considerably, both in shape, size, and markings. In a majority of specimens in my collection, the ground-color is a rich reddishcream, and covered with numerous blotches of different shades of brown. In a number of specimens, these blotches are confluent, and the primary color is nearly hidden. Their form raries from nearly spherical to ovoidal, and the dimensions from 2.28 to 2.44 inches in length, and from 1.65 to 1.83 in breadth. 


\section{Family STRIGIDA. The Owls.}

Form usually short and heavy, with the head disproportionately large, and frequently furnished with erectile tufts of feathers, resembling the ears of quadrupeds. General organization adapted to vigorous and noiseless, but not rapid, flight, and to the capture of animals in the morning and evening twilight.

Eyes usually very large, directed forwards, and, in the greater number of species, formed for seeing by twilight or in the night; bill rather strong, curved, nearly concealed by projecting, bristle-like feathers; wings generally long, outer edges of primary quills fringed; legs generally rather short, and in all species, except in one Asiatic genus (Ketupa), more or less feathered, generally densely; cavity of the ear very large; face encircled by a more or less perfect disc of short, rigid feathers, which, with the large eyes, gives to those birds an entirely peculiar and frequently catlike expression. Female larger than the male.

\section{Sub-Family Bubonive. - The Horned Owls.}

Mead large, with erectile and prominent ear-tufts; eyes large; facial disc not complete above the eyes and bill; legs, feet, and claws usually very strong.

\section{BUBo, Cuvier.}

Bubo, Cuvier, Règne Animal, I. 331 (1817).

Size large; general form very robust and powerful; head large, with conspicuous ear-tufts; eyes very large; wings long; tail short; legs and toes very strong, densely feathered; claws very strong; bill rather short, strong, curved, covered at base by projecting feathers.

This genus includes the large Horned Owls, or Cat Owls, as they are sometimes called. These birds are most numerous in Asia and Africa, and there are in all countries about fifteen species.

\section{BUBO VIRGINIANUS. - Bonaparte.}

\section{The Great Horned 0wl.}

Strix Virginiana, Gm. Syst. Nat., I. 287 (1788). Bonap. Syn., p. 37. Nutt., I. 124. Wilson, Audubon, and others.

Bubo articus, Swains. Faun. Bor. Am. Birds, p. 86 (1831).

\section{DESCRIPTION.}

Adult. - Large and strongly organized; ear-tufts large, erectile; bill strong, fully curved; wing rather long; third quill usually longest; tail short; legs and toes robust, and densely covered with short, downy feathers; claws very strong, sharp, curved; variable in plumage, from nearly white to dark-brown, usually with the upper parts dark-brown, every feather mottled, and with irregular transverse lines of pale-ashy and reddish-fulvous, the latter being the color of all the nlumage at the bases of the feathers; ear-tufts dark-brown, nearly black, edged on 
their inner webs with dark-fulvous; a black spot above the eye; radiating feathers behind the eye, varying in color from nearly white to dark reddish-fulvous, usually the latter; feathers of the facial dise tipped with black; throat and neck before, white; breast with wide longitudinal stripes of black; other under parts varjegated w th white and fulvous, and every feather having transverse, narrow lines of dark-brown, middle of the abdomen frequently, but not always, white; legs and toes varying from white to dark-fulvous, usually pale-fulvous; in most specimens unspotted, but frequently, and probably always in fully mature specimens, with transverse, narrow bars of dark-brown; quills brown, with wide transverse bands of cinereous, and usually tinged on the inner webs with pale fulvous; tail the same, with the fulvous predominating on the outer feathers; iris yellow; bill and claws bluish-black.

Dimensions. - Female, length, twenty-one to twenty-five inches; wing, fourteen and $a$ half to sixteen; tail, ten inches. Male, eighteen to twenty-one inches; wing, fourteen to fifteen; tail, nine inches.

\section{THIS well-known bird is a resident in all the New-England \\ 1 States throughout the year. It is not so common in Mas-} sachusetts, Connecticut, and Rhode Island as in the other States, where, in the vast tracts of forest, it is quite abundant; so much so, that I have heard several of them at the same time making "night hideous with their discordant, mournful cries." Never shall I forget a serenade I once had the pleasure of hearing in the State of Maine, in which this bird maintained the basso. We were encamped on the shores of Lake Umbagog: our tent was pitched on a bluff overlooking the lake, and behind us was the deep, dark forest of pines and hemlocks. We had just got fairly into our first nap, the sweet follower of our day's toils, when we were arvakened by the hootings of one of these owls, "Waugh, hoo, hoo, hoo!" or "Who cooks for you?" as the Western traveller understood it, which seemed to be addressed to us from a tree almost over our tent. We listened: presently another took up the theme, and then both together. They had scarcely finished their duet, when, from away up the lake, came the shrill, mournful cry or scream of the Loon: this was continued and answered by others, until, with owls and loons, the night was vocal with melodious sounds. After this had died away, and all was still, there came from a bush near our tent the almost heavenly song of the Whitethroated Sparrow, the "Nightingale of the North." One 
cannot imagine the effect produced by the contrast: he must be on the spot in the dark night, and, through the sighing of the winds amid the grand old trees, hear the owls and loons; then, silence, broken by the beautiful song of the Nightingale.

The flight of the Great Horned Owl is rapid, noiseless, and vigorous: he passes through the mazes of the forest with great dexterity and ease; and, when flying above the trees, frequently soars in the manner of the Hawks. He is very destructive among domestic poultry, frequently pouncing on fowls that are roosting on trees in the night, and bearing them off in his powerful grasp. This habit has rendered him obnoxious to the farmers, who lose no opportunity for destroying him. Rabbits, grouse, and other birds, fall victims to his rapacity; and I have often shot individuals of this species, whose feathers were so impregnated with the peculiar odor of the skunk as to be unbearable at a near approach.

When a flock of crows discover the presence of one of these birds, they immediately collect from all quarters, and attack him on every side, uttering their harsh, discordant cries : the owl is kept dancing and dodging on the limb, his perch, in a ludicrous manner; if he takes to flight, he is pursued by his enemies, and soon forced to alight. I have often been enabled to procure a specimen, by following a noisy mob of this description; just as we often are able to secure one of the smaller owls by proceeding to the copse where numbers of small birds - cat-birds, chewinks, and thrushes - are scolding at their enemy.

I have had several specimens of the Great Horned Owl in captivity: they make amusing pets. When fed with raw meat, they seldom take it freely from the hand or tongs; and often can be made to swallow it, only by our opening their bills, and putting in the meat. They seem to have the powver of seeing by daylight; for, if a living animal is introduced into their cage, they instantly seize it. I have 


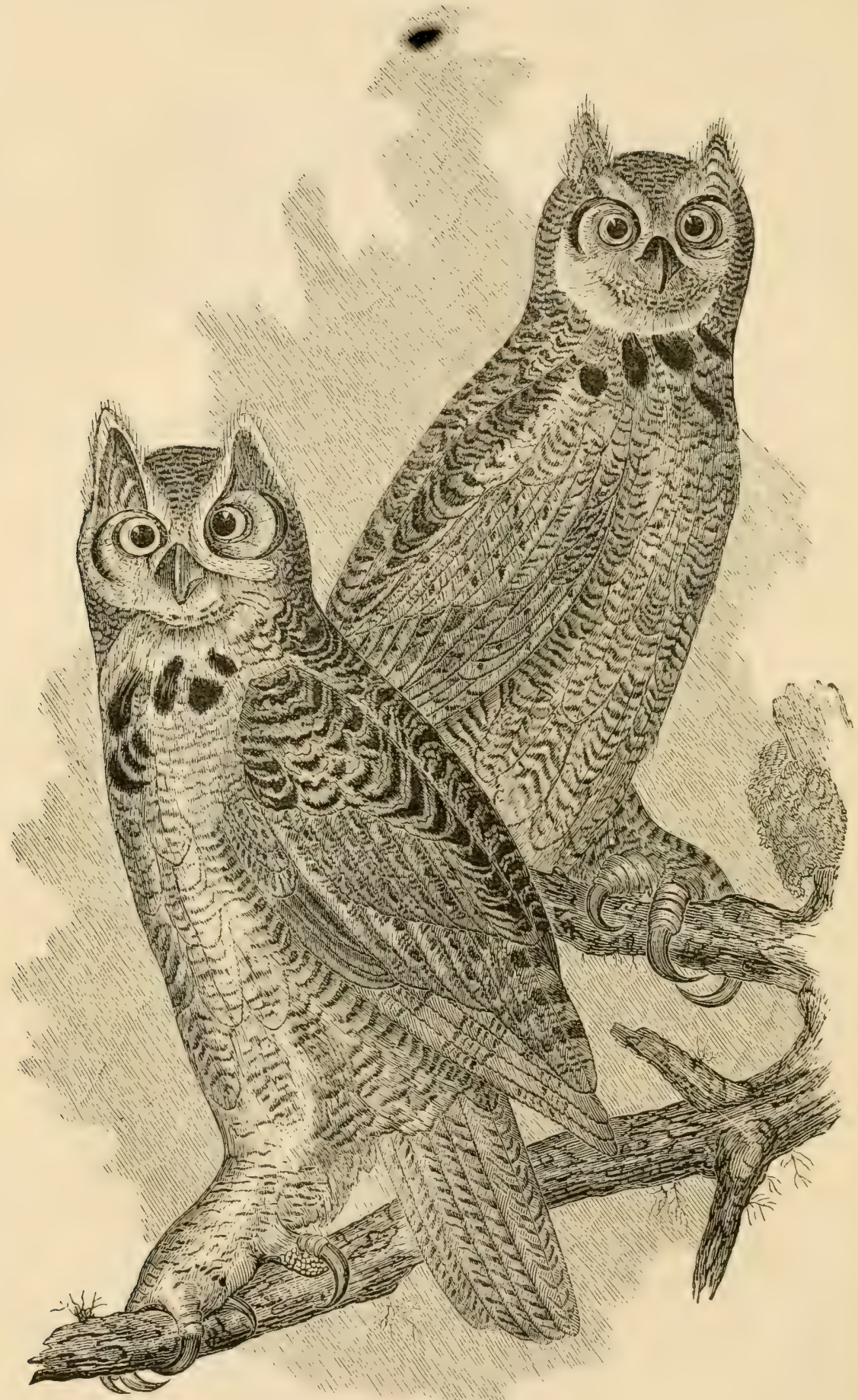

Great Horned Owl, Bubo Virginianus. Bonaparte. 
often put in a dead mouse, with a string attached to it, by which I dragged it across the eage: an owl instantly seized it, as if it were alive, and ate it. A living bat (Vespertilio Carolinensis), on being introduced, was instantly seized, but, after being killed, was rejected. The strong musky scent peculiar to these animals may have been the reason for the owl's not eating it: if not, I cannot account for it.

In eating its prey, the 0 wl stands on it with both feet, and tears it with its bill: if the piece torn off is large, the head is thrown back, and the repeated contraction of the muscles of the throat forces it down. In holding a mouse or other small object, all the talons of one foot are clenched in it, while the other foot is left free. On being approached, this Owl, as indeed do almost all the others, faces the intruder, and follows his motions by turning his head, at the same time snapping his bill.

In drinking, the bill is immersed, and repeated swallows are taken, after the manner of the pigeons.

The Great Horned Owl chooses for its breeding-places the most retired and inaccessible places in the deep forests ; and the student might search for weeks for its nest, and not find it unless by accident. It is usually built in a fork of a tall tree, but is sometimes made in a hollow of a tree or in the top of a stub or stump. Audubon found it twice in fissures of rocks. It is constructed of sticks and twigs, and is lined. with leaves, grasses, and moss. The eggs are usually three in number; sometimes four, rarely more: they are of a white color, with a very faint yellowish tint; their shape is nearly spherical, and they average in size 2.25 inches by 2 inches.

A nest that I found a few miles from Marietta, Ohio, about the middle of March, 1865, was built in a tall, hollow stub of a beech, which was cut down for the purpose of being examined. It was built of twigs and sticks, in numbers sufficient to fill the cavity: in the middle of these were 
arranged a few leaves and pieces of moss, and a few feathers from the body of the parent; on this nest were found three young birds, apparently but a few days old, as they were covered with gray down, and a few grayish feathers. On being taken in the hand, they clutched it tight with their claws, and squatted perfectly still. The iris of their eyes was a light-grayish color: the inside of their mouths, eyelids, and ears, were yellowish. At the foot of the stump were found small pellets of feathers, small bones, and hairs. I have heard of the deserted nest of a crow or hawk being occupied by this $\mathrm{Owl}$; but usually it builds its own nest.

\section{SCOPS, SAVigny.}

SAvigyr, Nat. Hist. Egypt, I. 105 (1809).

Size small; ear-tufts conspicuous; head large; facial disc imperfect in front and about the eyes; bill short, nearly covered by projecting feathers; wings long; tail rather short, and frequently curved inwards; tarsi rather long, more or less fully covered with short feathers; toes long, generally partially covered with hair-like feathers; head large.

General form short and compact. This genus contains twenty-five to thirty species of small owls, inhabiting all parts of the world except Australia.

$$
\text { SCOPS ASIO. - Bonaparte. }
$$

\section{The Mottled 0wl; Screech 0wl; Red 0wl.}

Strix Asio, Linnæus. Syst. Nat., I. 132 (1766). Audubon, Wilson, and others Strix naeria, Gm. Syst. Nat., I. 289 (1788).

Bubo striatus, Vieillot. Ois. d'Am. Sept., I. 54 (1808).

\section{Description.}

"Short and compact; ear-tufts prominent; tail short; tarsi rather long.

"Adult. --.-Upper parts pale ashy-brown, with longitudinal lines of brownish-black, and mottled irregularly with the same and with cinereous; under parts ashy-white, with longitudinal stripes of brownish-black, and with transverse lines of the same color; face, throat, and tarsi ashy-white, irregularly lined and mottled with palebrownish; quills brown, with transverse bands, nearly white on the outer webs; tail pale ashy-brown, with about ten transverse narrow bands of pale-cinereous; under wing coverts white, the larger tipped with black; bill and claws light horncolor; irides yellow.

"Younger. - Entire upper parts pale brownish-red, with longitudinal lines of brownish-black, especially on the head and scapulars; face, throat, under wing coverts, and tarsi reddish-white; quills reddish-brown; tail rufous, with bands of brown, darker on the inner webs. 


\footnotetext{
"Young. - Entire plumage transversely striped with ashy-white and pale-brown; wings and tail pale-rufous.

"Total length, nine and a half to ten inches; wing, seven; tail, three and a half inches. Sexes nearly alike in size and color.

"The stages of plumage described above have been regarded as characterizing distinct species; and they do present a problem scarcely to be considered as fully solved. This bird pairs and rears young while in the red plumage; and it is not unusual to find a mottled male and red female associated, or the reverse." - Jown Cassin.
}

As with many of the other birds of prey, the different plumages in which this owl is taken have caused great confusion; and, as Mr. Cassin truly remarks, the matter is not yet settled beyond doubt. The observation has generally been, that the young birds are in the red plumage; but I have certainly known of one instance when the young bird was in the gray. A nest, was found in a hollow tree in Milton, Mass., in which there were three young birds. They were permitted to remain; and I visited the nest as often as every two days until they flew off. The last time that I saw them, - the day before they left the

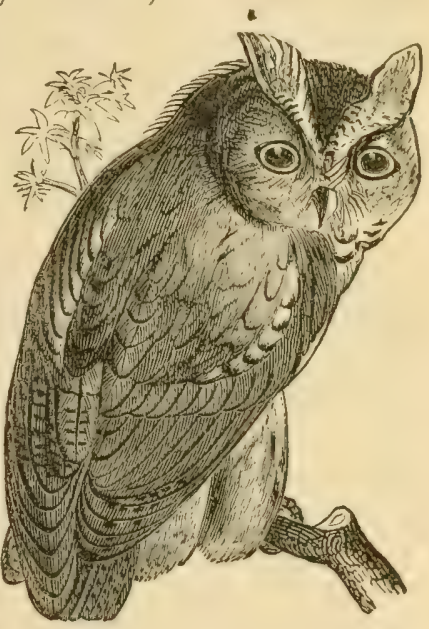
nest, - they were fully fledged, and they had very few marks of brownish-red in their plumage. Whether this was an exceptional case, I know not; but I will present the observations of different ornithologists which conflict with my own. I will also quote Audubon's description of the habits of the bird, as it is better than I can give from my own experience, though it corresponds to my observations so far as they go. He says, -

"The flight of the Mottled Owl is smooth, rapid, protracted, and noiseless. It rises at times above the top branches of the highest of our forest trees whilst in pursuit of large beetles; and at other 
times sails low and swiftly over the fields, or through the woods, in search of small birds, field-mice, moles, or wood-rats, from which it chiefly derives its subsistence. On alighting, - which it does plumply, - the Mottled Owl immediately bends its body, turns its head to look behind it, performs a curious nod, utters its notes, then shakes and plumes itself, and resumes its flight in search of prey. It now and then, while on the wing, produces a clicking sound with its mandibles, but more frequently when perched near its mate or young. This I have thought was done by the bird to manifest its courage, and let the hearer know that it is not to be meddled with; although few birds of prey are more gentle when seized, as it will suffer a person to touch its feathers and caress it without attempting to bite or strike with its talons, unless at rare intervals.

"The notes of this Owl are uttered in a tremulous, doleful manner, and somewhat resemble the chattering of the teeth of a person under the influence of extreme cold, although much louder. They are heard at a distance of several hundred yards, and by some people are thought to be of ominous import."

These notes almost exactly resemble the whimpering whine of a small dog, for which I have mistaken them on different occasions.

"The little fellow is generally found about farm-houses, orchards, and gardens. It alights on the roof, the fence, or the garden-gate, and utters its mournful ditty, at intervals, for hours at a time, as if it were in a state of great suffering; although this is far from being the case, - the song of all birds being an indication of content and happiness. In a state of confinement, it utters its notes with as much satisfaction as if at liberty. They are chiefly heard during the latter part of winter, - that being the season of love, when the male bird is particularly attentive to the fair one which excites his tender emotions, and around which he flies and struts much in the manner of the common Pigeon, adding numerous nods and bows, the sight of which is very amusing.

"The young remain in the nest until they are able to fly. At first, they are covered with a downy substance of a dull yellowishwhite. By the middle of August, they are fully feathered, and 
are then generally of a reddish-brown, although considerable differences exist between individuals, as I have seen some of a deepchocolate color, and others nearly black. The feathers change their colors as the pairing season advances, and in the first spring the bird is in the perfect dress.".

J. P. Norris, writing in the "Country Gentleman," Jan. 11, 1866, says that he secured two young birds of this species when covered with down, and kept them until they had become feathered, when their plumage was decidedly red in color.

J. P. Giraud, in his "Birds of Long Island," gires a letter from J. G. Bell, of New York, in which that gentleman says, that he has taken the young birds from the nest, covered with grayish-brown, and kept them through their first plumage, which was red in color.

These and other writers seem to agree that the red plumage is that of the bird in the first year. I leave it to future experimenters to determine the matter beyond a doubt.

This bird feeds largely on the injurious night-flying moths and beetles. Numbers of specimens that I have examined, contained in their stomachs parts of these insects and small mammals: very seldom indeed did they have feathers or other parts of birds.

The Mottled Owl selects for a nesting-place a hollow tree, often in the orchard, and commences laying at about the first of May, in the latitude of the middle of Massachusetts. The nest is made at the bottom of the hollow, and is constructed of grass, leaves, moss, and sometimes a few feathers. It is not elaborately made, being nothing more than a heap of soft materials. The eggs are usually four in number: they are pure-white, smooth, and nearly spherical in form. Their length varies from 1.30 to 1.37 inch; breadth from 1.18 to 1.25 inch. The eggs are often laid on the chips at the bottom of the hollow; no attempt at a nest being made. 


\section{OTUS, Cuvier.}

Otus, Cuvier, Règne Animal, I. 327 (1817).

General form longer and more slender than in the preceding genera; head moderate; ear-tufts long, erectile; bill rather short, curved from the base; facial disc more perfect than in the preceding; wings long; tail moderate; tarsi and toes covered with short feathers; claws long, curved; eyes rather small, and surrounded by radiating feathers.

This genus contains ten or twelve species of various countries, all of which are more handsome birds than are usually met with in this family.

\section{OTUS WILSONIANUS. - Lesson.}

The Long-eared 0 wl.

Otus Wilsonianus, Lesson. Traite d'Orn., I. 110 (1831).

Otus Americanus, Bonaparte. Comp. List, 7 (1838). Syn., 37.

Strix otus, Wilson. Bonaparte's edition, 449.

Strix otus, Linnæus. Aud. Orn. Biog., IV. 572. Nuttall, I. 130.

\section{DESCRIPTION.}

Ear-tufts long and conspicuous; eyes rather small; wings long; tarsi and toes densely feathered; upper parts mottled with brownish-black, fulvous, and ashywhite, the former predominating; breast pale-fulvous, with longitudinal stripes of brownish-black; abdomen white; every feather with a wide longitudinal stripe, and with transverse stripes of brownish-black; legs and toes pale-fulvous, usually unspotted, but frequently with irregular narrow transverse stripes of dark-brown; eye nearly encircled with black; other feathers of the face ashy-white, with minute lines of black; ear-tufts brownish-black edged with fulvous and ashy-white; quills pale-fulvous at their bases, with irregular transverse bands of brown; inferior coverts of the wing pale-fulvous, frequently nearly white; the larger widely tipped with black; tail brown, with several irregular transverse bands of ashy-fulvous, which are mottled, as on the quills; bill and claws dark horn-color; irides yellow.

Total length, female, about fifteen inches; wing, eleven to eleven and a half; tail, six inches. Male rather smaller.

This species is rather common in New England, rather preferring the less settled districts to the others. It is eminently nocturnal in its habits, and has the power of seeing in the daytime to a less degree than any of the other species with which I am acquainted.

A specimen that I once had, as a pet, could not see my hand as it approached him, and would permit my finger to touch his eye before he drew over it the thin nictitating membrane given to all birds to protect this delicate organ.

I do not remember of ever hearing this owl utter a cry 
in its nocturnal :ambles; and I think that it hunts in silence, except, perhaps, in the mating season.

The specimen in my possession would not eat in the daytime; and, if I fed it then, was obliged to push the food down its throat with my finger: at night, it fed readily on raw meat, but was rather loath to eat when I was by, or when a lamp was near its cage. I had water always accessible to it, but never saw it drink, and think, that, in the space of two months, it drank not more than two or three times; or, if it did, the quantity it took was so small as not to be appreciable.

Notwithstanding the comparative abundance of this species, its breeding habits are not well known. I have been so fortunate as to find several nests, all of which were built in forks of tall pines, and constructed of twigs and leaves. Audubon says :-

"The Long-eared Owl is careless as to the situation in which its young are to be reared, and generally accommodates itself with the abandoned nest of some other bird that proves of sufficient size, whether it be high or low, in the fissure of a rock or on the ground. Sometimes, however, it makes a nest itself; and this I found to be the case in one instance near the Juniata River, in Pennsylvania, where it was composed of green twigs, with the leaflets adhering, and lined with fresh grass and wool, but without any feathers."

Wilson describes its breeding habits as follows :-

"About six or seven miles below Philadelphia, and not far from the Delaware, is a low swamp, thickly covered with trees, and inundated during a great part of the year. This place is the resort of great numbers of the qua bird (Night Heron), where they build in large companies. On the 25th of April, while wading through the dark recesses of this place, observing the habits of these birds, I discovered a Long-eared Owl, which had taken possession of one of their nests, and was setting. On mounting to the nest, I found it contained four eggs; and, breaking one of them, the young appeared almost ready to leave the shell. There were numbers of 
the qua birds' nests on the adjoining trees all around, and one of them actually on the same tree."

The reader will perceive from the above account of the breeding habits of this bird, that it is variable in its choice of a nesting-place, although every nest that I have found, or known of, was built in tall pines, and constructed as above; and 'I have known instances where the same nest was used for successive breeding seasons.

The eggs are generally four in number, seldom more. They are nearly spherical in form, and of a pure-white color. Dimensions of specimens in my collection vary from 1.40 to 1.60 inch in length, by from 1.30 to 1.40 inch in breadth.

\section{BRACHYOTUS, GOULD.}

Brachyotus, Gould, Proc. Zool. Soc., London, 1837, 10.

Ear-tufts very short and inconspicuous; general form rather strong; wings long; tail moderate; legs rather long, which, with the toes, are fully covered with short feathers; claws long, very sharp, and rather slender; head moderate; eyes rather small, surrounded by radiating feathers; facial disc imperfect on the forehead and above the eyes; tail moderate.

This genus contains four or five species only, the two best known of which are the European.

\section{BRACHYOTUS CASSINII. - Brewer.}

The Short-eared 0wl.

Brachyotus Cassinii, Brewer. Proc. Boston Soc. of Nat. Hist.

Strix brachyotus, Forster. Phil. Trans., London, LXII. 384 (1772).

Strix brachyotus, Linnæus. Wilson and others.

\section{DESCRIPTION}

Ear-tufts very short; entire plumage buff or pale-fulvous; every feather on the upper parts with a wide longitudinal stripe of dark-brown, which color predominates on the back; under parts paler, frequently nearly white on the abdomen, with longitudinal stripes of brownish-black, most numerous on the breast, very narrow and less numerous on the abdomen and flanks; legs and toes usually of a deeper shade of the same color as the abdomen; quills pale reddish-fulvous at their bases, brown at their ends, with wide irregular bands and large spots of reddish-fulvous; tail pale reddish-fulvous, with about five irregular transverse bands of dark-brown, which color predominates on the two central feathers; under tail coverts usually nearly white; throat white; eyes enclosed by large spots of brownish-black; eartufts brown, edged with fulvous; bill and claws dark; irides yellow.

Total length, female, about fifteen inches; wing, twelve; tail, six inches. Male rather smaller. 
I regret being unable to add any thing to our knowledge of the history of this bird. I have had no opportunities for observing its habits, and know of nothing that has been noted recently which will add to our information. It is not common in any part of New England, and is, I believe, more often met with in the neighborhood of the seacoast than elsewhere. I have never met with its nest, but have no doubt that it breeds in these States, as specimens are occasionally taken here in summer.

Richardson says that its nest is formed of withered grass and moss, and is built on the ground. Dr. Bryant ("Proceedings of Boston Society of Natural History," January, 1857) describes a nest found on an island in the Bay of Fundy as follows:-

"A nest of this bird was found by Mr. Cabot in the thidst of a dry peaty bog. It was built on the ground, in a very slovenly manner, of small sticks and a few feathers, and presented hardly any excavation. It contained four eggs on the point of being hatched."

The eggs of this species are of a pure-white color, and vary in dimensions from 1.65 inch by 1.25 inch to 1.50 inch by 1.23 inch.

\section{Sub-Family Srrninæ. - The Gray Owls.}

Head large, with very small and concealed ear-tufts, or entirely without. Facial disc nearly perfect; eyes small for the family of owls; wings rather short, or not so long as in the preceding; tarsi and toes generally fully feathered. This group contains some of the largest of owls; generally, however, the size is medium, and frequently small.

\section{SYRNIUM, SAVIGNY,}

Syrnium, SAvigry, Nat. Hist. Egypt, I. 112 (1809).

Size usually large; head large, without ear-tufts; eyes rather small; facial dise somewhat imperfect in front; bill strong, curved from its base; wings moderate, somewhat rounded; fourth and fifth quills longest; tail rather long, wide, and usuqlly rounded at the end; legs moderate, or rather long, which, with the toes, are densely covered with short feathers; claws long, strong, very sharp. 
Species of this genus inhabit principally the northern parts of the world, and are generally characterized by the prevalence of gray or cinereous, of various shades, in their plumage.

\section{SYRNIUM CINEREUM. - Audubon.}

The Great Gray 0wl.

Strix cinerea, Gm. Syst. Nat., I. 291 (1788). Aud. Orn. Biog., IV. 364.

Strix acclimator, Bartram. Travels, 289 (1790).

\section{DESCRIPTION.}

The largest $\mathrm{Owl}$ of North America. Head very large; eyes small; tail rather long; upper parts smoky or ashy brown, mottled and transversely barred with ashy-white; under parts ashy-white, with numerous longitudinal stripes of dark ashy-brown predominating on the breast, and with transverse stripes of the same on the abdomen, legs, and under tail coverts; quills brown, with about five wide, irregular bands of ashy-white; tail brown, with five or six wide, irregular bands of ashywhite, mottled with dark-brown; feathers of the disc on the neck tipped with white; eye nearly encircled by a black spot; radiating feathers around the eye, with regular transverse narrow bars of dark-brown and ashy-white; bill pale-yellow; claws pale yellowish-white, darker at their tips; iris bright-yellow.

Total length, twenty-five to thirty inches; wing, eighteen; tail, twelve to fifteen inches.

This bird is an extremely rare winter visitor in New England; appearing only in the southern districts of these States, in Massachusetts even, in very severe seasons. I never saw one alive; have, of course, never seen its nest, and can add nothing at all to our knowledge of its habits. It breeds in the most northern regions; and, according to Dr. Brewer, "nests in high trees." Its eggs I have never seen. Audubon gives the following account of this species :-

"The comparatively small size of this bird's eyes renders it probable that it hunts by day; and the remarkable smallness of its feet and claws induces me to think that it does not prey on large animals. Dr. Richardson says, that 'it is by no means a rare bird in the fur countries; being an inhabitant of all the woody districts lying between the Lake Superior and latitudes $67^{\circ}$ or $68^{\circ}$, and between Hudson's Bay and the Pacific. It is common on the borders of Great Bear Lake; and there, and in the higher parallels of latitude, it must pursue its prey, during the summer months, by daylight. It keeps, however, within the woods, and does not frequent the barren grounds, like the Snowy Orvl; nor is it so often met 



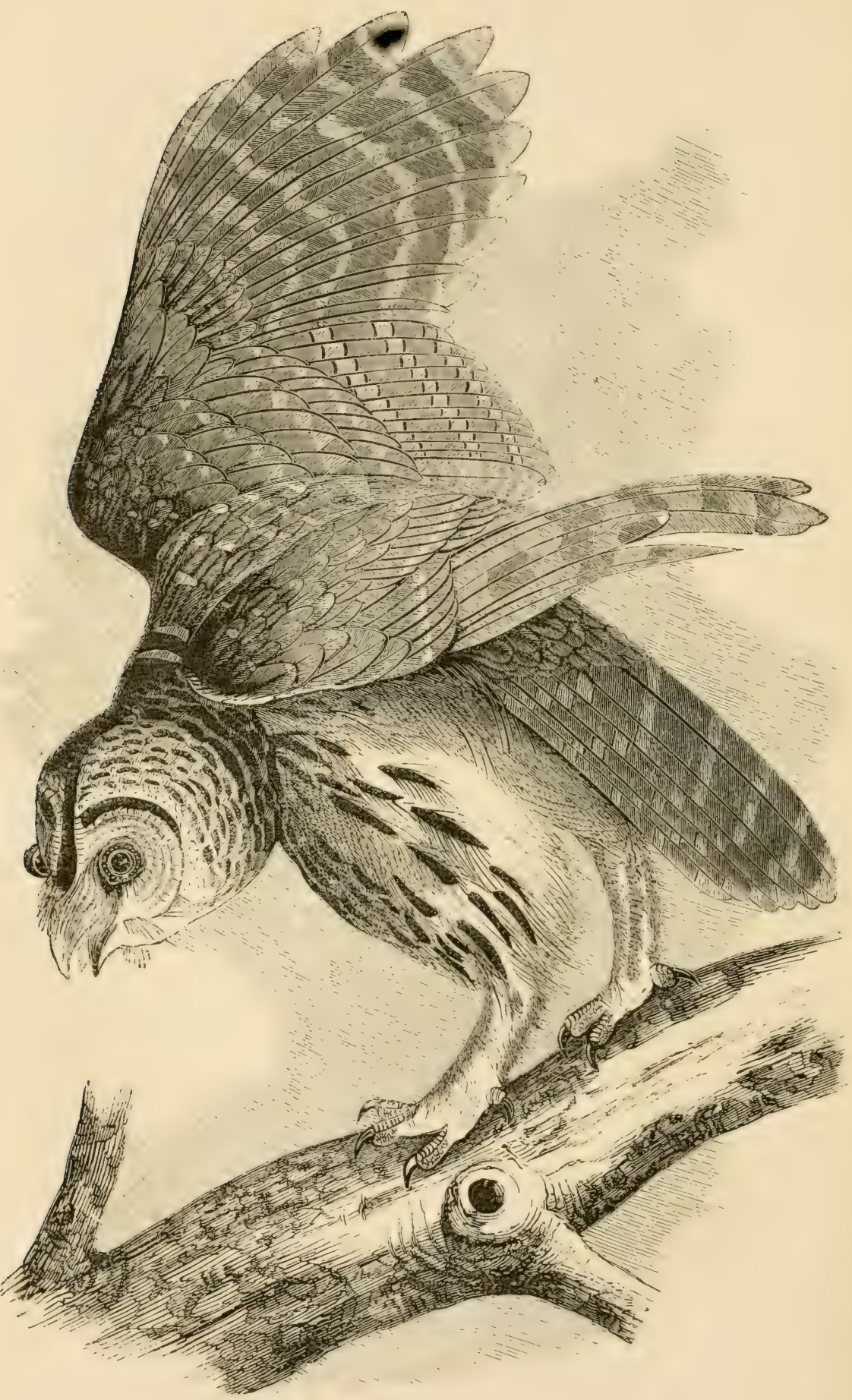

Barred OwL, Syrnium nebulosum. Gray. 
with in broad daylight as the Hawk Owl, but hunts principally when the sun is low: indeed, it is only at such times, when the recesses of the woods are deeply shadowed, that the American Hare, and the murine animals on which the Cinereous Owl chiefly preys, come forth to feed." "

Audubon speaks of a gentleman in Salem, Mass., who kept one of these birds alive for several months: it was fed on fish and small birds, of which it was very fond. It uttered at times a tremulous cry, not unlike that of the little Screechowl (Scops asio), and showed a great antipathy to cats and dogs.

\section{SYRNIUM NEBULOSUM. - Gray.}

The Barred 0wl.

Strix nebulosa, Forster. Trans. Philosoph. Soc., London, LXIr. 386, 424 (1772). I. 242 .

Strix nebulosa, Linnæus. Wilson, 304. Bonap. Syn., 38. Nutt., I. 133. Aud.,

\section{DESCRIPTION.}

Head large, without ear-tufts; tail rather long; upper parts light ashy-brown, frequently tinged with dull-yellow, with transverse narrow bands of white, most numerous on the head and neck behind, broader on the back; breast with transverse bands of brown and white; abdomen ashy-white, with longitudinal stripes of brown; tarsi and toes ashy-white, tinged with fulvous, generally without spots, but frequently mottled and banded with dark-brown; quills brown, with six or seven transverse bars, nearly pure-white on the outer webs, and ashy-fulvous on the inner webs; tail light-brown, with about five bands of white, generally tinged with reddish-yellow; discal feathers tipped with white; face ashy-white, with lines of brown, and a spot of black in front of the eye; throat dark-brown; claws horn-color; bill pale-yellow; irides bluish-black. Sexes alike.

Total length, about twenty inches; wing, thirteen to fourteen; tail, nine inches. Sexes nearly of the same size.

This Owl is rather common in most sections of New England; is more often seen in the more sputhern localities, and less frequently met with in sections where the Great Horned $\mathrm{Owl}$ is most abundant, and vice versâ. Its flight is soft and rapid, the great breadth of the wings and comparative lightness of the body giving it remarkable speed. Its vision is almost as good in the daylight as in the night, and surpasses that of most of our other owls. A specimen that I kept alive for a few weeks, often, in the daytime, flew about the room in which his cage was placed: he alighted with 
ease on the backs of chairs, or on other pieces of furniture; seldom miscalculating the distance or missing a footing, as many of the other owls would in the same circumstances. This bird soon became tame, and would accept food at almost any time in the day or night: on receiving a piece of meat, he sometimes attempted to clutch it with his foot, and my fingers often had narrow escapes from his sharp, crooked talons. Usually, he would seize it with his mouth, and, if not too large, swallow it without tearing: if the piece was more bulky than he could manage, he stood on it, and tore it with his beak. Fish he invariably rejected, but greedily ate mice and small birds: a dead pigeon, that I put in his cage, was untouched for several days. He died in consequence of a hurt he received in flying against a window.

The Barred Owl subsists principally upon small birds, field-mice, and reptiles. He is frequently seen, in early twilight, flying over the low meadow-lands, searching for the mice that dwell there: he usually takes a direct course, and sometimes flies so low that the tips of his wings seem to touch the grass. When he discovers his prey, he drops on it instantly, folding his wings and protruding his feet, in which his quarry is always secured: he often captures frogs that are sitting on the shores of ponds and rivers; but I am inclined to think that the statement, quoted by Audubon, that he often "catches fish, is incorrect. The Barred Owl usually nests in high trees, placing the structure of sticks and leaves in a crotch near the trunk. The eggs are usually three in number. I have one only in my collection: this is pure-white, almost globular, and, except in shape, hardly distinguishable from the egg of the domestic hen. It is 2 inches in length by 1.68 in breadth.

\section{NYCTALE, BREHM.}

Nyctale, BrenMr, Isis (1828), 1271.

Size small; head with very small ear-tufts, only observable when erected; eyes small; bill moderate, or not very strong; facial disc nearly perfect; wings rather long; tail short; legs and toes densely feathered. 
Contains five species of small and quite peculiar owls, four of which are American, and one European.

NYCTALE RICHARDSONII. - Bonaparte.

The Sparrow Owl.

Nyctale Richardsonii, Bonaparte. Comp. List, 7 (1838).

"Strix Tengmalmi, Gm." Aud. Orn. Biog., IV. 559, and other American authors.

\section{DESCRIPTION.}

The largest of this genus; wings long; upper parts pale reddish-brown, tinged with olive, and with partially concealed spots of white, most numerous on the head and neck behind, scapulars, and rump; head in front with numerous spots of white; face white, with a spot of black in front of the eye; throat with brown stripes; under parts ashy-white, with longitudinal stripes of pale reddish-brown; legs and toes pale-yellowish, nearly white, sometimes barred and spotted with brown; quills brown, with small spots of white on their outer edges, and large spots of the same on their inner webs; tail brown, every feather with about ten pairs of white spots; bill light-yellowish horn-color; irides yellow.

Total length, about ten and a half inches; wing, seven and a half inches; tait, four and a half inches.

This species is an exceedingly rare winter visitor in New England. I have never met with it alive, and can give from my own observation no account of its habits. Dr. Richardson, in the "Fauna Boreali-Americana," says :-

"When it accidentally wanders abroad in the day, it is so much dazzled by the light of the sun as to become stupid; and it may then be easily caught by the hand. Its cry in the night is a single melancholy note, repeated at intervals of a minute or two. Mr. Hutchins says that it builds a nest of grass half-way up a pine-tree, and lays two white eggs in the month of May."

\section{NYCTALE ACADICA. - Bonaparte.}

\section{The Saw-Whet 0wl; Acadican 0wl.}

Strix Acadica, Gm. Syst. Nat., I. 296 (1788). Bonap. Syn., 38. Nuttall and other authors.

"Strix passerina, Linnæus." Wilson, Am. Orn., IV. 66.

\section{DESCRIPTION.}

Small; wings long; tail short; upper parts reddish-brown, tinged with olive; head in front with fine lines of white, and on the neck behind, rump, and scapulars, with large, partially concealed spots of white; face ashy-white; throat white; under parts ashy-white, with longitudinal stripes of pale reddish-brown; under coverts 
of wings and tail white; quills brown, with small spots of white on their outer edges, and large spots of the same on their inner webs; tail brown, every feather with about three pairs of spots of white; bill and claws dark; irides yellow.

Total length, about seven and a half to eight inches; wing, five and a half inches; tail, two and three quarters to three inches. Sexes nearly the same size, and alike in colors.

This species is also quite rare in New England; but, as it is occasionally found in the summer months, is probably a resident here through the year. Says Audubon, in his description of this bird, which is very full and perfect:-

"The Little Owl is known in Massachusetts by the name of the 'Saw-whet,' the sound of its love-notes bearing a great resemblance to the noise produced by filing the teeth of a large saw. These notes, when coming, as they frequently do, from the interior of a deep forest, produce a very peculiar effect on the traveller, who, not being aware of their real nature, expects, as he advances on his route, to meet with shelter under a saw-mill at no great distance. Until I shot the bird in the act, I had myself been more than once deceived in this manner.

"A nest of our Little Owl, which I found near the city of Natchez, was placed in the broken stump of a small decayed tree, not more than four feet from the ground. I was attracted to it by the snoring notes of the young, which sounded as if at a considerable elevation; and I was so misled by them, that, had not my dog raised himself to smell at the hole where the brood lay concealed, I might not have discovered them. In this instance, the number was five. It was in the beginning of June; and the little things, which were almost ready to fly, looked exceedingly neat and beautiful. Their parents I never saw, although I frequently visited the nest before they left it. The Little Owl breeds more abundantly near the shores of the Atlantic than in the interior of the country, and is frequent in the swamps of the States of Maryland and New Jersey during the whole year. Wherever I have found the young or the eggs placed in a hollow tree, they were merely deposited on the rotten particles of wood; and, when in an old crow's nest, the latter did not appear to have undergone any repair. Being quite nocturnal, it shows great uneasiness when disturbed by day, and flies off in a hurried, uncertain manner, throwing itself into the 



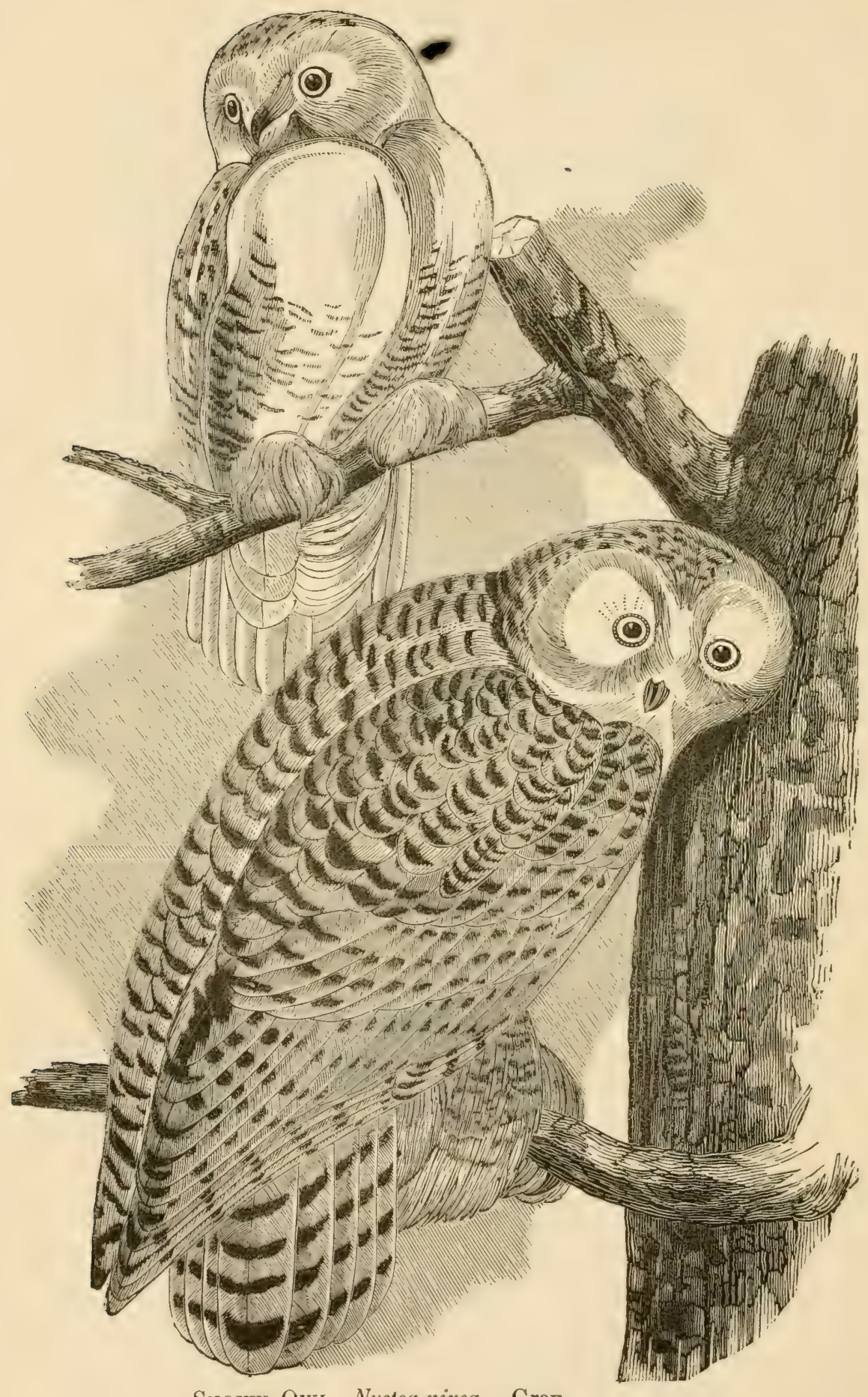

SNowy OwL, Nyctea nivea. Gray 
first covert that it meets with, where it is not difficult to catch it, provided the necessary caution and silence be used. Towards dusk, it becomes full of animation, flies swiftly - gliding, as it were-over the low grounds like a little spectre, and pounces on small quadrupeds and birds with the quickness of thought."

The Saw-whet 0 wl ${ }^{1}$ nests in hollow trees, in cavities of rocks, and in deserted crows' and woodpeckers' nests. The eggs are from three to five or six in number; and, according to Dr. Brewer, are of a bright, clear white, and more like a woodpecker's than an owl's in their crystalline clearness. Dimensions, $1 \frac{2}{16}$ by $\frac{14}{16}$ inch.

\section{Sub-Family Nrcteinine. - The Day Owls.}

General form compact and robust; head moderate, without ear-tufts; wings and tail rather long; tarsi strong, which, with the toes, are more densely covered than in any other division of this family.

This division embraces two species only, which inhabit the arctic regions of both continents; migrating southward in the winter.

\section{NYCTEA, STEPIENS.}

Nyctea, STEPIIENs, Cont. of Shaw's Zool., XIII. 62 (1826).

Large; head rather large, without ear-tufts; no facial disc; legs rather short, and with the toes covered densely with long hair-like feathers, nearly concealing the claws; bill short, nearly concealed by projecting feathers, very strong; wings long; tail moderate, or rather long, wide; claws strong, fully curved. Contains one species only.

\section{NYCTEA NIVEA, - Gray.}

\section{The Snowy 0wl.}

Strix nivea, Daudin. Traite d'Orn., $190(1800)$.

Strix nyctea, Linnæus. Syst. Nat. I. 132 (1766).

"Strix nyctea, Linnæus." Bonap. Syn., 36. Nutt. I. 116. Aud. II. 135. Wiison and others.

\section{Description.}

Bill nearly concealed by projecting plumes; eyes large; entire plumage white, frequently with a few spots or imperfect bands, only on the upper parts dark-brown, and on the under parts with a few irregular and imperfect bars of the same; quills and tail with a few spots or traces of bands of the same dark-brown; the prevalence of

1 See Appendix. 
the dark-brown color varies much in different specimens; frequently both upper and under parts are very distinctly banded transversely, and sometimes this color predominates on the back; plumage of the legs and toes pure snowy-white; bill and claws horn-color; irides yellow.

Total length, female, about twenty-six inches; wing, seventeen to nineteen; tail, ten inches. Male, about twenty-two inches; wing, seventeen; tail, nine inches.

As a winter visitor, throughout all New England, this bird is a rather common species. It is often taken on the islands in Massachusetts Bay, where it feeds on fish that have been thrown up on the shore by the tide, birds, wounded seafowl, and even dead animals, as I am informed by a reliable person who once shot one while perched on and eating a dead horse on the beach. The flight of this $\mathrm{Owl}$ is rapid and protracted. I have seen an individual chase and capture a Snow Bunting ( $P$. nivalis) from a flock; and once saw one make a swoop at a flock of poultry which had come out from their house on a fine day, but which immediately retreated on the appearance of their enemy. The Snowy Owl hunts both in the daylight and twilight: he seems to prefer cloudy, gloomy days to bright ones, and is most active just before a storm. Audubon says that this Owl captures living fish in the water by standing quietly by the margin, and seizing its prey with its claws, as it appears near the surface: whether this is a regular habit or not, I cannot say. I never saw one do so; and I have conversed with several hunters who have shot numbers of specimens, and they all were ignorant of such a fact.

Of the breeding habits of this 0 wl, we are ignorant. The Hudson's Bay, and other northern countries, are its summer homes. Wheelwright, in his "Spring and Summer in Lapland," gives the only description of its nest and eggs accessible to me at present. He says :-

"The egg of the Snowy Owl measures $2 \frac{1}{4}$ inches in length, and $1 \frac{3}{4}$ inches in breadth: its color is pure-white. The nest is nothing more than a large boll of reindeer moss, placed on the ledge of a bare fell. The old birds guard it most jealously; in fact, the Laplanders often kill them with a stick when they are robbing the 
nest, which they do upon every occasion that presents itself. The Snowy Owl will occasionally make its nest on the large turf-hillocks in some of the mosses.

\section{SURNIA, DUMERIL}

Surnia, DumentL, Zoologie Analytique, 34 (1806).

General form rather long, but robust; size medium; head moderate, without eartufts; facial disc obsolete; bill moderate, curved from the base, covered with projecting plumes; wings long; tail long, wide, graduated; legs rather short, and with the toes densely feathered; contains one species only, which inhabits the arctic regions of both continents.

\section{SURNIA ULULA. - Bonaparte.}

The Hawk 0wl; Day Owl.

Strix ulula, Linnæus. Syst. Nat, I. 133 (1766).

"Strix funerea," Gm. Bonap. Syn. 25. Nutt., I. 115. Aud. Orn. Biog., IV. 550 .

"Strix Hudsonica." Wilson, VI. 64.

\section{DESCRIPTION.}

Wings rather long; first three quills incised on their inner webs; tail long, with its central feathers about two inches longer than the outer; tarsi and toes densely feathered; upper parts fuliginous-brown, with numerous partially concealed circular spots of white on the neck behind, scapulars and wing coverts; face grayish-white; throat white, with longitudinal stripes of dark-brown; a large brown spot on each side of the breast; other under parts with transverse lines or stripes of pale ashybrown; quills and tail brown, with transverse bands of white; bill pale-yellowish; irides yellow; color of upper parts darker on the head, and the white markings more or less numerous in different specimens.

Total length, female, sixteen to seventeen inches; wing, nine; tail, seren inches. Male rather smaller.

This bird is occasionally met with in different localities in New England; rarely in the summer, most often in the winter. As its name implies, it is diurnal in its habits, and hunts its prey in the hours when most of the other owls are hidden in their retreats. Its food consists of small birds and mice, which it seizes in the manner of the hawks. A specimen was obtained in Vermont on a wood-pile in a door-yard, where it was eating a woodpecker that it had just captured. Dr. Richardson, in his "Fauna BorealiAmericana," says that, "when the hunters are shooting grouse, this bird is occasionally attracted by the report of 
the gun, and is often bold enough, on a bird being killed, to pounce down upon it, though unable, from its size, to carry it off.

The Hawk Owl occasionally breeds in New England.

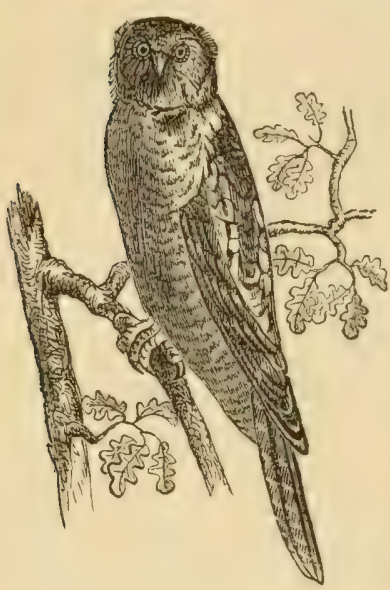

My friend, George A. Boardman of Milltown, Me., has been so fortunate as to find its nest, with eggs, in that neighborhood. It usually builds in a hollow tree, but sometimes constructs a habitation in the crotch of a tall tree, of sticks, grass, and feathers. According to Richardson, it lays two white globular eggs.

Two beautiful specimens in my collection, from William Couper, Esq., Quebec, collected at Northern Labrador by the Montanaz

Indians, are a trifle more elongated and pointed than the eggs of the Red Owl (Scops asio). They are of a purewhite color, and measure 1.50 by 1.25 inch and 1.47 by 1.22 inch.

\section{NOTES.}

I append the following notes, that have been kindly furnished me by William Couper, of Quebec, Lower Canada, for the purpose of showing the northern distribution of the birds of prey described in the preceding pages:-

HYPOTRIORCHIS COLUMBARIUS. - Only young specimens occur, and those rarely, in the latitude of Quebec: they are more common toward the western portions of Lower and Upper Canada. It has not, to my knowledge, been found breeding in Canada.

TINNUNCULUS SPARVERIUS. - This species is more abundant than the preceding; but the majority of the specimens shot in the neighborhood of Quebec are young. I am informed that it breeds in the vicinity of the river St. Maurice, which falls into the river St. Lawrence, west of Quebec. 
ASTUR ATRICAPILLUS. - The adult of this species is very rare in this latitude, and it occurs in this plumage about midwinter. 'The young, however, are sometimes common during the autumn.

ACCIPITER FUSCUS. - This is one of the most common of our Harks. It occurs in young plumage in the fall also. I am told that it breeds in Canada; but I have not had the good fortune to find its nest. Sportsmen have told me incidents of the audacity of this little species. They say it is always on the alert for woodcock and snipe, and knows the moment that one of these birds is wounded. It is sometimes so bold, that, as soon as the shot strikes the intended game, the Hark pounces upon it to carry it away.

BUTEO PENNSYLVANICUS. - This species is very common here during the months of September and October. It is generally found preying upon frogs and a species of common field locust. I have not learned that it breeds in Upper or Lower Canada.

ARCHIBUTEO LAGOPUS, - Sometimes this species is very abundant in the northern mountains, especially where there is a plenty of hares and grouse. It breeds in Labrador.

CIRCUS HUDSONIUS, - Occurs only in the fall, and then in young plumage. Breeds in Western Canada. It has not been detected breeding in the northern swamps of Lower Canada.

AQUILA CANADENSIS. - The adult and young of this species are occasionally shot here during autumn and winter. I think it breeds on some of our high northern mountains. The specimens that I have examined had their bodies and legs stuck full of porcupine quills.

PANDION CAROLINENSIS. - This is a very rare visitor in the northern regions. I understand that a pair arrive annually, and breed at Lake St. Joseph, north of this city. I never saw an adult specimen in Quebec.

BUBO VIRGINIANUS. - This Owl occurs here during summer and winter. I am almost certain it breeds in the mountains behind the eity. I have had the young in the down from Bay St. Paul, on the north side of the river St. Lawrence, below Quebec.

OTUS WILSONIANUS and BRACHYOTUS CASSINII are extremely rare here, and $I$ cannot give any facts in relation to them.

SYRNIUM NEBULOSUM. - This is the common Owl of our forests.

SYRNIUM CINEREUM. - Is an accidental vinter visitor.

SURNIA DLULA. - This bird is also very common during some winters. It breeds in the northern portions of Hudson's Bay and Labrador.

NYCTEA NIVEA. - This Owl is more abundant this winter (1867) than it has been for years.

NYCTALE RICHARDSONII and N. ACADICA also occur here. The former is occasional; but the latter, extremely rare. 


\section{ORDER II. - SCANSORES. ClimbERS.}

The characteristics of this order are given on page 4 of this volume. It is represented in the New-England States by two families, - the Cuculidae or Cuckoos, and the Picida or Woodpeckers.

These families have the arrangement of two pairs of toes opposed to each other in common; otherwise, they are much different in their characteristics.

The Cuculide have "bill thin, usually slender, and rather long, the tip more or less decurved, the base usually without rictal bristles; tarsi usually rather long, clothed with broad plates anteriorly; the tail feathers usually ten, sometimes eight or twelve, all long."

The Picida have "bill straight, rigid, and chisel-shaped at the tip, the base without rictal bristles; the feet are stout, and clothed anteriorly with broad plates; tail feathers twelve, the exterior very small and concealed." 1

1 See Introduction. 


\title{
Famity CUCUlide. The Cuckoos.
}

\author{
COCCYGUS, VieILLOT.
}

Coccyzus, Vieillot. Analyse (1816).

Erythrophrys, Swainson. Class. Birds, II. (1837), 322.

Head without crest; feathers about base of bill soft; bill nearly as long as the head, decurved, slender, and attenuated towards the end; nostrils linear; wings lengthened, reaching the middle of the tail; the tertials short; tail of ten graduated feathers; feet weak; tarsi shorter than the middle toe.

The species of Coccygus are readily distinguished from those of Geococcys by their arborial habits, confining themselves mainly to trees, instead of living habitually on the ground. The plumage is soft, fine, and compact.

The American cuckoos differ from the European cuckoos (Cuculus) by having lengthened naked tarsi, instead of very short feathered ones; the nostrils are elongated, too, instead of rounded.

\section{COCCYGUS AMERICANUS. - Bonaparte.}

\section{The Yellow-billed Cuckoo.}

Cuculus Americanus, Linnæus. Syst. Nat., I. (1766).

Coccyzus Americanus, Audubon. Orn. Biog., I. (1832). Bonap. Syn., 42.

Cuculus Carolinensis. Wilson, 267.

\section{DESCRIPTION.}

Upper mandible, and tip of lower black; rest of lower mandible, and cutting edges of the upper yellow; upper parts of a metallic greenish-olive, slightly tinged with ash towards the bill; beneath white; tail feathers (except the median, which are like the back) black, tipped with white for about an inch on the outer feathers, the external one with the outer edge almost entirely white; quills orange-cinnamon; the terminal portion and a gloss on the outer webs olive; iris brown.

Length, twelve inches; wing, five and ninety-five one-hundredths; tail, six and thirty-five one-hundredths.

THIS bird is very irregularly distributed through New England as a summer visitor. A. E. Verrill, in his catalogue of birds found at Norway, Me., says that "it is not common as a summer visitor." George A. Boardman writes me, that, near Calais, Me., it is "extremely rare." J. A. Allen, in his paper on Springfield birds (before referred to), calls it "extremely rare." Dr. Wood says it is "very rare" at East-Windsor Hill, Conn., where 
he has found it breeding. While I have noticed, that, though in former years it was equally abundant with the Black-billed Cuckoo, this bird is now growing scarce in the neighborhood of Boston.

This species arrives from the South from about the 25th of April to the 1st of May. We are first notified of his arrival by hearing his harsh notes in the opening foliage; and presently we see him moving about the twigs, busily picking off and swallowing the caterpillars and other larvæ which are so destructive to our fruit and shade trees. Soon he passes to another tree, still pursuing his profitable search; and, when he has gleaned to his heart's - or rather stomach's - content, he launches himself into the air, and takes flight for another grove or orchard, perhaps a half-mile off, or even farther. His flight is rapid, consisting of repeated strokes of his wings, but it is not - always direct; for he frequently turns from a straight course and flies off at an angle, then back again in a wavering manner. Occasionally, he pauses in his flight, and suddenly descends and alights on a shrub or low bush, as if he perceived an enemy in the air or a friend in the bush. After repeating his song, - "Krow-krow-krow-krow-krow; kru$k r \bar{u}, k r u-k r \bar{u}, k r u-k r \bar{u}, "$ - he is off again, and is soon out of sight.

The male arrives about ten days before the female. As soon as the latter makes her appearance, the male commences his courtship. He is very attentive to her, watching her every movement, and following her every flight. Although usually very cowardly, he is at this period tolerably brave, and will even attempt to molest any other bird that happens to be near, but usually with poor success ; for, as his cowardice is traditional among the birds, they will turn upon him, and drive him off discomfited. When the couple have mated, they soon commence building. The nest is placed in a low bough of a tree, or in a shrub or barberry bush. It is a loose, straggling affair, composed of 
sticks and twigs, and sometimes a few pieces of moss. The eggs are usually four in number; they are of a light greenish-blue color, and almost invariably larger than those of the Black-billed Cuckoo. A number of specimens before me vary from 1.07 to 1.25 of an inch in length, by from .84 to .96 inch in breadth. But one brood is reared in the season.

\section{COCCYGUS ERYTHROPHTHALMUS, - Bonaparte.}

The Black-billed Cuckoo.

Cuculus erythrophthalmus, Wilson. Am. Orn., IV. (1811), 16.

Coccyzus erythrophthalmus, Audubon. Orn. Biog., I. (1832), 170. Bonap. Syn., 42.

\section{DEsCRiption.}

Bill entirely black; upper parts generally of a metallic greenish-olive, ashy towards the base of the bill; beneath pure-white, with a brownish-yellow tinge on the throat; inner webs of the quills tinged with cinnamon; under surface of all the tail feathers hoary ash-gray; all beneath the central, on either side, suffused with darker to the short, bluish-white, and not well-defined tip; a naked red skin round the eye; iris, hazel.1

Length about twelve inches; wing, five; tail, six and a half.

This species is quite abundantly distributed throughout New England as a summer visitor, reaching to more northern latitudes than the other. It arrives from the South about the first week in May; and, like the Yellow-billed Cuckoo, the males precede the females. I have examined numbers of the first birds that arrived in different seasons, and they were invariably males; the females making their appearance about ten days or a fortnight later. The habits of the two

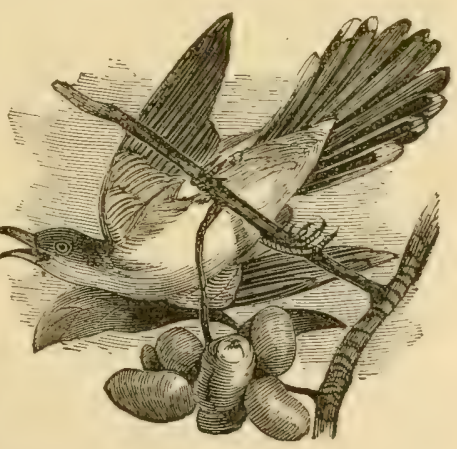
species are very similar, although the present bird prefer's the more cultivated and open districts, while the other

1 In succeeding species, when the color of the iris is not given, it is understood to be dark-hazel or black. 
seems to delight in the more retired and wooded localities.

In flight, the Black-billed Cuckoo is more swift than the other; in breeding habits, the same; and its food is similar, consisting principally of insects and their larvæ, small fruits, and the eggs and young of small birds. Like the other, the Black-billed Cuckoo is very cowardly, and is quickly driven from the neighborhood of the nest of almost any of the other birds. If a robin, or other bird of equal size, discover one of these, to him pirates, in the vicinity of his nest, he immediately assaults the intruder, with lond outcries, pouncing upon him, and pecking with great ferocity. Others of his neighbors, who are near, join in the attack: the Cuckoo, in retreating, dives into the recesses of a stone wall, or the first secure retreat available; very seldom taking to his wings, as another bird would do. I have known of a cuckoo being driven into a barn by a Blue-bird (S. sialis), who sat perching on a fence outside for several minutes, keeping his enemy prisoner; and the latter, when pursued and captured by myself, preferred being my prisoner to facing his enemy outside.

The nest of the Black-billed Cuckoo is usually placed in a low tree or barberry-bush. It is constructed of twigs, roots, and sometimes a few leaves and moss. I have examined a great number of these, from different sections ; and I have noticed that those from northern localities were invariably lined with gray moss, called Spanish moss, and leaves, while others, from more southern districts, were without such linings.

The eggs are usually four in number: they are of a darker greenish-blue than those of the other bird, and average a little smaller; their length varying from 1 to $1.12 \mathrm{inch}$, by from .84 to .92 inch in breadth. 


\section{Family PICID Re. The Woodpeckers.}

\section{Sub-Family Picrna.}

Although all the woodpeckers have a certain resemblance to each other, and agree more or less in habits, there are distinctions among them which serve readily for division into sub-genera, genera, or even higher groups. Thus, the difference between the Ivory-billed. Woodpecker and the common Flicker, which may be taken as representing the extremes of the scale in North-American species, will be palpable to any observer.

In the woodpeckers inhabiting the United States, there are three distinct groups, which may be taken, with some authors, as so many sub-families; or if, with Bonaparte, we unite all the Picidoe.with stiffened, acuminate, and pointed tails into a subfamily Picince, they will constitute so many separate sections. They may be severally characterized as follows:-

Picrna or Picece. - Bill more or less long; the outlines above and below nearly straight; the ends truncated; a prominent ridge on the side of the mandible, springing from the middle of the base or a little below, and running out either on the commissure, or extending parallel to and a little above it, to the end; sometimes obliterated or confluent with the lateral bevel of the bill; nostrils considerably overhung by the lateral ridge, more or less linear, and concealed by thick bushy tufts of feathers at the base of the bill; outer posterior toe generally longer than the anterior.

MELANERPIN E or Centurea. - Bill rather long; the outlines, that of the culmen especially, decidedly curved. The lateral ridge much nearest the culmen, and, though quite distinct at the base, disappearing before coming to the lower edge of the mandible; not overhanging the nostrils, which are broadly oval, rounded anteriorly, and not concealed by the bristly feathers at the base; outer pair of toes nearly equal, the anterior rather longer.

Colaptiva or Colaptece. - Bill much depressed, and the upper outline much curved to the acutely pointed (not truncate) tip; the commissure considerably curved; bill without any ridges; the nostrils broadly oval, and much exposed; anterior outer toe longest.

\section{PICUS VILLOSUS, - Linnous. 1}

\section{The Hairy Woodpecker.}

Picus villosus, Linnæus. Syst., I. 175. Bonap. Syn., 46, and others.

\section{DESCRIPTION.}

"The Hairy Woodpecker is nine inches long and fifteen in extent; crown black; line over and under the eye white; the eye is placed in a black line, that widens as it descends to the back; hind head scarlet, sometimes intermixed with black; nostrils hid under remarkably thick, bushy, recumbent hairs, or bristles; under the bill are certain long hairs thrown forward and upward; bill

I See p. 84, vol. IX., Pacific R.R. Reports. 
a bluish horn-color, grooved; wedged at the end, straight, and about an inch and a quarter long; touches of black, proceeding from the lower mandible, end in a broad black strip that joins the black on the shoulder; back black, divided by a broad, lateral strip of white, the feathers composing which are loose and unwebbed, resembling hairs, - whence its name; rump and shoulders of the wing black; wings black, tipped and spotted with white, three rows of spots being visible on the secondaries and five on the primaries; greater wing coverts also spotted with white; tail, as in the others, cuneiform, consisting of ten strong-shafted and pointed feathers, the four middle ones black, the next partially white, the two exterior ones white, tinged at the tip with a brownish burnt-color; tail coverts black; whole lower side pure-white; legs, feet, and claws light-blue, the latter remarkably large and strong; inside of the mouth flesh-colored; tongue pointed, beset with barbs, and capable of being protruded more than an inch and a half; the os hyoides, in this species, passes on each side of the neck, ascends the skull, passes down towards the nostril, and is wound round the bone of the right eye, which projects considerably more than the left for its accommodation. The great mass of hairs that cover the nostril appears to be designed as a protection to the front of the head, when the bird is engaged in digging holes into the wood. The membrane which encloses the brain in this, as in all the other species of woodpeckers, is also of extraordinary strength; no doubt, to prevent any bad effects from violent concussion while the bird is employed in digging for food. The female wants the red on the hind head, and the white below is tinged with brownish." - WILsON.

TTHE above description, as given by Wilson, is very full and complete. This Woodpecker is a rather common visitor in New England, in the spring, fall, and winter

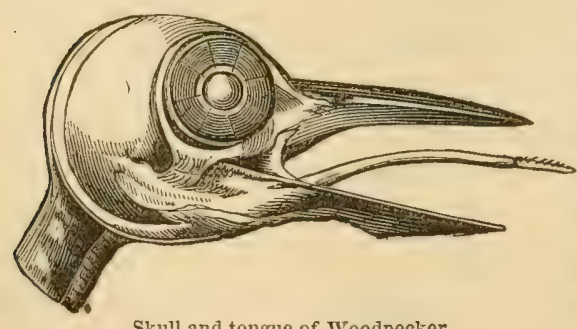

Skull and tongue of Woodpecker. months, and is, to some extent, a resident through the year. Probably the greater number retire to the North in the breeding season; and those that remain in the southern districts of these States most usually seek the woods for their summer homes, and are, as a general thing, seldom met with in the thickly settled districts. The flight is a wavering, undulating one, like that of all the woodpeckers; consisting of a series of short vibrations of the wings, followed by a downward, soaring movement, which is succeeded by another similar series. On alighting, the bird 


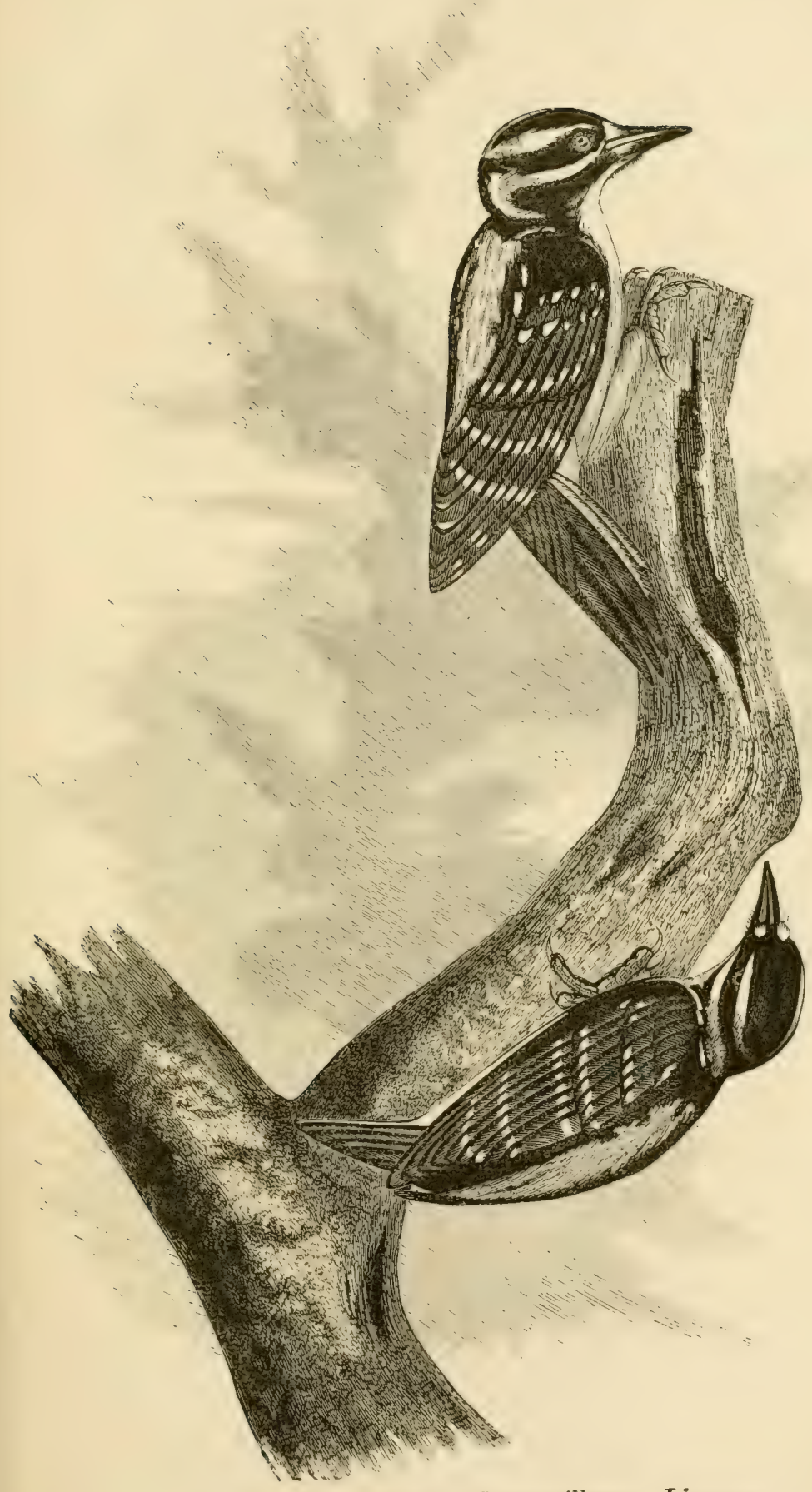

Hairy Woodpecker, Picus villosus. Linnæus. 

strikes its object with both feet, and makes no discrimination between a horizontal branch or limb and a perpendicular one. It commences its building operations quite early, often by the 20th of April. The nest is made by excavating in old trees in the woods, rarely in orchards: the hole made is often as much as eighteen inches in depth, in some cases hardly five inches. A post in a fence is sometimes taken for a brecding-place, the hole in which the rail is inserted furnishing a starting-place for the excavation of the nest.

The eggs are usually five in number; seldom more, often less: they are of a beautiful clear-white color, and the shell is very smooth and rather thin; and, before the contents of the egg are remored, they impart a rosy tint to it. Specimens vary in size from .77 to .84 inch in length, by from .62 to .68 inch in breadth.

The nest is never lined with leaves or other soft materials, so far as my observation has been; but the eggs are deposited on a small pile of chips of the rotten wood, which seem to be left by the bird designedly for this purpose.

The food of this species consists principally of the eggs and larvæ of injurious insects that are burrowing in the wood of our fruit and forest trees: these he is enabled to obtain by chiselling out a small hole with his powerful bill, and drawing them from their lurking-places with his long barbed tongue. He also eats some small fruits and berries, but never, so far as I am aware, the buds or blossoms of trees, as some persons assert.

\section{PICUS PUBESCENS. - Linnceus.}

The Downy Woodpecker.

Picus pubescens, Linnæus. Syst. Nat., I. (1766) 15. Vieill. Ois. Am. (1807) 65.

"Picus pubescens," Linnæus, Wilson. Am. Orn. I. (1808) 153. Aud. Orn. Biog. II. (1834).

\section{Description.}

A miniature of $P$. villosus. Above black, with a white band down the back; two white stripes on the side of the head; the lower of opposite sides always separated; the upper sometimes confluent on the nape; two stripes of black on the side of the 
head, the lower not running into the forehead; beneath white; wing much spotted with white; the larger coverts with two series each; tertiaries or inner secondaries all banded with white; two outer tail feathers white, with two bands of black at the end, third white at tip and externally. Male, with red terminating the white feathers on the nape; legs and feet bluish-green; claws light-blue tipped with black; iris dark-hazel.

Length, about six and a quarter inches; wing, three and three-quarters.

This little Woodpecker - the smallest we have - is abundantly distributed throughout New England, and is a resident throughout the year. The exceedingly interesting description of its habits, by Wilson, is so full that I will give it entire. He says:-

"About the middle of May, the male and female look out for a suitable place for the reception of their eggs and young. An apple, pear, or cherry tree - often in the near neighborhood of the farmhouse - is generally fixed upon for this purpose. The tree is minutely reconnoitred for several days previous to the operation; and the work is first begun by the male, who cuts out a hole in the solid wood as circular as if described with a pair of compasses. He is occasionally relieved by the female, both parties working with the most indefatigable diligence. The direction of the hole, if made in the body of the tree, is generally downwards, by an angle of thirty or forty degrees, for the distance of six or eight inches, and then straight down for ten or twelve more: within, roomy, capacious, and as smooth as if polished by the cabinet-maker; but the entrance is judiciously left just so large as to admit the bodies of the owners. During this labor, they regularly carry out the chips, often strewing them at a distance, to prevent suspicion. This operation sometimes occupies the chief part of a week. Before she begins to lay, the female often visits the place, passes out and in, examines every part-both of the exterior and interior - with great attention (as every prudent tenant of a new house ought to do), and at length takes complete possession. 'The eggs are generally six, pure-white, and laid on the smooth bottom of the cavity. The male occasionally supplies the female with food while she is sitting; and, about the last week in June, the young are perceived making their way up the tree, climbing with considerable dexterity. All this goes on with great regularity where no interruption is met 
with; but the House Wren, who also builds in the hollow of a tree, but who is neither furnished with the necessary tools nor. strength for excavating such an apartment for himself, allows the woodpeckers to go on till he thinks it will answer his purpose, then attacks them with violence, and generally succeeds in driving them off. I saw, some weeks ago, a striking example of this, where the Woodpeckers we are now describing, after commencing in a cherry-tree, within a few yards of the house, and having made considerable progress, were turned out by the Wren. The former began again on a pear-tree in the garden, fifteen or twenty yards off, whence, after digging out a most complete apartment, and one egg being laid, they were once more assaulted by the same impertinent intruder, and finally forced to abandon the place.

"The principal characteristics of this little bird are diligence, familiarity, perseverance, and a strength and energy in the head and muscles of the neck which are truly astonishing. Mounted on the infected branch of an old apple-tree, where insects have lodged their corroding and destructive brood in crevices between the bark and wood, he labors sometimes for half an hour incessantly at the same spot, before he has succeeded in dislodging and destroying them. At these times, you may walk up pretty close to the tree, and even stand immediately below it, within five or six feet of the bird, without in the least embarrassing him. The strokes of his bill are distinctly heard several hundred yards off; and I have known him to be at work for two hours together on the same tree. Buffon calls this 'incessant toil and slavery;' their attitude, 'a painful posture;' and their life, 'a dull and insipid existence,' expressions improper because untrue, and absurd because contradictory. The posture is that for which the whole organization is particularly adapted; and though to a Wren or a Hummingbird the labor would be both toil and slavery, yet to him it is, I am convinced, as pleasant and as amusing as the sports of the chase to the hunter, or the sucking of flowers to the Hummingbird. The eagerness with which he traverses the upper and lower sides of the branches, the cheerfulness of his cry, and the liveliness of his motions while digging into the tree and clislodging the vermin, justify this belief. He has a single note, or chink, which, like the former species, he frequently repeats; and when he flies 
off, or alights on another tree, he utters a rather shriller cry, composed of nearly the same kind of note, quickly reiterated. In fall and winter, he associates with the Titmouse, Creeper, \&c., both in their wood and orchard excursions, and usually leads the van. Of all our Woodpeckers, none rid the apple-trees of so many vermin as this, digging off the moss which the negligence of the proprietor had suffered to accumulate, and probing every crevice. In fact, the orchard is his favorite resort in all seasons; and his industry is unequalled and almost incessant, which is more than can be said of any other species we have. In fall, he is particularly fond of boring the apple-trees for insects, digging a circular hole through the bark, just sufficient to admit his bill; after that, a second, third, \&c., in pretty regular horizontal circles round the body of the tree: these parallel circles of holes are often not more than an inch or an inch and a half apart, and sometimes so close together that I have covered eight or ten of them at once with a dollar. From nearly the surface of the ground up to the first fork, and sometimes far beyond it, the whole bark of many apple-trees is perforated in this manner, so as to appear as if made by successive discharges of buck-shot; and our little Woodpecker - the subject of the present account - is the principal perpetrator of this supposed mischief: I say supposed, for, so far from these perforations of the bark being ruinous, they are not only harmless, but, I have good reason to believe, really beneficial to the health and fertility of the tree. I leave it to the philosophical botanist to account for this; but the fact I am confident of. In more than fifty orchards which I have myself carefully examined, those trees which were marked by the Woodpecker (for some trees they never touch, perhaps because not penetrated by insects) were uniformly the most thriving, and seemingly the most productive. Many of these were upwards of sixty years old, their trunks completely covered with holes, while the branches were broad, luxuriant, and loaded with fruit. Of decayed trees, more than three-fourths were untouched by the Woodpecker. Several intelligent farmers, with whom I have conversed, candidly acknowledge the truth of these observations, and with justice look upon these birds as beneficial : but the most common opinion is, that they bore the tree to suck the sap, and so destroy its vegetation: though pine and other resinous trees, 
on the juices of which it is not pretended they feed, are often found equally perforated. Were the sap of the tree their object, the saccharine juice of the birch, the sugar-maple, and several others, would be much more inviting (because more sweet and nourishing) than that of either the pear or apple tree; but I have not observed one mark on the former for ten thousand that may be seen on the latter. Besides, the early part of spring is the season when the sap flows most abundantly; whereas, it is only during the months of September, October, and November, that Woodpeckers are seen so indefatigably engaged in orchards, probing every crack and crevice, boring through the bark - and, what is worth remarking, chiefly on the south and south-west sides of the tree-for the eggs and larvæ deposited there by the countless stvarms of summer insects. These, if suffered to remain, would prey upon the very vitals - if I may so express it - of the tree, and in the succeeding summer give birth to myriads more of their race, equally destructive.

"Here, then, is a whole species, I may say genus, of birds, which Providence seems to have formed for the protection of our fruit and forest trees from the ravages of vermin, which every day destroy millions of those noxious insects that would otherwise blast the hopes of the husbandman; they even promote the fertility of the tree, and, in return, are proscribed by those who ought to have been their protectors, and,incitements and rewards held out for their destruction! Let us examine better into the operations of nature, and many of our mistaken opinions and groundless prejudices will be abandoned for more just, enlarged, and humane modes of thinking."

The nest and eggs are of the saine description as the Hairy Woodpecker's, except with regard to size; the egg's of the present species being considerably smaller on the average, measuring from .73 to .77 inch in length, by from .60 to .53 inch in breadth. I think that the nests of this species, as of some others, are used for successive seasons, as I have found apparently old nests occupied by breeding birds. I am not aware that the Hairy Woodpecker uses the same nest several seasons. The Downy 
Woodpecker sometimes rears two broods in the southern portion of Nerw England; usually, but one.

\section{PICOIDES, LACEPEDE.}

Picoides, LAcepede, Mem. Inst. (1799).

Bill about as long as the head, very much depressed at the base; the outlines nearly straight; the lateral ridge at its base much nearer the commissure than the culmen, so as to bring the large rather linear nostrils close to the edge of the commissure; the gonys very long, equal to the distance from the nostrils to the tip of the bill; feet with only three toes; the outer lateral a little longer than the inner, but slightly exceeded by the hind toe, which is about equal to the tarsus; wings very long, reaching beyond the middle of the tail; fourth and fifth quills longest; color black, with a broad patch of yellow on the crown; transversely banded on the sides; quills with round spots.

\section{PICOIDES ARCTICUS, - Gray.}

\section{The Black-backed, Three-toed Woodpecker.}

Picus (Apternus) arcticus. Sw. F. Bor. Am., II. (1831) 313.

Picus arcticus. Aud. Syn. (1839)-182. Ib., Birds Amer., IV.(1842) 266. Nuttall, Man., I. (20 ed. 1840) 691.

Picus tridactylus, Bonaparte. Am. Orn., II. (1828) 14. Aud. Orn. Biog., II. (1834).

\section{Description.}

Above entirely uniform glossy bluish-black; a square patch on the middle of the crown saffron-yellow, and a few spots on the outer edges of both webs of the primary and secondary quills; beneath white, on the sides of the breast longitudinally striped, and on the sides of the belly and on the flanks and tibial region banded transversely with black; a narrow concealed white line from the eye a short distance backwards, and $\mathrm{a}$ white stripe from the extreme forehead (meeting anteriorly) under the eye, and down the sides of the neck; bristly feathers of the base of the bill brown; exposed portion of the two outer tail feathers (first and second) white; bill bluish-black, the lower mandible grayish-blue; iris bluish-black. Female, without yellow on the head.

Length, about nine and $a_{6}$ half inches; wing, five; tail, three eighty-five onehundredths.

This species is rare in the three southern New-England States, where it is found only as a winter visitor. In the others, it is not very abundant, and is only resident, in the most northern sections, in the neighborhood of, or in, the deep forests and uninhabited districts, through the year.

Its habits are similar to those of the other woodpeckers. I have had abundant opportunities of noticing them, and have discovered nothing peculiar in them, or worthy of re- 
mark. Its breeding habits are not well known; but it probably breeds in all the large forests of Northern Maine, New Hampshire, and Vermont.

I was so fortunate as to find two nests in the month of June, 1864, in the valley of the Magalloway River, about forty miles north of Lake Umbagog, Me. The holes were both excavated in hemlock stumps, about ten feet from the ground; they were not over an inch and a half in diameter, and were about ten inches in depth: the bottom of the hole formed the nest, which, as with the other species, was nothing but a few chips and bits of wood. The first nest, found on the 15th of June, had three young birds, apparently about a week old. The second nest had three eggs: these were of a beautiful clear-white color, and the shells remarkably smooth to the touch. Their dimensions varied only from .83 to .85 inch in length, by .75 to .77 inch in breadth.

$$
\text { PICOIDES HIRSUTUS. - Gray. }
$$

\section{The Banded Three-toed Woodpecker.}

Picus hirsutus, Vieillot. Ois. Am. Sept., II. (1807) 68. Aud. Orn. Biog., V. 16, 39, 184. Ib., Birds Am., IV. (1842), pl. 269. Nutt. Man., I. (2d ed. 1840) 692.

\section{DESCRIPTION.}

Black above; the back with transverse bands of white to the rump; a white line from behind the eye, widening on the nape, and a broader one under the eye from the loral region, but not extending on the forehead; occiput and sides of the head uniform black; quills spotted on both webs with white; under parts white; the sides banded transversely with black; top of the head spotted with white; the crown of the male with a yellow patch; bill bluish-black; iris dark-hazel.

Length, about nine inches; wing, four forty-five one-hundredths; tail, three thirty-five one-hundredths.

This bird is rarely found in New England, except in the midst of severe winters, and then it seldom penetrates so far south as Massachusetts. I have known of but two or three specimens being obtained in this State, and never heard of any being shot in the others south of it. Having had no opportunities for observing its habits, I can add nothing to our knowledge of this species. 


\section{SPHYRAPICUS, BAIRD.}

Pilumnus, Bonaparte. Consp. Zygod. Ateneo Italiano, May, 1854. (P. thyroideus.)

Bill as in Picus, but the lateral ridge, which is very prominent, running out distinctly to the commissure at about its middle, beyond which the bill is rounded without any angles at all; the culmen and gonys are very nearly straight, but slightly convex, the bill tapering rapidly to a point; the lateral outline concave to very near the slightly bevelled tip; outer pair of toes longest; the hinder exterior rather longest; the inner posterior toe very short, less than the inner anterior without its claw; wings long and pointed, the fourth longest; tail feathers very broad, abruptly acuminate, with a very long linear point.

\section{SPHYRAPICUS VARIUS. - Baird.}

\section{The Yellow-bellied Woodpecker.}

Picus varius, Linnæus. Syst. Nat., I. (1766) 176. Wilson, Am. Orn., I. (1808) 147. Aud. Orn. Biog., II. (1834) 519.

\section{Description.}

Fourth quill longest; third a little shorter; fourth considerably shorter; general color above black, much variegated with white; feathers of the back and rump brownish-white, spotted with black; crown scarlet, bordered by black on the sides of the head and nape; a streak from above the eye, and another from the bristles of the bill, passing below the eye and into the yeliowish of the belly, and a stripe along the edges of the wing coverts white; a triangular broad patch of scarlet on the chin, bordered on each side by black stripes from the lower mandible, which meet behind, and extend into a large quadrate spot on the breast; rest of under parts yellowishwhite, streaked on the sides with black; inner web of inner tail-feather white, spotted with black; outer feathers black, edged and spotted with white. Female, with the red of the throat replaced by white. Young male, without black on the breast, or red on the top of the head; iris dark-hazel.

Length, eight and a quarter inches; wing, about four and three-quarters; tail, three thirty one-hundredths.

This bird is very irregularly distributed in New England as a summer visitor. Verrill, in his Catalogue, before referred to, says that it is a common summer visitor, and breeds at Norway, Me. J. A. Allen says, that near Springfield " it is not common, and is only seen in fall and spring, when migrating. I have never seen this species here in summer, and do not think it breeds here; though I am informed by W. H. Niles that 'they breed plentifully on the hills in Western Massachusetts, twenty or thirty miles west of Springfield." " 
So far as my own observation has been, it is not found at all abundant in any part of these States ; and I think, that, on the seaboard, it is rare.

It arrives from the South, from about the 10 th to the 20 th of April, and soon commences pairing. I have never noticed any great peculiarity in its habits. It seems to prefer the woods to the more open districts, and very seldom indeed makes its appearance, in the breeding season, in the orchards and nurseries, where, as it is often said by persons who are prejudiced, it does considerable damage in boring into appletrees and sucking the sap; hence it is called the "Sapsucker." I am not sufficiently acquainted with its habits, in the Western States, to say positively that it does not eat some of the inner bark of trees, when in pursuit of its favorite insect-food; but I cannot help thinking that the denunciations of it, so often seen in the Western papers, are exaggerated.

Dr. Bryant, who has paid some attention to the examination of the food of this bird, gives, in the "Proceedings of the Boston Society of Natural History," vol. X. 91, the following remarks :-

"It has long been known that some of our smaller woodpeckers pick out portions of the sound bark of trees, particularly of appletrees, where there are no larvæ, and apparently no inducement for them to do so. What their object is has never been satisfactorily established. In Massachusetts, I am not aware that these holes are ever sufficiently large or numerous to cause any material injury to the apple-trees: they are generally seen in circles round the limbs or trunks of small irregularly rounded holes, and in this vicinity are made almost exclusively by the Downy Woodpecker ( $P$. pubescens), aided occasionally by the Hairy Woodpecker ( $P$. villosus). In certain parts of the West, however, it is said that great damage is done to orchards by the Yellow-bellied Woodpecker (S. varius); and Dr. Hoy, of Racine, Wis., has advanced the theory that the object of the bird in so doing is to obtain the inner bark for food. A number of specimens of this bird, forwarded by Dr. Hoy to the Smithsonian Institution, have been 
placed in my hands by Professor Baird for examination: as the specimens are alcoholic, the soft parts are, as is always the case, too much distorted to be available for correct comparisons; the . gizzard, however, seems smaller, and the proventriculus larger, than in other species of this family with which I have compared them. The contents of the stomach are berries, small coleoptera, larvæ of boring beetles, ants, and fragments of the inner bark of the appletree."

After giving minuto analyses of the characteristics of the tongues and portions of the skulls of the different small woodpeckers, and comparing them with the Yellow-bellied Woodpecker's, showing how the latter differ from the others, he says:-

"The general shape of the whole tongue is not much unlike that of the Robin; the ciliated edges show an analogy to the Melipha gida, and indicate that the sap of the trees pecked by them may form a portion of their food. In the stomachs of the six individuals examined by me, fragments of the inner bark were found in all, so that it can hardly be presumed to have been accidentally introduced. It is evident, from the shape of the tongue, that it is not used as a dart, in the manner of the true Woodpecker, to draw out insects from their lurking-places, but that these are seized by the bill, as in other insectivorous birds. Insects, however, probably form their chief diet, as all the stomachs examined also contained insects, the quantity of which was greater than that of the fragments of bark: in one bird, there were two larvæ of a boring beetle, so large that there was not room for both in the stomach at once, and one remained in the lower part of the œsophagus. If these were, as is probable, the larvæ of the Saperda, they would do more damage than twenty woodpeckers; and I sincerely hope that these birds are not to be exterminated, unless it is clearly demonstrated that the injury caused by the destruction of the bark is not more than compensated by their destruction of noxious insects."

About the 1st of May, the Yellow-bellied Woodpecker commences excavating its hole, which is usually in a decayed tree in the woods, but occasionally in a sound tree. 
This excavation is often eighteen or twenty inches deep. It is not lined with any soft material, and the eggs are deposited on chips of the wood left in the bottom. These are usually five in number; they are of a pure-white color, and small for the size of the bird, measuring from .82 to .86 inch in length, by from .74 to .77 inch in breadth.

\section{HYLATOMUS, BAIRD.}

Dryotomus, Malnerie, Mem. Ac. Metz. (1849) 322. (Not of Swainson, 1831.)

Dryopicus, Borap. Consp. Zygod. in Aten. Ital. (May, 1854). (Not of Malherbe.)

Bill a little longer than the head; considerably depressed, or broader than high at the base; shaped much as in Campephilus, except shorter, and without the bristly feathers directed forwards at the base of the lower jaw; gonys about half the length of the commissure; tarsus shorter than any toe except the inner posterior; outer posterior toe shorter than the outer anterior, and a little longer than the inner anterior; inner posterior very short, not half the outer anterior, about half the inner anterior one.

Tail long, graduated, the longer feathers much incurved at the tip; wing longer than the tail, reaching to the middle of the exposed surface of tail, considerably graduated, though pointed, the fourth and fifth quills longest.

Color uniform black, with white patches on the side of the head; head with pointed crest.

\section{HYLATOMUS PILEATUS. - Baird.}

\section{The Pileated Woodpecker; Log Cock.}

Picus pileatus, Linnæus. Syst. Nat., I. (1766) 173. Vieill. Ois. Am. Sept., II. (1807) 58. Wilson, Am. Orn., IV. (1811) 27. Aud. Orn. Biog., II. (1834) 74.

\section{Description.}

Fourth and fifth quills equal and longest, third intermediate between the sixth and seventh; bill blue-black; general color of body, wings, and tail, dull greenishblack; a narrow white streak from just above the eye to the occiput, a wider one from the nostril feathers (inclusive) under the eye and along the side of the head and neck; side of the breast (concealed by the wing), axillaries, and under wing coverts, and concealed bases of all the quills, with chin and beneath the head, white, tinged with sulphur-yellow; entire crown, from the base of the bill to a well-developed occipital crest, as also a patch on the ramus of the lower jaw, scarlet-red; a few white crescents on the sides of the body and on the abdomen; iris very dark hazel.

Female without the red on the cheek, and the anterior half of that on the top of the head replaced by black.

Length, about eighteen inches; wing, nine and a half inches.

This species is a resident in the northern districts of New England throughout the year. It has been known 
to breed in Massachusetts; but, as a general thing; it is not found south of the northern border of this State. Verrill, in his Catalogue of Maine birds, before referred to, says "it is a common resident, and breeds :" he also says it is " most common in winter."

The great size and strength of this bird enable it to pierce into and tear apart the decaying trees in which its food is burrowing, with wonderful facility and ease. I have at times, in passing through the forest, found huge trees that had died and fallen to the ground, with their bark stripped off, and large chips torn out, as if some animal had been at work on them; and I always supposed that a bear had been amusing himself, as those animals sometimes do, in this employment. One day I discovered the author of the demolition, and it proved to be the Pileated Woodpecker. While seated in the woods near the settlement known as Wilson's Mills in Maine, I heard a large animal, as I supposed, rooting and tearing into a dead tree a few rods off. I crept up near the sound, hoping to get a shot at a bear, when I discovered this bird, which looked very much like a black hen, busily at work. He was searching for the borers and large black ants that hide beneath the bark; and so earnestly was he employed, that he permitted me to approach very near him. He would force his powerful bill, by repeated strokes, into the bark, in holes in a direct line with the grain, until he had marked out a patch, perhaps six or eight inches square, and then, striking into it diagonally, tear it off, thus exposing the living vermin beneath, which he lost no time in securing. After clearing that spot, he moved to another, and repeated the same operation, until, by a sudden movement, I startled him, when he flew off, uttering a rattling cackle similar to that of a garrulous hen. His flight was similar to that of the other woodpeckers described in another place in this volume. In addition to insects, this Woodpecker eats acorns, beech-nuts, berries, and Indian corn, but is not at all troublesome to farmers; 
and the little that it pilfers is much more than repaid by the immense numbers of injurious larræ that it destroys.

Wilson, in a very interesting account of the general habits of this bird, says:-

"Almost every trunk in the forest where he resides bears the marks of his chisel. Wherever he perceives a tree beginning to decay, he examines it round and round with great skill and dexterity, strips off the bark in sheets of five or six feet in length, to get at the hidden cause of the disease, and labors with a gayety and activity really surprising. He is sometimes observed among the hills of Indian corn, and it is said by some that he frequently feeds on it. Complaints of this kind are, however, not general; many farmers doubting the fact, and conceiving that at these times he is in search of insects which lie concealed in the husk. I will not be positive that they never occasionally taste maize, yet $I$ have opened and examined great numbers of these birds, killed in various parts of the United States, from Lake Ontario to the Alatamaha River, but never found a grain of Indian corn in their stomachs."

Audubon in his description of the breeding habits of this bird says, -

"The hole was about eighteen inches deep, and I could touch the bottom with my hand. The eggs, which were laid on fragments of chips expressly left by the birds, were six, large, white, and translucent. Before the woodpeckers began to set, I robbed them of their eggs, to see if they would lay a second time. They waited a few days, as if undecided, when, on a sudden, I heard the female at work again in the tree. She once more deepened the hole, made it broader at the bottom, and recommenced laying. This time she laid five eggs. I suffered her to bring out her young, both sexes alternately incubating, each visiting the other at intervals, peeping into the hole to see that all was right and well there, and flying off afterwards in search of food." 


\section{MELANERPES, SwAINSON.}

Melanerpes, Swainson, F. B. A., II. (1831) (type Mr. erythrocephalus).

Bill about equal to the head, broader than high at the base, but becoming compressed immediately anterior to the commencement of the gonys; culmen and gonys with a moderately decided angular ridge; both decidedly curved from the very base; a rather prominent acute ridge commences at the base of the mandible, a little below the ridge of the culmen, and proceeds but a short distance anterior to the nostrils (about one-third of the way), when it sinks down, and the bill is then smooth; the lateral outlines are gently concave from the basal two-thirds, then gently convex to the tip, which does not exhibit any abrupt bevelling; nostrils open, broadly oval, not concealed by the feathers, nor entirely basal; the outer pair of toes equal; wings long, broad; third and fourth quills longest; tail feathers broad.

The species all have the back black, without any spots or streaks anywhere.

MELANERPES ERTTHROCEPHALUS. - Swainson.

The Red-headed Woodpecker.

Picus erythrocephalus, Linnæus. Syst. Nat., I. (1766) 174. Wilson, Am. Orn., I. (1810) 142. Aud. Orn. Biog., I. (1832).

\section{DESCRIPTION.}

Head and neck all round crimson-red, margined by a narrow crescent of black on the upper part of the breast; back, primary quills, and tail, bluish-black; under parts generally, a broad band across the middle of the wing, and the rump white; iris hazel; bill and feet bluish-black. The female is not different.

Length about nine and three-quarters inches; wing, five and a half.

This handsome Woodpecker is a not very common summer inhabitant of New England. It makes its appearance from the South about the 10th of May. Its habits are similar to those of the other species; and I recollect nothing of any importance that is peculiar to them except, perhaps, that these birds seem to be much fonder of the small fruits than either of the others. Wilson says of this fact:-

"Wherever there is a tree, or trees, of the wild cherry, covered with ripe fruit, there you see them busy among the branches; and, in passing orchards, you may easily know where to find the earliest, sweetest apples, by observing those trees on or near which the Red-headed Woodpecker is skulking: for he is so excellent a connoisseur in fruit, that, wherever an apple or pear is found broached by him, it is sure to be among the ripest and best flavored. When 



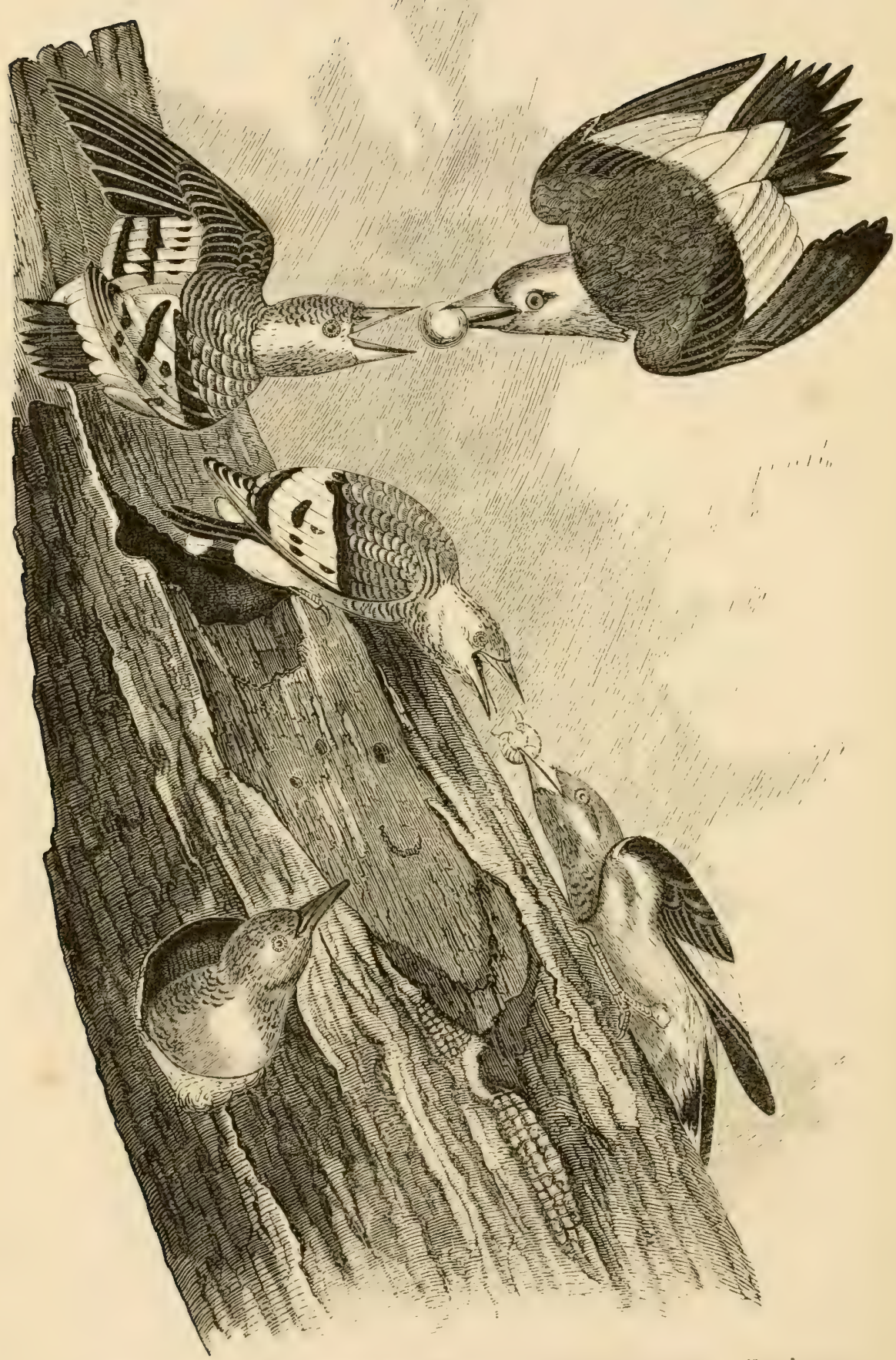

Red-Headed WoOdpecker, Melanerpes erylleroceplenlus. Swainson. 
alarmed, he seizes a capital one by striking his open bill deep into it, and bears it off to the woods. When the Indian corn is in its rich, succulent, milky state, he attacks it with great eagerness, opening a passage through the numerous folds of the husk, and feeding on it with voracity. The girdled or deadened timber, so common among corn-fields in the back settlements, are his favorite retreats, whence he sallies out to make his depredations. He is fond of the ripe berries of the sour gum, and pays pretty regular visits to the cherry-trees, when loaded with fruit. 'Towards fall, he often approaches the barn or farm-house, and raps on the shingles and weather-boards: he is of a gay and frolicsome disposition; and half a dozen of the fraternity are frequently seen diving and vociferating around the high, dead limbs of some large tree, pursuing and playing with each other, and amusing the passenger with their gambols. Their note, or cry, is shrill and lively; and so much resembles that of a species of tree-frog, which frequents the same tree, that it is sometimes difficult to distinguish the one from the other.

"Such are the vicious traits, if I may so speak, in the character of the Red-headed Woodpecker; and I doubt not but, from what has been said on this subject, that some readers would consider it meritorious to exterminate the whole tribe as a nuisance; and, in fact, the legislatures of some of our provinces, in former times, offered premiums to the amount of twopence per head for their destruction. ${ }^{1}$ But let us not condemn the species unheard: they exist, they must therefore be necessary. If their merits and usefulness be found, on examination, to preponderate against their vices, let us avail ourselves of the former, while we guard as well as we can against the latter.

"Though this bird occasionally regales himself on fruit, yet his natural and most useful food is insects, particularly those numerous and destructive species that penetrate the bark and body of the tree to deposit their eggs and larva, the latter of which are well known to make immense havoc. That insects are his natural food is evident from the construction of his wedge-formed bill, the length, elasticity, and figure of his tongue, and the strength and position of his claws, as well as from his usual habits. In fact,

1 KaLM. 
insects form at least two-thirds of his subsistence; and his stomach is scarcely ever found without them. He searches for them with a dexterity and intelligence, I may safely say, more than human: he perceives, by the exterior appearance of the bark, where they lurk below; when he is dubious, he rattles vehemently on the outside with his bill, and his acute ear distinguishes the terrified vermin shrinking within to their inmost retreats, where his pointed and barbed tongue soon reaches them. The masses of bugs, caterpillars, and other larvæ, which I have taken from the stomachs of these birds, have often surprised me. These larvæ, it should be remembered, feed not only on the buds, leaves, and blossoms, but on the very vegetable life of the tree, - the alburnum, or newly forming bark and wood. The consequence is, that the whole branches and whole trees decay under the silent ravages of these destructive vermin; witness the late destruction of many hundred acres of pine-trees in the north-eastern parts of South Carolina, and the thousands of peach-trees that yearly decay from the same cause. Will any one say, that, taking half a dozen, or half a hundred, apples from a tree, is equally ruinous with cutting it down? or that the services of a useful animal should not be rewarded with a small portion of that which it has contributed to preserve? We are told, in the benevolent language of the Scriptures, not to muzzle the mouth of the ox that treadeth out the corn; and why should not the same generous liberality be extended to this useful family of birds, which forms so powerful a phalanx against the inroads of many millions of destructive vermin ?"

About the middle of May, this species pairs, and soon commences excavating a hole in a tree, either in the woods or orchard, as he is not particular in his choice. This work is done by both the birds, who labor with industry and cheerfulness until the excavation is finished; this is from fourteen to eighteen inches deep, and, like those of other woodpeckers, is roomy at the bottom, and tapering gradually to the entrance, which is only large enough for the comfortable passage of the bird: it is not lined, but the bottom is partly covered with chips from the sides of the hole. The 
eggs are generally five or six in number, and of a beautiful clear-white. Dr. Thompson says, in his "Birds of Vermont," that "they are marked with reddish spots at the large end." This was a mistake; for the eggs of woodpeckers are always immaculate. The shell is smoother than that of any other woodpecker's egg of my acquaintance. Length of specimens vary from 1.07 to $1.12 \mathrm{inch}$, breadth from .77 to .84 inch.

\section{COLAPTES, Swainson.}

Colaptes, Swainson, Zool. Jour., III. (Dec. 1827) 353 (type C. auratus).

Bill slender, depressed at the base, then compressed; culmen much curved; gonys straight, both with acute ridges, and coming to quite a sharp point with the commissure at the end; the bill consequently not truncate at the end; no ridges on the bill; nostrils basal, median, oval, and exposed; gonys very short, about half the culmen; feet large, the anterior outer toe considerably longer than the posterior; tail long, exceeding the secondaries, the feathers suddenly acuminate, with elongated points.

\section{COLAPTES AURATUS. - Swainson.}

The Golden-winged Woodpecker; Flicker; Pigeon Woodpecker.

Picus auratus, Linnæus. Syst. Nat. (1766) 174. Wilson, Am. Orn., I. (1810) 45. Aud. Orn. Biog., I. (1832) 191.

\section{DESCRIPTION.}

Shafts and under surfaces of wing and tail feathers gamboge-yeliow; a black patch on each side of the cheek; a red crescent on the nape; throat and stripe beneath the eye pale lilac-brown; back glossed with olivaceous-green; female without the black cheek patch; a crescentic patch on the breast, and rounded spots on the belly, black; back and wing coverts with interrupted transverse bands of black; neck above and sides ashy.

Length, about twelve and a half inches; wing, six.

This is a very common summer inhabitant of New England. It is probably the most abundant of all the woodpeckers, and is very generally known. It is in the southern districts of these States a resident throughout the year; and in Massachusetts I have often met with it in midwinter, when the season was not of the mildest either. They begin to arrive from the south at about the second week in March. 
The habits of this bird are so well known, that any description here seems to be a work of supererogation. About the first week in May, the males begin to pay court to the females; at this period their movements are amusing.

"Their note is merriment itself, as it imitates a prolonged and jovial laugh, heard at a considerable distance. Several males pursue a female, reach her, and, to prove the force and truth of their love, bow their heads, spread their tails, and move sidewise, backwards, and forwards, performing such antics as might induce any one witnessing them, if not of a most morose temper, to join his laugh to theirs. The female flies to another tree, where she is closely followed by one, two, or even half a dozen of these gay suitors, and where again the same ceremonies are gone through. No fightings occur, no jealousies seem to exist among these beaux, until a marked preference is shown to some individual, when the rejected proceed in search of another female. In this manner, all the Goldenwinged Woodpeckers are soon happily mated. Each pair immediately proceed to excavate the trunk of a tree, and finish a hole in it sufficient to contain themselves and their young. They both work with great industry and apparent pleasure. Should the male, for instance, be employed, the female is close to him, and congratulates him on the removal of every chip which his bill sends through the air. While he rests, he appears to be speaking to her on the most tender subjects, and when fatigued is at once assisted by her. In this manner, by the alternate exertions of each, the hole is dug and finished." - AdDUBon.

This is often as much as twenty inches in depth, and in a solid tree very often at that. On the bottom of this hole, the female lays six pure-white eggs: these are generally of uniform ovoidal shape, and vary in size from 1 to 1.16 inch in length, by from .82 to $.92 \mathrm{in}$ breadth.

When the eggs are removed, the female, after a couple of days' deliberation, lays another litter ; and I have known of this being repeated several times by a bird that was unwilling to leave the nest which she and her mate had been at so much labor to prepare. Instances have occurred 


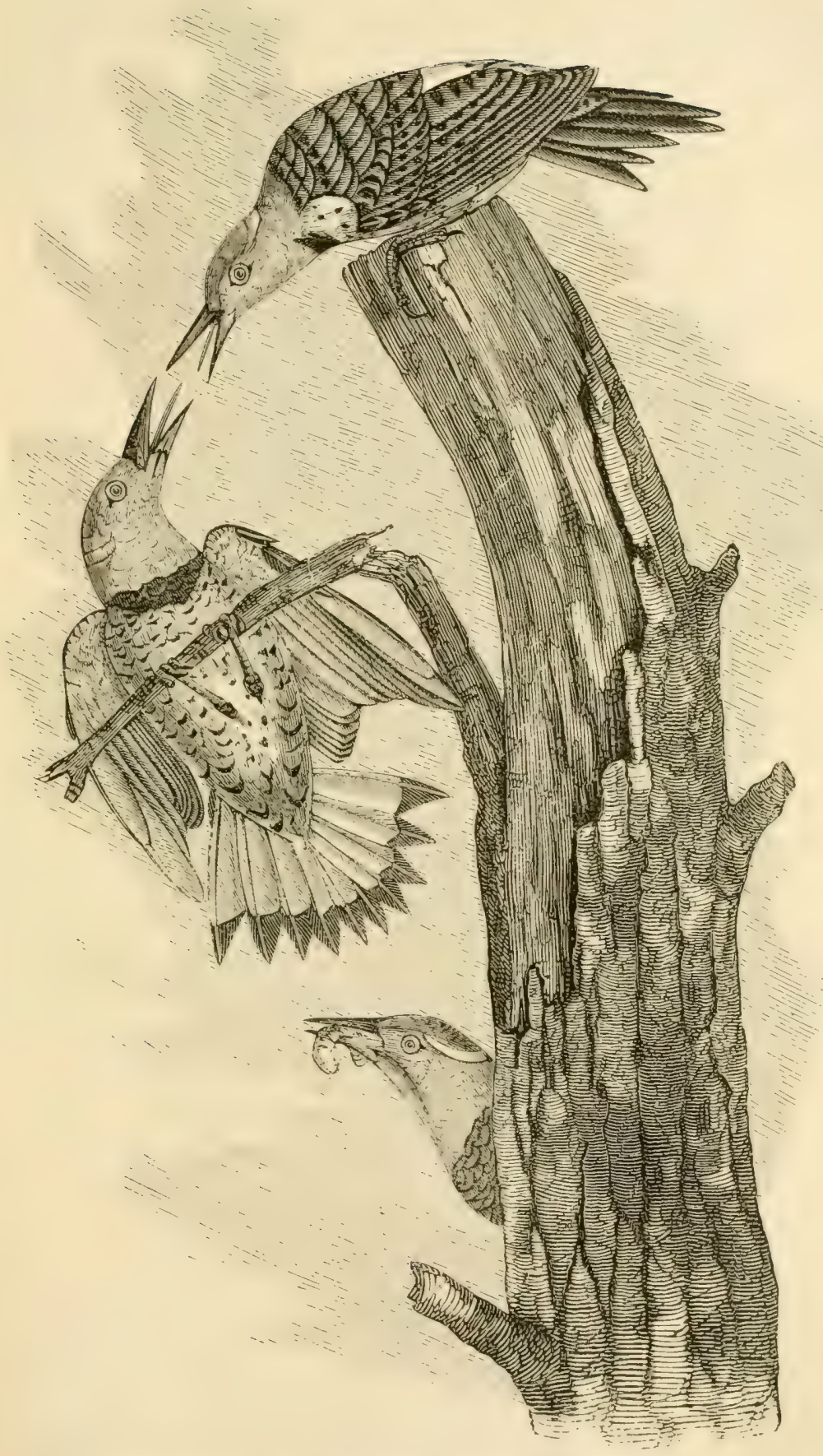

Golden-winged Woodiecker, Coluptes auratus. Siwainson. 

of this bird's laying eighteen or twenty eggs in a few days, they being removed as soon as laid, and only two or three being left in the nest at a time. The food of this species consists of insects, berries, and grains. Ants are greedily eaten by it, and constitute no inconsiderable portion of its diet. On visiting the nest at night, I have very seldom been able to catch the old bird in it; she almost always heard my approach, and took flight: once I caught her on the nest; but, as I put my hand in to secure her, she attacked it with fierce pecks of her bill, and made such an onslaught that I was glad to permit her to escape. But one brood is reared in the season. 


\section{ORDER III. - INSESSORES. PERChERS.}

In accordance with the views of many systematic writers, it may perhaps be as well to retain an order Insessores, and to place in it the Strisores, Clamatores, and Oscines as sub-orders. The characters of the order will then consist chiefly in the possession of three toes in front and one behind (or, at least, never with two toes directed backwards), as in Scansores. The claws are not retractile, nor the bill with a cere, as in the Raptores; nor is the hind toe situated appreciably above the plane of the others, as in Rasores, Grallatores, and Natatores.

The hind toe of the Insessores corresponds to the thumb or inner toe of the mammals, and is usually quite short. The joints of the anterior toes generally follow the law of number characteristic of birds; namely, two to the hinder, three to the inner, four to the middle, and five to the outer toes: but a deviation is seen in some Strisores, where there are sometimes but three joints each to. the anterior toes, and sometimes only four in the outer. The tarsi are generally covered anteriorly with plates, and furnished behind with granulations or small scales, or else with two long plates covering the sides, the latter feature especially characteristic of the Oscines, or singing-birds: in the latter alone is the tarsus sometimes covered anteriorly with a single plate. Sometimes the tarsus is entirely or partly naked, or destitute of plates altogether.

The carpal joint or the hand part of the wing is in most Insessores furnished with ten quills (primaries), although the first quill is sometimes very short, or even entirely wanting, as in many Oscines. The fore-arm has from six (in the Humming-birds) to thirteen quills, the average being eight or nine.

There are certain peculiarities in the arrangement of he wing coverts of the different sub-orders of Insessores, constituting important distinctive features. Some of these will be hereafter referred to. 
The tail of the Insessores exhibits considerable differences. The number of feathers is usually twelve; sometimes ten only, as in the Strisores.

The different groups of the order Insessores are subject to considerable variations in respect to the structure of the lower larynx attached to the trachea or windpipe just anterior to its division into the two bronchial tubes. Cuvier long since showed, that the true singing-birds had the larynx provided with a peculiar apparatus for the purpose of effecting a modulation of the voice, composed of five pairs of muscles, of which other birds were destitute in greater part, or entirely. The characteristic of the groups Strisores, Clamatores, and Oscines, and of their subdivisions, as will be shown hereafter, depend very much on these peculiarities of the larynx.

The tongue of the Insessores varies to a considerable degree. In the Humming-birds, it is thread-like and bifurcated. In most other insessorial or perching birds, it is long or short, flat, and triangular, the posterior extremity bilobed, the anterior usually with the tip horny, serrated, or with fibres, more rarely smooth. These furnish important characteristics for the division into families, and even genera; the variations being quite considerable.

See Introduction, and vol. IX., Pacific R.R. Reports, 128. 


\section{SUB-ORDER STRISORES.}

\section{Famly TROCHILID AE. The Huming-BIRDs.}

There is no group of birds so interesting to the ornithologist or to the casua observer as the Humming-birds; at once the smallest in size, the most gorgeously beautiful in color, and almost the most abundant in species of any single family of birds. They are strictly confined to the continent and islands of America, and are most abundant in the Central-American States; though single species range almost to the Arctic regions on the north and to Patagonia on the south, as well as from the seacoast to the frozen summits of the Andes. The number of known species considerably exceeds three hundred, and new ones are being constantly brought to light; so that an estimate of four hundred species is, perhaps, not too large. Many are very limited in their range; some confined to particular islands, even though of small dimensions.

The bill of the Humming-bird is awl-shaped or subulate, thin, and sharppointed, straight or curved; sometimes as long as the head, sometimes much longer. The mandibles are excavated to the tip for the lodgement of the tongue, and form a tube by the close apposition of their cutting edges. There is no indication of stiff bristly feathers at the base of the mouth. The tongue has some resemblance to that of the Woodpeckers in the elongation of the cornua backwards, so as to pass round the back of the skull, and then anteriorly to the base of the bill. The tongue itself is of very peculiar structure, consisting anteriorly of two hollow threads closed at the ends and united behind. The food of the Hummingbird consists almost entirely of insects, which are captured by protruding the tongue into flowers of various shapes, without opening the bill very wide.

The wings of the Humming-birds are long and falcate; the shafts very strong; the primaries usually ten in number, the first always longest; there are six secondaries. The tail has but ten feathers. The feet are small; the claws very sharp and strong.1

The species known to inhabit the United States, though few, are yet nearly twice as many as given by Mr. Audubon. It is probable that additional ones will hereafter be detected, particularly on our southern borders.

The different authors who have made a specialty of the Humming-birds have named a great many sub-families and genera; but there has as yet been no published systematic description of the higher groups. It is probable that the North-Ameri-

1 Most of the above general remarks are borrowed from Burmeister (Thiere Brasiliens, Vogel, 311), to which I would refer for an excellent article on the structure and habits of Humming-birds. 
can species belong to two different sub-families, - the Lampornithince and the Trow chilino, - and to at least four genera; but the precise character and limits of these I am unable to give. The following remarks, however, may serve to sketch out the characters of the North-American species:-

A. Edges of mandible serrated near the end; throat without metallic, scale-like feathers.

Lampornis. - Bill depressed, slightly curved; tail broad, slightly emarginate, the outer feather as broad as the rest; wings reaching the tip of tail; no metallic feathers on the throat.

B. Edges of mandible nearly even towards the tip, without distinct serrations; throat with metallic, scale-like feathers.

Trochilus. - Feathers of throat but little elongated laterally; lateral tail feathers but little narrower than the others, and lanceolate-acute; tail forked.

Selasphorus. - Feathers of the throat much elongated laterally into a ruff; lateral tail feathers much narrower than the middle ones, and linear in shape, or with the sides parallel to the end, which is rounded; tail graduated or cuneate; outer primary attenuated at the tip; crown without metallic scales.

Atthis. - Similar to the last, but the top of the head with metallic scales like the throat; the outer primary. not attenuated; tail emarginated, or deeply forked.

TROCHILUS, LINNAUS.

\section{TROCHILUS COLUBRIS. - Linncus.}

\section{The Ruby-throated Humming-bird.}

Trochilus colubris, Linnæus. Syst. Nat., I. (1766) 191. Wilson, Am. Orn., II. (1810) 26. Aud. Orn. Biog., I. (1832) 248. Ib., Birds Amer., IV. (1842) 190.

Ornismya colubris, Deville. Rev. et. Mag. Zool. (May, 1852) (habits).

\section{DESCRIPTION.}

Tail in the male deeply forked, the feathers all narrow lanceolate-acute; in the females lightly rounded and emarginate; the feathers broader, though pointed; male, uniform metallic-green above; a ruby-red gorget with no conspicuous ruff; a white collar on the throat; sides of body greenish; tail feathers uniformly brownish-violet; female, without the red on the throat; the tail is rounded and emarginate, the inner feathers shorter than the outer; the tail feathers banded with black, and the outer tipped with white; no rufous or cinnamon on the tail in either sex.

Length, three and twenty-five one-hundredths inch; wing, one and sixty onehundredths; tail, one and twenty-five one-hundredths inch; bill, sixty-five onehundredths.

TTHIS beautiful little winged gem is distributed through1 out New England as a summer visitor. It arrives from the south from about the 15th to the 25th of May, according to latitude, and usually in pairs. The first notice that we have of his arrival is a humming sound, and now 
and then a sharp chirp, like that of a large beetle, among the carliest flowers in the garden. We look in the direction of the sound, and perceive our little stranger darting about,

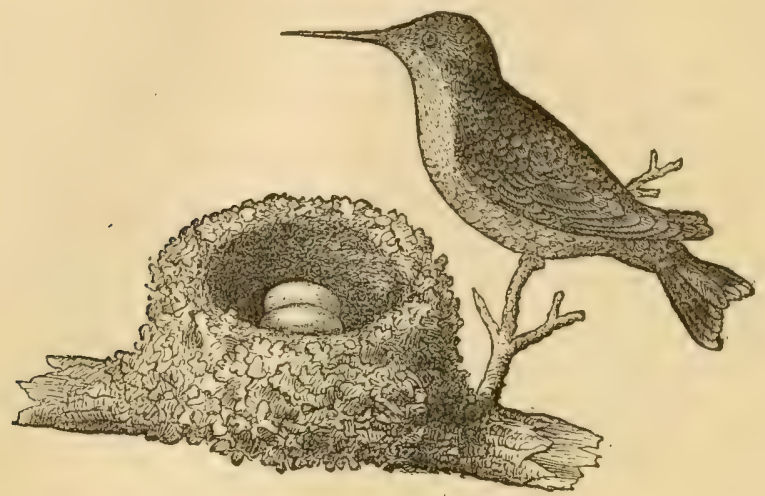

and thrusting his bill and little head into the flowers, busily searching for the small insects that inhabit them, and which constitute the principal part of his food. While we are looking at him, he suddenly alights on a twig, turns his gorgeous throat towards us, and scans us with his bright little black eyes. While he is perched, he busies himself in arranging his plumage, and cleaning from his feathers the drops of dew that have perhaps fallen upon him, uttering occasionally his merry chirp; presently his mate appears, and alights by his side. The little lovers (for they are still such) then indulge in mutual caresses, and apparently talk over with much earnestness their plans for future housekeeping. Woe to another humming-bird, if he comes in sight! for our little friend is not only jealous of his mate, but is very quarrelsome also, and protects his honor with great courage. As he darts off like a bullet at the intruder, his mate watches with no little interest for the results of the battle that is inevitable. The two males meet in the air, and fierce is the contest; their little wings beat the air with such force that their humming is heard at the 
distance of several rods; up they mount, rushing against and striking each other with their sharp little bills, until they are both lost to the sight: presently our acquaintance descends to the twig where his mate is seated, and struts before her with a pride much larger than his body, apparently anxious for her approval of his courage. She caresses him; and, after he has adjusted his plumage, off they shoot for other scenes and pleasures.

About the first week in June, the Humming-bird commences building its nest: this is composed of a soft down, that is taken from the stems of some of the ferns; it is covered entirely with lichens, which are glued on with the saliva of the bird, giving it the appearance of a mossy knot. It is usually built on the upper side of a limb; but I have known of cases of its being built in a forked twig. The whole fabric is about an inch and a half in diameter, and about that in depth externally; it is hollowed about half an inch, and is three-fourths of an inch in diameter internally; it is lined with soft, downy substances detached from flying seeds. The eggs are two in number, white, and nearly elliptical in shape, being of about equal size at both ends. Length of eggs, about .45 inch; breadth; about .31 inch. I am inclined to think, that, in the latitude of New England, this bird raises only one brood in the season; but further south it undoubtedly rears two. The period of incubation is ten days.

On approaching the nest, the parent bird immediately flies at the intruder; and it was by this means that I have been enabled to find specimens of the nests, when I could not possibly have done so if their locality had not been betrayed by the bird herself. I have heard of young birds being taken from the nest when nearly fledged, kept for several weeks, and fed with nothing but sweetened water; but they always died after a short confinemént, and I believe that it is impossible to keep this bird as a pet, from the 
fact that its actuai food is insects, and it cannot live on any other.

Wilson gives the following facts in relation to this. $\mathrm{He}$ says :-

"The singularity of this little bird has induced many persons to attempt to raise them from the nest, and accustom them to the cage. Mr. Coffer, of Fairfax County, Va., a gentleman who has paid great attention to the manners and peculiarities of our native birds, told me that he raised and kept two, for some months, in a cage, supplying them with honey dissolved in water, on which they readily fed. As the sweetness of the liquid frequently brought small flies and gnats about the cage and cup, the birds amused themselves by snapping at them on wing, and swallowing them with eagerness, so that these insects formed no inconsiderable part of their food. Mr. Charles Wilson Peale, proprietor of the Museum, tells me that he had two young Humming-birds, which he raised from the nest. They used to fly about the room, and would frequently perch on Mrs. Peale's shoulder to be fed. When the sun shone strongly in the chamber, he has observed them darting after the motes that floated in the light, as Flycatchers would after flies. In the summer of 1803, a nest of young Hummingbirds was brought me, that were nearly fit to fly. One of them actually flew out by the window the same evening, and, falling against a wall, was killed. The other refused food, and the next morning I could but just perceive that it had life. A lady in the house undertook to be its nurse, placed it in her bosom, and, as it began to revive, dissolved a little sugar in her mouth, into which she thrust its bill, and it sucked with great avidity. In this manner, it was brought up until fit for the cage. I kept it upwards of three months, supplied it with loaf sugar dissolved in water, which it preferred to honey and water, gave it fresh flowers every morning sprinkled with the liquid, and surrounded the space in which I kept it with gauze, that it might not injure itself. It appeared gay, active, and full of spirit, hovering from flower to flower as if in its native wilds; and always expressed, by its motions and chirping, great pleasure at seeing fresh flowers introduced to its cage. Numbers of people visited it from motives of curiosity; and I took every precaution to preserve it, if possible, 
through the winter. Unfortunately, however, by some means it got at large; and, flying about the room, so injured itself that it soon after died.

"This little bird is extremely susceptible of cold; and, if long deprived of the animating influence of the sunbeams, droops, and soon dies. A very beautiful male was brought me this season (1809), which I put into a wire cage, and placed in a retired, shaded part of the room. After fluttering about for some time, the weather being uncommonly cool, it clung by the wires, and hung in a seemingly torpid state for a whole forenoon. No motion whatever of the lungs could be perceived, on the closest inspection, though, at other times, this is remarkably observable; the eyes were shut; and, when touched by the finger, it gave no signs of life or motion. I carried it out to the open air, and placed it directly in the rays of the sun, in a sheltered situation. In a few seconds, respiration became very apparent; the bird breathed faster and faster, opened its eyes, and began to look about, with as much seeming vivacity as ever. After it had completely recovered, I restored it to liberty; and it flew off to the withered top of a pear-tree, where it sat for some time dressing its disordered plumage, and then shot off like a meteor."

About the latter part of August, or perhaps by the 8th or 10th of September, the Humming-bird takes his departure for the south. The young birds travel with their parents, or, at any rate, leave this section with them; for I have invariably noticed that these little groups were together up to the time when they left. The parents return to the same breeding-place in the succeeding year; and I have known of a pair breeding on the same apple-tree for three successive seasons. 


\section{Famly CyPSELId}

Bill very small, without notch, triangular, much broader than high, the culmen not one-sixth the gape; anterior toes cleft to the base, each with three joints (in the typical species), and covered with skin, the middle claw without any serrations, the lateral toes nearly equal to the middle; bill without bristles, but with minute feathers extending along the under margin of the nostrils; nostrils elongated, superior, and very close together; plumage compact; primaries ten, elongated, falcate.

\section{CH五TURA, StepHens.}

\footnotetext{
Chootura, StepHens. Shaw's Gen. Zool. Birds, XIII. (1825) 76 (type C. pelasgia).

Tail very short, scarcely more than two-fifths the wings, slightly rounded, the shafts stiffened and extending some distance beyond the feathers in a rigid spine; first primary longest; legs covered by a naked skin, without scutellæ or feathers; tarsus longer than middle toe; lateral toes equal, nearly as long as the middle; hind toe scarcely versatile, or quite posterior, with the claw, less than the middle anterior without it; toes slender, claws moderate; feathers of the base of the bill not extending beyoud the beginning of the nostrils.
}

\section{CH正TURA PELASGIA. - Stephens.}

The Chimney Swallow.

Hirundo pelasgia, Linnæus. Syst. Nat. I. (1766) 345. Wils. Am. Orn. V. (1812) 48.

Cypselus pelasgia, Audubon. Orn. Biog. II. (1834) 329; V. 419.

Chotura pelasgia, Stephens. Shaw's Gen. Zool. Birds, XIII. (1825) 76.

\section{DESCRIPTION.}

Tail slightly rounded; of a sooty-brown all over, except on the throat, which becomes considerably lighter from the breast to the bill; above with a greenish tinge; the rump a little paler.

Length, five and a quarter inches; wing, five ten one-hundredths; tail, two fifteen one-hundredths.

7 HIS well-known bird is a common summer inhabitant 1 of New England. It arrives in great numbers from the South, about the 1st to the 10th of May. Immediately on arriving, the birds pair, and commence building. The nest is usually constructed in an unused flue of a chimney; but, before the country was settled, they bred, and I have no 
doubt that great numbers of them in thinly settled districts still breed in hollow trees. The nest is composed of twigs, which are glued together and to the side of the chimney with the saliva of the bird. It is very rarely lined with a few feathers. The strength of these structures is wonderful : and they are so durable that I have known of instances of their remaining in the chimney during three seasons. Usually, the bird displays great sagacity in the choice of a location for a nest, in securing protection from storms and from the attacks of animals; but occasionally the nest is built in a chimney, open at the top sufficiently wide to permit the rain to trickle down the sides: the result is, that the moisture softens the glue by which the nest is attached to the chimney, and it is, with its living contents, precipitated to the bottom. Again, if the nest is built too low in the chimney, the young or eggs furnish agreeable food for rats, which, unfortunately, are sometimes found in dwellinghouses in the country in uncomfortable numbers. The eggs are generally four or five in number, pure-white in color, rather long in shape. Dimensions of five eggs, in a nest collected in Upton, Me.: .84 by .44 inch, .81 by .46 inch, .80 by .46 inch, .78 by .48 inch, .76 by .51 inch.

This species is somewhat nocturnal in its habits. From earliest dawn until seven or eight in the-morning, it is busy in the pursuit of insects : it then retires to its roosting-places in the chimneys, and is seldom seen until late in the afternoon. From early twilight until late in the night, it is again actively employed; and, having heard its notes, as it sped through the air, often as late as midnight, I have no doubt that, in pleasant weather, it is busy through the whole night.

In descending the chimneys where their young are, the birds fly rapidly until they are immediately over them, when, partially closing their wings, they drop suddenly, and with apparent ease, down the flue.

In ascending, the noise of their wings in the chimney is 
like that of distant thunder. The flight of these birds is very rapid, surpassing, I think, that of any other species: it is so peculiar, - the long wings vibrating in short, quick, energetic strokes, - that it furnishes a ready means of distinguishing it, from all other species, at a great height.

About sunset, the great multitudes of these birds are out, and the numbers of insects they destroy must be immense. Everywhere they may be seen: away up in the blue sky, as far as the eye can reach, they are coursing in wide-extended circles, chasing each other in sport, and even caressing and feeding their mates while on the wing; a little lower, they are speeding over the tops of the trees, gleaning the insects that have just left the foliage; over the surface of the lake or river they fly so low, in the pursuit of aquatic insects, that their wings often touch the water; everywhere they are busy. Truly, they are deserving of much better treat ment than they too often receive at the hands of the farmer, to whom they are his best friends; yet it is a fact, that, in a great many sections, they are driven from the chimneys of the farm-houses, and even destroyed, at every opportunity.

About the last of August, the Chimney Swallow, in large scattered flocks, leaves for the South, and spends the winter in Honduras and the West Indies. On returning in the spring, the same pair occupies the chimney used in the previous season, as has been proved by actual observation. 


\section{Famly Caprinulgid E. The Goat-suckers.}

\section{Sub-Family Caprinduginæ.}

Bill very short, triangular, the culmen less than one-sixth the gape; the anterior tocs united at the base by a membrane; the inner anterior toe with three joints, the others with four, all with distinct scutellæe above; the toe much elongated, its middle claw pectinated on the inner edge; hind toe directed a little more than half forwards; tarsi partly feathered superiorly; the bill more or less bristled, the nostrils separated, rather nearer the commissure than the culmen; plumage soft, lax, and owl-like; primary quills, ten; secondaries, eleven or twelve.

\section{ANTROSTOMUS, GOULD.}

Antrostomus, Goulv. Icones Avium (1838), Agassiz.

Bill remarkably small, with tubular nostrils, and the gape with long, stiff, sometimes pectinated, bristles; wings long, somewhat rounded, second quill longest, the primaries emarginated; tail rounded; plumage loose and soft.

\section{ANTROSTOMUS VOCIFERUS. - Bonaparte.}

The Whippoorwill.

Caprimulgus vociferus, Wilson. Am. Orn., V. (1812) 71; Aud. Orn. Biog., I. (1832) 443 ; V. 405.

Antrostomus vociferus, Bonaparte. List, 1838.

\section{DESCRIPTION.}

Bristles without lateral filaments; wing about six and a half inches long; top of the head ashy-brown, longitudinally streaked with black; terminal half of the tail feathers (except the four central) dirty-white on both outer and inner webs; iris darkhazel. Female, without white on the tail.

Length, ten inches; wing, six and a half.

TTHIS familiar species is a summer inhabitant of New 1 England: it arrives from the South about the second week in May. Its habits are not well known, as it is not a very common species, and it inhabits the most secluded spots in the deep woods; but its song is well known to all, as are its nocturnal wanderings in search for insect food. This bird, as also the Night-hawk, is, to the farmer, one of the most valuable among the feathered tribes: its food consists almost entirely of night-flying Lepidoptera, and the number of these insects destroyed is immense. 
The peculiar song of this bird is heard at early eve, and until late into the night, during the mating and part of the breeding seasons. It is not uttered in the depths of the wilderness alone; but the bird, perching on the well-sweep, on the eaves of a low shed, or even on the door-sill of the farmer's house, pours out its melancholy strain. The description, by Alexander Wilson, of the habits of this bird, is so accurate and comprehensive, that I will not presume to attempt another. He says:-

"The notes seem pretty plainly to articulate the words which have been generally applied to them, whip-poor-will, the first and last syllables being uttered with great emphasis, and the whole in about a second to each repetition; but, when two or more males meet, their whip-poor-will altercations become much more rapid and incessant, as if each were straining to overpower or silence the other. When near, you often hear an introductory cluck between the notes. At these times, as well as at almost all others, they fly low, not more than a few feet from the surface, skimming about the house and before the door, alighting on the wood-pile, or settling on the roof. Towards midnight, they generally become silent, unless in clear moonlight, when they are heard, with little intermission, till morning. If there be a creek near, with high, precipitous, bushy banks, they are sure to be found in such situations. During the day, they sit in the most retired, solitary, and deep-shaded parts of the woods, generally on high ground, where they repose in silence. When disturbed, they rise within a few feet, sail low and slowly through the woods for thirty or forty yards, and generally settle on a low branch or on the ground. Their sight appears deficient during the day, as, like owls, they seem then to want that vivacity for which they are distinguished in the morning and evening twilight. They are rarely shot at or molested; and, from being thus transiently seen in the obscurity of dusk, or in the deep umbrage of the woods, no wonder their particular markings of plumage should be so little known, or that they should be confounded with the Night-hawk, whom, in general appearance, they so much resemble. The female begins to lay about the second week in May, selecting, for this purpose, the most unfrequented part of the wood, 
often where some brush, old logs, heaps of leaves, \&c., had been lying, and always on a dry situation."

The Whippoorwill constructs no nest, but lays its eggs, which are two in number, in a slight hollow which it scratches in the earth, usually near a rock, or fallen trunk of a tree. These eggs are of an elliptical form, being as large at one end as at the other; their ground-color is a delicate creamy-white, with blotches, lines, and spots of different shades of light-brown and lavender: taken altogether, it is one of the handsomest eggs found in New England. The length of several specimens before me varies from 1.21 to 2.27 inches, breadth from .75 to .79 inch. The bird commences laying about the last week in May, and the period of incubation is fourteen days.

The young are soon able to walk, and in a very few days can run with considerable speed; and they hide with such adroitness that it is a work of no little difficulty to capture them. The female, when her young are discovered, immediately throws herself before the intruder, counterfeiting lameness so well, that, unless he is well acquainted with the habits of birds, he will quickly be misled into following her. As soon as the young birds are able to shift for themselves, they are turned adrift by their parents, and are seen only singly, or at most in pairs, during the remainder of their stay. By the latter part of August, or seldom later than the 10th of September, all of them depart for the South, the old males remaining a few days later; uttering; occasionally, their song, but always in the woods, or in localities far removed from human habitation.

\section{CHORDEILES, SWAINSON.}

Swatwson. Fauna Bor. Amer. (1831) 496.

Bill very small, the gape with very short, feeble bristles; wings very long and pointed, with the first quill nearly or quite equal to the second, and the primaries not emarginated on the inner edge; tail long, slightly forked in the North-American species; plumage rather compact. 


\section{CHORDEILES POPETUE. - Baird.}

The Night-hawk; Bull Bat.

Caprimulgus popetue, Vieillot. Ois. Am. Sept., I. (1807) 56.

Caprimulgus Americanus, Wilson, V. (1812) 65.

Caprimulgus Virginianus. Aud. Orn. Biog., II. (1834) 273.

\section{DESCRIPTION.}

Male, above greenish-black, with but little mottling on the head and back; wing coverts varied with grayish; scapulars with yellowish-rufous; a nuchal band of fine gray mottling, behind which is another coarser one of rufous spots; a white V-shaped mark on the throat; behind this a collar of pale-rufous blotehes, and another on the breast of grayish mottling; under parts banded transversely with dull-yellowish or reddish-white and brown; wing quills quite uniformly brown; the five outer primaries with a white blotch midway between the tip and carpal joint, not extending on the outer web of the outer quill; tail with a terminal white patch.

Female, without the caudal white patch, the white of the throat mixed with reddish.

Length of male, nine and fifty one-hundredths inches; wing, eight and twenty one-hundredths inches.

This bird is much more abundantly distributed throughout New England than the preceding; and its habits are, consequently, better known. It arrives from the south about the 10th of May. At this time, great numbers may be observed, at early twilight, coursing through the air in different directions, sometimes at a great height, sometimes just above the trees in the country, or houses in the city; occasionally, very near the earth or water, or, when near the seacoast, but just above the marshes, where they destroy great numbers of insects. Their flight is very rapid, their long wings giving quick, powerful sweeps; and, as they dart about in many eccentric movements, busily gleaning their food, they utter, at oft-repeated intervals, their short note or squeak, which almost exactly resembles that of the Common Snipe.

About the middle of May, or by the 20th of that month, in Maine, the male commences his attentions to the female. His movements at this time are interesting, and, from their common occurrence, familiar to all who live in the country. 
At early evening, and in cloudy weather throughout the greater part of the day, he ascends into the air; and when he has attained a considerable height, partially closing his wings, he drops with great velocity through the distance of seventy-five or one hundred feet, sometimes nearly to the "earth. The sound made by the air passing through the wing quills is so lond that I have often heard it at certainly the distance of half a mile: it resembles, as Nuttall truly says, the sound produced by blowing into the bung-hole of an empty hogshead. This act is often repeated, the bird darting about at the same time in every direction, and uttering his sharp squeak. Wilson was of the opinion, that this habit of the Night-hawk was confined to the period of incubation; the male acting in this manner, as he thought, to intimidate any person from approaching the nest. I have had abundant opportunities for observing the bird in all times of the summer, and during its stay with us; and I should unhesitatingly affirm, that, from the time of early courtship, until the young are hatched, if not after, the male acts in this manner.

This species constructs no nest, but lays its eggs on the bare ground in a slight hollow scratched by the female, or often on a bare rock. I have found numbers of these eggs, particularly in the northern parts of Maine, where, in walking over a pasture or rocky field, I have flushed sometimes a bird in every ten rods. I remember a ledge of rocks back of the settlement known as Wilson's Mills, which seemed a favorite breeding-place for these birds; and, in the space of every four or five rods, a female was sitting on her eggs. The eggs are two in number, elliptical in shape, of a dirty-white color, which is covered with fine dottings of different shades of brown, with obscure markings of slate-color, and some spots of lavender. Length from 1.23 to 1.25 inch; breadth, from .82 to .85 inch. A great number of specimens from different sections do not exhibit an appreciable variation from these dimensions. In the south- 
ern districts, it lays about the 20th of May ; in the northern, about the 10th of June.

The male assists the female in incubating, as I have witnessed many times. When perched by her on a tree or fence-rail, during the light of mid-day, he always sits along the limb or rail, instead of across it - a peculiarity which is also noticeable in the Whippoorwill. Some authors, in speaking of this fact, explain it by noticing the comparatively small size of the feet, and apparent weakness of the legs. I think this can hardly be a sufficient cause; for both these birds, while on the ground, can run with considerable speed, and, if captured, can not only perch across the finger of a hand or the back of a chair, as I have often proved, but can rest on one foot, drawing the other up into the feathers of the belly, like other birds.

About the 20th of August, after the young have become able to provide for themselves, all the families in a neighborhood assemble in a large, scattered flock; and; after having become completely recruited from the labors of incubation, they all leave for the south. 


\section{SUB-ORDER CLAMATORES. ScrEAMERS.}

\section{Fanilt ALCEDINID瓜. The Kingfishers.}

Head large; bill long, strong, straight, and sub-pyramidal, usually longer than the head; tongue very small; wings short; legs small, the outer and middle toes united to their middle; toes with the usual number of joints $(2,3,4,5)$.

The gape of the bill in the Kingfishers is large, reaching to beneath the eyes; the third primary is generally longest, the first decidedly shorter; the secondaries vary from twelve to fifteen in number, all nearly equal; the secondaries cover at least three-quarters of the wing; the tail is short, the feathers twelve in number, they are rather narrow, the outer usually shorter; the lower part of the tibia is bare, leaving the joint and the tarsus uncovered; the tarsus is covered anteriorly with plates, behind, it is shagreen-like or granulated; the hind toe is connected with the inner, so as to form with it and the others a regular sole, which extends unbroken beneath the middle and outer as far as the latter are united; the inner toe is much shorter than the outer; the claws are sharp, the middle expanded on its inner edge, but not pectinated.

\section{CERYLE, BoIE.}

Ceryle, Bore, Isis (1828) 316 (type C. rudis).

Bill long, straight, and strong, the culmen slightly advancing on the forehead, and sloping to the acute tip; the sides much compressed; the lateral margins rather dilated at the base, and straight to the tip; the gonys long and ascending; tail rather long and broad; tarsi short and stout.

\section{CERYLE ALCYON. - Boie.}

\section{The Belted Kingfisher.}

Alcedo alcyon, Linnæus. Syst. Nat., I. (1766) 180. Wilson, Am. Orn., III. (1811) 59. Aud. Orn. Biog., I. (1831) 394.

Ceryle alcyon, Boie. Isis, (1828) 316.

\section{DESCRIPT́ION.}

Head with a long crest; above blue, without metallic lustre; beneath, with a concealed band across the occiput, and a spot anterior to the eye, pure-white; a band across the breast, and the sides of the body under the wings, like the back; primaries white on the basal half, the terminal unspotted; tail with transverse bands and spots of white.

Young, with the sides of body and a transverse band across the belly below the pectoral one, light-chestnut; the pectoral band more or less tinged with the same

Length of adult, about twelve and three-quarters inches; wing, six or more.

$H a b$. - The entire continent of North America. 
THIIS species is a very common summer inhabitant of all 1 the New-England States. It arrives from the south about the 1st of April, often earlier, particularly in early springs: indeed, Mr. Verrill says they are sometimes seen in Maine in winter, and they are often found in the southern districts of these States in this season. The birds, on arriving, commence pairing; and they soon begin excavating in a sand-bank a long, winding hole of about three inches and a half in diameter at the entrance, and gradually larger to the end, at which the nest, composed of grasses, leaves, and feathers, is built, —or laid, which would perhaps be the better term. 'This hole is sometimes as much as six or eight feet, usually, from four to six, in length. The female deposits in this nest six eggs usually: these are of a clear-white color, and of a nearly spherical shape, being from 1.35 to 1.42 inch in length, by from 1.05 to 1.08 inch in breadth. I am aware that these measurements excecd any heretofore given; but they are accurately taken from a large number of specimens in my collection. Dr. Brewer gives the dimensions as averaging $1 \frac{5}{16}$ in length by $1 \frac{1}{16}$ in breadth. The period of incubation is stated by Audubon and other ornithologists to be sixteen days.

The habits of this bird are so well known that any description here is almost superfluous. Its food, as its name implies, consists almost entirely of fish, which he obtains by diving into the water, and seizing with his bill. When passing over a sheet of water, he attentively scans the surface beneath him: if he observes a small fish, he pauses in his flight, and remains over it a few seconds, maintaining his position by short, quick vibrations of his wings. If the fish is sufficiently near the surface, he suddenly dives at it, and, plunging into the water, seizes it, and bears it off to some rock or post, where he can eat it at his leisure. The note of the Kingfisher is a loud, harsh cry, similar to the sound of a watchman's rattle: it is easily heard above the rushing of the waters at a dam or other 
waterfall, and, when heard in such a locality, is not disagreeable. When perched on a limb overhanging the water, he frequently jets his tail in the manner of the Pewee, and often descends from such a perch and seizes a frog or a fish; and $I$ once shot one that had just seized a meadow mouse (arvicola) in this manner. The young usually remain in the hole in the bank until they are about fledged. I am inclined to think, that usually they return to these holes at night and in stormy weather, as I have frequently seen them about their nests long after they were fledged, and have even seen them passing into them at the close of the day. In migrating, the young leave their parents, and these even separate, and pursue their journey alone; and it is a case of rare occurrence that two are seen together after the latter part of August. 


\title{
Family COLOPTERId 2 . The Flycatchers.
}

\author{
Sub-Family Trranninit.-Tyrant Flycatchers.
}

Bill broader than high at the base, much depressed, more or less triangular; culmen nearly as long as the head, or shorter, straight to near the tip, then suddenly bent down into a conspicuous hook, with a notch behind it; tip of lower jaw also notched; commissure straight to near the notch; gonys slightly convex; nostrils oval or rounded in the anterior extremity of the nasal groove, and more or less concealed by long bristles which extend from the posterior angle of the jaws along the base of the bill, becoming smaller, but reaching nearly to the median line of the forehead; these bristles with lateral branches at the base; similar bristles mixed in the loral feathers and margining the chin; tarsi short, generally less than the middle toe, completely enveloped by a series of large scales which meet near the posterior edge of the inner side, and are separated either by naked skin or by a row of small scales. Sometimes a second series of rather large plates is seen on the posterior face of the tarsus; these, however, usually on the upper extremity only; basal joint of middle toe united almost throughout to that of the outer toe, but more than half free on the inner side; outer lateral toe rather the longer; wings and tail variable, first quill always more than three-fourths the second; the outer primaries sometimes attenuated near the tip.

\section{TYRANNUS, CUVIEts.}

Tyrannus, Cuvier, Leçons Anat. Comp., 1799-1800 (Agassiz).

Tail nearly even, or moderately forked, rather shorter than the wings; the feathers broad, and widening somewhat at the ends; wings long and pointed; the outer primaries rather abruptly attenuated near the end, the attenuated portion not linear, however; head with a concealed patch of red on the crown.

\section{TYRANNUS CAROLINENSIS. - Baird.}

\section{King-bird; Bee Martin.}

Lanius tyrannus, Linnæus. Syst. Nat., I. (1766) 136. This belongs to the Cuban T. matutinus, according to Bonaparte.

Mfuscicapa tyrannus (Brisson?), Wilson. Am. Orn., I. (1808) 66. Aud. Orn. Biog., I. (1832) 403; V. (1839) 420. Ib., Birds Amer., I. (1840) 204.

\section{DEscription.}

Two, sometimes three, outer primaries abruptly attenuated at the end; second quill longest, third little shorter, first rather longer than fourth, or nearly equal; tail slightly rounded, above dark bluish-ash; the top and sides of the head to beneath the eyes bluish-black; a concealed crest on the crown, vermilion in the 
centre, white behind, and before partially mixed with orange; lower parts purewhite, tinged with pale bluish-ash on the sides of the throat and across the breast; sides of the breast and under the wings similar to, but rather lighter than, the back; axillaries pale grayish-brown tipped with lighter; the wings dark-brown, darkest towards the ends of the quills; the greater coverts and quills edged with white, most so on the tertials; the lesser coverts edged with paler; upper tail coverts and upper surface of the tail glossy-black, the latter very dark brown beneath; all the feathers tipped, and the exterior margined externally with white, forming a conspicuous terminal band about twenty-five one-hundredths of an inch broad.

The young of the year is similar, the colors duller, the concealed colored patch on the crowu wanting; the tail more rounded, the primaries not attenuated.

Specimens vary in the amount of white margining the wing feathers; the upper tail coverts are also margined sometimes with white.

Length, eight and fifty one-hundredths inches; wing, four and sixty-five onehundredths inches; tail, three and seventy one-hundredths inches; tarsus, seventyfive one-hundredths inches.

TTHIS common species is abundantly distributed throughout New England as a summer resident. It arrives from the South about the 1st to the 10th of May: the males precede the females in small parties of three or four, the latter arriving about a week or ten days later.

Soon after the arrival of the females, the males begin their attentions to them; and, as the season of courtship is comparatively short, the new-made couple soon begin their selection of a locality for their nest. This seems to be with them a rather difficult matter to settle; for I have known of a pair remaining in an orchard a fortnight, examining every tree and its peculiar advantages, before they made a selection.

At last, when the location is decided, both birds commence work, and the nest is soon completed. It is usually placed on the branch of an apple or pear tree, in a small cluster of twigs or a crotch of a limb: it is constructed outwardly of coarse grasses, mosses, twigs, roots, and weeds; and is deeply hollowed, and lined with fine roots, horse-hairs, and grasses. About the 1st of June, the eggs are laid: these are usually five in number; their groundcolor is a very delicate creamy-white, with irregular spatters and spots of different shades of brown, and some obscure 
spots of lavender. Dimensions of a nest complement of five eggs: 1.06 by .71 inch ; 1.04 by .70 inch ; 1.02 by .72 inch; 1 by .74 inch; and .94 by .75 inch.

During the mating and breeding season, the pugnacity and courage of the King-bird are proverbial: if any bird approach the neighborhood of his nest, he immediately attacks it; and, whether crow (his particular dislike), hawk, or eagle, the intruder is obliged to flee, so fierce an onslaught does this little warrior make on him. As soon as the cry of a crow is heard, he is all activity: he flies from the tree where he is perching to reconnoitre, uttering his shrill twitter, and vibrating his wings in short, quick, nervous strokes; as soon as the crow appears, the Kingbird pursues it, his flight now being very swift and powerful. As soon as he nears his foe, he flies above him, and, darting down on his back and head, attacks him with such vigor that the crow dives and dodges to avoid him. He repeats his attack, and follows his enemy, sometimes to the distance of a mile and more: then, returning to his mate, he perches on the tree by her nest, and twitters a volley of courageous songs.

The food of the King-bird consists principally of insects, which he captures usually while on the wing. It seems a provision of nature, that all the Flycatchers shall only take those insects that have taken flight from the foliage of trees and shrubs, at the same time making the warblers and other birds capture those which remain concealed in such places. The King-bird, in seizing a flying insect, flies in a sort of half-flitting hover, and seizes it with a sharp snap of the bill. Sometimes he descends from his perch, and captures a grasshopper that has just taken a short flight, and occasionally seizes one that is crawling up some tall stalk of grass. Those farmers who keep bees dislike this bird because of his bad habit of eating as many of those insects as show themselves in the neighborhood of his nest; but they should remember that the general 


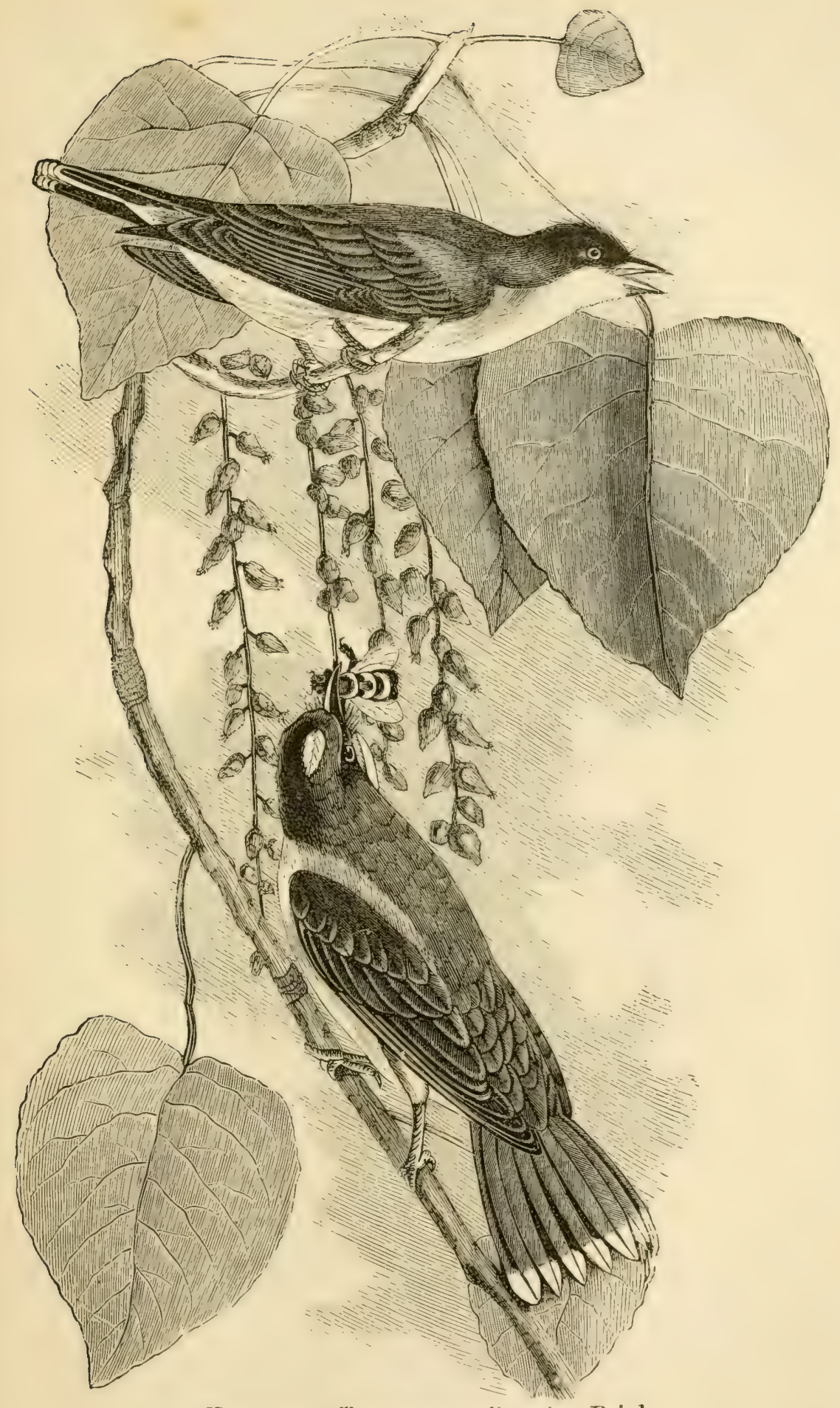

King-Bird, Tyramus Carolinensis. Baird. 



\section{interests of agriculture are greater than those of a hive of bees.}

About the middle of September, this bird with his family and neighbors gather into a scattered flock, and depart for the south, spending the winter in Central America and Southern Mexico.

\section{MYLARCHUS, CABANIS.}

Myiarchus, CAвAnis, Fauna Peruana (1844-46) 152. Burmeister, Thiere Brasiliens, II. Vogel (1856) 469.

Tarsus equal to, or not longer than, the middle toe, which is decidedly longer than the hinder one; bill wider'at base than half the culmen; tail broad, long, even, or slightly rounded, about equal to the wings, which scarcely reach the middle of the tail, the first primary shorter than the sixth; head with elongated lanceolate distinct feathers; above brownish-olive; throat ash; belly yellow; tail and wing feathers varied with rufous.

\section{MYIARCHUS CRINITUS. - Cabanis.}

\section{The Great-crested Flycatcher.}

Mfuscicapa crinita, Linnæus. Syst. Nat., I. (1766) 325. Wilson, Am. Orn., II. (1810) 75. Aud. Orn. Biog., II. (1834) 176; V. 423.

Tyrannus crinitus. Nutt. Man., I. (2d ed., 1840) 302.

\section{DESCRIPTION.}

Head with a depressed crest; third quill longest, fourth and second successively but little shorter, first a little longer than seventh, much shorter than sixth; tail decidedly rounded or even graduated, the lateral feather about twenty-five onehundredths of an inch shorter; upper parts dull greenish-olive, with the feathers of the crown, and to some extent of the back, showing their brown centres; upper tail coverts turning to pale rusty-brown; small feathers at the base of the bill, ceres, sides of the head as high as the upper eyelid, sides of the neck, throat, and forepart of - the breast, bluish-ashy; the rest of the lower parts, including axillaries and lower wing coverts, bright sulphur-yellow; a pale ring round the eye; sides of the breast and body tinged with olivaceous; the wings brown, the first and second rows of coverts, with the secondary and tertial quills, margined externally with dull-white, or on the latter slightly tinged with olivaceous-yellow; primaries margined externally for more than half their length from the base with ferruginous, great portion of the inner webs of all the quills very pale-ferruginous; the two middle tail feathers light brown, shafts paler, the rest have the outer web and a narrow line on the inner sides of the shaft brown, pale olivaceous on the outer edge, the remainder ferruginous to the very tip; outer web of exterior feather dull brownish-yellow; feet black; bill dark-brown above and at the tip below, paler towards the base.

The female appears to have no brown on the inner web of the quills along the ohaft, or else it is confined chiefly to the outer feathers.

Length, eight and seventy-five one-hundredths inches; wing, four and twenty- 
five one-hundredths; tail, four and ten one-hundredths; tarsus, eighty-five onehundredths.

Hab. - Eastern North America to the Missouri, and south to Eastern Texas (not yet observed further west).

This species is a rare summer inhabitant of New England. It arrives from the South about the 10th of May in the latitude of Massachusetts, - that is, so far as so irregular a visitor may be said to arrive, - and spreads throughout these States. It is less rare in the southern districts than in the middle, and hardly penetrates as far north as the latitude of the middle of Maine. It has been ascertained to breed in all these States; and two nests, with their contents, are before me. One of these was found in a hollow tree in Plymouth, Mass., on the 10th of June; the other was found in Middleton, Mass., on the 4th of June. These nests are composed of straws, leaves, feathers, and the castoff skins of snakes; and it seems a distinguishing characteristic of the nests of this species to have the skins of one or more snakes woven into the other materials. The first of these nests had five eggs ; the other, three. These are of a beautiful creamy-buff, and covered with irregular scratches and lines of different shades of purple. Wilson says of these eggs, "The female lays four eggs of a dull cream-color, thickly scratched with purple lines of various tints, as if done with a pen." Dimensions of eggs vary from .95 by .78 inches to 1 by .80 inch.

As this species is quite rare in these States, I have had but very few chances for observing its habits. It appears to be equally courageous and quarrelsome with the Kingbird, and has many of the peculiarities of that bird. Its food consists of insects, which it captures while on the wing, after the manner of the other species. When the young leave the nest, they feed on berries and caterpillars, and are fond of crickets and grasshoppers. By the middle of September, the whole family leave for the South. 


\section{SAYORNIS, BONAPARTE.}

Sayornis, Bonaparte? Ateneo Italiano (1854). Ib., Comptes Rendus (1854), Notes Orn. Delattre.

Head with a blended depressed moderate crest; tarsus decidedly longer than middle toe, which is scarcely longer than the hind toe; bill rather narrow, width at base about half the culmen; tail broad, long, slightly forked, equal to the wings, which are moderately pointed, and reach to the middle of the tail, first primary slorter than the sixth.

\section{SAYORNIS FUSCUS, - Baird.}

\section{The Pewee; Phebe-bird.}

Muscicapa fusca, Gmelin. Syst. Nat., I. (1788) 931. Aud. Orn. Biog., II. (1834) 122; V. (1839) 424. Ib., Birds Amer., I. (1840) 223.

Tyrannus fuscus, Nuttall. Man., I. (2d ed., 1840) 312.

Mfuscicapa nunciola, Wilson. Am. Orn., II. (1810) 78; pl. xiii.

\section{DESCRIPTION.}

Sides of "breast and upper parts dull olive-brown, fading slightly toward the tail; top and sides of head dark-brown; a few dull-white feathers on the eyelids; lower parts dull yellowish-white, mixed with brown on the chin, and in some individuals across the breast; quills brown, the outer primary, secondaries, and tertials edged with dull-white; in some individuals the greater coverts faintly edged with dullwhite; tail brown, outer edge of lateral feather dull-white, outer edges of the rest like the back; tibix brown; bill and feet black; bill slender, edges nearly straight; tail rather broad, and slightly forked, third quill longest, second and fourth nearly equal, the first shorter than sixth.

Length, seven inches; wing, three and forty-two one-hundredths; tail, three and thirty one-hundredths.

Hab. - Eastern North America.

In autumn, and occasionally in early spring, the colors are much clearer and brighter. Whole lower parts sometimes bright sulphur-yellow, above greenish-olive, top and sides of the head tinged with sooty; in the young of the year, the colors are much duller; all the wing coverts broadly tipped with light-ferruginous, as also the extreme ends of the wings and tail feathers; the brown is prevalent on the whole throat and breast; the hind part of the back, rump, and tail, strongly ferruginous.

The tail of this species is quite deeply forked, the external feather being from thirty-five one-hundredths to forty one-hundredths of an inch longer than the middle one.

This well-known bird is a very common summer inhabi tant of all New England. It arrives from the South often as early as the middle of March, sometimes before the last snowstorm of the season. As soon as the birds have paired, usually by the last of April, they commence build- 
ing. 'The nest is usually placed under' a bridge, sometimes under an eave, or ledge of rock, sometimes in a barn or other building. It is constructed of fine roots, grasses, fine moss, and hairs, which are plastered together, and to the object the nest is built on, by pellets of mud: it is hollowed about an inch and a half, and lined with soft grasses, wool, and feather's. The eggs are usually five in number : their color is white, with a very delicate cream tint. There are usually in each litter one or two eggs with a few spots thinly scattered over the larger end: these spots are of a reddish-brown. The period of incubation is thirteen days, and two broods are often reared in the season in this latitude. The length of eggs varies from .72 to $.78 \mathrm{inch}$; breadth, from .54 to .56 inch.

The familiar cheerful habits of this species, and the fact that it is one of the first birds to remind us of the return of spring, have made it a universal favorite; and many residents in the country are so attached to it, that they protect it, and encourage its visits, and even provide quarters for the establishment of its nest. It seems to prefer the neighborhood of a pond or stream of water for its home, where, perching on the branch of an overhanging tree, or on the railing of a bridge, or darting about in different directions, it busies itself through the day in catching the insects that swarm in myriads in such localities. When perching, it frequently flirts its tail, and erects the feathers of its head, uttering the notes phebé-phebée in a soft plaintive key. Sometimes, this note is more lively, resembling the word pewéet, pewéet, uttered in a quick, cheerful manner. The beautiful description of the habits of this bird, given by Audubon, is certainly one of the best efforts of that naturalist; and I would advise all who are interested in the history of the bird to read it.

After the young have left the nest, the parents remain together in the neighborhood of their home until their departure, about the middle of Oetober. At this time, they 
are a little more shy than they were during the season of incubation, and their note is seldom heard; and, when it is, it consists of a melancholy strain, quite different from that uttered in the spring and early summer.

\section{CONTOPUS, Cabanis.}

Contopus, Caвanis, Journal für Ornithologi\&, III. (Nov., 1855) 479. (Type Jfuscicapa virens, L.)

Tarsus very sliort, but stout, less than the middle toe, and scarcely longer than the hinder; bill quite broad at the base, wider than half the culmen; tail moderately forked, much shorter than the wings (rather more than three-fourths); wings very long and much pointed, reaching beyond the middle of the tail,' the first primary about equal to the fourth; all the primaries slender and rather acute, but not attenuated; head moderately crested; color, olive above, pale-yellowish beneath. with a darker patch on the sides of the breast; under tail coverts streaked.

\section{CONTOPUS BOREALIS, - Baird.}

\section{The Olive-sided Flycatcher.}

Tyrannus borealis, Sw. and Rich. F. Bor. Am., II. (1831) 141; plate.

Muscicapa Cooperi, Nuttall. Man, I. (1832) 282. Aud. Orn. Biog., II. (1834) 422; V. (1839) 422.

Tyrannus Comperi, Bonaparte. List (1838). Nutt. Man., I. (2d ed., 1840) 298.

If uscicapa inomata, Nuttall. Man. I. (1832) 282.

\section{Desciription.}

Wings long, much pointed, the second quill longest, the first longer than the third; tail deeply forked; tarsi short; the upper parts ashy-brown, showing darker brown centres of the feathers, this is eminently the case on the top of the head; the sides of the head and neck, of the breast and body resembling the back, but with the edges of the feathers tinged with gray, leaving a darker central streak; the chin, throat, narrow line down the middle of the breast and body, abdomen, and lower tail coverts white, or sometimes with a faint tinge of yellow; the lower tail coverts somewhat streaked with brown in the centre; on each side of the rump, generally concealed by the wings, is an elongated bunch of white silky feathers; the wings and tail very dark brown, the former with the edges of the secondaries and tertials edged with dull-white; the lower wing coverts and axillaries grayishbrown; the tips of the primaries and tail feathers rather paler; feet and upper mandible black, lower mandible brown; the young of the year similar, but the color duller; feet light-brown.

Length, seven and fifty one-hundredths inches ; wing, four and thirty-three onehundredths; tail, three and thirty one-hundredtbs; tarsus, sixty one-hundredths.

Hab. - Rare on the Atlantic and Pacific coasts of the United States. Not observed in the interior, except to the north. Found in Greenland. (Reinhardt.)

This bird is a not very common summer inhabitant of New England. It arrives from the South about the 20th 
- of May, and is most frequently observed in low growths of oak and chestnut: it seems always busily employed in catching winged insects, of which its food almost entirely consists; these it seizes in the manner of the King-bird, which bird it resembles in both its habits and disposition I have sometimes seen two birds of this species engaged in a fight, which, for fierceness, I have hardly seen surpassed. They would rush together in mid-air, snapping their bills, beating with their wings, and pecking each other, until they both descended to the trees beneath, actually exhausted with their exertions.

Mr. Verrill says that it breeds quite common near the Umbagog Lakes, Me.; but I have never been able to find its nest there or elsewhere, although I have looked for it with great care.

It has been found breeding in Vermont; and Dr. Thompson, in his work on the birds of that State, gives a description of the nest and eggs. Three nests have been found in Massachusetts within two years; two in West Roxbury, and one in Dorchester. These were all built in forked twigs of apple-trees, in old neglected orchards, facing to the southward, and were constructed of the same material that the King-bird uses in its nest. In fact, they were almost exactly like the King-bird's nest, but were a little smaller.

Two of the nests had three eggs each, and the other had but two. They were all found in the first week in June, and the eggs were freshly laid: probably, if they had been unmolested, more eggs would have been deposited. Three of these eggs are in my cabinet. To compare them with the eggs of any other bird, I should say they seem like exceedingly large Wood Pewee's : for they are almost exactly like them in shape, color, and markings; being of a creamywhite, with large blotches and spatters of lilac, lavender, and brownish-red. Their dimensions are .88 by $.68 ; .88$ by $.66 ; .86$ by .68 inch.

Mr. Nuttall, who found a nest in Cambridge, Mass., 
describes it as follows: "It was built in the horizontal branch of a tall red cedar, forty or fifty feet from the ground. It was formed much in the manner of the Kingbird's, externally made of interlaced dead twigs of the cedar ; internally, of the wire stolons of the common Lichen or Usnea. It contained three young, and had had probably four eggs. The eggs had been hatched about the 20th of June, so that the pair had arrived in this vicinity about the close of May." He also describes the bird's note as follows: "The female had a whistling, oft-repeated, whin-

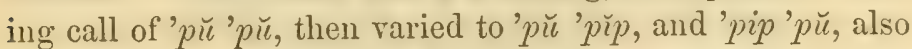

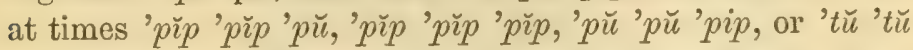
' $t \breve{u}$, and ' $t \breve{u}$ ' $t \breve{u}$. The male, besides this note, had, at long intervals, a call of seh' phèbe-é or ' $h$ ' phebéc in the tone of the circular tin whistle or bird-call."

By the second week in September, none of these birds are to be seen; and, probably before that time, they have all departed on their migrations.

\section{CONTOPUS VIRENS. - Cabanis.}

The Wood Pewee.

Muscicapa virens, Linnæus. Syst. Nat., I. (1766) 327. Nutt. Man., I. (1832) 285. Aud. Orn. Biog., II. (1834) 93; V. (1839) 425.

Muscicapa rapax, Wilson. Am. Orn., II. (1810) 81.

Tyrannus virens, Nuttall. Man., I. (2d ed., 1840) 316.

\section{DESCRIPTION.}

The second quill longest, the third a little shorter, the first shorter than the fourth, the latter nearly forty one-hundredths longer than the fifth; the primaries more than an inch longer than the secondaries; the upper parts, sides of the head, neck, and breast, dark olivaceous-brown, the latter rather paler, the head darker; a narrow white ring round the eye; the lower parts pale-yellowish, deepest on the abdomen; across the breast tinged with ash; this pale ash sometimes occupies the whole of the breast, and even occasionally extends up to the chin; it is also sometimes glossed with olivaceous; the wings and tail dark-brown, generally deeper than in S. fuscus; two narrow bands across the wing, the outer edge of first primary and of the secondaries and tertials dull-white; the edges of the tail feathers like the back, the outer one scarcely lighter; upper mandible black, the lower yellow, but brown at the tip.

Length, six and fifteen one-hundredths inches; wing, three and fifty one-hundredths; tail, three and five one-hundredths.

Hab. - Eastern North America to the borders of the high central plains, south to New Granada. 
This bird is a common summer inhabitant of New England, making its appearance from the South from about the 10 th to the 20 th of May. It prefers the solitudes of

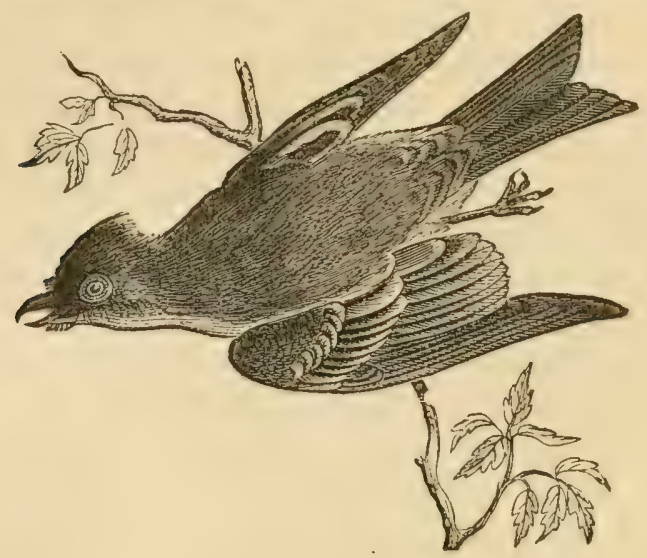

the deep forests to the more open districts, and is a more retiring species than any of its cousins in these States. About the last of May, the birds, having chosen their mates, commence building. The nest is placed usually on the horizontal limb of a tree, generally at a height of about twenty feet from the ground: it is composed of pine leaves and cottony substances, and covered with lichens and mosses, which are fixed on after the manner of the Humming-bird. I think Nuttall's description of the nest the best that I have seen: it is as follows:-

"The nest is extremely neat and curious, almost universally saddled upon an old moss-grown and decayed limb in a horizontal position, and is so remarkably shallow, and incorporated upon the branch, as to be easily overlooked. The body of the fabric consists of wiry grass and root fibres, often blended with small branching lichens, held together with cobwebs and caterpillars' silk, moistened with saliva; externally, it is so coated over with bluish, crustaceous lichens as to be hardly discernible from the moss upon the tree. It is lined with finer root-fibres, or slender grassstalks." 
The eggs are generally four in number. They are very beautiful, being. of a delicate cream-color, with blotches and spots of lilac and brown around the larger end: there are two shades of lilac, - one obscure, and the other decided, even a lavender. The eggs are generally oval in shape, and but little larger at one end than at the other. Length from .72 to .78 inch; breadth from .54 to .56 inch. But one brood is reared in the season in New England. The period of incubation is fourteen days.

The habits of this species are not generally so well known as those of the Phebe, which bird it resembles in many respects. Although it is usually found in the wildest and most thickly wooded localities, it sometimes frequents the orchards and open pastures; and I have occasionally seen individuals on the trees on Boston Common, busily engaged in hunting insects, and apparently having families in the neighborhood. The note is different from that of the Phebe, being more plaintive and drawling, sounding like the syllables "pe-weêee," "pe-weêee." When the nest is approached, both the parents fly to meet the intruder, hovering over his head, snapping their bills, and uttering short notes of complaint like chip-pēe-, pé-peu: they often alight on a twig near him, and flirt their tails and quiver their wings in a nervous, irritable manner. After the young have left the nest, the old birds separate; and, though still frequenting the same localities they inhabited during the season of incubation, they are seldom seen together, each seeming to avoid the other. They are now generally silent, and, when approached, are quite shy. They leare the New-England States by the 10th of September, and probably winter in South America.

\section{EMPIDONAX, CABANIS.}

Empidonax, Cabanis, Journal für Ornithologie, III. (Nov., 1855) 480 (type Tyrannula pusilla.

Tyrannula of most authors. 
Tarsus leggthened, considerably longer than the middle toe, which is decidedly longer than the hind toe; bill variable; tail very slightly forked, even, or rounded, a little shorter only than the wings, which are considerably rounded, the first primary much shorter than the fourth; head moderately crested; color olivaceous above, yellowish beneath; throat generally gray.

\section{EMPIDONAX TRAILLII. - Baird.}

The Traill's Flycatcher.

Muscicapa traillii, Audubon. Orn. Biog., I. (1832) 236; V. (1839) 426.

Tyrannus traillii, Nuttall. Man., I. (2d ed., 1840) 323.

Description.

Third quill longest, second scarcely shorter than fourth, first shorter than fifth, about thirty-five one-hundredths shorter than the longest; primaries about seventyfive one-hundredths of an inch longer than secondaries; tail even; upper parts dark olive-green, lighter under the wings, and duller and more tinged with ash on nape and sides of the neck; centre of the crown feathers brown; a pale yellowish-white ring (in some specimens altogether white) round the eye; loral feathers mixed with white; chin and throat white; the breast and sides of throat light-ash tinged with olive, its intensity varying in individuals, the former sometimes faintly tinged with olive; sides of the breast much like the back; middle of the belly nearly white; sides of the belly, abdomen, and the lower tail coverts sulphur-yellow; the quills and tail feathers dark-brown, as dark (if not more so) as these parts in $C$. virens; two olivaceous yellow-white bands on the wing, formed by the tips of the first and second coverts, succeeded by a brown one, the edge of the first primary and of secondaries and tertials a little lighter shade of the same; the outer edge of the tail feathers like the back, that of the lateral one rather lighter; bill above darkbrown, dull-brownish beneath.

Length, nearly six inches; wing, two and ninety one-hundredths; tail, two and sisty one-hundredths.

Hab. - Eastern United States, and south to Mexico.

This bird is occasionally found as a spring and autumn visitor in New England, arriving about the 15th or 20th of May. In its habits, it resembles the Least Flycatcher ( $E$. minimus), as it does also in its plumage: in fact, these two birds and the Green-crested Flycatcher have been so much mistaken for each other by different naturalists, the confusion in whose descriptions is so great, that it requires a very careful examination to identify either of these birds perfectly and accurately. I have had no opportunities for observing the habits of the bird now before us, and can add nothing to its history. Thompson, in his "Vermont Birds," 
gives it as breeding in that State; and I have no doubt it occasionally passes the summer in each of the New-England States. I had a nest and four eggs brought me in June, 1864, found in Eastern Massachusetts, that were almost exactly like those of $E$. minimus; but the bird brought with the nest was unquestionably of this species: whether or not the two belonged together I cannot say, but think that they probably did. The person who collected them informed me that the nest was found in an apple-tree in an old orchard: it was built in a small fork about twenty feet from the ground. The bird attacked the person who fomd it, courageously flying in his face, and snapping its bill with anger, and uttering a querulous twitter like that of the Phebe. The eggs were nearly hatched; and, as they were found on the 20th of June, they must have been laid by the 10 th of that month.

Two eggs in my cabinet, from near Quebec, Lower Canada, collected by William Couper, Esq., who informs me this species is occasionally met with there, are of a creamywhite color, like that of the eggs of $E$. minimus; each egg having a very few pale reddish-brown dots. The form of the eggs is more elongated than that of the eggs of minimus, the dimensions being .77 by .53 inch, and .76 by .55 inch.

\section{EMPIDONAX MINIMUS. - Baird.}

\section{The Least Flycatcher; Chebêc.}

Tyrannula minima, William M. and S. F. Baird. Pr. A. N. Sc. I. (July, 1643) 284. Ib., Sillim. Am. Jour. Sc. (July, 1844). Aad., Birds Amer. VII. (1844) 343, pl. 491.

\section{DESCRIPTION.}

Second quill longest, third and fourth but little shorter, fifth a little less, first intermediate between fifth and sixth; tail even; above olive-brown, darker on the head, becoming paler on the rump and upper tail coverts; the middle of the back most strongly olivaceous; the nape (in some individuals) and sides of the head tinged witl ash; a ring round the eye, and some of the loral feathers white, the chin and throat white; the sides of the throat and across the breast dull-ash, the color on the latter sometimes nearly obsolete; sides of the breast similar to the back, but of a lighter tint; middle of the belly very pale yellowish-white, turning to pale sulphuryellow on the sides of the belly, abdomen, and lower tail coverts; wings brown 
two narrow white bands on wing, formed by the tips of the first and second coverts, succeeded by one of brown; the edge of the first primary, and of the secondaries and tertials, white; tail rather lighter brown, edged externally like the back; feathers narrow, not acuminate, with the ends rather blunt. In autumn, the white parts are strongly tinged with yellow.

Length, about five inches; wing, two and sixty-five one-hundredths; tail, two and fifty one-hundredths.

Hab. - Eastern United States to Missouri plains.

This species arrives from the South usually about the last week in April. The birds commence building about the 20th or 25th of May. The nest is placed usually in a small fork of a limb of an apple-tree, in the orchard, and often quite near the house : it is composed of soft, fine grass, cobwebs, twine, cotton, - in fact, almost any thing that will help to make a smooth, compact fabric: the interior is lined with soft grass, bristles, fine roots, feathers, and wool. The eggs are usually four in number, sometimes three, sometimes five: they are of a beautiful creamy-white color; and their form is nearly pyriform, being abruptly tapered to the small end. Dimensions of a nest complement of four eggs, taken at random from a large number, collected in different parts of New England: .63 by .50 inch, .64 by .51 inch, .61 by .53 inch, .60 by .53 inch. This species often breeds twice in the season in New England. The period of incubation is thirteen days.

This bird, being very abundantly distributed as a summer resident throughout New England, is well known, and its habits are familiar to all. It prefers the neighborhood of civilization, and is most frequently found in orchards and gardens. A pair once built in an apple-tree, immediately beneath my chamber window, - so near that I could touch the nest with a rod four feet in length. The nest was commenced on the 5th of June, and was finished by the 10th; both birds working in its construction. The female laid four eggs in three days' time, and commenced sitting when the fourth was laid. Both birds incubated, and the male remained on the nest nearly as long as his mate. When he 
was off the nest, he was very pugnacious; attacking every bird that came near, and even forcing a robin to retreat, so fierce was the onslaught he made on it. He always, in attacking other birds, uttered his shrill cry, chebêc, chebêc, and snapped his bill loudly and fiercely. When perching, he often flirted his tail in the manner of the Phebe; and, every few seconds, he emitted his note,-chebêc, chebêc, chebêc; varied sometimes into chebêe-trree-treo, chebêc-treeecheu.

The young were all hatched by the fourteenth day, and left the nest within a month from their birth. They were fed abundantly, while on the nest, by the parents, with insects, which they caught and crushed between their bills: they were fed a few days after they left the nest, and then turned adrift; the parents having begun another nest on the same tree.

The Least Flycatcher has often been called the Small Green-crested or Acadican Flycatcher. I would caution those who are interested in the history of these birds to observe great care, and be certain of their identity before naming them.

By the second week in September, it leaves on its southern migration.

\section{EMPIDONAX ACADICUS. - Baird."}

The Small Green-crested Flycatcher.

\& Muscicapa acadica, Gmelin. Syst. Nat., I. (1788) 947. Aud. Orn. Biog., II. (1834) 256; V. (1839) 429. Nutt. Man., I. (1832) 208.

Muscicapa querula, Wilson. Am. Orn., II. (1810) 77.

Tyrannus acadica, Nuttall. Man. I. (2d ed., 1840) 320 .

\section{DESCRIPTION.}

The second and third quills are longest, and about equal; the fourth a little shorter, the first about equal to the fifth, and about thirty-five one-hundredths less than the longest; tail even; the upper parts, with sides of the head and neck, olivegreen, the crown very little if any darker; a yellowish-white ring round the eye; the sides of the body under the wings like the back, but fainter olive, a tinge of the same across the breast; the chin, throat, and middle of the belly white; the abdomen, lower tail and wing coverts, and sides of the body not covered by the wings, pale greenish-yellow; edges of the first primary, secondaries, and tertials margined 
with dull yellowish-white, most broadly on the latter; two transverse bands of paleyellowish across the wings, formed by the tips of the secondary and primary coverts, succeeded by a brown one; tail light-brown, margined externally like the back; upper mandible light-brown above, pale-yellow beneath. In autumn, the lower parts are more yellow.

Length, five and sixty-five one-hundredths inches; wing, three; tail, two and seventy-five one-hundredths inches.

Uab. - Eastern United States to the Mississippi.

This bird is a rare summer inhabitant of any of the NewEngland States, seldom coming so far north. I have had no opportunities of observing its habits, and can give no description from my own observation. Mr. Allen says that it breeds in swamps and low moist thickets, which are its exclusive haunts.

Giraud, in his "Birds of Long Island," says, "In habits, it is solitary; generally seen on the lower branches of the largest trees; utters a quick, sharp note; arrives among us in the latter part of May, and retires southward early in September."

I have no nest, but understand that it resembles that of the Least Flycatcher. Five eggs before me, furnished by J. P. Norris, Esq., of Philadelphia, are of a pale creamywhite color, with a few thin spots of reddish-brown scattered. over their larger end. They vary in size from .78 inch in length by about .56 inch in breadth, to .72 inch in length by .55 inch in breadth. The form is like that of $E$. traillii; but the spots are larger and more numerous. 


\section{SUB-ORDER OSCINES. Singing Birds.}

Toes, three anterior, one behind, all at the same level, and none versatile, the outer anterior never entirely free to the base; tail feathers twelve; primaries, either nine only, or else the first is spurious or much shorter than the second, making the tenth; tail feathers usually twelve; tarsi feathered to the knee, the plates on the anterior face either fused into one or with distinct divisions, the posterior portion of the sides covered by one continuous plate on either side, meeting in a sharp edge behind, or with only a few divisions inferiorly. Occasionally, the hinder side has transverse plates, corresponding in number to the anterior; but there are then usually none on the sides. Larynx provided with a peculiar muscular apparatus for singing, composed of five pairs of muscles.

\section{Famix TURDIDA. The Thrushes.}

The following characteristics of this family and its genera, represented in New England, are given by Professor Spencer F. Baird, in his recent "Review of the Birds of North America," published in the Smithsonian Miscellaneous Collections:-

"Primaries ten, the first of which is either spurious or much shorter than the second. The bill is elongated and subulate, moderately slender, and usually notched at tip; nostrils uncovered; the culmen moderately curved from the base, and the mouth well provided with bristles, except in a few cases. Usually, the scutellæ covering the front and sides of the tarsus are fused into one continuous plate, or else scarcely appreciable, except on the inner edge only; in the Mocking Thrushes, they are, however, distinctly marked. The lateral toes are nearly equal, the outer rather the longer." These general characteristics apply also to the Saxicolido, more fully spoken of in a succeeding page.

The peculiar characteristics of the family Turdidoe are: "Wings moderate, more rounded, not reaching beyond middle of the often rounded tail, and not more than one and a third the latter, usually more nearly equal. Spurious primary sometimes half the length of second quill, the second quill shorter than the fourth. In the closed wing, the outer secondary reaches three-fourths or more the length of longest primary."

Professor Baird divides this family into the sub-families Turdince, which have "tarsi covered anteriorly with a continuous plate;" and the Mimince, whose tarsi are scutellate anteriorly; scutella seven.

\section{Sub-Family Turdine.}

Nostrils oval; bristles along the base of the bill from gape to nostrils, those of rictus not reaching beyond nostrils; the loral feathers with bristly points; second quill longer than sixth; outer lateral toes longer; wings long. 


\section{TURDUS, LINNæUS.}

Turdus, Linn sus, Syst. Nat. (1735). (Type T. viscivorus, fide G. R. Gray.)

Bill rather stout; commissure straight to near the tip, which is quite abruptly decurved, and usually distinctly notched; culmen gently convex from base; bill shorter than the head, both outlines curved; tarsi longer than the middle toe; lateral toes nearly equal, outer longer; wings much longer than the tail, pointed; the first quill spurious and very small, not one-fourth the length of longest; tail short, nearly even, or slightly emarginate.

\section{TURDUS MUSTELINUS. - Gmelin.}

The Song Thrush; Wood Thrush.

Turdus mustelinus, Gmelin. Syst. Nat., I. (1788) 817. Nutt. Man., I. (1832) 343. Aud. Orn. Biog., I. (1832) 372; V. (1839) 446.

Turdus melodus, Wilson. Am. Orn., I. (1808) 35, pl. ii.

\section{DESCRIPTION.}

Above, clear cinnamon-brown, on the top of the head becoming more rufous, on the rump and tail olivaceous; the under parts are clear-white, sometimes tinged with buff on the breast or anteriorly, and thickly marked beneath, except on the chin and throat, and about the vent and tail coverts, with sub-triangular, sharply defined spots of blackish; the sides of the head are dark-brown, streaked with white, and there is also a maxillary series of streaks on each side of the throat, the central portion of which sometimes has indications of small spots.

Length, eight and ten-liundredths inches; wing, four and twenty-five one-hundredths; tail, three and five one-hundredths; tarsus, one and twenty-six onehundredths.

Hab. - Eastern United States to Missouri River, south to Guatemala.

THIS beautiful songister is a pretty common summer
inhabitant of Massachusetts, Connecticut, and Rhode Island. In the other New-England States, it is rarely seen; and, when we hear of a Song Thrush occurring there, reference is probably made either to the Hermit or Olive-backed Thrush. It arrives from the South about the 10th of May, both sexes making their appearance at about the same time. They soon commence pairing, and frequent the moist thickets and thickly wooded glens, where their amours are conducted in privacy and peace.

At this season, the beautiful song of the male is heard at early dawn and early twilight: it seldom sings in the middle of the day, unless the weather is dark and cloudy. This song is a beautiful, melancholy strain, similar to the tone 
produced on a flute: the notes are difficult of description. Mr. Nuttall, who was particularly happy in his descriptions of bird-songs, speaks of this as follows:-

"The prelude to this song resembles almost the double-tonguing of the flute, blended with a tinkling, shrill, and solemn warble, which re-echoes from his solitary retreat like the dirge of some sad recluse, who shuns the busy haunts of life. The whole air consists usually of four parts, or bars, which succeed, in deliberate time, and finally blend together in impressive and soothing harmony, becoming more mellow and sweet at every repetition. Rival performers seem to challenge each other from various parts of the wood, vying for the favor of their mates with sympathetic responses and softer tones. And some, waging a jealous strife, terminate the warm dispute by an appeal to combat and violence. Like the Robin and the Thrasher, in dark and gloomy weather, when other birds are sheltered and silent, the clear notes of the Wood Thrush are heard through the dropping woods, from dawn to dusk; so that, the sadder the day, the sweeter and more constant is his song. His clear and interrupted whistle is likewise often nearly the only voice of melody heard by the traveller, to mid-day, in the heat of summer, as he traverses the silent, dark, and wooded wilderness, remote from the haunts of men. It is nearly impossible by words to convey any idea of the peculiar warble of this vocal hermit; but, amongst his phrases, the sound of 'airǒee, peculiarly liquid, and followed by a trill, repeated in two separate bars, is readily recognizable. At times, their notes bear a considerable resemblance to those of Wilson's Thrush: such as eh rhehu 'vrhehu, then varied to 'eh villia villia, 'eh villia vrhehu, then 'eh. velu villu, high and shrill."

About the 20th of May, the Song Thrush builds its nest. This is placed usually in a low alder or birch shrub, in a retired locality, almost always in the deep woods. It is composed outwardly of grass, leaves, and weeds, bent and twined together. In this is built a nest composed of mud and grass, and the whole is lined with fibrous roots and soft grass and moss. It is placed on a low branch of a tree, or in the branches of a shrub. I give Wilson's description of 
the nest, not because it is essentially different from my own, but to confirm my own observation, and to help clear up the confusion that exists in many districts concerning the identity of the thrushes. It is as follows:-

"The favorite haunts of the Wood Thrush are low, thick-shaded hollows, tbrough which a small brook or rill meanders, overhung with cedar-bushes that are mantled with wild vines. Near such a scene, he generally builds his nest in a laurel or alder bush. Outwardly, it is composed of withered beech-leaves of the preceding year, laid at bottom in considerable quantities, no doubt to prevent damp and moisture from ascending through, being generally built in low, wet situations: above these are layers of knotty stalks or withered grass, mixed with mud, and smoothly plastered, above which is laid a slight lining of fine black fibrous roots of plants."

The eggs are usually four in number; they are of a uniform light-blue color, without spots, and with a very slight tint of green; their form is rather long and pointed. The following are the dimensions of a nest complement of four eggs, found in Milton, Mass. : 1.12 by .68 inch, 1.12 by .69 inch, 1.07 by 70 inch, 1 by .73 inch. But one brood is usually reared in the season in New England.

\section{TURDUS PALLASII. - Cabanis.}

The Hermit Thrush.

Turdus pallasii, Cabanis. Wieggman's Archiv. (1847), I. 205.

Turdus solitarius, Wilson. Am. Orn., V. (1812) 95 (not of Linnæus. The figure quoted pl. xliii. fig. 2, belongs to $T$. Swainsonii). Aud. Syn. (1839). Ib., Birds Am., III. (1841) 29, pl. 146.

Turdus minor, Bonaparte. Obs. Wilson (1825), No. 72. Ib., Syn. (1828), 75. Nutt. Man., I. (1830) 346. Aud. Orn. Biog., I. (1831) 303; V. 445, pl. 58.

\section{DESCRIPTION.}

Fourth quill longest; third and fourth a little shorter; second about equal to the sixth (about a thirtieth of an inch shorter than the longest); tail slightly emarginate; above light olive-brown, with a scarcely perceptible shade of reddish, passing, however, into decided rufous on the rump, upper tail coverts, and tail, and to a less degree on the outer surface of the wings; beneath white, with a scarcely appreciable shade of pale-buff across the fore part of the breast, and sometimes on the throat; the sides of the throat and the fore part of the breast with rather sharply defined 
subtriangular spots of dark olive-brown; the sides of the breast with paler and less distinct spots of the same; sides of the body under the wings of a paler shade than the back; a whitish ring round the eye; ear coverts very obscurely streaked with paler.

Length, seven and fifty one-hundredths inches; wing, three and eighty-four onehundredths; tail, three and twenty-five one-hundredths; tarsus, one and sixteen one-hundredths.

Hab. - Eastern North America to the Mississippi River.

This bird, although not so well known in Massaclusetts, Comnecticut, and Rhode Island, is quite familiar to the people of the other States in New England. It arrives from the South about the middle of April, and passes leisurely to the North, where it arrives about the middle of May. It very seldom breeds in any districts south of the latitude of the middle of Maine; and from thence north it is quite abundant, where it is known by the name of the Swamp Robin. I have been so fortunate as to find several nests of this species; and they were all built in very low scrubby trees or bushes, quite near the ground. They were composed of twigs, grasses, mosses, and leaves; they were deeply hollowed, and no mud was used in their composition, as with several other species; they were lined with soft grasses, mosses, and fine fibrous roots. The eggs were, in one nest, three in number; and, in the others, four. This was about the 10th of June. The localities were in the neighborhood of Lake Umbagog and in the valley of the Magalloway River, in Maine. The eggs of this species are of a somewhat elongated oval form, and their color is a lightblue with a very faint tint of green: " about one in every four has very thinly scattered spots of reddish-brown, and occasionally one is met with having an abundance of coarser spots of two shades of brown." Dimensions of specimens from various localities vary from .92 by .65 to .88 by .60 inch.

Mr. C. L. Paine, of Randolph, Vt., writes me that he has found numbers of the nests of this bird, and that they were invariably built on the ground. He also says that the eggs 
are always blue in color, and he has never met with one that was spotted in any manner. I have quite a number of specimens in my collection, and not one is spotted. I have also seen many others, and they were not marked; and I think that the above quotation must be received with caution. A nest sent me from Upton, Me., is composed almost entirely of mosses. It contains five eggs, all unspotted.

Mr. Paine writes me that the Olive-backed Thrush breeds in his neighborhood, which, with the other, are the only thrushes breeding there. In answer to his remark that the Hermit Thrush always builds on the ground, I can only say that I found the nests as above. I have noticed that the Tawny or Wilson's Thrush builds on the ground in some localities and in bushes in others, and conclude that the Hermit is also variable in its choice of a nesting-place.

The habits, song, and general characteristics of this bird are almost exactly similar to those of the Song Thrush. Its song resembles it so much, that I always supposed the bird was the same, until I examined some of them that I heard singing, when I found my mistake. About the middle of October, the last individuals that are seen in Massachusetts leave for the South. At this time, as in the spring, they are silent and shy: their note is a faint chirp, uttered in a listless, melancholy tone; and their whole appearance is in keeping with the great change which has come over the face of Nature. In fact, the Hermit Thrush is always associated in my mind with the falling of leaves, the rattling of acorns, and the whirring of the Ruffed Grouse through the birches and alders of the swampy glens.

\section{TORDUS FUSCESCENS. - Stephens.}

The Tawny Thrush; Wilson's Thrush.

Turdus fuscescens, Stephens. Shaw's Zool. Birds, X. (1817) 182. Gray, Genera (1849).

Turdus mustelinus, Wilson. Am. Orn., V. (1812) 98 (not of Gm.).

Turdus Wilsonii, Nuttall. Man., I. (1832) 349. Aud. Orn. Biog., II. (1834) 362 ; V. 446. Ib., Birds Am., III. (1841) 27, pl. 145. 


\section{DESCRIPTION.}

Third quill lcngest, fourth a little shorter, second nearly a quarter of an inch longer than the fith; above, and on sides of head and neck, nearly uniform light reddish-brown, with a faint tendency to orange on the crown and tail: beneath white, the fore part of the breast and throat (paler on the chin) tinged with pale brownish-yellow, in decided contrast to the white of the belly; the sides of the throat and the fore part of the breast, as colored, are marked with small triangular spots of light-brownish, nearly like the back, but not well defined; there are a few obsolete blotches on the sides of the breast (in the white) of pale-olivaceous, the sides of the body tinged with the same; tibire white; the lower mandible is brownish only at the tip; the lores are ash-colored.

Length, seren and fifty one-hundredths inches; wing, four and twenty-five onehundredths; tail, three and twenty one-hundredths inches; tarsus, one and twenty one-hundredths.

Hab. - Eastern North America to the Missouri, north to fur countries.

This species is well distinguished among the American thrushes by the indistinctness of the spots beneath, and their being confined mainly to the fore part of the breast. In some specimens, there is a faint tendency to a more vivid color on the rump; but this is usually like the back, which is very nearly the color of the rump in $T$. pallasii.

This quite common species is a summer inhabitant of southern New England. It is quite abundant until we reach the southern portions of Maine, New Hampshire, and Vermont, when it begins to grow less common until we reach the latitude of the middle of these States, where it begins to be replaced by the Hermit Thrush, and soon ceases to occur to the north of this latitude. It makes its appearance from the South about the first week in May, often earlier, and commences building about the 20th of May. The nest is placed occasionally in a low shrub, or tangled clump of briers, usually on the ground. The situation is retired, often in the depths of the woods. The nest is constructed of grass, leaves, and weeds; in some cases, the outer bark of the grape-vine is the principal material used: it is quite thoroughly made, and is deeply hollowed, and lined with fine roots and horsehair. The eggs are usually four in number, sometimes five ; their color is bluish-green, deeper than that of the eggs of the Hermit Thrush, but not so dark as in those of the Cat Bird; their form is generally an oval, sometimes lengthened and sharpened; their average size is 
about .90 by .66 inch. As in many other eggs', the longest specimens are not always the broadest. The following are the dimensions of four eggs, taken at random from a large number of this species: .92 by .64 inch, .88 by .64 inch, .86 by .66 inch, .87 by .67 inch.

From the first arrival of this bird, during its whole stay here, it seems to prefer the neighborhood of a swampy wood for its home. There, during the mating and incubating seasons, the notes of the male may be heard at the earliest hours of the morning and evening; and, in cloudy weather, through the day, and sometimes in the night. The song is a peculiar one, with a singular metallic ring, exceedingly difficult to describe: it begins quite loud, the syllables chéury, chéury, chéury, chéury, decreasing in tone to a quite faint lisp; then, after a short pause, the notes, cheou 'twit, tritter, 'tritter, are uttered; and the whole is finished usually with the ejaculation, chickwhêu. This song is often repeated; and sometimes two or three males, perching on a low shrub or tree, emulate each other in a musical contest that is very pleasing to hear. This thrush, as are all the others, is eminently insectivorous; and through the whole day he may be heard busily searching among the fallen leaves for his favorite food.

About the 10th of September, it leaves for the South: at this time, like most of the others, it is silent and retiring, and is found only in localities that are thickly wooded with a growth of small birches and oaks.

TURDUS SWAINSONII. - Cabanis.

The Olive-backed Thrush; Swainson's Thrush.

Turdus Swainsonii. Cab. in Tschudi F. Peruana (1844-46) 188.

Turdus solitarius, Wilson. Am. Orn., V.

Description.

Third quill longest, second and fourth but little shorter, and much longer than the fifth (by thirty-five one-hundredths of an inch); upper parts uniform olivaceous, with a decided shade of green; the fore part of breast, the throat, and chin, pale brownish-yellow; rest of lower parts white, the sides washed with brownish-olive; 
sides of the throat and fore part of the breast with sub-rounded spots of well-defined brown, darker than the back; the rest of the breast (except medially) with rather less distinct spots that are more olivaceous; tibix yellowish-brown; broad ring round the eye; loral region, and a general tinge on the side of the head, clear reddish-buff.

Length, seven inches; wing, four and fifteen one-hundredths; tail, three and ten one-hundredths inches; tarsus, one and ten one-hundredths.

Hab. - Eastern North America to the Black Hills, south to Mexico and Peru, north to Greenland. Accidental in Europe and Siberia.

This species is at once distinguished from the others by the perfectly uniform and pure dull-olivaceous shade of its upper parts, most strongly marked and appreciable on the rump and tail. The throat and breast are perhaps more reddish than in any of our species, and the tinge in the marking on the side of the head is very much more decided than in any other. The spots on the breast larger than in $T$. ustulatus, and rather more numerous than in pallasii.

This species is the least common of all the New-England thrushes. It is rarely observed in its passage through the southern portions of these States, and only begins to choose a home for the summer on arriving at the northern districts. I have looked for it repeatedly, but have not been able to find it south of the latitude of Lake Umbagog, in the breeding season; and even there it is not often met with. It arrives in the localities where it breeds about the first week in June. In common with the Hermit Thrush, it is called the "Swamp Robin," and can hardly be distinguished from that bird, either by its song, which is beautiful, or by its breeding habits or nests. The eggs are different, being of a deeper green color: they are always (so far as my experience goes) thinly spotted with dots and blotches of reddish and brown. The following are the dimensions of four eggs that I found in a nest near Wilson's Mills, Me., on the 16th of June, 1864: .93 by $.64 \mathrm{inch}, .93$ by .63 inch, .92 by .60 inch, .90 by .61 inch.

The only difference in the habits of this species from those of the Hermit Thrush is, that, while the latter is most usually found in swampy localities, the other is most often seen in dry, scrubby woods, where it is almost always busily engaged in the pursuit of its favorite insect food.

J. A. Allen, in his paper on the birds of Springfield, Mass., before referred to, is of the opinion that this species 
and the Turdus alicice are the same. In a conversation with Professor Baird, since the issue of Allen's paper, I was informed, that, in a large suite of specimens of both species, to which he had access, he could identify each by characteristics so fixed that any confusion was impossible: he was of the opinion that Mr. Allen had not seen the bird he calls alicioe. I have therefore not given that species as a bird of New England, and think that it yet remains to be proved as such.

Dr. Bryant, in describing the habits of the Olive-backed Thrush, says :-

"Its note differs entirely from that of $T$. pallasii, and the birds also differ very much in their habits; the latter species being generally seen on the ground, while the Olive-backed Thrush prefers to procure its food among the branches. The one seen at Big Mud Lake, Grand Manan, was perched on the top of a small dwarf-fir, and was hunting the passing insects with all the dexterity of a typical Flycatcher."

\section{TURDUS MIGRATORIUS. - Linnaus.}

The Robin.

Turdus migratorius, Linnæus. Syst. Nat,, I. (1766) 292. Wilson, Am. Orn., I. (1808) 35. Aud. Orn. Biog., II. (1834) 190.

Iferula migratoria, Sw. and Rich. Fauna Bor. Amer., II. (1831) 176.

\section{DESCRIPTION.}

Third and fourth quills about equal, fifth a little shorter, second longer than sixth; tail slightly rounded; above olive-gray, top and sides of the head black; chin and throat white, streaked with black; eyelids, and a spot above the eye anteriorly, white; under parts and inside of the wings chestnut-brown; the under tail coverts and anal region with tibix white, showing the plumbeous inner portions of the feathers; wings dark-brown, the feathers all edged more or less with pale-ash; tail still darker, the extreme feathers tipped with white; bill yellow, dusky along the ridge and at the tip.

Length, nine and seventy-five one-hundredths inches; wing, five and forty-three one-hundredths; tail, four and seventy-five one-hundredths.inches; tarsus, one and twenty-five one-hundredths.

$H a b$. - Continent of North America to Mexico.

It is very seldom that specimens exhibit the colors exactly as described. Nearly always in winter, and in most cases at other times, the rufous feathers are margined with whitish, sometimes quite obscuring the color. The black feathers of the head, 
too, have brownish edgings. The white spot above the eye sometimes extends forwards towards the nostrils, but is usually quite restricted. The white patches on the two eyelids are separated from each other, anteriorly and posteriorly.

This very common and well-known bird is a summer inhabitant of all New England, and, in mild winters, remains in the southern districts of these States through the year. The great body of the birds, however, arrive from the South about the middle of March. They commence building from the middle of April to the first week in May, according to latitude. The nest is built more often in the trees of

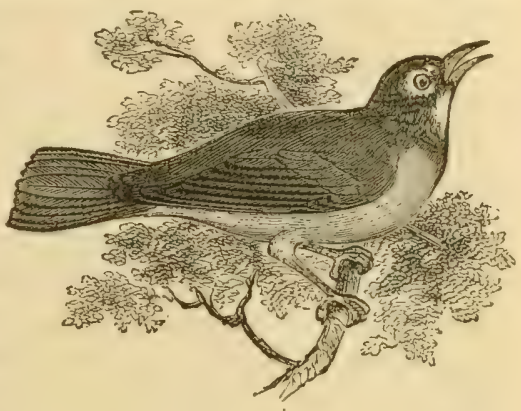
the orchards and gardens, near houses, than in the deep woods. It is a large, elaborately built affair, constructed first of a thick layer of straws, weeds, roots, and mosses : on this is built the nest proper, which is made of straws and weeds, woven together in a circular form, and plastered together with mud; this is lined with soft grasses and moss, the whole making a durable structure, often holding together through the entire year. The eggs are usually four in number: their color is a beautiful greenish-blue, almost the same as that of the Wood 'Thrush's egg, which they resemble in shape, except they are a trifle broader. Dimensions of a nest-complement of four eggs : 1.16 by $.82 \mathrm{inch}, 1.16$ by .82 inch, 1.10 by .75 inch, 1.10 by .80 inch. Many cases occur, in the southern districts of New England, of two broods being reared in the season, and I have known of three broods being reared in Massachusetts; but, in the northern districts, I think that the second brood is the exception, instead of the rule.

Perhaps none of our birds are more unpopular with horticulturists than this; and I will here give the observations 
of different scientific men, and my own, to show that the prejudice against the bird is unjust and unfounded. Mr. Trouvelot, of Medford, Mass., who is engaged in rearing silkworms, for the production of silk, is troubled by the Robin to a degree surpassing most other birds. He has a tract of about seven or eight acres enclosed, and mostly corered with netting. He is obliged, in self-defence, to kill the birds which penetrate into the enclosure and destroy the worms. Through the season, probably ten robins, for one of all others, thus molest him; and, of scores of these birds which he has opened and examined, none had any fruit or berries in their stomachs, - nothing but insects. It is to be understood that this was not in a part of the summer when berries were unripe: on the contrary, it was all through the season. His land is surrounded with scruboaks and huckleberry-bushes. These latter were loaded with fruit, which was easier of access to the birds than the worms; but none were found in them. He says they came from all quarters to destroy his silkworms, and gave him more trouble than all the other birds together. He said that, in his opinion, if the birds were all killed off, vegetation would be entirely destroyed. To test the destructiveness of these marauders, as he regarded them, he placed on a small scrub-oak near his door two thousand of his silkworms. (These, let me say, resemble, when small, the young caterpillar of the apple-tree moth.) In a very few days they were all eaten by Cat-birds and Robins, - birds closely allied, and of the same habits. This was in the berry season, when an abundance of this kind of food was easily accessible; but they preferred his worms. Why? Because the young of these, as well as those of most other birds, must be fed on animal food. Earthworms assist in the regimen; but how often can birds like the Robin, Catbird, Thrush, \&c., get these? Any farmer knows, that, when the surface of the ground is dry, they go to the subsoil, out of the reach of birds; and it is not necessary here to say 
what proportion of the time the ground is very dry through the summer. Caterpillars, grubs of various kinds, and insects, therefore constitute the chief food of these birds; and of these, caterpillars and grubs being the most abundant, and most easily caught, furnish, of course, the larger proportion.

In fact, the Thrushes seem designed by nature to rid the surface of the soil of noxious insects not often pursued by most other birds. The warblers capture the insects that prey on the foliage of the trees; the flycatchers seize these insects as they fly from the trees; the swallows capture those which have escaped all these; the woodpeckers destroy them when in the larva state in the wood; the wrens, nuthatches, titmice, and creepers eat the egg's and young that live on and beneath the bark; but the thrushes subsist on those that destroy the vegetation on the surface of the earth. They destroy nearly all kinds of grubs, caterpillars, and worms that live upon the greensward and cultivated soil, and large quantities of crickets and grasshoppers before they have become perfect insects. The grubs of locusts, of harvest-flies, and of beetles, which are turned up by the plough or the hoe, and their pupx when emerging from the soil ; apple-worms, when they leave the fruit and crawl about in quest of new shelter; and those subterranean caterpillars, the cutworms, that come out of the earth to take their food,all these, and many others, are eagerly devoured by the Robin and other Thrushes. The cutworms emerge from the soil during the night to seek for food; and the Robin, which is one of the earliest birds to go abroad in the morning, is very diligent at the dawn of day in hunting for these vermin before they have gone back into their retreat. The number of these destructive grubs is immense. "Whole cornfields," says Dr. Harris, "are sometimes laid waste by them. Cabbage-plants, till they are grown to a considerable size, are very apt to be cut off and destroyed by them. Potato-vines, beans, beets, and various other culinary plants, 
suffer in the same way." The services of the robins, in destroying these alone, would more than pay for all the fruit they devour. Indeed, during the breeding season, a robin is seldom seen without having in his mouth one of these caterpillars, or some similar grub, which he designs for his young; and as the Robin often raises three broods of young during the season, his species must destroy more of this class of noxious insects than almost all other birds together. In my own gardening experiences, I have had my full share of cutworms; and I have always noticed the Robin, Brown Thrush, and Cat-bird busy early in the morning, - almost before other birds are out of their feather-beds, figuratively speaking, - catching these vermin and eating them, or carrying them for food to their young.

To show further the food of this bird, I present the following experiment. At a meeting of the Boston Society of Natural History, a communication was read from Professor Treadwell, of Cambridge, giving a detailed account of the feeding and growth of this bird during a period of thirtytwo days, commeneing with the 5th of June. The following is the substance of this report:-

When caught, the two were quite young, their tail feathers being less than an inch in length, and the weight of each about twenty-five pemyweights, - less than half the weight of the full-grown birds: both were plump and vigorous, and had evidently been very recently turned out of the nest. He began feeding them with earthworms, giving three to each bird that night. The second day, he gave them ten worms each, which they ate ravenously. Thinking this beyond what their parents could naturally supply them with, he limited them to this allowance. On the third day, he gave them cight worms each in the forenoon; but in the afternoon he found one becoming feeble, and it soon lost its strength, refused food, and died. On opening it, he found the proventriculus, gizzard, and intestines entirely empty, and concluded therefore that it died from want of sufficient food; 
the effect of hunger being increased perhaps by the cold, as the thermometer was about sixty degrees.

The other bird, still vigorous, he put in a warmer place, and increased its food, giving it the third day fifteen worms, on the fourth day twenty-four, on the fifth twenty-five, on the sixth thirty, and on the seventh thirty-one worms. They seemed insufficient, and the bird appeared to be losing plumpness and weight. He began to weigh both the bird and its food, and the results were given in a tabular form. On the fifteenth day, he tried a small quantity of raw meat, and, finding it readily eaten, increased it gradually, to the exclusion of worms. With it the bird ate a large quantity of earth and gravel, and drank freely after eating. By the table, it appears that though the food was increased to forty worms, weighing twenty pennyweights, on the eleventh day the weight of the bird rather fell off; and it was not until the fourteenth day, when he ate sixty-eight worms, or thirtyfour pennyweights, that he began to increase. On this day, the weight of the bird was twenty-four pennyweights: he therefore ate forty-one per cent more than his own weight in twelve hours, weighing after it twenty-nine pennyweights, or fifteen per cent less than the food he had eaten in that time. The length of these worms, if laid end to end, would be about fourteen feet, or ten times the length of the intestines.

To meet the objection, that the earthworm contains but a small quantity of nutritious matter, on the twenty-seventh day he was fed exclusively on clear beef, in quantity twentyseven pennyweights. At night, the bird weighed fifty-two pennyweights, but little more than twice the amount of flesh consumed during the day, not taking into account the water and earth swallowed. This presents a wonderful contrast with the amount of food required by the cold-blooded vertebrates, fishes, and reptiles, many of which can live for months without food, and also with that required by mammalia. Man, at this rate, would eat about seventy 
pounds of flesh a day, and drink five or six gallons of water.

The question immediately presents itself, How can this immense amount of food, required by the young birds, be supplied by the parents? Suppose a pair of old robins, with the usual number of four young ones. These would require, according to the consumption of this bird, two hundred and fifty worms, or their equivalent in insect or other food, daily. Suppose the parents to work ten hours, or six hundred minutes, to procure this supply: this would be a worm to every two and two-fifths minutes; or each parent must procure a worm or its equivalent in less than five minutes during ten hours, in addition to the food required for its own support.

After the thirty-second day, the bird had attained its full size, and was intrusted to the care of another person during his absence of eighteen days. At the end of that period, the bird was strong and healthy, with no increase of weight, though its feathers had grown longer and smoother. Its food had been weighed daily, and averaged fifteen pennyweights of weight, two or three earthworms, and a small quantity of bread each day, the whole being equal to eighteen pennyweights of meat, or thirty-six pennyweights of earthworms; and it continued up to the time of the presentation of the report. The bird having continued in confinement, with certainly much less exercise than in the wild state, to eat one-third of its weight in clear flesh daily, the Professor concludes that the food it consumed when young was not much more than must always be provided by the. parents of wild birds. The food was never passed undigested; the excretions were made up of gravel and dirt, and a small quantity of semi-solid urine.

He thought that every admirer of trees may derive from these facts a lesson, showing the immense power of birds to destroy the insects by which our trees, especially our apple-trees, elms, and lindens, are every few years stripped of their foliage, and often many of them killed. 
"The food of the Robin," the Professor says, "while with us, consists principally of worms, various insects, their larva and eggrs, and a few cherries. Of worms and cherries they can procure but few, and those during but a short period; and they are obliged, therefore, to subsist principally upon the great destroyers of leaves, - canker-worms, and some other kinds of caterpillars and bugs. If each robin, old and young, requires for its support an amount of these equal to the weight consumed by this bird, it is easy to see what a prodigious havoc a few hundred of these must make upon the insects of an orchard or nursery."

Wilson Flagg, an acute and careful observer of the habits of our birds, gives some of his experiences of the Robin, as follows. He says, -

"Before I had investigated the habits of this bird, with particular reference to the service he renders to agriculture, I supposed he was only of secondary importance, compared with the Blackbird and others that possess the faculty of discovering and seizing the grubs that lie concealed beneath the surface of the ground. Though the Robin does not possess this faculty, he is pre-eminently serviceable in other ways; and the more I have studied his habits, the more am convinced of his usefulness. Indeed, I am now fully persuaded that he is valuable beyond all other species of birds, and that his services are absolutely indispensable to the farmers of New England. Some persons believe that the Robin is exclusively a frugivorous bird, and that for fruit he will reject all other food that is within his reach. Others believe that his diet consists about equally of fruits and angle-worms, but that he is not a general consumer of insects. The truth is, the Robin is almost exclusively insectivorous, and uses fiuit, as we do, only as a dessert, and not for his subsistence, except in the winter, when his insect food cannot be obtained. He is not omnivorous, like the Crow, the Jay, and the Blackbird. He rejects farinaceous food unless it is artificially prepared, derives almost his entire support from insects and grubs, and consumes, probably, a greater variety of species than any other bird. I am entirely at a loss to account for this very prevalent and mistaken notion respecting the frugivorous habits of the Robin. 
"Early in May," he says, "my son caught and caged three young Robins, and I encouraged him in the act, that I might be enabled to study their habits of feeding. He commenced by feeding them with angle-worms and soaked bread, giving them the latter very sparingly. They soon died, evidently from an excess of the farinaceous part of their diet. He then took three others from different nests, and fed them more exclusively on worms, and some fruit. Two of these also soon died, and the remaining one appeared ill and drooping. I suggested that the bird probably needed insects as well as worms, which alone were not sufficient to supply all the wants of the system; though he had access to cherries and soaked bread, of which he could eat whenever he wanted them. After this, he was supplied with all sorts of grubs and insects which my son was able to capture. The robin devoured these indiscriminately and with great eagerness. He was never known to refuse one of any description. All kinds of beetles, moths, bugs, grubs, vineworms, chrysalids, and caterpillars, which were presented to him, he devoured. After this improvement of his diet, the bird soon recovered his health; and the experiment proved conclusively that this variety of insect food was necessary to the life of the bird, at least while he was young.

"These insects were not put into his mouth: they were placed upon the floor of his cage, and he picked them up, killing them in a way that showed that he knew instinctively how to manage them.

"He was particular in beating the vine-worm considerably before he swallowed it; but he never refused one, or neglected to eat it. On one occasion, having swallowed a hard beetle, and finding it incommodious, he threw it out of his crop by a voluntary effort, beat it awhile with his bill against the floor, and then swallowed it again. This fact also proved his instinctive knowledge of the mode of proceeding in such emergencies.

"It is a fact worthy of notice, that the Baltimore Oriole, or Golden Robin, which has the reputation of performing more service than the common Robin, may, when confined in a cage, be fed almost entirely on farinaceous food, without injury to his health. This fact is good evidence that the common Robin is more entirely insectivorous than the other. The contrary is generally believed. The fondness of the Robin and others for fruit is not peculiar to his 
species : it is equally remarkable in almost all other insectivorous birds."

I have given these accounts, as I remarked before, for the purpose of removing a prejudice that is too well established against this bird. Instances like the above might be presented to almost any extent; but my limits will not permit a further notice of this species. ${ }^{2}$

\section{Sub-Family Mumn无. - Mocking Birds.}

Tall long, vaulted at the base, the feathers more or less graduated; size large; general appearance thrush-like; rictus with distinct bristles; frontal feathers normal, directed backwards; anterior half of outer side of tarsi distinctly scutellate.

\section{HARPORHYNCHUS, CABANTS.}

Zarporhynchus, CABANIs, Wiegmann's Archiv. (1848), I. 98. (Type Harpes redivivus.)

Bill from front as long as, or longer than the head, nearly straight to near the tip, or bow-shaped, without any notch; tarsus as long as, or longer than the middle toe, conspicuously scutellate; outer lateral toe a little the longer, not reaching the base of the middle claw; hind toe longer than lataral, its claw equal to its remaining portion; wings short, rounded, the fourth or fifth longest; the exposed portion of the first about half that of longest; tail longer than the wings, broad, more or less graduated.

\section{HARPORHYNCHUS RUFUS, - Cabanis.}

The Brown Thrush; Brown Thrasher.

Turdus rufus, Linnæus. Syst. Nat., I. (1766) 293. Wilson, Am. Orn., II. (1810) 83. Aud. Orn. Biog., II. (1834) 102; V. (1839) 441.

Orpheus rufus, Swainson. F. Bor. Am., II. (1831) 187. Nuttall, Man. I. (1832) 328.

\section{Description.}

Fifth quill longest; the third, fourth, and sixth little shorter; second equal to ninth; exposed portion of the bill shorter than the head; outline of lower mandible straight; above light cinnamon-red, beneath pale rufous-white with longitudinal

1 This genus, together with the following, has been removed from its position in the Liotrichider, as given in vol. IX. Pac. R.R. Reports, and placed in the Turdida by Professor Baird, in his recent Review of the Birds of North America.

2 See Appendix. 
streaks of dark-brown, excepting on the chin, throat, middle of the belly, and under tail coverts; these spots, anteriorly, are reddish-brown in their terminal portion; the inner surface of the wing and the inner edges of the primaries are cinnamon; the concealed portion of the quills otherwise is dark-brown; the median and greater wing coverts become blackish-brown towards the end, followed by white, producing two conspicuous bands; the tail feathers are all rufous, the external ones obscurely tipped with whitish; the shafts of the same color with the vanes.

Length, eleven and fifteen one-hundredths inches; wing, four and fifteen onehundredths; tail, five and twenty one-hundredths inches; tarsus, one and thirty one-hundredths; iris, golden-yellow.

Probably none of our summer visitors are better known, and none are greater favorites than this bird. Its beautiful song and well-known beneficial habits have endeared it to the farmer, who takes it under his protection, as he should all the Thrushes, and encourages its approach to the garden and orchard. The Brown Thrush arrives from the South about the middle of April in Connecticut and Rhode Island, and the 10th of May in Maine and the other northern districts. The birds seem to be mated before their arrival here, as they are almost always observed in pairs at their first appearance. The nest is built about the middle of May, sooner or later, according to latitude. It is usually placed in a bush or thicket of briers or vines, sometimes on the ground at the foot of a clump of bushes. It is composed first of a layer of twigs, then leaves and strips of cedar and grape-vine bark, and the whole is covered with fibrous roots : the nest is pretty deeply hollowed, and lined with fine roots and hairs. The eggs are from three to five in number. Their color is a greenish or dirty white, over which are thickly sprinkled minute dots of reddish-brown: their shape is ovate, and their dimensions vary from 1.16 by .80 inch to 1.06 by .76 inch. A great number before me exhibit these variations, which probably are the greatest of this species, as the eggs are generally nearly of a size. Four eggs in a nest collected in New Hampshire have the following measurements : 1.12 by .78 inch, 1.12 by .76 inch, 1.08 by .76 inch, 1.06 by .76 inch. But one brood is reared in the season in the Northern States. 
The song of this bird is difficult of description: it is a sort of confused mixture of the notes of different birds, or rather seems to be, but is really its own song; as different individuals all sing nearly alike. The fact that it resembles the Mocking-bird in its medley of notes has caused it to be called, in some localities, the Brown Mocker; and it is also sometimes called the Mavis and Nightingale, from its habit of singing in the night during the mating season.

The description of Wilson's, of the habits of this bird, is pretty comprehensive, in fact, the best that I have seen, and I give it almost entire. He says, -

"It is the largest of all our Thrushes, and is a well-known and very distinguished songster. About the middle or 20th of April, or generally about the time the cherry-trees begin to blossom, he arrives in Pennsylvania; and, from the tops of our hedge-rows, sassafras, apple, or cherry trees, he salutes the opening morning with his charming song, which is loud, emphatical, and full of variety. At that serene hour, you may plainly distinguish his voice fully half a mile off. These notes are not imitative, as his name would import, and as some people believe, but seem solely his own, and have considerable resemblance to the notes of the Song Thrush (Turdus musicus) of Britain. Early in May he builds his nest, choosing a thorn-bush, low cedar, thicket of briers, dogwood-sapling, or cluster of vines, for its situation, generally within a few feet of the ground. Outwardly, it is constructed of small sticks; then, layers of dry leaves; and, lastly, lined with fine, fibrous roots, but without any plaster. The eggs are five, thickly sprinkled with ferruginous grains, on a very pale-bluish ground. They generally have two broods in a season. Like all birds that build near the ground, he shows great anxiety for the safety of his nest and young, and often attacks the black snake in their defence; generally, too, with success, his strength being greater, and his bill stronger and more powerful, than any other of his tribe within the United States. His food consists of worms, which he scratches from the ground, caterpillars, and many kinds of berries. Beetles, and the whole race of coleopterous insects, wherever he can meet with them, are sure to suffer. He is accused, by some people, of scratching up the hills 
of Indian corn, in planting time. This may be partly true; but, for every grain of maize he pilfers, I am persuaded he destroys five hundred insects, particularly a large dirty-colored grub, with a black head, which is more pernicious to the corn, and other grain and vegetables, than nine-tenths of the whole feathered race. $\mathrm{He}$ is an active, vigorous bird, flies generally low, from one thicket to another, with his long, broad tail spread like a fan; is often seen about brier and bramble bushes, along fences; and has a single note or chuck, when you approach his nest. In Pennsylvania, they are numerous, but never fly in flocks. About the middle of September, or as soon as they have well recovered from moulting, in which they suffer severely, they disappear for the season. In passing through the southern parts of Virginia, and south as far as Georgia, in the depth of winter, I found them lingering in sheltered situations, particularly on the border of swamps and rivers. On the 1st of March, they were in full song round the commons at Savannah, as if straining to outstrip the Mocking-bird, that prince of feathered musicians.

"The Thrasher is a welcome visitant in spring, to every lover of rural scenery and rural song. In the months of April and May, when our woods, hedge-rows, orchards, and cherry-trees, are one profusion of blossoms; when every object around conveys the sweet sensations of joy, and Heaven's abundance is, as it were, showering around us, - the grateful heart beats in unison with the varying, elevated strains of this excellent bird: we listen to its notes with a kind of devotional ecstasy, as a morning hymn to the great and most adorable Creator of all. The human being who, amidst such scenes, and in such seasons of rural serenity and delight, can pass them with cold indifference, and even contempt, I sincerely pity; for abject must that heart be, and callous those feelings, and depraved that taste, which neither the charms of nature, nor the melody of innocence, nor the voice of gratitude or devotion, can reach.

"Concerning the sagacity and reasoning faculty of this bird, my venerable friend, Mr. Bartram, writes me as follows: 'I remember to have reared one of these birds from the nest, which, when full grown, became very tame and docile. I frequently let him out of his cage, to give him a taste of liberty. After fluttering, and dusting 
himself in dry sand and earth, and bathing, washing, and dressing himself, he would proceed to hunt insects, such as beetles, crickets, and other shelly tribes; but, being very fond of wasps, after catching them, and knocking them about to break their wings, he would lay them down, then examine if they had a sting, and, with his bill, squeeze the abdomen to clear it of the reservoir of poison before he would swallow his prey. When in his cage, being very fond of dry crusts of bread, if upon trial the corners of the crumbs were too hard and sharp for his throat, he would throw them up, carry and put them in his water-dish to soften, then take them out and swallow them." "

By the first week in October, the Brown Thrush departs on its southern migration, and passes the winter in the West Indies and Mexico.

MIMUS, BoIE.

Mimus, BoIE, Isis (Oct., 1826) 972. (Type Turdus polyglottus.)

Bill shorter than the head, decurved from the base, distinctly notched at tip; tarsi longer than the middle toe; lateral toes equal, not reaching the base of the middle claw, and shorter than the hind toe, the claw of which is half the total length; tail variable, equal to or longer than the wings, moderately graduated; wings rounded, the exposed portion of the first nearly or quite half that of the second, which is considerably shorter than the third.

\section{MIMUS POLTGLOTTUS. - Boie.}

The Mocking-bird,

Turdus polyglottus, Linnæus. Syst. Nat., I. (1766) 293. Wilson, Am. Orn., II. (1810) 14. Aud. Orn. Biog., I. (1831) 108; V. (1839) 438.

Mimus polyglottus, Boie. Isis (Oct., 1826), 972.

Orp̈heus polyglottus, Swainson. Zool. Jour., III. (1827) 167.

\section{DesCRIPTION.}

Third to sixth quills nearly equal, second shorter than seventh; tail considerably graduated, above ashy-brown, the feathers very obsoletely darker centrally, and towards the light plumbeous downy basal portion (scarcely appreciable, except when the feathers are lifted); the under parts are white, with a faint brownish tinge, except on the chin, and with a shade of ash across the breast; there is a pale superciliary stripe, but the lores are dusky; the wings and tail are nearly black, except the lesser wing coverts, which are like the back, the middle and greater tipped with white, forming two bands, the basal portion of the primaries white, most extended on the inner primaries; the outer tail feather is white, the second is mostly white, 
except on the outer web and towards the base, the third with a white spot on the end, the rest, except the midale, very slightly tipped with white; the bill and legs are black.

Length, nine and fifty one-hundredths inches; wing, four and fifty one-hundredths; tail, five inches; iris, light-yellow.

This bird is so exceedingly rare in New England, that it can scarcely be regarded otherwise than as an accidental visitor; and Massachusetts is certainly its northern limit.

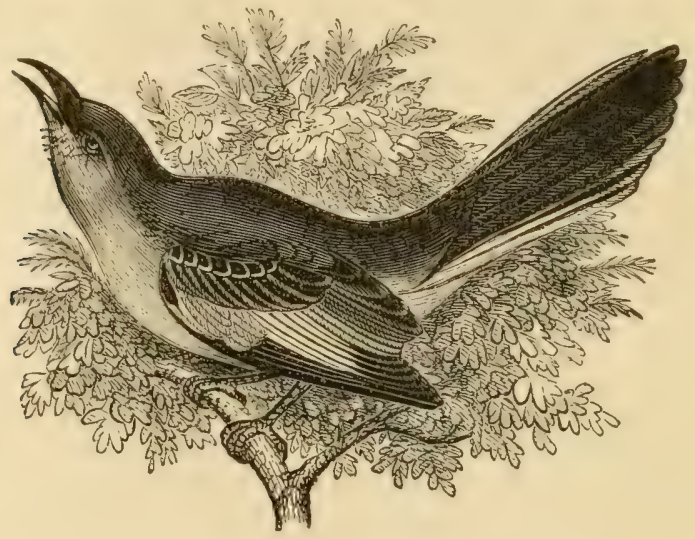

Mr. Allen, before referred to, says that it has been known to breed in Springfield several times within five years, and in 1860 two pairs nested there. In June, 1860, he found a nest containing three freshly laid eggs, incubation not having been begun: the locality was a sandy field, growing up to pitch-pines, in one of which the nest was placed, about three feet from the ground; the pair was secured with the nest and eggs.

As I have had no opportunities of observing the habits of this beautiful songster, I will give the very interesting description by Wilson. He says, -

"The precise time at which the Mocking-bird begins to build his nest varies according to the latitude in which he resides. In the lower parts of Georgia, he commences building early in April, but in Pennsylvania rarely before the 10th of May; and in New 
York, and the States of New England, still later. There are particular situations to which he gives the preference. A solitary thorn bush, an almost impenetrable thicket, an orange-tree, cedar, or holly bush, are favorite spots, and frequently selected. It is no great objection with him, that these happen, sometimes, to be near the farm or mansion-house. Always ready to defend, but never over-anxious to conceal, his nest, he very often builds within a small distance of the house, and not unfrequently in a pear or apple tree; rarely at a greater height than six or seven feet from the ground. The nest varies a little in different individuals, according to the conveniency of collecting suitable materials. A very complete one is now lying before me, and is composed of the following substances: First, a quantity of dry twigs and sticks; then, withered tops of weeds, of the preceding year, intermixed with fine straws, hay, pieces of wool and tow; and, lastly, a thick layer of fine fibrous roots, of a light-brown color, lines the whole. The eggs are four, sometimes five, of a cinereous-blue, marked with large blotches of brown. The female sits fourteen days, and generally produces two broods in the season, unless robbed of her eggs, in which case she will even build and lay the third time. She is, however, extremely jealous of her nest, and very apt to forsake it if much disturbed. It is even asserted by some of our bird-dealers, that the old ones will actually destroy the eggs, and poison the young, if either the one or the other have been handled. But I cannot give credit to this unnatural report. I know, from my own experience at least, that it is not always their practice; neither have I ever witnessed a case of the kind above mentioned. During the period of incubation, neither cat, dog, animal, nor man can approach the nest without being attacked. The cats, in particular, are persecuted whenever they make their appearance, till obliged to retreat. But his whole vengeance is most particularly directed against that mortal enemy of his eggs and young, the black snake. Whenever the insidious approaches of this reptile are discovered, the male darts upon it with the rapidity of an arrow, dexterously eluding its bite, and striking it violently and incessantly about the head, where it is very vulnerable. The snake soon becomes sensible of its danger, and seeks to escape; but the intrepid defender of his young redoubles his exertions, and, unless his 
antagonist be of great magnitude, often succeeds in destroying him. All its pretended powers of fascination avail it nothing against the vengeance of this noble bird. As the snake's strength begins to flag, the Mocking-bird seizes and lifts it up partly from the ground, beating it with his wings; and, when the business is completed, he returns to the repository of his young, mounts the summit of the bush, and pours out a torrent of song in token of victory.

"The plumage of the Mocking-bird, though none of the homeliest, has nothing gaudy or brilliant in it, and, had he nothing else to recommend him, would scarcely entitle him to notice; but his figure is well proportioned, and even handsome. The ease, elegance, and rapidity of his movements, the animation of his eye, and the intelligence he displays in listening and laying up lessons from almost every species of the feathered creation within his hearing, are really. surprising, and mark the peculiarity of his genius. To these qualities we may add that of a voice full, strong, and musical, and capable of almost every modulation, from the clear, mellow tones of the Wood Thrush, to the savage scream of the Bald Eagle. In measure and accent, he faithfully follows his originals. In force and sweetness of expression, he greatly improves upon them. In his native groves, mounted on the top of a tall bush or half-grown tree, in the dawn of dewy morning, while the woods are already vocal with a multitude of warblers, his admirable song rises pre-eminent over every competitor. The ear can listen to his music alone, to which that of all the others seems a mere accompaniment. Neither is this strain altogether imitative. His own native notes, which are easily distinguishable by such as are well acquainted with those of our various song-birds, are bold and full, and varied seemingly beyond all limits. They consist of short expressions of two, three, or, at the most, five or six syllables, generally interspersed with imitations, and all of them uttered with great emphasis and rapidity, and continued with undiminished ardor for half an hour or an hour at a time. His expanded wings and tail, glistening with white, and the buoyant gayety of his action, arresting the eye, as his song most irresistibly does the ear, he sweeps round with enthusiastic ecstasy; he mounts and descends as his song swells or dies away; and; as my friend Mr. 
Bartram has beautifully expressed it, ' $\mathrm{He}$ bounds aloft with the celerity of an arrow, as if to recover or recall his very soul, expired in the last elevated strain.' ${ }^{1}$ While thus exerting himself, a bystander destitute of sight would suppose that the whole feathered tribes had assembled together, on a trial of skill, each striving to produce his utmost effect, so perfect are his imitations. He many times deceives the sportsman, and sends him in search of birds that perhaps are not within miles of him, but whose notes he exactly imitates; even birds themselves are frequently imposed on by this admirable mimic, and are decoyed by the fancied calls of their mates, or dive with precipitation into the depth of thickets at the scream of what they suppose to be the Sparrow-hawk.

"The Mocking-bird loses little of the power and energy of his song by confinement. In his domesticated state, when he commences his career of song, it is impossible to stand by uninterested. He whistles for the dog, - Cæsar starts up, wags his tail, and runs to meet his master. He squeaks out like a hurt chicken, - and the hen hurries about with hanging wings and bristled feathers, clucking to protect its injured brood. The barking of the dog, the mewing of the cat, the creaking of a passing wheelbarrow, follow with great truth and rapidity. He repeats the tune taught him by his master, though of considerable length, fully and faithfully. He runs over the quiverings of the Canary, and the clear whistlings of the Virginia Nightingale, or Red-bird, with such superior execution and effect, that the mortified songsters feel their own inferiority, and become altogether silent, while he seems to triumph in their defeat by redoubling his exertions.

"This excessive fondness for variety, however, in the opinion of some, injures his song. His elevated imitations of the Brown Thrush are frequently interrupted by the crowing of cocks; and the warblings of the Blue-bird, which he exquisitely manages, are mingled with the screaming of swallows, or the cackling of hens; amidst the simple melody of the Robin, we are suddenly surprised by the shrill reiterations of the Whippoorwill; while the notes of the Killdeer, Blue Jay, Martin, Baltimore, and twenty others, succeed with such imposing reality, that we look round for the origi-

1 Travels, p. 32. Introd. 
nals, and discover, with astonishment, that the sole performer in this singular concert is the admirable bird now before us. During this exhibition of his powers, he spreads his wings, expands his tail, and throws himself around the cage in all the ecstasy of enthusiasm, seeming not only to sing, but to dance, keeping time to the measure of his own music. Both in his native and domesticated state, during the solemn stillness of night, as soon as the moon rises in silent majesty, he begins his delightful solo, and serenades us the livelong night with a full display of his vocal powers, making the whole neighborhood ring with his inimitable medley."

A number of eggs in my collection average about .98 of an inch in length by about .70 inch in breadth; their form is generally ovate, and their color a pale emerald-green, with spots of ferruginous and brown.

\section{GalEOSCOPTES, Cabanis.}

Galeoscoptes, Cabanis, Mus. Hein., I. (1850) 82. (Type Mfuscicapa Carolinensis.)

Bill shorter than the head, rather broad at base; rictal bristles moderately developed, reaching to the nostrils; wings a little shorter than the tail, rounded; secondaries well developed, fourth and fifth quills longest, third and sixth little shorter, first and ninth about equal, and about the length of secondaries, first quill more than half the second, about half the third; tail graduated, tail feather about seventy one-hundredths inch shorter than the middle; tarsi longer than lateral middle toe and claw by about an additional half claw, scutellate anteriorly, more or less distinctly in different specimens; scutellæ about seven.

The conspicuous naked membranous border round the eye of some thrushes, with the bare space behind it, not appreciable.

\section{GALEOSCOPTES CAROLINENSIS. - Cabanis.}

\section{The Cat-bird.}

Muscicapa Carolinensis, Linnæus. Syst. Nat., I. (1766) 328.

Orpheus Carolinensis, Audubon. Syn. (1839), 88.

Mimus Carolinensis, Gray. Genera (1844-49).

Turdus felivox, Vieillot. Ois. Am. Sept., II. (1807) 10. Aud. Orn. Biog., II. (1831) $171 ;$ V. 1839, 440.

Orpheus felivox, Swainson. F. Bor. Am., II. (1831) 192.

Turdus lividus, Wilson. Am. Orn., II. (1810) 90. 
Description.

Third quill longest, first shorter than sixth; prevailing color dark plumbeous, more ashy beneath; crown and nape dark sooty-brown; wings dark-brown, edged with plumbeous; tail greenish-black, the lateral feathers obscurely tipped with plumbeous; the under tail coverts dark-brownish chestnut; female smaller.

Length, eight and eighty-five one-hundredths inches; wing, three and sixty-five one-hundredths; tail, four; tarsus, one and five one-hundredths inch.

This very common and well-known species arrives in New England about the first week in May, - in Maine, perhaps about the 15th of that month. It is distributed abundantly throughout these States, and its habits are so well known that a description here is hardly necessary. During the mating season, and indeed through the greater part of the summer, the song of the male is heard in the woods, pastures, and gardens at early morning, and sometimes through the day; and, although most persons describe it as being harsh and uncouth, it is really very pleasing and melodious. It is a sort of medley, like that of the Brown Thrush, but not near so loud: the bird usually perches on a low tree, where, standing nearly erect, his wings slightly expanded, and his tail spread beneath him, he pours forth his notes sometimes for half an hour at a time. In addition to this song, he, in common with the female, has a plaintive note almost exactly like the mewing of a cat; and the specific name of felivox, given it by some authors, is much more descriptive and appropriate than that of Carolinensis, which is neither descriptive nor proper.

The alarm-note is a rattling cry, like the sound of quick breaking of several strong sticks : it is perhaps well expressed by the syllables trat-tat-tat-tat, uttered very quickly. I have noticed that this bird, as do many others, prefers the neighborhood of thickly settled districts, even a home in their midst, to others of a wilder character; and, when travelling through the deep forests, I have invariably found, that, when these birds became abundant, a settlement was near.

Soon after mating, the birds build: this is from about the 
20th of May to the first week in June. The nest is usually placed in bushes and shrubs, seldom more than four or five feet from the ground; the location as often in the deep woods as in the fields or pastures. It is constructed first of a layer of twigs and sticks, on which is built the body of the nest, which is composed of strips of grape-vine bark, fine twigs, leaves, and straws : it is deeply hollowed, and lined with fibrous roots and hairs, and sometimes fine grass. The eggs are usually four in number, sometimes five: their color is a bright, deep emerald-green, and their form generally ovate. A great number of specimens before me do not exhibit great variations in measurement from the dimensions of a nest complement of four collected in Thornton, N.H.; they are as follows: .95 by .67 inch; .95 by .66 inch; .93 by .67 inch; .93 by .66 inch. Two broods are reared in the season, seldom three in this latitude.

About the middle of October, this species moves in its Southern migration. 


\section{Fanily SAXICOLID瓜. ${ }^{1}$ The Rock Inhabiters.}

Wings very long and much pointed, reaching beyond the middle of the short square or emarginated tail, and one and a half times or more the length of the latter; the spurious primary very short, the second quill longer than the fourth; in the closed wing, the outer secondary reaches only about two-thirds the length of the longest primary.

\section{STALIA, SwATNSON.}

Sialia, Swarnson, Zool. Jour., III. (Sept., 1827) 173. (S. Wilsonii.)

Bill short, stout, broader than high at the base, then compressed, slightly notched at tip; rictus with short bristles; tarsi not longer than the middle toe; claws considerably curved; wings much longer than the tail, the first primary spurious, not one-fourth the longest; tail moderate, slightly forked.

\section{SIALIA SIALIS, - Baird.}

\section{The Blue-bird; Red-breasted Blue-bird.}

Motacilla sialis, Linnæus. Syst. Nat., I. (1758) 187. Gmelin, Syst. Nat., I. (1788) 989.

Sylvia sialis, Latham. Index Om., II. (1790) 522. Wilson, Am. Orn., I. (1808) 56. Aud. Orn. Biog., II. (1834) 84; V. (1839) 452.

Ampelis sialis, Nuttall. Man., I. (1832) 444.

\section{DESCRIPTION.}

Entire upper parts, including wings and tail, continuous and uniform azure-blue, the cheeks of a duller tint of the same; beneath reddish-brown; the abdomen, anal region, and under tail coverts white; bill and feet black; shafts of the quills and tail feathers black; female with the blue lighter, and tinged with brown on the head and back.

Length, six and seventy-five one-hundredths inches; wing, four inches; tail, two and ninety one-hundredths inches.

\section{THIS beautiful bird is a very common summer inhabitant 1 of all New England. It is one of the earliest in its arrival from the South, often making its appearance by the middle of March, sometimes even earlier. About the middlo of April, immediately after mating, the birds commence pre- paring their nest: this is made in a deserted woodpecker's}

1 I have adopted the arrangement given by Professor Baird in his recent review, in this family and the succeeding, as far as Sruvicolid z. 
hole, in a martin's box, or in a knot-hole in a fence-post. The materials used in its construction are generally soft grasses, feathers, and wools: these are thrown together

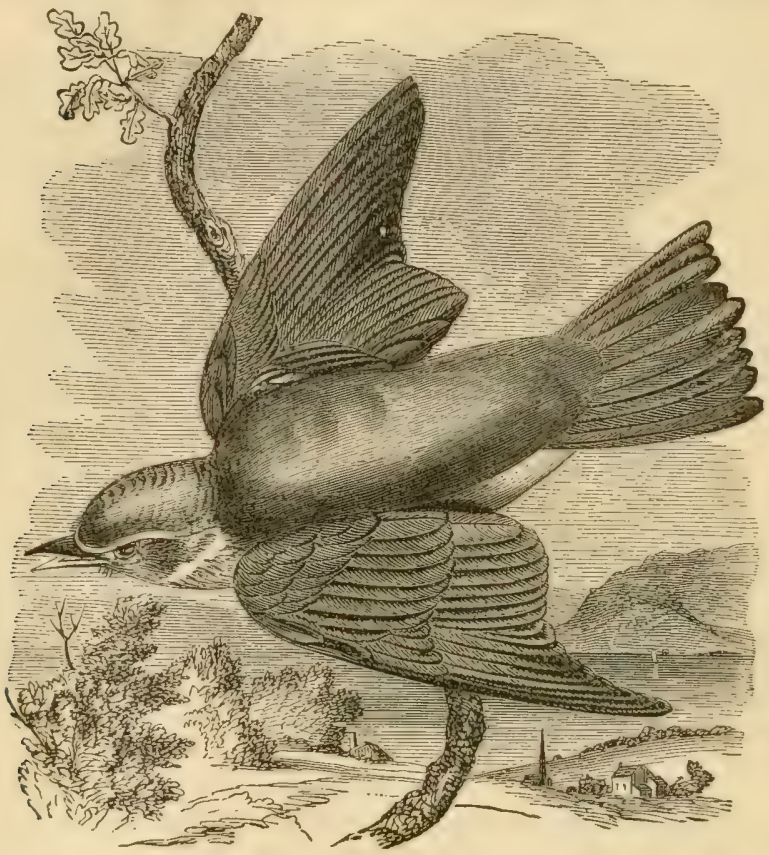

without any great care, the object being to get comfort and warmth in the early season in which the first litter of eggs is laid. The eggs are either four or five in number: they are of a light-blue color, with a very faint greenish tint. Five specimens, taken at random from a great number, exhibit the following measurements: .86 by .62 inch, .85 by .62 inch, .84 by .61 inch, .82 by .60 inch, .80 by .60 inch. This species raises two broods, usually in the same nest, in the season.

The Blue-bird's habits are pretty well known; and its insectivorous character, and social and happy disposition, have established it as a great favorite. 
Its song is a soft pleasing warble, which is often repeated, and is uttered by the bird both when flying and perching. In capturing insects, it has many of the habits of the Flycatchers. It remains perching on a post or twig until its prey shows itself, when it suddenly flies at it flapping its wings rapidly, seizes it, and returns to its perch to eat it. It often descends quickly, and seizes a grasshopper that is crawling on a straw or weed; and, if it misses its aim, even follows it while flying.

About the last week of October, the parents and young leave in a detached flock for the South. 


\section{FAMILY SYLVIUDA. ThE WOOD-INHabiters.}

"Bill slender, broad, and depressed at the base, distinctly notched and decurved at the tip; culmen sharp ridged at base; frontal feathers reaching to the nostrils, which are oval, with membrane above, and overhung - not concealed - by a few bristles or by a feather; rictal bristles extending beyond nostrils; tarsi booted or scutellate; basal joint of middle toe attached its whole length externally, half-way internally; primaries ten; spurious primary about half the second, which is shorter than the seventh; lateral toes equal." - BAIRD.

\section{REGULUS, Cuvier.}

Regulus, Cuvier, Leçons d'Anat. Comp., 1799-1800 (Agassiz). (Type Dfotacilla regulus, Linnæus; Regulus cristatus, Koch.)

Bill slender, much shorter than the head, depressed at base, but becoming rapidly compressed, moderately notched at tip; culmen straight to near the tip, then gently curved; commissure straight; gonys convex; rictus well provided with bristles; nostril covered by a single bristly feather directed forwards; tarsi elongated, exceeding considerably the middle toe, and without scutellæ; lateral toes about equal, hind toe with the claw longer thian the middle one, and about half the toe; claws all much curved; first primary about one-third as long as the longest, second equal to fifth or sixth; tail shorter than the wings, moderately forked, the feathers acuminate; colors olive-green above, whitish beneath; size very small.

REGULUS CALENDULA, - Licht.

\section{The Ruby-crowned Wren.}

Motacilla calendula, Linnæus. Syst. Nat., I. (1766) 337.

Sylvia calendula, Wilson. Am. Orn., I. (1808) 83.

Requlus calendula, Nuttall. Man., I. (1832) 415. Aud. Orn. Biog., II. (1834) 546

\section{Description.}

Above dark greenish-olive, passing into bright olive-green on the rump and outer edges of the wings and tail; crown with a large concealed patch of scarlet feathers, which are white at the base; the under parts are grayish-white tinged with pale olive-yellow, especially behind; a ring round the eye, two bands on the wing coverts, and the exterior of the inner tertials white. Young without the red on the crown. The female differs very little in color. It is quite probable that the species does not attain the red patch in the crown until the second year, as the spring migrations of the species always embrace a considerable number with the head perfectly plain.

Length, four and fifty one-hundredths inches; wing, two and thirty-three onehundredths; tail, one and eighty-five one-hundredths. 
7 HIS diminutive species is a quite common spring and South from April the in New England, arriving from the later are found among the opening foliage and blossoms of forest and orchard trees, - particularly the oak, elm, maple and apple, - darting about, climbing on the small twiss, and prying in all directions in search of minute flying insects, their eggs and larvæ, frequenting the tops of the trees as well as the lower branches. By the 12th of May, they depart for the North to rear their young,-breeding in Canada, Labrador, \&c. From about the 1st of October to the last of that month, they are again with us, and are seen diligently engaged in pursuit of food in our woods and orchards.

They are not shy in their habits, and will permit one to approach quite near them. I have noticed that they remain in one cluster of twigs until it is completely cleared of insects, and they often employ ten minutes in searching it thoroughly.

The Ruby Crown winters in the more southern States of the Union and in Mexico. On clear, fine days in spring, I have heard this bird warble a beautiful song; and it has also a peculiar guttural, querulous call-note, which often precedes this song.

\section{REGULUS SATRAPA, - Licht.}

The Golden-crested Wren.

Regulus satrapa, Lichtenstein. Verzeich. Doubl. (1823), No. 410 (Quotes Parus satrapa, Illiger, - probably a museum name). Aud. Syn. (1839), 82. Ib., Birds Amer., II. (1841) 165.

Sylvia regulus, Wilson. Am. Orn., I. (1808) 126.

Regulus tricolor, Nuttall. Man., I. (1832), 420. Aud. Orn. Biog., II. (1834) 476

\section{DESCRIPTION.}

Above olive-green, brightest on the outer edges of the wing; tail fenthers tinged with brownish-gray towards the head; forehead, a line over the eye and a space 
beneath it, white; exterior of the crown before and laterally black, embracing a central patch of orange-red, encircled by gamboge-yellow; a dusky space around the eye; wing coverts with two yellowish-white bands, the posterior covering, a similar band on the quills, succeeded by a broad dusky one; under parts dull whitish.

The black of the head immediately succeeds the white frontal band as one of about the same width, passing behind on each side. Generally the white line over the eye is separated from the white forehead by a dusky lore. There is also a dusky space beneath the whitish under the eye. The yellow of the crown generally overlies and conceals the orange. The orange is wanting in the female. The young birds always appear to have at least the yellow and black of the crown.

Length, under four inches; wing, two and twenty-five one-hundredths inches; tail, one and eighty one-hundredths inches.

This handsome and active species is also a common bird, coming to us from the North the last of September, but, unlike the preceding, braving the rigors of our winter; and it leaves again by the 15th of April. Numbers, however, winter farther south; and it is in spring and autumn that the species is most abundant. On their arrival in autumn, they frequent orchard trees, feeding among the leaves of the apple-trees, which, at this season, are infested with insects. Later, and in winter, they resort more often to the evergreens, - such as the pine, spruce, and cedar, but rove wherever they can find food, generally in company with the Chickadees, and occasionally the White-breasted Nuthatch, Brown Creeper, and Downy Woodpecker; the whole forming a lively, busy winter party, as they perambulate the country, intent on gathering their now scanty food. Their call-note at this scason, indeed the only note that I have heard at any time, is a faint pipe or whistle, sounded quickly three or four times. I have never heard this bird utter the querulous note assigned to it by Audubon and Nuttall, but have often heard the Ruby Crown give this strain. In spring, having similar habits and diet with the Ruby Crowns, they frequent the same hunting-grounds, and are seen hanging to the extremities of twigs, head downwards, and sometimes fluttering in the air in front of them, seizing small flies, "and often exposing the golden feathers 
of their head, which are opened and shut with great adroitness." This species may possibly breed in Maine, having been seen there in summer; but I do not remember of its having been found in the breeding season south of that State. 


\section{FAMILY PARIDA.}

Bill generally short, conical, not notched nor decurved at tip; culmen broad and rounded, not sharp-ridged at base; nostrils rounded, basal, and concealed by dense bristles or bristly feathers; loral feathers rough and bristly, directed forwards; tarsi distinctly scutellate; basal joints of anterior toes abbreviated, that of middle toe united about equally for three-fourths its length to the lateral, in Parince forming a kind of palm for grasping; outer lateral toe decidedly longer than the inner; primaries ten, the first much shorter than the second; tail feathers without soft tips.

The two sub-families may be thus distinguished:-

Parince. - Body compressed; bill shorter than the head; wings rounded, equal to or shorter than the rounded tail, second quill as short as the tenth; tarsus longer than the middle toe and claw, which are about equal to the hinder; soles of toes widened into a palm; plumage rather soft and lax.

Sittince.-Body depressed; bill about equal to or longer than the head; wings much pointed, much longer than the nearly even tail; tarsus shorter than the middle toe and claw, which are about equal to the hinder; plumage more compact.

\section{Sub-Family Parine. - The Titmice.}

\section{PARUS, Linn eUS.}

Parus, Lrns.eus, Syst. Nat., 1735 (Agassiz). (Type P. major.)

Head not crested; body and head stout; tail moderately long, and slightly rounded; bill conical, not very stout, the upper and under outlines very gently and slightly convex; tarsus but little longer than middle toe; crown and throat generally black.

\section{PARUS ATRICAPILLUS. - Linncus.}

\section{The Black-cap Titmouse; Chick-a-dee.}

Parus atricapillus, Linnæus. Syst. Nat., I. (1766) 341. Wilson, Am. Orn., I (1808) 134. Aud. Orn. Biog., IV. (1838).

Parus palustris, Nuttall. Man., I. (1832) 79.

\section{Description.}

Second quill as long as the secondaries; tail very slightly rounded, lateral feathers about ten one-hundredths shorter than middle; back brownish-ashy; top of head and throat black, sides of head between them white, beneath whitish; brownish-white on the sides; outer tail feathers, some of primaries, and secondaries conspicuously margined with white.

Length, five inches; wing, two and fifty one-hundredths inches; tail, two and fifty one-hundredths inches.

\section{TYHIS well-known little bird is a very common resident 1 of all New England throughout the year. It is one of the very few species that are as abundant in the depths of}


winter as through the summer, and it is deservedly one of the greatest favorites. It commences building as early as the second week in May. The nest is placed in a hole excavated in a dead tree or stump. This hole is, like that of the Woodpecker, gradually widened at the bottom, and is about nine or ten inches in depth. nest is constructed of soft moss and the hairs of different animals. One beautiful specimen that I found in the northern part of Maine is composed of the hair of the common deer, moose, and hare, a few feathers

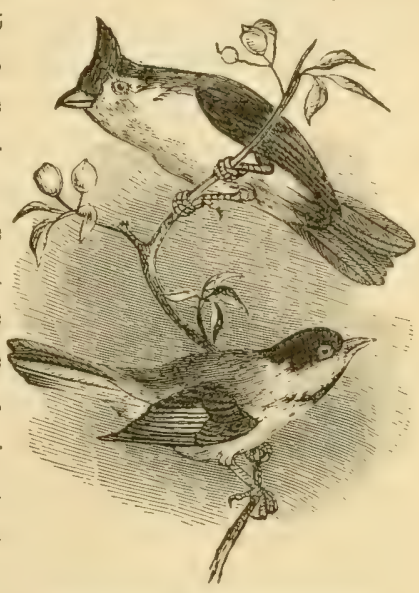

Hudson's Bay Titmouse, upper flg. Black-cap Titmouse, lower fig. of the Ruffed Grouse, and a few fragments of soft mosses. They are woven into a warm and comfortable tenement.

The eggs are from six to ten in number, usually about six. They are of a nearly pure-white color, with a faint reddish tint, and are spotted thickly, at the greater end, with markings of reddish-brown: their form is nearly spherical, and their dimensions vary from .65 by .52 inch to .60 by .50 inch. Two broods are often reared in the season.

The habits of this little bird are so well known, and have been written about so much, that any description here is almost superfluous. It is eminently kindly and sociable in its disposition; and, although almost always in company with other birds, - such as the Golden-crested and Rubycrowned Wrens, Nuthatches, \&c., - it is never seen quar relling with them, but fraternizes with them in the most cordial manner. Often, when seated in the woods, have I been surrounded by them; and their curiosity to learn the cause of my presence and my employment was so great, that they would often perch on a twig within two feet of my 
head, and scrutinize me with their shining black eyes in a manner amusing to witness.

Ostensibly, they were searching beneath the bark for their food; but really they were watching me. I once had one perch on my boot, and look in my face with a perfectly plain "what-do-you-want-here" expression on its countenance. Always at short intervals, while perched in trees, and sometimes while flying, this bird utters its song, which consists of several notes, that may be described by the syllables chewêê-a-dee-dee-dee, chewêêk- $\alpha$-dee-dee-dee, emitted in a clear, sweet tone, easily recognized, and not to be mistaken for any other song. The flight of this species is wavering, and not protracted; the bird seldom extending it further than from one tree to another. When in the air at any considerable height, it resembles the flight of the Woodpeckers, being undulating and partly gliding.

In some localities, the Titmouse is regarded as injurious, from the fact that it is often seen among the branches and leaves of the fruit-trees and shrubs, pecking off and destroying the buds. It does not do this to the bud for food, but really for the grub contained in it. If these buds be examined after the Chick-a-dee has thrown them away, the burrow of a grub or caterpillar will appear in the very heart of them. The bird is able to discover the presence of these vermin much more readily than man could; and it is thus able to assail them at a period of their existence when they are doing the most harm. But it is not the insects and their larvæ alone that he destroys. His microscopic eyes enable him to discover their eggs deposited on and in the crevices of the bark and in the buds, and in an instant he can destroy the whole future brood. The eggs of the moth of the destructive leaf-rolling caterpillar, those of the cankerworm, the apple-tree moth, and others of these well-known plagues, are greedily eaten by it; and this is in the inclement winter, when most of our other birds have abandoned us for a more genial climate. 
In the summer time, the Chick-a-dee's labors are more easily noticed; and as he raises a large brood of young, the female laying six or eight eggs at a litter, he is very busy through the whole day in capturing vast quantities of caterpillars, flies, and grubs. It has been calculated that a single pair of these birds destroy, on the arerage, not less than five hundred of these pests daily; a labor which could hardly be surpassed by a man, even if he gave his whole time to the task.

"Moreover, the man could not be as successful at so small a cost; for, setting aside the value of his time and the amount of a laborer's daily wages, he could not reach the denser and loftier twigs on which the caterpillars revel, and which the Titmouse can traverse with perfect ease. No man can investigate a tree, and clear it of the insect hosts that constantly beleaguer it, without doing some damage to the buds and young leaves by his rough handling; whereas the Chick-a-dee trips along the branches, peeps under every leaf, swings himself round upon his perch, spies out every insect, and secures it with a peck so rapid that it is hardly perceptible."

In some observations made on the habits of this and some other birds in Paris, it was found that the Titmouse destroys, at the lowest computation, over two hundred thousand eggs alone of noxious insects in the course of a year. That one small bird is thus able to accomplish so much good in destroying these myriads of vermin is an appeal to the good sense of the farmer, for the protection of the whole class, that should not be slighted.

\section{PARUS HUDSONICUS. - Forster.}

The Hudson's Bay Titmouse.

Parus IIudsonicus, Forster. Philos. Trans., LXII. (1772) 383, 430. Aud. Orn. Biog., II. (1834) 543. Ib., Birds Amer., II. (1841) 155.

\section{Description.}

Above yellowish olivaceous-brown; top of head purer brown, not very different in tint; chin and throat dark sooty-brown; sides of head white; beneath white; 
sides and anal regions light brownish-chestnut; no whitish on wings or tail; tail nearly even, or slightly emarginate and rounded; lateral feathers about twenty unebundredths inch shortest.

Length, about five inches; wing, two and forty one-hundredths inches; tail, two and sixty-six one-hundredths inches.

Hab. - North-eastern portions of North America to the North Atlantic States.

This bird occurs in New England only in the most northern parts of Maine, New Hampslaire, and Vermont, where it is sometimes resident. I have never met with it alive, and will be obliged to avail myself of Audubon's description of its habits, nest, \&c. He says, in describing the nest:-

"It was placed at the height of not more than three feet from the ground, in the hollow of a decayed low stump, scarcely thicker than a man's leg; the whole so rotten that it crumbled to pieces on being touched. I cautiously removed the woody enclosure, and took possession of the nest, which I obtained in perfect order. It was shaped like a purse, eight inches in depth, two in diameter inside; its sides about half an inch thick. It was entirely composed of the finest fur of different quadrupeds, but principally of the great northern hare, so thickly and ingeniously matted throughout, that it looked as if it had been 'felted' by the hand of man. It was quite elastic throughout, and rather wider at the bottom, probably in consequence of the natural growth of the young."

This hardy little bird resembles in its manners the other species of its interesting and beautiful tribe: its notes resemble those of our southern Black-headed Titmouse, but are much weaker.

\section{Sub-Family Sitrivæ. - The Nuthatches.}

SITTA, Linneus.

Sittx, Lins zus, Syst. Nat. 1735 (Agassiz).

Bill subulate, acutely pointed, compressed, about as long as the head; culmen and commissure nearly straight; gonys convex and ascending; nostrils covered by a tuft of bristles directed forward; tarsi stout, scutellate, about equal to the middle toe, much shorter than the hinder, the claw of which is half the total length; outer 
lateral toe much longer than inner, and nearly equal to the middle; tail very short, broad, and nearly even, the feathers soft and truncate; wings reaching nearly to the end of the tail, long and acute, the first primary one-third of (or less) the third, or longest.

SITTA CAROLINENSIS. - Gmelin.

The White-bellied Nuthatch.

Sitla Carolinensis, Latham. Ind. Orn., I. (1790) 262. Wilson, Am. Orn., I. (1808) 40. Nutt. Mlan., I. (1832) 581. Aud. Orn. Biog., II. (1834) 299 ; V. (1839) 473.

\section{DEscription,}

Above ashy-blue; top of head and neck black; under parts and sides of head, to a short distance above the eye, white; under tail coverts and tibial feathers brown; concealed primaries white; bill stout.

Length, about six inches; wing, about three and three-quarters inches.

Hab. - Eastern North America to the high central plains. West of this, replaced by S. aculeata.

This species is a not uncommon one in New England, where it is found through the winter. In the more northern districts, it is a summer resident; and it regularly breeds as far south as Massachusetts. A nest was found in Cambridge, Mass., in June, 1865. It was made in an excavation in a dead tree (or rather stump), which was carried to the depth of perhaps eight inches. The nest was composed of soft grasses, hairs, and a few feathers: these were arranged compactly in the bottom of the hole to the depth of perhaps an inch and a half. The eggs were six in number, four of them are now before me: they are ovoidal in shape, of a beautiful roseate-white color, and covered more or less thickly with fine spots and dashes of light-reddish. Their dimensions are .80 by .61 inch, .80 by .60 inch, .78 by .58 inch, .75 by .57 inch. Another specimen, collected in the Adirondack Mountains, is marked more sparingly with coarser and darker spots: its dimensions are .70 by .57 inch.

The habits of this species are very similar to those of the small woodpeckers; and they are equally industrious with those birds in their search for the larvæ and eggs of insects, which they obtain by boring in the bark, and knocking off 
the moss and dead pieces of trees with their sharp, powerful bill.

In traversing the limbs of trees, they resemble in their morements the Downy Woodpecker; and their flight is also similar to that bird's. 'The note is a short, harsh call, similar to the syllables cha-cha-cha-chat uttered quickly, and with emphasis.

\section{SITTA CANADENSIS, - Linnceus.}

\section{The Red-bellied Nuthatch.}

Sitta Canadensis, Linnæus. Syst. Nat., I. (1766) 177. Nutt. MIan., I. (1832) 583. Aud. Orn. Biog., II. (1884) 24; V. 474.

Sitta varia, Wilson. Am. Orn., I. (1808) 40.

\section{Description.}

Above ashy-blue; top of head black; a white line above and a black one through the eye; chin white; rest of under parts brownish-rusty.

Length, about four and a half inches; wing, two and two-thirds inches.

Hab. - North America to the Rocky Mountains, probably also to the Pacific.

The same remarks as to distribution, habits, \&c., will apply to this species as to the preceding. It is quite abundant as a summer resident in the wilds of Maine; and its notes are almost the first sound heard by the traveller on awakening in the early morning. I have sometimes heard its note in the night, while floating in my canoe on the bosom of some tranquil lake or between the banks of a sombre river; and frequently they seemed to be high up in the air, as if the bird had taken flight. These notes are a sort of drawling repetition of the syllable chape, like perhaps the following: CheaÂpe, cheâipe, cheaâpe.

The nest is built in a hole in a tree or stump, usually excavated by the birds for the purpose: it is of the same description as that of the preceding, as are also the eggs with the exception of size; the present being considerably smaller, averaging .64 by .53 inch.

Audubon, in describing the nest of the Red-bellied Nuthatch, says, - 
"I found it building its nest near Eastport, in Maine, on the 19th of May, before the Blue-bird had made its appearance there, and while much ice still remained on the northern exposures. The nest is dug in a low, dead stump, seldom more than four feet from the ground; both the male and the female working by turns until they have got to the depth of about fourteen inches. The eggs, four in number, are small, and of a white color, tinged with a deep blush, and sprinkled with reddish dots. They raise, I believe, only one brood in the season."

Although I found a pair on Nantucket in June, 1866, which had young without doubt, the only other occurrence of this bird's breeding in New England that has come to my knowledge was in West Roxbury, Mass., in June, 1866, when a nest was found in an old stump by my young friend, William Minot, jun. The eggs were four in number, and were of the description given above. 


\section{Family CERThitade. The Creepers.}

First primary very short, less than half the second; outer lateral toe much longest; hind toe exceeding both the middle toe and the tarsus, which is scutellate anteriorly, and very short; bill slender, as long as, or longer than, the head, much compressed and greatly decurved; gonys concave, without any notch; entire basal joint of the middle toes united to the lateral, the feathers stiffened at the tips; tail long, cuneate.

\section{CERTHIA, LINNELS.}

\section{Certhia, Linn aus, Syst. Nat., 1735 (Gray). (Type C. familiaris.)}

Bill as long as the head, slender, much compressed and decurved from the base, without notch or rictal bristles; tarsi distinctly scutellate, very short, not longer than the outer lateral toes, which much exceeds the inner, reaching nearly as far as the middle toe; hind toe longer than the middle one, its claw more than half the total length; claws all very long and acute; tail rather longer than the wings, arched or vaulted, graduated or cuneate; the feathers very acute at the tips, the shafts stiffened; first primary rather more than one-third the fourth or longest one; color above brown, streaked with white, beneath white.

\section{CERTHIA AMERICANA.-Bonaparte.}

\section{The American Creeper.}

Certhia Americana, Bonaparte. Consp. List (1838).

Certhia familiaris, Wilson. Am. Orn., I. (1808) 122. Aud. Orn, Biog., V. (1839) 158.

\section{DEscriptron.}

Bill about the length of the head; above dark-brown, with a slightly rufous shade, each feather streaked centrally, but not abruptly, with whitish; rump rusty; beneath almost silky-white; the under tail coverts with a faint rusty tinge; a white streak over the eye; the ear coverts streaked with whitish; tail feathers brown centrally, the edges paler yellowish-brown; wings with a transverse bar of pale reddishwhite across both webs.

Length, about five and fifty one-hundredths inches; wing, two and sixty onehundredths inches; tail, two and ninety one-hundredths inches.

Hab. - North America generally.

7 HIS species is a resident of the three southern NewEngland States through the year: in the other States, it is not a common summer visitor. It arrives from the South about the middle of April, and, on pairing, commences building about the second week in May. The nest 
is built in a hollow limb of a tree, in a deserted nest of a woodpecker or squirrel, or a hole in a fence-post. Usually the locality is chosen in the deep woods, and seldom near dwellings or in the orchards. The materials used in the construction are soft grasses, feathers, and the bark of the cedar and grape-vine. The eggs are usually about six in number: their color is a dull-gray; and they are marked, thickest near the great end, with small spots of reddishbrown, and a few dabs of a darker-color. Mr. Allen speaks of a nest being found "in a large elm in Court Square, Springfield, about ten feet from the ground, and built behind a strip of thick bark that projected in such a way as to leave a protected cavity behind it." Dimensions of eggs average about .70 by .50 inch. But one brood is reared in the season in New England. 


\section{FAmLy TROGLODYTIDA. The Wrens.}

"Rictal bristles wanting; the loral feathers with bristly points; the frontal feathers generally not reaching to nostrils; nostrils varied, exposed or not covered by feathers, and generally overhung by a scale-like membrane; bill usually without notch; wings much rounded, about equal to tail, which is graduated; primaries ten, the first generally about half the second; basal joint of middle toe usually united to half the basal joint of inner, and the whole of that of the outer, or more; lateral toes about equal, or the outer a little the longer; tarsi scutellate."-BAInD.

\section{CISTOTHORUS, CABANIS.}

Cistothorus, CABAnis, Mus. Hein. (1850-51), 77. (Type Troglodytes stellaris.)

Bill about as long as the head or much shorter, much compressed, not notched, gently decurved from the middle; the gonys slightly concave or straight; toes reaching to the end of the tail; tarsus longer than the middle toe; hind toe longer than the lateral, shorter than the middle, lateral toes about equal, hind toe longer than or equal to its digit; wings rather longer than the tail, all the feathers of which are much graduated, the lateral only two-thirds the middle; the feathers narrow; back black, conspicuously streaked with white.

\section{CISTOTHORUS PALUSTRIS. - Cabanis.}

The Long-billed Marsh Wren.

Certhia palustris, Wilson. Am. Orn., II. (1810) 58.

Troglodytes palustris, Bonaparte. Obs. Wils. (1824), No. 66. Aud. Orn. Biog., I. (1831) 500 ; V. (1839) 467.

Thryothorus palustris, Nuttall. Man., I. (1832) 439.

\section{DEscription.}

Bill about as long as head; tail and wing nearly equal; upper parts of a dull reddish-brown, except on the crown, interscapular region, outer surface of tertials, and tail feathers, which are almost black, - the first with a median patch like the ground-color; the second with short streaks of white, extending round on the sides of the neck; the third indented with brown; the fourth barred with whitish, decreasing in amount from the outer feather, which is marked from the base to the fifth, where it is confined to the tips; the two middle feathers above like the back, and barred throughout with dusky; beneath rather pure-white, the sides and under tail coverts of a lighter shade of brown than the back; a white streak over the eye.

Length, five and fifty one-hundredths inches; wing, two and eight one-hundredths inches; tail, two inches.

Hab. - North America from Atlantic to Pacific, north to Greenland.-ReiNIARDT. 
TाHIS interesting and not generally well-known little bird 1 is a summer inhabitant of New England. Although not uncommon in Massachusetts and the other two southern States, it seldom ventures north of the first State, where it is confined to the neighborhood of the salt-water marshes. It makes its appearance about the middle of May; and its presence is soon made known by its lively, chattering song, and grotesque dodgings among the reeds and tall grass in which it makes its home. I cannot refrain from giving the exceedingly interesting account of its habits, \&c., by Wilson.

\section{He says, -}

"The Marsh Wren arrives in Pennsylvania about the middle of May, or as soon as the reeds and a species of nymphea, usually called splatter-docks, which grow in great luxuriance along the tidewater of our rivers, are sufficiently high to shelter it. To such places it almost wholly limits its excursions, seldom venturing far from the river. Its food consists of flying insects and their larvæ, and a species of green grasshopper that inhabits the reeds. As to its notes, it would be mere burlesque to call them by the name of song. Standing on the reedy borders of the Schuylkill or Delaware, in the month of June, you hear a low crackling sound, somewhat similar to that produced by air-bubbles forcing their way through mud or boggy ground when trod upon. This is the song of the Marsh Wren : but as, among the human race, it is not given to one man to excel in every thing, and yet each perhaps has something peculiarly his own; so, among birds, we find a like distribution of talents and peculiarities. The little bird now before us, if deficient and contemptible in singing, excels in the art of design, and constructs a nest which, in durability, warmth, and convenience, is scarcely inferior to one, and far superior to many, of its more musical breth ren. This is formed outwardly of wet rushes mixed with mud, well intertwined, and fashioned into the form of a cocoanut. A small hole is left two-thirds up for entrance, the upper edge of which projects like a pent-house over the lower to prevent the admission of rain. The inside is lined with fine soft grass, and sometimes feathers; and the outside, when hardened by the sun, resists every kind of weather. This nest is generally suspended 
among the reeds, above the reach of the highest tides, and is tied so fast to every part of the surrounding reeds as to bid defiance to the winds and the waves. The eggs are usually six, of a dark-fawn color, and very small. The young leave the nest about the 20 th of June, and they generally have a second brood in the same season."

I am unable to add any thing of value to this description. Several nests in my collection, from various localities in New England and elsewhere, agree with the above description of nest. They are formed of reeds and grasses twined strongly together in a bulky fabric; and the entrance, a small round hole, is on one side (facing the south always, I believe). The cavity is deep, and lined with soft grasses and feathers. The eggs are of a mahogany-color, with fine dots covering the entire surface. These dots are darker than the ground-color, and so fine as to be hardly visible. A great number of eggs in my collection vary from .60 by .48 to .56 by .42 inch in dimensions.

\section{CISTOTHORUS STELLARIS. - Cabanis.}

The Short-billed Marsh Wren.

Cistothorus stellaris, Cabanis. Mus. Hein. (1851), 77. Type.

Troglodytes brevirostris, Nuttall. Trans. Amer. Acad. Arts and Sc., New Ser., I. (1833) 98, with figure (quoted in Manual, though date of volume is subsequent to 1832). Ib., Man., I. (1832) 436. Aud. Orn. Biog., II. (1834) 427; V. (1839) 469.

\section{DESCRIPTION.}

Bill very short, scarcely half the length of the head; wing and tail about equal; hinder part of the crown and the scapular and interscapular region of the back and rump almost black, streaked with white; tail dusky, the feathers barred throughout with brown (the color grayish on the under surface); beneath white; the sides, upper part of the breast, and under tail coverts reddish-brown; upper parts, with the exceptions mentioned, reddish-brown.

Length, four and fifty one-hundredths inches; wing, one and seventy-five one. hundredths inch; tail, one and seventy-five one-hundredths inch.

Hab. - Eastern United States to the Loup fork of Platte.

Like the preceding species, this bird is limited to the southern districts of New England; Massachusetts being its northern limit. It makes its first appearance about the middle of May, sometimes a little earlier. The nest is built 
about the last week in May: it is constructed of grasses and sedges, and is pensile, or rather suspended in tall grass in fresh-water meadows, which is woven into the body of the fabric. I have never noticed any mud in the materials, and doubt if any is used. The entrance is on the side; it is a small hole, just under the greatest bulge of the nest: the whole fabric is lined with soft down from flying-seeds, and sometimes a few feathers. The eggs are sometimes eight or nine in number, usually about six : their color is pure-white, and the shell is extremely thin and brittle. The dimensions vary from .57 by .44 to .50 by .40 inch. But one brood is reared in New England.

The habits of this bird are not so well known as those of the preceding, as it is a much more shy bird, and always avoids the presence of man. When its nest is approached, it hovers near the intruder, chattering and scolding in a violent manner. It is hardly ever seen in the neighborhood of the salt water, and seems to be found only in the meadows in the vicinity of fresh water: its food consists principally of small insects, and spiders, which it is almost constantly employed in capturing. Its song is short, and consists of a repetition of the syllables, 'che, 'chet, de-de-dede-de. This is uttered when the bird is perched on a low bush, or tuft of grass. A peculiarity of this bird, and also of the preceding species, is its habit of building a number of nests in the same season: it is believed by many persons, that this is done to secure protection; because, when a person searches for the nest occupied by the female, the male always decoys the intruder to the neighborhood of one of these empty ones.

\section{TROGLODYTES, ViEILLOT.}

Troglodytes, ViemLlot, Ois. Am. Sept., II. (1807) 52. (Type T. adon.)

Wings longer than the tail, or nearly equal; tail rounded, the lateral feathers graduated; hind claw shorter than the rest of the toe; back brown, obsoletely waved with dusky; bill nearly as long as the head. 
TROGLODTTES EDON. - Vieillot.

The House Wren.

Troglodytes cedon, Vieillot. Ois. Am. Sept., II. (180̂7) 62. Aud. Orn. Biog., I. (1831) 427 ; V. (1839) 470.

Sylvia domestica, Wilson. Am. Orn., I. (1808) 129.

Troglodytes fulvus, Nuttall. Man., I. (1832) 422.

\section{Description.}

Tail and wings about equal; bill shorter than the head; above reddish-brown, darker towards the head, brighter on the rump; the feathers everywhere, except on the head and neck, barred with dusky; obscurely so on the back, and still less on the rump; all the tail feathers barred from the base; the contrast more vivid on the exterior ones; beneath pale fulvous-white, tinged with light-brownish across the breast; the posterior parts rather dark-brown, obscurely banded; under tail coverts whitish, with dusky bars; an indistinct line over the eye, eyelids, and loral region, whitish; cheeks brown, streaked with whitish.

Length, four and ninety one-hundredths inches; wing, two and eight one-hundredths inches; tail, two inches.

Hab. - Eastern United States to the Missouri, or to the high central plains.

The bill of this species, even from the extreme base, is shorter than the head. The wing is very nearly equal to the tail, and reaches over its basal fourth. The tail is moderately graduated, the lateral feather about . 32 of an inch shorter than the middle. The outstretched feet reach about to the end of the tail.

There are a few whitish spots on the wing coverts.

This interesting and well-known little bird is very generally distributed throughout New England. It arrives from the South as early as the first week in May, and soon appears

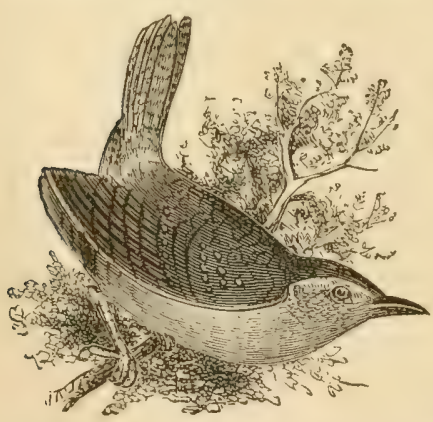
about its old haunts in the garden and orchard. The familiarity of this species with man is well known; and comfortable quarters are provided for its reception, oftentimes in the piazza of a dwelling-house, or in the casement of a window. This little bird is rather quarrelsome, and often drives from

its home the Blue-bird and Martin, occupying the prepared nest for its own domicile. When building a nest of its own, it selects a hole in a tree, or post in a fence, and fills the whole cavity with sticks and twigs: this mass is hollowed 
in the centre, and lined with fine grasses, feathers, wool, and other soft materials. The eggs are usually six in number, sometimes eight, and I have known as many as ten being found in one nest: their color is a pale-reddish flesh-color, covered with fine dots or sprinkling of a darker color. Dimensions vary from .62 by .50 to .59 by .48 inch. Occar sionally, two broods are reared in the season; but, as a general thing, one brood only. The wrens are extremely beneficial in the garden and orchard: they destroy immense numbers of insects and their larvæ, and are, in consequence of their sociable habits and pleasant dispositions, great favorites. It is hardly necessary to say a good word in their favor, as they are well appreciated and protected.

- As with many other birds, this species, although very generally distributed, is not, by any means, regularly spread through these States. It may be quite abundant in one town; and in another, perhaps five miles off, not an individual is to be seen. In Cambridge, Mass., it is one of the most abundant of birds ; but, in Newton or Dorchester, it is comparatively rare. I cannot account for this irregularity, and have never heard a plausible or satisfactory reason for it given. Some species of insects, which are favorites with it for food, may possibly be found less abundantly in some localities than in others; but I am unable to say if this is the case, since I do not know of any particular insect which this bird prefers. Numbers that I have examined, contained in their stomachs spiders in abundance; but what species they were, or what were their peculiar localities, I am ignorant.

\section{TROGLODYTES HYEMALIS. - Vieillot.}

The Winter Wren.

Sylvia troglodytes, Wilson. Am. Orn., I. (1808) 139.

Troglodytes hyemalis, Vieillot. Nouv. Dict., XXXIV. (1819) 514. Aud. Orn. Biog., IV. (1838) 430.

Troglodytes Europaus, Bonaparte. Obs. Wils. (1825), No. 137. Nutt. Man., I. 1832) 427 . 


\section{Description.}

Bill very straight, slender, and conical; shorter than the head; tail considerably shorter than the wings, which reach to its middle; upper parts reddish-brown, becoming brighter to the rump and tail; everywhere, except on the head and upper part of the back, with transverse bars of dusky and of lighter; scapulars and wing coverts with spots of white; beneath pale reddish-brown, barred on the posterior half of the body with dusky and whitish, and spotted with white more anteriorly; outer web of primaries similarly spotted with pale brownish-white; an indistinct pale line over the eye.

Length, about four inches; wing, one and sixty-six one-hundredths inch; tail, one and twenty-six one-hundredths inch.

$H a b$. - North America generally.

This bird is quite abundant in the three northern NewEngland States, and, as a winter visitor, is not uncommon in the others. 'Wilson gives the following account of its habits : -

"This little stranger. visits us from the north in the month of October, sometimes remaining with us all the winter, and is always observed, early in spring, on his route back to his breeding-place. In size, color, song, and manners, he approaches nearer to the European Wren (M. troglodytes) than any other species we have. During his residence here, he frequents the projecting banks of creeks, old roots, decayed logs, small bushes, and rushes, near watery places: he even approaches the farm-house, rambles about the wood-pile, creeping among the interstices like a mouse. With tail erect, which is his constant habit, mounted on some projecting point or pinnacle, he sings with great animation. Even in the yards, gardens, and outhouses of the city, he appears familiar, and quite at home. In short, he possesses almost all the habits of the European species. $\mathrm{He}$ is, however, migratory, which may be owing to the superior coldness of our continent. Never having met with the nest and eggs, I am unable to say how nearly they approximate to those of the former."

I know nothing of the breeding habits, nest, or eggs of this species. It has, while in its summer home, one of the most beautiful warbling songs that I ever heard. 


\section{Family SyLVicOLIDAE. The Warblers.}

Primaries nine, the first quill nearly as long as the second or third; tarsi distinctly scutellate the whole length anteriorly; bill conical, slender, or depressed, usually half the length of head, more or less bristled or notched; nostrils oval or rounded; lateral toes nearly or quite equal, and shorter than the middle; the basal joint of the middle free nearly to its base externally, united for about half internally.

This family is well marked by its scutellate tarsi in front, the absence of any spurious or short first primary, and the rather weak, slenter, conical, or depressed, sometimes decurved, bill. The base of the bill, with the nostrils, is not covered in any genera by setæe, as in Parus, Alauda, \&c. In many respects, there is a close relationship to some Fringillide; and there are some forms, such as the Tanagrido, which it is difficult to assign to the one family rather than to the other. The chief difference, however, is to be found in the longer, slenderer, and less abruptly conical bill of the Tanagers.

The following synopsis will serve to point out the sub-families of the Sylvicolides:-

Motaculinæ.-Bill slender; culmen slightly concave at base; legs long; claws but little curved; hind toe considerably longer than the middle one; its claw much longer (twice) than the middle claw; all the claws but slightly curved; tertials elongated, much longer than the secondaries.

SYLVICOLIN.E. - Bill rather slender, conical or depressed; culmen straight or convex; hind toe shorter than the middle; the claws all much curved; hind claw not conspicuously longer than the middle one; when the hind toe is lengthened, it is usually in the digit, not the claw; tertials generally not longer than the secondaries.

TANAGRINE. - Bill very stout, conical, as high as broad, or considerably broader than high; tarsi short, not exceeding the hind toe; claws much curved, the hinder scarcely larger than the middle anterior.

- Sub-Family Motacilline.-The Wagtails.

\section{ANTHUS, BechsteiN.}

Anthus, Becristein, Gemein. Naturg. Deutschl, 1802 (Agassiz). (Type Alauda spinoletta.)

Bill slender, much attenuated, and distinctly notched; a few short bristles at the base; culmen concave at the base; tarsi quite distinctly scutellate, longer than the middle toe, inner lateral toe the longer; hind toe rather shorter than the tarsus, but longer than the middle toe, owing to the long, attenuated, and moderately curved hind claw, which is considerably more than half the total length of the toe; tail rather long, emarginate; wing very long, considerably longer than the lengthened tail, reaching to its middle; the first primary nearly equal to the longest; the tertials almost as long as the primaries. 
ANTHUS LUDOVICIANUS, - Licht.

The Tit-lark.

Alauda Ludoviciana, Gmelin. Syst. Nat., I. (1788) 793.

Anthus Ludovicianus, Licht. Verz. (1823), 37, No. 421. Aud. Syn. (1839), 84.

Alauda rufa, Wilson. Am. Orn., V. (1812) 89.

Anthus spinoletta, Audubon. Orn. Biog., I. (1832) 408, V. (1839), 449. Nutt. Man., I. (1832) 450.

Anthus pipiens, Auduhon. Orn. Biog., I. (1832) 408, V. (1839) 449.

DESCRIPTION.

(Female, in spring.) Above olive-brown, each feather slightly darker towards the central portion; beneath pale dull-buff, or yellowish-brown, with a maxillary series of dark-brown spots and streaks across the breast and along sides; ring round the eye, and superciliary stripe yellowish; central tail feathers like the back, others dark blackish-brown, the external one white, except at the base within, a white spot at the end of the second; primaries edged with whitish, other quills with pale-brownish.

Length, six and fifty onc-hundredths inches; wing, three and forty-five onehundredths inches; tail, two and ninety-five one-hundredths inches.

Hab. - North America generally. Greenland (Reinhardt). Accidental in Europe.

THIS bird is a not uncommon fall and spring visitor in 1 New England; and, in the southern parts of these States, in mild seasons, it remains through the entire winter. It is most frequently found in the neighborhood of the seacoast or its large marshes, and in large tracts of level, dry, weedy pastures and fields.

While with us, it flies in loose, detached flocks, in a jerking, irregular sort of flight, uttering occasionally its feeble, lisping quêt, queêt. It seems always busily employed, either on the beach, in gathering the small shell-fish and animalcules thrown up by the tide, or, in pastures and stubble-fields, in gleaning the seeds of weeds and grasses: it also feeds upon spiders and such insects as it is able to find in the dead grass and weeds.

As this species breeds in the most northern parts of the continent, I am unable to give any account of its breeding habits; and, having no egg in my collection, I can give no description of it here. Nuttall says the "nest is built in the fissures of cliffs, is composed of dry grass and a 
little moss, and lined with finer blades of the former and a few long hairs. The eggs are four or five in number, of a sullied-white color, and covered with small brown spots, collected chiefly towards the larger end."

\section{Sub-Family SrLvicoline. - The Wood-warblers.}

\section{MNIOTILTA, VieILLOT.}

Mniotilta, Vreillot, Analyse, 1816 (Agassiz).

General form sylvicoline; bill rather long, compressed, shorter than the head, with very short rictal bristles and a shallow notch; wings considerably longer than the tail, which is slightly rounded; first quill shorter than second and third; tarsi rather short; toes long, middle one equal to the tarsus; hind toe nearly as long, the claw considerably shorter than its digit. Color white streaked with black.

This genus differs from other Sylvicolines in the elongation of the toes, especially the hinder one, by means of which the species is enabled to move up and down the trunks of trees, like the true Creepers. But one species is recognized as North American, although Nuttall describes a second.

\section{MNIOTILTA VARIA. - Vieillot.}

The Black and White Creeper.

Motacilla varia, Linnæus. Syst. Nat., I. (1766) 333.

Aniotilta varia, Vieillot. Analyse.(1016). 1b., Galerie Ois., I. (1834) 276. Aud. Syn. (1839), 71。 Ib., Birds Am., II. (1841) 105.

Sylvia varia, Bonaparte. Syn. (1828), 81. Nutt. Man., I. (1832) 384.

Certhia maculata, Wilson. Am. Orn., III. (1811) 22.

\section{DESCRIPTION.}

Bill with the upper mandible considerably decurved, the lower straight; general color of the male black, the feathers broadly edged with white; the head all round black, with a median stripe in the crown and neck above, a superciliary and a maxillary one of white; middle of belly, two conspicuous bands on the wings, outer edges of tertials and inner of all the wing and tail feathers, and a spot on the inner webs of the outer two tail feathers, white; rump and upper tail coverts black, edged externally with white; female similar; the under parts white, obsoletely streaked with black on the sides and under tail coverts.

Length, five inches; wing, two and eighty-five one-hundredths inches; tail, two and twenty-five one-hundredths inches.

Hab. - Eastern North America to Missouri River, south to Guatemala.

This is a rather common summer inhabitant of all New England. It arrives from the South before the 20th of 
April, and sometimes is seen by the first week in that month. In its habits, it resembles both the Creepers and Warblers; moving about the bodies and limbs of trees with the ease of the former, and gleaning amongst the foliage the insect hosts like the latter. I have sometimes seen it seize a flying insect while on the wing, although this must have been a departure from its general habits.

The song of the male during the mating season is a sort of lisping rendition of the syllables whêchee, whêchee, whêchee, whêchee, uttered at first loud, and gradually weakening to a subdued note, like cheet. At other times, it has only a faint chirp or chink, which is uttered by both sexes. About the 10th of May, after the birds have paired, they commence building the nest: this, Audubon says, in Louisiana "is usually placed in some small hole in a tree, and is composed of mosses in a dry state, and lined with cottony substances." In New England, it is almost always built, or rather placed, on the ground; the situation is chosen usually beneath an overhanging point of rock, or beneath a fallen trunk of a tree: it is made of mosses, straw, leaves, and other soft materials, and is lined with cotton from ferns, soft grass, or hair. The eggs are laid by the middle of May. They are usually four or five in number: their color is white, with a slight cream tinge; and they are spotted irregularly with fine dots and confluent blotches of reddishbrown, thickest near the largest end of the egg. Dimensions of four eggs found in a nest in Reading; Mass. : .66 by .54 inch, .66 by .54 inch, .65 by .54 inch, .65 by .54 inch. Two broods are occasionally reared by this species in southern New England.

Probably the greater number breed in more northern localities; for it is much more common in the spring and fall than in summer. By the 10th of September, they, move on their southern migration; and, after the 15th or 20 th of that month, none are to be seen in New England. 


\section{PARUla, Bonatarte.}

Parula, Ronapante, Geog. and Comp. List, 1838. (Type Parus Americanus.)

In the species of this genus, the bill is conical and acute; the culmen very gently curved from the base; the commissure slightly concave, the notch when visible is further from the tip than in Dendroica, but usually is either obsolete or entirely wanting; bristles very short; the tarsi are longer than the middle toe; the tail is nearly even, and considerably shorter than the wing.

\section{PARULA AMERICANA. - Bonaparte.}

The Blue Yellow-backed Warbler.

Parus Americanus, Linnæus. Syst. Nat., I. (1758) 190.

Sylvia Americana. Aud. Orn. Biog., I. (1832) 78.

Parula Americana, Bonaparte. List (1838). Ib., Consp. (1850), 310.

Sylria pusilla, Wilson. Am. Orn., IV. (1811) 17.

\section{DEScRiption.}

Above blue, the middle of the back with a patch of yellowish-green; beneatn yellow anteriorly, white behind; a reddish-brown tinge across the breast; lores and space round the eye dusky; a small white spot on either eyelid; sides of head and neck like the crown; two conspicuous white bands on the wings; outer two tail feathers with a conspicuous spot of white; female similar, with less brown on the breast.

Length, four and seventy-five one-hundredths inches; wing, two and thirty-four one-hundredths inches; tail, one and ninety one-hundredths inch.

Hab. - Eastern North America to the Missouri, south to Guatemala.

This species, I am inclined to think, is rather common in all of New England; and it undoubtedly breeds more or less abundantly in each of these States. It arrives from the South about the middle of May, sometimes a little earlier. The birds, on their arrival, seem to be mated; for they are almost always seen in pairs, often two males with one female. Their habits are very similar to those of the Titmice, and they are equally at home in the high foliage of trees and in the low thickets and shrubbery. When travelling through the trees, they run nimbly both across and along the branches, sometimes hanging head downwards, sometimes fluttering at the extremity of a small twig: they are very nervous and active, and are almost continually employed in catching caterpillars and insects, of which their food consists. While thus engaged, they emit, occa- 
sionally, a feeble note like the syllables cheweêch, cheweêch, cheweêch, uttered at first low, and rapidly increasing in volume. When passing through the forests of Maine and New Hampshire, I have seen numbers of these birds, particularly in the neighborhood of swamps, flying from the tops of the huge hemlocks, and seizing the small lacewinged flies (ephemerides) that are abundant in those regions in May and June. I also noticed that they fed largely upon the small caterpillars (geometridee); and I saw them occasionally descend to the surface of a lake or river, and seize small spiders that were struggling in the water. The habits of this bird have caused it to be classed in many different ways. Linnæus and others placed it in the genus Parus, Latham and many others called it Sylvia, some have named it Motacilla, and Stephens named it Thryothorus. It, however, belongs properly among the Warblers; and the position given it as above seems its most natural one. About the first of June, the birds commence building their nest: this is placed in a fork near the end of a branch of a tree, about twenty feet from the ground. It is usually constructed of the long, gray Spanish moss that is so plentiful in the States of Maine, New Hampshire, and Vermont. A beautiful specimen in my collection, found in Maine by John Krider of Philadelphia, who kindly presented it to me, is of this description, and one of the most curious specimens of bird architecture : the long hairs of the moss are woven and twined together in a large mass, on one side of which is the entrance to the nest, a mere hole left in the moss; the lining is nothing but the same material, only of a finer quality. There is another nest of this description in the collection of the Museum of Comparative Zoology in Cambridge, which was also found in Maine. The eggs are usually four in number, and they are laid about the first week in June. Their color is white, with a very slight creamy tint, and covered more or less thickly with spots and confluent blotches of brownish-red and obscure- 
lilac, thickest at the large end. Two eggs in my collection are of the following measurements : .62 by .48 inch, and .63 by .46 inch.

\section{GEOTHLYPIS, CABANIS.}

Geothlypis, Caranis, Wiegmann's Archiv. (1847), I. 316, 349. 1b., Schomburgk's Reise Guiana (1848).

Bill sylvicoline, rather depressed, and distinctly notched; rictal bristles very short or wanting; wings short, rounded, scarcely longer than the tail; the first quill shorter than the fourth; tail long, much rounded or graduated; legs stout; tarsi elongated as the head; olive-green above, belly yellow; tail feathers immaculate: legs yellow.

\section{GEOTHLYPIS TRICHAS. - Cabanis.}

\section{The Maryland Yellow-throat.}

Turdus trichas, Linnæus. Syst. Nat., I. (1766) 293.

Sylvia trichas, Audubon. Orn. Biog., I. (1832) 120; V. (1838) 463.

Geothlypis trichas, Cabanis. Mus. Hein. (1850), 16.

Sylvia Marilandica, Wilson. Am. Orn., I. (1808) 88.

Trichas roscoe, Nuttall. Man., I. (2d ed., 1840) 457.

\section{DESCRIPTION.}

Upper parts olive-green, tinged with brown towards the middle of the crown; chin, throat, and breast as far as the middle of the body, with the under tail coverts, bright-yellow; belly dull whitish-buff; sides of body strongly tinged with light olive-brown; under coverts glossed with the same; a band of black on the forehead (about twenty one-hundredths of an inch wide in the middle), passing backward so as to cover the cheek and ear coverts, and extending a little above the eye; this band bordered behind by a suffusion of hoary-ash, forming a distinct line above the eye, and widening behind the ear coverts into a larger patch, with a yellow tinge. In winter dress, and in the female, without the black mask, the forehead tinged with brown, the yellow of the throat less extended, the eyelids whitish, and an indistinct superciliary line yellowish.

Length of male, five and fifty one-hundredths inches; wing, two and forty onehundredths inches; tail, two and twenty one-hundredths inches.

This bird is a common inhabitant of all the New-England States. It arrives from the South about the second week in May, sometimes earlier, and soon commences building. The nest is usually placed on the ground, although often in thickets of briers and bushes. It is constructed of leaves and grasses, and is lined with fine grasses and hairs. It is often built over at the top, with the entrance through a hole in the side. The whole makes a bulky affair, almost imper- 
vious to water. ${ }^{1}$ The eggs are laid about the last week in May or first week in June. They are variable in size and markings, but are usually five in number. To illustrate the difference in size and markings, I will describe five eggs found in a nest in Milton, Mass.: No. 1 is creamy-white in color, with numerous spots of dark-brown and obscure spots of lilac; these markings are thinly scattered over the eggs, but are quite thick at the larger end: dimensions, .70 by .52 inch. No. 2 has the same ground-color, but the markings consist of numerous spots and confluent blotches of light-brown and lilac at the large end of the egg: dimensions, .70 by .56 inch. No. 3 is pure-white, with thinly scattered spots of brown and black running like a ring around the larger end of the egg; dimensions, .74 by .50 inch. No. 4 is of a pure-white color, with thinly scattered spots of light-brown around the larger end: dimensions, .66 by .52 inch. No. 5 of the same color, size, and markings as No. 4. Other eggs of this species in my collection exhibit other markings from spots and blotches of lilac and brown at the larger end to thinly scattered dots of reddish over the entire surface; and one specimen has numerous irregular lines in a circle around the larger end of the egg. This species rears two broods in the season in southern New England. I have found nests often as late as the middle of July. The habits of the Maryland Yellow-throat are well known. He is first noticed in the swrampy thickets, darting in and out through the tangled shrubbery. Soon he makes his appearance in the flower-garden and orchard, where he may be seen at almost all times throughr the breeding season, busily engaged searching for his insect food; occasionally pausing to carol his pretty song, whe-tit-te-tee, whe-tit-te-tee, then darting away for a discovered insect, then caressing his mate, or flying to his nest with food for their young.

1 A nest sent me from Delaware is constructed of grasses, which are woven into a loose fabric, quite different from northern specimens. 
In the woods, this species is more often found in low thickets in or near wet, swampy localities, and is very seldom seen in high, dry, heavily wooded countries. It seems to prefer the neighborhood of human habitations for its home, and its genial disposition and beneficial habits have established it as a great favorite with the farmers.

As soon as the last brood of young leaves the nest, the old birds become silent; and, by the middle of September, the whole family leave for the South.

\section{GEOTHLYPIS PHILADELPHIA. - Baird.}

\section{The Mourning Warbler.}

Sylria Philadelphia, Wilson. Am. Orn., II. (1810) 101. Aud. Orn. Biog., V. (1839) 78. Nutt. Man., I. (1832) 404.

\section{DESCRIPTIOX.}

Wings but little longer than the tail, reaching but little beyond its base; head and neck all round, with throat and fore part of breast, ash-gray, paler beneath; the feathers of the chin, throat, and fore breast in reality black, but with narrow ashy margins, more or less concealing the black, except on the breast; lores and region round the eye dusky, without any trace of a pale ring; upper parts and sides of the body clear olive-green; the under parts bright-yellow; tail feathers uniform olive; first primary, with the outer half of the outer web, nearly white. Female, with the gray of the crown glossed with olive; the chin and throat paler centrally, and tinged with fulvous; a dull whitish ring round the eye.

Length, five and fifty one-hundredths inches; wing, two and forty-five one-hundredths inches; tail, two and twenty-five one-hundredths inches.

This bird is very rarely found in New England. It has been taken in all these States, but in such small numbers that it can hardly be called one of our birds. Mr. Allen shot two; I have taken but one; and Mr. Verrill gives one or two instances of its being taken in Maine. The specimen that I captured had all the motions and habits of the Maryland Yellow-throat; and I neglected to shoot it for some time, supposing it to be the female of that bird. Its note was a simple chirp, with a warbling termination like the syllables chirpchreee, chirpchreee, uttered in a soft, pensive tone. Of its breeding habits, nest, and eggs, I am ignorant. 


\section{OPORORNIS, BAIRD.}

Bill sylvicoline, rather compressed; distinctly notched at tip; rictal bristles very much reduced; wings elongated, pointed, much longer than the tail; the first quill nearly or quite the longest; tail very slightly rounded; tail feathers acuminate, pointed; the under coverts reaching to within less than half an inch of their tip; tarsi elongated, longer than the head; claws large, the hinder one as long as its digit, and longer than the lateral toes; above olive-green, beneath yellow; tail and wings immaculate; legs yellow.

\section{OPORORNIS AGILIS, - Baird.}

\section{The Connecticut Warbler.}

Sylvia agilis, Wilson. Am. Orn., V. (1812) 64. Aud. Orn. Biog., II. (1834) 227. Sylvicola agilis, Orn. Biog., II. (1841) 71.

Trichas agilis, Nuttall. Man., I. (2d ed., 1840) 403.

Trichas tephrocotis, Nuttall. Man., I. (2d ed., 1840) 462.

\section{Description.}

Upper parts and sides of the body uniform olive-green, very slightly tinged with ash on the crown; sides of the head ash, tinged with dusky beneatly the eye (entire head sometimes ash); chin and throat grayish-ash, gradually becoming darker to the upper part of the breast, where it becomes tinged with dark-ash; sides of the neck, breast, and body olive, like the back; rest of under parts light-yellow; a broad, continuous white ring round the eye; wings and tail feathers olive (especially the latter), without any trace of bars or spots; bill brown above; feet yellow.

Length, six inches; wing, three; tail, two and twenty-five one-hundredths.

This is another very rare bird in New England, and I have never met with a specimen that was taken north of Massachusetts. In West Roxbury, of this State, in a large tract of pine forest, two or three specimens have been taken within as many years. So far as I can learn, this species has all the habits and motions of the two preceding. It has no song, but utters the note queet often, and in a sprightly tone, as it searches among the shrubbery for its favorite food of spiders and small caterpillars.

\section{ICTERIA, VIEILLOT.}

Icteria, Viemllot, Ois. Am. Sept. I., (1790) 85.

Bill shorter than the head; broad at the base, but rapidly becoming compressed or much higher than broad, with the ridge elevated and sharp from the very base of the bill; the upper outline much curved throughout; the commissure less curved, 
but strongly concave; the gonys nearly straight, the upper edge of the lower jaw as convex as the commissure is concave; no notch in the bill, and the rictal bristles small; tarsi longer than the toes, without scutellx, except faint indications on the inner side; lateral toes about equal, shorter than the hinder; wings about equal to the tail, rounded; the first quill longer than the secondaries; tail graduated, above olive, beneath yellow; abdomen, eyelids, maxillary patch, and line to the bill, white.

\section{ICTERIA VIRIDIS, - Bonaparte.}

\section{The Yellow-breasted Chat.}

Mfuscicapa viridis, Gmelin. Syst. Nat., I. (1788) 936.

Icteria viridis, Bonaparte. Obs. Wilson (1826), No. 163. Nutt. Man., I. (1832) 289. Aud. Orn. Biog., II. (1834) 223; V. 433.

Pipra polyglotta, Wilson. Am. Orn., I. (1808) 90.

\section{DESCRIPTION.}

Third and fourth quills longest, second and fifth little shorter, first nearly equal to the sixth; tail graduated; upper parts uniform olive-green; under parts, including the inside of wing, gamboge-yellow as far as nearly half-way from the point of the bill to the tip of the tail; rest of under parts white, tinged with brown on the sides; the outer side of the tibia plumbeous; a slight tinge of orange across the breast; forehead and sides of the head ash, the lores and region below the eye blackish; a white stripe from the nostrils over the eye and involving the upper eyelid; a patch on the lower lid, and a short stripe from the side of the lower mandible, and running to a point opposite the hinder border of the eye, white; bill black; feet brown. Female like the male, but smaller; the markings indistinct; the lower mandible not pure-black.

Length, seren and forty one-hundredths inches; wing, three and twenty-five one-hundredths; tail, three and thirty one-hundredths inches.

Massachusetts seems to be the northern limit of this bird's habitat in New England; and, even in this State, it is a very rare species. Every season, for the last three years, a pair has nested near Lynn, in this State; and Mr. Allen says, that they are sometimes seen, in the breeding season, near Springfield. I have seen great numbers of these birds in the Western States; their habits, song, \&c., are well described by Nuttall in the following:

"The males, as in many other migrating birds, who are not continually paired, arrive several days before the females. As soon as our bird has chosen his retreat, which is commonly in some thorny or viny thicket, where he can obtain concealment, he becomes jealous of his assumed rights, and resents the least intrusion, scolding all who approach in a variety of odd and uncouth tones, very 
difficult to describe or imitate, except by a whistling; in which case the bird may be made to approach, but seldom within sight. His responses on such oceasions are constant and rapid, expressive of anger and anxiety; and, still unseen, his voice shifts from place to place amidst the thicket, like the haunting of a fairy. Some of these notes resemble the whistling of the wings of a flying duck, at first loud and rapid, then sinking till they seem to end in single notes. A succession of other tones are now heard, some like the barking of young puppies, with a variety of hollow, guttural, uncommon sounds, frequently repeated, and terminated occasionally by something like the merring of a cat, but hoarser; a tone, to which all our Vireos, particularly the young, have frequent recurrence. All these notes are uttered with vehemence, and with such strange and various modulations as to appear near or distant, like the manœuvres of ventriloquism. In mild weather also, when the moon shines, this gabbling, with exuberance of life and emotion, is heard nearly throughout the night, as if the performer were disputing with the echoes of his own voice.

"About the middle of May, soon after their arrival, the icterias begin to build, fixing the nest commonly in a bramble-bush, in an interlaced thicket, a vine, or small cedar, four or five feet from the ground. The outside is usually composed of dry leaves, or thin strips of grape-vine bark, and with root-fibres and dry, slender blades of grass. The eggs are about four, pale flesh-colored, spotted all over with brown or dull-red. The young are hatched in the short period of twelve days, and leave the nest about the second week in June."

Four eggs in my collection exhibit the following dimensions: .71 by .60 inch, .70 by .60 inch, .68 by .59 inch, .67 by .58 inch.

The food of this bird consists of those small insects and spiders that are found in the thick shrubbery of brier patches, and on the ground among the fallen leaves. It also occasionally captures flying insects in the manner of the Vireos; and this fact has caused it, more than its peculiarities of form, to be classed by some authors with those birds.

By the first week in September, none are seen in New 
England; they having left for the tropical countries of South America, where they spend the winter.

\section{HELMITHERUS, RAFINESQUE.}

Helmitherus, Rafinesque, Journal de Physique, LXXXVIII. (1819) 417. (Type SIotacilla vermivora.)

Bill large and stout, compressed, almost tanagrine; nearly or quite as long as the head; culmen very slightly curved; gonys straight; no notch in the bill; rictal bristles wanting; tarsi short, - but little longer, if any, than the middle toe; tail considerably shorter than the wings, rather rounded; wings rather long, the first quill a little shorter than the second and third.

\section{HELMITHERUS VERMIVORUS, - Bonaparte.}

\section{The Worm-eating Warbler.}

\$ Motacilla vermivora, Gmelin. Syst. Nat., I. (1788) 951. 177.

Sylvia vermivora, Wilson. Am. Orn., III. (1811) 74. Aud. Orn. Biog., I. (1832)

Sylvia (Dacnis) vermirora, Nuttall. Man., I. (1832) 409.

\section{Description.}

Bill nearly as long as the head; upper parts generally rather clear olive-green; head with four black stripes and three brownish-yellow ones, namely, a black one on each side of the crown, and one from behind the eye (extending, in fact, a little anterior to it), a broader median yellow one on the crown, and a superciliary from the bill; under parts pale brownish-yellow, tinged with buff across the breast, and with olivaceous on the sides; tail unspotted. Female nearly similar.

Length, five and fifty one-hundredths inches; wing, three; tail, two and thirtyfive one-hundredths inches.

This species is so rarely seen in New England, that it can be regarded only as a straggler. I have never met with a specimen alive, although it has been taken in all these States. Audubon describes its habits as follows:-

"It is an inhabitant of the interior of the forests, and is seldom found on the borders of roads or in the fields. In spring, they move in pairs; and, during their retrograde marches, in little groups, consisting each of a family, seven or eight in number: on which account I am inclined to believe that they raise only a single brood in the year. They are ever amongst the decayed branches of trees or other plants, such as are accidentally broken off by the wind, and are there seen searching for insects or cater- 
pillars. They also resort to the ground, and turn over the dried leaves in quest of the same kind of food. They are unsuspecting, and will suffer a person to approach within a few paces. When disturbed, they fly off to some place where withered leaves are seen. They have only a few weak notes, which do not deserve the name of song. Their industry, however, atones for this defect, as they are seen continually moving about, rustling among the leaves, and scarcely ever removing from one situation to another, until after they have made a full inspection of the part in which they have been employed."

Mr. T. H. Jackson, of Westchester, Pa., describes, in the Am. Naturalist, the nest and eggs of this bird as follows:-

"On the 6th of June, 1869, I found a nest of this species containing five eggs. It was placed in a hollow on the ground much like the nest of the oven bird (Seiurus aurocapillus), and was hidden from sight by the dry leaves that lay thickly around. The nest was composed externally of dead leaves, mostly those of the beech, while the interior was prettily lined with the fine thread-like stalks of the hair-moss (Polytrichium). Altogether it was a very neat structure, and looked to me as if the owner was habitually a ground-nester. The eggs most nearly resemble those of the white-bellied Nuthatch (Sitta Carolinensis), though the markings are fewer and less distinct. So close did the female sit that I captured her without difficulty by placing my hat over the nest."

\section{helminthophaGa, Cabanis.}

Helminthophaga, CABanis, Mus. Hein. (1850-51) 20. (Type Sylvia ruficapilla.)

Bill elongated, conical, very acute; the outlines very nearly straight, sometimes slightly decurved; no trace of notch at the tip; wings long and pointed; the first quill nearly or quite the longest; tail nearly even or slightly emarginate; short and rather slender; tarsi longer than the middle toe.

\section{HELMINTHOPHAGA PINUS.-Baird.}

\section{The Blue-winged Yellow Warbler.}

Certhia pinus, Linnæus. Syst. Nat., I. (1766) 187. Gm., I. (1788) 478.

Sylvia solitaria, Wilson. Am. Orn., II. (1810) 109. Aud. Orn. Biog., I. (1832) 102.

Sylvia (Dacnis) solitaria, Nuttall. Man., I. (1832) 410. 


\section{Description.}

Upper parts and cheeks olive-green, brightest on the rump; the wings, tail, and upper tail coverts, in part, bluish-gray; an intensely black patch from the blueblack bill to the eye, continued a short distance behind it; crown, except behind, and the under parts generally, rich orange-yellow; the inner wing and under tail coverts white; eyelids, and a short line above and behind the eye, brighter yellow; wing with two white bands; two outer tail feathers with most of the inner web, third one with a spot at the end white. Female and young similar, duller, with more olivaceous on the crown.

Length, four and fifty one-hundredths inches; wing, two and forty one-humdredths inches; tail, two and ten one-hundredths inches.

This species is also very rare in New England. In 1857, in the month of May, about the 12th or 15th, I found a small flock in a swamp in Dedham, Mass. They were actively employed in catching flying insects, and were so little mistrustful, that they permitted me to approach quite near, and observe their motions. I noticed nothing peculiar in them; but they had all the activity and industry of the true arboreal Warblers. I know nothing of their breeding habits, and will give the description by Wilson of the nest and eggs. He says, -

"This bird has been mistaken for the Pine Creeper of Catesby. It is a very different species. It comes to us early in May from the South; haunts thickets and shrubberies, searching the branches for insects; is fond of visiting gardens, orchards, and willow-trees, of gleaning among blossoms and currant-bushes; and is frequently found in very sequestered woods, where it generally builds its nest. This is fixed in a thick bunch or tussock of long grass, sometimes sheltered by a brier bush. It is built in the form of an inverted cone or funnel, the bottom thickly bedded with dry beech-leaves, the sides formed of the dry bark of strong weeds lined within with fine, dry grass. These materials are not placed in the usual manner, circularly, but shelving downwards on all sides from the top; the mouth being wide, the bottom very narrow, filled with leaves, and the eggs or young occupying the middle. The female lays five eggs, pure-white, with a few very faint dots of reddish near the great end; the young appear the first week in June. I am not certain whether they raise a second brood in the same season.

"I have met with several of these nests, always in a retired though open part of the woods, and very similar to each other." 


\section{HELMTNTHOPHAGA CHRYSOPTERA. - Cabanis.}

The Golden-winged Warbler.

Motacilla chrysoptera, Linnæus. Syst. Nat., I. (1766) 333. Gm. Syst. Nat., I. (1788) 971 .

Sylvia chrysoptera, Wilson. Am. Orn., II. (1810) 113.

\section{DESCRIPTION.}

Upper parts uniform bluish-gray; the head above and a large patch on the wings yellow; a broad streak from the bill through and behind the eye, with the chin, throat, and forepart of the breast, black; the external edge of the yellow crown continuous with a broad patch on the side of the occiput above the auriculars, a broad maxillary stripe widening on the side of the neck, the under parts generally, with most of the inner webs of the outer three tail feathers white; the sides of the body pale ash-color. Female similar, but duller.

Length, about five inches; wing, two and sixty-five one-hundredths inches; tail, two and twenty-five one-hundredths inches.

1 " This handsomely marked species has hitherto been considered a very rare bird in New England; but it is less uncommon than it is supposed to be. The first one I saw was caught by a cat in a garden in West Newton, Mass. This was on May 16, 1861. That year, and since, I have found it occurring, in small numbers, from the 14th to the 30th of May. The higher branches of trees, in the vicinity of swampy land, appear to be its favorite hunting-places. It may be seen seeking its food quite diligently along the branches and among the twigs, moving by short leaps, and stopping often to utter its drawling note, 'zee-zee-zee-zee' or 'dee-dee-dee-dee.'

"I once saw one, who, having seemingly finished his morning meal, was perched on the topmost twig of a tree, quite motionless, occasionally uttering the above song, which is easily recognized from that of any of our other Warblers. On my alarming him, he flew down among the undergrowth of young birches, and permitted me to approach quite near him: while watching his movements, I observed a Nashville Warbler alight on the same bush in which he was moving, when the Golden-wing immediately gave fight, and chased the intruder away. I have never observed the

1 See Appendix. 
species in autumn, and all the specimens that I have met with were males. It rears its young in the more northern regions probably; and winters beyond the southern limits of the Union, in the West Indies, Central America, and even as far south as Bogota, S.A. This Warbler is not given in any of the lists of the birds of Maine or Vermont that I have seen; but, as it occurs in such small numbers, it may have been overlooked, or perhaps is now becoming a regular visitor, during the spring migrations, in New England." - Letter from Henry A. Purdie.

HELMINTHOPHAGA RUFICAPILLA.-Baird.

The Nashville Warbler.

Sylvia ruficapilla, Wilson. Am. Orn., III. (1811) 120. Aud. Orn. Biog., 1. (1832) 450.

Sylvia rubricapilla, Wilson. Am. Orn., VI. (1812) 15.

Sylvia (Dacnis) rubricapilla, Nuttall. Man., I. (1832) 412.

\section{DESCRIPTION.}

Head and neck above and on sides ash-gray, the crown with a patch of concealed dark brownish-orange hidden by ashy tips to the feathers; upper parts olive-green, brightest on the rump; under parts generally, with the edge of the wing deep yellow; the anal region paler; the sides tinged with olive; a broad yellowish-white ring round the eye; the lores yellowish; no superciliary stripe; the inner edges of the tail feathers margined with dull-white. Female similar, but duller; the under parts paler; but little trace of the red of the crown.

The bill is very acute; the wings long and pointed; the tail emarginate, not rounded.

In autumn, the entire upper parts are olive-green, tinged with yellowish on the rump, sometimes with brownish on the head; the patch on the crown more or less concealed; the female has the white on the middle of the belly more extended.

Length, four and sixty-five one-hundredths inches; wing, two and forty-two one-hundredths inches; tail, two and five one-hundredths inches.

This species is quite common in the spring migrations, arriving about the first week in May; but few breed in the southern districts of New England. Like some other species, it has grown much more abundant than it was a few years since, and is now quite common in localities where it was once a stranger. Its habits are like those of the other Warblers, eminently active and industrious: it seems always 
moving through the foliage, gleaning its insect food. Its note is a peculiar one, and easily recognized: it is best described or illustrated by the sound produced by striking two pebbles together with some force.

About the 20th of June, after the birds have paired, they commence building the nest: this is usually placed on the ground, in a slight depression usually made by the birds themselves. A specimen before me containing three eggs, collected in Malden, Mass., by Mr. H. A. Purdie, is constructed of the leaves of the pine, which are very neatly woven into a compact, circular fabric, deeply hollowed, and lined with horsehair and fine leaves of the pine: the eggs are of a white color, with a very faint rosy tint, and covered irregularly with dots of reddish-brown and obscure lilac. Dimensions of the three specimens: .61 by .50 inch, .60 by .48 inch, .58 by .48 inch. J. A. Allen, in his "Catalogue of the Birds of Springfield, Mass.," gives the following: exceedingly interesting description of the nest and eggs of this bird:-

"I have found the nest of this species for two successive seasons as follows: May 31, 1862, containing four freshly laid eggs. The nest was placed on the ground, and sunken so that the top of the nest was level with the surface of the ground, and protected and completely concealed above by the dead grass and weeds of the previous year. It was composed of fine rootlets and dry grass, lined with fine, dry grass and a few horsehairs, and covered exteriorly with a species of fine, green moss. The eggs were white, sprinkled with light reddish-brown specks, most thickly near the larger end. Longer diameter sixty, and the shorter fifty one-hundredths inch. The following year, June 5, 1863, I found another nest of this species, within three or four feet of where the one was discovered the previous year, and containing three eggs of this species, and one of the Cow Bunting, in all of which the embryos were far advanced. The nest, in every particular, was built and arranged like the one above described; and the eggs must have been laid at just about the same season. In both cases, the female bird was secured, and the identity ascertained beyond 
question. The locality of the nests was a mossy bank, at the edge of young woods, sloping southward, and covered with bushes and coarser plants."

\section{HELMINTHOPHAGA PEREGRINA. - Cabanis.}

\section{The Tennessee Warbler.}

Sylvia peregrina, Wilson. Am. Orn., III. (1811) 83. Aud. Orn. Biog., II. (1834) 307.

Sylvia (Dacnis) peregrina, Nuttall. Man., I. (1832) 412.

\section{DEscription.}

Top and sides of the head and neck ash-gray; rest of upper parts olive-green, brightest on the rump; beneath dull-white, faintly tinged in places, especially on the sides, with yellowish-olive; eyelids and a stripe over the eye whitish; a dusky line from the eye to the bill; outer tail feather with a white spot along the inner edge, near the tip. Female, with the ash of the head less conspicuous; the under parts more tinged with olive-yellow.

Length, four and fifty one-hundredths inches; wing, two and seventy-five one. hundredths; tail, one and eighty-five one-hundredths inches.

This bird is an extremely rare summer visitor in New England. Mr. Allen says he has taken it on Sept. 19 and May 29: this shows that it passes north to breed, but where it passes the season of incubation we are ignorant. The species itself seems to be a very small one; and, as the members are so few, they may be easily overlooked in the forest through the whole season, particularly as they are quiet and retiring in habits. I think that, perhaps, the wilder sections of Maine and New Hampshire may give it a summer home, but of course can only judge from the above reasons.

Mr. Geo. A. Boardman says in the Am. Naturalist that a few remain in his locality (Calais, Me.) through the season, from which I judge that it breeds there.

\section{SEIURUS, SwaINSoN.}

Seiurus, Swainson, Zool. Jour., III. (1827) 171. (Sufficiently distinct from Sciurus. Type Motacilla aurocapilla, L.)

Bill rather sylvicoline, compressed, with a distinct notch; gonys ascending; rictal bristles very short; wings moderate, about three-quarters of an inch longer than the tail; first quill scarcely shorter than the second; tail slightly rounded; feathers acu- 
minate; tarsi about as long as the skull, considerably exceeding the middle toe; under tail coverts reaching within about half an inch of the end of the tail; color above olivaceous; beneath whitish, thickly streaked on the breast and sides; wings and tail immaculate.

\section{SEIURUS AUROCAPILLUS, - Swainson.}

The Oven-bird; Golden-crowned Thrush.

Motacilla aurocapilla, Linnæus. Syst. Nat; I. (1766) 334. Gm., I. (1788) 982.

Turdus aurocapillus, Wilson. Am. Orn., II. (1810) 88. Aud. Orn. Biog., II. (1834) 253 ; V. (1839) 447.

Turdus (Seiurus) aurocapillus, Nuttall. Man., I. (1832) 355.

\section{DESCRIPTION.}

Above uniform olive-green, with a tinge of yellow; crown with two narrow streaks of black from the bill, enclosing a median and much broader one of brownishorange; beneath white; the breast, sides of the body, and a maxillary line streaked with black. The female, and young of the year, are not appreciably different. inches.

Length, six inches; wing, three inches; tail, two and forty one-hundredths

This beautiful and well-known bird is a common summer inhabitant of New England, breeding abundantly in all the States. It arrives from the South about the last week in April or first in May, and soon commences building. The birds are not often paired on their arrival, and many are the little quarrels and battles that occur between two or three males for the possession of one of the opposite sex. The birds both work diligently in the construction of the nest, which is a model of neatness and ingenuity. It is built on the ground in the woods, usually in a dry situation. The materials used are dry leaves and grasses: these are arranged compactly together, and built over at the top, the entrance being on the side, like an old-fashioned oven; hence the familiar name of the "Oven-bird." The nest is usually placed in a slight hollow in the earth, scratched by the birds, and is lined with soft grasses and hairs. The eggs are from three to five in number, usually four. They are of a delicate creamy-white color, and spotted irregularly with different shades of reddish-brown; and some specimens have a number of spots of obscure lilac-color. The mark- 
ings are usually thickest at the larger end of the egg, where they are often confluent, and cover the primary color. Dimensions of four specimens collected in a nest in West Roxbury, Mass. : .80 by .64 inch, .79 by .64 inch, .79 by .62 inch, .78 by .62 inch. A great number of specimens, collected in different localities of New England, show no great variations from these measurements.

The habits of this bird are so well known that an extended description here is scarcely needed. It is seldom found in any but the most retired and thickly wooded localities, and it generally prefers the neighborhood of a swamp for its home. Its song is a peculiar one, and easily recognized: it consists of the repeated utterance of the syllables, quîcha, quîcha, quîcha, quîcha, quîcha, begun at first very low, and rapidly increasing in volume. I have heard this song, in the mating and incubating seasons, at all hours of the night: the bird seems, at that time, to ascend into the air to a considerable height, and utters its notes while hovering and slowly descending. I have noticed the same habit in the Maryland Yellow-throat and some other birds; and suppose that it is owing to, and to show, his great affection for his mate, and to anxiety for the success of her labors.

When on the ground, the Oven-bird runs with great rapidity, frequently jetting its tail and uttering its sharp alarm-note: if the nest is approached, the male throws himself in the way of the intruder, and endeavors to draw him from its vicinity, scolding all the time with the greatest vehemence. If the female is driven from her domicile, she suddenly flutters along the ground, her wings extended, counterfeiting lameness in a very natural and generally effective manner.

This species, in consequence of its eminently terrestrial habits, often falls a victim to snakes and skunks. I have repeatedly found nests, and left them, in order that I might acquaint myself with the breeding peculiarities of the bird; and in a day or two, on paying it a second visit, found 
that a skunk or other depredator had destroyed the whole family.

The Oven-bird feeds principally upon small insects and smooth caterpillars, which it obtains usually on the ground, among the fallen leaves: when berries are in season, it feeds occasionally upon them; and it seems particularly fond of small spiders, with which I have sometimes found its stomach filled. About the 12th or 15th of September, after the young birds have become capable of providing for themselves, the whole family leave for the South.

\section{SEIORUS NOVEBORACENSIS. - Nuttall.}

The Water Thrush; Water Wagtail.

Motacilla Noveboracensis, Gmelin. Syst. Nat., I. (1788) 958.

Turdus (Seiurus) Noveboracensis, Nuttall. MIan., I. (1832) 355.

Turdus aquaticus, Wilson. Am. Orn., III. (1811) 66. Aud. Orn. Biog., V. (1839) 284.

\section{Description.}

Bill, from rictus, about the length of the skull; above olive-brown, with a shade of green; beneath pale sulphur-yellow, brightest on the abdomen; region about the base of the lower mandible, and a superciliary line from the base of the bill to the nape, brownish-yellow; a dusky line from the bill through the eye; chin and throat finely spotted; all the remaining under parts and sides of the body, except the abdomen, and including the under tail coverts, conspicuously and thickly streaked with olivaceous-brown, almost black on the breast.

Length, six and fifteen one-hundredths inches; wing, three and twelve one-hundredths inches; tail, two and forty one-hundredths inches; bill, from rictus, sixtyfour one-hundredths of an inch.

This bird is not very uncommon in New England in the spring and fall migrations (arriving about the 1st of May, and departing about the last week in September); and I have sometimes seen it in summer in Massachusetts. It undoubtedly breeds in the three northern of these States, and probably in them all. In its habits, it much resembles the preceding species; but it is seldom found in any but a wet locality.

Wilson says, "This bird is remarkable for its partiality to brooks, rivers, shores, ponds, and streams of water; 
wading in the shallows in search of aquatic insects, wagging the tail almost continually, chattering as it flies ; and, in short, possesses many strong traits and habits of the Water Wagtail. It is also exceedingly shy, darting away on the least attempt to approach it, and uttering a sharp chip repeatedly, as if greatly alarmed."

Although I have met with quite a number of these birds in their sylvan haunts, I have never heard them sing. That it possesses a beautiful song most writers agree; its notes are described as follows: "They are eminently distinguished by the loudness, sweetness, and expressive vivacity of their notes, which begin very high and clear, falling with an almost imperceptible gradation till they are scarcely articulated. At these times, the musician is perched on the middle branches of a tree over the brook or river bank, pouring out his charming melody, that may be distinctly heard for nearly half a mile. The voice of this little bird appeared to me so exquisitely sweet and expressive, that I was never tired of listening to it, while traversing the deepshaded hollows of those cane-brakes where it usually resorts."

Although I have looked repeatedly for the nest of this species, I have never been able to find one, and will be obliged to use the description of others. Mr. Verrill says, in his paper on Maine birds, before referred to :-

"A nest found, June 8, 1861, in a dense cedar swamp, was built in an excavation in the side of a decayed, moss-covered $\log$, so that the excavation itself formed an arch over the nest, instead of one made by the bird, as in the preceding species. The nest was constructed of moss, and lined with fine roots. The five eggs were of a delicate flesh-color, spotted with light reddish-brown."

\section{Nuttall says of the nest:-}

"It is placed usually at the foot of a tree, or by the side of a decayed $\log$, and is formed of dry leaves, moss, and fine grass; being lined with hair or the similar fibres of the Spanish moss 
(Tilandsia). The eggs are four or five, flesh-colored, with dark spots at the greater end."

Several eggs in my collection agree with the above description: they exhibit an arerage of .81 by .63 inch in dimensions.

\section{DENDROICA, Gray.} son.)

Sylvicola, Grar, Genera Birds (2d ed., 1841), 32. (Not of Humphreys or Swain-

Dendroica, Gray, Genera Birds, Appendix (1842) 8.

Bill conical, attenuated, depressed at the base, where it is, however, scarcely broader than high, compressed from the middle; culmen straight for the basal half, then rather rapidly curving, the lower edge of upper mandible also concave; gonys slightly convex and ascending; a distinct notch near the end of the bill; bristles, though short, generally quite distinct at the base of the bill; tarsi long, decidedly longer than middle toe, which is longer than the hinder one; the claws rather small and much curved, the hind claw nearly as long as its digit; the wings long and pointed; the second quill usually a very little longer than the first; the tail slightly rounded and emarginate.

Colors. - Tail always with a white spot; its ground-color never clear olive-green.

DENDROICA VIRENS, - Baird.

The Black-throated Green Warbler.

Botacilla virens, Gmelin. Syst. Nat., I. (1788) 985.

Sylvia virens, Wilson. Am. Orn., II. (1810) 127. Nutt. Man., I. (1832) 376. Aud. Orn. Biog., IV. (1838) 70.

Sylvicola virens.

\section{Description.}

Male, upper parts, exclusive of wing and tail, clear yellow olive-green, the feathers of the back with hidden streaks of black; forehead and sides of head and neck, including a superciliary stripe, bright yellow; a dusky-olive line from the bill through the eye, and another below it; chin, throat, and fore part of breast, extending some distance along on the sides, continuous black; rest of under parts white, tinged with yellow on the breast and flanks; wings and tail feathers dark-brown, edged with bluish-gray; two white bands on the wing; the greater part of the three outer tail feathers white. Female, similar, but duller; the throat yellow; the black on breast much concealed by white edges; the sides streaked with black.

Length, five inches; wing, two and fifty-eight one-hundredths; tail, two and thirty one-hundredths inches.

This beautiful bird is a quite common species in Rhode Island, Connecticut, and Massachusetts, and is not rare in the other New-England States, in which, I have no doubt, it 
breeds, though not nearly so abundantly as in those first mentioned. It arrives from the South from about the 25th of April to the 1st of May, in Massachusetts. I have often seen this species, as late as the last week in May, busily engaged in destroying insects (of which its food, as also that of the other Warblers, consists), apparently without being mated, as several individuals of both sexes were together, seemingly in harmony, but without those little fondlings and attentions peculiar to mated birds. The nest is seldom built before the 10th of June in this latitude. It is constructed of fine grasses, fibrous roots, fine strips of bark from the cedar, and the leares of the pine: these are entwined together strongly and neatly, and the interior of the nest is lined with horsehair and fine moss. Nuttall, in describing the only nest of this bird that he ever saw, says, -

"On the 8th of June, I was so fortunate as to find a nest of this species in a perfectly solitary situation, on the Blue Hills of Milton, Mass. The female was now sitting, and about to hatch. The nest was in a low, thick, and stunted Virginia juniper. When I approached near the nest, the female stood motionless on its edge, and peeped down in such a manner that I imagined her to be a young bird: she then darted directly to the earth, and ran; but when, deceived, I sought her on the ground, she had very expertly disappeared, and I now found the nest to contain four roundish eggs, white, inclining to flesh-color, variegated, more particularly at the great end, with pale, purplish points of various sizes, interspersed with other large spots of brown and blackish. The nest was formed of circularly entwined fine strips of the inner bark of the juniper, and the tough, fibrous bark of some other plant, then bedded with soft feathers of the Robin, and lined with a few horsehairs, and some slender tops of bent grass (Agrostis)."

Early in June, 1863, a nest of this species was discorered in a grove of pines in West Roxbury: it was built in a small fork of a pine, about ten feet from the ground. The nest and its contents, four eggs, were removed; but the birds remained in the neighborhood, and soon commenced 
building another nest in the same tree, but a few feet higher. In it the female laid three eggs, after which this nest and eggs were removed; but soon after they built another nest in another pine, near the first: this nest was perhaps twentyfive feet from the ground; in this, two eggs were laid, which were allowed to be hatched. One of these nests, with four eggs, is in my collection, and is already described above. The eggs are a pale, creamy-white color, with a very faint roseate tint, and one marked with coarse and fine spots of brown of different shades, and obscure spots of lilac. These markings are quite thick at the large end of the egg, - in fact, are almost confluent into a sort of girdle. Their dimensions are .66 by .53 inch, .66 by .52 inch, .64 by .52 inch, and $.62 \mathrm{by} .51$ inch. A large number of nests, with eggs collected in Massachusetts, have, within a few year's, passed through my hands: they were all of the above description.

This bird prefers the foliage of high trees to the lower shrubbery, and I have noticed that it is most usually found in or near the different pines. Its song is heard through the mating and breeding seasons, as the bird is actively moving about the trees searching for its food.

This song is something like the syllables, ta-te-te-ît-tă-tee, uttered in a plaintive tone; the first syllable low, the second higher, the third and fourth quickly together and high, and the fifth and sixth a little slower and lower. Its song is peculiar, and cannot be confounded with that of any other Warbler in New England.

\section{DENDROICA CANADENSIS. - Baird.}

The Black-throated Blue Warbler.

Motacilla Canadensis, Linnæus. Syst. Nat., I. (1766) 336. Gm., I. (1788) 991.

Sylvia Canadensis, Wilson. Am. Orn., II. (1810) 115. Nutt. Man., I. (1832) 398. Aud. Orn. Biog., II. (1834) 309.

Sylvia pusilla, Wilson. Am. Orn., V. (1812) 100.

\section{DESCRIPTION.}

Above uniform continuous grayish-blue, including the outer edges of the quill and tail feathers; a narrow frontal line, the entire sides of head and neck, chin and 
throat, lustrous black, this color extending in a broad lateral stripe to the tail; rest of under parts, including the axillary region, white; wings and tail black above, the former with a conspicuous white pateh formed by the bases of all the primaries (except the first); the inner webs of the secondaries and tertials with similar patches towards the base and along the inner margin; all the tail feathers, except the innermost, with a white patch on the inner web, near the end.

Female, olive-green above and dull-yellow beneath; sides of head dusky-olive, the eyelids and a superciliary stripe whitish; traces of the white spot at the base of the primaries and of the tail.

Length, five and fifty one-hundredths inches; wing, two and sixty one-hundredths; tail, two and twenty-five one-hundredths inches.

This Warbler is not uncommon in the mountainous districts of Massachusetts, from the middle to the end of May; and I found several specimens in the Green-Mountain country as late as the 10th of June. This occurrence, together with the fact that it has been 'found, in the breeding season, on Mount Holyoke, in Mass., and along the ridges in the western part of this State, shows that it probably breeds, sometimes at least, in Massachusetts.

The individuals that I saw were in tall oaks and chestnuts, actively moving about through the foliage, snapping at flies and other insects: they often uttered a faint, drawling wéesy, wéesy, and occasionally a louder chirp or chink, like that of the Nashville Warbler.

Being unacquainted with the nest and eggs, I give Audubon's description of them:-

"The nest is usually placed on the horizontal branch of a fir-tree, at a height of seven or eight feet from the ground. It is composed of slips of bark, mosses, and fibrous roots, and is lined with fine grass, on which is laid a warm bed of feathers.

"The eggs, four or five in number, are of a rosy tint, and, like those of most other Sylvice, scantily sprinkled with reddish-brown at the larger end. Only one brood is raised in a season."

About the first week in September, this species leaves New England on its southern migration. 
DENDROICA CORONATA. - Gray.

The Yellow-rumped Warbler.

Motacilla coronata, Linnæus. Syst. Nat., I. (1766) 333. Gm. Syst. Nat., I. (1788) 974.

Sylvia coronata, Wilson. Am. Orm., II. (1810) 138. Nutt. Man., I. (1832) 361 Aud. Orn. Biog., II. (1834) 303.

\section{DESCRIPTION.}

Above bluish-ash, streaked with black; under parts white; the fore part of breast and the sides black, the feathers mostly edged with white; crown, rump, and sides of breast yellow; cheeks and lores black; the eyelids and a superciliary stripe, two bands on the wing, and spots on the outer three tail feathers, white. Female, of duller plumage, and browner above.

Length, five and sixty-five one-hundredths inches; wing, three inches; tail, two and fifty one-hundreths inches.

Thie Yellow-rumped or Golden-crowned Warbler is very abundant in all parts of New England as a spring and fall visitor. It arrives from the South about the 20th of April, and passes quickly northward. But few breed south of

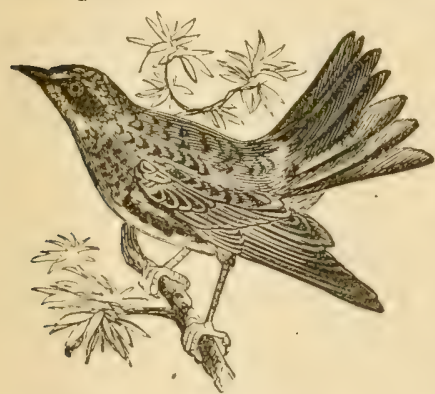
the northern parts of Maine, and probably not a great many pass the season of incubation there. When with us in the spring, they are found in the pastures, woods, orchards, and swamps, equally distributed, and evincing no partiality for any particular locality. They are then very active, and are constantly engaged in their search for insects.

Their note is nothing but a kind of tchip and a tinkling twéeter, which they utter occasionally, both while on the wing and while perching.

I have heard of no nest being found in either of the southern New-England States, - have met with but one in Massachusetts, and have heard of but two or three others. 
This nest was built in a low barberry-bush in Waltham : it was constructed of fine grasses and the down from ferns. These materials were carefully woven together into a neat fabric, which was lined with cottony substances and a few horsehairs. The eggs were three in number: these were of a creamy-white color, covered sparsely with spots and blotches of different shades of reddish-brown, thickest at the large end of the egg. Dimensions of the eggs: .68 by .50 inch, .67 by .50 inch, .66 by .49 inch. Audubon describes a nest and eggs sent him from Nova Scotia as follows : -

"It resembles that of the Sylvia astiva of Latham, being firm, compact, the outer parts formed of silky fibres from different plants, attached to the twigs near it by means of glutinous matter, mixed with the inner bark of some tree unknown to me. Within this is a deep and warm bed of thistle-down, and the inner layer consists of feathers and the fine hair of small quadrupeds.

"The eggs are rather large, of a light rosy tint, the shell thin and transparent: they are sparingly dotted with reddish-brown near the larger end, but in a circular manner, so that the extremity is unspotted."

From the last of September until the middle of October, they become very plentiful again, and may be seen in large detached flocks in all the fields, orchards, and woods of the country: they are very abundant in stubble-fields; and I have seen as many as fifty in a flock start at the report of my gun, when $I$ have been quail-shooting.

DENDROICA BLACKBURNI丑.-Baird.

The Blackburnian Warbler.

Motacilla Blaclburnia, Gmelin. Syst. Nat., I. (1788) 977.

Sylvia Blackburnice, Wilson. Am. Orn., III. (1811) 67. Nutt. Man., I. (1832) 379.

Aud. Orn. Biog., II. (1834) 208; V. 73.

Sylvia parus, Wilson. Am. Orn., V. (1812).114.

Hemlock Warbler, Authors. 


\section{Description.}

Upper parts nearly uniform black, with a whitish scapular stripe and a large white patch in the middle of the wing coverts; an oblong patch in the middle of the crown, and the entire side of the head and neck (including a supereiliary stripe from the nostrils), the chin, throat, and forepart of the breast, bright orange-red; a black stripe from the commissure passing over the lower half of the eye, and including the ear coverts, with, however, an orange crescent in it, just below the eye, the extreme lid being black; rest of under parts white, strongly tinged with yellowish-orange on the breast and belly, and streaked with black on the sides; outer three tail feathers white, the shafts and tips dark-brown, the fourth and fifth spotted much with white, the other tail feathers and quills almost black. Female similar; the colors duller; the feathers of the upper parts with olivaceous edges.

Length, five and fifty one-hundredths inches; wing, two and eighty-three onehundredth inches; tail, two and twenty-five one-hundredths inches.

This, the most beautiful of all our Warblers, is a rare summer inhabitant of all New England. Dr. Brewer found it breeding in the eastern part of Massachusetts. Verrill says it breeds in Maine; Dr. Thompson says it breeds in Vermont; and I have seen it in New Hampshire in the season of incubation. It is a shy and mistrustful species, and is found only in the deepest woods, where it keeps in the thickest foliage of tall trees. Its nest and eggs I have not seen, and I am obliged to give the description by Audubon: "It [the nest] is composed externally of different textures, and lined with silky fibres and thin delicate strips of fine bark, over which lay a thick bed of feathers and horsehair. The eggs are small, very conical towards the smaller end, pure-white, with a few spots of light-red towards the larger end. It was found in a small fork of a tree, five or six feet from the ground, near a brook."

\section{DENDROICA CASTANEA. - Baird.}

The Bay-breasted Warbler.

Sylvia castanea, Wilson. Am. Orn., II. (1810) 97. Nutt. Man., I. (1832) 382. Aud. Orn. Biog., I. 358.

\section{DESCRIPTION.}

Male. - Crown dark reddish-chestnut; forehead and cheeks, including a space above the eye, black; a patch of buff-yellow behind the cheeks; rest of upper parts bluish-gray, streaked with black; the edges of the interscapulars tinged with yellowish, of the scapulars with olivaceous; primaries and tail feathers edged ex- 
ternally with bluish-gray, the extreme outer ones with white; the secondaries edged with olivaceous; two bands on the wing and the edges of the tertials white; the under parts are whitish with a tinge of buff; the chin, throat, forepart of breast, and the sides, chestnut-brown, lighter than the crown; two outer tail feathers with a patch of white on the inner web near the end; the others edged internally with the same.

Female with the upper parts olive, streaked throughout with black, and an occasional tinge of chestnut on the crown; lower parts with traces of chestnut, but no stripes.

Length of male, five inches; wing, three and five one-hundredths inches; tail, two and forty one-hundredths inches.

The Bay-breasted Warbler is, in most localities of New England, not common, in some quite rare. In the eastern localities of Massachusetts it is very seldom met with. Allen mentions instances when specimens conld be obtained by the " bushel-basket full;" but I think that generally it is rarely seen. Mr. Tripp, in the Am. Naturalist, says of this species: "It is not quite so active as the other warblers, and keeps more on the lower boughs, seldom ascending to the tops of the trees. The young are totally different in their colors from the adults, and so closely resemble the young of the Black-polled Warbler that it is often very difficult to distinguish them apart." It is seen in New England only in the migrations.

\section{DENDROICA PINUS, - Baird.}

The Pine-creeping Warbler.

Sylvia pinus, TVilson. Am. Orn., III. (1811) 25. Nutt. Man., I. (1832) 387. Aud. Orn. Biog., II. (1834) 232.

\section{Description.}

Upper parts nearly uniform and clear olive-green, the feathers of the crown with rather darker shafts; under parts generally, except the middle of the belly behind, and under tail coverts (which are white), bright gamboge-yellow, with obsolete streaks of dusky on the sides of the breast and body; sides of head and neck olivegreen like the back, with a broad superciliary stripe; the eyelids and a spot beneath the eye very obscurely yellow; wings and tail brown; the feathers edged with dirty white, and two bands of the same across the coverts; inner web of the first tail feather with nearly the terminal half, of the second with nearly the terminal third, dull inconspicuous white.

Length, five and fifty one-hundredths inches; wing, three inches; tail, two and forty one-hundredths inches. 
This species arrives from the South very early, often before the last snow-storm of the season, and remains in the deep swamps of hemlocks or pines until the weather opens. About the first week in June, the birds become scarce, and soon but very fer can be found. A nest with two eggs, found in Woburn, Mass. ; and another nest with three eggs, from West Roxbury, in the same State, - are all the specimens accessible to me at the present time. These nests were built in forks of pine-trees, about twenty feet from the ground. They are constructed of the bark of the cedar and leaves of the pine: these materials are intwined into a neat structure, which is warmly lined with mosses, and hairs of different animals. The eggs are of a bluishwhite, with a slight roseate tint: this primary color is dotted with spots of two shades of brown and reddish, and some spots of purple. Dimensions vary from .69 by .50 inch to .67 by .51 inch.

In the migrations, these birds associate in detached flocks : in the spring they are in company with the Red-poll Warblers; and, in the fall, with the Yellow-rumps.

They are, in the summer, almost always observed in the pine-groves, actively traversing the limbs and branches, sometimes with the movements of the Creepers and Titmice, sometimes with those of the Warblers, and often flying from the foliage and seizing an insect on the wing, like the Flycatchers.

Their song is now somewhat similar to that of the Field Sparrow, or perhaps more like a mixture of that and the song of the Indigo-bird, if such can be imagined. It consists of the syllables tweet 'weet 'weet 'weet 'weet 'weet, uttered at first slow and faint, but rapidly increasing in utterance and volume. Besides this, it has a sort of trilling note, like fre 're 're 're 're 're, uttered softly and listlessly.

In the autumn, they add to their usual insect-food small berries and seeds: they are now nearly silent, having only a quick, sharp chirp. .They are scattered through the fields 
and woods, and seem to be as much on the ground as in the trees. They depart for the South by the 10th or 15 th of October.

\section{DENDROICA PENNSYLANICA. - Baird.}

\section{The Chestnut-sided Warbler.}

Motacilla Pennsylvanica, Linnæus. Syst. Nat., I. (1766) 333.

Sylvia Pennsylvanica, Wilson. Am. Orn., I. (1808) 99.

Sylcia icterocephala, Audubon. Orn. Biog., I. (1832) 306. Nutt. Man., I. (1832) 380 .

\section{Description.}

Male. - Upper parts streaked with black and pale bluish-gray, which becomes nearly white on the forepart of the back; the middle of the back glossed with greenish-yellow; the crown is continuous yellow, bordered by a frontal and superciliary band, and behind by a square spot of white; loral region black, sending off a line over the eye, and another below it; ear coverts and lower eyelid and entire under parts pure-white, a purplish-chestnut stripe starting on each side in a line with the black moustache, and extending back to the thighs; wing and tail feathers dark-brown, edged with bluish-gray, except the secondaries and tertials, which are bordered with light yellowish-green; the shoulders with two greenish-white bands; three outer tail feathers with white patches near the end of the inner webs.

Female like the male, except that the upper parts are yellowish-green, streaked with black; the black moustache scarcely appreciable.

Length, five inches; wing, two and fifty one-hundredths inches; tail, two and twenty one-hundredths inches.

This bird is a rather common summer inhabitant of all New England, being most plentiful in Massachusetts and the States south, and gradually growing more rare as we advance north. It makes its appearance from the South about the first to the middle of May, according to latitude, and commences to build about the last week in this month or the first in June. The nest is usually built in a small fork of a low tree, often in bushes, but a few feet from the ground. It is constructed of thin strips of pliable bark and fine grasses: these materials are bent and intwined together, and over the outside are pieces of caterpillar silk and cobwebs, which are plastered on, seemingly to give the fabric compactness and consistency. The nest is deeply hollowed, and lined with horsehairs and slender strips of the bark of 
the grape-vine. Nuttall describes a nest found in Acton, Mass., as follows :-

"It is fixed in the forked twigs of a hazel, about breast-high. The fabric is rather light and airy, being made externally of a few coarse blades and stalks of dead grass, then filled in with fine blades of the same; the whole matted and tied with caterpillars' silk, and lined with very slender strips of brown bark and similar white-pine leaves."

The nests which I have collected, and some I have before me, are of a different character from his description, being compactly and neatly made of bark from the cedar, and grasses, and lined with horsehair; but I have no doubt that this species, like many others, varies in breeding habits in different localities. The eggs are three or four in number, and are laid about the first week in June. They are of a delicate creamy-white color, and marked at the great end with spots of brown, which are often confluent: the spots are of two colors, a reddish-brown and purplish-brown. The dimensions vary from .70 by .51 inch to .63 by .50 inch. But one brood is raised in the season in this latitude.

This is another of those birds which seem to have become quite abundant within a few years. Wilson, Nuttall, and others speak of it as being a very rare species; and it is now one of the most common of birds in localities where it was, a few years since, quite rare. It prefers a growth of low shrubs and scrub-oaks and birches to a forest of tall trees, and is seldom seen in the latter.

Its note consists of the syllables 'che 'che 'ch 'chéea, repeated at short intervals : it has also, at times, a rattling cry something like the alarm-note of the Maryland Yellowthroat.

The female has nothing but a sharp chirp, which she often emits in answer to the song of the male. When approached while on the nest, she sits quietly until the intruder is quite near. I once had a dog make a point 


\section{Plate II.}
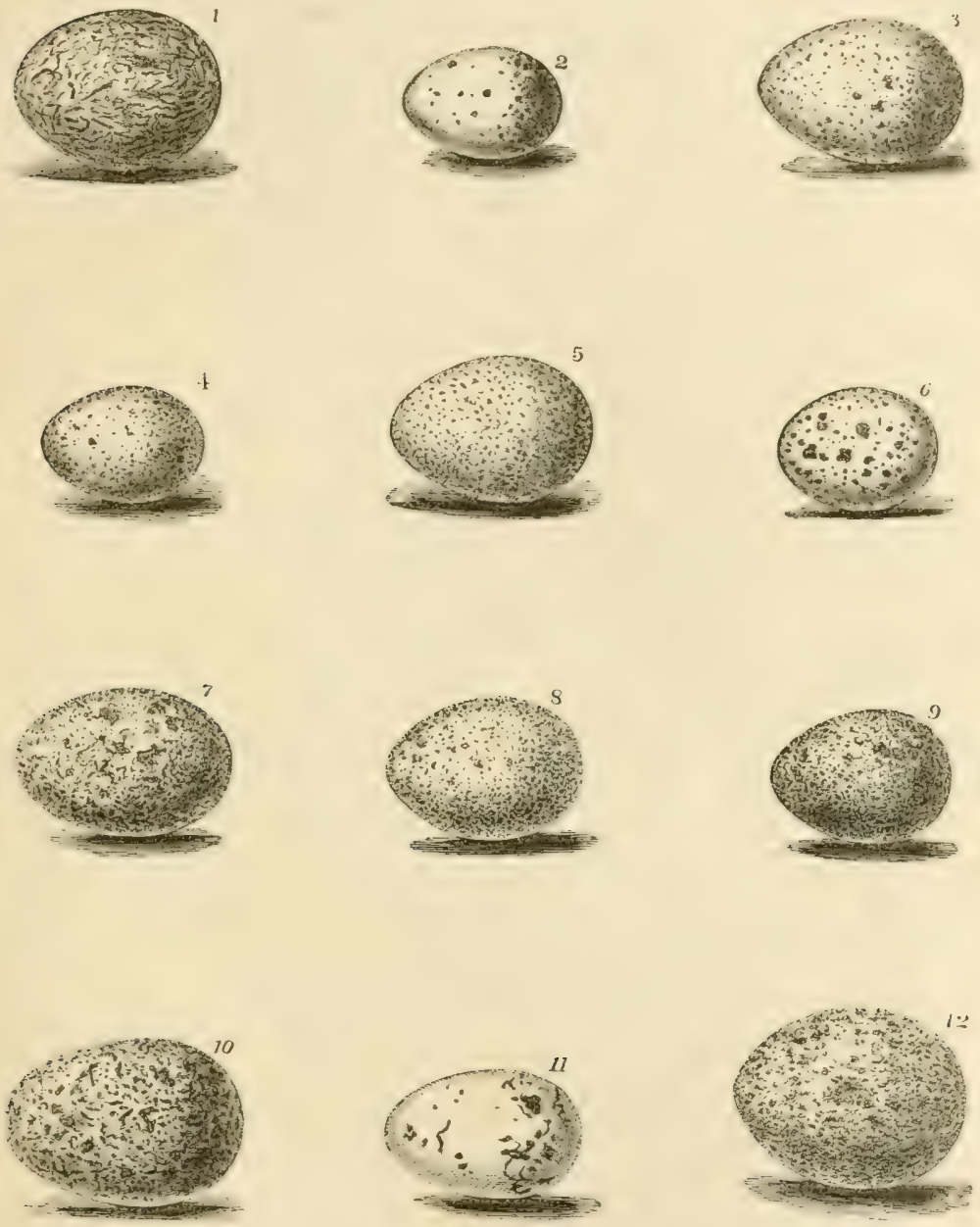

Fir. 1. Great-crested Flycatcher, Mryiarchus crinitus. Cabanis.

2. Blue Fellow-backed Farbler, Parula Americana. Bonaparte

,. 3. Water Thrush, Seiurus Noveboracensis. Nuttall.

4. Black-throated Green Warbler, Dendroica virens. Baird.

.. 5. White-bellied Nuthatch. Sitta Carolinensis. Gmelin

.. G. Red-bellied Nuthatch, Sitta Canadensis. Linnæus.

.. T. White-throated Sparrow, Zonotrichia albicollis. Bonaparte

.. 8. Snow-bird, Junco hyemalis. Sclater.

.. 9. Tree Sparrow, Spizella monticola. Baird.

.. 10. Rose-breasted Grosbeak, Guiraca ludovicıana. Swainson.

.. 11. Orchard Oriole. Icterits spurius. Bonaparte.

“. 12. Rusty Blackbird, Scolecophagus ferrugineus. Swainson. 

at one while she was sitting on her nest, and she almost permitted me to touch her before she flew off.

By the first week in September, the old birds and young, apparently in a group by themselves, leave for the South, and winter in Panama and the Bahamas.

\section{DENDROICA STRIATA.-Baird.}

\section{The Black-poll Warbler.}

Mfuscicapa striata, Forster. Philos. Trans., LXII. (1772) 383, 428. Gm. Syst. Nat., I. (1788) 930.

- Sylvia striata, Wilson. Am. Orn., IV. (1811) 40. Nutt. Man., I. (1832) 383. Aud. Orn. Biog., II. (1834) 201.

Sylvig autumnalis, Wilson. Am. Orn., III. (1811) 65. Aud. Orn. Biog., I. (1832) 447. Nutt. Man., I. (1832), 390. (Female or young in autumn.)

\section{DESCRIPTION.}

Male. - Crown, nape, and upper half of the head black; the lower half, including the ear coverts, white, the separating line passing through the middle of the eye; rest of upper parts grayish-ash, tinged with brown, and conspicuously streaked with black; wing and tail feathers brown, edged externally (except the inner tail feathers) with dull olive-green; two conspicuous bars of white on the wing coverts, the tertials edged with the same; under parts white, with a narrow line on each side the throat from the chin to the sides of the neck, where it runs into a close patch of black streaks continued along the breast and sides to the root of the tail; outer two tail feathers with an oblique patch on the inner web near the end, the others edged internally with white.

Female similar, except that the upper parts are olivaceous, and, even on the crown, streaked with black; the white on the sides and across the breast tinged with yellowish; a ring of the same round the eje, cut by a dusky line through it.

Length of male, five and seventy-five one-hundredths inches; wing, three inches; tail, two and twenty-five one-hundredths inches.

This bird, although very abundant in all parts of New England in the spring migrations, passes far to the north to breed; but few remain in the States through the breeding season, and these in the most northern districts. It arrives from the South about the last week in May, and proceeds leisurely on its journey, arriving at its destination about the second week in June. I have two nests in my collection, both found in the northern part of Maine: they were placed in low trees or saplings, and are constructed of first a layer of twigs and grass, then the 
leaves of the pine, and moss; these materials are twined into a compact structure, somewhat bulky, and deeply hollowed, and lined with feathers of wild birds and hairs of different animals. A nest complement of four eggs in my collection, furnished by my friend, George A. Boardman, are of a grayish-white color, thickly marked with spots and blotches of two or three shades of brown and purple. Dimensions vary from .71 by .54 inch, to .66 by .50 inch. Audubon describes the only nest of this bird that he ever met with as follows:-

"It was placed about three feet from the ground, in the fork of a small branch, close to the main stem of a fir-tree. Its diameter internally was two inches, the depth one and a half: externally, it resembled the nest of a white-crowned sparrow, being formed of green and white moss and lichens, intermixed with coarse dried grass; within this was a layer of bent grass, and the lining was of very dark-colored, dry moss, looking precisely like horsehair, arranged in a circular direction with great care. Lastly, there was a thick bed of large, soft feathers, some of which were from ducks, but most of them from willow-grouse."

The same author describes the habits of this bird as follows:-

"You see it darting in all directions after insects, chasing them on the wing, and not unfrequently snapping, so as to emit the clicking sound characteristic of the true Flycatcher. Its activity is pleasing; but its notes have no title to be called a song. They are shrill, and resemble the noise made by striking two small pebbles together, more than any other sound I know."

I cannot agree with Professor Baird, that the Autumnal Warbler of authors, and the young of the Bay-breasted, are identical, at least in New England; but I am persuaded that the young of the present species is the Sylvia autumnalis. And it seems to me, that no other argument is needed to establish this beyond a doubt, than the fact, that the Baybreasted Warbler is very rare, in all this section of the coun- 
try, in spring and summer; and that it should become exceedingly abundant in autumn is inconsistent with reason and nature. The description of the young of the Black-poll also agrees with that of the Autumnal Warbler, as do also its habits and characteristics.

I will append Wilson's description of the habits of the Black-poll and Autumnal Warbler, and also their general description. He says of the Autumnal Warbler, -

"This plain little species regularly visits Pennsylvania from the North, in the month of October, gleaning among the willow-leaves, but, what is singular, is rarely seen in spring. From the 1st to the 15th of October, they may be seen in considerable numbers, almost every day, in gardens, particularly among the branches of the weeping-willow, and seem exceedingly industrious. 'They have some resemblance, in color, to the Pine-creeping Warbler, but do not run along the trunk like that bird, neither do they give a preference to the pines. They are also less. After the 1st of November, they are no longer to be found, unless the season be uncommonly mild. These birds doubtless pass through Pennsylvania, in spring, on their way to the North; but either make a very hasty journey, or frequent the tops of the tallest trees: for I have never yet met with one of them in that season, though in October I have seen more than a hundred in an afternoon's excursion.

"Length, four inches and three-quarters; breadth, eight inches; whole upper parts olive-green, streaked on the back with dusky stripes; tail coverts ash, tipped with olive; tail black, edged with dull-white; the three exterior feathers marked near the tip with white; wings deep-dusky, edged with olive, and crossed with two bars of white; primaries also tipped, and three secondaries next the body edged with white; upper mandible dusky-brown; lower, as well as the chin and breast, dull-yellow; belly and vent white; legs dusky-brown; feet and claws yellow ; a pale-yellow ring surrounds the eye. The males of these birds often warble out some low but rery sweet notes, while searching among the leaves in autumn."

He says of the Black-poll Warbler, -

"This species has considerable affinity to the Flycatchers in its habits. It is chiefly confined to the woods, and, even there, to the 
tops of the tallest trees, where it is descried skipping from branch to branch in pursuit of winged insects. Its note is a single screep, scarcely audible from below. It arrives in Pennsylvania about the 20 th of April, and is first seen on the tops of the highest maples, darting about among the blossoms. As the woods thicken with leaves, it may be found pretty generally, being none of the least numerous of our summer birds. It is, however, most partial to woods in the immediate neighborhood of creeks, swamps, or morasses, probably from the greater number of its favorite insects frequenting such places. It is also pretty generally diffused over the United States, having myself met with it in most quarters of the Union, though its nest has hitherto defied all my researches."

He then says of the female Black-poll, -

"From its habit of keeping on the highest branches of trees, it probably builds in such situations, and its nest may long remain unknown to us.

"Pennant, who describes this species, says that it inhabits, during summer, Newfoundland and New York, and is called in the last Sailor. This name, for which, however, no reason is given, must be very local ; as the bird itself is one of those silent, shy, and solitary individuals that seek the deep retreat of the forest, and are known to few or none but the naturalist.

"Length of the female Black-cap five inches and a quarter, extent eight and a quarter; bill brownish-black; crown yellowolive, streaked with black; back the same, mixed with some paleslate; wings dusky-brown, edged with olive; first and second wing coverts tipped with white; tertials edged with yellowish-white; tail coverts pale-gray; tail dusky, forked, the two exterior feathers marked on their inner vanes with a spot of white; round the eye is a whitish ring; cheeks and sides of the breast tinged with yellow, and slightly spotted with black; chin white, as are also the belly and vent; legs and feet dirty-orange.

"The young bird of the first season, and the female, as is usually the case, are very much alike in plumage. On their arrival, early in April, the black feathers on the crown are frequently seen coming out, intermixed with the former ash-colored ones.

"This species has all the agility and many of the habits of the Flycatcher." 
About the middle of October, sometimes not before the last of that month, the Black-poll Warbler leaves on its southern migration: at that time, it has, in New England certainly, all the characteristics and habits of the Autumnal Warbler described above; and, having examined numbers of specimens, I conclude, from the reasons expressed above, that the species are identical.

DENDROICA ESTIVA. - Baird.

The Yellow Warbler.

Motacilla cestiva, Gmelin. Syst. Nat., I. (1788) 996.

Sylvia citrinella, Wilson. Am. Orn., II. (1810) 111.

Sylvia childreni, Audubon. Orn. Biog., I. (1831) 180.

Motacilla petechia, Linnxus. Syst. Nat., I. (1766) 334.

\section{DEsciription.}

Bill lead-color; head all ronnd, and under parts generally, bright-yellow; rest of upper parts yellow-olivaceous, brightest on the rump; back with obsolete streaks of dusky reddish-brown; fore breast and sides of the body streaked with brownishred; tail feathers bright-yellow; the outer webs and tips, with the whole upper surfaces of the innermost one, brown; extreme outer edges of wing and tail feathers olivaceous, like the back; the middle and greater coverts and tertials edged with yellow, forming two bands on the wings. Female similar, with the crown olivaceous, like the back, and the streaks wanting on the back, and much restricted on the under parts; tail with more brown.

Length of male, five and twenty-five one-hundredths inches; wing, two and sixtysix onerhundredths; tail, two and twenty-five one-hundredths inches.

This exceedingly abundant species is a summer resident, and breeds in all the New-England States. It arrives from the South about the last of April or first of May, and commences building about the 15 th of the latter month. The nest is usually placed in a low bush, frequently the barberry. Occasionally, it is built in an alder or maple tree, seldom more than fifteen or twenty feet-from the ground, although Mr. Nuttall gives instances of its being built in the forks of a sugar-maple-tree, fifty feet from the ground: this, however, is a very rare case. Nuttall's description of the nest is the best I have seen, and I give it entire :-

"The nest is extremely neat and durable; the exterior is formed of layers of asclepias, or silk-weed lint, glutinously though slightly 
attached to the supporting twigs, mixed with some slender strips of fine bark and pine-leaves, and thickly bedded with the down of willows, the nankeen wool of the Virginia cotton-grass (Eriophorum Virginicum), the down of fine stalks, the hair of the downy seeds of the button-wood (Platanus), or the papus of compound flowers, and then lined either with fine bent grass (Agrostis), or down, and horsehair, and rarely with a few accidental feathers."

The eggs are usually four in number, sometimes five: they vary in color from creamy-white, with numerous spots and blotches of different shades of brown, to a grayish-white with a greenish tint, and marked with the same spots and blotches; these markings are thickest at the larger end of the egg, where they are often confluent. Dimensions vary from .67 by .50 inch to .64 by $.50 \mathrm{inch}$. The habits of this bird are well known; and its genial nature and confiding disposition have rendered it a great favorite with the farmer.

\section{DENDROICA MACULOSA. - Baird.}

The Black and Yellow Warbler; Magnolia Warbler.

Motacilla maculosa, Gmelin. Syst., I. (1788) 984.

Sylvia maculosa, Nuttall. Man., I. (1832) 370. Aud. Orn. Biog., I. (1831) 260 ; II. (1834) 145 ; V. (1839) 458.

Sylvia magnolia, Wilson. Am. Orn., III. (1811) 63.

\section{DESCRIPTION.}

Male, in spring. - Bill dark bluish-black, rather lighter beneath; tail dusky, top of head light grayish-blue; front, lore, cheek, and a stripe under the eye, black, running into a large triangular patch on the back, between the wings, which is also black; eyelids and a stripe from the eye along the head white; upper tail coverts black, some of the feathers tipped with grayish; abdomen and lower tail coverts white; rump and under parts, except as described, yellow; lower throat, breast, and sides streaked with black, the streaks closer on the lower throat and fore breast; lesser wing coverts, and edges of the wing and tail, bluish-gray, the former spotted with black; quills and tail almost black, the latter with a square patch of white on the inner webs of all the tail feathers (but the two inner), beyond the middle of the tail; two white bands across the wings (sometimes coalesced into one), formed by the small coverts and secondaries; part of the edge of the inner webs of the quills white; feathers margining the black patch on the back behind and on the sides tinged with greenish.

Second and third quills longest, first shorter than fourth; tail rounded, emarginate.

Female, in spring. - In general appearance like the male, but with the corresponding colors much duller; the black on the back reduced to a few large proxi- 
mate spots; the spots on the under parts much fewer; upper parts dirty-ash, tinged with greenish on the lower back; on the rump dull-yellow.

Male, in autumn. - Bill brown, lighter along the edges and base of lower mandible; head and hind neck dirty-ash, tinged above with green; back greenishyellow, obsoletely spotted with black; rump yellow; throat and breast yellow, obsoletely spotted with black, strongly tinged with light-ash on the lower throat; eyelids dirty-white; differs from the spring plumage in being without the black on the back, front, sides of the head and cheeks, and in a great degree on the under parts; much less white on the wing and side of the head; the colors generally also are duller.

Female, in autumn. - Similar, generally, to the male in fall. Back greenishyellow, brighter on the rump; rest of upper parts deep-ash; lower parts yellow, obsoletely streaked with black, the light-ash on the lower throat decided; the white on the wings reduced to two narrow bands. There is a continuous white ring round the eye; bill light brown; basal part of lower mandible dirty-white; feet lighter brown.

Specimens vary somewhat in the amount of black on the under parts.

Length, five inches; wing, two and fifty one-hundredths; tail, two and twenty-five one-hundredths inches.

This beautiful bird is not uncommon in the migrations in the three southern New-England States, and is a summer resident in the others. It does not make its appearance before the 10 th of May, and proceeds slowly in its travels. I found numbers in Northern Maine and New Hampshire as late as the 17th of June. They were industrious, and seemed to be, at that late date, but just mating. Hence $I$ infer that they rear but one brood, and not until late in the season.

The note of the male is very similar to that of the Chestnutsided Warbler; and I was deceived by it into mistaking this for that species. It had the habits of that bird also, and seemed Lower fig., Black and Yellow Warbler to prefer the low, swampy woods to the higher ones.

Although I looked very carefully and diligently for the nest, I could not find it. From the fact that the birds were 
almost always in or near clearings or young growth, I judge that they nest in such localities. Mr. Hutchins informs us, that, in the Hudson's Bay country, the nest is built in willows, and that it is constructed of grass and feathers: he also says that the female lays four eggs. I can find no other description of the nest or eggs.

After the 25th of September, none are to be found in New England.

\section{DENDROICA TIGRINA. - Baird.}

\section{The Cape-May Warbler.}

Motacilla tigrina, Gmelin. Syst. Nat., I. (1788) 985.

Sylvia maritima, Wilson. Am. Orn., VI. (1812) 99. Nutt. Man., I. (1832) 156. Aud. Orn. Biog., V. (1839) 156.

\section{DESCRIPTION.}

Bill very acute, conical, and decidedly curved; bill and feet black; upper part of head dull-black, some of the feathers faintly margined with light yellowish-brown; collar scarcely meeting behind; rump and under parts generally rich-yellow; throat, fore part of breast, and sides, streaked with black; abdomen and lower tail coverts pale-yellow, brighter about the vent; ear coverts light reddish-chestnut; back part of a yellow line from nostrils over the eye, of this same color; chin and throat tinged also with it; a black line from commissure through the eye, and running into the chestnut of the ear coverts; back, shoulder, edges of the wing and tail, yellowisholive, the former spotted with dusky; one row of small coverts, and outer bases of the secondary coverts, form a large patch of white, tinged with pale-yellow; tertials rather broadly edged with brownish-white; quills and tail dark-brown, the three outer feathers of the latter largely marked with white on the inner web; edge of the outer web of the outer feathers white, more perceptible towards the base.

Length, five and twenty-five one-hundredths inches; wing, two and eighty-four one-hundredths; tail, two and fifteen one-hundredths inches.

This species appears to be quite rare in New England, but it probably occurs regularly in the migrations. It is said to breed in south-eastern Maine, and it probably does so in the northern sections.

\section{DENDROICA PALMARUM. - Baird.}

\section{The Yellow Red-poll Warbler.}

Motacilla palmarum, Gmelin. Syst. Nat., I. (1788) 951.

Sylvia petechia, Wilson. Am. Orn., VI. (1812) 19. Nutt. Man., I. (1832) 364. Aud. Orn. Biog., II. (1834) 259, 360 . 


\section{Description.}

Head above chestnut-red; rest of upper parts brownish olive-gray; the feathers with darker centres, the color brightening on the rump, upper tail coverts, and outer margins of wing and tail feathers, to greenish-yellow; a streak from nostrils over the eye, and under parts generally, including the tail coverts, bright-yellow; paler on the body; a maxillary line; breast and sides finely but rather obsoletely streaked with reddish-brown; cheeks brownish (in highest spring plumage, chestnut like the head); the eyelids and a spot under the eye olive-brown; lores dusky; a white spot on the inner web of the outer two tail feathers at the end.

Length, five inches; wing, two and forty-two one-hundredths; tail, two and twenty-five one-hundredths inches.

This is one of the earliest of our spring visitors, arriving sometimes as early as the first week in April: it is quite abundant until the second week of May, when it moves on to its northern breeding-homes. While here, it prefers the neighborhood of a swampy thicket, and is seldom seen in high dry woods. It is, like the other Warblers, always actively employed in searching for insects, which it captures as often while on the wing as otherwise. Its note is a faint tinkle like that of the Golden-crested Wren. There are only a few that breed in New England. I have in my collection a nest and eggs collected in Northern Maine by Mr. George A. Boardman, of Calais. The nest was placed on the ground. It is constructed loosely, first of stalks of weeds and grasses: above these is placed a layer of fine roots and grass; then are laid pieces of moss, caterpillars' silk, fine grasses, and hairs; and the whole is deeply hollowed, and lined with fine roots and pine-leares. Two eggs in the nest are of a delicate white, with a faint roseate tint: they are marked at the larger end with fine spots and blotches of reddish and brown. They are about the size of the eggs of the Blue Yellow-backed Warbler, being .61 by .50 inch and .62 by .51 inch.

\section{DENDROICA DISCOLOR. - Baird.}

The Prairie Warbler.

Sylvia discolor, Vieillot. Ois. Am. Sept., II. (1807) 37. Aud. Orn. Biog., 1. (1831) 76. Nutt. Man., I. (1832) 294.

Sylvia minuta, Wilson. Am. Orn., III. (1811) 87. 


\section{DESCRIPTION.}

Above uniform olive-green; the middle of the back streaked with brownish-red. Under parts and sides of the head, including a broad superciliary line from the nostrils to a little behind the eye, bright-yellow, brightest anteriorly; a well-defined narrow stripe from the commissure of the mouth through the eye, and another from the same point curving gently below it, also a series of streaks on each side of the body, extending from the throat to the flanks, black; quills and tail feathers brown, edged with white; the terminal half of the inner web of the first and second tail feathers white; two yellowish bands on the wings. Female similar, but duller; the dorsal streaks indistinct.

Length, four and eighty-six one-hundredths inches; wing, two and twenty-five one-hundredths; tail, two and ten one-hundredths inches.

This beautiful bird is not very common in any part of New England; and it appears to be a rather rare species north of Massachusetts, which State seems to be its northern breeding limit. It makes its appearance about the third week in May, and commences building about the last of that month. I have been so fortunate as to find two nests in Norfolk County, and have had another nest and eggs sent me from Belmont, in this State: I have also known of several other nests being found, and judge that the species breeds not uncommonly in Massachusetts and the other two southern New-England States. These nests were all placed in low barberry bushes, in rocky localities. They are exceedingly neat structures, the most so of any of our NewEngland Warblers' nests: they are constructed of various soft cottony substances, after the manner of the nest of the Yellow Warbler, and are lined with soft feathers and wool. The eggs are usually three in number. These are of a beautiful pearly-white color, with a slight roseate tint, and covered irregularly with small spots of different shades of brown and lilac, thickest at the large end. Dimensions of three eggs collected in Belmont, Mass. : .64 by .52 inch, .63 by .52 inch, .60 by .50 inch. The above-described nests were invariably placed in the fork of the bush in which they were built: the materials were the same, consisting of the down from different plants, cotton, wool, and other like substances. I find, on referring to Audubon, Wilson, and 
others, considerable differences in the description of the nest, \&c. Wilson's description is as follows:-

"The nest of this species is of very neat and delicate workmanship, being pensile, and generally hung on the fork of a low bush or thicket. It is formed outwardly of green moss, intermixed with rotten bits of wood and caterpillars' silk: the inside is lined with extremely fine fibres of grape-vine bark; and the whole would scarcely weigh a quarter of an ounce."

\section{Audubon says, -}

"Its nest, which forms by far the most interesting part of its history, is uncommonly small and delicate. Its eggs I have uniformly found to be four in number, and of a white color, with a ferr brownish spots near the larger end. The nest is sometimes attached to three or four blades of tall grass, or hangs between two small sprigs of a slender twig. At first sight, it seems to be formed like that of the Humming-bird; the external parts being composed of delicate gray lichens and other substances, and skins of black caterpillars, and the interior finished with the finest fibres of dried vines."

\section{Nuttall says, in contradiction to these descriptions, -}

"The nest was hardly distinguishable from that of the Summer Yellow-bird (Yellow Warbler), being fixed in a trifid branch (not pensile), and formed of strips of inner red-cedar bark and asclepias fibres, also with some caterpillar silk, and thickly lined with cudweed down (Ginaphalium plantagineum), and slender tops of bent grass (Agrostis). The eggs, four or five, were white, rather sharp at the lesser end, marked with spots of lilac-purple, and others of two different shades of brown, rather numerous at the great end, where they appear most collated together in a circle."

Nuttall's description of the nest is certainly the most correct, so far as shown in all the specimens that I have: probably, in different sections, the breeding habits of this bird are, like those of some others, subject to great rariations. 
Wilson says, in his description of the habits of these birds, -

"They seem to prefer these open plains and thinly wooded tracts, and have this singularity in their manners, that they are not easily alarmed, and search among the leaves the most leisurely of any of the tribe $I$ have yet met with; seeming to examine every blade of grass and every leaf; uttering, at short intervals, a feeble chirr. I have observed one of these birds to sit on the lower branch of a tree for half an hour at a time, and allow me to come up nearly to the foot of the tree, without seeming to be in the least disturbed, or to discontinue the regularity of its occasional note. In activity, it is the reverse of the preceding species; and is rather a scarce bird in the countries where I found it. Its food consists principally of small caterpillars and winged insects."

In closing with the genus Dendroica, I give the remarks of J.A. Allen concerning the distribution of the different species at Springfield, Mass.:-

"Of the twenty-two species of Dendroica inhabiting the United States, thirteen have been found at Springfield, and one other (D. coerulea) may occur as accidental or extremely rare. Four of them (D. virens, pinus, Pennsylvanica, restiva) are known to breed here, and two others (D. Blackburnice, castanea) have been taken in the breeding season. None are permanent residents, and none are seen in the winter. The remaining five $(D$. coronata, striata, maculosa, tigrina, palmarum) are at present known merely as spring and autumn visitants. D. coronata is most abundant; striata next so; virens, Canadensis, maculosa, astiva, and palmarum are but little less common; Blackburnice is more rare; castanea and discolor are quite rare, while tigrina is extremely rare. The earliest to arrive are pinus and palmarum, commonly appearing early in April; striata is rarely seen before May 30 : the others commonly arrive from May 5 th to May 12th, and stragglers remain till June. D. coronata is decidedly gregarious in its migrations, and is everywhere about equally abundant. The others are usually seen in small parties, and keep pretty closely to the woods, except D. restiva and palmarum, astiva, being never found in the deep woods." 


\section{MYIODIOCTES, AUDUBON.}

Myiodioctes, ADDubox, Syn. (1839), 48. (Type Motacilla mitrata.)

Bill depressed, Flycatcher like; broader than high at the base; gape with bristles nearly as long as the bill, which is distinctly notched at tip; both outlines gently convex; tarsi longer than the head, considerably exceeding the middle toe; claws all considerably curved; tail decidedly rounded or slightly graduated; the lateral feathers one-fifth of an inch shorter; wing very little longer than the tail; the first quill decidedly shorter than the fourth; colors yellow.

\section{MYIODIOCTES MITRATUS, - Audubon.}

The Hooded Warbler.

Mrotacilla mitrata, Gmelin. Syst. Nat., I. (1788) 977.

Sylvia mitrata, Nuttall. Man., I. (1832) 373. . Aud. Orn. Biog., II. (1834) 68.

Sylvania mitrata, Nuttall. Man., I. (2d ed., 1840) 333.

Ifuscicapa cucullata, Wilson. Am. Orn., III. (1811) 101.

\section{DESCRIPTION.}

Mfale. - Bill black; feet pale-yellow; head and neck all round, and fore part of the breast, black; a broad patch on the forehead extending round on the entire cheeks and ear coverts, with the under parts, bright-yellow; upper parts and sides of the body olive-green; greater portion of inner web of three outer tail feathers white.

Female similar; the crown like the back; the forehead yellowish; the sides of the head yellow, tinged with olive on the lores and ear coverts.

Length, five inches; wing, two and seventy-five one-hundredths; tail, two and fifty-five one-hundredths inches.

This bird is so extremely rare in New England, that it can be regarded only as a straggler. It has been known to occur in Connecticut, but its regular habitat is more a southern one. Audubon describes its habits as follows :-

"The Hooded Flycatcher is one of the liveliest of its tribe, and is almost continually in motion. Fond of secluded places, it is equally to be met with in the thick cane-brakes of the high or low lands, or amid the rank weeds and tangled rushes of the lowest and most impenetrable swamps. You recognize it instantly, on seeing it; for the peculiar graceful opening and closing of its broad tail distinguishes it at once, as it goes on gambolling from bush to bush, now in sight, now hidden from your eye, but constantly within hearing. 
"The nest of this species is always placed low, and is generally attached to the forks of small twigs. It is neatly and compactly formed of mosses, dried grasses, and fibrous roots, and is carefully lined with hair, and, not unfrequently, a few large feathers. The eggs are from four to six, of a dull-white, spotted with reddishbrown towards the larger end. The male and female sit by turns, and show extreme anxiety for the safety of their eggs or young."

MYIODIOCTES PUSILLUS, - Bonaparte.

The Green Black-cap Flycatcher; Wilson's Black-cap.

Mruscicapa pusilla, Wilson. Am. Orn., III. (1811) 103.

Sylvania pusilla, Nuttall. Man., I. (2d ed., 1840) 335.

Sylvia Wilsonii, Nuttall. Man., I. (1832) 408.

DIuscicapa Wilsonii, Audubon. Orn. Biog., II. (1834) 148.

DESCRIPTION.

Forehead, line over and around the eye and under parts generally bright-yellow; upper part olive-green; a square patch on the crown lustrous-black; sides of body and cheeks tinged with olive; no white on wings or tail. Female similar; the black of the crown obscured by olive-green.

Length, four and seventy-five one-hundredths inches; wing, two and twentyfive one-hundredths; tail, two and thirty one-hundredths inches.

Occurs in sparing numbers from May 12th to 27th. Have seen it in apple-orchards, actively engaged in hunting insects, at which times it was quite tame, uttering its song at intervals. It has also been observed in August. Probably breeds in Northern New England.

"It has all the habits of a true Flycatcher, feeding on small insects, which it catches entirely on the wing, snapping its bill with a smart clicking sound. It frequents the borders of the lakes, and such streams as are fringed with low bushes, from which it is seen every moment sallying forth, pursuing its insect prey for many yards at a time, and again throwing itself into its favorite thickets.

"The nest is placed on the extremity of a small horizontal branch, among the thick foliage of dwarf firs, not more than from three to five feet from the ground, and in the centre of the thickets of these trees so common in Labrador. The materials of which it is composed are bits of dry moss and delicate pine twigs, agglutinated together and to the branches or leaves around it, and beneath 
which it is suspended, with a lining of extremely fine and transparent fibres. The greatest diameter does not exceed three and a half inches, and the depth is not more than one and a half. The eggs are four, dull-white, sprinkled with reddish and brown dots towards the larger end, where the marks form a circle, leaving the extremity plain. The parents show much uneasiness at the approach of any intruder, skipping about and around among the twigs and in the air, snapping their bill, and uttering a plaintive note. They raise only one brood in the season. The young males show their black cap as soon as they are fully fledged, and before their departure to the South."-Audubon.

This bird, according to Audubon, is not very rare in Maine, and it becomes more abundant the farther north we proceed. He found it in Labrador and all the immediate districts; it reaching that country early in June, and returning southward by the middle of August.

\section{MYIODIOCTES CANADENSIS. - Audubon.}

The Canada Flycatcher.

Muscicapa Canadensis, Linnæus. Syst. Nat., I. (1766)-327. Wil. Am. Orn., III. (1811) 100. Aud. Orn. Biog., II. (1834) 17.

Sylvia pardalina, Bonaparte. Nutt. Man., I. (1832) 372.

\section{DESCRIPTION.}

Upper parts bluish-ash; a ring round the eye, with a line running to the nostrils, and the whole under part (except the tail coverts, which are white), brightyellow; centres of the feathers in the anterior half of the crown, the cheeks, continuous with a line on the side of the neck to the breast, and a series of spots across the fore part of the breast, black; tail feathers unspotted. Female similar, with the black of the head and breast less distinct. In the young obsolete.

Length, five and thirty-four one hundredths inches; wing, two and sixty-seven one-hundredths; tail, two and fifty one-hundredths inches.

This beautiful species is a rather common spring and autumn visitor in all New England, and, in the northern sections of these States, is an inhabitant through the whole summer. It sometimes breeds in Massachusetts; and I have no doubt, that, in a few years, it will be found to breed abundantly in this State, as it has increased in num- 
bers greatly within four or five years. It arrives from the South from about the 10th to the 25th of May. The birds seem to be mated on their arrival; for I have noticed, that, if a male is seen, a female is almost always to be found in his immediate vicinity.

About the first week in June, the nest is built. ${ }^{1}$ This is fixed in a fork of a low cedar or pine bush, very near the ground, and is constructed of pine leaves, fine roots and grasses, and a few hairs : it is loosely put together, and is lined with fine pieces of the same materials and lichens.

The eggs are four in number. They are small and abruptly pointed: they are of a grayish-white color, with a slight roseate tint, and are marked with spots and fine blotches of lilac and brown, usually thickest near the larger end. The only nest and eggs that I have seen were of this description : they were found in Quincy, Mass., in an old pasture, partly grown up with bushes.

The eggs were nearly of a uniform size and shape, and measured about .65 by .48 inch in dimensions.

The habits of this species are so much like those of the preceding, that, if the Wilson's Black-cap were more common, the two birds might be easily confounded. The flight of the present is rapid; and all the motions of the bird, when it is pursuing insects, are those of the true Flycatchers. Its note is a shrill weêchy, wéechy, which is uttered at short intervals by the bird, both while on the wing and when perching. About the first week in September, it begins to grow abundant; and, by the 15th of that month, it has departed on its southern migration.

\section{SETOPHAGA, Swaisson.}

Setophaga, Swarnsox, Zool. Jour., III. (Dec., 1827) 360. (Type Mfuscicapa ruticilla, Linnaus.)

Bill depressed, broader than high; rictus with long bristles; wings rounded, equal to or shorter than the tail; first quill shorter than the fourth; tail long, somewhat graduated, the outer feathers about twenty one-hundredths of an inch or more shorter; all the feathers unusually broad, and widened at the end; feet short; tarsus

1 See Appendix. 
shorter than the head; hind toe equal to the lateral; coloration embracing more or less of red in northern species.

This genus differs from Mfyiodioctes chiefly in the longer, broader tail, and rather shorter tarsi and toes, the hinder especially; the bill is more muscicapine; the culmen nearly straight to the abruptly decurved and much notched tip; the gonys straight; in Myiodioctes the vertical outlines are more convex; the gonys more ascending; the tip gently and but slightly decurved.

\section{SETOPHAGA RUTICILLA. - Swainson.}

The Red Start.

Muscicapa ruticilla, Linnæus. Syst. Nat., I. (1766) 326. Wil. Am. Orn., I. (1808) 103. Aud. Orn. Biog., I. (1831) 202; V. (1839) 428.

Sylvania ruticilla, Nuttall. Man., I. (1832) 291.

\section{DESCRIPTION.}

Mfale. - Prevailing color black; a central line on the breast, the abdomen, and under tail coverts, white; some feathers in the latter strongly tinged with darkbrown; bases of all the quills, except the inner and outer, and basal half of all the tail feathers, except the middle one, a patch on each side of the breast, and the axillary region orange-red, of a vermilion shade on the breast. Female with the black replaced by olive-green above, by brownish-white beneath; the head tinged with ash; a grayish-white lore and ring round the eye; the red of the male replaced by yellow.

Length, five and twenty-five one-hundredths inches; wing, two and fifty onehundredths inches; tail, two and forty-five one-hundredths inches.

This quite common species is a summer resident, and breeds in all the New-England States. It arrives from the South from about the first to the middle of May, according to latitude, and commences building about the first week in June. The nest is usually placed on a low limb of a small tree, often in a horizontal fork, seldom more than ten feet from the ground. It is constructed of strips of cedar bark, grape-vine bark, grasses, and fine weeds: these

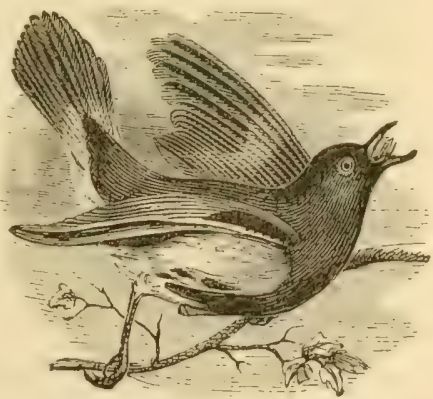
materials are adjusted neatly, and aggrlutinated by the bird's saliva into a compact structure, to the exterior of which are attached, or plastered on by the bird's saliva, fragments 
of soft lichens, caterpillars' silk, and down from the ferns. It is deeply hollowed, and lined with thin strips of grape-vine bark and cottony substances, and sometimes a few hairs or fibrous roots. Nuttall, in describing the nest, says "the lining is neither soft nor downy;" but Wilson and Audubon both assert to the contrary. I have examined a great num. ber of the nests, and have found them to agree with the foregoing description. The eggs are usually four in number. Their color is a beautiful creamy-white, which is covered, more or less thickly, with spots of reddish-brown and lilac. Average dimensions of eggs, about .63 by .50 inch.

Perhaps the best description I can give of the habits of this bird is to say that they are a combination of those of the Flycatchers and Warblers; for, like the former, it pursues flying insects in the air, and seizes them with a loud snapping of the bill, and, like the latter, gleans industriously for them among the foliage and branches of trees. The note of the Red Start is a shrill chewêea, which is uttered at intervals of perhaps a half or whole minute.

I have not noticed that it prefers any particular locality; but it seems to frequent the woods, pastures, and orchards in equal abundance: and I have known of a pair building, and rearing a brood, in a garden, within five rods of a house.

About the 15th of September, the Red Start leaves for the South; and, after the 20th of that month, none are to be seen in New England.

\section{Sub-Family TANAgrinæ. - The Tanagers.}

\section{PYRANGA, ViEILLOT.}

Pyranga, Vieillor, Ois. Am. Sept., I. (1807) IV. Ib., Analyse (1816), 32. Sclater, Pr. Zool. Soc. (1856), 123.

Bill somewhat straight; sub-conical, cylindrical, notched at tip; culmen moderately curved; commissure with a median acute lobe; wings elongated; the four first primaries about equal; tail moderate, slightly forked. Colors of the male chiefly scarlet, of the female yellowish. 
PYRANGA RUBRA, - Vieillot.

\section{The Scarlet Tanager.}

T'anagra rubra. Linn., I. (1766) 314. Wil. Am. Orn., II. (1810) 42. Aud. Orn. Biog., IV. (1838) 388.

\section{DESCRIPTION.}

Bill shorter than the head; second quill longest; first and third a little shorter; tail moderately forked; general color of male bright-carmine; wings and tail velvetblack, the quills internally edged with white towards the base. Female olive-green above, yellowish beneath; wing and tail feathers brown, edged with olivaceous.

The young males are colored like the females, but generally exhibit more or less of red feathers among the greenish ones. Sometimes the full plumage is varied by a few yellow feathers, or by olivaceous edges to the wings; not unfrequently there is a partly concealed bar of red or yellow on the wing, across the median coverts. Young miles are sometimes seen with the body like the female, the wings and tail like the male.

Length, seven and forty one-hundredths inches; wing, four inches; tail, three inches.

This gaudy summer visitor breeds in all the New-England States; less plentifully, however, in the northern than in the southern districts. It arrives from the South about the fifteenth of May, and commences building about the last of that month. The farorite localities of this bird seem to be oak-groves, situated near swamps: here I have often heard several males singing at the same time, and have watched them in their active movements in their pursuit of insects, of which this species destroys great numbers. The nest is placed on a horizontal limb of a tree, usually from fifteen to twenty feet from the ground, in the deep woods. It is constructed of slender twigs of the oak, huckleberry or whortleberry bush, and weeds: thẹse are loosely put together; so much so, that, were it not for the interlacing of the small joints of the twigs, it would soon fall apart. It is not deeply hollowed, and is lined with thread-like fibrous roots and the leaves of the various pines. The whole structure is so thinly made as almost to fall to pieces on removal from the tree. The eggs are usually four in number, sometimes three, seldom five. They are of a dull light greenish-blue color, of different shades, and spattered with 
purplish-brown, in some specimens quite thickly, in others less so. The ground-color is the most prominent; the markings never completely liiding it, or sufficiently confluent to

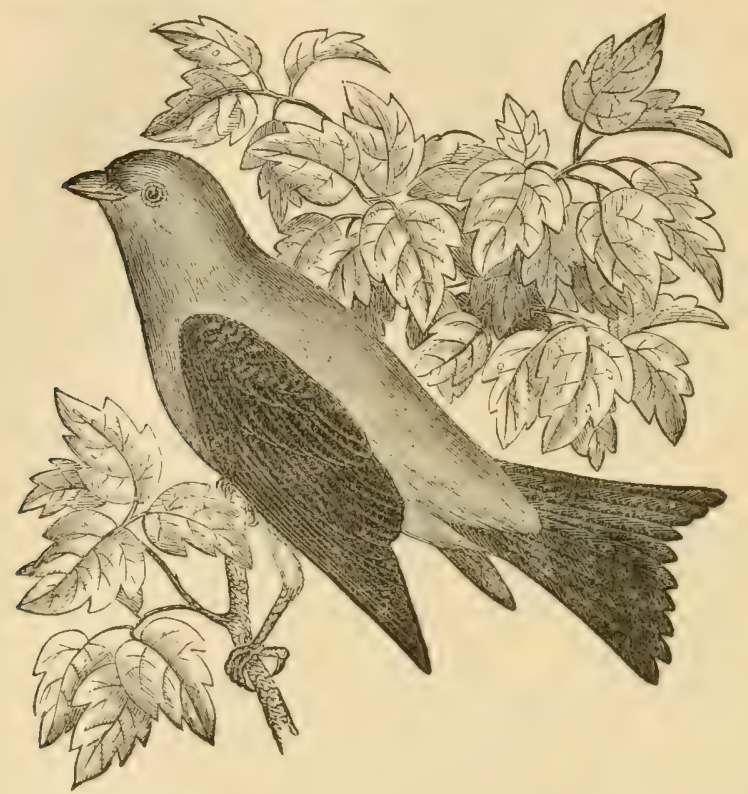

be called blotches. A nest complement of four eggs, in a nest collected in Milton, Mass., exhibit the following measurements: .97 by .66 inch, .93 by .65 inch, .90 by .62 inch, .88 by .64 inch. Other specimens show no great variations from these dimensions.

The Scarlet Tanager thrives well in confinement, and makes a beautiful and interesting pet. I once kept one caged for over six months. He eat seeds and small fruits, and, within a week after his capture, chanted his warbling song with perfect freedom. He had, and I have also noted that all of this species have, a sort of ventriloquism in his song: it at times sounded as if at quite a distance; and I have been deceived in this manner, by birds that were almost over my head, into supposing that they were far away. 
The song is almost exactly like that of the Robin, but is often broken with a pensive call-note, sounding like the syllables chip churr.

Early in September, the Tanagers leave for their Southern homes; from which they seem, while here, hardly more than wanderers, so commonly do we associate gaudy plumages with tropical climes. They winter, probably, in Central America and the Bahamas. 


\section{Family Hirundinid e. The Sifallows.}

\section{Sub-Family Hirundinine.}

Bill triangular, very short and broad, much depressed; the ridge much less than half the head; the gonys two-thirds this length; the gape extending to below the eye; primaries nine; the first longest, and, with the second, considerably Jonger than the others; the secondaries and tertials not reaching the middle of the primaries; the secondaries deeply emarginate; wings very long, reaching beyond the commencement of the fork of the tail, which is generally more or less deep; tarsi scutellate, very short, less than the lateral toes, the inner of which is more deeply cleft than the outer.

\section{HIRUNDO, LINNeUs.}

Hirundo, Lins aus, Syst. Nat. (1735). Gray, Genera, I. (1845).

Nostrils basal, small, oblong, and covered partly by a membrane; tail more or less forked; the outer lateral feather sometimes greatly lengthened; tarsi shorter than the middle toe, and scutellated; tarsi naked; toes long, slender, the lateral ones unequal; claws moderate, curved, acute.

\section{HIRUNDO HORREORUM. - Barton.}

\section{The Barn Swallow.}

Hirundo horreorum, Barton. Fragments N. H. Penna. (1799) 17.

Hirundo Americana, Wilson. Am. Orn., V. (1812) 34.

Hirundo rustica, Audubon. Orn. Biog., II. (1834) 413.

\section{DESCRIPTION.}

Tail very deeply forked; outer feathers several inches longer than the inner, very narrow towards the end; above glossy-blue, with concealed white in the middle of the back; throat chestnut; rest of lower part reddish-white, not conspicuously different; a steel-blue collar on the upper part of the breast, interrupted in the middle; tail feathers with a white spot near the middle, on the inner web. Female with the outer tail feather not quite so long.

Length, six and ninety one-hundredths inches; wing, five inches; tail, four and fifty one lundredths inches.

7 YHIS beautiful and well-known bird arrives in New 1 England from about the 10th of April to the 25th of that month, according to latitude: it is quickly dispersed in great numbers through these States, and soon commences mating. Its habits are so well known that any description 
here is hardly needed. About the 10th of May, after the birds have paired, they commence building; or sometimes the same couple begin repairing the nest of the preceding year or years, as the same nest is occupied several seasons. It is built in the eaves of houses or barns, or on rafters of barns and other buildings. It is constructed outwardly of a strong shell of pellets of mud, which are plastered together, and, as Nuttall says, "tempered with fine hay, and rendered more adhesive by

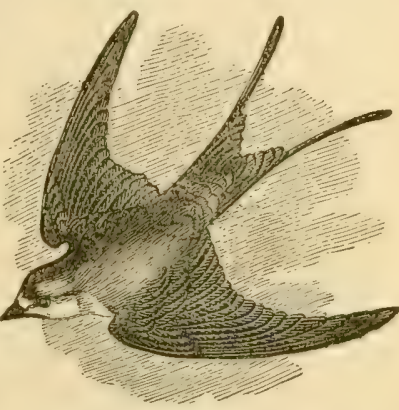
the glutinous saliva of the bird." This nest is built out and up until the top is about horizontal, and then lined with a layer of fine grass or hay, which is covered with loose feathers. This bird is fond of society, often as many as twenty nests being in the same eaves. The eggs are usually four in number, sometimes five: they are of a nearly pure-white color, with a slight roseate tint; and are spotted more or less thickly with fine dots of two shades of browni, reddish, and purplish. The dimensions of four eggs, collected in Upton, Me., are .76 by .56 inch, .70 by .52 inch, .76 by .52 inch, .69 by .53 inch. The largest specimen, in a great number, is .78 by .57 inch; the smallest, .67 by .50 inch. Two broods, and sometimes three, are reared in the season. The period of incubation is thirteen days.

About the first week in September, the old and young birds of different families gather in immense flocks; and, after remaining about the marshes near the seacoast for a few days, they leave for their winter homes. 


\section{HIRUNDO LUNIFRONS. - Say.}

The Cliff Swallow; Eave Swallow.

Hirundo lunifrons, Say. Long's Exped. R. Mts., II. (1823) 47.

Hirundo respublicana, Audubon. Ann. N.Y. Lyc., I. (1824) 164.

Hirundo fulva, Audubon. Orn. Biog., I. (1831) 353.

Hirundo melanogaster, Swainson. Philos. Mag., I. (1827) 366.

Petrochelidon melanogastra, Cabanis. Mus. Hein., 47.

\section{DESCRIPTION.}

Crown and back steel-blue; the upper part of the latter with concealed pale edges to the feathers; chin, throat, and sides of the head dark-chestnut; breast fuscous; belly white; a steel-blue spot on throat; rump light-chestnut; forehead brownish-white; a pale nuchal band; tail slightly emarginate.

Length, about five inches; wing, four and forty one-hundredths; tail, two and twenty one-hundredths.

Hab. - North America from Atlantic to Pacific.

The Cliff Swallow is very generally distributed as a summer inhabitant of New England. It arrives from the South from about the 25th of April to the 1st of May. It has all the habits and characteristics of the preceding species, and is probably as well known throughout New England as that bird. About the 10th of May (sometimes earlier, sometimes Iater, according to latitude), it pairs, and commences building. The nest is usually fixed beneath eaves or cornices, or other jutting portions of buildings, or on cliffs, beneath overhanging portions of rock: it is constructed externally of pellets of mud and earth, which are gradually plastered together into a large gourd-shaped structure; the larger part attached to the building or cliff, and the neck curving outward and downward. At the part of the nest resembling the neck of the gourd is the entrance. The whole fabric is much more brittle than the nest of the Barn Swallow, for the reason that no grass or hay is worked into the mud to give it strength. A lining of fine grass and feathers is fixed in this, and the whole makes a very neat and comfortable structure. The eggs are usually five in number. They can hardly be distinguished from those of the preceding 
species; and, in fact, identification is next to impossible. In a majority of the present species, the spots are somewhat coarser, and the eggs are generally longer. Four eggs, collected in Dorchester, Mass., are of the average dimensions of .84 by .54 inch; other specimens, from various localities, are about this size.

Like the Barn Swallow, this species gathers into large flocks at the end of the summer, and frequents the same localities, but not at the same time; as it leaves usually a week or ten days before the other bird.

\section{HIRUNDO BICOLOR。 - Vieillot.}

The White-bellied Swallow; Blue-backed Swallow. 491.

Hirundo bicolor, Vieillot. Ois. Am. Sept., I. (1807) 61. Aud. Orn. Biog. (1831),

\section{DESCRIPTION.} color.

Glossy metallic-green above; entirely white beneath. Female much duller in

Length, six and twenty-five one-hundredths inches; wing, five inches; tail, two and sixty-five one-hundredths inches.

This very common and well-known species is a summer inhabitant of all New England; being most abundant in localities near sheets of water, and less common in high, dry districts. Its habits are well known; and arriving, as it does, early in the season, and fraternizing with man, it is a great favorite. It makes its appearance as early as the first week in April, but does not commence building before the middle of May. Near cities and towns, the nest is built in martin-boxes provided for its reception: but, in less thickly settled districts, it is built in holes in stumps and trees; and cases are on record of its being built in a deserted nest of the common Barn Swallow. When passing through the chain of the Umbagog lakes, in Maine, I observed great numbers of these birds whose nests were built in holes in dead trees standing in the lake near the shores. These nests were so plenty, that, in the area of 
about ten rods square, I counted over fifty. Of course, the birds were in myriads, and the species constitutes the common Swallow of the districts in that latitude. The materials used in the construction of the nest are fine grasses, hay, and feathers: these are adjusted loosely in the cavity of the tree, and without any form. The eggs are, most commonly, five in number. Their color is a beautiful clear-white, with a roseate tint before their contents are removed: they are extremely thin and fragile, much more so than most of the other species; and their form is a slender oval. Of a great number of specimens, collected in various localities, the largest is .79 by .56 inch; the smallest, .69 by .51 inch. Two broods are generally reared in the season, and the period of incubation is fourteen days.

This species leaves New England in the fall migration about the 10th of September.

\section{COTYLE, BoIE.}

Cotyle, Bore, Isis (1822), 550. (Type H. riparia.)

Bill very flat, extremely broad at the base, and gradually narrowed towards the tip; nostrils prominent and rounded; tail moderate, nearly straight, or somewhat emarginated; tarsi rather shorter than the middle toe, slender and scutellated; toes very slender, the claws slightly curved; colors generally dull brown above, without gloss.

\section{COTYLE RIPARIA. - Boie.}

\section{The Bank Swallow.}

Hirundo riparia, Linnæus. Syst. Nat., I. (1766) 344. Wils. Am. Orn., V. 46. Aud. Orn. Biog., IV. (1838) 584.

Cotyle riparia, Boie. Isis (1822), 550 .

\section{DESCRIPTION.}

The smallest of American swallows; tail slightly emarginate; outer web of first primary soft, without hooks; lower part of the tarsus with a few scattered feathers; above grayish-brown, somewhat fuliginous, with a tendency to paler margins to the feathers; beneath pure-white, with a band across the breast and sides of the body like the back.

Length, four and seventy-five one-hundredths inches; twing, four; tail, two inches. 
Unlike all our other swallows, this species avoids the neighborhood of man in selecting its breeding-place; and it is abundant only in the neighborhood of streams or other sheets of water. It is distributed, as a summer resident, in all the New-England States, and in many localities is very abundant. It arrives the first week in May, often earlier; and soon pairs, and commences building, or rather excavating, for the nest. The excavations are made in sand-banks, in the same manner as those of the Kingfisher, and are often three or four feet in depth, usually about eighteen inches. At the end of this burrow, which is widened and enlarged, is placed the nest, composed of dried grasses, hay, feathers, and other like soft materials. The birds are sociable in their habits, as are all the other species; and often as many as twenty and thirty holes may be seen in the same bank. The number of eggs is either five or four. These are of a pure-white color, and vary but little in size or shape; the latter being almost always oval, and the size ranging from .72 by .52 inch to .68 by .49 inch. Usually two broods are reared in the season, but often only one.

In habits, this bird resembles the other swallows, but is not so quarrelsome as they, and I never noticed two of this species fighting: its note is not, like theirs, shrill and oft repeated, but is only a seldom-uttered lisping chatter. It leaves New England by the last week in August.

\section{PROGNE, BoIE.}

- Progne, Biox, Isis (1826), 971. (Type Hirundo purpuren, L.)

Bill, strong, short; the gape very wide; the sides gradually compressed, the culmen and lateral margins arched to the tip, the latter inflected; the nostrils Sasal, lateral, open, and rounded; tail considerably forked; tarsi shorter than the middle toe and claw, about equal to the toe alone; toes long, strong; lateral ones equal.

The large size, very stout bill and feet (for this family), with the usually uniform black glossy plumage, readily distinguish this genus among the swallorrs. But one species is well established as North American. 
PROGNE PURPUREA. - Boie.

The Purple Martin.

Hirundo purpurea, Linnæus. Syst. Nat., I. (1766) 344. Aud. Orn. Biog., I. (1831) 115.

Progne purpurea, Boie. Isis (1826), 971.

\section{Description.}

Largest of North-American Swallows; closed wings rather longer than the deeply forked tail; tarsi and toes naked; color, in the old male, everywhere glossy steel-blue, with purple and violet reflections. Female and immature male less brilliant above, pale-brownish beneath, blotched with darker or with bluish.

Length, seven and thirty one-hundredths inches; wing, five and eighty-five one-hundredths; tail, three and forty one-hundredths inches.

The Purple Martin is the least abundant of all our Swallows, and, indeed, in some localities is quite rare. It arrives from the South about the first week in May, and is distributed in single pairs through all New England.

The description, by Wilson, of the habits of the bird, is so well written that 1 present quite a liberal extract from it. He says, -

"The summer residence of this agreeable bird is universally among the habitations of man, who, having no interest in his destruction, and deriving considerable advantage as well as amusement from his company, is generally his friend and protector. Wherever he comes, he finds some hospitable retreat fitted up for his accommodation and that of his young, either in the projecting wooden cornice, on the top of the roof or sign-post, in the box appropriated to the Blue-bird, or, if all these be wanting, in the dove-house among the pigeons. In this last case, he sometimes takes possession of one quarter or tier of the premises, in which not a pigeon dare for a moment set its foot. Some people have large conveniences formed for the Martins, with many apartments, which are usually full tenanted, and occupied regularly every spring; and, in such places, particular individuals have been noted to return to the same box for several successive years. Even the solitary Indian seems to have a particular respect for this bird. 
The Choctaws and Chickasaws cut off all the top branches from a sapling near their cabins, leaving the prongs a foot or two in length, on each of which they hang a gourd or calabash, properly hollowed out, for their convenience. On the banks of the Mississippi, the negroes stick up long canes, with the same species of apartment fixed to their tops, in which the Martins regularly breed. Wherever I have travelled in this country, I have seen with pleasure the hospitality of the inhabitants to this favorite bird.

"About the middle or 20th of April, the Martins first begin to prepare their nest. The last of these which I examined was formed of dry leaves of the weeping willow, slender straws, hay, and feathers in considerable quantity. The eggs were four, very small for the size of the bird, and pure-white, without any spots. The first brood appears in May, the second late in July. During the period in which the female is laying, and before she commences incubation, they are both from home the greater part of the day. When the female is sitting, she is frequently visited by the male, who also occupies her place while she takes a short recreation abroad. He also often passes a quarter of an hour in the apartment beside her, and has become quite domesticated since her confinement. He sits on the outside, dressing and arranging his plumage, occasionally passing to the door of the apartment, as if to inquire how she does. His notes, at this time, seem to have assumed a peculiar softness; and his gratulations are expressive of much tenderness. Conjugal fidelity, even where there is a number together, seems to be faithfully preserved by these birds. On the 25th of May, a male and female Martin took possession of a box in Mr. Bartram's garden. A day or two after, a second female made her appearance, and stayed for several days; but from the cold reception she met with, being frequently beat off by the male, she finally abandoned the place, and set off, no doubt, to seek for a more sociable companion.

"The Purple Martin, like his half-cousin the King-bird, is the terror of crows, hawks, and eagles. These he attacks whenerer they make their appearance, and with such rigor and rapidity that they instantly have recourse to flight. So well known is this to the lesser birds, and to the domestic poultry, that, as soon as they 
hear the Martin's voice engaged in fight, all is alarm and consternation. To observe with what spirit and audacity this bird dives and sweeps upon and around the Hawk or the Eagle is astonishing. He also bestows an occasional bastinading on the King-bird when he finds him too near his premises; though he will, at any time, instantly co-operate with him in attacking the common enemy.

"The Martin differs from all the rest of our Swallows in the particular prey which he selects. Wasps, bees, large beetles, particularly those called by the boys goldsmiths, seem his favorite game. I have taken four of these large beetles from the stomach of a Purple Martin, each of which seemed entire, and even unbruised.

"The flight of the Purple Martin unites in it all the swiftness, ease, rapidity of turning, and gracefulness of motion of its tribe. Like the Swift of Europe, he sails much with little action of the wings. He passes through the most crowded parts of our streets, eluding the passengers with the quickness of thought; or plays among the clouds, gliding about at a vast height, like an aërial being. His usual note, peuo, peuo, peuo, is loud and musical; but is frequently succeeded by others more low and guttural. Soon after the 20th of August, he leaves Pennsylvania for the South."

In New England, this species begins to prepare its nest about the 20th of May: this is composed of dried grasses, leaves, and feathers, and is deposited usually in a box prepared for this purpose. The eggs are from four to six in number, of a pure-white color, and vary but little in form from exactly oval. Four specimens, collected in Connecticut, exhibit the following measurements : 1.04 by .70 inch, 1 by .70 inch, 1 by .68 inch, .97 by .68 inch. Other specimens vary but little from these dimensions. Two broods are often reared in the season, and the period of incubation is fourteen days.

In dismissing this family, it is hardly necessary, at this late day, to say a word in favor of their beneficial habits; 
for every farmer has recognized them, and encouraged the presence of the birds, and protected them for years; but the immense amount of injurious and noxious insects they destroy is astonishing, and hardly realized; amount. ing probably to several hundreds by every bird in the day. 


\section{Family BOMbycillid 瓜. The Chatterers.}

Primaries ten, the first very short or moderate, always less than half the second; bill short, broad, triangular, much depressed; gape opening nearly to the eyes, twice the length of the culmen; both mandibles notched, the upper with a tooth behind the notch; tarsi scutellate anteriorly, with indications also of scales inferiorly on the sides (except in Afyiadestes?), shorter than the middle toe; outer lateral too longest; toes unequally cleft; head generally crested.

\section{Sub-Family Bonbrcillins. - The Wax Wings.}

\section{AMPELIS, LINNAUS.}

Ampelis, Live eus, Syst. Nat. (1735). (Type A. garrulus.)

Head with a broad, depressed crest; bill very broad, opening nearly to the eye; a series of short, velvety feathers at the base of the bill, with bristles directed forwards and covering the nostrils, but none along the rictus; commissure straight; culmen and gonys curved, convex; both mandibles notched at tip; legs stout; tarsi shorter than the middle toe, scutellate anteriorly, and slightly on the lower half on the sides behind, slightly feathered above; hind toe shorter than the lateral, which are equal; wings very long, pointed, reaching almost to the tip of the nearly even tail; first primary so short as to be with difficulty discernible, the second quill longest; tips of secondary quills with horny appendages, like sealing-wax.

\section{AMPELIS GARRULUS. - Linncers.}

\section{The Was-wing; Bohemian Chatterer.}

"Lanius garv"ulus, Linnæus. Fauna Suecica, II. No. 82." Ampelis garrulus, Linnæus. Syst. Nat., I. (1766) 297.

Bombycilla garrula. Aud. Orn. Biog., IV. (1838) 462.

\section{DESCRIPTION.}

Highly crested; general color brownish-ash, with a faint shade of reddish, especially anteriorly; the forehead, sides of the head, and under tail coverts, brownish-orange; the hinder parts purer ash; the region about the vent white; primaries and-tail feathers plumbeous black, especially towards the tips; the tail with a terminal band of yellow; a narrow frontal line passing backward and involving the eye, and extending above and behind it; chin and upper part of throat black; tips of the secondary coverts, and a spot on the end of the outer webs of all the quills, white; those on the inner primaries glossed with yellow; secondaries with red, horny tips, like sealing-wax; side of the lower jaw whitish.

Length, seven and forty one-hundredths inches; wing, four and fifty one-hundredths inches; tail, three inches. 
This species, with the general appearance of the Cedar-bird, is readily distinguished by its superior size, much larger crest, black chin and throat, instead of chin alone, brownish-chestnut under tail coverts, instead of white, and the white marks on the wing not found at all in the other. In the closed wing, the white on the ends of the primaries forms a continuous narrow stripe nearly parallel with the outer edge of the wing.

THIS bird is an extremely rare winter visitor in New 1 England, appearing only in severe seasons. It is seen in small flocks of perhaps six or eight individuals, usually in groves of cedars or Virginia junipers, where it feeds on the small blue berries or seeds that are found on those trees. This species breeds in the most northern portions of the continent.

\section{AMPELIS CEDROROM. - Baird.}

The Cedar-bird; Cherry-bird.

Ampelis garrulus, Linnæus. Syst. Nat., I. (1766) 297.

Bombycilla Carolinensis, Audubon. Orn. Biog., I. (1831) 227; V. 494.

Ampelis Americana, Wilson. Am. Orn., I. (1808) 107.

DESCRIPTION.

Head crested; general color reddish-olive, passing anteriorly on the neck, head, and breast into purplish-cinnamon, posteriorly on the upper parts into ash, on the lower into yellow; under tail coverts white; chin dark sooty-black, fading insensibly into the ground-color on the throat; forehead, loral region, space below the eye, and a line above it on the side of the head, intense black; quills and tail dark-plumbeous, passing behind into dusky; the tail tipped with yellow; the primaries, except the first, margined with hoary; a short maxillary stripe, a narrow crescent on the inferoposterior quarter of the eye, white; secondaries with horny tips, like red sealing-wax.

Length, seven and twenty-five one-hundredths inches; wing, four and five onehundredths; tail, two and sixty one-hundredths inches.

Hab. - North America generally, south to Guatemala.

This very common and well-known bird is a summer inhabitant of all New England. It remains in the southern districts through the winter, but usually arrives, in flocks of twenty or thirty, as early as the first or second week in March. About the middle of May, these flocks are divided into smaller ones, and these soon into pairs, which commence building about the second week in June. The nest is placed in the midst of twigs on a horizontal 
branch, generally of a tree in the orchard; sometimes in a cedar or other tree in a pasture or wood. It is constructed of stalks of weeds, long fine roots, grass, grape-

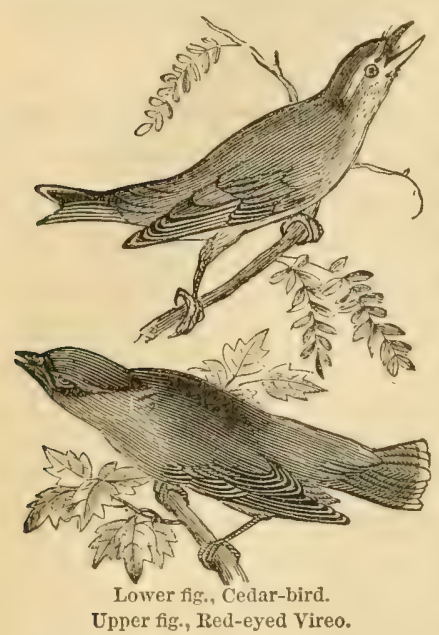
vine bark, and leaves: it is deeply hollowed, and lined with fine roots, horsehairs, and fine grass. One specimen in my collection is partly composed of strips of twine and thread, which are woven together in a very neat and compact manner, and interlaced with inumerous fine roots and weeds. The eggs are usually four or five in number: they are laid about the twentieth of June, and a second litter often in $\mathrm{Au}-$ gust. They are of a light-bluish or clay-white color, with a slight purple tint, and are marked, more or less thickly, with distinct spots of black, and more obscure spots of purplish-brown: the appearance of these latter spots is as if they were "beneath the surface of the shell." Dimensions of five eggs collected in New Hampshire: .86 by .64 inch, .86 by .63 inch, .86 by .60 inch, .80 by $.62 \mathrm{inch}, .80 \mathrm{by} .60 \mathrm{inch}$. A great number of specimens from different localities do not exhibit any great variations from these measurements.

There is a great deal of ill feeling manifested towards this well-known bird by the farmers, on account of its occasionally helping itself to a few cherries or other small fruits. Its valuable services in the orchard and nursery seem to be overlooked, and its life is often forfeited for this little weakness. But if the farmer will observe it in its insect-destroying labors, watch it as it devours caterpillar after caterpillar, or draws from its lurking-place the larva of some injurious insect, he will come to the conclusion, as many have already 
done, that this bird is worthy his protection, instead of deserving his anger.

Says Nuttall, in speaking of this fact, -

"At this season (April), to repay the gardener for the tithe of his crop, their natural due, they fail not to assist in ridding his trees of more deadly enemies which infest them, and the small caterpillars, beetles, and various insects now constitute their only food; and for hours at a time they may be seen feeding on the alldespoiling canker-worms, which infest our apple-trees and elms. On these occasions, silent and sedate, after plentifully feeding, they sit dressing their feathers, in near contact on the same branch, to the number of five or six; and, as the season of selective attachment approaches, they may be observed pluming each other, and caressing with the most gentle fondness. This friendly trait is carried so far, that an eye-rvitness assures me he has seen one among a row of these birds seated upon a branch dart after an insect, and offer it to his associate when caught, who very disinterestedly passed it to the next; and, each delicately declining the offer, the morsel has proceeded backwards and forwards before it was appropriated."

The note of the Cedar-bird, like that of the Wax-wing, is a feeble, plaintive twée, twée, uttered often, and by both sexes. 


\section{FAMILx LANUDAE.}

Bill strong and compressed, the tip abruptly hooked; both mandibles distinctly notched, the upper with a distinct tooth behind, the lower with the point bent up; tarsi longer than the middle toe, strongly scutellate; primaries ten; first primary half the second, or shorter (occasionally wanting).

The sub-families of Laniido belonging to the United States are as follows:-

LANIIN.E. - Bill very powerful, much compressed, and abruptly hooked, with a very prominent tooth behind the notch; wings considerably rounded; tail rather long and graduated; sides of the tarsi scutellate behind.

Vireonin E. - Bill moderate, cylindrical, somewhat compressed; wings long, the first primary sometimes wanting; tail short and nearly even; sides of the tarsi behind not scutellate.

\section{Sub-Family Laniñe. - The Shrikes.}

\section{COLLYRIO, Moehrixg.}

Collyrio, Moefrang, Genera Avium (1752), 28. (Type Lanius excubitor, L.)

Lanius, of Autrors.

Feathers of forehead stiffened; base of bill, including nostrils, covered by bristly feathers directed forward; bill shorter than the head, much compressed, and very powerful; culmen decurved from base, the mandible abruptly bent down in a powerful hook, what in acute lobe near the tip; tip of lower mandible bent upwards in a hook; the gonys very convex; rictus with long bristles; legs stout; the tarsi are rather short, longer than the middle toe; the lateral equal; the claws all very sharp and much curved; wings rounded; the first primary about half the second, which is equal to the sixth or seventh; tail longer than the wings, much graduated, the feathers broad.

\section{COLLYRIO BOREALIS. - Baird.}

\section{The Great Northern Shrike; Butcher-bird.}

Lanius septentrionalis, Bonaparte. Syn. (1828), 72. Bon. List (1838). Nutt. Man., I. (1832) 258.

Lanius borealis, Audubon. Syn. (1839), 157.

Lanius excubitor. Wils., I. (1808) 74. Aud. Orn. Biog., II. (1834) 534.

\section{Descritrion.}

Above light bluish-ash, obscurely soiled with reddish-brown; forehead, sides of the crown, scapulars, and upper tail coverts hoary-white; beneath white, the breast with fine transverse lines; wings and tail black, the former with a white patch at base of primaries and tips of small quilis, the latter with the lateral feathers tipped with white; bill blackish-brown, considerably lighter at the base; black stripe from the bill through and behind the eye, but beneath the latter interrupted by a whitish crescent. Female and young with the gray soiled with brownish. 


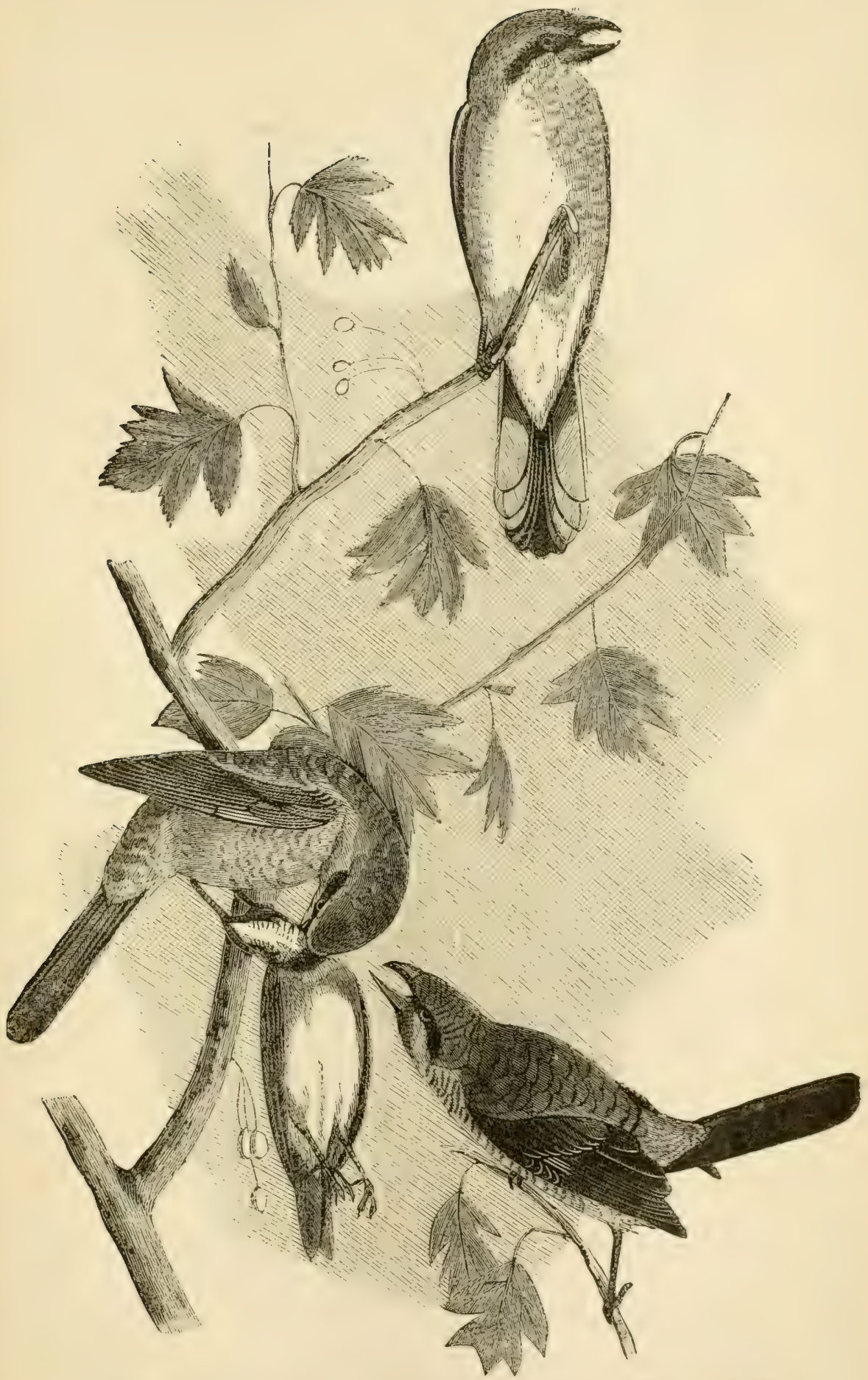

Great Northern Shrike, Butcher-bird, Collyrio borealis. Baird. 

Length, nine and eighty-five one-hundredths inches; wings, four and fifty onehundredths inches; tail, four and eighty one-hundredths inches; its graduation, ninety one-liundredths inches.

THIS species, although not uncommon as a winter visitor 1 in New England, is seldom seen here during the summer months; and I think that it very rarely breeds in these States, and then only in the most northern and retired sections.

It makes its appearance about the last week in October, and is seen until the last week in April. During this period, it preys upon small birds, mice, and such insects and larræ as it finds in exposed situations, such as fences, piles of stones, \&e.

In watching for its prey, it usually remains perched on a stake or small tree, in a field or meadow, carefully scamning the surrounding neighborhood. When a mouse or other small mammal presents itself in the grass, the bird folds its wings, drops on it with an unerring aim, and seizes it with its bill. If a flock of small birds, such as Pine-finches or Red-polls, appear in sight, he immediately purstes them, and generally secures one or two before they are dispersed. I have seen an individual dart into a flock of Tree Sparrows, and kill three of them before they could escape; and it seems a characteristic of this bird to secure more than enough food for its present wants. Its habit of suspending small birds, mice, and insects on thorns and small twigs, is well known. This is done, I am inclined to think, not because, as many writers assert, that it will not eat its food when freshly killed, and it thus suspends it in order that it may become tainted, but rather to have this food stored for future need. We see many other birds with this same habit of providing for future wants; particularly the Blue Jay, and some of the Woodpeckers.

I have never met with the nest of this species, and will borrow the description by Audubon:-

"About the 20th of April, the male and his mate are seen 
engaged in building their nest in the covered and secluded parts of the forests. I found several of their nests placed on bushes not above ten feet from the ground, without any appearance of choice as to the tree, but generally towards the top, and placed in a fork. The nest is as large as that of the Robin, and is composed externally of coarse grasses, leaves, and moss ; internally of fibrous roots, over which is a bed of the feathers of the wild turkey and pheasant (Tetrao umbellus)."

"Nuttall, in describing the nest, says that it is "large and compact, in the fork of a small tree, and sometimes in an apple-tree, composed externally of dried grass, with whitish moss, and well lined with feathers."

The eggs are from four to six in number, of a dirty leadcolored white, and marked more or less thickly, around the greater end, with dashes and spots of brown of different shades. Dimensions of four eggs : 1.12 by .80 inch, 1.12 by $.78 \mathrm{inch}, 1.08$ by $.78 \mathrm{inch}, 1.04$ by $.77 \mathrm{inch}$.

\section{Sub-Family VIreoninæ. - The Vireos. \\ VIREO, VIEILLOT.} Gm.)

Vireo, Vieillor, Ois. Am. Sept, I. (1807) 83. (Type Mfuscicapa Noveboracensis,

Bill short, strong, straight; the culmen slightly curved, the sides much compressed to the tip, which is rapidly curved and deflected; the gonys long and ascending; the gape with short, weak bristles; the nostrils basal, rounded, and exposed, the feathers of the head advancing forward on the bill to the nostril; wings variable, rather long, and pointed; the first quill sometimes spurious, the larger outer one always graduated a little; tail nearly even and rather short; tarsi longer than the middle toe; outer toe a little longer than the inner; hind toe rather shorter than the middle one.

\section{VIREO OLIVACEUS. - Vieillot.}

\section{The Red-eyed Vireo.}

Muscicapa olivacea, Linnæus. Syst. Nat., I. (1766) 327. Wils. Am. Orn., Il. (1810) 55. V. 430 .

Vireo olivaceus, Nuttall. Man., I. (1832) 312. Aud. Orn. Biog., II. (1834) 287: 
DESCRIPTION.

Second and third quills about equal, and longest; first a little shorter than the fourth, but considerably longer than the fifth; back, rump, and edges of wing and tail feathers bright olivaceous-green; side of head and neck paler; crown dark-ash, sharply defined; a well-defined whitish line from the bill, over the eye, nearly to the occiput; a dark line separating it above from the ashy crown; a dusky line through the eye; beneath white; under tail coverts pale sulphur-yellow; iris, red.

Length, about six and fifty one-hundredths inches; wing, three and fifty onebundredths.

I feel that no description of mine can begin to do justice to the genial, happy, industrious disposition of this one of our most common, and perhaps best-loved birds. From the time of its arrival, about the first week in Nay, until its departure, about the first week in October, it is seen in the foliage of elms and other shade-trees in the midst of our cities and villages, in the apple-trees near the farm-houses, and in the tall oaks and chestnuts in the deep forests. Everywhere in these States, at all hours of the day, from early dawn until evening twilight, his sweet, half-plaintive, half-meditative carol is heard. I know that I am not singulas in my preference, when I say, that, of all my feathered acquaintances, this is the greatest farorite I have. I always loved it; and I can never look upon one, after it is killed, no matter how naturally it is preserved, without a sad feeling, as if it were one of my own most dear friends dead before me.

The Red-eyed Vireo is one of the most industrious of our birds. Whenever we see him, we notice that he is busily searehing in the foliage of trees for caterpillars and noxious larvæ, or pursuing winged insects that have taken flight from the trees. While thus engaged, he utters at short intervals his warbling song. This consists sometimes of a few syllables like 'wée chewêo turrullit chewêeo, given in a singularly sweet tone. This is only a part of its song; and the whole is so difficult of description that I cannot put it on paper.

Says Nuttall, - 
"The whole is delivered almost without any sensible interval, with earnest animation, in a pathetic, tender, and pleasing strain, well calculated to produce calm and thoughtful reflection in the sensitive mind. Yet, while this heavenly reverie strikes on the human ear with such peculiar effect, the humble musician himself seems but little concerned: for all the while, perhaps, that this flowing chorus enchants the hearer, he is casually hopping from spray to spray in quest of his active or crawling prey; and, if a cessation occurs in his almost untiring lay, it is occasioned by the caterpillar or fly he has fortunately just captured. So unaffected are these delightful efforts of instinct, and so unconscious is the performer, apparently, of this pleasing faculty bestowed upon him by nature, that he may truly be considered as a messenger of harmony to man alone, appointed by the fiat of the Creative power. Wantonly to destroy these delightful aids to sentimental happiness ought therefore to be viewed, not only as an act of barbarity, but almost as a sacrilege."

The Red-eyed Vireo commences building about the first week in June, frequenting the woods rather more commonly than the pastures and orchards, although it often breeds in these places. The nest is pensile, and is hung from the fork of a small limb of a tree, seldom more than fifteen or twenty feet from the ground: it is constructed of thin strips of cedar bark, pieces of wasps' nests, spiders' nests, pieces of caterpillars' silk, and other pliable materials. These are woven together neatly and compactly, and agglutinated together by the bird's saliva. It is suspended in the form of a basket from the forked twig to which it is attached, or rather sewed firmly. It is lined with narrow strips of grape-vine bark, pine leaves, and sometimes fine grass. On the outside are often visible bits of rotten wood, fragments of newspapers, and hornet's nests. One specimen in my collection, obtained in Maine, is constructed almost entirely of pieces of the bark of the white birch: it is a very neat fabric. The eggs are four in number, pure-white in color, and thinly spotted, chiefly at the great end, with dots of 
brownish-black. The measurement of four eggs in a nest collected in Milton, Mass., are .84 by .60 inch, .80 by .60 inch, .80 by .59 inch, .78 by .59 inch. Other specimens vary but little from these dimensions. Two broods are often reared in the season. The period of incubation is twelve days.

\section{VIREO GILVUS,-Bonaparte.}

The Warbling Vireo.

Mfuscicapa gilva, Vieillot. Ois., I. (1807) 65. 433.

Virreo giluus, Nuttall. I. (1832) 309. Aud. Orn. Biog., II. (1834) 114; V. (1839,

Mfuscicapa melodia, Wilson. Am. Orn., V. (1812) 85.

\section{DESCRIPTION.}

Third, fourth, and fifth quills nearly equal; second and sixth usually about equa, and about twenty-five one-hundredths of an inch shorter than third; the exposed portion of spurious quill about one-fourth the third; above greenish-olive; the head and hind neck ashy, the back slightly tinged with the same; lores dusky; a white streak from the base of the upper mandible above and a little behind the eye; beneath the eye whitish; sides of the head pale yellowish-brown; beneath white, tinged with very pale yellow on the breast and sides; no light margins whatever on the outer webs of the wings or tail.

Length, about five and a half inches; wings nearly three. Spurious primary, one-fourth the length of second.

This species is a not very common summer inhabitant of New England, arriving and departing at about the same time as the preceding species. It is seldom seen in the deep forests; and, while usually found about farm-houses and villages, is most commonly seen in localities where there are numbers of the trees of the poplar and ash. In these trees, it inhabits the higher branches; and is, with the Redeyed Vireo, equally industrious in its search for insects. Its song is difficult of description : it is, unlike that of our other Vireos, a long-continued, cheerful warble; and is perhaps best described by saying that it almost exactly resembles the love-song of the Purple Finch. In fact, I have sometimes mistaken the song of this bird for that of the other, and only discovered my error after carefully watching the bird in his movements in the tree-tops. 
The Warbling Vireo seems to arrive here in pairs ; for they seem to be mated when we first discover them. Whether their attachment continues through several seasons, I am ignorant.

About the first of June, the pair commence building. The nest is pensile, and usually built in tall trees (usually poplars), often fifty feet from the ground. It is constructed of strips of grape-vine bark, grass, leaves, or bass-wood bark; and sometimes bunches of caterpillars' silk are left on the outside, as if for ornament. 'The following very interesting account of the breeding habits of this bird is given by Audubon, who watched a pair building in a Lombardy poplar :-

"One morning, I observed both of them at work: they had already attached some slender blades of grass to the knots of the branch and the bark of the trunk, and had given them a circular disposition. They continued working downwards and outwards until the structure exhibited the form of their delicate tenement. Before the end of the second day, bits of hornets' nests and particles of corn husks had been attached to it by pushing them between the rows of grass, and fixing them with silky substances. On the third day, the birds were absent, nor could $I$ hear them anywhere in the neighborhood; and, thinking that a cat might have caught them from the edge of the roof, I despaired of seeing them again. On the fourth morning, however, their notes attracted my attention before $I$ arose; and $I$ had the pleasure of finding them at their labors. The materials which they now used consisted chiefly of extremely slender grasses, which the birds worked in a circular form within the frame which they had previously made. The little creatures were absent nearly an hour at a time, and returned together, bringing the grass, which, I concluded, they found at a considerable distance. Going into the street to see in what direction they went, I watched them for some time, and followed them as they flew from tree to tree towards the river. There they stopped, and looked as if carefully watching me, when they resumed their journey, and led me quite out of the village to a large meadow, where stood an old hay-stack. They alighted on it, and, in a few minutes, each had 
sélected a blade of grass. Returning by the same route, they moved so slowly from one tree to another, that my patience was severely tried. Two other days were consumed in travelling for the same kind of grass. On the seventh, I saw only the female at work, using wood and horsehair: the eighth was almost entirely spent by both in smoothing the inside. They would enter the nest, sit in it, turn round, and press the lining. In the course of five days, an equal number of eggs were laid: they were small, of a rather narrow oval form, white, thinly spotted with reddish-black at the larger end. The birds sat alternately, though not with regularity as to time; and, on the twelfth day of incubation, the young came out. I observed that the male would bring insects to the female, and that, after chopping and macerating them with her beak, she placed them in the mouth of her young with a care and delicacy which were not less curious than pleasing to me."

This account is so full and complete that I can add nothing to the history of the breeding habits of this bird. But one brood is reared in the season in this latitude. The dimensions of four eggs in my collection from different localities are .83 by .56 inch, .80 by .56 inch, .78 by .54 inch, .78 by .53 inch. These will be found to be the average size of this species. The nest is about three inches in exterior diameter, and about two and a half in depth.

\section{VIREO NOVEBORACENSIS. - Bonaparte.}

The White-eyed Vireo.

Muscicapa Noveboracensis, Gmelin. Syst. Nat., I. (1788) 947.

Vireo Noreboracensis, Bonaparte. Obs. Wils. (1825), No. 122. Aud. Orn. Biog., I. (1831) 328; V. 431, 433; Birds Am., IV. (1842) 146; Nutt. Man., I. (1832) 306.

Juscicapa cantatrix, Wilson. Am. Orn., II. (1810) 266.

\section{DESCRIPTION.}

Spurious primary about half the second, which is about equal to the eighth quill; entire upper parts bright olivaceous-green; space around the eyes and extending to the bill greenish-yellow, interrupted by a dusky spot from the anterior cantlius to the base of the gape; beneath white; the sides of the breast and body well defined, almost gamboge-yellow; edges of greater and middle wing coverts (forming two bands) and of inner tertiaries greenish-yellow white; iris white.

Length, five inches; wing, two and fifty one-hundredths. 
This species is very irregularly distributed in New England as a summer inhabitant. In Maine, New Hampshire, and Vermont it is rare; and, while it is quite abundant in the eastern parts of Massachusetts, it is rare in the western. Says J. A. Allen of it, at Springfield, -

"I have never known the White-eyed Vireo taken here; and if occurring, as it very probably does, being not very uncommon in the eastern parts of the State, it must be excessively rare. In about a thousand specimens of the smaller land birds taken at Springfield during the last three years by different collectors, not a single White-eyed Vireo has been found."

This species arrives from the South, usually in pairs, from about the 25th of April to the 1st of May. It generally frequents low thickets and swamps. I do not remember of ever meeting with one in deep, high woods; but have often found a pair in a brier-patch in the middle of an old field or pasture. In such localities, its peculiar note 'chip cheweêo, 'chip 'chip cheweêo, is often heard; together with another rattling, scolding note, difficult of description. When the bird is approached, it meets the intruder with this scolding rattle; and, if the nest is approached, the Vireo becomes almost outrageous in its remonstrances. The nest is usually placed in a thicket of briers or vines, often in the gardens and fields. It is constructed of fibres of the inner bark of trees, fine twigs, grasses, pieces of hornets' nests, and fragments of paper. These are built in a pensile form, suspended by the upper edge, and lined with slender strips of grape-vine bark and roots. The eggs are usually four in number, and can hardly be distinguished from those of the Red-eyed Vireo in shape or color; the average dimensions being a trifle smaller. Several eggs collected in different localities exhibit, as an average measurement, .82 by .59 inch. A nest complement of four eggs, collected in Milton, Mass., vary but a trifle from this size; their measurement peing .83 by .59 inch, .82 by .59 inch, .82 by .58 inch, .80 
by .58 inch. But one brood is usually reared in New England in the season, and the period of incubation is twelve days.

VIREO SOLITARIUS. - Vieillot.

The Solitary Vireo; Blue-headed Vireo.

Mruscicapa solitaria, Wilson. Am. Orn., II. (1810) 143.

Vireo solitarius, Vieillot. Nouv. Dict. (1817). Aud. Orn. Biog., I. (1831), 147; V. (1839) 432. Nutt. Man., I. (1832) 305.

\section{DESCRIPTION.}

Spurious primary very small, not one-fourth the second, which is longer than the sixth; top and sides of the head and upper part of the neck dark bluish-ash; rest of upper parts clear olive-green; a white ring round the eye, interrupted in the anterior canthus by a dusky lore, but the white color extending above this spot to the base of the bill; under parts white; the sides under the wings greenish-yellow; two bands on the wing coverts, with the edges of the secondaries, greenish-white; outer tail feather with its edge all round, including the whole outer web, whitish.

Length, about five and a half inches; wing, two and forty one-hundredths.

This bird occurs as a summer resident in New England. It has been taken in all these States, but not in any numbers.

It makes its appearance about the first or second week in May, usually in pairs, and commences building its nest about the last week in that month. I have never met with its nest; and Audubon's description, though meagre, is the best available. It is as follows:-

"The nest is prettily constructed, and fixed, in a partially pensile manner, between two twigs of a low bush on a branch running horizontally from the main stem. It is formed externally of gray lichens slightly put together, and lined with hair, chiefly from the deer and raccoon. The female lays four or five eggs, which are white, with a strong tinge of flesh-color, and sprinkled with brownish-red dots at the larger end."

A number of eggs in my collection correspond in color and markings to the above description, and measure on the average .81 by .59 inch. But one brood is reared in the season, although there have been specimens taken as late as 
October. But little is known of the habits of this bird, as it prefers the deep woods and swamps to the more open districts.

VIREO FLAVIFRONS, - Vieillot.

\section{The Yellow-throated Vireo.}

Vireo flavifrons, Vieillot. Oiso Am., I. (1807) 85. Aud. Orn. Biog., II. (1834) 119; V. 428. Ib., Syn. Ib., Birds Am., IV. (1842) 141.

Muscicapa sylvicola, Wilson. Am. Orn., II. (1810) 117.

\section{DESCRIPTION.}

No spurious quill; the first and fourth equal; from bill to middle of back, sides of head, neck, and fore part of breast olive-green; beneath, from bill to middle of belly, with a ring round the eyes, sulphur-yellow; lores dusky; rest of under parts white; of upper, ashy-blue, tinged with green; two white bands on the wing; tertiaries edgred with white, other quills with greenish; outer tail feathers edged with yellowish-white; the outer web of first feather entirely of this color, except near the end.

Length, nearly six inches; wing, three and twenty one-hundredths.

This beautiful Vireo is not very common in New England, although it is found in all these States as a summer visitor. It arrives from the South about the tenth of May, sometimes not earlier than the fifteenth, and commences building about the first or second week in June. The nest is placed in a small fork of a tree, usually the apple-tree, at a height of about fifteen or twenty feet from the ground. It is the most beautiful nest made by birds of this genus : it is built of nearly the same materials as the others, but is covered in the most tasty manner with pieces of lichens and caterpillars' silk and spiders' webs, which are plastered or agglutinated on over the entire surface, giving the nest the appearance of a large bunch of moss hanging from a forked twig. Several of these nests, collected in different localities, are in my collection. They are invariably of this description, and are all lined with pieces of paper, wasps'. nest, and fine grasses. With the exception of the nest of the Humming-bird, and perhaps two or three of the Warblers, the nest of this species is the most beautiful specimen of 
bird architecture that I am acquainted with. The eggss are usually four in number. They are of a pure-white color, with thinly scattered spots of two shades of reddish-brown and black. The dimensions of four eggs collected in Connecticut are .83 by $.61 \mathrm{inch}, .82$ by $.60 \mathrm{inch}, .82$ by $.60 \mathrm{inch}$, and .80 by .59 inch. But one brood is reared in the season in New England.

Wilson, in describing the habits of this bird, says, -

"This summer species is found chiefly in the woods, hunting among the high branches; and has an indolent and plaintive note, which it repeats, with some little variation, every ten or twelve seconds, like preeò, preeà, \&c. It is often heard in company with the Red-eyed Flycatcher (Muscicapa olivacea); the loud, energetic notes of the latter, mingling with the soft, languid warble of the former, producing an agreeable effect, particularly during the burning heat of noon, when almost every other songster but these two is silent. Those who loiter through the shades of our magnificent forests at that hour will easily recognize both species. It arrives from the south early in May, and returns again with its young about the middle of September. Its nest, which is sometimes fixed on the upper side of a limb, sometimes on a horizontal branch among the twigs, generally on a tree, is composed outwardly of thin strips of the bark of grape-vines, moss, lichens, \&c., and lined with fine fibres of such like substances : the eggs, usually four, are white, thinly dotted with black, chiefly near the great end. Winged insects are its principal food."

In dismissing this beautiful and favorite family of our birds, I feel that it is impossible to say too much in their favor: their neat and delicate plumage and sweet song, their engaging and interesting habits, and their well-known insectdestroying proclivities, have justly rendered them great favorites; and the farmer, in protecting them, and encouring them to take up homes near his orchards and gardens, but extends a care and welcome for his best friends. 


\section{Family ALAUDIDA. The Skylarks.}

First primary very short or wanting; tarsi scutellate anteriorly and posteriorly, with the plates nearly of corresponding position and number; hind claw very long and nearly straight; bill short, conical, frontal feathers extending along the side of the bill; the nostrils usually concealed by a tuft of bristly feathers directed forwards; tertials greatly elongated beyond the secondaries.

\section{EREMOPHILA, BOIE.}

Eremophila, BoIE, Isis (1828), 322. (Type Alauda alpestris.) Sufficiently distinct from Eremophilus, Humboldt (Fishes, 1805).

First primary wanting; bill scarcely higher than broad; nostrils circular, concealed by a dense tuft of feathers; the nasal fossæ oblique; a pectoral crescent and sheek patches of black.

\section{EREMOPHILA CORNUTA, - Boie.}

The Skylark; Shore-lark.

\section{Eastern and Northern variety.}

Alauda cornuta, Wilson. Am. Orn., I. (1808) 85.

Eremoplita cornuta, Boie. Isis (1828), 322.

Alauda alpestris, Wilson. Am. Orn., I. (1808) 85. Nutt. Man., I. (1832) 455. Aud. Orn. Biog., II. (1834) 570; V. 448.

\section{Description.}

Above pinkish-brown, the feathers of the back streaked with dusky; a broad band across the crown, extending backwards along the lateral tufts; a crescentic patch from the bill below the eye and along the side of the head: a jugular crescent, and the tail feathers, black; the innermost of the latter like the back; a frontal band extending backwards over the eye, and under parts, with outer edge of wings and tail, white; chin and throat yellow.

Length of Pennsylvania specimens, seven and seventy-five one-hundredths inches; wing, four and fifty one-hundredths inches; tail, three and twenty-five onehundredths inches; bill, above, fifty-two one-hundredths of an inch.

THIS bird is found in New England only as a winter 1 visitor. It makes its appearance by the latter part of November, in flocks of thirty or forty, which repair to the salt-marshes, and low pastures and fields, where they remain during their stay with us. Here they feed on the seeds of various grasses and weeds, and such insects as they may be 
able to obtain at that inclement season. They often associate with the Snow Buntings, and sometimes make short excursions inland. I have seen them on the beach busily searching among the seaweed for small shell-fish and animalcules; and, in country roads, have observed that they visit the droppings of horses and cattle for the seeds contained in them.

By the middle of March, the Shore-larks leave New England for the North, where they breed, and spend the summer. Audubon says, of their breeding habits, -

"The Shore-lark breeds on the high and desolate tracts of Labrador, in the vicinity of the sea. The face of the country appears as if formed of one undulated expanse of dark granite, covered with mosses and lichens, varying in size and color; some green, others as white as snow, and others again of every tint, and disposed in large patches or tufts. It is on the latter that the Lark places her nest, which is disposed with so much care, while the moss so resembles the bird in hue, that, unless you almost tread upon her as she sits, she seems to feel secure, and remains unmoved. Should you, however, approach so near, she flutters away, feigning lameness so cunningly that none but one accustomed to the sight can refrain from pursuing her. The male immediately joins her in mimic wretchedness, uttering a note so soft and plaintive that it requires a strong stimulation to force the naturalist to rob the poor birds of their treasure.

"The nest, which is embedded in the moss to its edges, is composed of fine grasses, circularly disposed, and forming a bed about two inches thick, with a lining of grouse-feathers and those of other birds. In the beginning of July, the eggs are deposited. They are four or five in number, large, grayish, and covered with numerous pale-blue and brown spots. The young leave the nest before they are able to fly, and follow their parents over the moss, where they are fed about a week. They run nimbly, emit a soft prep, and squat closely at the first appearance of danger. If observed and pursued, they open their wings to aid them in their escape, and, separating, make off with great celerity. On such sccasions, it is difficult to secure more than one of them, unless several persons be present, when each can pursue a bird. The 
parents, all this time, are following the enemy overhead, lamenting the danger to which their young are exposed. In several instances, the old bird followed us almost to our boat, alighting occasionally on a projecting crag before us, and entreating us, as it were, to restore its offspring. By the first of August, many of the young are fully fledged, and the different broods are seen associating together to the number of forty, fifty, or more. They now gradually remove to the islands of the coast, where they remain until their departure, which takes place in the beginning of September. They start at the dawn of day, proceed on their way south at a small elevation above the water, and fly in so straggling a manner that they can scarcely be said to move in flocks."

A number of eggs in my collection, from Wisconsin and Illinois, where these birds breed in considerable numbers, are of a faint grayish-brown color, and marked with numerous dots and spots of umber, of different shades, over the entire surface of the egg. On one or two specimens, these markings are confluent into coarser blotches of the two shades of umber and lilac. The greatest dimensions of my specimens are .93 by .65 inch; the least dimensions, .85 by .63 inch. 


\section{Family FringILLID $A$. The Seed-eaters.}

Primaries nine; bill very short, abruptly conical and robust; commissure strongly angulated at base of bill; tarsi scutellate anteriorly, but the sides with two undivided plates meeting behind along the median line, as a sharp posterior ridge.

\section{Sub-Family Coccothraustinæ. - The Finches.}

Wings very long and much pointed, generally one-third longer than the more or less forked tail; first quill usually nearly as long or longer than the second; tertiaries but little longer, or equal to the secondaries, and always much exceeded by the primaries; bill very variable in shape and size, the upper mandible, however, as broad as the lower; nostrils rather more lateral than usual, and always more or less concealed by a series of small bristly feathers applied along the base of the upper mandible; no bristles at the base of the bill; feet şhort and rather weak; hind claw usually longer than the middle anterior one, sometimes nearly the same size.

\section{PINICOLA, Vieillot.}

Pinicola, Viemlot, Ois. Am. Sept., I. (1807).

Bill short, nearly as high as long, upper outline much curved from the base; the margins of the mandibles rounded; the commissure gently coneave, and abruptly deflexed at the tip; base of the upper mandible much concealed by the bristly feathers covering the basal third; tarsus rather shorter than the middle toe; lateral toe short, but their long claws reach the base of the middle one, which is longer than the hind claw; wings moderate, the first quill rather shorter than the second, third, and fourth; tail rather shorter than the wings, nearly even.

But one species of this genus belongs to the American fauna, and is closely allied to, if not identical with, that belonging to the northern portions of the Old World.

\section{PINICOLA CANADENSIS. - Cabanis.}

\section{The Pine Grosbeak.}

Pinicola Canadensis, Cabanis. Mus. Hein. (1851), 167.

Loxia enucleaton", Wilson. Am. Orn., I. (1808) 80.

Pyrrhula enucleator, Audubon. Orn. Biog., IV. (1838) 414.

\section{Description.}

Bill and legs black; general color carmine-red, not continuous above, however, except on the head; the feathers showing brownish centres on the back, where, too, the red is darker; loral region, base of lower jaw all round, sides and posterior part of body, with under tail coverts, ashy, whitest behind; wing with two white bands 
across the tips of the greater and middle corerts; the outer edges of the quills also white, broadest on the tertiaries.

Female, ashy; brownish above, tinged with greenish-yellow beneath; top of head, rump, and upper tail coverts brownish gamboge-yellow; wings as in the male.

Length, about eight and fifty one-hundredths inches; wing, four and fifty onehundredths; tail, four inches.

\begin{abstract}
LTHOUGH we find in Verrill's list of birds found at A Norway, Me., that this species is there a very common winter visitor, my experience has been, that it is an extremely rare one in Massachusetts, and is only found with us in very severe seasons.

This winter (1866-67), they have been very abundant, and good opportunities have b'een obtained for studying their habits.
\end{abstract}

Like other northern species, the Pine Grosbeak is very tame and familiar while here in winter. Mr. Maynard, of Newtonville, Mass., informs me, that he has repeatedly, during this season, captured specimens in his hands, and has had no difficulty in slipping a noose over their heads, as the birds were employed in opening the pine seeds, or eating the berries of the cedar; and he has now in captivity a number of specimens that are exceedingly tame and interesting, feeding readily on various seeds and fruits. A pair that I have in my possession, which he captured, are so tame that they take food from my hand, and even perch upon my finger. Their song is a soft, pleasing warble, not unlike that of the canary.

Both sexes have a number of call-notes, and they keep up a continuous twitter through the day: they are always lively and good-tempered, and are really entertaining pets.

Mr. Wheelwright, in his valuable and exceedingly interesting book, "A Spring and Summer in Lapland," gives the following account of the habits of the European Pine Grosbeak, a bird nearly allied to, if not identical with, our own: "By the first week in May, they had paired; and we took our first nest on June 4, with three eggs, in a small fir, about ten feet from the ground, on the side of a small fell, 
in by 110 means a large wood: and I may observe, that all the nests we took were built in small firs, never high from the ground, or in deep woods, and generally in conspicuous situations. The nest is neither large nor deep, but very compactly and cleanly built, like basket-work, the outside walling of very fine fir branches and thin cranberry fibres tightly interlaced, and lined with fine stiff grass and a little hair. The eggs vary much, both in size and coloring; but are usually of a pale blue-green ground-color, blotched and lined with light-purple and dark burnt-umber spots and pricks, always thickest towards the large end. Average size, 1 inch by .75 inch."

The food of the Grosbeak is not, as in the Crossbills, from the seed of the fir cones, but the small buds or embryo of the joung branches which shoot out from the lateral branches of the fir; but they can pick out the seeds from the cones, both of the pine and fir, quite as eleverly as the Crossbills.

For a very full and interesting description of the habits of this species, I will refer the reader to vol. IV. Audubon's Am. Orn. Biog., p. 414.

\section{CARPODACUS, KAUP.}

Carpodacus, KAUP, "Entw. Europ. Thierw., 1829," (Type Loxia erythrina, Pall.)

Bill short, stout, vaulted; the culmen decurved towards the end; the commissure nearly straight to the slightly decurved end; a slight development of bristly feathers along the sides of the bill, concealing the nostrils; tarsus shorter than the middle toe; lateral claws reaching to the base of the middle one; claw of hind toe much curved, smaller than the middle one, and rather less than the digital portion; wings long and pointed, reaching to the middle of the tail, which is considerably shorter than the wing, and moderately forked; colors red, or red and brown.

\section{CARPODACUS PURPOREUS. - Gray.}

The Purple Finch.

Fringilla purpurea, Wilson. Am. Orn., I. (1808) 119. Aud. Orn. Biog., I. (1831) $24 ;$ V. 200 .

\section{Description.}

Second quill longest; first shorter than third, considerably longer than the fourth; body crimson, palest on the rump and breast, darkest across the middle of back and wing coverts, where the feathers have dusky centres; the red extends below continu- 
ously to the lower part of the breast, and in spots to the tibiæ; the belly and under tail coverts white, streaked faintly with brown, except in the very middle; edges of wings and tail feathers brownish-red; lesser coverts like the back; two reddish bands across the wings (over the ends of the middle and greater coverts); lores dull-grayish.

Female olivaceous-brown, brighter on the rump; beneath white; all the feathers everywhere streaked with brown, except, on the middle of the belly and under coverts, a superciliary light stripe.

Length, six and twenty-five one-hundredths inches; wing, three and thirty-four one-hundredths; tail, two and fifty one-hundredths; bill, above, forty-six one-hundredths of an inch.

This species, although quite common in many localities of New England, is very irregularly distributed. For instance, it breeds abundantly in and near Cambridge, Mass., but is not found in any other part of the State in any thing like the abundance that it is there. In that locality, it is one of the most common birds breeding; in other localities, it is occasionally found in only detached pairs. So, in Maine, it is common in the neighborhood of the Umbagog lakes; but elsewhere it is not often seen. There seems to be, as Mr. Allen justly remarks, a great increase of this species within the last few years; and it is beginning to be one of our most common species. The birds separate into pairs soon after their arrival, about the middle of April, but do not commence building before the middle of May. They are occasionally resident here through the mild winter; but, as a general thing, they arrive in New England in flocks of ten or a dozen about the last of March. The nest is usually built in a pine or cedar tree, and is sometimes thirty or even forty feet from the ground, - oftener about fifteen or twenty. It is constructed of fine roots and grasses, and is lined with horsehair and hogs' bristles. One specimen in my collection has the cast-off skin of a snake woven in the rest of the fabric; and I have seen nests lined with mosses. Generally, hairs of different animals form the lining, and roots and grass the main structure.

The eggs are of a beautiful bluish-green color, and marked with spots and streaks of black: their form is a sharply pointed oval, and their dimensions vary from .94 by .64 inch 
to .88 by .60 inch. Two broods are often reared in the season.

This species is one of the few injurious birds that we have; and, although it has a beautiful warbling song, and is altogether a fine-looking bird, it is much disliked in the country in consequence of its bad habit of cutting off and eating the buds and blossoms of fruit-trees. Wilson says of this habit, -

"This is a winter bird of passage, coming to us in large flocks from the North, in September and October; great numbers remaining with us in Pennsylvania during the whole winter, feeding on the seeds of the poplar, button-wood, juniper, cedar, and on those of many rank weeds that flourish in rich bottoms and along the margin of creeks. When the season is very severe, they proceed to the South, as far at least as Georgia, returning North early in April. They now frequent the elm-trees, feeding on the slender but sweet covering of the flowers ; and, as soon as the cherries put out their blossoms, feed almost exclusively on the stamina of the flowers: afterwards, the apple-blossoms are attacked in the same manner; and their depredations on these continue till they disappear, which is usually about the 10th or middle of May. I have been told that they sometimes breed in the northern parts of New York, but have never met with their nests. About the middle of September, I found these birds numerous on Long Island, and around Newark in New Jersey. They fly at a considerable height in the air ; and their note is a single chink, like that of the Ricebird. Threy possess great boldness and spirit, and, when caught, bite violently, and hang by the bill from your hand, striking with great fury; but they are soon reconciled to confinement, and in a day or two are quite at home. I have kept a pair of these birds upwards of nine months to observe their manners. One was caught in a trap, the other was winged with the gun: both are now as familiar as if brought up from the nest by the hand, and seem to prefer hemp-seed and cherry-blossoms to all other kinds of food. Both male and female, though not crested, are almost constantly in the habit of erecting the feathers of the crown. They appear to be of a tyrannical and domineering disposition: for they nearly 
killed an Indigo-bird, and two or three others, that were occasionally placed with them, driving them into a corner of the cage, standing on them, and tearing out their feathers, striking them on the head, munching their wings, \&c., till I was obliged to interfere; and, even if called to, the aggressor would only turn up a malicious eye to me for a moment, and renew his outrage as before. They are a hardy, vigorous bird. In the month of October, about the time of their first arrival, I shot a male, rich in plumage, and plump in flesh, but which wanted one leg, that had been taken off a little above the knee: the wound had healed so completely, and was covered with so thick a skin, that it seemed as though it had been so for years. Whether this mutilation was occasioned by a shot, or in party quarrels of its own, I could not determine: but our invalid seemed to have used his stump either in hopping or resting; for it had all the appearance of having been brought in frequent contact with bodies harder than itself."

\section{CHRYSOMITRIS, BOIE.}

Chrysomitris, Bore, Isis (1828), 322. (Type Fringilla spinus, Linnæus.)

Bill rather acutely conic, the tip not very sharp; the culmen slightly convex at the tip; the commissure gently curved; nostrils concealed; obsolete ridges on the upper mandible; tarsi shorter than the middle toe; outer toe rather the longer, reaching to the base of the middle one; claw of hind toe shorter than the digital portion; wings and tail as in Aegiothus.

The colors are generally yellow, with black on the crown, throat, back, wings, and tail, varied sometimes with white.

\section{CHRYSOMITRIS TRISTIS. - Bonaparte.}

The Yellow-bird; Thistle-bird.

Fringilla tristis, Linnæus. Syst. Nat., I. (1766) 320. Wils: Am. Orn., I. (1808) 20. Aud. Orn. Biog., I. (1831) 172; V. 510.

\section{Description.}

Bright gamboge-yellow; crown, wings, and tail, black; lesser wing coverts, band across the end of greater ones, ends of secondaries and tertiaries, inner margins of tail feathers, upper and under tail coverts, and tibia, white. Female replacing the yellow of the male by a greenish-olive color.

Length, five and twenty-five one-hundredths inches; wing, three inches.

This well-known bird is a very common summer inhabitant of all New England, and in the southern districts 
remains through the year. Notwithstanding its being here through the early spring, it does not begin to build before the middle of June. The earliest nest that I ever heard of was found June the 10th, and very few are found as early as the middle of that month. The nest is usually placed in a forked branch in an apple-tree in the orchard, sometimes in a maple or birch tree near the roadside: It is constructed of soft strips of the cedar and grape-vine bark: these are very neatly woven together into a compact structure, which is deeply hollowed, and lined with soft down from the thistle, and sometimes a few feathers. The eggs are usually four in number: their form is generally oval, and their color a bluish-white. Dimensions vary from .68 by .53 inch to .62 by .50 inch. But one brood is reared in the summer.

The habits of this bird are so well known that I will not give them an extended notice here. It seems to be a persistently gregarious species: for, even in the breeding season, several families are usually found in one neighborhood; and the males often assemble together, and pass the time in collecting food, trimming their feathers, and bathing. In fact, this bird seems to be more of a dandy, and consequently less of a family man, than most of our other species; and I have noticed that he leaves the greater part of the burden of the family cares upon the shoulders of his attentive mate.

When the season of incubation has passed, the birds assemble in flocks of from ten to twenty or thirty in number, and frequent the gardens and stubble-fields, where they subsist upon the seeds of various weeds and grasses. They have a short note like che weee, which is uttered often, sometimes in a drawling, plaintive key, and at other times in a brisk, cheerful tone. Their flight is undulating and irregular, and resembles very much that of the Woodpeckers. When on the wing, they have a short, simple chatter, like 'che 'ché 'che 'che, uttered rapidly, and with 
emphasis on the second syllable. Occasionally, the male emits a continued warbling song, very similar to that of the Canary-bird; and I have heard one of this species sing in confinement almost as sweetly and often as its more familiar and domesticated relative.

CHRISOMITRIS PINUS.-Bonaparte.

The Pine Finch.

Fringilla pinus, Wilson. Am. Orn., II. (1810) 133. Aud. Orn. Biog., II. (1834) $455 ;$ V. 509.

Chrysomitris pinus, Bonaparte. Consp. (1850), 515.

\section{Descruption.}

Tail deeply forked; above brownish-olive; beneath whitish, every feather streaked distinctly with dusky; concealed bases of tail feathers and quills, together with their inner edges, sulphur-yellow; outer edges of quills and tail feathers yellowish-green; two brownish-white bands on the wing.

Length, four and seventy-five one-hundredths inches; wing, three inches; tail, two and twenty one-hundredths inches.

This bird is found in New England, usually as a winter visitor. While here, it has all the habits of the preceding species, and might, at a little distance, be mistaken for that bird. The Pine Finch, as its name implies, prefers the groves and forests of pines to other trees; and it is found in all our pine woods in flocks of twenty or thirty, where it feeds on the seeds contained in the cones on these trees. It has been known to breed in Cambridge, in this State; and breeds regularly in the northern sections of New England.

\section{CURVIROSTRA, Scopolr.}

Loxia, Linn zus, Syst. Nat., 1758. (Type Loxia curvirostra, L. Not of 1735, which has for type Loxia coccothraustes, L.)

Curvirostra, Scopoli, 1777. (Type L. curvirostra.)

Mandibles much elongated, compressed, and attenuated; greatly curved or falcate, the points crossing or overlapping to a greater or less degree; tarsi very short; claws all very long, the lateral extending beyond the middle of the central; hind claw longer than its digit; wings very long and pointed, reaching beyond the middle of the narrow, forked tail.

Colors reddish in the male. 
The elongated, compressed, falcate-curved, and overlapping mandibles readily characterize this genus among birds.

The United-States species of Curvirostra are readily distinguished by the presence of white bands on the wing in Leucoptera and their absence in Americana.

CURVIROSTRA AMERICANA. - Wilson.

The Red Crossbill.

Curvirostra Americana, Wilson. Am. Orn., IV. (1811) 44.

Laxia curvirostra. Aud. Biog., II. (1834) 559; V. 511.

DESCRIPTION.

Male dull-red; darkest across the back; wings and tail dark blackish-brown.

Female dull greenish-olive above, each feather with a dusky centre; rump and crown bright greenish-yellow; beneath grayish; tinged, especially on the sides of the body, with greenish-yellow; young entirely brown; paler beneath.

The immature and young birds exhibit all imaginable combinations of the colors of the male and female. They all agree in the entire absence of white bands on the rings.

- Male about six inches; wing, three and thirty one-hundredths inches; tail, two and twenty-five one-hundredths inches.

This bird is very irregularly distributed in New England, usually as a winter visitor. Sometimes it is quite rare at that season in all sections; and occasionally it is very abundant. It also occurs here during the summer, breeding regularly in the pine and hemlock forests of the northern sections. Wilson says of the habits of this bird, -

"On first glancing at the bill of this extraordinary bird, one is apt to pronounce it deformed and monstrous: but on attentively observing the use to which it is applied by the owner, and the dexterity with which he detaches the seeds of the pine-tree from the cone, and from the husks that enclose them, we are obliged to confess, on this, as on many other occasions where we have judged too hastily of the operations of nature, that no other conformation could have been so excellently adapted to the purpose; and that its deviation from the common form, instead of being a defect or monstrosity, as the celebrated French naturalist insinuates, is a striking proof of the wisdom and kind superintending care of the great Creator. 
"This species is a regular inhabitant of almost all our pine forests situated north of $40^{\circ}$, from the beginning of September to the midale of April. It is not improbable that some of them remain during the summer within the territory of the United States to breed. Their numbers must, however, be comparatively few, as I have never yet met with any of them in summer, though lately I took a journey to the Great Pine Swamp beyond Pocano Mountain, in Northampton County, Pa., in the month of May, expressly for that purpose; and ransacked, for six or seven days, the gloomy recesses of that extensive and desolate morass, without being able to discover a single Crossbill. In fall, however, as well as in winter and spring, this tract appears to be their favorite rendezvous; particularly about the head waters of the Lehigh, the banks of the Tobyhanna, Tunkhannock, and Bear Creek, where I have myself killed them at these seasons. They then appear in large flocks, feeding on the seeds of the hemlock and white-pine; have a loud, sharp, and not unmusical note; chatter as they fly; alight, during the prevalence of deep snows, before the door of the hunter, and around the house, picking off the clay with which the logs are plastered, and searching in corners where urine, or any substance of a saline quality, had been thrown. At such times, they are so tame as only to settle on the roof of the cabin when disturbed, and, a moment after, descend to feed as before. They are then easily caught in traps, and will frequently permit one to approach so near as to knock them down with a stick. Those killed and opened at such times are generally found to have the stomach filled with a soft, greasy kind of earth or clay. When kept in a cage, they have many of the habits of the Parrot; often climbing along the wires, and using their feet to grasp the cones in, while taking out the seeds."

\section{Nuttall says of its breeding habits, -}

"They often breed in winter in more temperate countries, as in January and February; and the young fly in March. The nest is said to be fixed in the forks of fir-trees; and the eggs, four or five, are of a greenish-gray, with a circle of reddish-brown spots, points, and lines, disposed chiefly at the larger end: the lines also often extend over the whole surface of the egg." 


\section{CURVIROSTRA LEUCOPTERA.-Wilson.}

The White-winged Crossbill.

Loxia leucoptera, Audubon. Orn. Biog., IV. (1838) 467.

Curvirostra leucoptera, Wilson. Am. Orn., IV. (1811) 48.

\section{DESCRIPTION.}

Bill greatly compressed, and acute towards the point; male carmine-red, tinged with dusky across the back; the sides of body under the wings streaked with brown; from the middle of belly to the tail coverts whitish, the latter streaked with brown; scapulars, wings, and tail, black; the broad bands on the wings across the ends of greater and median coverts; white spots on the end of the inner tertiaries.

Female brownish, tinged with olive-green in places; feathers of the back and crown with dusky centres; rump bright brownish-yellow.

Length, about six and twenty-five one-hundredths inches; wing, three and fifty one-hundredths inches; tail, two and sixty one-hundredths inches.

\section{This beautiful bird seems to} be much less frequent in its winter visits to New England than the preceding. It has all the general characteristics of that bird. In May, in the Hudson's Bay country, according to Mr. Hutchins, it builds its nest in a pine-tree. This is constructed of grass, mud, and feathers, and is lined with moss and other soft materials. The female lays five white eggs, marked with yellowish spots.

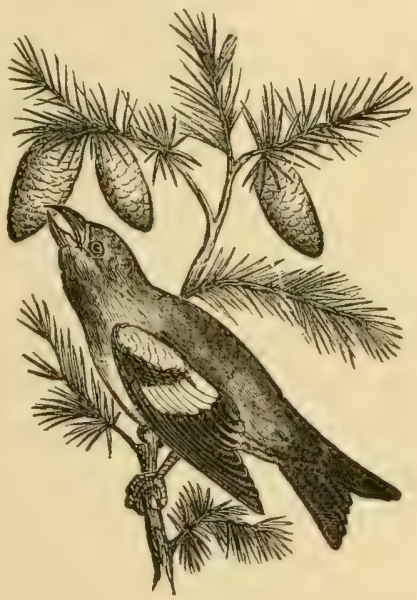

\section{egiothus, Cabanis.}

Egiothus, СавAnIs, Mus. Hein., 1851, 161. (Type Fringtla linaria, Linn.)

Bill very short, conical, and acutely pointed, the outlines even concave; the commissure straight; the base of the upper mandible and the nostrils concealed by stiff, appressed bristly feathers; middle of the mandible having several ridges narallel with the culmen; inner lateral toe rather the longer, its claw reaching the middle of the middle claw; the hind toe rather longer, its claw longer than the digital portion; wings very long, reaching the middle of the tail; second quill a little longer than the first and third; tail deeply forked. 


\section{ÆৈGIOTHUS LINARIA. - Cabanis.}

\section{The Lesser Redpoll.}

Fringilla linaria, Linnæus. Syst. Nat., I. (1766) 322. Aud. Orn. Biog., IV. 1838) 533.

Egiothus linaria, Cabanis. Mus. Hein. (1851), 161.

\section{DESCRIPTION.}

Above light-yellowish, each feather streaked with dark-brown; crown darkcrimson; upper part of breast and sides of the body tinged with a lighter tint of the same; the rump and under tail coverts also similar, but still less vivid, and with dusky streaks; rest of under parts white, streaked on the sides with brown; loral region and chin dusky; cheeks (brightest over the eye), and a narrow front, whitish; wing feathers edged externally, and tail feathers all round with white; two yellowish-white bands across the wing coverts; secondaries and tertiaries edged broadly with the same; bill yellowish, tinged with brown on the culmen and gonys; the basal bristles brown, reaching over half the bill.

The specimen described above is a male in winter dress. The spring plumage has much more of the red. The female winter specimens lack the rose of the under parts and rump; the breast is streaked across with dusky.

Length, five and fifty one-hundredths inches; wing, three and ten one-hundredths inches; tail, two and seventy one-hundredths inches.

This species is a pretty common winter visitor in all parts of New England. It congregates in large flocks, which frequent old fields and pastures and stubble-fields, and feed on the seeds of weeds and grasses. It has, while with us, the note and general habits of the Goldfinch and Pine Finch, and might easily, at a little distance, be mistaken for those birds. They seem fond of the seeds of the white birch; and they cluster so thick on a branch of this tree, while securing the seeds, that I have killed as many as a dozen at a shot. Mr. Selby's account of the nest and eggs is as follows :-

"It is only known in the southern parts of Britain as a winter visitant; and is at that period gregarious, and frequently taken, in company with the other species, by the bird-catchers, by whom it is called the Stone Redpoll. In the northeru counties of England, and in Scotland and its isles, it is resident through the year. It retires, during the summer, to the underwood that covers the bases of many of our mountains and hills, and that often fringes the 
banks of their precipitous streams; in which sequestered situations it breeds. The nest is built in a bush or low tree (such as willow, alder, or hazel), of moss and the stalks of dry grass, intermixed with down from the catkin of the willow, which also forms the lining, and renders it a particularly soft and warm receptacle for the eggs and young. From this substance being a constant material of the nest, it follows that the young are produced late in the season, and are seldom able to fly before the end of June or the beginning of July. The eggs are four or five in number : their color pale bluish-green, spotted with orange-brown, principally towards the larger end. In winter, the Lesser Redpoll descends to the lower grounds in considerable flocks; frequenting woods and plantations, more especially such as abound in birch or alder trees, the catkins of which yield it a plentiful supply of food. When feeding, its motion affords both interest and amusement; since, in order to reach the catkins, which generally grow near the extremities of the smaller branches, it is obliged, like the Titmouse, to hang with its back downwards, and assume a variety of constrained attitudes: and, when thus engaged, it is so intent upon its work, as frequently to allow itself to be taken by a long stick smeared with bird-lime; in which way I have occasionally captured it when in want of specimens for examination. It also eats the buds of trees, and (when in flocks) proves in this way seriously injurious to young plantations. Its call-note is very frequently repeated when on wing, and by this it may be always distinguished from the other species. The notes it produces during the pairing season, although few, and not delivered in continuous song, are sweet and pleasing."

\section{IEGIOTHUS CANESCENS. - Cabanis.}

\section{The Mealy Redpoll.}

Egiothus canescens, Cabanis. Mus. Hein. (1851), 161.

Fringilla borealis, Audubon. Orn. Biog., V. (1839) 87.

\section{DESCRIPTION.}

Size large; bill short; claws elongated; rump white (in the spring, male tinged with rose), nerer streaked; the quills broadly margined with white.

Length, six inches; tail, three and seventeen one-hundredths.

This bird occurs only as an exceedingly rare winter visitor in New England. I have never met with it myself, but 


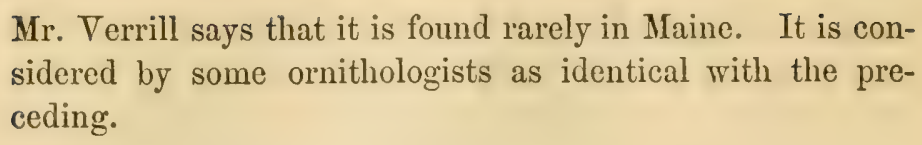

PLECTROPHANES, Meyer.

Plectrophanes, MEYer, Taschenbuch (1810). Agassiz. (Type Emberiza nivalis.)

Bill variable, conical, the lower mandible higher than the upper; the sides of both mandibles (in the typical species) guarded by a closely applied brush of stiffened bristly feathers directed forwards, and in the upper jaw concealing the nostrils; the outlines of the bill nearly straight, or slightly curved; the lower jaw considerably broader at the base than the upper, and wider than the gonys is long; tarsi considably longer than the middle toe; the lateral toes nearly equal (the inner claw largest), and reaching to the base of the middle claw; the hinder claw very long; moderately curved and acute; considerably longer than its toe; the toe and claw together reaching to the middle of the middle claw, or beyond its tip; wings very long and much pointed, reaching nearly to the end of the tail; the first quill longest, the others rapidly graduated; the tertiaries a little longer than the secondaries; tail moderate, about two-thirds as long as the wings; nearly even, or slightly emarginated.

\section{PLECTROPHANES NIVALIS. - Meyer.}

\section{The Snow Bunting.}

Emberiza nivalis, Linnæus. Syst. Nat., I. (1766) 308. Wils. Am. Orn., III. (1811) 86; Aud. Orn. Biog., II. (1834) 515; V. (1839) 496.

"Plectrophanes nivalis, Meyer." Bon. List (1838).

\section{DESCRIPTION.}

Colors, in full plumage, entirely black and white; middle of back between scapulars, terminal half of primaries and tertiaries, and two innermost tail feathers, black; elsewhere pure-white; legs black at all seasons. In winter dress white beneath; the head and rump yellowish-brown, as also some blotches on the side of the breast; middle of back brown, streaked with black; white on wings and tail much more restricted.

This species varies much in color; and the male in full plumage is seldom, if ever, seen within the limits of the United States.

Length, about six and seventy-five one-hundredths inches; wing, four and thirtyfive one-hundredths; tail, three and five one-hundredths inches; first quill longest.

This is a very common winter visitor in all parts of New England, but is most abundant in localities near the seacoast. I have seen flocks of hundreds of individuals in the marshes in Plymouth County, Mass., and have almost always noticed that they were accompanied by Shore-larks and Redpolls. They feed on seeds of various wild plants 
and small shell-fish, and become, during their stay here, very fat, and are accounted as delicate eating by epicures, for whose tables they are killed in great numbers.

The following interesting account of the habits of this species is by Wilson. It is partly compiled from the observations of Mr. Pennant:-

"These birds," says Mr. Pennant, "inhabit, not only Greenland, but even the dreadful climate of Spitzbergen, where vegetation is nearly extinct, and scarcely any but cryptogamous plants are found. It therefore excites wonder, how birds which are graminivorous in every other than those frost-bound regions subsist, yet are there found in great flocks, both on the land and ice of Spitzbergen. They annually pass to this country by way of Norway; for, in the spring, flocks innumerable appear, especially on the Norwegian isles, continue only three weeks, and then at once disappear. As they do not breed in Hudson's Bay, it is certain that many retreat

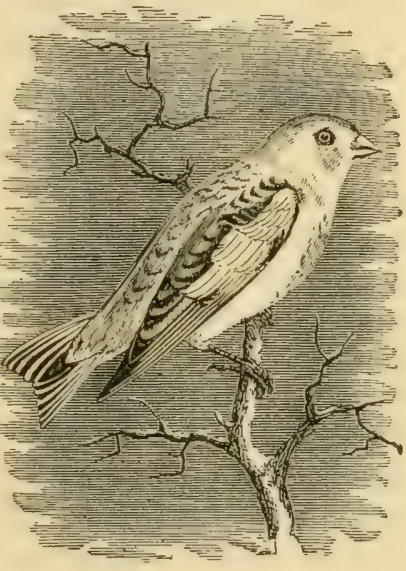
to this last of lands, and totally uninhabited, to perform, in full security, the duties of love, incubation, and nutrition. That they breed in Spitzbergen is very probable; but we are assured that they do so in Greenland. They arrive there in April, and make their nests in the fissures of the rocks on the mountains in May: the outside of their nest is grass, the middle of feathers, and the lining the down of the arctic fox. They lay five eggs, - white, spotted with brown: they sing finely near their nest.

"They are caught by the boys in autumn, when they collect near the shores in great flocks, in order to migrate, and are eaten dried.

"In Europe, they inhabit, during summer, the most naked Lapland alps; and descend in rigorous seasons into Sweden, and fill the roads and fields, - on which account the Dalecarlians call them 
Illwarsfogel, or bad-weather birds; the Uplanders, Hardwarsfogel, expressive of the same. The Laplanders style them Alaipg. Leems remarks, I know not with what foundation, that they fatten on the flowing of the tides in Finmark, and grow lean on the ebb. The Laplanders take them in great numbers in hair springs, for the tables; their flesh being very delicate.

"They seem to make the countries within the whole arctic circle their summer residence, from whence they overflow the more southern countries in amazing multitudes at the setting-in of winter in the frigid zone. In the winter of 1778-79, they came in such multitudes into Birsa, one of the Orkney Islands, as 'to cover the whole barony; yet, of all the numbers, hardly two agreed in colors.

"Lapland, and perhaps Iceland, furnishes the north of Britain with the swarms that frequent these parts during winter, as low as the Cheviot Hills, in latitude $52^{\circ} 32^{\prime}$; their resting-places, the Feroe Isles, Shetland, and the Orkneys. The Highlands of Scotland, in particular, abound with them. Their flights are immense; and they mingle so closely together in form of a ball, that the fowlers make great havoc among them. They arrive lean, soon become very fat, and are delicious food. They either arrive in the Highlands very early, or a few breed there; for I had one shot for me, at Invercauld, the 4th of August. But there is a certainty of their migration; for multitudes of them fall, wearied with their passage, on the vessels that are sailing through the Pentland Firth.

"In their summer dress, they are sometimes seen in the south of England, the climate not having severity sufficient to affect the colors; yet now and then a milk-white one appears, which is usually mistaken for a white Lark.

"Russia and Siberia receive them in their severe seasons annually, in amazing flocks, overflowing almost all Russia. They frequent the villages, and yield a most luxurious repast. They vary there infinitely in their winter colors, are pure-white, speckled, and even quite brown. This seems to be the influence of difference of age, more than of season. Germany has also its share of them. In Austria, they are caught and fed with millet, and afford the epicure a treat equal to that of the Ortolan.

"These birds appear in the northern districts of the United States 
early in December, or with the first heavy snow, particularly if drifted by high winds. 'They are usually called the White Snowbird, to distinguish them from the small dark-bluish Snowbird already described. Their numbers increase with the increasing severity of weather, and depth of snow. Flocks of them sometimes reach as far south as the borders of Maryland; and the whiteness of their plumage is observed to be greatest towards the depth of winter. They spread over the Genesee country and the interior of the District of Maine, flying in close, compact bodies, driving about most in a high wind; sometimes alighting near the doors, but seldom sitting long, being a roving, restless bird. In these plentiful regions, where more valuable game is abundant, they hold out no temptation to the sportsman or hunter; and, except the few caught by boys in snares, no other attention is paid to them. They are, however, universally considered as the harbingers of severe cold weather. How far westward they extend I am unable to say. One of the most intelligent and expert hunters, who accompanied Captains Lewis and Clark on their expedition to the Pacific Ocean, informs me that he has no recollection of seeing these birds in any part of their tour, not even among the bleak and snowy regions of the Stony Mountains; though the little blue one was in abundance.

"The Snow Bunting derives a considerable part of its food from the seeds of certain aquatic plants, which may be one reason for its preferring these remote northern countries, so generally intersected with streams, ponds, lakes, and shallow arms of the sea, that probably abound with such plants. In passing down the Seneca River towards Lake Ontario, late in the month of October, I was surprised by the appearance of a large flock of these birds, feeding on the surface of the water, supported on the tops of a growth of weeds that rose from the bottom, growing so close together that our boat could with great difficulty make its way through them. They were running about with great activity; and those I shot and examined were filled, not only with the seeds of this plant, but with a minute kind of shell-fish that adheres to the leaves. In this kind of aquatic excursions, they are doubtless greatly assisted by the length of their hind heel and claws. I also observed a few on Table Rock, above the Falls of Niagara, seemingly in search of the same kind of food. 
According to the statements of those traders who have resided near Hudson's Bay, the Snow Buntings are the earliest of their migratory birds; appearing there about the 11th of April, staying about a month or five weeks, and proceeding farther north to breed. They return again in September, stay till November, when the severe frosts drive them southward."

PLECTROPHANES LAPPONICUS. - Selby.

The Lapland Longspur.

Emberiza 7apponica, Audubon. Orn. Biog., IV. (1838) 472.

Plectrophanes lapponicus, "Selby." Bon. List (1838).

Description.

First quill longest; legs black; head all round black, this extending as a sem1circular patch to the upper part of breast; sides of lower neck and under parts white, with black streaks on the sides, and spots on the side of the breast; a short brownish-white streak back of the eye; a broad chestnut collar on the back of the neck; rest of upper parts brownish-yellow, streaked with dark-brown; outer tail feathers white, except on the basal portion of the inner web.

This species is very seldom seen in full spring plumage in the United States. In perfect dress, the black of the throat probably extends further down over the breast. In winter, the black is more or less concealed by whitish tips to the feathers beneath, and by yellowish-brown on the crown. Some fall specimens, apparently females, show no black whatever on the throat, which, with the under parts generally, are dull-white, with a short black streak on each side of the throat.

Length, about six and twenty-five one-hundredths inches; wing, three and ninety one-bundredths; tail, two and eight one-hundredths.

This bird is found only as an extremely rare winter visitor in the interior of New England; but in some localities on the seaboard it is not uncommon, associating with flocks of Snow Buntings. We are informed by Dr. Richardson, that it breeds in the moist meadows on the shores of the Arctic Sea. The nest is placed on a small hillock, among moss and stones; is composed externally of the dry stems of grass, interwoven to a considerable thickness ; and lined, very neatly and compactly, with deer's hair. The eggs, usually seven, are pale ochre-yellow, spotted with brown. 


\section{Sub-Family SPIZeluinds. - The Sparrows.}

Bill variable, usually almost straight; sometimes curved; commissure generally nearly straight, or slightly concave; upper mandible wider than lower; nostrils exposed; wings moderate; the outer primaries not much rounded; tail variable; feet large; tarsi mostly longer than the middle toe.

The species are usually small, and of dull color. Nearly all are streaked on the back and crown; often on the belly. None of the United-States species have any red, blue, or orange; and the yellow, when present, is as a superciliary streak, or on he elbow edge of the wing.

\section{PASSERCULUS, BoNAPARTE.}

Passerculus, Bonaparte, Comp. List Birds (1838). (Type Fringilla Savanna.)

Bill moderately conical; the lower mandible smaller; both outlines nearly straight; tarsus about equal to the middle toe; lateral toes about equal, their claws falling far short of the middle one; hind toe much longer than the lateral ones, reaching as far as the middle of the middle claw; its claws moderately curved; wings unusually long, reaching to the middle of the tail, and almost to the end of the upper coverts; the tertials nearly or quite as long as the primaries; the first primary longest; the tail is quite short, considerably shorter than the wings, as long as from the carpal joint to the end of the secondaries; it is emarginate, and slightly rounded; the feathers pointed and narrow.

Entire plumage above, head, neck, back, and rump, streaked; thickly streaked beneath.

\section{PASSERCULUS SAVANNA. - Bonaparte.}

\section{The Savannah Sparrow.}

Fringilla Savanna, Wilson. Am. Orn., III. (1811) 55. Aud. Orn. Biog., II. (1834) 63; V. (1839), 516.

Passerculus Savanna, Bonaparte. List (1838).

\section{DESCRIPTION.}

Feathers of the upper parts generally with a central streak of blackish-brown; the streaks of the back with a slight rufous suffusion laterally; the feathers edged with gray, which is lightest on the scapulars; crown with a broad median stripe of yellowish-gray; a superciliary streak from the bill to the back of the head, eyelids, and edge of the elbow, yellow; a yellowish-white maxillary stripe curving behind the ear coverts, and margined above and below by brown; the lower margin is a series of thickly crowded spots on the sides of the throat, which are also found on the sides of the neck, across the upper part of the breast, and on the sides of the body; a few spots on the throat and chin; rest of under parts white; outer tail feather and primary edged with white.

Length, five and fifty one-hundredths inches; wing, two and seventy one-huntredths inches; tail, two and ten one-hundredths inches. 
This bird seems to be rather irregularly distributed throughout New England in the summer season. In the eastern part of Massachusetts, it is quite common; in the western part, "chiefly a spring and summer visitant," but "not common." Mr. Allen has never found it breeding in the neighborhood of Springfield; but, in the neighborhood of the seacoast in the same State, it is abundant in the breeding season. On the contrary, in Maine, it is not very common near the seacoast; but in the interior, even as far as the western borders, it is one of the most plentiful of Sparrows. It arrives in Massachusetts as early as the first week in April ; in Maine, seldom before the middle of that month. About the first week in May in Massachusetts, and later as we advance north, the birds commence building. The nest is placed on the ground, usually under a tussock of grass: it is constructed of fine grasses and roots, which are bent and twined together rather neatly; and the whole is lined with hairlike roots and fine grass. The eggs are usually four in number, grayish-white in color, and covered irregularly with spots of umber-brown and lilac. Their form varies from long and slender to quite short and thick: their dimensions vary from .76 by .60 to .72 by .58 ineh. Two broods are often reared in the season. This species rather prefers pastures and fields at a distance from houses for a home to their more immediate neighborhood.

On the seaboard, this species is most often found on or near the sandy beaches, where it is observed busily gleaning, in the seaweed and little bunches of beach-grass, the insects and mollusks that are found there. In the interior, it prefers the dry, sandy fields and pastures, where, running about with great rapidity, its white outer tail feathers spread, it is always industrious in its search for coleopterous insects and seeds.

The female, when the nest is approached, leaves it, and runs limping off, her wings extended, uttering the chattering cry peculiar to the Sparrows. 
The male, during the mating and the early part of the breeding season, has a very sweet and pretty song which he chants most often at morning and early evening, and during dark and cloudy weather.

This song is difficult of description: it resembles nearly the syllables 'chewée 'chewitt 'chewitt' 'chewitt 'chewé et 'chewée, uttered slowly and plaintively. It has also a short chirp, quite faint, yet shrill, which, as Mr. Nuttall truly remarks, almost exactly resembles the chirping of a cricket.

About the first week in October, this species gathers in small, detached flocks; and, after frequenting the stubblefields and gardens a week or two, the whole leave for the South.

\section{POOCETES, BAIRD.}

Bill rather large; upper outline slightly decurved towards the end, lower straight; commissure slightly concave; tarsus about equal to the middle toe; outer toe a little longer than the inner, its claw reaching to the concealed base of the middle claw; hind toe reaching to the middle of the middle claw; wings unusually long, reaching to the middle of the tail, as far as the coverts, and pointed, the primaries considerably longer than the secondaries, which are not much surpassed by the tertiaries; second and third quills longest; first little shorter, about equal to the fourth, shorter than the tail; the outer feathers scarcely shorter; the feathers rather stiff, each one acuminate and sharply pointed; the feathers broad nearly to the end, when they are obliquely truncate; streaked with brown above everywhere; beneath, on the breast and sides; the lateral tail feather is white.

\section{POOCETES GRAMINEUS. - Baird.}

\section{The Grass Finch; Bay-winged Bunting.}

Fringilla graminea, Gmelin. Syst. Nat., I. (1788) 922. Aud. Orn. Biog., I. (1831) 473 ; V. 502.

Emberiza graminea, Wilson. Am. Orn., IV. (1811) 51.

\section{DESCRIPTION.}

Tail feathers rather acute; above light yellowish-brown; the feathers everywhere streaked abruptly with dark-brown, even on the sides of the neck, which are paler; beneath yellowish-white; on the breast and sides of neck and body streaked with brown; a faint light superciliary and maxillary stripe; the latter margined above and below with dark-brown; the upper stripe continued around the ear coverts, which are darker than the brown color elsewhere; wings with the shoulder light chestnut-brown, and with two dull-whitish bands along the ends of the coverts; the outer edge of the secondaries also is white; outer tail feather, and edge and tip of the second, white. 
Length, about six and twenty-five one-hundredths inches; wing, three and ten one-hundredths inches.

Hab. - United States from Atlantic to the Pacific; or else one species to the high central plains, and another from this to the Pacific.

This Sparrow is abundantly distributed throughout New Eingland in the breeding season. It arrives about the first week in April, and commences building about the last of that month in Massachusetts; in Maine, about the first of June. The nest, like that of the preceding species, is built in open, dry pastures and fields, at the foot of a tuft of grass, and is composed of the same materials and constructed in the same form as the others; and I would here remark, that, of our New-England sparrows, it is impossible to distinguish most species, either in manner and material of nest, and form and color of eggs, in the great variations which exist in them. The descriptions already given, and those which follow, are made from the average specimens, or in the forms in which they are most often met. The eggs of the Grass Finch are usually about four in number : they are of a grayish, livid-white color, and marked irregularly with spots of obscure brown, over which are blotches of black. Dimensions of specimens from various localities vary from .88 by .60 to .76 by .58 inch. Two broods, and sometimes three, are reared in the season.

The habits of this and the succeeding species so much resemble those of the preceding, that it is difficult to describe either so that they may be readily recognized. The present bird is more civilized in its habits, and usually resides much nearer the habitations of man than tlie others; but in other respects it resembles them in all their characteristics.

\section{COTURNICULUS, BONAPARTE.}

Coterniculus, BoNApArte, Geog. List (1838). (Type Fringilla passerina, Wils.) Bill very large and stout; the under mandible broader, but lower than the upper, which is considerably convex at the basal portion of its upper outline; legs moderate, apparently not reaching to the end of the tail; the tarsus appreciably longer 
than the middle toe; the lateral toes equal, and with their claws falling decidedly short of the middle claw; the hind toe intermediate between the two; the wings are short and rounded, reaching to the base of the tail; the tertiaries almost as long as the primaries; not much difference in the lengths of the primaries, although the outer three or four are slightly graduated; the tail is short and narrow, decidedly shorter than the wing, graduated laterally, but slightly emarginate; the feathers all lanceolate and acute, but not stiffened, as in Ammodromus.

The upper parts generally are streaked; the blotches on the interscapular. region very wide; the breast and sides are generally streaked more or less distinctly; the edge of the wing is yellow.

\section{COTURNICULUS PASSERINUS. - Bonaparte.}

\section{The Yellow-winged Sparrow.}

Fringilla passerina, Wilson. Am. Orn., III. (1811) 76. Aud. Orn. Biog., II (1834) $180 ;$ V. 497.

Coturniculus passerina, Bonaparte. List (1838).

Fringilla Savanarum (Gmelin), Nuttall. Man., I. (1832) 494. Ib. (2d ed., 1840), 570 .

\section{DESCRIPTION.}

Feathers of the upper parts brownish-rufous, margined narrowly and abruptly with ash-color; reddest on the lower part of the back and rump; the feathers all abruptly black in the central portion; this color visible on the interscapular region, where the rufous is more restricted; crown blackish, with a central and superciliary stripe of yellowish tinged with brown, brightest in front of the eye; bend of the wing bright-yellow; lesser coverts tinged with greenish-yellow; quills and tail feathers edged with whitish; tertiaries much variegated; lower parts brownishyellow, nearly white on the middle of the belly; the feathers of the upper breast and sides of the body with obsoletely darker centres.

Length, about five inches; wing, two and forty one-hundredths inches; tail, two inches.

The young of this species has the upper part of the breast streaked with black, much more distinct than in the adult, and exhibiting a close resemblance to $C$. Henslowi.

Specimens from the Far West have the reddish of the back considerably paler; the light stripe on the head, with scarcely any yellow; a decided spot in front of the eye quite yellow.

This bird is irregularly distributed. In Massachusetts it is rare near the seacoast, but in the western part is an "abundant summer visitant; arrives about the first week in May, and leaves in autumn the earliest of the Sparrows." - Allen. It is not included in Mr. Verrill's list of Maine birds; and I have never met with it in that State or the other two northern ones, although it probably occurs there, 
but not abundantly. The nest is built, like the two preced ing species, on the ground, in the same localities, and of the same materials; but the eggs are different, being pure-white in color, with thinly scattered spots of reddish-brown: they are usually five in number, and their dimensions vary from .78 by .60 to .74 by .58 inch. Two broods are often reared in the same season. Its habits are similar to those of the Savannah Sparrow.

\section{COTURNICULUS HENSLOWI. - Bonaparte.}

\section{Henslow's Bunting.}

Emberiza Henslowi, Audubon. Orn. Biog., I. (1831) 360. Nutt. Man., I. (1832) App.

Coturniculus Henslowi, Bonaparte. List (1838). Ib., Consp. (1850), 481.

Fringilla Henslowi, Nuttall. Man., I. (2d ed., 1840) 571.

\section{Description.}

Upper parts yellowish-brown; the head, neck, and upper parts of back tinged with greenish-yellow; interscapular feathers dark-brown, suffused externally with bright brownish-red; each feather with grayish borders; tertiaries, rump, and tail feathers abruptly dark-brown centrally, the color obscurely margined with dark-red; crown with a broad black spotted stripe on each side, these spots continued down to the back; two narrow black maxillary stripes on each side the head, and an obscure black crescent behind the auriculars; under parts light brownish-yellow, paler on the throat and abdomen; the upper part of the breast, and the sides of the body, conspicuously streaked with black; edge of wing yellow; a strong tinge of pale-chestnut on the wings and tail.

Length, five and twenty-five one-hundredths inches; wing, two and fifteen onehundredths inches; tail, two and fifteen one-hundredths inches.

This bird is a rare summer resident in Nerr England as far north as Massachusetts, in which state it probably breeds regularly in certain localities. A nest found in Berlin, Mass., by Mr. E. S. Wheeler, contained four eggs. Mr. Allen says that "this species must still be considered a rare summer visitor, though it proves more common than was supposed a few years since."

Individuals are occasionally found in the eastern part of the state, and their nests discovered. Mr. Maynard conjectures that it may have been confounded with the yellowwinged sparrow by some collectors. 


\section{AMMODROMUS, SWAINSON.}

Ammodromus, Swaisson, Zool. Jour., III. 1827. (Type Oriolus caudacutus, Gmelin.)

Bill very long, slender, and attenuated, considerably curved towards the tip above; the gonys straight; the legs and toes are very long, and reach considerably beyond the tip of the short tail; the tarsus is about equal to the elongated middle toe; the lateral toes equal, their claws falling considerably short of the base of the midcle one; the hind claw equal to the lateral one; wings short, reaching only to the base of the tail; much rounded; the secondaries and tertials equal, and not much shorter than the primaries; the tail is short, and graduated laterally, each feather stiffened, lanceolate, and acute.

Color. - Streaked above and across the breast; very faintly on the sides.

\section{AMMODROMUS CAUDACUTUS. - Swainson.}

\section{The Sharp-tailed Finch.}

Oriolus caudacutus. Gm., I. (1788) 394.

Fringilla caudacuta, Wilson. Am. Orn., IV. (1811) 70. Aud. Orn. Biog., II. (1834) 281; V. 499.

Ammodromus caudacutus, Swainson. Birds, II. (1837) 289.

Fringilla litloralis, Nuttall. Man., I. (1832) 504 (2d ed., 1840, 590).

\section{DESCRIPTION.}

Upper parts brownish-olivaceous; head brownish, streaked with black on the sides, and a broad central stripe of ashy; back blotched with darker; a broad superciliary and maxillary stripe, and a band across the upper breast buff-yellow; the sides of the throat with a brown stripe; the upper part of the breast and the sides of the body streaked with black; rest of under parts white; edge of wing yellowish-white.

The young is of a more yellowish tinge above and below; the streaks on the back more conspicuous; the scapular feathers without the whitish edging.

Length, five inches; wing, two and thirty one-hundredths inches.

Hab. - Atlantic Coast of the United States.

Massachuisetts seems to be the northern limit of this species. In this State and those south, it is not uncommon; but it is confined to the districts in the neighborhood of the coast, and is never found more than a mile or two from those localities in the breeding season. About the last week in May, the nest is built: this is placed in a tussock of grass above the tide-marks, and is constructed of coarse grasses, which are woven into a strong fabric, and lined with finer grasses and seaweed. The eggs are generally five in 
number. Their color is a bluish-white, which is covered with fine brown dots: these dots are coarser in some specimens, and almost confluent near the greater end. Dimensions vary from .80 by .64 inch to .76 by .60 inch. But one brood is generally reared in the season in this latitude.

The description, by Wilson, of the habits of the Seaside Finch is so applicable to this species, that I give it here: "It inhabits the low, rush-covered sea islands along our Atlantic Coast, where I first found it; keeping almost continually within the boundaries of tide-water, except when long and violent east and north-easterly storms, with high tides, compel it to seek the shore. On these occasions, it courses along the margin, and among the holes and interstices of the weeds and sea-wrack, with a rapidity equalled only by the nimblest of our Sand-pipers, and very much in their manner. At these times, also, it roosts on the ground, and runs about after dusk.

"This species derives its whole subsistence from the sea. I examined a great number of individuals by dissection, and found their stomachs universally filled with fragments of shrimps, minute shell-fish, and broken limbs of small sea-crabs. Its flesh, also, as was to be expected, tasted of fish, or what is usually termed sedgy. Amidst the recesses of these wet sea-marshes, it seeks the rankest growth of grass and seaweed, and climbs along the stalks of the rushes with as much dexterity as it runs along the ground, which is rather a singular circumstance, most of our climbers being rather awkward at running."

\section{AMMODROMUS MARITIMUS. - Swainson.}

The Seaside Finch.

Fringilla maritima, Wilson. Am. Orn., IV. (1811)68. Aud. Orn. Biog., I. (1831). Ammodromus maritimus, Swainson. Zool. Jour., III. (1827) 328.

Fringilla (Ammodromus) maritima, Nuttall. Man., I. (2d ed., 1840) 592.

Fringilla Macgillivrayi, Audubon. Orn. Biog., II. (1834) 285; IV. (1838) 394; V. (1839) 499.

Fringilla (Ammodromus) Macgillivrayi, Nuttall. Man., I. (2d ed., 1840) 593. 


\section{DESCRIPTION.}

Above olivaceous-brown; beneath white; the breast and sides of body yellowishbrown, obsoletely streaked with plumbeous; sides of head and body, a central stripe on the head above, a maxillary stripe, and indistinct longitudinal streaks on the breast, ashy-brown; the sides and the breast tinged with yellowish; the maxilary stripe cuts off a white one above it; a superciliary stripe is bright-yellow anterior to the eye, and plumbeous above and behind it; edge of wing yellow; bill blue.

Length, about six inches; wing, two and fifty one-hundredths inches.

This bird's habits and distribution are the same as those of the preceding species, as also are the nests and eggs, which are impossible of identification when placed side by side.

\section{ZONOTRICHLA, SWAINSON.}

Zonotrichia, Swazwsox, Fauna Bor. Am., II. (1831). (Type Emberiza leucophrys.)

Body rather stout; bill conical, slightly notched, somewhat compressed, excavated inside; the lower mandible rather longer than the upper; gonys slightly convex; commissure nearly straight; feet stout; tarsus rather longer than middle toe; the lateral toes very nearly equal; hind toe longer than the lateral ones, their claws just reaching to base of middle one; inner claw contained twice in its toe proper; claws all slender and considerably curved; wings moderate, not reaching to the middle of the tail, but beyond the rump; secondaries and tertials equal and considerably less than longest primaries; second and third quills longest; first about equal to the fith, much longer than tertials; tail rather long, moderately rounded; the feathers not very broad; buck streaked; rump and under parts immaculate; head black, or with white streaks, entirely different from the back.

\section{ZONOTRICHIA LEUCOPHRYS, - Swainson.}

The White-crowned Sparrow.

Emberiza leucophrys, Forster. Philos. Trans., LXII. (1772) 382, 426. Wils. Am. Orn., IV. (1811) 49.

Fringilla (Zonotrichia) leucophrys, Swainson. F. B. Am., II. (1831) 255.

Fringilla leucophrys, Audubon. Orn. Biog., II. (1834) 88; V. 515.

\section{DESCRIPTION。}

Head above, upper half of loral region from the bill, and a narrow line through and behind the eye to the occiput, black; a longitudinal patch in the middle of the srown, and a short line from above the anterior corner of the eye, the two confluent on the occiput, white; sides of the head, fore part of breast, and lower neck all -ound, pale-ash, lightest beneath and shading insensibly into the whitish of the belly and chin; sides of belly and under tail coverts tinged with yellowish-brown; interscapular region streaked broadly with dark chestnut-brownish; edges of the tertiaries brownish-chestnut; two white bands on the wing. 
- Female similar, but smaller; immature male with the black of the head replaced by dark chestnut-brown, the white tunged with brownish-yellow.

The white of the crown separates two black lines on either sides, rather narrower than itself; the black line behind the eye is continued anterior to it into the black at the base of the bill; the lower eyelid is white; there are some obscure cloudings of darker on the neck above; the rump is immaculate; no white on the tail, except very obscure tips; the white crosses the ends of the middle and greater coverts.

Length, seven and ten one-hundredths inches; wing, three and twenty-five onehundredths.

This beautiful bird is a rare spring and autumn visitor in New England. It arrives about the first week in May, sometimes as late as the 20th of that month, and returns from the North about the 10th of October. While with us, it has all the habits of the succeeding species, with which it usually associates.

The following description of its breeding habits, nest, and eggs, is given by Audubon:-

"One day, while near American Harbor, in Labrador, I observed a pair of these birds resorting to a small 'hummock' of firs, where I concluded they must have had a nest. After searching in vain, I intimated my suspicion to my young friends, when we all crept through the tangled branches, and examined the place without success. . . . Our disappointment was the greater, that we saw the male bird frequently flying about with food in his bill, no doubt intended for his mate. In a short while, the pair came near us, and both were shot. In the female we found an egg, which was pure-white, but with the shell yet soft and thin. On the 6 th of July, while my son was creeping among some low bushes to get a shot at some Red-throated Divers, he accidentally started a female from her nest. It made much complaint. The nest was placed in the moss, near the foot of a low fir, and was formed externally of beautiful dry green moss, matted in bunches, like the coarse hair of some quadruped; internally of very fine dry grass, arranged with great neatness to the thickness of nearly half an inch, with a full lining of delicate fibrous roots of a rich transparent yellow. It was five inches in diameter externally, two in depth; two and a quarter in diameter within, although rather oblong, and one and three-quarters deep. In one nest, we found a single feather of the Willow Grouse. The eggs, five in number, average seven-eighths 
of an inch in length, are proportionally broad, of a light sea-green color, mottled toward the larger end with brownish spots and blotches; a few spots of a lighter tint being dispersed over the whole. ... We found many nests, which were all placed on the ground or among the moss, and were all constructed alike. This species deposit their eggs from the beginning to the end of June. In the beginning of August, I saw many young that were able to fly; and, by the twelfth of that month, the birds had already commenced their southward migration. The young follow their parents until nearly full grown.

"The food of this species, while in Labrador, consists of small coleopterous insects, grass seeds, and a variety of berries, as well as some minute shell-fish, for which they frequently search the margins of ponds or the seashore. At the approach of autumn, they pursue insects on the wing to a short distance, and doubtless secure some in that manner."

The song of the White-crowned Sparrow consists of six or seven notes, the first of which is loud, clear, and musical, although of a plaintive nature; the next broader, less firm, and seeming merely a second to the first; the rest form a cadence, diminishing in power to the last note, which sounds as if the final effort of the musician. These notes are repeated at short intervals during the whole day, - even on those dismal days produced by the thick fogs of the country where it breeds, and where this species is, of all, the most abundant.

ZONOTRICHIA ALBICOLLIS. - Bonaparte.

The White-throated Sparrow; Peabody Bird.

Fringilla albicollis, Gmelin. Syst. Nat., I. (1788) 926. Wils. Am. Orn., III. (1811) 51.

Zonotrichia albicollis, Bonap. Consp. (1850), 478.

Fringilla Pennsylvanica, Audubon. Orn. Biog., I. (1831) 42; V. 497.

\section{DESCRIPTION.}

Two black stripes on the crown separated by a median one of white; a broad superciliary stripe from the base of the mandible to the occiput, yellow as far as the middle of the eye and white behind this; a broad black streak on the side of the 
head from behind the eye; chin white, abruptly defined against the dark-ash of the sides of the head and upper part of the breast, fading into white on the belly, and margined by a narrow black maxillary line; edge of wing and axillaries yellow; back and edges of secondaries rufous-brown, the former streaked with dark-brown; two narrow white bands across the wing coverts.

Female smaller, and the colors rather duller. Immature and winter specimens have the white chin-patch less abruptly defined; the white markings on the top and sides of the head tinged with brown. Some specimens, apparently mature, show quite distinct streaks on the breast, and sides of throat and body.

Length, seven inches; wing, three and ten one-hundredths; tail, three and twenty one-hundredths inches.

This beautiful Sparrow arrives in Massachusetts by the last week in April. It does not tarry long, but passes north, and breeds abundantly in the northern districts of

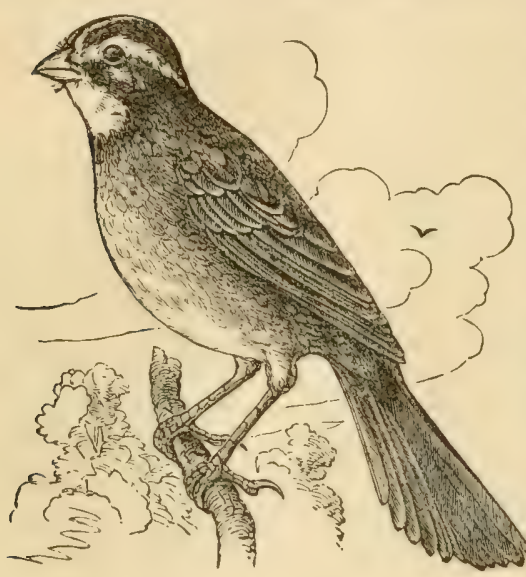
New England. I have found the nests as early as the last week in May; but generally they are not built before the 10th of June. They are placed under a low bush on the ground, sometimes in swamps and pastures, sometimes in high woods and ledges. They are constructed of fine grasses, twigs, and mosses, and lined with finer grasses, and sometimes a few hair-like roots. Some specimens that I have collected in Northern Maine were placed in a hollow in a mossy knoll, which was scratched by the birds to the depth of the whole nest. The eggrs are usually four in number: their color is a grayish-white, and marked with spots and confluent blotches of brown and obscure lilac. A number of specimens, collected in different localities in Maine, exhibit the following variations in size: .92 by .64 inch, .92 by .60 inch, .90 by .62 inch, .86 by .62 inch. But one brood is reared in the season. This 
bird is a great farorite in the North, and justly so. It is one of the sweetest songsters of the localities where it is found; and, having no bad precedents with the farmer, and being of a sociable, lively disposition, it is no wonder that it meets with great favor.

The song of this species is very beautiful. It is difficult of description, but resembles nearly the syllables 'chéa dêe de; $d \hat{e}-d-d e,-d \hat{e}-d-d e, d \hat{e}-d-d e, d \hat{e}-d-d e$, uttered at first loud and clear, and rapidly falling in tone and decreasing in volume.

This is chanted during the morning and the latter part of the day, and, in cloudy weather, through the whole day. I have often heard it at different hours of the night, when I have been encamped in the deep forests; and the effect, at that time, was indescribably sweet and plaintive. The fact that the bird often sings in the night has given it the name of the "Nightingale" in many localities; and the title is well earned.

While in its spring and autumn migrations, this Sparrow prefers low moist thickets and young woods; but, in its summer home, it is found equally abundant in fields, pastures, swamps, and forests.

It feeds on insects, various seeds, and berries, and sometimes pursues flying insects in the mamner of the preceding species.

About the last week in October; the birds, after congregating in loose flocks of a dozen or fifteen, leave New England for their winter homes.

\section{JUNCO, WAgLER.}

Junco, Wagler, Isis (1831). (Type Fringilla cinerea, Sw.)

Bill small, conical; culmen curved at the tip; the lower jaw quite as high as the upper; tarsus longer than the middle toe; outer toe longer than the inner, barely reaching to the base of the middle claw; hind toe reaching as far as the middle of the latter; extended toes reaching about to the middle of the tail; wings rather short, reaching over the basal fourth of the exposed surface of the tail; primaries, however, considerably longer than the nearly equal secondaries and tertials; the second quill longest, the third to fifth successively but little shorter; first longer than sixth, much exceeding secondaries; tail moderate, a little shorter than the wings; 
slightly emarginate and rounded; feathers rather narrow, oval at the end; no streaks on the head or body; color above uniform on the head, back, or rump, separately or on all together; beliy white; cuter tail feathers white.

The essential characters of this genus are, the middle toe rather shorter than the short tarsus; the lateral toes slightly unequal, the outer reaching the base of the middle claw; the tail a little shorter than the wings, slightly emarginate. In Junco cinereus the claws are longer; the lower mandible a little lower than the upper; the species have the upper parts ashy or plumbeous, the belly and lateral tail feathers white.

\section{JUNCO HYEMALIS. - Sclater.}

The Snowbird.

Fringilla hyemalis, Linnæus. Syst. Nat., I. (10th ed., 1758) 183. Aud. Orn. Biog., I. (1831) $72 ;$ V. 505 .

Junco hyemalis, Sclater. Pr. Zool. Soc. (1857), 7.

Fringilla nivalis. Wils., II. (1810) 129.

\section{DESCRIPTION.}

Everywhere of a grayish or dark ashy-black, deepest anteriorly; the middle ot the breast behind and of the belly, the under tail coverts, and first and second external tail feathers, white; the third tail feather white, margined with black.

Length, six and twenty-five one-hundredths inches; wing, about three inches.

This interesting and well-known little species is an abun

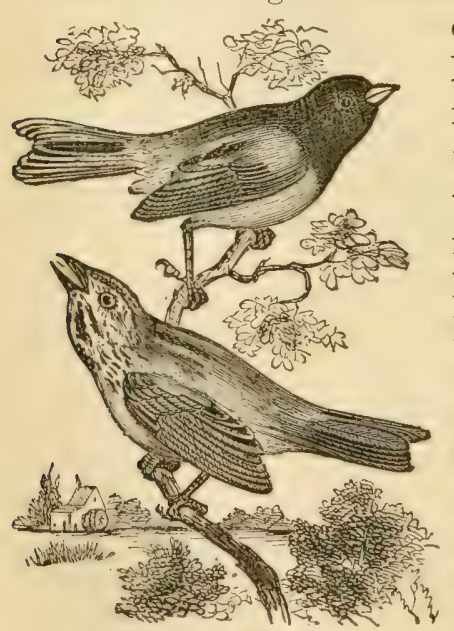

Snowbird, upper fig. Song Sparrow, lower fig. dant inhabitant of New England. In the spring it migrates from the southern districts, where it spends the winter, to the northern sections, and late in fall returns to its winter home. A few pairs breed in Massachusetts on the Holyoke Mountains, and in New Hampshire on the White Mountains: but the great numbers pass to the northern districts to spend the summer; and near the Umbagog lakes, and north to the Canada frontier, it is the most common species. I have been so fortunate as to find a number of the nests: some had eggs as early as the last week in May, and others as late as the 
middle of July; therefore two broods are probably reared. The nests are constructed of fine grasses and leares, and are placed sometimes in a slight hole scratched in a mossy knoll, sometimes in an old stump of a tree or in a tuft of grass in a thicket of bushes. The eggs are usually four in number: they vary in color from nearly pure-white with reddish spots, to grayish-white with reddish-brown spots, and bluish-white with a roseate tint and spots of umber, reddishbrown, and lilac. Dimensions vary from .76 by .60 inch to .70 by .56 inch.

The description by Wilson of the habits of this species is so full and accurate that I can do no better than give it here:-

"This well-known species, small and insignificant as it may appear, is by far the most numerous, as well as the most extensively disseminated, of all the feathered tribes that visit us from the frozen regions of the North, - their migrations extending from the arctic circle, and probably beyond it, to the shores of the Gulf of Mexico, spreading over the whole breadth of the United States, from the Atlantic Ocean to Louisiana; how much farther westward, I am unable to say. About the 20th of October, they make their first appearance in those parts of Pennsylvania east of the Alleghany Mountains. At first they are most generally seen on the borders of woods among the falling and decayed leaves, in loose flocks of thirty or forty together, always taking to the trees when disturbed. As the weather sets in colder, they approach nearer the farm-house and villages; and, on the appearance of what is usually called falling weather, assemble in larger flocks, and seem doubly diligent in searching for food. This increased activity is generally a sure prognostic of a storm. When deep snows cover the ground, they become almost half domesticated. They collect about the barn, stables, and other out-houses, spread over the yard, and even round the steps of the door, not only in the country and villages, but in the heart of our large cities; crowding around the threshold early in the morning, gleaning up the crumbs ; appearing very lively and familiar. They have also recourse, at this severe season, when the face of the earth is shut up from them, to the seeds of many 
kinds of weeds that still rise above the snow in corners of fields, and low, sheltered situations, along the borders of creeks and fences, where they associate with several other species of Sparrows. They are, at this time, easily caught with almost any kind of trap; are generally fat, and, it is said, are excellent eating.

"I cannot but consider this bird as the most numerous of its tribe of any within the United States. From the northern parts of the District ${ }^{1}$ of Maine to the Ogeechee River in Georgia, - a distance, by the circuitous route in which I travelled, of more than eighteen hundred miles, - I never passed a day, and scarcely a mile, without seeing numbers of these birds, and frequently large flocks of several thousands. Other travellers with whom I conversed, who had come from Lexington, in Kentucky, through Virginia, also declared that they found these birds numerous along the whole rotd. It should be observed, that the roadsides are their favorite haunts, where many rank weeds that grow along the fences furnish them with food, and the road with, gravel. In the vicinity of places where they were most numerous, I observed a Small Hawk, and several others of his tribe, watching their opportunity, or hovering cautiously around, making an occasional sweep among them, and retiring to the bare branches of an old cypress to feed on their victims. In the month of April, when the weather begins to be warm, they are observed to retreat to the woods, and to prefer the shaded sides of hills and thickets; at which time, the males warble out a few very low, sweet notes, and are almost perpetually pursuing and fighting with each other. About the 20th of April, they take their leave of our humble regions, and retire to the North and to the high ranges of the Alleghany to build their nests and rear their young. In some of those ranges, in the interior of Virginia, and northward, about the waters of the west branch of the Susquehanna, they breed in great numbers. The nest is fixed in the ground, or among the grass; sometimes several being within a small distance of each other. According to the observations of the gentlemen residing at HudsonBay Factory, they arrive there about the beginning of June, stay a week or two, and proceed farther north to breed. They return to that settlement in the autumn, on their way to the South.

1 Now State 
"In some parts of New England, I found the opinion pretty general, that the Snowbird, in summer, is transformed into the Small Chipping Sparrow, which we find so common in that season. I had convinced a gentleman of New York of his mistake in this matter, by taking him to the house of a Mr. Gautier there, who amuses himself by keeping a great number of native as well as foreign birds. This was in the month of July; and the Snowbird appeared then in the same colored plumage he usually has. Several individuals of the Chipping Sparrow were also in the same apartment. 'The evidence was, therefore, irresistible; but, as I had not the same proofs to offer to the eye in New England, I had not the same success.

"There must be something in the temperature of the blood or constitution of this bird, which unfits it for residing, during summer, in the lower parts of the United States, as the country here abounds with a great variety of food, of which, during its stay, it appears to be remarkably fond. Or perhaps its habit of associating in such numbers to breed, and building its nest with so little precaution, may, to insure its safety, require a solitary region, far from the intruding footsteps of man."

\section{SPIZELLA, Bonaparte.}

Spizella, Bowaparte, Geog. and Comp. List (1838). (Type Fringilla Canadensis, Lath.)

Bill conical, the outlines slightly curved; the lower mandible decidedly lower than the upper; the commissure gently sinuated; the roof of the mouth not knobbed; feet slender; tarsus rather longer than the middle toe; the hinder toe a little longer than the outer lateral, which slightly exceeds the inner; the outer claw reaching the base of the middle one, and half as long as its toe; claws moderately curved; tertiaries and secondaries nearly equal; wing somewhat pointed, reaching not quite to the middle of the tail; first quill a little shorter than the second and equal to the fifth, third longest; tail rather long, moderately forked, and divaricated at the tip; the feathers rather narrow; back streaked; rump and beneath immaculate; hood generally, uniform.

The genus differs from Zonotrichia in the smaller size, and longer and forked instead of rounded tail.

SPIZELLA MONTICOLA. - Baird.

The Tree Sparrow.

Fringilla monticola, Gmelin. Syst. Nat., I. (1788) 912.

Fringilla Canadensis, Audubon. Orn. Biog., II. (1834) 511; V. 504.

Fringilla arborea, Wilson. Am. Orn., II. (1810) 12. 


\section{Description.}

Middle of back with the weathers dark-brown centrally, then rufous, and edgerl with pale-fulvous (sometimes with whitish). Hood and upper part of nape continuous chestnut; a line of the same from behind the eye; sides of head and neck ashy; a broad light supereiliary band; beneath whitish, with a small circular bloteh of brownish in the middle of the upper part of the breast; edges of tail feathers, primary quills, and two bands across the tips of the secondaries, white; tertiaries nearly black; edged externally with rufous, turning to white near the tips; lower jaw yellow ; upper black.

This species varies in the amount of whitish edging to the quills and tail.

Length, six and twenty-five one-hundredths inches; wing, three inches.

Hab. - Eastern North America to the Missouri; also on Pole Creek and Little Colerado River, New Mexico.

This species occurs in New England only as a winter visitor. It arrives from the North about the last of October, and remains in swamps and sheltered thickets through the winter, and until the first week in May. While with us, it is gregarious, and often visits stubble-fields and gardens, where it feeds upon the seeds of grasses and various weeds. It has, at this season, a persistent twitter, which is uttered by all the members of the flock at short intervals. As it sometimes utters a sweet soft warble in the spring, it undoubtedly possesses quite a song during the mating season.

It is not impossible that this bird sometimes breeds in the most northern sections of these States; but there is no authenticated instance on record of its doing so. The bird alluded to in the "Proceedings of the Boston Society of Natural History" (vol. V. p. 213) was undoubtedly the Chipping Sparrow.

The Tree Sparrow breeds, according to Mr. Hutchins, around the Hudson's Bay settlements. "Its nest is placed in the herbage, is formed externally of mud and dry grass, and lined with soft hair or down, - probably from plants, - in the manner of the Yellow-bird." The eggs are about five in number: they are of a light grayish-blue color, and are marked with spots and blotches of two shades of brown and red. To compare them with anothier species, I would say that they almost exactly resemble small specimens of the eggs of the common Song Sparrow. They are 
orate or ovoidal in form, and average about .73 by 56 inch in dimensions.

SPIZELLA PUSILLA. - Bonaparte.

The Field Sparrow.

Fringilla pusilla, Wilson. Am. Orn., II. (1810) 121; Aud. Orn. Biog., II. (1834) 299.

Spizella pusilla, Bonaparte. List (1838).

Fringilla juncorum, Nuttall. Jan., I. (1832) 499. Ib. (2d ed., 1840), 577.

\section{DESCRIPTION.}

Bill red; crown continuous rufous-red; back somewhat similar, streaked with blackish; sides of head and neck (including a superciliary stripe) ashy; ear coverts rufous; beneath white, tinged with yellowish anteriorly; tail feathers and quills faintly edged with white; two white bands across the wing coverts.

This species is about the size of $S$. socialis, but is more rufous above; lacks the black forehead and eye-stripe; has chestnut ears instead of ash; has the bill red instead of black; lacks the clear ash of the rump; has a longer tail, \&c. It is more like Monticola, but is much smaller; lacks the spot on the breast and the predominance of white on the wings, \&c. The young have the breast and sides streaked.

Length, about five and seventy-five one hundredths inches; wing, two and thirtyfour one hundredths inches.

$H a b$. - Eastern North America to the Missouri River.

This bird makes its appearance about the first week in April, 'in Massachusetts, and soon scatters throughout New England. It prefers dry bushy pastures and low open woods, and is seldom found in the near vicinage of human habitations.

The male sings during the season of incubation, and, indeed, through nearly all the summer: mounted on a low tree or fence-rail, he utters his pleasing yet plaintive ditty at early morning and evening, and, in dark and cloudy weather, through the whole day. The song is a peculiar warble, something like the syllables, 'te 'de 'de 'de 'de'de'de ' $d$ ' $d$ ' $d d r$, uttered at first low, and rapidly increasing, and then decreasing in tone to a faint chatter, something like the twitter of the Chipping Sparrow.

About the middle of May, the first nest is built. It is con structed of stalks of dried grass and fine twigs, is loosely put together, and placed usually on the ground beneath a 
bush, sometimes in a bush : it is lined with fine grass and horsehairs. The egg's are usually four in number: they are of a grayish-white color, with thinly scattered spots and blotches of reddish-brown and lavender; and their dimensions vary from .72 by .52 to .70 by .50 inch. Two broods are reared in the season.

Early in September, these birds collect in loose flocks, when they have all the habits and notes of the Tree Sparrow. In October, they all leave New England for the South.

\section{SPIZELLA SOCIALIS. - Bonaparte.}

The Chipping Sparrow; Hair-bird.

Fringilla socialis, Wilson. Am. Orn., II. (1810) 127; Aud. Orn. Biog., II. (1834) 21; V. 517.

Spinites socialis, Cabanis. Mus. Hein. (1851), 133.

\section{DESCRIPTION.}

Rump, back of neck, and sides of neck and head, ashy; interscapular region with black streaks, margined with pale-rufous; crown continuous and uniform chestnut; forehead black, separated in the middle by white; a white streak over the eye, and a black one from the base of the bill through and behind the eye; under parts unspotted whitish, tinged with ashy, especially across the upper breast; tail feathers and primaries edged with paler, not white; two narrow white bands across the wing coverts; bill black.

Length, five and seventy-five one-hundredths inches; wing, nearly three inches.

Hab. - North America, from Atlantic to Pacific.

This very common and well-known little species makes its appearance in Massachusetts sometimes as early as the 25th of March, ${ }_{1}^{1}$ usually about the 5th of April, and spreads throughout New England. The habits are so well known that any description here is superfluous.

About the fifteenth of May, the nest is built. It is placed in an apple-tree in the orchard, or in a lilac-bush under the windows of a dwelling-house; and I found nests in low juniper bushes in the deep woods in Maine. It is

1 I am indebted for the time of the arrival of this and of many other birds to Mr. H. A. Purdie, of Boston, who has kindly furnished me with full and copious notes and memoranda on the arrival of species, which are of value, having been conducted for several years. 
constructed of fine twigs and roots and grasses, and is almost invariably lined with horsehairs; hence its name, in some localities, of "Hair-bird," "Hair Sparrow." The eggs are usually five in number. Their color is a bluish-green; and they are marked with spots and lines of black and obscurebrown, which are thickest at the great end: some specimens have these spots confluent into a sort of ring. The dimensions vary from .74 by .50 to .70 by .48 inch. This species is the most often chosen by the parasitic Cow-bird as a parent for its young; and many ornithologists account by this fact for its persistent familiarity with man.

About the middle of October, the old and young birds gather into small flocks, and proceed leisurely on the southern migration.

\section{MELOSPIZA, BAIRD.}

Body stout; bill conical, very obsoletely notched or smooth, somewhat compressed; lower mandible not so deep as the upper; commissure nearly straight; gonys a little curved; feet stout, not stretching beyond the tail; tarsus a little longer than the middle toe; outer toe a little longer than the inner, its claw not quite reaching to the base of the middle one; hind toe appreciably longer than the middle one; wings quite short and rounded, scarcely reaching beyond the base of the tail; the tertials considerably longer than the secondaries; the quills considerably graduated; the fourth longest; the first not longer than the tertials, and almost the shortest of the primaries; tail moderately long, and considerably graduated; the feathers oval at the tips; crown and back similar in color and streaked; beneath thickly streaked; tail immaculate.

This genus differs from Zonotrichia in shorter, more graduated tail, rather longer hind toe, much more rounded wing, which is shorter; the tertiaries longer; the first quill almost the shortest, and not longer than the tertials. The under parts are spotted; the crown streaked and like the back.

\section{MELOSPIZA MELODIA.-Baird.}

\section{The Song Sparrow.}

Fringilla melodia, Wilson. Am. Orn., II. (1810) 125; Aud. Orn. Biog., I. (1832) $126 ;$ V. 507 .

\section{DEscription.}

General tint of upper parts rufous-brown, streaked with dark-brown and ashygray; the crown is rufous, with a superciliary and median stripe of dull-gray, the former lighter; nearly white anteriorly, where it has a faint shade of yellow; each feather of the crown with a narrow streak of dark-brown; interscapulars darkbrown in the centre, then rufous, then grayish on the margin; rump grayer than 
upper tail coverts, both with obsolete dark streaks; there is a whitish maxillary stripe, bordered above and below by one of dark rufous-brown, with a similar one from behind the eye; the under parts are white; the breast and sides of body and throat streaked with dark-rufous, with a still darker central line; on the middle of the breast, these marks are rather aggregated so as to form a spot; no distinct white on tail or wings.

Specimens vary somewhat in having the streaks across the breast more or less sparse; the spot more or less distinct. In autumn, the colors are more blended, the light maxillary stripe tinged with yellowish, the edges of the dusky streaks suffused with brownish-rufous.

The young bird has the upper parts paler, the streaks more distinct, the lines on the head scarcely appreciable. The under parts are yellowish; the streals narrower and more sharply defined dark-brown.

Length of male, six and fifty one-hundredths inches; wing, two and fifty-eight one-hundredths; tail, three inches.

Hab. - Eastern United States to the high central plains.

This beautiful songster is one of the most common and well-known of our summer visitors. It arrives from about the first week in March to the middle of that month. On its first appearance, it prefers the low thickets and bushy woods, where, at all hours of the day, it chants its beautiful song. It is somewhat gregarious at this time, and is usually found in flocks of half a dozen individuals. It soon commences mating; and, after a short season of courtship, both birds begin building their first nest. This is about the middle of April, sometimes earlier; and I have found the nest with eggs when there was an inch or two of snow on the ground. The nest is usually built on the ground, sometimes in a low bush, and occasionally in low trees: it is constructed of stalks and leaves, of grasses and weeds, and is lined with softer grasses and fine weeds. The eggs are four or five in number, and they are subject to great variations in form and markings: they exhibit all the changes from grayish to bluish-white, with spots, thinly scattered, of reddish-brown, to confluent blotches of umber-brown, thickest at the greater end. Their dimensions vary from .94 by .64 to .78 by .62 inch. Four eggs in one nest measure .94 by $.64, .84$ by $.66, .80$ by $.58, .78$ by .62 . inch. Two broods, and sometimes three, are reared in the season. 
There has been considerable discussion among ornithologists regarding this bird; and many are of the belief, that, from its irregular habits, there are two species found in New England. I have examined with great care many specimens, and have attentively observed their habits, and think that it yet remains to be proved that we have more than one species. Late in October, this species assembles in small detached flocks, and leaves New England for its southern home.

\section{MELOSPIZA PALUSTRIS. - Baird.}

The Swamp Sparrow.

Fringilla palustris, Wilson. Am. Orn., III. (1811) 49. Aud. Orn. Biog., I. (1831) 331; V. 508.

Fringilla (Ammodromus) Georgiana, Nuttall. Man., I. (2d ed., 1840) 588.

\section{DESCRIPTION。}

Middle of the crown uniform chestnut; forehead black; superciliary streak, sides of head and back and sides of neck, ash; a brown stripe behind the eye; back broadly streaked with black; beneath whitish, tinged with ashy anteriorly, especially across the breast, and washed with yellowish-brown on the sides; a few obsolete streaks across the breast, which become distinct on its sides; wings and tail strongly tinged with rufous; the tertials black, the rufous edgings changing abruptly to white towards the end.

Female with the crown scarcely reddish streaked with black, and divided by a light line.

In autumn the male of this species has the feathers of the crown each with a black streak; and the centre of the crown with an indistinct light stripe, materially changing its appearance.

The forehead is usually more or less streaked with black.

Length, five and seventy-five one-hundredths inches; wing, two and forty onehundredths inches.

$H a b$. - Eastern United States from the Atlantic to the Missouri.

This bird, although not rare, is not so common as the preceding. It is about equally distributed throughout New England, and breeds in all these States. It arrives from the South about the first week in April in Massachusetts; in Maine, about a fortnight later. It prefers the swampy localities to all others, and is seldom found at any distance from such places. The nest is built about the 10th of May. It is constructed of leaves of grass and fine hair-like roots, 
and lined with finer of the same: these are adjusted into a loose fabric, and placed in or beneath a tussock of grass in a swamp. I have known of instances of its being found in a low barberry-bush; but such cases are extremely rare, and form exceptions to the rule. The eggs are four or five in number: their color is a grayish-white, with sometimes a bluish tint, and marked with thinly scattered spots of brown over the entire surface, except a circle around the greater end, where they are confluent, and hide the primary color. Dimensions of a number in my cabinet vary from .80 by .58 to .76 by .54 inch. Two broods are reared in the season.

Wilson, in describing the general habits of this species, says, -

"It is one of our summer visitants, arriving in Pennsylvania early in April ; frequenting low grounds and river courses; rearing two, and sometimes three, broods in a season; and returning to the South as soon as the cold weather commences. The immense cypress swamps and extensive grassy flats of the Southern States, that border their numerous rivers, and the rich rice plantations, abounding with their favorite seeds and sustenance, - appear to be the general winter resort and grand annual rendezvous of this and all the other species of Sparrow that remain with us during summer. From the river Trent in North Carolina to that of Savannah, and still farther south, I found this species very numerous; not flying in flocks, but skulking among the canes, reeds, and grass, seeming shy and timorous, and more attached to the water than any other of their tribe. In the month of April, numbers pass through Pennsylvania to the northward; which I conjecture from the circumstance of finding them at that season in particular parts of the woods, where, during the rest of the year, they are not to be seen. The few that remain frequent the swamps and reedy borders of our creeks and rivers. They form their nest in the ground, sometimes in a tussock of rank grass surrounded by water, and lay four eggs, of a dirty-white, spotted with rufous. So late as the 15th of August, I have seen them feeding their young that were scarcely able to fly. Their principal food is grass seeds, 
wild oats, and insects. They have no song ; are distinguished by a single chip or cheep, uttered in a rather hoarser tone than that of the Song Sparrow; flirt the tail as they fly; seldom or never take to the trees, but skulk from one low bush or swampy thicket to another."

\title{
Sub-Family Passerelline. - The Buntings.
}

Toes and claws very stout; the lateral claws reaching beyond the middle of the middle one; all very slightly curved.

Bill conical, the outlines straight; both mandibles equal; wings long, longer than the even tail, reaching nearly to the middle of its exposed portion; hind claw longer than its digit; its toe nearly as long as the middle toe; tarsus longer than the middle toe; brown above, either uniformly so or faintly streaked; triangular spots below.

PASSERELLA, SwAINSON.

\begin{abstract}
Passerella, Swarsson, Class. Birds, II. (1837) 288. (Type Fringilla iliaca, Merrem.)

Body stout; bill conical, not notched, the outlines straight; the two jaws of equal depth; roof of upper mandible deeply excavated, and vaulted, not knobbed; tarsus scarcely longer than the middle toe; outer toe little longer than the inner, its claw reaching to the middle of the central one; hind toe about equal to the inner lateral; the claws all long, and moderately curved only; the posterior rather longer than the middle, and equal to its toe; wings long, pointed, reaching to the middle of the tail; the tertials not longer than secondaries; second and third quills longest; first equal to the fifth; tail very nearly even, scarcely longer than the wing; inner claw contained scarcely one and a half times in its toe proper.

Color. - Rufous or slaty; obsoletely streaked or uniform above; thickly spotted with triangular blotches beneath.
\end{abstract}

\section{PASSERELLA ILIACA. - Swainson.}

The Fox-colored Sparrow.

Fringilla iliaca, Audubon. Orn. Biog., II. (1834) 58; V. 512.

Passerella iliaca, Swainson. Birds, II. (1837) 288.

Fringilla r'ufa, Wilson. Am. Orn., III. (1811) 53.

\section{Description.}

Middle of the back dull-ash, each feather with a large blotch of brownish-red; top of head and neck, with rump, similar, but with smaller and more obsolete blotches; upper tail coverts, with exposed surface of wings and tail, bright-rufous; beneath white, with the upper part of the breast and sides of throat and body with triangular spots of rufous, and a few smaller ones of blackish on the middle of the 
breast; inner edges of quills and tail feathers tinged with rufous-pink; no light lines on the head, but a patch of rufous on the cheeks; first quill rather less than the fifth; hind toe about equal to its claw; sometimes the entire head above is reddish, like the back.

Length, about seven and fifty one-hundredths inches; wing, three and fifty onehundredths inches.

Hab. - Eastern United States to the Mississippi.

This beautiful Sparrow is very abundant in spring and autumn in New England, arriving in spring early in March, and departing for the North by the third week in April ; and arriving in autumn from the North about the 10th of October, and departing for the South late in November. While with us, it remains in low, moist thickets and woody pastures; and occasionally risits the stubble-fields and gardens, where it busies itself in searching among the dead leaves and weeds for its food of seeds and insects. It generally has, while in New England, only a short, lisping note, occasionally a pretty warble; but it is said to have in its northern home a beautiful song, that is excelled by that of hardly any other species. Audubon, in describing the nest and eggs, says, "The nest of the Fox-colored Sparrow, which is large for the size of the bird, is usually placed on the ground, among moss or tall grass, near the stem of a creeping fir, the branches of which completely conceal it from view. Its outside is loosely formed of dry grass and moss, with a carefully disposed inner layer of finer grasses, circularly arranged; and the lining consists of very delicate fibrous roots, together with some feathers from different species of water-fowls. The period at which the eggs are laid is from the middle of June to the 5th of July. They are proportionally large, four or five in number, rather sharp at the smaller end, of a dull-greenish tint, sprinkled with irregular small blotches of brown." Their dimensions average about .86 by .62 inch. 


\section{Sub-Family Spizinæ.}

Bill variable, always large, much arched, and with the culmen considerably surved; sometimes of enormous size, and with a great development backwards of the lower jaw, which is always appreciably, sometimes considerably, broader behind than the upper jaw at its base; nostrils exposed; tail rather variable; bill generally black or red; wings shorter than in the first group; gape almost always much more strongly bristled; few of the species sparrow-like or plain in appearance; usually olue, red, or black and white; seldom (or never?) streaked beneath.

\section{EUSPIZA, BoNAPARTE.}

Euspiza, Bonaparte, List (1838). (Type Emberiza Americana, Gm.)

Bill large and strong, swollen, and without any ridges; the lower mandible nearly as high as the upper; as broad at the base as the length of the gonys, and considerably broader than the upper mandible; the edges much inflexed, and shutting much within the upper mandible; the commissure considerably angulated at the base, then decidedly sinuated; the tarsus barely equal to the middle toe; the lateral toes nearly equal, not reaching to the base of the middle claw; the hind toe about equal to the middle one without its claw; the wings long and acute, reaching nearly to the middle of the tail; the tertials decidedly longer than the secondaries, but much shorter than the primaries; first quill longest, the others regularly graduated; tail considerably shorter than the wings, though moderately long, nearly even, although slightly emarginate; the outer feathers scarcely shorter; middle of back only striped; beneath without streaks.

\section{EUSPIZA AMERICANA.-Bonaparte.}

\section{The Black-throated Bunting.}

Emberiza Americana, Gmelin. Syst. Nat., I. (1788) 872. Wils. Am. Orn., III. (1811) 86. Aud. Orn. Biog., IV. (1838) 579.

Euspiza Americana, Bonaparte. List (1838). (Type.) Tb., Consp. (1850), 469.

Euspina Americana, Cabanis. Mus. Hein. (1851), 133. (Type.)

DESCRIPTION. -

Male. - Sides of the head, and sides and back of the neck, ash; crown tinged with yellowish-green and faintly streaked with dusky; a superciliary and short maxillary line, middle of the breast, axillaries, and edge of the wing, yellow; chin, loral region, spots on sides of throat, belly, and under tail coverts white; a black patch on the throat diminishing to the breast, and a spot on the upper part of the belly; wing coverts chestnut; interscapular region streaked with black; rest of back immaculate.

F'emale with the markings less distinctly indicated; the black of the breast replaced by a black maxillary line and a streaked collar in the yellow of the upper part of the breast.

Length, about six and seventy one-hundredths inches; wing, three and fifty onehundredths inches.

$H a b$. - United States from the Atlantic to the border of the high central plains. 
This bird can be regarded only as an extremely rare summer visitor in New England, Massachusetts apparently being its northern limit. I have heard of two or three specimens being found in this State, and it is possible that others may have occurred here.

The nest of this species is placed on the ground, usually in a dry pasture or field, and most generally beneath a tuft of grass or a small bush. It is loosely constructed of grass and fine roots arranged circularly, and with a finer lining. The eggs are four in number : they are of an ovoidal shape, and are but little pointed. Their dimensions vary from .82 by .60 inch to .79 by .58 inch: their color is a delicate greenish-blue, without spots or markings.

I have had no opportunities for observing the habits of this bird, and can present nothing of value with relation to them.

\section{GUIRACA, Swainson.}

Guiraca, Swainson, Zool. Jour., III. (Nov., 1827) 350. (Type Loxia ccerulea, L.) Bill very large, nearly as high as long; the culmen curved, with a rather sharp ridge; the commissure conspicuously angulated just below the nostril, the posterior leg of the angle nearly as long as the anterior, both nearly straight; lower jaw deeper than the upper, and extending much behind the forehead; the width greater than the length of the gonys, considerably wider than the upper jaw; a prominent $\mathrm{knob}$ in the roof of the mouth; tarsi shorter than the middle toe; the outer toe a little longer, reaching not quite to the base of the middle claw; hind toe rather longer than to this base; wings long, reaching the middle of the tail; the secondaries and tertials nearly equal; the second quill longest; the first less than the fourth; tail very nearly even, shorter than the wings.

GUIRACA LUDOVICIANA. - Swainson.

The Rose-breasted Grosbeak.

Lnxia Irudoviciana, Linnæus. Syst. Nat., I. (1766) 306. Wils. Am. Orn., II. (1810) 135.

Guiraca Ludoviciana, Swainson. Phil. Mag., I. (1827) 438.

Fringilla Ludoviciana, Audubon. Orn. Biog., II. (1834) 166; V. 513.

\section{DESCRIPTION.}

Upper parts generally, with head and neck all round, glossy black; a broaa crescent across the upper part of the breast, extending narrowly down to the belly, axillaries, and under wing coverts, carmine; rest of under parts, rump, and upper tail coverts, middle wing coverts, spots on the tertiaries and inner great wing coverts, 


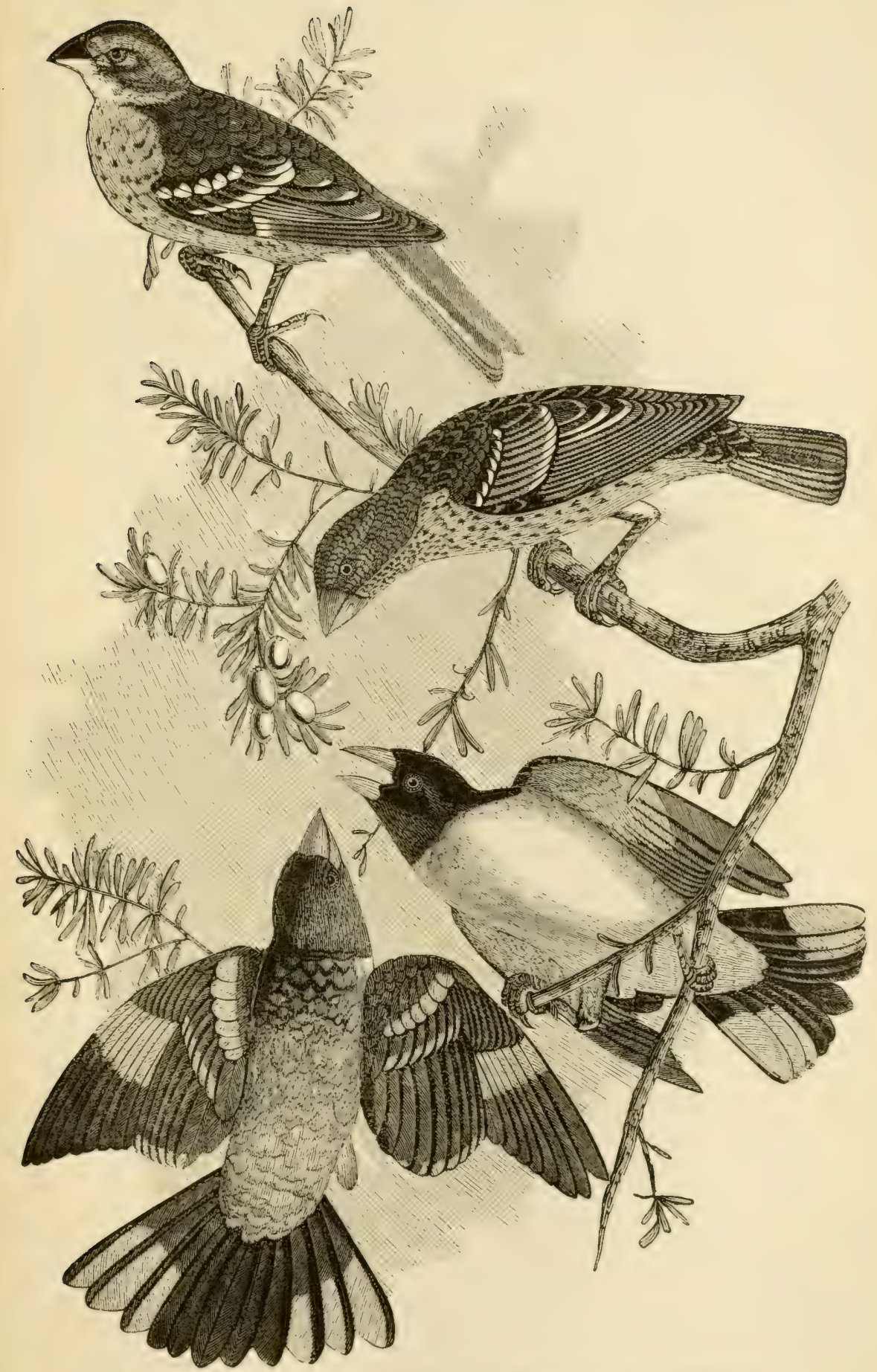

Rose-breasted Grosbeak, Guiraca ludoviciana. Swainson. 

basal half of primaries and secondaries, and a large patch on the ends of the inner webs of the outer three tail feathers, pure-white.

Female, without the white of quills, tail, and rump, and without any black or red; above yellowish-brown streaked with darker; head with a central stripe above, and a superciliary on each side, white; beneath dirty-white, streaked with brown on the breast and sides; under wing coverts and axillaries saffron-yellow.

In the male, the black feathers of the back and sides of the neck have a subterminal white bar: there are a few black spots on the sides of the breast just below the red.

The young male of the year is like the female, except in having the axillaries, under wing coverts, and a trace of a patch on the breast, light rose-red.

The tint of carmine on the under parts varies a good deal in different specimens.

Length, eight and fifty one-hundredths inches; wing, four and fifteen one-hundredths inches.

Hab. - Eastern United States to the Missouri plains, south to Guatemala.

This beautiful bird is a not very common summer inhabitant of New England. It seems to be pretty generally distributed, but is in no locality plenty. It arrives about the first week in May in the southern districts of these States, and a fortnight later in the northern sections. It prefers the neighborhood of a swamp, and is most often found in low growths of birches and alders. The nest is placed in low shrubs and trees, often in the barberry-bush and alder, usually in the deep woods, sometimes in a pasture. It is loosely constructed of twigs and roots, and lined with grass and hair-like roots, and sometimes a fer leaves. The eggs are usually four in number, more often less than more. Their ground-color is a greenish-blue: this is irregularly covered with fine spots and dashes of umber-brown, thickest at the greater end of the egg. Dimensions vary from 1 by .74 to .90 by .70 inch. One brood only is reared in the season in New England. I am aware that this description differs from those which have been written of the nest and eggs of this bird ; ${ }^{1}$ but it is correct. I have had a number of the eggs, and have seen several of the nests: these were invariably of the above description, and differed in no essential particular, though from various localities.

1 According to Bonaparte, its nest is concealed amidst the thick foliage of the thady forest; externally, it is composed of twigs, and lined with slender grass; and the eggs are four or five, white, spotted with brown. - NuTralL. 
The habits of this bird are pretty well known. It is a very fine songster, and is hardly excelled by any of our other species; its notes being uttered, not only through the day, but also during the night, as I have heard on several occasions. The song is difficult of description: it is a sweet warble, with various emphatic passages, and sometimes a plaintive strain, exceedingly tender and affecting.

The Grosbeak feeds upon the seeds of the birches and alders, which it obtains very expertly. It also is very fond of various berries and buds, and it occasionally searches among the fallen leaves for insects and worms.

After the young birds have become capable of providing for themselves, the whole family sometimes visit the orchards and gardens, where they eat a few berries and currants. By the middle of September, they proceed leisurely on their southern migration.

\section{CYANOSPIZA, BAIRD.}

Passerina, Vieillot, Analyse (1816). Not of Linnæus; used in Botany.

Cyanospiza, BAInD. (Type Tanagra cyanea, L.)

Bill deep at the base, compressed; the upper outline considerably curved; the commissure rather concave, with an obtuse, shallow lobe in the middle; gonys slightly curved; feet moderate; tarsus about equal to middle toe; the outer lateral toe barely longer than the inner, its claw falling short of the base of the middle; hind toe about equal to the middle without claw; claws all much curved, acute; wings long and pointed, reaching nearly to the middle of the tail; the second and third quills longest; tail appreciably shorter than the wings, rather narrow, very rearly even.

The species of this genus are all of very small size and of showy plumage, usually blue, red, or green, in well-defined areas.

\section{CYANOSPIZA CYANEA, - Baird.}

The Indigo-bird.

Tanagra cyanea, Linnæus. Syst. Nat., I. (1766) 315.

Fringilla cyanea. Wils., I. (1810) 100; Aud. Orn. Biog., I. (1832) 377; V. 503.

Description.

Male. - Blue, tinged with ultramarine on the head, throat, and middle of breast; elsewhere with verdigris-green; lores and anterior angle of chin velvet-black; wing feathers brown, edged externally with dull bluish-brown. 
Female. - Brown above; whitish, obscurely streaked or blotched with brownishyellow beneath; immature males similar, variously blotehed with blue.

Length, about five and seventy-five one-hundredths inches; wing, nearly three inches.

Hab. - Eastern United States to the Missouri, south to Guatemala.

This beautiful species is pretty generally distributed throughout New England as a summer visitor, and is rather common in thickly settled districts. It arrives from the south about the 10th of May, and soon mates and selects its home for the ensuing summer. Says Nuttall, -

"Though naturally shy, active, and suspicious, they still, at this interesting period of procreation, resort chiefly to the precincts of habitations, around which they are far more common than in the solitary woods, seeking their borders, or the thickets by the sides of the road; but their favorite resort is the garden, where, from the topmost bough of some tall tree, which commands the whole wide landscape, the male regularly pours out his lively chant, and continues it for a considerable length of time. Nor is this song confined to the cool and animating dawn of morning; but it is renewed and still more vigorous during the noonday heat of summer. This lively strain seems composed of a repetition of short notes, commencing loud and rapid, and then, slowly falling, they descend almost to a whisper, succeeded by a silent interval of about half a minute, when the song is again continued as before. The most common of these vocal expressions sounds like, tshe tshe tshe - tshé tshéé tshéé - tshé tshe tshe. The middle syllables are uttered lispingly in a very peculiar manner, and the three last gradually fall: sometimes it is varied and shortened into tshea tshea tshea tshreh, the last sound being sometimes doubled. This shorter song is usually uttered at the time that the female is engaged in the cares of incubation, or as the brood already appear, and when too great a display of his music might endanger the retiring security of his family."

The Indigo-bird commences building about the last of May. The nest is usually placed in low bushes, often bramble and brier bushes, usually near houses and gardens: it is constructed of coarse sedge grass, some withered 
leaves, and lined with fine stalks of the same and the slender hair-like tops of the bent grass (agrostis), with a very few cow-hairs, though sometimes they make a substantial lining of hair. The eggs are four or five in number; and their color is a nearly pure white, sometimes with a bluish tint. In a large number in my collection from L. E. Ricksecker, of Pennsylvania, a few have scattered blotches of reddish-brown. Their size varies from .80 by .60 to .70 by .52 inch. But one brood is reared in the season in New England.

About the middle of September, the whole family leaves New England, and winters in tropical America.

\section{PIPILO, VieILLot.}

\section{Linn.)}

Pipilo, Vieillot, Analyse (1816) Agassiz. (Type Fringilla erythrophthalma,

Bill rather stout; the culmen gently curved, the gonys nearly straight; the commissure gently concave with a decided notch near the end; the lower jaw not so deep as the upper, not as wide as the gonys is long, but wider than the base of the upper mandible; feet large, the tarsus as long or a little longer than the middle toe; the outer lateral toe a little the longer, and reaching a little beyond the base of the middle claw; the hind claw about equal to its toe; the two together about equal to the outer toe; claws all stout, compressed, and moderately curved; wings reaching about to the end of the upper tail coverts; short and rounded, though the primaries are considerably longer than the nearly equal secondaries and tertials; the outer four quills are graduated; the first considerably shorter than the second, and about as long as the secondaries; tail considerably longer than the wings; moderatelv oraduated externally; the feathers rather broad; most rounded off on the inner wets at the end.

The colors vary; the upper parts are generally uniform black or brown; the under white or brown; no central streaks on the feathers. The hood sometimes differently colored.

The essential characters of the genus are in the curved culmen and commissure; the strong feet; the outer toe rather longer than the inner; the wings rounded, but the primaries decidedly longer than the others; the outer four quills considerably graduated, but the first usually not shorter than the secondaries. The graduated tail longer than the wings.

\section{PIPILO ERTTHROPHTHALMUS, - Vieillot.}

The Ground Robin; Towhee; Chewink.

Fringilla erythrophthalma, Linnæus. Syst. Nat., I. (1766) 318; Aud. Orn. Biog., I. (1832) $151 ;$ V. 511 . 
Emberiza erythrophthalma, Gmelin. Syst. Nat., I. (1788; 874; Wils. Am. Orn., VI. (1812) 90 .

Pipillo erythrophthalmus, Vieillot. Gal. Ois., I. (1824) 109.

Description.

Upper parts generally, head and neck all round, and upper part of the breast, glossy black, abruptly defined against the pure white which extends to the anus, but is bounded on the sides and under the wings by light-chestnut; under coverts similar to sides, but paler; edges of outer six primaries with white at the base and on the middle of the outer web; inner two tertiaries also edged externally with white; tail feathers black; outer web of the first, with the ends of the first to the third white, decreasing from the exterior one. Female with the black replaced by brown; iris red.

Length, eight and seventy-five one-hundredths inches; wing, three and seventyfive one-hundredths; tail, four and ten one-hundredths inches.

This beautiful and well-known species, although common in Massachusetts and the other southern New-England States, is rare in the three northern. It begins to grow scarce in the northern districts of Massachusetts; and, before we have passed fifty miles beyond its northern limits, it is very rarely seen. It makes its appearance about the 20th of April, the males preceding the females by a week or ten days. As soon as the females arrive, the pairing season commences. The male, perched on a low limb of a tree or high bush, chants his pleasing song, sometimes for half an hour at a time: this song resembles the syllables, tow-hée 'che'de'de'de'de, uttered at first slowly and plaintively, and quickly increased in volume and rapidity of utterance. He has also a sort of quavering warble difficult of description. If he is approached, he watches the intruder, and, after ascertaining his bủsiness, utters his note tow-hêe, and proceeds his search among the fallen leaves for his favorite food of worms, insects, and seeds, which he is almost continually scratching for among the dead regetation.

About the second week in May, the birds commence building. The locality usually chosen is in low, thick woods, or in thickets of briers and bushes near streams of water, in which places this species is most often found. The nest is placed on the ground, usually beneath a bunch of grass, 
or in a pile of old brush and fagots : it is constructed of fine twigs, leaves, and grasses, and is lined with fine leaves of grasses, and sometimes a few hair-like roots.

The eggs are usually four in number. Their ground color varies from grayish to reddish-white: this is covered, over the entire surface, with fine dots and points of reddishbrown: in some specimens these dots run into each other, and from small blotches. The average dimensions of a great number of specimens in my collection is about .94 by .76 inch. When placed in a tray beside an equal number of the eggs of the Brown Thrush, the eggs of this species appear much paler, and with a more roseate tint; otherwise, except with regard to size, the two species resemble each other much.

In New England, but one brood is usually reared in the season. I have found nests with young in June and August, but generally the first brood leaves the nest too late for another to be brought out before the early frosts.

About the middle of October, the old birds and their young, in small detached flocks, leave New England on their southern migration. 


\section{FAMILY ICTERID屟。}

Primaries nine; tarsi scutellate anteriorly; plated behind; bill long, generally equal to the head or longer, straight or gently curved, conical, without any notch, the commissure bending downwards at an obtuse angle at the base; gonys generally more than half the culmen; basal joint of the middle toe free on the inner side, united half-way on the outer; tail rather long, rounded; legs stout.

\section{Sub-Family Agelaeins. - The Starlings.}

Bill stout, conical, and acutely pointed, not longer than the head; the outlines nearly straight, the tip not decurved; legs adapted for walking, longer than the head; claws not much curved; tail moderate, shorter than the wings; nearly even

\section{DOLICHONYX, SwaINSON.}

Dolichonyx, Swainson, Zool. Jour., III. (1827) 351. (Type Emberiza oryziro$r a, \mathrm{~L}$.

Bill short, stout, conical, little more than half the head; the commissure slightly sinuated; the culmen nearly straight; middle toe considerably longer than the tarsus (which is about as long as the head); the inner lateral toe longest, but not reaching the base of the middle claw; wings long, first quill longest; tail feathers acuminately pointed at the tip, with the shafts stiffened and rigid, as in the Wood. peckers.

The peculiar characteristic of this species is found in the rigid scansorial tail and the very long middle toe, by means of which it is enabled to grasp the vertical stems of reeds or other slender plants. The color of the known species is black, varied with whitish patches on the upper parts.

\section{DOLICHONYX ORYZIVORUS. - Swainson.}

The Bobolink; Reed-bird; Rice-bird.

Emberiza oryzivora, Linnæus. Syst. Nat., I. (1766) 311. Wils. Am. Orn., II. (1810) 48 .

Dolichonyx oryzivora, Swainson. Zool. Jour., III. (1827) 351.

Icterus agripennis, Bonaparte. Obs. Wils. (1824), No. 87. Aud. Orn. Biog., I. (1831) 283; V. (1839) 486. Nutt. Man., I. (1832) 185.

\section{DESCRIPTION.}

General color of male in spring black; the nape brownish-cream color; a patch on the side of the breast, the scapulars and rump white, shading into light ash on the upper tail covers and the back below the interscapular region; the outer primaries sharply margined with yellowish-white, the tertials less abruptly; the tail feathers margined at the tips with pale brownish-ash. In autumn similar to the female. 
Female, yellowish beneath; two stripes on the top of the head, and the upper parts throughout, except the back of the neck and rump, and including all the wing feathers generally, dark-brown, all edged with brownish-yellow; which becomes whiter nearer the tips of the quills; the sides sparsely streaked with dark-brown, and a similar stripe behind the eye; there is a superciliary and a median band of yellow on the head.

Length of male, seven and seventy one-hundredths inches; wing, three and eighty-three one-hundredths; tail, three and fifteen one-hundredths inches.

$H a b$. - Eastern United States to the high central plains. Seen fifty miles east of Laramie.

TTHIS well-known merry songster of the North, Reed 1 Bird or Ortolan of the Middle States, and Rice Bird of the South, is abundantly distributed throughout most sections of the eastern half of the continent, ranging from the latitude of Quebec, in Lower Canada (which is its most northern breeding point), through New England and its latitude in summer, to Mexico, Central America, West Indies, and the northern portions of the Southern Continent, where it passes the winter.

Early in spring it makes its appearance in the Southern United States, usually in small detached parties of from eight to a dozen individuals, and proceeds leisurely to its summer home in the North, generally at about the following dates: being abundant in Georgia about April 20; in District of Columbia, "distributed about orchards and meadows in flocks, from May 1st to 15th ;" arrives on Long Island, N. Y., "about the 20th of May;" and is abundant in the latitude of Middle New England by the latter part of that month.

The males usually arrive in the North several days before the females, during which interim they frequent meadows and fields in cultivated districts, preferring them to thinly settled localities, and soon become very tame and familiar, considering the severity with which they were pursued by the inhabitants of all the countries they traversed in their migration, by whom they are regarded only as a pest and a nuisance. The Bobolink knows when he has arrived among his friends; and the same bird which would have risen be- 


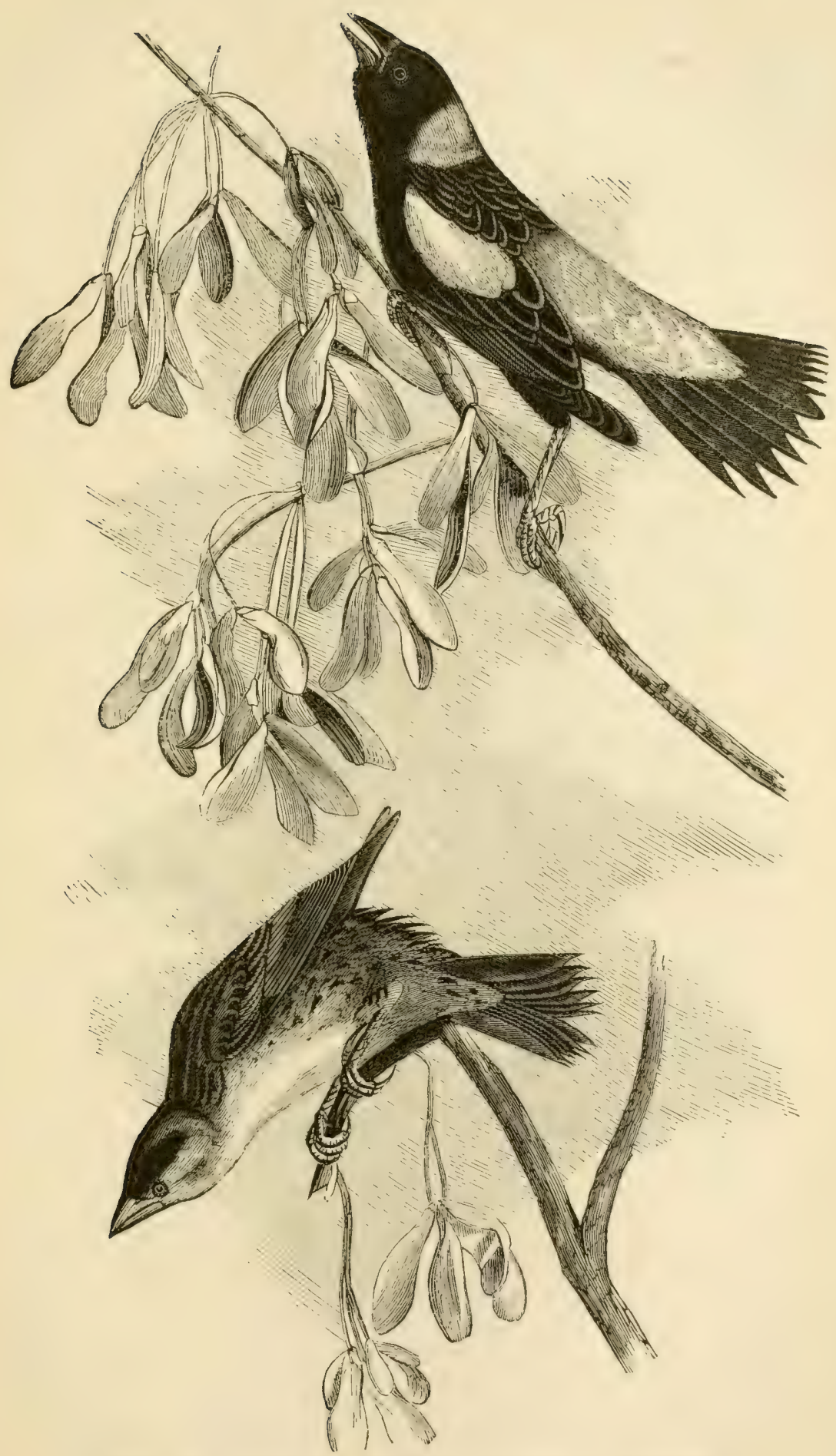

Bовоцик, Reed-bird, Dolichonyx oryzivorus. Swainson. 

yond gunshot from you in the South will perch on your garden fence in New England as familiarly as if he were "to the manor born," and regale you with a flood of his choicest melodies.

Almost everybody in the North knows the song of this bird, and has laughed, in spite of him or herself, at the grotesque singer, as, perched on a twig in the cherry-tree by the house, or in the elm by the roadside, or alder by the brook, he nodded his head, quivered his wings, opened his mouth, and rattled out the most curious, incomprehensible, jingling, roundabout, careless, joyous, laughable medley that any bird throat ever uttered.

As soon as the females arrive, they become the especial objects of attention with their male neighbors; and the little contentions, both in music, and something more severe, we must confess, for the possession of a favored one, between the contesting suitors, are almost innumerable.

When the birds are mated, usually early in June, they commence the structure in which their family is to be reared. Selecting a thick tussock of grass in a field or meadow, through which, or near which, a brook prattles of cool and delicious draughts, and sweet and refreshing baths, beneath the bending and concealing leaves, they entwine fine grasses and rootlets into a loose and not deeply hollowed nest, which they line with softer pieces of the same material.

The position is so well chosen that, nine times out of ten, if you walk the meadow over again and again, knowing it to be there, you will not discover the nest; the male bird flies orer your head, chiding and complaining at your presence, and his mate skurrying off through the thick grass, rises away from the nest, that you may not discover its locality.

The eggs, four or five in number, vary in color from a light ashy-blue, with spots of blackish-brown, to a pale- 
brownish clay, with spots and blotches of umber of different shades; their form is usually a perfect ovate, and they vary in dimensions from .90 of an inch in length by .65 of an inch in breadth, to .86 of an inch in length by .62 of an inch in breadth.

As soon as the young birds are hatched, the father, hitherto full of song and merriment, becomes more quiet, spending a great part of his time in family cares. The young birds are fed on grasshoppers, crickets, and various other insects; and this food is the chief sustenance of the parents as well, at this period, for the seeds of the wild grasses are not yet ripened, and incursions in the grainfields are tabooed while the young are in the nest. Is there not a little of judicious reasoning in this ? look at it: if the bird cultivates the good will of the farmer, by destroying his insect enemies, and letting his crops grow in peace, he is permitted to rear his family in security, and is even rather liked, his song being a most pleasant companionship to the farmer who delves and plods in the fields around him.

When the young birds leave the nest, the parents provide for them for a few days, and then turn them away to shift for themselves: this is in about the middle of July. The old birds then pass a comparatively idle season, - roaming through the country, recuperating from the cares of parentage, and exchanging their nuptial dress for one more in accordance with their matured, respectable, old folks' condition; the male assumes the sober, and lately more sober, attire of his mate, and dropping his song, contents himself with repeating her simple "chink."

So much do the old and young birds resemble each other that, in the flocks of from fifty to one hundred individuals, in which they gather in early fall, it is almost impossible by the plumage to distinguish either.

Early in September the Bobolinks begin to move southward, and although they obtain a great portion of their 
sustenance from ficlds and meadows, gleaning seeds of grasses and weeds, and capturing orthopterous and other insects, they make sad havoc in the fields of late grain and rice; and the firing of guns during their passage through the Middle and Southern States, not only by farmers' and planters' boys, but by sportsmen and pot-hunters, who shoot them for the table and market, is often almost incessant.

\section{MOLOTIIRUS, SWAINSON.}

Molothrus, Swatnson, F. Bor. Am., II. (1831) 277. (Type Fringilla pecoris, Gm.) Bill short, stout, about two-thirds the length of head; the commissure straight; culmen and gonys slightly curved, convex, the former broad, rounded, convex, and running back on the head in a point; lateral toes nearly equal, reaching the base of the middle one, which is shorter than the tarsus; claws rather small; tail nearly even; wings long, pointed, the first quill longest.

\section{MOLOTHRUS PECORIS, - Swainson.}

The Cow Blackbird; Cowbird.

Fringilla pecoris, Gmelin. Syst. Nat., I. (1788) 910.

Emberiza pecoris, Wilson. Am. Orn., II. (1810) 145.

Icterus pecoris, Bonaparte. Obs. Wils. (1824), No. 88. Aud. Orn. Biog., I. (1831) 493; V. (1839) 233, 490.

Icterus (emberizoides) pecoris, Nuttall. Man., I. (1832) 178; 2d ed., 190.

Fringilla ambigua, Nuttall. Man. I. (1832) 484. (Young.)

\section{DESCRIPTION.}

Second quill longest; first scarcely shorter; tail nearly even, or very slightly rounded; male with the head, neck, and anterior half of the breast, light chocolatebrown, rather lighter above; rest of body lustrous-black, with a violet-purple gloss, next to the brown, of steel-blue on the back, and of green elsewhere. Female, light olivaceous-brown all over, lighter on the head and beneath; bill and feet black.

The young bird of the year is brown above, brownish-white beneath; the throat immaculate; a maxillary stripe and obscure streaks thickly crowded across the whole breast and sides; there is a faint indication of a pale superciliary stripe; the feathers of the upper parts are all margined with paler; there are also indications of the light bands on the wings; these markings are all obscure, but perfectly appreciable, and their existence in adult birds may be considered as embryonic, and showing an inferiority in degree to the species with the under parts perfectly plain.

Length, eight inches; wing, four and forty-two one-hundredths inches; tail, three and forty one-hundredths inches.

Hab. - United States from the Atlantic to California: not found immediately on the coast of the Pacific. 
This common and well-known bird is abundantly distributed throughout New England as a summer visitor. It makes its first appearance about the middle of March in Massachusetts, and, instead of mating and separating into pairs, remains in small flocks through the summer.

At all times, the males and females congregate together and risit the fields and pastures, (where they destroy numbers of insects, principally Orthoptera), and are usually in greatest numbers where droves of cattle are assembled. The male, in spring and early summer, has a guttural song, which he utters from a tall tree, sometimes an hour at a time. This song resembles the syllables 'cluk'seēe-. When he emits this note, he bristles out the feathers of his neck, and spreads his tail, and seems to swell out his body with the effort to produce an agreeable tone.

When the desire for laying is awakened in the female, instead of building a nest of her own, she seeks the tenement of some other bird, usually a smaller species than herself; and, watching an opportunity when the other bird has left it, she drops an egg in it, and leaves it to the tender mercies of the owner of the nest. The birds most often chosen for this purpose are the Vireos, Warblers, and Sparrows: sometimes the Small Thrushes are thus imposed upon, and rarely the Wrens.

Some birds build over the stranger egg a new nest. I have in my collection' a nest of the Yellow Warbler thus doubled, and another of the Goldfinch. Sometimes the nest is abandoned, particularly if the owner has no eggs of her own; but usually the intruding egg is hatched, and the young bird attended with all the care given to the legitimate young. The eggs of this species are of a grayish-white, with fine spots of brown over the entire surface. Their dimensions vary from .96 by .70 to .80 by .62 inch : some specimens are marked with very minute reddish dots, which are scattered over the entire surface; others have bold 


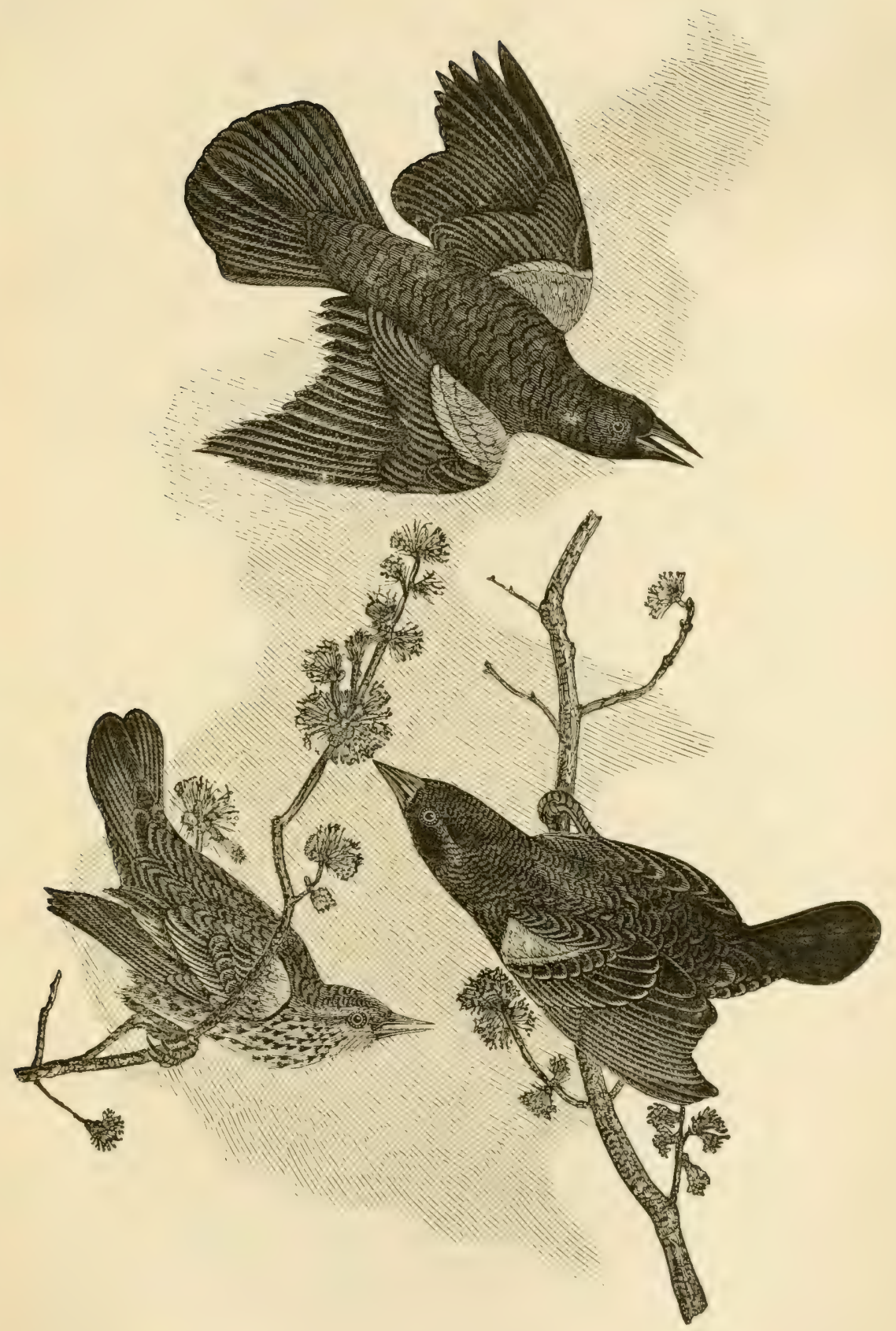

Red-winged Blackbird, Agelaius phoniceus. Vieillot. 

dashes and confluent blotches of brown, thickest at the greater end. ${ }^{1}$

By the last week in October, the young and old birds assemble in large flocks, and leave for the South.

\section{AGELAIUS, Vieillot.}

Agelaius, Vremllot, "Analyse, 1816." (Type Oriolus Phoniceus, L.)

First quill shorter than second; claws short; the outer lateral scarcely reaching the base of the middle; culmen depressed at base, parting the frontal feathers; length equal to that of the head, shorter than tarsus; both mandibles of equal thickness and acute at tip, the edges much curved, the culmen, gonys, and commissure nearly straight or slightly sinuated; the length of bill about twice its height; tail moderately rounded, or very slightly graduated; wings pointed, reaching to end of lower tail coverts; colors black, with red shoulders in North-American species.

The nostrils are small, oblong, overhung by a membranous scale; the bill is higher than broad at the base; there is no division between the anterior tarsal scutellæ and the single plate on the outside of the tarsus.

\section{AGELAIUS PHGNICEUS - Vieillot.}

\section{The Swamp Blackbird; Red-wing Blackbird.}

Oriolus Phœniceus, Linnæus. Syst. Nat., I. (1766) 161.

Agelaius Phœniceus, Vieillot. Anal. (1816).

Icterus Phøeniceus, Audubon. Orn. Biog., I. (1831) 348; V. (1839) 487.

Icterus (Xanthornus Phœniceus), Bonaparte. Syn. (1828), 52. Nutt. Man., I. (1832) 167.

Sturnus prredatorius, Wilson. Am. Orn., IV. (1811) 30.

\section{DESCRIPTION.}

Tail much rounded; the lateral feathers about half an inch shorter; fourth quill longest; first about as long as the fifth; bill large, stout; half as high, or more than half as high as long.

IIale. - General color uniform lustrous velvet-black, with a greenish reflection; shoulders and lesser wing coverts of a bright-crimson or vermilion-red; middle coverts brownish-yellow, and usually paler towards the tips.

$1 \mathrm{By}$ an amusing yet incomprehensible mistake of the printer, the subjoined description of eggs, \&c., was annexed to this species, in an article published in the "Report of the U. S. Department of Agriculture for 1864," p. 426. It belongs to the Chewink or Ground Robin, page 425 of that volume: "Their form varies from elongated oval to nearly spherical. The dinensions of a nest complement of four eggs, collected in Quincy, Mass., are 1 by .74 inch, .96 by .72 inch, .90 by .70 inch, 90 by .68 inch: other specinens do not vary materially from these measurements. But one brood is usually reared in the season. This bird, although subsisting principally on various seeds and small fruits, destroys great numbers of insects, particularly in the breeding season: in fact, its young are fed entirely on insects and their larvæ, and the well-known wire-worms." 
Female. - Brown abore, the feathers edged or streaked with rufous-brown and yellowish; beneath white, streaked with brown; forepart of throat, superciliary, and median stripe strongly tinged with brownish-yellow.

The female differs greatly in appearance; the prevailing color above is brownishblack, all the feathers margined with reddish-brown; some of those on the back with brownish-yellow, which, on the median and greater wing coverts, forms two bands; the under parts are dull-whitish, each feather broadly streaked centrally with dark-brown; the chin and throat yellowish, and but little streaked; there is a distinct whitish superciliary streak alongside the head, tinged anteriorly with brownishyellow, and another less distinct in the median line of the crown; there is usually no indication of any red on the wing; the immature males exhibit every possible condition of coloration between that of the old male and of the female.

Length of male, nine and fifty one-hundredths inches; wing, five inches; tail, four and fifteen one-hundredths inches.

This common and well-known species makes its appearance about the middle of March. It arrives in small "flocks, the males preceding the females a week or ten days. On its arrival, it frequents the meadows and swamps, where, from early dawn to twilight, its song of quonk a rêe is heard, sometimes uttered by a half-dozen birds at a time. As soon as the females arrive, the birds mate, and disperse through these States, but not so abundantly in the northern as in the southern districts. It commences building about the first week in May. The nest is usually placed in a tussock of grass or low bush in a meadow and swamp: it is constructed of coarse grasses, which are woven and intwined into a strong fabric, into which are incorporated the grass to which it is suspended, or the twigs of the bush in which it is built. It is deeply hollowed, and lined with fine grasses, and sometimes a few hair-like roots. The eggs are four or five in number; and they vary, in color, two or three shades of light-blue: they are marked with spots and streaks of vandyke-brown and black, generally distributed thickest at the greater ond. Their dimensions vary from 1.05 by .75 inch to .90 by .66 inch. Average size about .97 by .70 inch.

Sometimes several pairs breed in the same swamp or meadow: they always fly to meet an intruder in their naunts, and hover over him, uttering their cries of anger 
and complaint; and, as the alarm passes along the country, sometimes as many as a dozen or twenty birds are hovering over him, scolding vociferously.

Two broods are usually reared in the season: as soon as the last brood leaves the nest, the whole family joins with its neighbors into a flock of sometimes a hundred or hundred and fifty or more. They then visit the grain-fields, and inflict considerable damage by eating and destroying the grain. In many localities, they are so numerous at this season, that they are a serious nuisance; and the farmers destroy great numbers of them with poison and with the gun.

Localities in the neighborhood of the scaboard are thus afflicted more than others; and I have seen flocks of these birds in Plymouth County, Mass., containing as many as a thousand individuals.

About the last of October, they depart on their southern migration.

\section{STURNELLA, VIEILLT}

Sturnella, Vieillot, Analyse (1816). (Type Alauda magna, L.)

Body thick, stout; legs large, toes reaching beyond the tail; tail short, even, with narrow acuminate feathers; bill slender, elongated; length about three times the height; commissure straight from the basal angle; culmen flattened basally, extending backwards, and parting the frontal feathers; longer than the head, but shorter than tarsus; nostrils linear, covered by an incumbent membranous scale; inner lateral toe longer than the outer, but not reaching to basal joint of middle; hind toe a little shorter than the middle, which is equal to the tarsus; hind claw nearly twice as long as the middle; feathers of head stiffened and bristly; the shafts of those above extended into a black seta; tertiaries nearly equal to the primaries; feathers above all transversely banded; beneath yellow, with a black pectoral crescent.

\section{STURNELLA MAGNA. - Swainson.}

\section{The Meadow-lark; Old Field-lark.}

Alauda magna, Linnæus. Syst. Nat., I. (1758) 167, 10th ed. (based on Alauda magna, Catesby, tab. 33). Wils. Am. Orn., III. (1811) 20.

Sturnella magna, Swainson. Phil. Mag., I. (1827) 436.

Sturnus Ludoviciants, Audubon. Orn. Biog., II. (1834) 216; V. (1839) 492.

Sturnella Ludoviciana, Nuttall. Man., I. (1832) 147. 
DESCRIPTION.

The feathers above dark-brown, margined with brownish-white, and with a terminal blotch of pale reddish-brown; exposed portions of wings and tail with transverse dark-brown bars, which on the middle tail feathers are confluent along the shaft; beneath yellow, with a black pectoral crescent, the yellow not extending on the side of the maxilla; sides, crissum, and tibix pale reddish-brown, streaked with blackish; a light median and superciliary stripe, the latter yellow anterior to the eye; a black line behind.

Length, ten and sixty one-hundredths inches; wing;, five; tail, three and seventy one-hundredths inches; bill above, one and thirty-five one-hundredths inches.

This beautiful and well-known bird is a common summer inhabitant of the three southern New-England States, but is more rare in the others. If a mild winter, it remains through

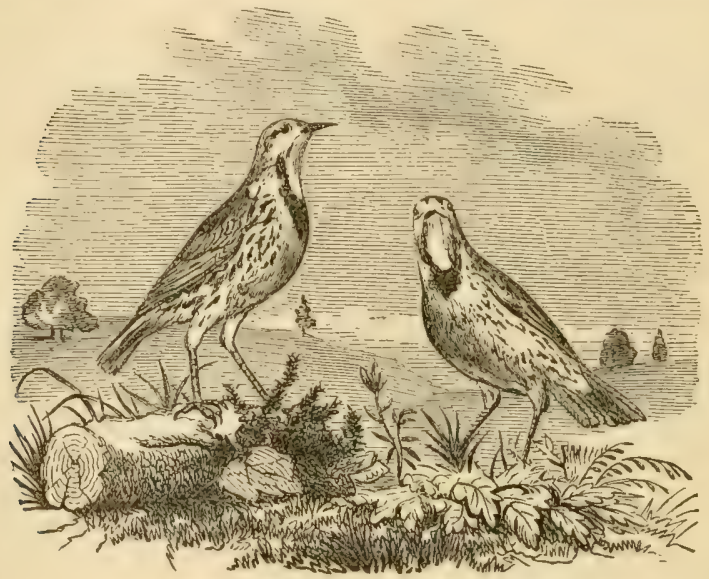

the year; but generally leaves for the South late in the fall, and returns about the "second or third week in March." It commences building about the second week in May, sometimes earlier: the locality is generally in a meadow or low field. The nest is usually built in a tussock of grass : it "is pretty compact, made of dry, wiry grass, to which a hidden and almost winding path is made, and generally so well concealed that the nest is only to be found when the bird is flushed." - Nutrall.

A number of nests that I have examined agree with this description: all were beneath bunches of grass; and, though 
some were only partly covered, still there was a decided roof to all. The eggs are usually four in number: their color is generally nearly pure-white, sometimes reddishwhite, with fine spots of reddish-brown diffused over the entire surface of some specimens; on others, thinly scattered spots, blotches of two or three shades of brown and lilac. Their dimensions vary from 1.10 by .85 to 1 by .78 inch. Their form is usually a rounded oval.

A rather peculiar specimen, kindly presented me by Mr. J. P. Norris, of Philadelphia, is nearly spherical in form, rosy-white in color, with exceedingly minute dots of reddish. Size, 1.05 by .90 inch. Nuttall says of the food of this species, -

"Their food consists of the larvæ of various insects, as well as worms, beetles, and grass seeds, to assist the digestion of which they swallow a considerable portion of gravel. It does not appear that this species ever adds berries or fruits of any kind to his fare, like the Starling, but usually remains the whole summer in moist meadows; and in winter retires to the open, grassy woods, having no inclination to rob the orchard or garden; and, except in winter, is of a shy, timid, and retiring disposition."

But one brood is reared in the season.

In the autumn, the Larks collect in small flocks of ten or a dozen, which visit the marshes and stubble-fields in their neighborhood. Their note at this season, as in other periods of the year, is nothing but a shrill, prolonged, plaintive whistle. Usually one bird of a flock is perched on a tree or fence-post as a sentinel; and, the moment a gunner approaches, the bird gives his alarm, and the flock is on the qui vive. They are so shy that it is extremely difficult to approach them; and, when shot at, they are secured only by guns of long range. Their flight is a peculiar hovering one, - the wings moving in short, almost imperceptible, vibrations. 


\section{Sub-Family ICTERNNæ. - The Orioles.}

Bill slender, elongated, as long as the head, generally a little decurved, and rery acute; tarsi not longer than the middle toe, nor than the head; claws short, much curved; outer lateral toe a little longer than the inner, reaching a little beyond base of middle toe; feet adapted for perching; tail rounded or graduated; prevailing colors yellow or orange, and black.

\section{ICTERUS SPURIUS.-Bonaparte.}

\section{The Orchard Oriole.}

Oriolus spurius, Linnæus. Syst. Nat., I. (1766) 162

Icterus spurius, Bonaparte. Obs. on Nom. Wils. (1525), No. 44. Aud. Orn. Biog., I. (1831) 221 ; V. 485.

Oriolus mutatus, Wilson. Am. Orn., I. (1808) 64.

\section{DESCRIPTION.}

Bill slender, attenuated, considerably decurved; tail moderately graduated.

Male. - Head and neck all round, wings, and interscapular region of back, with tail feathers, black; rest of under parts, lower part of back to tail, and lesser upper wing coverts, with the lower one, brownish-chestnut; a narrow line across the wing, and the extreme outer edges of quills, white.

Female. - Uniform greenish-yellow beneath, olivaceous above, and browner in the middle of the back; two white bands on the wings. Young male like the female, with a broad black patch from the bill to the upper part of the breast; this color extending along the base of the bill so as to involve the eye and all anterior to it to the base of the bill.

In this species the bill is slender, attenuated, and a good deal decurred to the tip. The second and third quills are longest; the first intermediate between the fourth and fifth. The tail is rather long; the feathers moderately graduated, the greatest difference in length amounting to half an inch.

The black of the throat extends backwards as far as the bend of the wing, and ends as an obtuse angle. The tail feathers are entirely black, with dull whitish tips when not fully mature.

Specimens are found in all stages between the characters giren above. When nearly mature, some yellowish feathers are found mixed in with the chestnut ones.

Length of specimens, seven and trenty-five one-hundredths inches; wing, three and twenty-five one-hundredths inches.

This bird is rather rare in New England, and is confined to the southern districts as a summer visitor. It arrives about the second week in May, and commences building about the first week in June. The nest is usually placed in a forked branch of a tree in the orchard, seldom more than twenty feet from the ground. It is constructed of different 


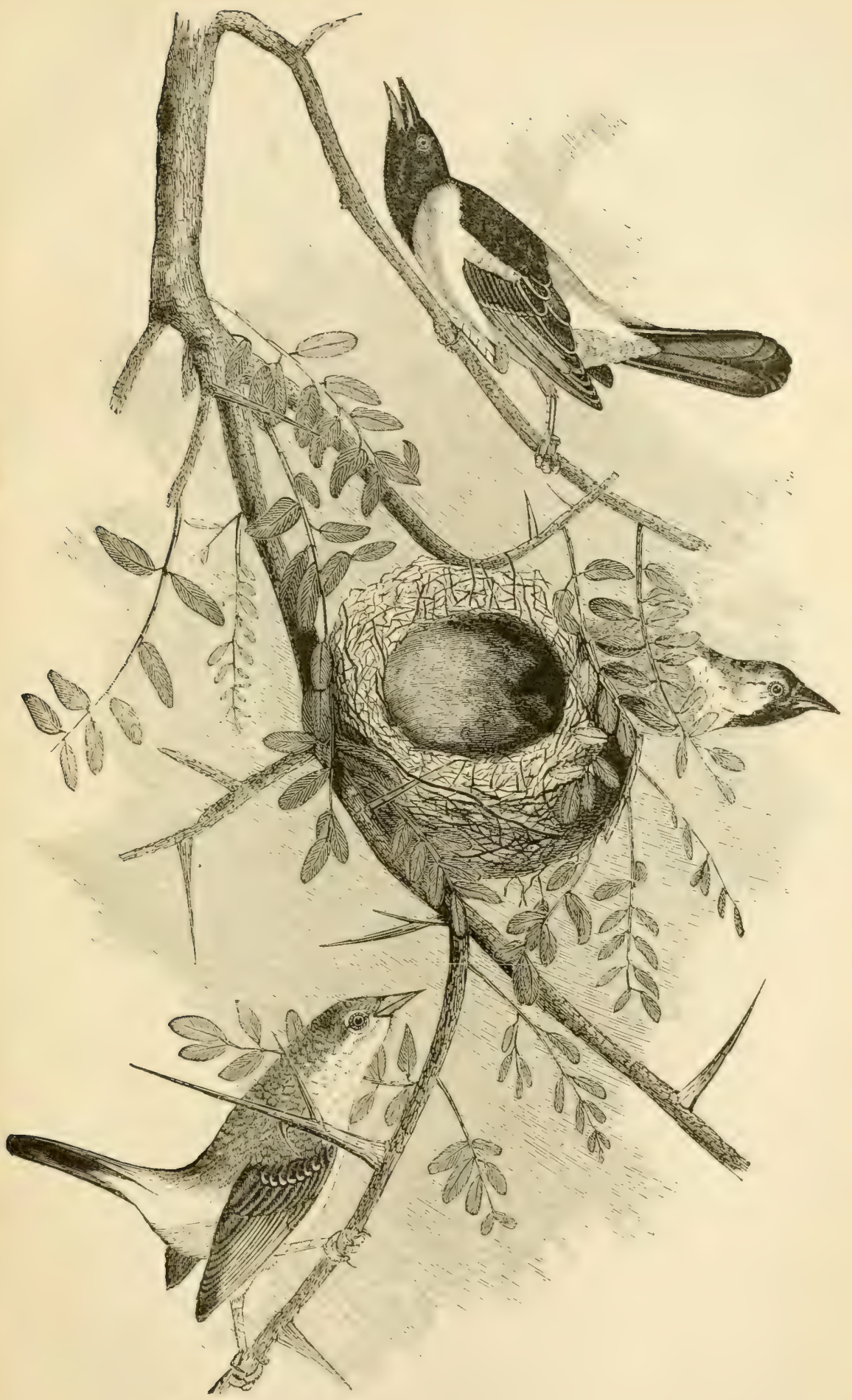

Orchard Orior., Icterus spurius. Bunaparte. 

grasses, which are woven together very neatly and com. pactly: the whole is lined with fine grass, and sometimes a few horsehairs. It is not pensile, but is built on the branch. The eggs are four or five in number: their color varies from a light-blue to a fleshy tint, which is marked with irregular spots and lines of obscure lavender, over which are bold spots and blotches of black and brown. The dimensions vary from .86 to .56 by .54 inch. But one brood is reared in the season.

Nuttall, in describing the habits of this species, says, -

"The Orchard Oriole is an exceedingly active, sprightly, and restless bird: in the same instant almost, he is on the ground after some fallen insect; fluttering amidst the foliage of the trees, prying and springing after his lurking prey; or flying, and tuning his lively notes in a manner so hurried, rapid, and seemingly confused, that the ear is scarce able to thread out the shrill and lively syllables of his agitated ditty. Between these hurried attempts, he also gives others, which are distinct and agreeable; but still his tones are neither so full nor so mellow as those of the brilliant and gay Baltimore."

After a description of the nest and eggs, he continues :-

"The female sits about fourteen days, and the young continue in the nest ten (?) days before they become qualified to flit along with their parents; but they are generally seen abroad about the middle of June. Previously to their departure, the young, leaving the care of their parents, become gregarious, and assemble sometimes in flocks of separate sexes, from thirty to forty upwards; in the South, frequenting the savannahs, feeding much on crickets, grasshoppers, and spiders. According to Audubon, they sing with great liveliness in cages, being fed on rice and dry fruits, when fresh cannot be procured. Their ordinary diet, it appears, is caterpillars and insects, of which they destroy great quantities. In the course of the season, they likewise feed on various kinds of juicy fruits and berries; but their depredations on the fruits of the orchard are very unimportant." 
In a large number of nests receired from Wisconsin, since the foregoing was in type, a proportion were pensile, being composed of fine grasses, neatly interwoven.

$$
\text { ICTERUS BALTIMORE. - Daudin. }
$$

The Baltimore Oriole; Golden Robin; Hang-nest.

Oriolus Ballimore, Linnæus. Syst. Nat, I. (1766) 162. Wils. Am. Orn., I. (1808) 23.

"Icterus Baltimore, Daudin." Aud. Orn. Biog., I. (1831) 66; V. (1839) 278.

Description.

Tail nearly even; head all round and to middle of back, scapulars, wings, and upper surface of tail, black; rest of under parts, rump, upper tail coverts, and lesser wing coverts, with terminal portion of tail feathers (except two innermost), orangered; edges of wing quills, with a band across the tips of the greater coverts, white.

The female is much less brilliant in color; the black of the head and back generally replaced by brownish-yellow, purer on the throat; each feather with a black spot.

Length, seven and fifty one-hundredths inches; wing, three and seventy-five one-hundredths inches.

This well-known species is abundantly distributed throughout New England as a summer visitor. It makes its appearance about the 8th of May in Massachusetts, and about the

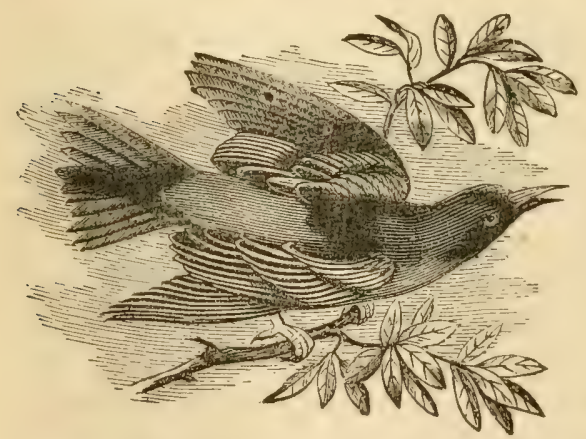
middle of that month or later, in the northern districts. It commences building about the 20th of May. The nest is usually fixed in an elm-tree near houses, or in an apple or pear tree in the orchard. Nuttall's description of the nest

is the best that I have ever seen, and much better than any I could make: although somewhat lengthy, I give it entire:- 
"There is nothing more remarkable in the whole instinct of our Golden Robin than the ingenuity displayed in the fabrication of its nest, which is, in fact, a pendulous, cylindric pouch of five to seven inches in depth, usually suspended from near the extremities of the high drooping branches of trees (such as the elm, the pear, or apple tree, wild cherry, weeping willow, tulip-tree, or buttonwood). It is begun by firmly fastening natural strings of the flax of the silkweed, or swamp hollyhock, or stout artificial threads, around two or more forked twigs, corresponding to the intended width and depth of the nest. With the same materials, willow-down, or any accidental ravellings, strings, thread, sewing-silk, tow, or wool, that may be lying near the neighboring houses, or around grafts of trees, they interweave and fabricate a sort of coarse cloth into the form intended, towards the bottom of which they place the real nest, made chiefly of lint, wiry grass, horse and cow hair: sometimes, in defect of hair, lining the interior with a mixture of slender strips of smooth vine-bark, and rarely with a fer feathers; the whole being of a considerable thickness, and more or less attached to the external pouch. Over the top, the leaves, as they grow out, form a verdant and agreeable canopy, defending the young from the sun and rain. There is sometimes a considerable difference in the manufacture of these nests, as well as in the materials which enter into their composition. Both sexes seem to be equally adepts at this sort of labor; and I have seen the female alone perform the whole without any assistance, and the male also complete this laborious task nearly without the aid of his consort, who, however, in general, is the principal worker."

The eggs are four or five in number. They are of a fleshcolor, with sometimes a bluish tint: they are marked with obscure lines of lavender, over which are irregular scratches and lines, as if done with a pen, of vandyke-brown and black. Their dimensions vary from 1 by .72 to .88 by .66 inch. The food of this bird, and also of the preceding species, consists of caterpillars and other injurious insects : great numbers of the hairy caterpillars are destroyed; and sometimes a large nest of the apple-tree caterpillars is depopulated in a few days. The Orioles are certainly, there- 
fore, worthy the highest consideration and protection from the farmer.

The familiarity of this bird with man, and its sociable and genial disposition, are so well known that any description of its habits here is unnecessary. About the middle of September, after forming into small detached flocks, this species leaves New England on its southern migration.

\section{Sub-Family Quiscalins. - The Grackles.}

Bill rather attenuated, as long or longer than the head; the culmen curved, the tip much bent down; the cutting edges inflected, so as to impart a somewhat tubular appearance to each mandible; the commissure sinuated; tail longer than the wings, usually much graduated; legs longer than the head, fitted for walking.

The bill of the Quiscalince is very different from that of the other Icterido, and is readily recognized by the tendency to a rounding inward along the cutting edges, rendering the width in a cross section of the bill considerably.less along the commissure than above or below. The culmen is more curved than in the Agelaince.

The only genera in the United States are as follows:-

Scolecopilagus. - Tail shorter than the wings, nearly even; bill shorter than the head.

QUiscalus. - Tail longer than the wings, much graduated; bill as long as or longer than the head.

\section{SCOLECOPHAGUS, SwAINSON.}

Scolecophagus, Swaixson, F. Bor. Am., II. (1831). (Type Oriolus ferrugineus, Gmelin.)

Bill shorter than the head, rather slender, the edges inflexed as in Quiscalus, which it otherwise greatly resembles; the commissure sinuated; culmen rounded, but not flattened; tarsi longer than the middle toe; tail even, or slightly rounded.

\section{SCOLECOPHAGUS FERRUGINEUS. - Swainson.}

\section{The Rusty Grackle.}

Gracula ferruginea, Wilson. Am. Orn., III. (1811) 41.

Quiscalus ferrugineus, Nuttall. Man., I. (1832) 199. Aud. Orn. Biog., II. (1834) 315; V. (1839) 483.

Scolecophagus ferrugineus, Swainson. F. Bor. Am., II. (1831) 286.

\section{DESCRIPTION.}

Bill slender, shorter than the head, about equal to the hind toe; its height not quite two-fifths the total length; wing nearly an inch longer than the tail; second quill longest; first a little shorter than the fourth; tail slightly graduated; the lateral 
feathers about a quarter of an inch shortest; general color black, with purple reflections; the wings, under tail coverts, and hinder part of the belly, glossed with green. Female, dull-brown. Iris, pale-straw color.

Length, nine and fifty one-hundredths inches; wing, four and seventy-five onebundredths; tail, four inches.

This bird is not uncommon in the New-England States in the spring and fall migrations, but is never plenty, and retires to high latitudes to breed. A few remain in the northern districts of Maine and New Hampshire through the breeding season; but their nests are seldom found. While in the valley of the Magalloway River, in Maine, in June, 1864, I found several; and two of them contained three eggs in each. These nests were all built in low alders overhanging the water: they were constructed of, first, a layer of twigs and brier-stalks; on this was built the nest proper, which was composed of stalks and leaves of grass, which were mixed with mud, and moulded into a firm, circular structure, and lined with fine leaves of grass and a few hair-like roots. The whole formed a large structure, easily seen at the distance of a few rods through the foliage.

The eggs are of a bluish-white color, of oval form, and covered with fine scratches and spots of light-brown. These markings are almost exactly similar to those on the egg of the Great-crested Flycatcher : they appear as if done with a pen, which, as soon as it is pressed forcibly on the object, is suddenly withdrawn, making a mark wide at one end, and sharply pointed at the other.

The dimensions of three eggs in my collection are 1.04 by .76 inch, 1.05 by .75 inch, 1 by .70 inch.

The habits of this species are less known than those of any of our other Blackbirds. This is owing. as much to its unsociable, retiring disposition as to the scarcity of its numbers. When it arrives in spring, - sometimes as early as the third week in March, - it frequents the low, swampy thickets, where, in companies of three or four, it employs itself in searching for seeds of various aquatic grasses, insects, worms, and the small crustacæ found in such localities. 
If approached, it flies a short distance into a low tree, and watches the intruder, uttering its alarm-note check, - sometimes, cheek-che wéech or check che weecha. This note is uttered by both sexes, and seems to be the only song possessed by either. I have observed them carefully, not only in the spring, but during the breeding season and in the autumn, and I never heard them emit any other. Both sexes incubate, and manifest great anxiety when the nest is approached; the males flying and scolding over the head of the intruder, in the manner of the Red-winged Blackbird. As I paddled my canoe up beneath one of the nests described above, the parent bird remained sitting, almost until my hand touched the limb on which the structure was placed. On flying off, she uttered a chattering cry, almost exactly like that of the female Redwing when disturbed in a similar manner.

Early in September, the old and young birds collect in small detached flocks, and frequent the same localities that they haunt in spring, from which they occasionally visit old cornfields and stubble-fields, where they catch grasshoppers and other insects, and eat the seed of weeds and such grains as are left by the farmer after harvesting.

They remain in southern New England until early in November.

\section{QUiscalus, Vieillot.}

Quiscalus, Vieiclot, Analyse (1816)。 (Gray.) (Type Gracula quiscala, L.)

Bill as long as the head, the culmen slightly curved, the gonys almost straight; the edges of the bill inflected and rounded; the commissure quite strongly sinuated; outlines of tarsal scutellæ well defined on the sides; wings shorter than the tail, sometimes much more so; tail long, the feathers conspicuously and decidedly graduated. Colors black.

QUISCALUS VERSICOLOR. - Vieillot.

The Crow Blackbird; Purple Grakle.

Gracula quiscala, Linnæus. Syst. Nat., I. (1766) 165. Wils. Am. Orn., III. (1811) 44.

Quiscalus versicolor, Vieillot. Analyse? (1816). 1b., Nouv. Dict., XXVIII. (1819) 488. Nutt. Man., I. (1832) 194. Aud. Orn. Biog., I. (1831) 35; V. (1838) 481. 


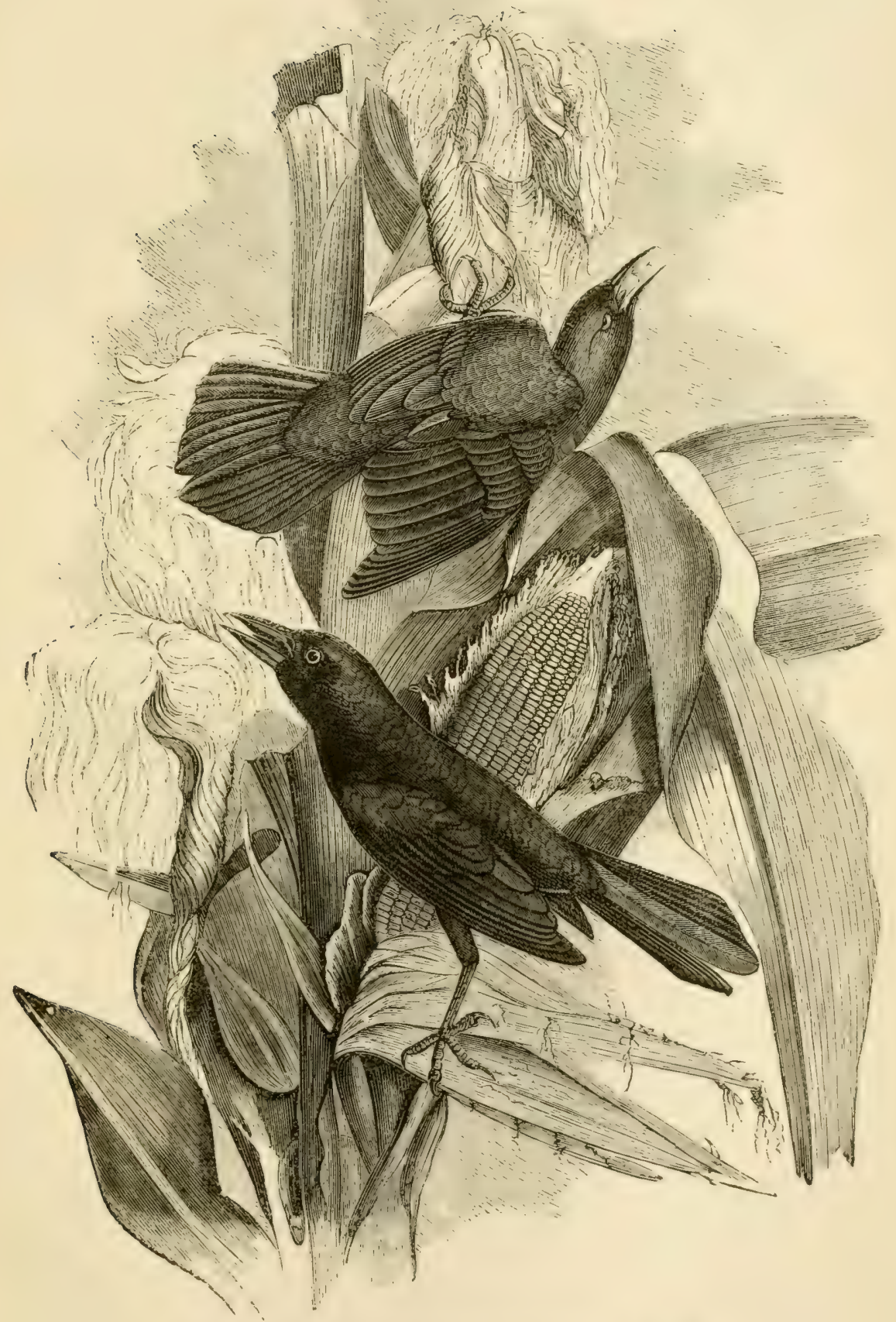

Crow Br.ackmizD, Quisculus versicolor. Vieillot. 



\section{DESCRIPTION.}

Bill above, about as long as the head, more than twice as long as high; the commissure moderately sinuated and considerably decurved at tip; tail a little shorter than the wing, much graduated, the lateral feathers one and ten one-hundredths inches shorter; third quill longest, first between fourth and fifth; head and neck all well defined steel-blue; the rest of the body with varied reflections of bronze, golden, green, copper, and purple, the latter most conspicuous on the tail, the tail coverts, and wings; the edges of primaries and of tail greenish. Female similar, but smaller and duller, with perhaps more green on the head. Iris, yellow.

Length, thirteen inches; wings, six; tail, five and eighty one-hundredths; bill above, one and twenty-five one-hundredths inches.

This very common and well-known bird is distributed throughout New England in the summer season; arriving about the first week in April. It is a social species; and, instead of breaking up into seattered pairs, the birds remain in flocks, and breed in communities, sometimes several pairs on one tree. The nest is composed of mud, in which grass, seaweed, fine roots, and other like materials, are mixed and woven into a large, compact structure, which is lined with fine grass, seaweeds, and sometimes a few horsehairs.

The eggs are four or five in number. They vary in color from light-blue to light-brown, and are marked with obscure spots of light-brown, over which are laid blotches and lines of black and umber-brown. They vary in dimensions from 1.30 by .88 to 1.18 by .84 inch. Usually, but one brood is reared in the season; and in September the birds collect into immense flocks, and do considerable mischief in the cornfields: in other seasons, their food consists of "larvæ, caterpillars, moths, and beetles, of which they derour such numbers, that, but for this providential economy, the whole crop of grain in many places would probably be destroyed by the time it began to germinate."

Wilson, in describing the habits of this species, says, -

"The trees where these birds build are often at no great distance from the farm-house, and overlook the plantations. From thence they issue in all directions, and with as much confidence, to make their daily depredations among the surrounding fields, as if the whole were intended for their use alone. Their chief attention, 
however, is directed to the Indian corn in all its progressive stages. As soon as the infant blade of this grain begins to make its appearance above ground, the Grakles hail the welcome signal with screams of peculiar satisfaction; and, without waiting for a formal invitation from the proprietor, descend on the fields, and begin to pull up and regale themselves on the seed, scattering the green blades around. While thus eagerly employed, the vengeance of the gun sometimes overtakes them; but these disasters are soon forgotten, and those -

'Who live to get awray,

Return to steal, another day.'

About the beginning of August, when the young ears are in their milky state, they are attacked with redoubled eagerness by the Grakles and Redwings, in formidable and combined bodies. They descend like a blackening, sweeping tempest on the corn, dig off the external covering of twelve or fifteen coats of leaves as dexterously as if done by the hand of man, and, having laid bare the ear, leave little behind to the farmer but the cobs and shrivelled skins that contained their favorite fare. I have seen fields of corn of many acres, where more than one-half was thus ruined."

About the last week in September, these birds, in immense flocks, depart on their southern migration: so abundant are they at that time, and so closely do they fly together in a flock, that I have killed, at one discharge of my gun, over a dozen birds. They visit the beech woods, and also the oak groves, and feed upon the nuts found on and beneath those trees. They also eat the seeds of weeds and various wild plants, as I have proved by examining the stomachs of different specimens.

In the evidence before the Committee on Agriculture, in the session of Massachusetts Legislature, for 1869 and '70, it appeared, from the testimony of numerous observers, that the Crow Blackbird, or Grakle, destroys, in the breeding season of the smaller birds, great numbers of eggs and young birds, eating them after the manner of the jays and crows. I have not observed this fact myself, but on inquiry find from different observers that such is often the habit of this species. 


\section{FAMIT, CORVID王.}

Primaries ten; the first short, generally about half as long as the second (or a little more), the outer four sinuated on the inner edge; the nasal fossa and nostrils usually more or less concealed by narrow stiffened bristles (or bristly feathers), with short appressed lateral branches extending to the very tip, all directed forwards; tarsi scutellate anteriorly, the sides undivided (except sometimes below) and separated from the anterior plates by a narrow, naked strip, sometimes filled up with small scales; basal joint of middle toe united about equally to the lateral, generally for about half the length; bill generally notched.

\section{Sub-Family Convine. - The Crows.}

Wings long and pointed; longer than the tail, and, when closed, reaching nearly to its tip, extending far beyond the under tail coverts; the third, fourth, and fifth quills forming the tip of the wing.

\section{CORVUS, LINN XUS.}

Corvus, Linnzeus, Syst. Nat. (1735). (Type Corves corax, L.)

The nasal feathers lengthened, reaching to or beyond the middle of the bill; nostrils large, circular, overhung behind by membrane, the edges rounded elsewhere; rictus without bristles; bill nearly as long as the tarsus, very stout; much higher than broad at the base; culmen much arched; wings reaching to or nearly to the tip of the tail; tarsi longer than the middle toe, with a series of small scales on the middle of each side separating the anterior scutellate portion from the posterior continuous plates; side of the head occasionally with nearly naked patches; tail graduated or rounded; the outer four primaries sinuated internally.

\section{CORVUS CARNIVORUS.-Bartram.}

\section{The American Raven.}

Comrus carnivorus, Bartram. Travels in E. Florida (1793), 290 ,

Corvus corax, Wilson. Am. Orn., IX. (1825) 136. Nutt. Man., I. (1832) 202. Aud. Birds Am., IV. (1842) 78.

\section{DESCRIPTION.}

Fourth quill longest; third and fifth about equal; second between fifth and sixth; first nearly equal to the eighth; entirely glossy black, with violet reflections.

In this species, the feathers of the head above and body are compact and blended; those of the back of the neck are very smooth and even, but do not show the outlines of each separately as elsewhere; on the chin and throat, the feathers aro alongated and lanceolate, each one more or less pendent or free, with the outlines distinct to near the base; the bill is very long (three inches), and considerably curved, the upper mandible extending considerably over the upper at the end. 
The feet appear very short and stout; the tarsi with but seven scutellø, rather Ionger than the middle toe and claw; the lateral claws about equal, and extending to a little beyond the base of the middle claw; the fourth quill is longest, the third about equal the fifth, the second considerably longer than the sixth, the first about equal to the eighth primary.

Length, about twenty-four or twenty-five inches; extent, fifty to fifty-one; wing, about seventeen; tail, ten. Tail moderately graduated; the outer about one and sixty one-hundredths to one and ninety one-hundredths of an inch less than the middle.

7 HIS bird is an extremely rare resident in New England. I I have never heard of its breeding here; but it occasionally rears its young on the island of Grand Menan,

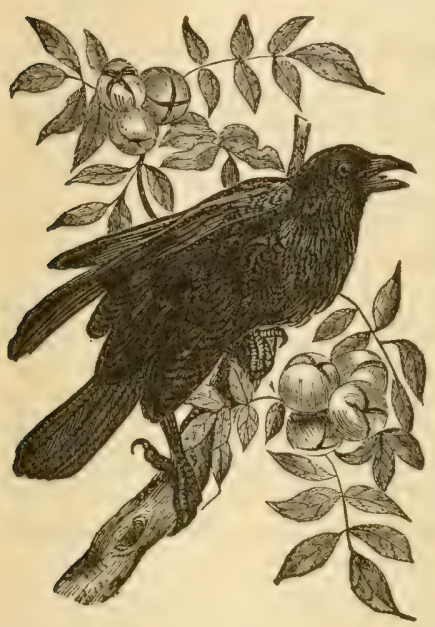
off the north-east coast of Maine. There, on the steep and almost inaccessible cliffs, its nest is built. This is composed of twigs, sticks, seaweed, and pieces of turf, and is lined with the finer seaweeds and algæ found on the seacoast.

A nest that I found in Ohio was built on a jutting rock in a large cave. On ascending to it, I found that it was built of coarse sticks and twigs, and was lined with leaves, strips of bark, and pieces of moss.

This nest had been occupied - so a settler told me - for a number of years, by the same pair of birds, who made the cave and its surrounding forest their permanent home through the year.

From its protected situation, it required but few alterations and additions each year; and many of the sticks of which it was composed were quite rotten and decayed.

It contained five young, about half-grown. As this was on the 18th of March, I judged the eggs must have been laid by the 20th of February.

The eggs of this species are generally four or five in 
number: they almost exactly resemble those of the Common Crow; but are considerably larger, averaging about two inches in length by 1.55 inch in breadth.

A specimen in my collection, of undoubted authenticity, collected on Grand Menan, is much smaller than the usual size, being but 1.70 by 1.24 inch in dimensions.

The habits of this bird have been described so many times, and are so familiar to all, that I will not give them an extended notice here.

\section{CORVUS AMERICANUS. - Audubon.}

\section{The Common Crow.}

Corvus corone, Wilson. Am. Orn., IV. (1811) 79. Nutt. Man., I. (1832) 209.

Corvus Americanus, Audubon. Orn. Biog., II. (1834) 317; V.477. Nutt. Man., I. (2d ed., 1840) 221.

\section{DESCRIPTION.}

Fourth quill longest, second shorter than sixth, first shorter than ninth; glossy black with violet reflections, even on the belly; tarsus longer than the middle toe and claw.

The bill is considerably narrower than high or much compressed; it is gently curved from the very base, rather more rapidly towards the tip; the incumbent feathers of the nostril reach half the distance from the base of the bill to the end of the lower jaw, and not quite half-way to that of the upper.

The tarsus has eight scutellæ anteriorly, and is rather longer than the middle toe and claw; the lateral toes are very nearly equal; the inner claw the larger, and reaching to the base of the middle claw.

The webs of the throat feathers are a little loose, but lie quite smoothly, without the pointed lanceolate character seen in the ravens.

Length, nineteen to twenty inches; wing, thirteen to thirteen and fifty one-hundredths; tail, about eight inches.

This well-known bird is abundant through New England in the summer, and in mild winters is a resident through the year. The species - as Mr. Allen justly remarks, in his Catalogue of the Birds of Springfield, Mass. — " seems to have diminished very materially in numbers in the last six or eight years; hundreds, and probably thousands, having been killed in the State by the use of strychnine almost every year."

About the first week in May, the birds separate into pairs, and soon commence building. The nest is usually built in a 
fork of a tall pine, sometimes in a thick birch or hemlock: it is constructed of, first, a layer of coarse twigs and sticks, then a layer of the bark of the cedar, moss, and sometimes bunches of grass; it is warmly lined with the bark of the cedar, and sometimes a few leaves. The eggs are usually four in number: their color is of different shades of green, which is covered with blotches and spots of different browns, and dusky. Dimensions vary from 1.65 by 1.20 to 1.50 by 1.08 inch. But one brood is reared in the season.

Perhaps no branch of American rural economy has been so little investigated as the food of our native birds. In Europe, within a few years, the attention of scientific men has been turned to the subject: but the information they have been able to obtain, although valuable, cannot, of course, be applied, otherwise than by a series of analogies, to this country; and the economical value of most of our species is as yet almost entirely unknown to us. This ignorance is owing, principally, to the difficulty attending such investigations, - the killing of great numbers of birds in all the seasons when they are found with us, which is absolutely necessary, but which is extremely distasteful to most persons; and it has been aggravated somewhat by the contradictory statements of various persons in different localities regarding the food of some species that they have had the means of observing.

Of these birds, none have given rise to more controversy than the Corvidee; and I propose to discuss briefly here this interesting topic, and bring a few facts and arguments, founded on reason or actual observation, to show their actual economical value.

Until very recently, I have been the earnest advocate of these birds, and have believed that the benefits they render much more than balance the injuries they inflict; but I must say, that, after careful consideration, my faith in their utility is sadly shaken.

At the outset I will say, that I have kept specimens in 


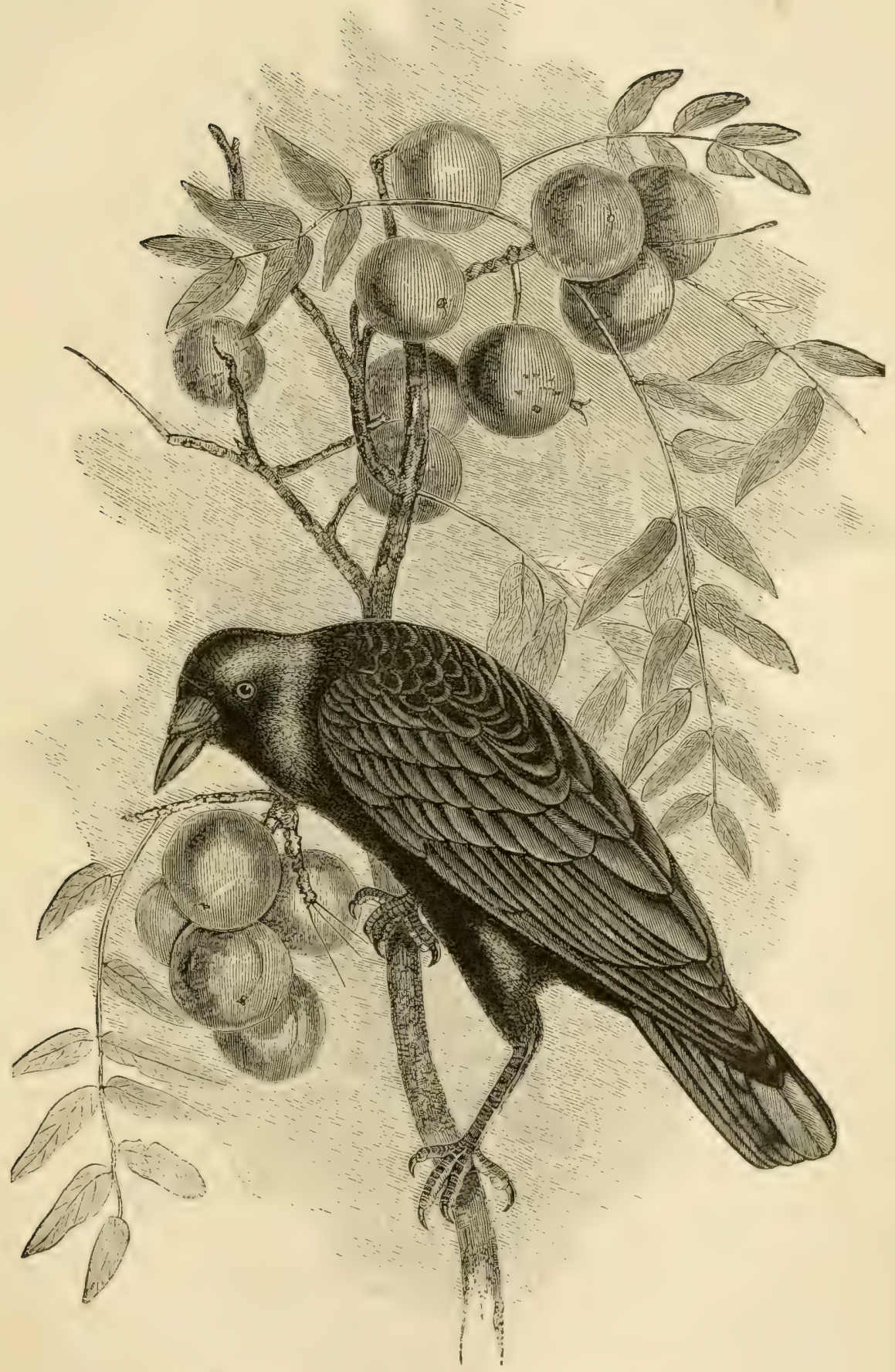

Common Crow, Corvus Americanus. Audubon. 

captivity; and have, by actual observation, proved that at least eight ounces of such food as frogs, fish, \&c., are eaten daily by our Common Crow. Of course, like other birds, it can live on a very limited allowance; but I think that the above is a reasonable amount: however, to be absolutely within bounds, we will fix the food of the Crow to be equal to five ounces of animal matter per diem. Beginning, then, with the new year, we will follow the life of this bird through all the seasons, and then compare the results arrived at together, good and bad.

During the months of January, February, and March, when the face of the country is covered with snow, the insects being dormant, and the small birds away to more southern districts, most of the Crows migrate from New England: and the few that remain depend upon a scanty subsistence of seeds of wild plants and weeds, acorns, apples that have been left on the trees in the orchard, and frozen; and they occasionally capture a field-mouse that strays from its nest in the stubble-field or swamp. The life of the Crow during these months is one continued starvation; and the expression, "poor as a crow," may be applied to it, as well describing its condition. It succeeds in finding a few cocoons of Lepidopterous insects; meets occasionally with a caterpillar or beetle; and, on the whole, its labors during these months may be called beneficial; although the good resulting from them is of so little amount that we might safely regard them as neutral. But, to be beyond the chance of doing it an injustice, we will assume, that, during the three months above mentioned, the Crow does as much good as during the whole month of April.

Let us adopt, in this discussion, a system of numerals to signify the relative values of this bird through the year; taking the unit one to represent the labors of each day. The Crow is therefore valuable, during January, February, and March, thirty units, and in April is unquestionably thirty units more; for its food then consists almost entirely of 
noxious insects in their different forms. It is perfectly safe to say, that it would destroy a thousand insects in making up the amount of food that I mentioned above; and it is not improbable, that, during this month, it actually eats that number daily.

During the first half of May, its labors are undoubtedly beneficial; for its food still consists almost entirely of insects : but after the middle of that month, when the small birds have begun to lay their eggs and hatch their young, the Crow divides its diet pretty equally between them and the insects. Now, it is not apparent; at the first glance, how immensely injurious it becomes the moment it begins to destroy the eggrs and young of our small birds; but we may demonstrate it to an approximation. We will allow, that, during the latter part of May, half of its food consists of injurious insects and other vermin : it is therefore beneficial in the whole month about twenty-three units. But it is perfectly reasonable to say, that it destroys at least the eggs or young of one pair of Sparrows, four in number ; one pair of Warblers, four in number; and one pair of Thrushes or Starlings, four in number: for I have known one pair of Canada Jays to kill and devour the half-grown young of four families of Snowbirds (Junco hyemalis), sixteen birds in all, in one forenoon; and have seen a pair of crows, in two visits to an orchard, within a half-hour's time, destroy the young birds in two robins' nests.

Now, let us see what the injury amounts to that it does in destroying the four eggs or young of the Sparrows, Warblers, and Thrushes. It is a well-known fact, that the young of all our small birds, whether insectivorous or graminivorous in the adult stage, are fed entirely on insects. Bradley says that a pair of Sparrows will destroy 3,360 caterpillars for a week's family supplies. For four weeks, at the lowest estimate, the young of our Sparrows are fed on this diet; and the family that the crow destroys would, in that time, eat at least 13,440 noxious insects; and, as they feed more 
or less upon the same diet during their stay with us, killing certainly as many as fifty insects each daily, the family would devour two hundred per diem, or, before they leave us in September, as many as twenty thousand. The Warblers are entirely insectivorous, and we can certainly allow them as great destructive capacity as the Sparrows. The four that the crow destroys would have devoured, before they leave us in autumn, at least thirty thousand caterpillars and other insects. A pair of thrushes has been actually seen to carry over a hundred insects, principally caterpillars, to their young in an hour's time: if we suppose that the family mentioned above be fed for only six hours in the day, they would eat six hundred per diem, at least while they remain in the nest, which being three weeks, the amount would be 12,600 ; and before they leave us in the fall, allowing only fifty each per day, - a very small number, - they would, in the aggregate, kill twenty thousand more.

Now, we find that the Crow in one day destroys birds that would together eat 96,040 insects before they wor'd leave us for their winter homes, or about ninety-six times as many as it would eat in a day if its food consisted entirely of them. It is therefore injurious, during the last half of May, - keeping our original calculation in view, -598 units.

During the whole month of June and the first half of July, while its family are in the nest, it is at least doubly destructive; for its young are possessed of voracious appetites, requiring an abundance of food to supply them. Allowing, then, that of its and their diet, half consists of insects during this period, it is beneficial about forty-six units; but, as at least one-half of the other half consists of young birds and eggs, it is injurious, during the same period, at least 96 units daily, or 4,320 units for June and the first half of July. The remaining quarter of its and their food, during this time, consists of berries and various small seeds and 
reptiles; and this diet may be considered as of neutral importance, economically speaking.

During the last half of July, and through August and the first half of September, its diet consists of about half insects and mice; and the balance, of berries and small fruits. It is therefore, during this time, beneficial about thirty units, and is not injurious, otherwise than by eating garden fruits or grains, -items that I do not consider in the present discussion. From the middle of September until November, its food loses much of its fruit character, because of the failure of supply, and it feeds at least twothirds on insects and other noxious animals : it is therefore beneficial thirty units, and is not injurious; and, during November and December, it is beneficial to about the same extent that it is in February and March, or about forty units.

We have now but to condense the foregoing results, and we have, in the aggregate, the sum total of the Crow's merits and demerits.

We find, that, during the whole year, it is beneficial to the amount of 229 units, and that it is injurious to the extent of 4,918 units. If, for the sake of the greatest indulgence, we take but one-fourth of this enormous disproportion as the actual fact, we still have an exhibit that proves at once that these birds are not only worthless, but are ruinously destructive.

In presenting this extended sketch, I will say that I am not moved in the least by prejudice or ill feeling for a muchdisliked bird, but that I state the facts as they are, and simply to throw a little light on a subject that has given rise to much discussion and controversy. In conclusion, I will say that the Jays are equally injurious with the Crows, and that they are not deserving of a moment's indulgence or protection at the hands of the ruralist. 


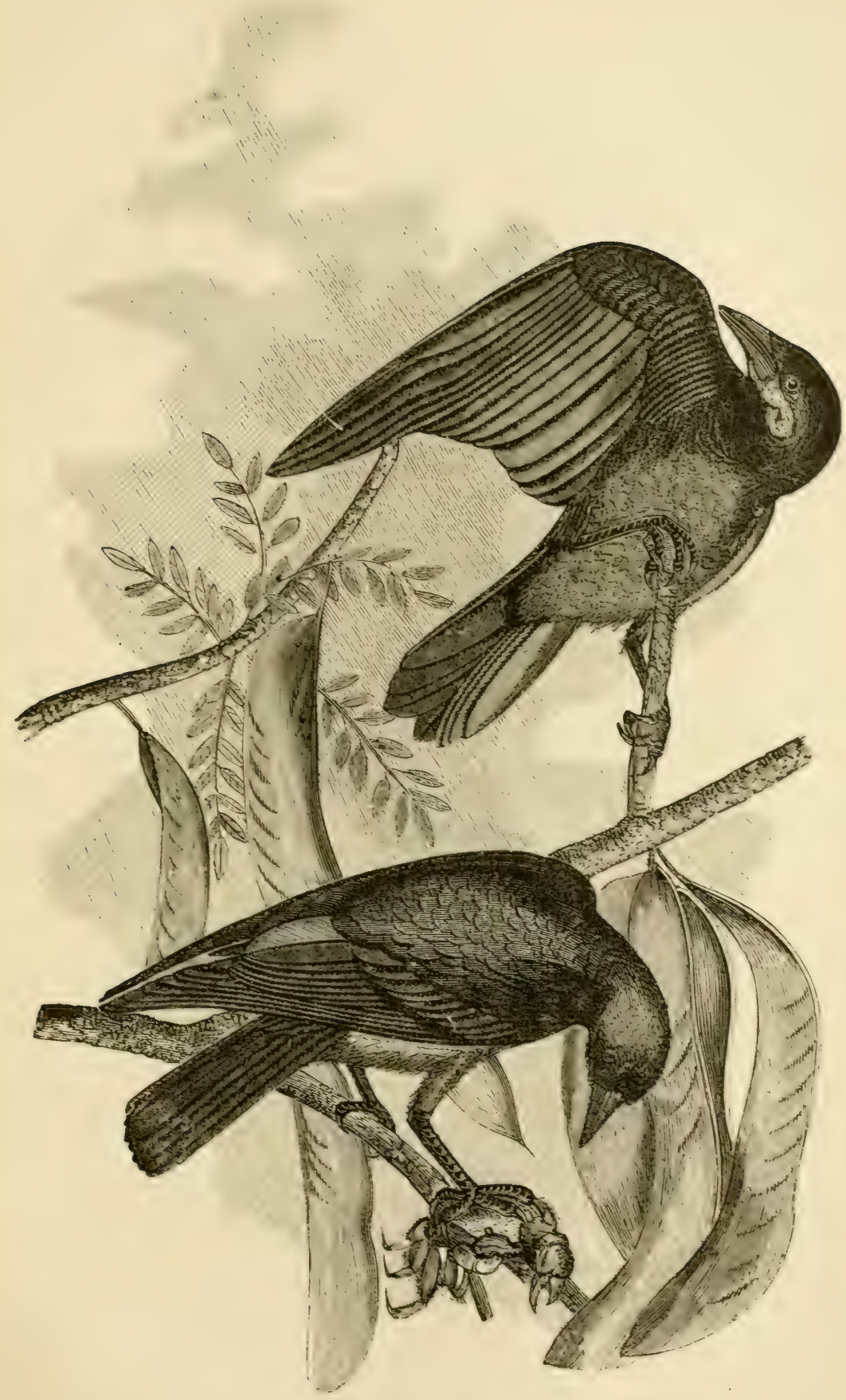

Fish Crow, Corrus ossifragus. Wilson. 



\section{CORVUS OSSIFRAGUS. - Wilson.}

\section{The Fish Crow.}

Corvus ossifragus, Wilson. Am. Orn., V. (1812) 27. Nutt. Man., I. (1832) 216. Aud. Orn. Biog., II. (1834) 268; V. 479.

\section{Description.}

Fourth quill longest; second rather longer than seventh; first shorter than the ninth; glossy-black, with green and violet reflections; the gloss of the belly greenish.

In this species the bill is shaped much as in the Common Crow, the upper outline perhaps a little more convex; the bristly feathers at the base of the bill reach nearly half-way to the tip; I find no bare space at the base of the lower mandible, although the feathers are not quite so thick there as in the Common Crow; the tarsus has eight transverse scutellx, and is decidedly shorter than the middle toe with its claw; the lateral claws do not reach within one-tenth of an inch of the base of the middle claw.

The wings are long and acute; the fourth is longest; next the third, fifth, second, and sixth; the first is about as long as the secondaries.

Length, about fifteen and fifty one-hundredths inches; wing, ten and fifty onehundredths inches; tail less than seven inches; tarsus shorter than the middle toe and claw.

Hab. - South Atlantic (and Gulf ?) coast.

This bird is so extremely rare in New England, that it can be regarded only as an occasional straggler. I understand that it has been taken on Long Island, and, on one or two occasions, in Connecticut, in company with the Common Crow.

\section{Audubon says of the habits of this species, -}

"While on the St. John's River in Florida, during the month of February, I saw flocks of Fish Crows, consisting of several hundred individuals, sailing high in the air, somewhat in the manner of the Raven. These aërial excursions would last for hours, during the calm of a fine morning, after which the whole would descend toward the water to pursue their more usual avocations in all the sociability of their nature. When their fishing, which lasted about half an hour, was over, they would alight in flocks on the live oaks and other trees near the shore, and there keep up their gabble, pluming themselves for hours.

"The nest of this species is smaller than that of the Common Crow, and is composed of sticks, moss, and grasses, neatly finished 
or lined with fibrous roots. The eggs are from four to six, and resemble those of the American Crow, but are smaller."

Two eggs in my collection, from Florida, are of the above description, and are almost exactly like the others, measuring a little smaller: their dimensions being 1.60 by 1.10 inch and 1.52 by 1.04 inch.

\section{Sub-Family Garroline. - The Jays.}

Wings short, rounded; not longer or much shorter than the tail, which is graduated, sometimes excessively so; wings reaching not much beyond the lower tail coverts; bristly feathers at base of bill, variable; bill nearly as long as the head, or shorter; tarsi longer than the bill or than the middle toe; outer lateral claws rather shorter than the inner.

\section{CYANURA, SwaINsox.} Linn.)

Cyanurus, Swainson, F. Bor. Am., II. (1831) 495, App. (Type Corvus cristatus,

Head crested; wings and tail blue, with transverse black bars; head and back of the same color; bill rather slender, somewhat broader than high at the base; culmen about equal to the head; nostrils large, nearly circular, concealed by bristles; tail about as long as the wings, lengthened, graduated; hind claw large, longer than its digit.

The culmen is straight to near the tip, where it is gently decurved; the gonys is convex at the base, then straight and ascending; the bill has a very slight notch at the tip; the nostrils are large, nearly circular, or slightly elliptical; the commissure is straight at the base, then bending down slightly near the tip; the legs present no special peculiarities; the crest on the head consists of a number of elongated, narrow, lanceolate occipital feathers.

CYANURUS CRISTATUS, - Swainson.

The Blue Jay.

Corvus cristatus, Linnæus. Syst. Nat., I. (10th ed., 1758) 106. Wils. Am. Orn., I. (1808) 2. Aud. Orn. Biog., II. (1834) 11; V. (1839) 475.

Cyanurus cristatus, Swainson. F. Bor. Am., II. (1831) App. 495.

\section{DESCRIPTION.}

Crest about one-third longer than the bill; tail much graduated; general color above, light purplish-blue; wings and tail feathers ultramarine-blue; the secondaries and tertials, the greater wing coverts, and the exposed surface of the tail, sharply 



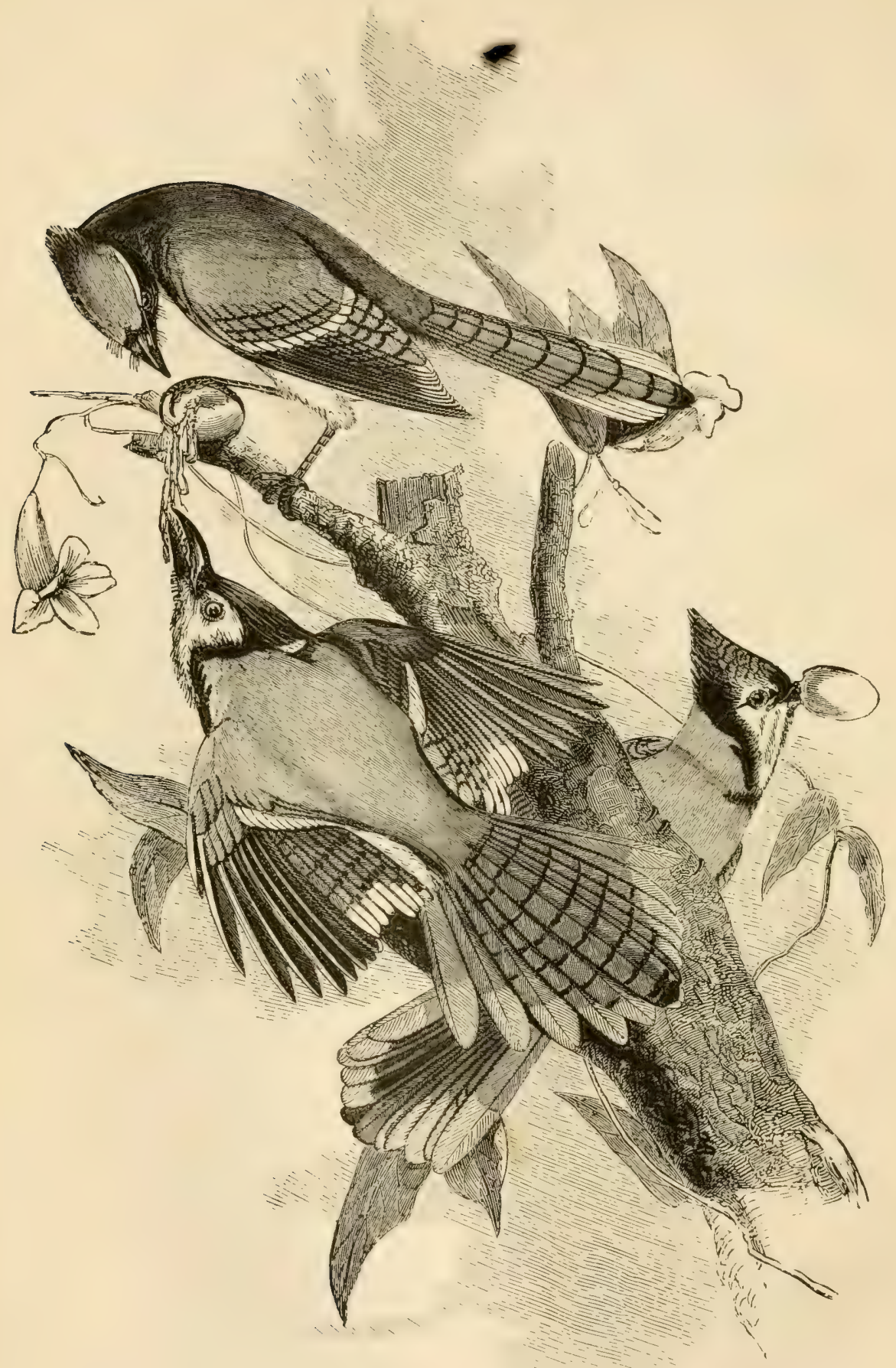

BıLE JAY, Cyanura cristula. Swainson. 
banded with black, and broadly tipped with white, except on the central tail feathers; beneath white; tinged with purplish-blue on the throat, and with bluish-brown on the sides; a black crescent on the forepart of the breast, the horns passing forward and connecting with a half-collar on the back of the neck; a narrow frontal line and loral region black; feathers on the base of the bill blue, like the crown. Female rather duller in color, and a little smaller.

Length, twelve and twenty-five one-hundredths inches; wing, five and sixty-five one-hundredths inches; tail, five and seventy-five one-hundredths inches.

This beautiful and well-known bird is abundantly distributed throughout New England. It is less common in the northern than in the southern districts, but is often seen there, not in company with the Canada Jay, however.

Its food is more varied than that of almost any other bird that we have. In winter, the berries of the cedar, bar. berry or black-thorn, with the few eggs or cocoons of insects that it is able to find, constitute its chief sustenance. In early spring, the opening buds of shrubs, caterpillars, and other insects, afford it a meagre diet. Later in the spring, and through the greater part of summer, the eggs and young of the smaller birds constitute its chief food, varied by a few insects and early berries. Later in the summer, and in early autumn, berries, small fruits, grains, and a few insects, afford it a bountiful provender; and later in the autumn, when the frosts have burst open the burrs of chestnuts and beechnuts, and exposed the brown, ripe fruit to-view, these form a palatable and acceptable food: and a large share of these delicious nuts fall to the portion of these busy and garrulous birds.

The notes of the Blue Jay consist of a shrill cry, like jay-jay-jay repeated often, and in a high key; a shrill whistle like the syllables whëèo-whèe-o-whēêo; a hoarse rattle, something like a Kingfisher's well-known alarum; and an exceedingly sweet bell-like note, that possesses a mournful tone, like that of a far-off hamlet bell tolling a funeral dirge.

I have often heard this tone in the autumn, when the leaves were falling from the trees, and all nature wore its 
funeral livery ; and it seemed to me. when the clear notes of the bird were echoed from hill-side to hill-side in the forest, that it was wandering like a forest elf through the trees, mourning the decay of all the charms that had made them so beautiful through the spring and summer.

About the first or second week in May, the Blue Jay commences building. The nest is usually placed in a fork of a low pine or cedar, in a retired locality : it is loosely constructed of trigs and coarse roots, and lined with the same materials, but of a finer quality, and sometimes a fer pieces of moss or a fer leares. The eggs are four or fire in number. Their color is generally light-green, with spots of light-brown: sometimes a dirty brownish-grar, spotted with different shades of brown and black. The dimensions rary from 1.20 by .85 to 1 by .80 inch. But one brood is reared in the season.

\section{PERISOREUS, BOXAPARTE.}

Perisoreus, Boxaparte, Saggio di una dist. met. (1\$31). (Type Corrus Canadensis?)

Feathers lax and full, especially on the back, and of rery dull colors, without any blue; head without distinct crest; bill rery short, broader than high; culmen scarcely half the length of the head, straight to near the tip, then slightly curred; gonys more curved than culmen; bill notched at tip; nostrils round, corered by bristly feathers; tail about to the wings, graduated; tarsi rather short, but little longer than the middle toe.

This genus includes the species of dullest colors among all of our Jays. It has, too, the shortest bill, and with this feature bears a very strong resemblance, in many respects, to some of the Titmice.

\section{PERISOREUS CANADENSIS. - Bonaparte.}

The Canada Jay.

Corvus Canadensis, Linnæus. Syst. Nat., I. (1766) 158. Wils. Am. Orn., III. (1811) 33. Aud. Orn. Biog., II. (183ł) 53; V. (1839) 20 .

Perisoreus Canadensis, Bonaparte. List (183S). Ib., Consp. (1850) 375.

\section{Description.}

Tail graduated; lateral feathers about one inch shortest; wings a little shorter than the tail; head and neck, and forepart of the breast, white; a plumbeous brown nuchal patch, becoming darker behind, from the middle of the cromn to the back, from which it is separated by an interrupted whitish color; rest of upper parts ashy- 
plumbeous; the outer primaries margined; the secondaries, tertials, and tail feathers obscurely tipped with white; beneath smoky-gray; crissum whitish; bill and feet black.

The young of this species are everywhere of a dull sooty-bromn, lighter on the middle of the belly, and more plumbeous on the wings and tail; with increasing age, the region about the base of the bill whitens, and this color gradually extends backirards until the whole head, excepting the occiput and nape, is white; the under parts are sometimes whiter than in the typical specimens.

Length, ten and serenty one-hundredths inches; wing, five and seventy-five onebundredths inches; tail, six inches; tarsus, one and forty one-hundredths inches.

This species is confined to the northern districts in New England, where it is resident through the year. I hare not been so fortunate as to find the nest, and will hare to borrow Audubon's description of that and the eggs:-

"The Canada Jay breeds in Maine, in New Brunswick, Nora Scotia, Nerfoundland, and Labrador. It begins as early as February or March to form its nest, which is placed in the thickest part of a fir-tree, near the trunk, and at a height of from fire to ten feet. The exterior is composed of dry twigs, with moss and grass; and the interior, which is flat, is formed of fibrous roots. The eggs, which are from four to sis, are of a light-gray color, faintly marked with brown."

This hird is not generally so well known as the preceding. I have had numerous opportunities for observing its habits, and I can positively affirm that it is equally rapacious and destructive with the Blue Jar, which it resembles in motions and cry.

I once knew of a single pair of these birds destroring the young in four nests of the Common Snowbird (J. hyematis) in a single day. I found these nests in an old abandoned lumber-road on the morning of June 20: in the afternoon, when I returned through the same path, every nest was depopulated; and a pair of these Jays were lurking in the trees, shouting defiance at us, while surrounded by the afflicted Snowbirds, that were uttering their cries of complaint and sorrow. I emptied both barrels of my gun in the direction of the Jays, and I am inclined to think that 
they have killed no young birds since. The familiarity with which this species fraternizes with man in the woods is interesting and amusing. I was once "snowed in," as the expression is, in a large tract of forest, and, with my companions, was obliged to wait until the storm had ceased before we could resume our march. We remained in camp two days. A pair of these birds, probably with young in the neighborhood, visited our camp, and even penetrated into our tent for crumbs and pieces of bread. They always flew off with their mouths full, and soon returned for more: their visits soon got to be any thing but a joke, particularly when they flew off with the last piece of our soap. We couldn't kill them, however; for any thing with life was company, and we felt that we had none of that to spare.

\section{NOTES.}

I present a continuation of Mr. Couper's valuable notes, taken at Quebec, Lower Canada, on the species described in the present Order.

TROCHILUS COLUBRIS. - Common in this neighborhood and in the mountain wilds and savannas north of the city. I have had the pleasure of finding its nest on more than one occasion. It generally arrives here about the middle of May.

CHÆTURA PELASGIA. - Very abundant. It builds its nest in unused chimneys in the city. I have remarked that no more than a single pair will occupy a flue; and, although there are many instances here of chimneys having unused flues, it is curious that they are not occupied while one is in possession of the Swallow. I have noticed this species flying over the woods many miles north of Quebec; and I think that it breeds within large foresttrees.

ANTROSTOMUS VOCIFERUS. - This bird is occasionally heard in the mountains north of Quebec. It is, however, very rare in this latitude, which may be considered its northern limit.

CHORDEILES POPETUE. - Very common. It deposits its eggs in a small cavity in the ground, in the midst of a woodland clearing, or wherever there is a young shrubbery. Its principal food in spring consists of ants. I can. not say how far north it goes. 
CERYLE ALCYON. - The Kingfisher occurs about all our northern lakes and rivers, and breeds plentifully. It probably extends three degrees north of Quebec.

TYRANNUS CAROLINENSIS. - Common. It builds its nest invariably near farm-houses.

CONTOPUS VIRENS. - I detected this species here this spring for the first time. I do not think it breeds commonly in high latitudes.

EMPIDONAX TRAILLII. - This species occurs during summer in the woodlands near Quebec. It rarely builds its nest high from the ground. It is extremely cunning, and invariably selects the most hidden portion of a clump of bushes.

TURDUS PALLASII. - This thrush breeds in the neighborhood of Quebec; but it is not common. It builds its nest much higher than Wilson's Thrush; that is to say, the latter is generally found concealed at the lower portion of a bush, while the former is often found on a heavily branched pine-tree The eggs of $T$.pallasii are blue and spotted. 1

TURDUS FUSCESCENS. - This is one of our most.common thrushes. It breeds plentifully in this neighborhood. Its nest is generally placed near the ground, at the lower portions of bushes growing near a swamp or river. The eggs are generally four or five, of a clear greenish-blue color.

SIALIA SIALIS. - The Redbreasted Bluebird is only seen here early in spring, while on its passage to the West. It does not breed in Lower Canada.

REGULUS CALENDULA. - This species, in company with $R$. satrapa, visit this locality, from the North, in the autumn.

ANTHUS LUDOVICIANUS, - Common in the autumn. They frequent fields and barnyards, and are generally in flocks. I think they breed in Labrador.

MNIOTILTA VARIA. - This species is not common in our Northern woods. It, however, breeds in the neighborhood of Quebec.

GEOTHLYPIS TRICHAS. - Very common. Breeds.

SEIURUS AUROCAPILLUS. - Common. Breeds.

DENDROICA VIRENS. - Only noticed in spring, on its way North. It was rather common in the spring of 1866.

DENDROICA CANADENSIS. - Common. Breeds.

DENDROICA CORONATA, - Very common in the autumn. I think they breed far north.

DENDROICA BLACKBURNIF. - This beautiful Warbler was very abundant here last spring. None of the young returned this way. There appears

1 Mr. Couper undoubtedly refers to $T$. Swainsonii.-E. A. S. 
to be some mystery connected with the breeding localities of many of our Warblers. Some of them are found breeding over the whole of temperate America, while others, who evidently eat the same kinds of food, pass to the inaccessible parts of the northern forests, where the foot of man never trod.

DENDROICA CASTANEA. - This is another of the mysterious Warblers that shows itself in spring, and afterwards slowly departs to its northern hermitage.

DENDROICA PINUS. - Spring. Not common. Follows its kindred, North. DENDROICA PENNSYLVANICA, - Not common. Breeds.

DENDROICA CERULEA. - This species was very common in this neighborhood in the spring of 1866 . I have never seen its nest or eggs.

DENDROICA STRIATA. - Not common. Breeds.

DENDROICA ESTIVA, - Common. Breeds.

DENDROICA MACULOSA. - Common. Breeds.

MYIODIOCTES CANADENSIS. - Common. Breeds.

SETOPHAGA RUTICILLA. - Common. Breeds.

PYRANGA RUBRA, - Rarely seen in the woods north of Quebec. They breed in the maple woods; and this latitude may be considered its northern limit of migration.

HIRUNDO HORREORUM. - Uncommon. It builds its nest on the beams of out-houses and barns in this neighborhood.

H. LUNIFRONS, - Very common. It builds mud or clay nests under the thatched barns and country-houses near Quebec. They are protected by farmers, who will not allow them to be disturbed during their stay here. They return annually to the old nests, which they repair.

H. BICOLOR. - Common. It builds its nest in any hole it may find in the houses in the city. In the woodland districts, it generally selects an abandoned Woodpecker's nest in trees.

COTYLE RIPARIA. - Common. Breeds in every sand-bank in the country.

PROGNE PURPUREA. - The breeding-place of this Swallow is confined to a building called the Jesuit Barracks, of this city, where they raise their young every season. I have repeatedly tried to induce them to occupy boxes, but the White-bellied Swallow always took possession first. In this locality, the Purple Martin loves its own community, and will not be induced to occupy the most tempting abode unless made sufficiently large to accommodate several pairs.

AMPELIS GARRULUS. - During severe winters, this species arrives here from the north to feed on the berries of the mountain-ash, which grows 
abundantly in the neighborhood of the city. They go in flocks. They must breed late in the season, as I had the young with the downy feathers attached to their heads during the depth of winter.

AMPELIS CEDROROM. - Common. Breeds.

COLLTRIO BOREALIS. - Arrives early in Spring. I think they go to high latitudes to breed. The specimens which I procure are either in spring or fall plumage.

VIREO OLIVACEUS. - Not.common. Breeds.

MIMUS CAROLINENSIS, - Not common. Breeds.

TROGLODTTES HYEMALIS. - Common. Breeds.

CERTHIA AMERICANA. - Common. Breeds.

SITTA CANADENSIS. - Common in summer and winter. Breeds.

PARUS ATRICAPILLUS. - Common. Breeds.

P. HUDSONICUS. - Arrives about the middle of September from the North, and remains until the snow falls. It has not been found breeding in this locality. They go in flocks, like the former species.

EREMOPHILA CORNUTA. - This Lark arrives here in the month of September. It gathers in flocks, which remain until the snow falls. It breeds in Labrador.

PINICOLA CANADENSIS. - Arrives from the North, sometimes in company with the Bohemian Waxwing, and feeds on the same berries. They frequently remain during winter.

CARPODACUS PURPUREUS. - Common. Breeds.

CHRYSOMITRIS TRISTIS. - Common. Breeds.

C. PINUS. - Sometimes common in winter.

CURVIROSTRA AMERICANA. - Sometimes very abundant in winter. I am told it breeds in Nova Scotia.

C. LEUCOPTERA. - Very numerous during winter. Breeds in Labrador. EGIOTHUS LINARIA. - Common in the fall. Breeds in Labrador and Northern Newfoundland.

PLECTROPHANES NIVALIS. - Common in winter. Breeds in Labrador.

POOCETES GRAMINEUS. - Common. Breeds.

ZONOTRICHIA LEUCOPHRYS.-Common. Breeds.

Z. ALBICOLLIS. - Common. Breeds.

JUNCO HYEMALIS. - Common. Breeds.

SPIZELLA MONTICOLA. - This species goes far north to breed, probably

Labrador. It returns in the fall. 
S. SOcialis. - Common. Breeds.

MELOSPIZA MELODIA. - Common. Breeds.

M. PALUSTRIS. - Not common here; but it breeds in some of the southern towns of Lower Canada.

PASSERELLA ILIACA. - Not common. Breeds. I think that this species is more abundant in Labrador during summer.

GUIRACA LUDOVICIANA. - Not common. Breeds. Quebec may be considered its northern limit.

CYANOSPIZA CYANEA. - Not common. Breeds.

DOLICHONYX ORYZIVORUS. - Common. Breeds. This is the most northern limit of this species.

AGELAIUS PHENICEUS, - This species is a very rare visitor in this neighborhood, and is seen only in the spring, when on its passage to the swamps in the West. It breeds abundantly at Toronto, Upper Canada.

SCOLECOPHAGUS FERRUGINEUS. - Very common in the fall, at which season they visit this locality on their passage south. Great numbers are shot, and sold like game in our markets. This species has been noticed here as late as the 2tth of May, when it disappears. It has not been found breeding within the habitable portions of this province.

QUISCALUS VERSICOLOR. - Rare in this district. A few pairs have been discovered breeding at Three Rivers, between this city and Montreal.

CORVUS AMERICANUS. - Common. Breeds in large numbers. A few generally remain here during winter. They feed on the berries of the mountain ash. The old nests are invariably occupied, and the birds lay their eggs very early. I have seen the young ones fully fledged before the 24th of May.

CORVUS CARNIVORUS. - Occasionally seen in this district. It breeds on the high, rocky portions of islands in the lower St. Lawrence.

CYANURA CRISTATA. - Abundant in the mountains north of this city, where they breed.

PERISOREUS CANADENSIS. - Sometimes very common in the fall. I have not noticed this bird in the vicinity of Quebec during summer; but, while on a collecting trip down the St. Lawrence, in the month of July, I saw numbers of the old and young in the woods, at a place called Mille Vaches. They were following each other in one direction, and appeared to me to have habits similar to those of the Black-cap Titmouse. From this fact of its occurrence on the north shore of the St. Lawrence at the above season, it is evident that they breed in our wild, unfrequented forests, such ns may be found north and east of the river Saguenay. I have offered a high price for the nests and eggs of the Canada Jay; but, as yet, nothing of the kind has appeared. 


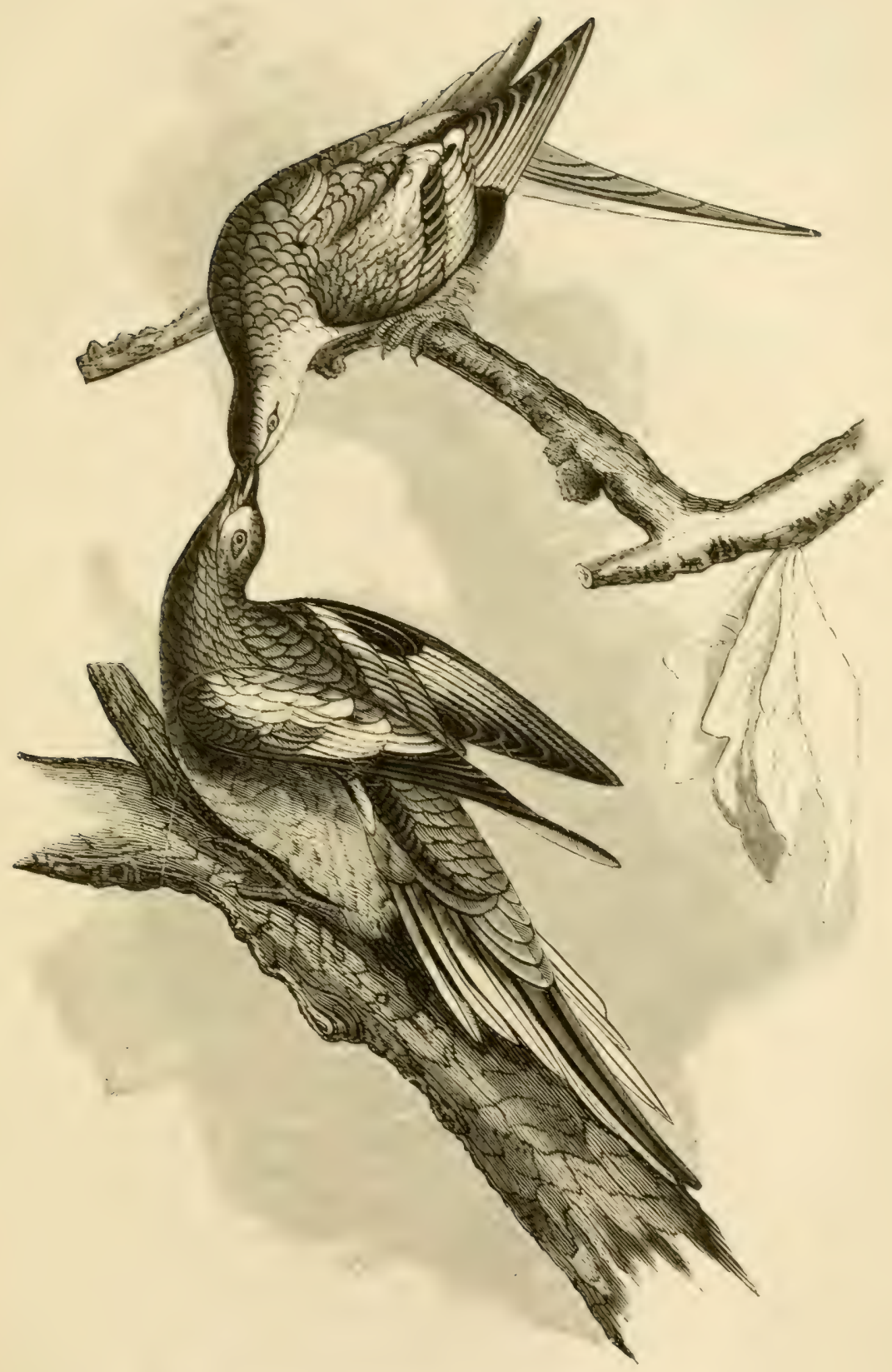

Wild Pigeon, Ectopistes migratoria. Swainson. 



\section{SUB-ORDER COLUMB开.}

The basal portion of the bill covered by a soft skin, in which are situated the nostrils, overhung by an incumbent fleshy valve, the apical portion hard and convex; the hind toe on the same level with the rest; the anterior toe without membrane at the base; tarsi more or less naked; covered laterally and behind with hexagonal scales.

\section{Family COLUMbid Ae. The Doves.}

Bill horny at the tip; tail feathers twelve, only occasionally fourteen; head smooth.

\section{Sub-Family Columbina.}

Tarsi stout, short, with transverse scutellæ anteriorly; feathered for the basal third above, but not at all behind; toes lengthened, the lateral decidediy longer than the tarsus; wings lengthened and pointed; size large; tail feathers twelve.

This section of doves embraces the largest North-American species, and among them the more arboreal ones.

\section{ECTOPISTES, SwAINSON.}

Ectopistes, Swanson, Zool. Jour., III. (1827) 362. (Type Columba migratoria, L.)

Head very small; bill short, black; culmen one-third the rest of the head; tarsi very short, half covered anteriorly by feathers; inner lateral claw much larger than outer, reaching to the base of the middle one; tail very long and excessively cuneate; about as long as the wings; first primary longest.

This genus is readily distinguished from the other Columbince by the excessively lengthened and acute middle feathers. It formerly included the Columba Carolinensis; but this, with more propriety, has been erected into a different genus, and will be found in the next section.

\section{ECTOPISTES MIGRATORIA. - Swainson.}

\section{The Wild Pigeon; Passenger Pigeon.}

Columba migratoria, Linnæus. Syst. Nat., I. (1766) 285. Wils. Am. Orn., I (1808) 102. Aud. Orn. Biog., I. (1831) 319; V. 561.

Ectopistes migratoria, Swainson. Zool. Jour., III. (1827) 355.

\section{DESCRIPTION.}

Tail with twelve feathers; upper parts generally, including sides of body, head, and neck, and the chin, blue; beneath, purple brownish-red, fading behind with a 
violet tint; anal region and under tail coverts, bluish-white; scapulars, inner tertials, and middle of back, with an olive-brown tinge; the wing caverts, scapulars, and inner tertials, with large oval spots of blue-black on the outer webs, mostly concealed, except on the latter; primaries blackish, with a border of pale-bluish tinged internally with red; middle tail feathers brown; the rest pale-blue on the outer web, white internally; each with a patch of reddish-brown at the base of the inner web, followed by another of black; sides and back of neck richly glossed with metallic golden-violet; tibia bluish-violet; bill black; feet yellow.

The female is smaller; much duller in color; more olivaceous above; beneath, pale-blue instead of red, except a tinge on the neck; the jugulum tinged with olive; the throat whitish.

The blue of the side of the head extends to the throat and chin; the upper part of the back and lesser coverts are of a darker blue than the head and rump; the inner primaries are more broadly margined with light-blue, which tapers off to the end; the axillars and under surface of the wing are light-blue; the longest scapulars have the black on both webs; there is no blue on the outer web of the first tail feather, which is white, and the inferior surface of the tail generally is white.

In some specimens the entire head all round is blue.

The immature male varies in having most of the feathers of the head and body. margined with whitish.

Length of male, seventeen inches; wing, eight and fifty one-hundredths inches; tail, eight and forty one-hundredths inches.

THIS bird has become of late years rather scarce in 1 New England; so much so, that, in localities where it was formerly abundant, it is now seen only occasionally in small flocks of a dozen or fifteen. It is a resident of these States through a greater part of the year; only absenting itself in the most severe portion of winter, when its food is usually covered with snow. It depends principally upon acorns and beechnuts for subsistence, and is most abundant in localities where these nuts are found. It also frequents grain-fields, where it gleans among the stubble and weeds; and, when berries are in season, it feeds plentifully upon them, and it is at that time when the greater number are seen in New England.

Early in May, the birds, although associating still in communities, as in sections where they are more abundant, separate into pairs, and build their nest. This is placed in a forked branch of a tree, usually in a swamp or thick wood. It is constructed of twigs and leaves, which are loosely arranged into a frail structure hardly strong enough 
to support the parent bird: it is but very little hollowed, and has no lining of softer material. The female deposits in this one or two eggs, on which both birds incubate. These eggs are pure-white in color, nearly oval in form, and have the slightest roseate tint before their contents are removed: they average in dimensions about 1.54 by 1.10 inch. Many writers affirm that but one egg is laid at a time. I think that in the greater number of nests two are deposited, as I have inquired of many hunters and woodsmen, and they all agree on that number.

\section{Sub-Family Zenaidinze.}

Tarsi stout, lengthened; always longer than the lateral toes, and entirely without feathers; the tibial joint usually denuded; tarsus sometimes with hexagonal scales anteriorly; tail feathers sometimes fourteen.

\section{ZENAIDURA, BoNAPARTE.}

Zenaidura, Bonaparte, Consp. Avium, II. (1854) 84. (Type Columba Carolinensis, L.) Probably named previously in Comptes Rendus.

Bill weak, black; culmen from frontal feathers, about one-third the head above; tarsus not quite as long as middle toe and claw, but considerably longer than the lateral ones; covered anteriorly by a single series of scutellæ; inner lateral claw considerably longer than outer, and reaching to the base of middle; wings pointed, second quill longest, first and third nearly equal; tail very long; equal to the wings; excessively graduated and cuneate, of fourteen feathers.

The fourteen tail feathers render this genus very conspicuous among the NorthAmerican doves. It was formerly placed with the Passenger Pigeon in Éctopistes, but has nothing in common with it but the lengthened tail, as it belongs to a different sub-family.

\section{ZENAIDURA CAROLINENSIS. - Bonaparte.}

\section{The Carolina Dove; Turtle Dove.}

Columba Carolinensis, Linnæus. Syst. Nat., I. (1766), 286, No. 37. Wils. Am. Orn., V. (1812) 91. Aud. Orn. Biog., I. (1831) 91; V. (1839) 555. Nutt. MIan., I. (1832) 626

Zenaidura Carolinensis, Bonaparte. Consp. Av., II. (1854) 84.

\section{Description.}

Tail feathers fourteen; above bluish, although this is overlaid with light brownish-olive, leaving the blue pure only on the top of the head, the exterior of the 
wings, ana upper surface of the tail, which is even slightly tinged with this color; the entire head, except the vertex, the sides of the neck, and the under parts generally, light brownish-red, strongly tinged with purple on the breast, becoming lighter behind, and passing into brownish-yellow on the anal region, tibia, and under tail coverts; sides of the neck with a patch of metallic purplish-red; sides of body and inside of wings clear light-blue; wing coverts and scapulars spotted with black, mostly concealed, and an oblong patch of the same below the ear; tail feathers seen from below blackish, the outer web of outermost white, the others tipped with the same, the color becoming more and more bluish to the innermost, which is brown; seen from above, there is the same graduation from white to light-blue in the tips; the rest of the feather, however, is blue, with a bar of black anterior to the light tip, which runs a little forward along the margin and shaft of the feather; in the sixth feather the color is uniform bluish, with this bar; the seventh is without bar; bill black; feet yellow. Female smaller, and with less red beneath.

Length of male, twelve and eighty-five one-hundredths inches; wing, five and seventy-five one-hundredths; tail, six and seventy one-hundredths inches.

This beautiful and well-known species is distributed throughout New England as a summer resident. It is more rarely seen in the more northern sections than in the southern; but it breeds in all these States. It arrives from the South early in spring, sometimes by the 10th of March. On its first appearance, it is found in small, loose flocks of five or six individuals, which frequent old stubblefields and orchards, where they feed on scattered grains and the seeds of various weeds. They also sometimes associate with domestic doves in the poultry yard, as I have witnessed on several occasions.

About the middle of May, they separate into pairs, and commence their duties of incubation. The nest is placed in a forked, horizontal branch of a tree, sometimes in the orchard, usually in a grove of pines or in a swamp. It is, like the nest of the Wild Pigeon, a loose, frail structure, in which the female deposits two eggs, which are pure-white in color, and usually nearly oval in form.

A great number of specimens in my collection, from different parts of the country, vary from 1.20 by .85 to .98 by .82 inch. The size most often found is about 1.12 by .80 inch. Two broods are reared in the season.

About the last of July, the old birds and young collect in flocks, and frequent grain-fields, where they feed upon the 
grain, and berry-patches, where they eat plentifully of berries: they are now fat, and very delicate eating; and, as they are much pursued by gunners, they soon become very shy, and difficult of approach.

During the mating season, and part of the period of incubation, the male has a soft, melancholy cooing note, which he utters often through the day. During the remainder of the year, he seems to have no note; for I have watched individuals for hours to ascertain, and never heard them emit any thing but the short chuckle peculiar to all doves.

By the first week in October, this species leaves New England on its southern migration. 


\section{SUB-ORDER GALLINÆ.}

Bill usually rather short and stout, and less than the head; basal portion hard, generally covered with feathers, and not by a soft naked skin; legs lengthened; the hind toe generally elevated above the level of the rest, and short; when lower dorn, it is longer; toes connected at the base by a membrane; the feathers of forehead not extending on the culmen in a point, but more restricted, and parted by the backward extension of the culmen.

\section{Fanily TETRAONID A. The Grouse.}

The Tetraonidce are pre-eminently characterized among gallinaceous birds by their densely feathered tarsi, and by the feathers of the nasal fossa or groore, which fill it completely, and conceal the nostrils; the toes are usually naked (feathered to the claws in the ptarmigans), and with pectinations of scales along the edges; the tail feathers vary from sirteen to eighteen and eren twenty in number; the tail is rounded, acute or forked; the orbital region is generally somewhat bare, with a naked stripe abore the upper eyelid, beset by short fringe-like processes.

\section{TETRAO, Lrsy aUS.}

Tetrao, Lixxaus, Syst. Nat. (1744) Gray. (Type T. urogallus, L.)

Tail lengthened, slightly narrowed to the square or somemhat rounded tip; about two-thirds the wing; the feathers with stiffened shafts; tarsus feathered to and between the bases of the toes; no unusual feathers on the side of throat; culmen between the nasal fossæ nearly half the total length; color mostly black.

Inhabit wooded regions.

\section{TETRAO CANADENSIS, - LinnceUs.}

\section{The Canada Grouse; Spruce Partridge.}

Tetrao Canadensis, Linnæus. Syst. Nat., I. (1766) 274. Nutt., Man. I. (1832) 667. Aud. Orn. Biog., II. (1834) 437 ; V. (1839) 563.

\section{Descriptiox.}

Tail of sixteen feathers; feathers abore distinctly banded with plumbeous; beneath uniform black, with a pectoral band of white, and white on the sides of the belly; chin and throat above black; tail with a broad bromnish-orange terminal band.

Prevailing color in the male black; each feather of the head, neck, and upper parts generally, having its surface waved with plumbeous-gray; this is in the form of two or three rell-defined concentric bars, parallel to each other, one along the exterior edge of the feather, the others behind it; the sides of the body, the 


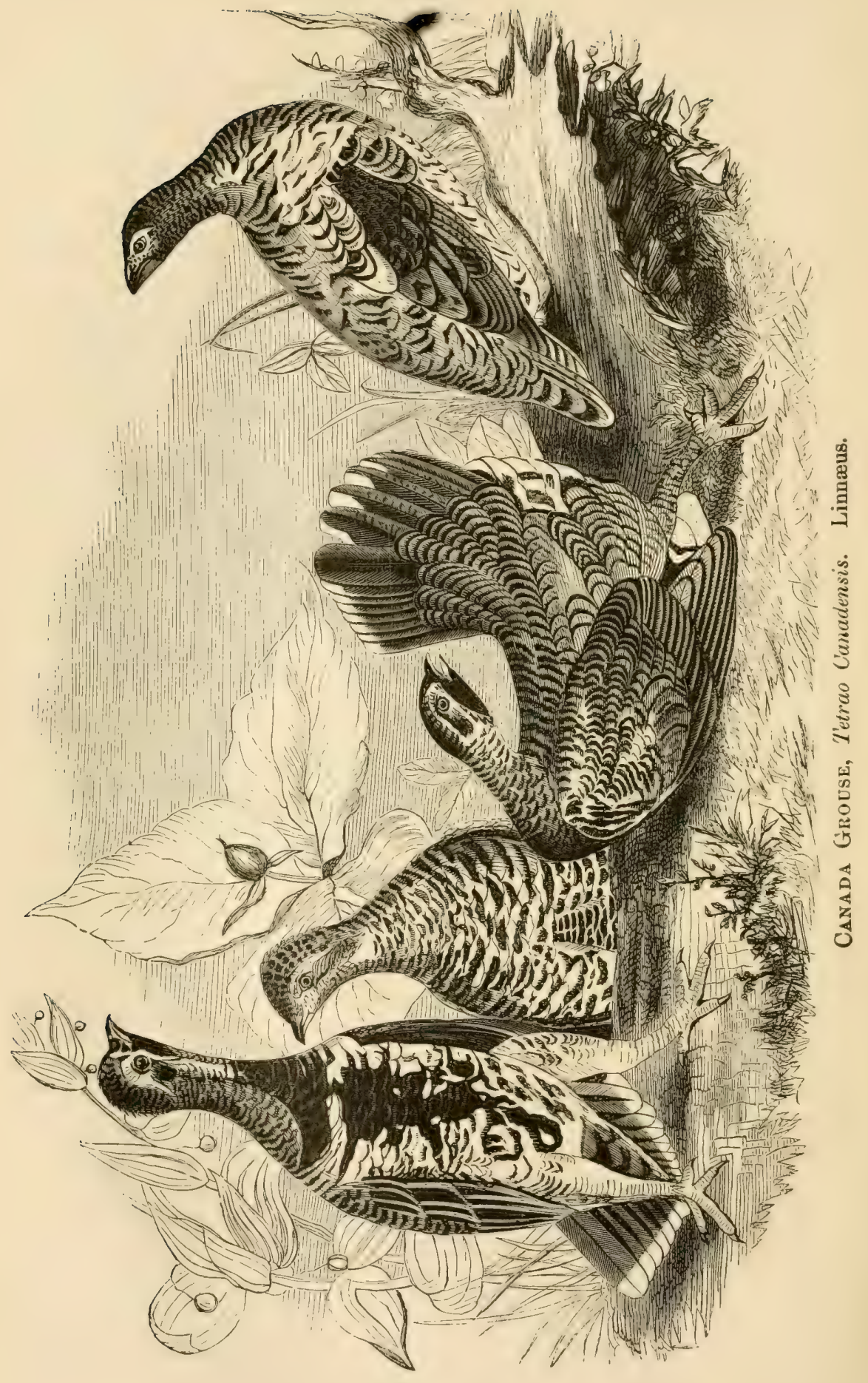


scapulars, and outer surface of the wings are mottled like the back, but more irregularly, and with a browner shade of gray, the feathers with a central white streak expanding towards the tip (on the wing these streaks seen only on some of the greater coverts); there is no white above, except as described; the under parts are mostly uniform black, the feathers of the sides of the belly and breast broadly tipped with white, which sometimes forms a pectoral band; there is a white bar across the feathers, at the base of the upper mandible, usually interrupted above; a white spot on the lower eyelid, and a white line beginning on the cheeks, and running into a series of white spots in the feathers of the throat; the lower feathers of this are banded terminally with whitish; the feathers at the base of the bill, and the head, below the eyes and beneath, are pure-black; the quills are darkbrown, without any spots or bands, the outer edges only mottled with grayish; the tail feathers are similar, but darker, and the tail is tipped with a band of orangechestnut, nearly half an inch wide, obscured on the central feathers, the under tail coverts are black, broadly barred and tipped with white; the feathers of the legs mottled-brown and whitish; dirty-white behind the tarsi; the bill is black.

The female is smaller but somewhat similar, the black bars above broader, the inner gray bars of each feather, including the tail, replaced by broader ones of brownish-orange; the under parts have the feathers black, barred with the brownishorange, which, on the tips of the belly feathers, is pure-white; the clear continuous black of the head and breast are wanting; the scapulars, greater coverts, and sides. are streaked as in the male.

Length, sixteen and twenty one-hundredths inches; wing, six and seventy onehundredths; tail, five and forty-four hundredths inches.

\section{$\mathrm{T}^{\mathrm{T}}$ is only in the most retired and unsettled localities in northern New England that this very beautiful grouse is} found. There, in the spruce and pine woods and swamps, it is not uncommon as a resident through the year. I have shot specimens in the White Mountains, between what is called Waterville, a hamlet in Thornton, N.H., and Bethlehem, in the same State; but they are more commonly found in the localities above mentioned. In its native haunts, it is very unsuspicious, permitting a person to walk within a few feet of it without stirring; and, when it does take flight, it goes but a few rods, when it alights on a tree, and turns to watch the intruder.

It is a very graceful bird on the ground, moving with a stately step over the long elastic moss so abundant in the woods of Maine.

It feeds upon the buds of the evergreens, and their seeds and foliage. This food imparts to the flesh of the bird a disagreeable resinous flavor, particularly in fall and winter, 
when it can get no other food. In fact, at all seasons, it is far inferior to all our other game birds in flesh, and is never delicate nor palatable.

About the middle of May, the female scratches together a loose nest, beneath the branches of a creeping fir, and lays in it from eight to twelve eggs. These are of a beautiful yellowish-buff color, with spots and blotches of two shades of brown: one a purplish-brown; the other, a burntsienna. They average in dimensions about 1.68 by 1.26 inch: their form is generally ovoidal; sometimes nearly oval, and occasionally more rounded. It is said, that, "when incubation begins, the males go apart by themselves to different portions of the forest, and remain until late in autumn, when they rejoin the females and young."

This species flourishes well in confinement: it tames readily, and soon eats all kinds of grains and seeds, and pieces of potatoes and fruits. It requires a large cage or coop, and is contented if it has, now and then, a spruce or cedar-tree given it to roost and climb upon.

\section{CUPIDONIA, REICHENBach.}

Cupidonia, Reichenbach, Av. Syst. Nat. (1850). (Type Tetrao Cupido, L.)

Tail short, half the lengthened wings; the feathers stiffened and more or less graduated; bare space of the neck concealed by a tuft of lanceolate feathers; tarsi feathered only to near the base, the lower joint scutellate; culmen between the nasal fossæ scarcely one-third the total length.

\section{CUPIDONIA CUPIDO. - Baird.}

\section{The Pinnated Grouse; Prairie Hen; Prairie Chicken.}

Tetrao Cupido, Linnæus. Syst. Nat., I. (1766) 274. Wils. Am. Orn., III. (1811) 104. Nutt. Man., I. 662. Aud. Orn. Biog., II. (1834) 490; V. (1839) 559.

Cupidonia Americana, Reichenbach. Av. Syst. Nat. (1850).

\section{DESCRIPTION.}

Tail of eighteen feathers, varied with whitish-brown and brownish-yellow; almost everywhere with well-defined transverse bars of brown on the feathers.

Body stout, compact; a tuft of long, pointed lanceolate feathers on each side of the neck, covering a bare space capable of much inflation; tail short, truncate, much graduated, composed of eighteen feathers, the lateral feathers about two-thirds the 
middle; the feathers stiffened, nearly linear and truncate; the tail is scarcely longer than the coverts, and half the length of the wing; tarsi covered with feathers anteriorly and laterally to the toes, but bare, with hexagonal scutells behind; the middle toe and claw longer than the tarsus; the toes margined by pectinated processes; a space above the eye provided with a dense pectinated process in the breeding season, sometimes separated from the eye by a superciliary space covered with feathers.

Length, sixteen and fifty one-hundredths inches; wing, eight and eighty onehundredths; tail, four and seventy one-hundredths inches.

This well-known bird is now found in New England only on Martha's Vineyard and Naushon, and perhaps one or two other islands off the southern coast of Massachusetts.

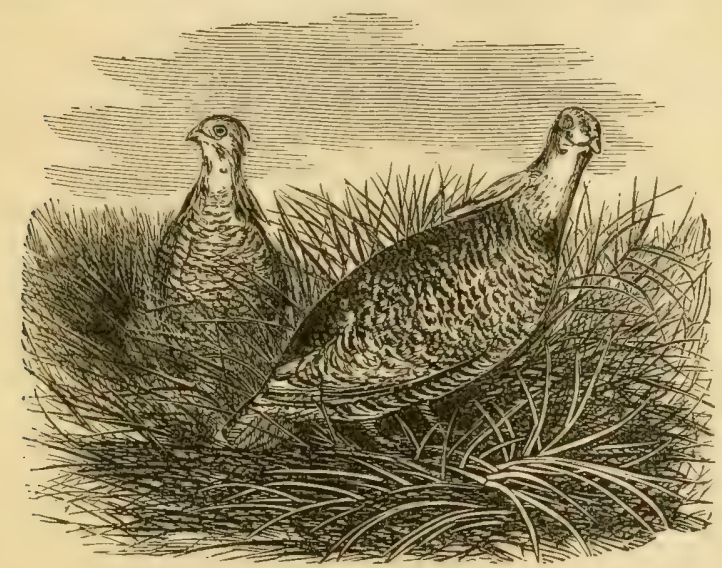

It was once probably very abundant in all the southern NewEngland States: but it is now nearly exterminated here; and very soon, in all probability, it will cease to be one. of our birds. Having had no opportunities for observing and studying its habits, I give the very full and interesting description presented by Wilson. He quotes a letter describing some of its habits as follows:-

"Amours. - The season for pairing is in March, and the breeding time is continued through April and May. Then the male Grouse distinguishes himself by a peculiar sound. When he utters it, the parts about the throat are sensibly inflated and swelled. It may be heard on a still morning for three or more miles; some say 
they have perceived it as far as fire or six. This noise is a sort of ventriloquism. It does not strike the ear of a bystander with much force, but impresses him with the idea, though produced within a few rods of him, of a voice a mile or two distant. This note is highly characteristic. Though very peculiar, it is termed tooting, from its resemblance to the blowing of a conch or horn from a remote quarter. The female makes her nest on the ground, in recesses very rarely discovered by men. She usually lays from ten to twelve eggs, which are of a brownish color, much resembling those of a Guinea Hen. When hatched, the brood is protected by her alone. Surrounded by her young, the mother-bird exceedingly resembles a domestic Hen and chickens. She frequently leads them to feed in the roads crossing the woods, on the remains of maize and oats contained in the dung dropped by the travelling horses. In that employment, they are often surprised by the passengers. On such occasions, the dam utters a cry of alarm. The little ones immediately scamper to the brush; and, while they are skulking into places of safety, their anxious parent beguiles the spectator by drooping and fluttering her wings, limping along the path, rolling over in the dirt, and other pretences of inability to walk or fly.

"Food.-A favorite article of their diet is the heath-hen plum, or partridge-berry. They are fond of whortleberries and cranberries. Worms and insects of several kinds are occasionally found in their crops. But, in the winter, they subsist chiefly on acorns and the buds of trees which have shed their leaves. In their stomachs have been sometimes observed the leaves of a plant supposed to be a wintergreen; and it is said, when they are much pinched, they betake themselves to the buds of the pine. In convenient places, they have been known to enter cleared fields, and regale themselves on the leaves of clover; and old gunners have reported that they have been known to trespass upon patches of buckwheat, and pick up the grains.

"Migration. - They are stationary, and never known to quit their abode. There are no facts showing in them any disposition to migration. On frosty mornings, and during snows, they perch on the upper branches of pine-trees. They avoid wet and swampy places, and are remarkably attached to dry ground. The low and 
open brush is preferred to high shrubbery and thickets. Into these latter places they fly for refuge when closely pressed by the hunters; and here, under a stiff and impenetrable cover, they escape the pursuit of dogs and men. Water is so seldom met with on the true Grouse ground, that it is necessary to carry it along for the pointers to drink. The flights of Grouse are short but sudden, rapid, and whirring. I have not heard of any success in taming them. They seem to resist all attempts at domestication. In this, as well as in many other respects, they resemble the Quail of New York or the Partridge of Pennsylvania.

"Manners. - During the period of mating, and while the females are occupied in incubation, the males have a practice of assembling, principally by themselves. To some select and central spot, where there is very little underwood, they repair from the adjoining district. From the exercise performed there, this is called a scratching-place. The time of meeting is the break of day. As soon as the light appears, the company assembles from every side, sometimes to the number of forty or fifty. When the dawn is past, the ceremony begins by a low tooting from one of the cocks. This is answered by another. They then come forth one by one from the bushes, and strut about with all the pride and ostentation they can display. Their necks are incurvated;. the feathers on them are exrected into a sort of ruff; the plumes of their tails are expanded like fans; they strut about in a style resembling, as nearly as small may be illustrated by great, the pomp of the Turkey-cock. They seem to vie with each other in stateliness; and, as they pass each other, frequently cast looks of insult, and utter notes of defiance. These are the signals for battles. They engage with wonderful spirit and fierceness. During these contests, they leap a foot or two from the ground, and utter a cackling, screaming, and discordant cry.

"They have been found in these places of resort even earlier than the appearance of light in the east. This fact has led to the belief that a part of them assemble over night. The rest join them in the morning. This leads to the further belief that they roost on the ground; and the opinion is confirmed by the discovery of little rings of dung, apparently deposited by a flock which had passed the night together. After the appearance of the sun, they disperse. 
"These places of exhibition have been often discovered by the hunters; and a fatal discovery it has been for the poor Grouse. Their destroyers construct for themselves lurking-holes made of pine branches, called bough houses, within a few yards of the parade. Hither they repair with their fowling-pieces, in the latter part of the night, and wait the appearance of the birds. Watching the moment when two are proudly eying each other, or engaged in battle, or when a greater number can be seen in a range, they pour on them a destructive charge of shot. This annoyance has been given in so many places, and to such extent, that the Grouse, after having been repeatedly disturbed, are afraid to assemble. On approaching the spot to which their instinct prompts them, they perch on the neighboring trees, instead of alighting at the scratching-place; and it remains to be observed how far the restless and tormenting spirit of the marksmen may alter the native habits of the Grouse, and oblige them to betake themselves to new ways of life.

"They commonly keep together in coveys, or packs, as the phrase is, until the pairing season. A full pack consists, of course, of ten or a dozen. Two packs have been known to associate. I lately heard of one whose number amounted to tiventy-two. They are so unapt to be startled, that a hunter, assisted by a dog, has been able to shoot almost a whole pack, without making any of them take wing. In like manner, the men lying in concealment near the scratching-places have been known to discharge several guns before either the report of the explosion, or the sight of their wounded and dead fellows, would rouse them to flight. It has further been remarked, that, when a company of sportsmen have surrounded a pack of Grouse, the birds seldom or never rise upen their pinions while they are encircled; but each runs along until it passes the person that is nearest, and then flutters off with the atmost expedition. Samuel L. Mitchile."

He then continues with his own observations:-

"This bird, though an inhabitant of different and very distant districts of North America, is extremely particular in selecting his place of residence; pitching only upon those tracts whose features and productions correspond with his modes of life, and avoiding 
immense, intermediate regions that he never visits. Open, dry plains, thinly interspersed with trees, or partially overgrown with shrub oak, are his favorite haunts. Accordingly, we find these birds on the Grouse plains of New Jersey, in Burlington County, as well as on the brushy plains of Long Island; among the pines and shrub oaks of Pocano, in Northampton County, Pennsylvania; over the whole extent of the Barrens of Kentucky; on the luxuriant plains and prairies of the Indiana Territory, and Upper Louisiana; and, according to the information of the late Governor Lewis, on the vast and remote plains of the Columbia River; in all these places preserving the same singular habits.

"Their predilection for such situations will be best accounted for by considering the following facts and circumstances: First, their mode of flight is generally direct and laborious, and ill calculated for the labyrinth of a high and thick forest, crowded and intersected with trunks and arms of trees, that require continual angular evolution of wing, or sudden turnings, to which they are by no means accustomed. I have always observed them to avoid the hightimbered groves that occur here and there in the Barrens. Connected with this fact is a circumstance related to me by a very respectable inhabitant of that country; viz., that, one forenoon, a cock Grouse struck the stone chimney of his house with such force as instantly to fall dead to the ground.

"Secondly, their known dislike of ponds, marshes, or watery places, which they avoid on all occasions; drinking but seldom, and, it is believed, never from such places. Even in confinement, this peculiarity has been taken notice of. While I was in the State of Tennessee, a person living within a few miles of Nashville had caught an old hen Grouse in a trap; and, being obliged to keep her in a large cage, as she struck and abused the rest of the poultry, he remarked that she never drank, and that she even avoided that quarter of the cage where the cup containing the water was placed. Happening, one day, to let some water fall on the cage, it trickled down in drops along the bars, which the bird no sooner observed than she eagerly picked them off, drop by drop, with a dexterity that showed she had been habituated to this mode of quenching her thirst, and probably to this mode only, in those dry and barren tracts, where, except the drops of dew and drops of rain, water is 
very rarely to be met with. For the space of a week, he watched her closely, to discover whether she still refused to drink; but, though she was constantly fed on Indian corn, the cup and water still remained untouched and untasted. Yet no sooner did he again sprinkle water on the bars of the cage, than she eagerly and rapidly picked them off as before.

"The last, and probably the strongest, inducement to their preferring these plains is the small acorn of the shrub oak, the strawberries, huckleberries, and partridge-berries, with which they abound, and which constitute the principal part of the food of these birds. These brushy thickets also afford them excellent shelter, being almost impenetrable to dogs or birds of prey.

"In all these places where they inhabit, they are, in the strictest sense of the word, resident; having their particular haunts and places of rendezvous (as described in the preceding account), to which they are strongly attached. Yet they have been known to abandon an entire tract of such country, when, from whatever cause it might proceed, it became again covered with forest. A few miles south of the town of York, in Pennsylvania, commences an extent of country, formerly of the character described, now chiefly covered with wood, but still retaining the name of Barrens. In the recollection of an old man born in that part of the country, this tract abounded with Grouse. The timber growing up, in progress of years, these birds totally disappeared; and, for a long period of time, he had seen none of them, until, migrating with his family to Kentucky, on entering the Barrens, he, one morning, recognized the well-known music of his old acquaintance, the Grouse, which, he assures me, are the very same with those he had known in Pennsylvania.

"But what appears to me the most remarkable circumstance relative to this bird is, that not one of all those writers who have attempted its history have taken the least notice of those two extraordinary bags of yellow skin which mark the neck of the male, and which constitute so striking a peculiarity. These appear to be formed by an expansion of the gullet, as well as of the exterior skin of the neck, which, when the bird is at rest, hangs in loose, pendulous, wrinkled folds along the side of the neck; the supplemental wings, at the same time, as well as when the bird is 
flying, lying along the neck. But when these bags are inflated with air, in breeding-time, they are equal in size, and very much resemble in color, a middle-sized, fully ripe orange. By means of this curious apparatus, which is very observable several hundred yards off, he is enabled to produce the extraordinary sound mentioned above, which, though it may easily be imitated, is yet difficult to describe by words. It consists of three notes of the same tone, resembling those produced by the Night Hawks in their rapid descent; each strongly accented, the last being twice as long as the others. When several are thus engaged, the ear is unable to distinguish the regularity of these triple notes; there being, at such times, one continued bumming, which is disagreeable and perplexing, from the impossibility of ascertaining from what distance, or even quarter, it proceeds. While uttering this, the bird exhibits all the ostentatious gesticulations of a Turkey-cock; erecting and fluttering his neck-wings, wheeling and passing before the female, and close before his fellows, as in defiance. Now and then are heard some rapid, cackling notes, not unlike that of a person tickled to excessive laughter; and, in short, one can scarcely listen to them without feeling disposed to laugh from sympathy. These are uttered by the males while engaged in fight, on which occasion they leap up against each other, exactly in the manner of Turkeys, seemingly with more malice than effect. This bumming continues from a little before daybreak to eight or nine o'clock in the morning, when the parties separate to seek for food.

"Fresh-ploughed fields, in the vicinity of their resorts, are sure to be visited by these birds every morning, and frequently also in the evening. On one of these I counted, at one time, seventeen males, making such a continued sound, as, I am persuaded, might have been heard for more than a mile off. The people of the Barrens informed me, that, when the weather becomes severe with snow, they approach the barn and farm-house, are sometimes seen sitting on the fences in dozens, mix with the poultry, and glean up the scattered grains of Indian corn, seeming almost half domesticated. At such times, great numbers are taken in traps. No pains, however, or regular plan, has ever been persisted in, as far as I was informed, to domesticate these delicious birds. A Mr. Reed, who lives between the Pilot Knobs and Bairdstown, told me, that, a few 
years ago, one of his sons found a Grouse's nest with fifteen eggs, which he brought home, and immediately placed beneath a hen then sitting, taking away her own. The nest of the Grouse was on the ground, under a tussock of long grass, formed with very little art, and few materials: the eggs were brownish-white, and about the size of a pullet's. In three or four days, the whole were hatched. Instead of following the hen, they compelled her to run after them, distracting her with the extent and diversity of their wanderings; and it was a day or two before they seemed to understand her language, or consent to be guided by her. They were let out to the fields, where they paid little regard to their nurse; and, in a few days, only three of them remained. These became extremely tame and familiar, were most expert flycatchers; but, soon after, they also disappeared.

The eggs of this species are generally oroidal in form, and are often pretty sharply tapered at their small ends. They vary in color from a dirty-drab to a grayish-white, and are covered more or less thickly with fine spots or dots of brown: some specimens have none of these markings, while others are abundantly spotted. A large number of specimens in my collection average about 1.80 by 1.25 inch in dimensions.

\section{BONASA, Stepuens.}

Bonasa, Stepmens, Shaw's Gen. Zool., XI. (1819). (Type Tetrao bonasia, L.)

Tail widening to the end, its feathers very broad, as long as the wings; the feathers soft, and eighteen in number; tarsi naked in the lower half; covered with two rows of hexagonal seales anteriorly, as in the Ortygince; sides of toes strongly pectinated; naked space on the side of throat covered by a tuft of broad soft feathers; portion of culmen between the nasal fossæ about one-third the total length; top of head with a soft crest.

BONASA UMBELLUS. - Stephens.

The Ruffed Grouse; Partridge; Pheasant.

Tetrao umbellus, Linnæus. Syst. Nat., I. (1766) 275 . Wils. Am. Orn., VI. (1812) 46. Aud. Orn. Biog., I. (1831) 211; V. 560.

Tetrao (Bonasia) umbellus, Bonaparte. Syn. (1828), 126. Nutt. Man., I. (1832) 657.

Bonasa umbellus, Stephens. Shaw, Gen. Zool, XI. (1824) 300. 
DEsCRIPTION.

Tail of eighteen feathers, reddish-brown or gray above; the back with cordate spots of lighter; beneath whitish, transversely barred with dull-brown; tail tipped with gray, and with a subterminal bar of black; broad feathers of the ruff black.

Tail lengthened, nearly as long as the wing; very broad, and moderately rounded; the feathers very broad and truncate, the tip slightly convex, eighteen in number; upper half of tarsus only feathered; bare behind and below, with two rows of hexagonal scutellse anteriorly; a naked space on the side of the neck, concealed by an overhanging tuft of broad, truncate feathers; there are no pectinated processes above the eye, where the skin instead is clothed with short feathers.

Length, eighteen inches; wing, seven and twenty one-hundredths; tail, seven inches.

This beautiful and well-known bird, commonly, but very improperly, called Partridge, is a general resident in all the New-England States throughout the year. In the most retired localities, and in the near vicinage of towns, it is found almost equally abundant; and its habits and characteristics are the same in all localities, except that in thickly settled districts, in consequence of its being more pursued by sportsmen, it is much wilder and more difficult of approach than in less settled neighborhoods. So tame and unsuspicious are these birds in the deep forests, that I have had considerable difficulty at times in flushing them. When I have approached them, instead of flying off, as they should, they stood watching me like so many barn-yard fowls; and when I walked up to within a few feet of them, to get them a-wing, - for no true sportsman will ever kill a game bird unless it is flying, - they only retreated slowly into a thicket of undergrowth, and remained there until actually forced to take flight.

About the first of May, sometimes a little earlier, more often later, the female withdraws from the society of the male, and repairs to a retired spot in the woods, where, usually beneath a thicket of evergreen, or a bunch of brush, or perhaps a fallen $\log$ or rock, she scrapes together a few leares into a loose nest, and deposits from eight to twelve eggs. These are usually of a yellowish-white, sometimes a darker color, sometimes nearly pure-white. They are 
usually ovoidal in form, sometimes nearly rounded, and their dimensions average about 1.65 by 1.20 inches: specimens are occasionally found much larger than this size, and many considerably smaller. In about fifty specimens before me, collected perhaps in ten different States, about five are of a yellowish-buff color, marked with numerous spots of brown; others are more yellowish, and have more obscure spots, while the greater number have no markings at all.

From several instances which have come to my knowledge, I am inclined to think that the female Ruffed Grouse, if persistently molested when nesting on the ground, avails herself of the abandoned nest of a crow, or the shelter afforded in the top of some tall broken trunk of a tree, in which she deposits her eggs. Two of my collectors in Northern Maine have sent me eggs which they positively declared were found in a crow's nest in a high pine, but which are undoubtedly of this species; and recently I hare heard of another occurrence from my friend L. E. Ricksecker, of Pennsylvania. The only satisfactory theory that I can advance to account for these departures from the usual habits of the Grouse is, that the birds had been much disturbed, their eggs or young perhaps destroyed; and as they are often in the trees, and are expert climbers, they laid their eggs in these lofty situations to secure protection from their numerous foes below.

During the season of incubation, the males congregate together and remain apart from the females, until the young birds are nearly full-grown: they then join them, and remain with them until the ensuing spring.

Early in spring, the male begins " drumming:" this habit is peculiar to this species, and is probably familiar to all persons who have passed much of their time in the rroods.

I have heard this drumming as early as February, and as late as September; but usually it is not heard much before the first of April. The bird resorts to a fallen trunk of a tree or $\log$, and, while strutting like the male Turkey, beats 


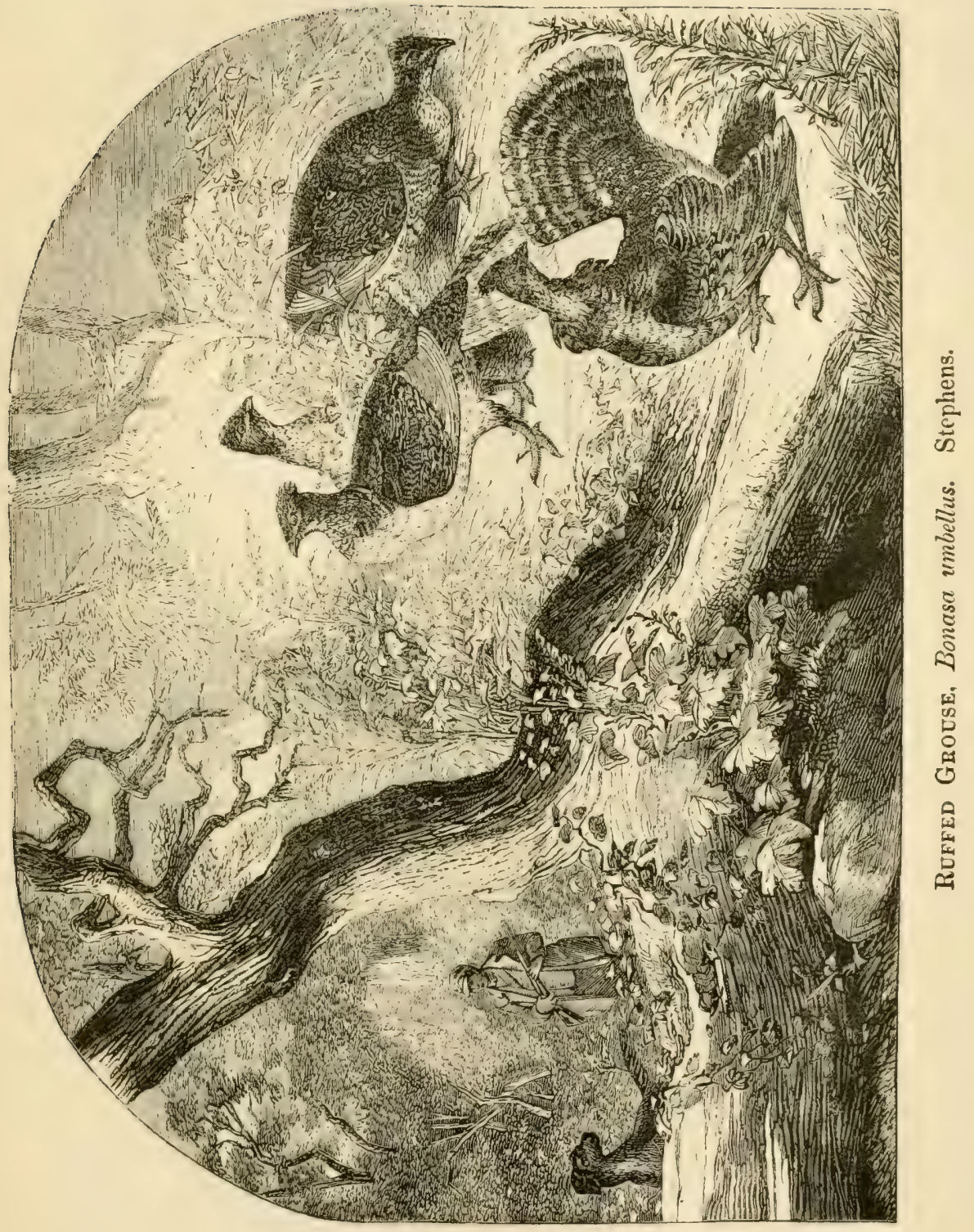



his wings against his sides and the $\log$ with considerable force. This produces a hollow drumming noise, that may be heard to a considerable distance: it commences very slowly, and, after a few strokes, gradually increases in velocity, and terminates with a rolling beat very similar to the roll of a drum.

I know not by what law of acoustics, but this drumming is peculiar in sounding equally as loud at a considerable distance off, as within a few rods. I have searched for the bird when I have heard the drumming, and, while supposing him to be at a considerable distance, have flushed him within the distance of fifty feet, and vice versa.

The young birds, like those of all our Gallinoe, follow their mother almost as soon as they are hatched. I have often found these broods in the woods, and can compare them to nothing so much as the chicks of domestic poultry.

The female, when her family is surprised, quickly gives a warning cluck, when the whole brood adroitly conceal themselves. I have known a number to disappear, as if by magic, beneath a bunch of leaves or grass; and it required a long, careful search to discover their whereabouts.

I once came suddenly upon a covey of these young birds, when the mother, taken by surprise, uttering a harsh cry, flew at my foot, and commenced pecking it fiercely: the young scrambled off, uttering faint peets, when the old bird, perhaps astonished at this departure from her usual modesty, suddenly retreated, and concealed herself. The young birds associate with the female until scattered by sportsmen or by a scarcity of provender. They are much more delicate as food, when about two-thirds grown, than the old birds, as they have less of that peculiar bitter taste, and have a rich flavor, almost similar to that of the Woodcock.

The food of this species consists of various seeds, berries, grapes, and insects. When nothing else can be obtained, they will eat the leaves of the evergreens, and buds of 
trees; and, when all other food is covered with snow, they eat dried pieces of apples that are left hanging on the trees, mosses, and leaves of the laurel. It is after feeding on this last plant that their flesh becomes dangerous to be eaten; and it is always safe not to eat these birds in winter, if they have been killed for any great length of time, or if their intestines and crops have been left in them.

One habit that this species has is, I believe, peculiar to it; and that is its manner of diving into the deep snow to pass the night in cold weather: this it does very frequently, and its snowy covering affords it a warm and effectual protection. But if it rains during the night, and then the weather changes to freezing, the Grouse, imprisoned beneath the crust that forms on the surface of the snow, soon dies; and it is noticed, that, in seasons after winters when the weather frequently changes from raining to freezing, there is a scarcity of these birds. It is a common occurrence to find them, in the spring, dead, having perished in this manner. 


\section{Famir PERDicid A. The Partridges.}

Nostrils protected by a naked scale; the tarsi bare and scutellate.

The Perdicida differ from the Grouse in the bare legs and naked nasal fossæ; they are much smaller in size and more abundant in species; they are widely distributed over the surface of the globe, a large number belonging to America, where the sub-families have no Old-World representatives whatever; the head seldom, if ever, shows the naked space around and above the eye, so common in the Tetraonides; and the sides of the toes scarcely exhibit the peculiar pectination formed by a succession of small scales or plates.

\section{Sub-Family Ortrginz.}

Bill stout; the lower mandible more or less bidentate on each side near the end.

The Ortygince of Bonaparte, or Odontophorince of other authors, are characterized as a group by the bidentation on either side of the edge of lower mandible, usually concealed in the closed mouth, and sometimes scarcely appreciable; the bill is short, and rather high at base, stouter and shorter than what is usually seen in OldWorld partridges; the culmen is curved from the base; the tip of the bill broad, and overlapping the end of the lower mandible; the nasal groove is short; the tail is rather broad and long.

\section{ORTYX, STEPHENS.}

Ortyx, Stephews, Shaw's Gen. Zool., XI. (1819). (Type Tetrao Virginianus, L.)

Bill stout; head entirely without any crest; tail short, scarcely more than half the wing, composed of moderately soft feathers; wings normal; legs developed, the toes reaching considerably beyond the tip of the tail; the lateral toes short, equal, their claws falling decidedly short of the base of the middle claw.

\section{ORTYX VIRGINIANUS. - Bonaparte.}

\section{The Virginia Partridge; Quail; Bob-white.}

Tetrao Virginianus, Linnæus. Syst. Nat., I. (1766) 277.

Perdix Virginiana, Wilson. Am. Orn., VI. (1812) 21. Aud. Orn. Biog., I. (1831) 388 ; V. (1839) 564.

Ortyx Virginiana, Jardine. Nat. Lib. Birds, IV.; Game Birds, 101.

Perdix (Colinia) Virginiana, Nuttall. Man., I. (1832) 646.

\section{Description.}

Forehead, and line through the eye and along the side of the neck, with chin and throat, white; a band of black across the vertex, and extending backwards on the sides, within the white, and another from the maxilla beneath the eye, and crossing on the lower part of the throat; the under parts are white, tinged with brown anteriorly, each feather with several narrow, obtusely V-shaped bands of 
black; the forepart of back, the side of the breast and in front just below the black collar, of a dull pinkish-red; the sides of body and wing coverts brownish-red; the latter almost uniform, without indication of mottling; scapulars and upper tertials coarsely blotched with black, and edged internally with brownish-yellow; top of head reddish; the lower part of neck, except anteriorly, streaked with white and black; primary quills unspotted brown; tail ash.

Female with the white markings of the head replaced by brownish-yellow; the black wanting.

This species is subject to considerable variations both of size and color, the more northern being considerably the larger; southern specimens are darker, with n:ore black about the head, on the wings, and the middle of the back; there is also a more appreciable mottling on the wings, and the feathers of the back are streaked with black.

Length, ten inches; wing, four and seventy one-hundredths inches; tail, two and eighty-five one-hundredths inches.

THIS beautiful bird, very improperly called the Quail, is not very common in any part of New England north of Massachusetts; and in that State it is rapidly becoming rare, both in consequence of the destructive pertinacity with which it is followed by all sportsmen, and the abominable practice of snaring and netting it, that is growing too common. In Massachusetts and the other southern NewEngland States, it is partially migratory in the fall; repairing to the neighborhood of the seacoast, where it remains two or three weeks: it returns to the fields and swamps, by the first fall of snow, where it passes the winter. Its habits are pretty well known in that section; but, that my readers may know about it elsewhere, I give the very interesting description by Wilson. He says, -

"They are most numerous in the vicinity of well-cultivated plantations, where grain is in plenty. They, however, occasionally seek shelter in the woods, perching on the branches, or secreting themselves among the brushwood; but are found most usually in open fields, or along fences sheltered by thickets of briers. Where they are not too much persecuted by the sportsmen, they become almost half domesticated; approach the barn, particularly in winter, and sometimes, in that severe season, mix with the poultry to glean up a subsistence. They remain with us the whole year, and often suffer extremely by long, hard winters and deep snows. At such 
times, the arts of man combine with the inclemency of the season for their destruction. To the ravages of the gun are added others of a more insidious kind; traps are placed on almost every plantation, in such places as they are known to frequent. These are formed of lath, or thinly split sticks, somerwat in the shape of an obtuse cone, laced together with cord, having a small hole at top, with a sliding lid, to take out the game by. This is supported by the common figure-four trigger, and grain is scattered below and leading to the place. By this contrivance, ten or fifteen have sometimes been taken at a time.

"The Partridge begins to build early in May. The nest is made on the ground, usually at the bottom of a thick tuft of grass, that shelters and conceals it. The materials are leaves and fine dry grass in considerable quantity. It is well covered above, and an opening left on one side for entrance. The female lays from fifteen to twenty-four eggs, of a pure-white, without any spots. The time of incubation has been stated to me, by various persons, at four weeks, when the eggs were placed under the domestic Hen. The young leave the nest as soon as they are freed from the shell, and are conducted about in search of food by the female; are guided by her voice, which, at that time, resembles the twittering of young chickens, and sheltered by her wings, in the same manner as those of the domestic fowl, but with all that secrecy and precaution for their safety which their helplessness and greater danger require. In this situation, should the little timid family be unexpectedly surprised, the utmost alarm and consternation instantly prevail. The mother throws herself in the path, fluttering along, and beating the ground with her wings, as if sorely wounded; using every artifice she is mistress of to entice the passenger in pursuit of herself; uttering, at the same time, certain peculiar notes of alarm, well understood by the young, who dive separately amongst the grass, and secrete themselves till the danger is over: and the parent, having decoyed the pursuer to a safe distance, returns, by a circuitous route, to collect and lead them off. This well-known manœuvre, which nine times in ten is successful, is honorable to the feelings and judgment of the bird, but a severe satire on s man. The affectionate mother, as if sensible of the avaricious cruelty of his nature, tempts him with a larger prize, to save her 
more helpless offspring; and pays him, as avarice and cruelty ought always to be paid, with mortification and disappointment."

In a great number of eggs in my collection, from many different localities, some specimens are nearly pure-white, while others are smeared with some blotches or confluent dabs of yellowish: whether these are stains caused by moisture or dirt, I am ignorant; but they are permanent, for I cannot remove them by water or alcohol. I judge they are stains from the earth or decayed vegetation on which they were laid. Their form is pyriform; and their average length about 1.20 inch, and greatest width 1 inch.

\section{NOTES.}

I continue Mr. Couper's notes, made at Quebec, Lower Canada:-

ECTOPISTES MigratoriUS. - The Passenger Pigeon is not so common in this portion of Lower as in Upper Canada, where they breed in large numbers. They are found breeding in the eastern townships of Lower Canada; but I have not ascertained that they breed in this district or north of it. I remember at one time finding a nest of this pigeon in the woods north of Toronto: it contained a single young one. I believe there are many instances of its breeding in solitary pairs, something like the Wood Pigeon of Europe.

ZENAIDURA CAROLINENSIS. - The Carolina Dove has never been noticed in Lower Canada. It occurs occasionally in the woods north of the city of Toronto, where, $\mathrm{I}$ believe, it breeds.

TETRAO CANADENSIS. - This species is very common from October to February. They are in prime condition during the last month. It breeds on both sides of the St. Lawrence, but more common on the south. During the above months, there are generally six males to one female exhibited on our markets. The inhabitants inform me that females are very scarce during winter. This is a parodox to me, when I know that both male and female feed on the same tree. What is also astonishing, the nest and eggs of this bird are as hard to discover in spring as the female is in winter. I have offered to purchase every nest of this species brought to me; but, strange to say, I have not been fortunate in seeing one yet.

BONASA UMBELLUS, - Common. Breeds. I have repeatedly found the nest of this species 


\section{ORDER V.-GRALLATORES. WADERS.}

Legs, neck, and usually the bill, much lengthened; tibia bare for a certain distance above the tarsal joint; nostrils exposed; tail usually very short; the species live along or near the water, more rarely in dry plains, wading, never swimming habitually, except perhaps in the case of the Phalaropes.

The bill of the Grallatores is usually in direct proportion to the length of legs and neck. The toes vary, but are usually connected at the base by a membrane, which sometimes extends almost or quite to the claws.

The Grallatores, like the Rasores and Natatores, are divisible into two sub-orders, according as the species rear and feed their young in nests, or allow them to shift for themselves. The following diagnoses express the general character of these subdivisions:

Herodiones. - Face or lores more or less naked, or else covered with feathers different from those on the rest of the body, except in some Gruida; bill nearly as thick at the base as the skull; hind toe generally nearly on same level with the anterior; young reared in nests, and requiring to be fed by the parent.

Grall_. - Lores with feathers similar to those on the rest of the body; bill contracted at base, where it is usually smaller than the skull; hind toe generally elevated; young running about at birth, and able to feed themselves. 


\section{SUB-ORDER HERODIONES.}

Bill generally thick at the base and much longer than the head; frontal feathers with a rounded outline; lores, and generally the region round the eye (sometimes most of the head), naked.

The primary characteristic of the Herodiones, though physiological rather than zoological, is of the highest importance; the young are born weak and imperfect, and are reared in the nest, being fed directly by the parent until able to take care of themselves, when they are generally abandoned. In the Gralloe, on the contrary, the young run about freely, directly after being hatched, and are capable of securing food for themselves under the direction of the parent.

The chief zoological character (not, however, entirely without exception) is to be found in the bill, which is generally very large, much longer than the head, and thickened at the base so as to be nearly or quite as broad and high as the skull; the lores are almost always naked, or, if covered, it is with feathers of a different kind from those on the rest of the body; the hind toe in most genera is lengthened and on a level with the anterior, so as to be capable of grasping; sometimes, however, it is elevated and quite short. - BAIRD.

\section{FAMily ARDEID瓜。 The Herons.}

Bill conical, acuminate, compressed, and acute; the edges usually nicked at the end; the frontal feathers generally extending beyond the nostrils; tarsi scutellate anteriorly; the middle toe connected to the outer by a basal web; claws acute; the edge of the middle one serrated or pectinated on its inner edge.

\section{GARZETTA, BONAPARTE.}

Garzetta, Bonaparte, Consp., II. (1855) 118. (Type Ardea garzetta, L., whether of Kaup, 1829 ?)

Bill slender; outlines nearly straight to near the tip, when they are about equally convex; middle toe more than half the tarsus; tarsi broadly scutellate anteriorly; tibia denuded for about one-half; outer toe longest; head with a full occipital crest of feathers having the webs decomposed, hair-like; feathers of lower part of throat similar; middle of back with long plumes reaching to the tail, recurving at tip; these plumes and the crest apparently permanent; lower part of neck behind,

* bare of feathers; colors pure-white in all ages.

\section{GARZETTA CANDIDISSIMA, - Bonaparte.}

The Snowy Heron.

Ardea candidissima, Gmelin. Syst. Nat., I. (1788) 633. Wils. Am. Orn., VII. (1813) 120. Nutt. Man., II. (1834) 49. Aud. Orn. Biog., III. (1835) 317; V. (1839) 606.

Garzetta candidissima, Bonaparte. Consp. (1855), 119. 


\section{DESCRIPTION.}

Occiput much crested; dorsal plumes reaching to the end of the tail ; colors purewhite; bill black; the base yellow; legs black; iris, hazel in young, yellow in adult.

Length, twenty-four inches; wing, ten and twenty one-hundredths inches; tarsus, three and eighty one-hundredths inches; bill, above, three and fifteen one-hundredths inches.

THIS beautiful bird is a very rare summer visitor in I the southern New-England States. I have never had an opportunity for observing its habits, and will give the description by Wilson:-

"The Snowy Heron seems particularly fond of the salt marshes during summer, seldom penetrating far inland. Its white plumage renders it a very conspicuous object, either while on wing, or while wading the meadows or marshes. Its food consists of those small crabs usually called fiddlers, mudworms, snails, frogs, and lizards. It also feeds on the seeds of some species of nymphr, and of several other aquatic plants.

On the 19th of May, I visited an extensive breeding-place of the Snowy Heron, among the red cedars of Summer's Beach, on the coast of Cape May. The situation was very sequestered, bounded on the land side by a fresh-water marsh or pond, and sheltered from

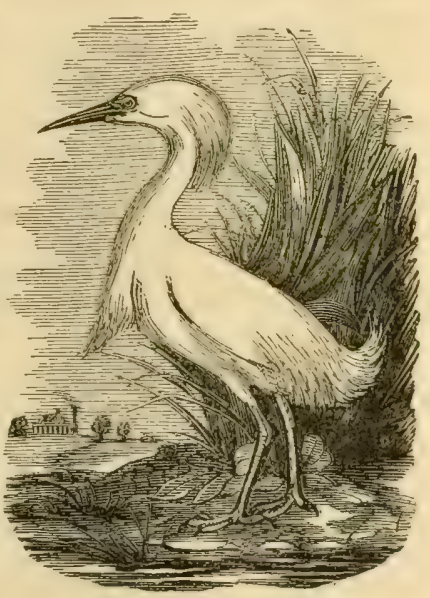
the Atlantic by ranges of sand-hills. The cedars, though not high, were so closely crowded together as to render it difficult to penetrate through among them. Some trees contained three, others four nests, built wholly of sticks. Each had in it three eggs of a pale greenish-blue color, and measuring an inch and three-quarters in length by an inch and a quarter in thickness. Forty or fifty of these eggs were cooked, and found to be well tasted: the white was of a bluish tint, and almost transparent, though boiled for a considerable time; the yolk very small in quantity. The birds 
rose in vast numbers, but without clamor, alighting on the tops of the trees around, and watching the result in silent anxiety. Among them were numbers of the Night Heron, and two or three Purpleheaded Herons. Great quantities of egg-shells lay scattered under the trees, occasioned by the depredations of the Crows, who were continually hovering about the place. On one of the nests I found the dead body of the bird itself, hale devoured by the Hawks, Crows, or Gulls. She had probably perished in defence of her eggs.

"The Snowy Heron is seen at all times during summer among the salt marshes, watching and searching for food, or passing, sometimes in flocks, from one part of the bay to the other. They often make excursions up the rivers and inlets, but return regularly in the evening to the red cedars on the beach to roost."

\section{ARDEA, LINNAUS.}

Ardea, Lins.xus, Syst. Nat., I. (1735). (Type A. cinerea.)

Bill very thick; culmen nearly straight; gonys ascending, its tip more convex than that of culmen; middle toe more than half the tarsus; tibia bare for nearly or quite one-half; claws short, much curved; outer toe longest; tarsus broadly scutellate anteriorly; occiput with a few elongated occipital feathers; scapulars elongate lanceolate, as long as the secondaries; no dorsal plumes; tail of twelve broad stiffened feathers; back of neck well feathered; size very large; colors plumbeous, streaked beneath.

\section{ARDEA HERODIAS, - Linnous.}

The Great Blue Heron, or Crane.

Ardea Herodias, Linnæus. Syst. Nat., I. (1766) 237. Wils. Am. Orn., VIII. (1814) 28. Nutt. Man., II. (1834) 42. Aud. Orn. Biog., III. (1835) 87; V. 599.

\section{DESCRIPTION.}

Lower third of tibia bare; above bluish-ash; edges of wing and the tibia rufous; neck cinnamon-brown; head black, with a white frontal patch; body beneath black, broadly streaked on the belly with white; crissum white; middle line of throat white, streaked with black and rufous.

Adult. - Bill yellow, dusky at the base and greenish above; the forehead and central part of the crown are white, encircled laterally and behind by black, of which color is the occipital crest and its two elongated feathers; the neck is of a light smoky cinnamon-brown, with perhaps a tinge of purple; the chin and throat rihitish; the feathers along the central line of the throat to the breast white, streaked with black, and also with reddish-brown, except on the elongated feathers of the 
breast; the body may be described as bluish-ash above and on the sides; the under parts, including the tuft of feathers on each side the breast and the belly to the white crissum, are sooty black, much varied along the middle line with white; the tibia and the edge of the wing are rufous; the quills are black, becoming more plumbeous internally until the innermost secondaries are ashy, like the back; the elongated tips of the scapular feathers have a whitish shade; the tail is of a bluishslate color; according to $\mathbf{M r}$. Audubon, the bill in life is yellow; dusky-green above; loral and orbital spaces light-green; iris yellow; feet olivaceous, paler above the tibio-tarsal joint; claws black.

Young. - The upper mandible is blackish; the lower yellow, except along the commissure; the head above is entirely dusky, without the much elongated occipital feathers; the breast is grayish, streaked with white and light-brown, but without any pure-black patches; the back is without the elongated scapular feathers; in still younger specimens, the coverts are all margined with rufous, which becomes lighter at the tip; the rufous of the tibia is much lighter.

Length, forty-two inches; wing, eighteen and fifty one-hundredths; tarsus about six and fifty one-hundredths inches; bill about five and fifty one-hundredths inches.

This, the largest of our New-England Herons, is pretty generally distributed throughout these States as a summer resident; and, although not very abundant in any section, it is of course more often found in localities near large bodies of water than elsewhere. It arrives from the South about the second week in April, sometimes a little earlier. During the day, it seems to prefer the solitudes of the forest for its retreat, as it is usually seen in the meadows only at early morning, and in the latter part of the afternoon. It then, by the side of a ditch or pond, is observed patiently watching for its prey. It remains standing motionless until a fish or frog presents itself, when, with an unerring stroke with its beak, as quick as lightning, it seizes, beats to pieces, and swallows it. This act is often repeated; and, as the Heron varies this diet with meadow-mice, snakes, and insects, it certainly does not lead the life of misery and want that many writers ascribe to it. In fact, it is always plump and in good condition; and by many is considered as a palatable bird on the table.

About the 10th of May, this species commences building: as with the other Herons, it breeds in communities, and several nests may be found in an area of a few rods. These 
are placed in high forks of trees, generally in retired, almost impassable swamps. I once visited a heronry of this species in Erroll, N.H. It was in a deep swamp, which was intersected by a small branch of the Androscoggin River. I think that I never penetrated a more villanous tract: every few rods a quagmire would present itself, which, although familiar to the persons who accompanied me, was generally unrecognizable by me, from any patches of green turf; and it was only by wading through mud and water, sometimes up to my waist, or by leaping from one fallen tree to another, through briers and brushwood, that I at last succeeded in arriving beneath the trees in which the nests were built. These were all dead hemlocks, white and smooth, without a branch for certainly forty feet, and unclimbable. We could see that the nests were nearly flat, and were constructed of twigs of different sizes, put together in a loose and slovenly manner. This was about the 25th of June: the young were, of course, then about two-thirds grown; and, as I had heard that they were excellent eating, I emptied both the barrels of my gun into one of the nests, when down tumbled two "squab Herons," as they are called. We had them broiled for supper: they tasted something like duck, but had a strong flavor that was not pleasant. "I don't hanker after any more," as one of our company said after supper. The old birds, at the report of my gun, began flying over our heads, uttering their hoarse honks and guttural cries. They were careful to keep out of gunshot; and, after flying back and forth a few minutes, they disappeared, and all was still. The eggs of this species are laid about the 15th or 20th of May: they are usually three or four in number, and their form is ovoidal. They are of a light bluish-green color, and average in dimensions about 2.62 by 1.75 inch. But one brood is reared in the season.

This is one of the most suspicious of our birds, and the most difficult to be approached. It is constantly on the lookout for danger; and its long neck, keen eyes, and deli- 
cate organs of hearing, enable it to detect the approach of a hunter long before he can get within gunshot.

About the middle of October, it leaves New England, in small detached groups, for the South.

\section{ARDETTA, Grax.}

Ardetta, GrAy, List of Genera, App. (1842), 13. (Type Ardea minuta, L.)

Bill slender, acute; both mandibles about equally curved; legs very short; tarsi less than middle toe; inner toe much longest; claws long, acute; tarsi broadly seutellate anteriorly.

Tail of ten feathers; neck short; body much compressed; head smooth; the occipital feathers somewhat lengthened; the lower neck bare of feathers behind; no plumes; plumage compact, lustrous; uniform above; sexes differently colored.

\section{ARDETTA EXILIS,-Gray.}

\section{The Least Bittern.}

Ardea exilis, Gmelin. Syst. Nat., I. (1788) 648. Wils. Am. Orn., VIII. (1814) 37. Aud. Orn. Biog., III. (1835) 77; V. (1839) 606. Ardea (ardeola) exilis, Nuttall. Man., II. (1834) 66. Ardetta exilis, Gray. Gen. (1842).

\section{DESCRIPTION.}

Head above and the back dark glossy green; upper part of neck, shoulders, greater coverts, and outer webs of some tertials, purplish-cinnamon; a brownishyellow scapular stripe. Female with the green of head and back replaced by purplish-chestnut: iris yellow.

Length, thirteen inches; wing, four and seventy-five one-hundredths; tarsus, one and sixty one-hundredths; bill, above, one and seventy-five one-hundredths inches.

This, the smallest of our Ardeidæ, is a rare summer inhabitant of New England. It is only seen in pairs or solitary individuals, and, unlike most of our birds in this family, seems persistently solitary in its habits. I have never met with an individual alive, and will give a short extract from the description by Audubon of its habits. He says, "Although the Least Bittern is not unfrequently started in salt marshes, it gives a decided preference to the borders of ponds, lakes, or bayous of fresh water; and it is in secluded situations of this kind that it usually forms its nest. This is sometimes placed on the ground, amid the 
rankest grasses, but more frequently it is attached to the stems several inches above it. It is flat, and composed of dried or rotten weeds. In two instances, I found the nests of the Least Bittern about three feet above the ground, in a thick cluster of smilax and other briery plants. In the first, two nests were placed in the same bush, within a few yards of each other. In the other instance, there was only one nest of this bird, but several of the Boat-tailed Grakle, and one of the Green Heron, the occupants of all of which seemed to be on friendly terms. When startled from the nest, the old birds emit a few notes resembling the syllable $q u \bar{a}$, alight a few yards off, and watch all your movements. If you go towards them, you may sometimes take the female with the hand, but rarely the male, who generally flies off, or makes his way through the woods.

"The food of this bird consists of snails, slugs, tadpoles or young frogs, and water lizards. In several instances, however, I have found small shrews and field-mice in their stomach. Although more nocturnal than diurnal, it moves a good deal about by day in search of food. The flight of this bird is apparently weak by day; for then it seldom removes to a greater distance than a hundred yards at a time, and this, too, only when frightened in a moderate degree, for, if much alarmed, it falls again among the grass, in the manner of the Rail: but in the dusk of the evening and morning, I have seen it passing steadily along, at the height of fifty yards or more, with the neck retracted, and the legs stretched out behind in the manner of the larger Herons."

The eggs of this species are usually four in number: they are nearly oval in form, and are of the size, and almost exactly the form, of eggs of the Yellow-billed Cuckoo, except with regard to color; the present species being considerably paler. It has been found to breed in all the New-England States, but seems to be more of a southern species, and it is not abundant anywhere north of the southern portions of the Middle States. 
BOTAURUS, Stephens.

Botaurus, Stephexs, Shaw's Gen. Zoolo, XI. (1819) 592. (Type Ardea steh laris, L.)

Bill moderate, scarcely longer than the head; bill outlines gently convex, gonys ascending; tarsi very short, less than the middle toe; broadly scutellate; inner lateral toe much longest; claws all very, long, acute, and nearly straight.

Tail of ten feathers; no peculiar crest; plumage loose, opaque, streaked; sexes similar.

BOTAURUS LENTIGINOSUS. - Stephens.

The Bittern; Stake-driver.

Botaurus lentiginosus, Stephens. Shaw's Gen. Zool., XI. (1819) 596.

Ardea (botaurus) lentiginosa, Nuttall. Man., II. (1834) 60 .

Ardea minor, Wilson. Am. Orn., VIII. (1814) 35. Aud. Orn. Biog., IV. (1838) 296.

\section{Description.}

Brownish-yellow, finely mottled and varied with dark-brown and brownish-red; a broad black stripe on each side the neck, starting behind the ear; iris golden yellow.

Length, twenty-six and fifty one-hundredths inches; wing, eleven; tarsus, three and sixty one-hundredths inches; bill, above, two and seventy-five one hundredths inches.

Hab. - Entire continent of North America.

Perhaps none of our Herons are more generally known than this species; for it is common in all New England as a summer resident, and in some localities, particularly the northern, is quite abundant. It arrives from the South from about the last week in March to the 10th of April, according to latitude, and remains in the meadows, where it makes its home until the middle of October. It seems to be more diurnal in its habits than most of our other Herons, and seems always employed in the pursuit of fishes, frogs, and other reptiles and insects, of which its food consists.

It breeds in communities, sometimes as many as a dozen pairs nesting within the area of a few rods. The nests are placed on low bushes, or thick tufts of grass, sometimes in low, thickly wooded trees; and are composed of coarse grasses, twigs, and a few leaves. I know of no other place in New England where these "birds breed in such abundance as in the neighborhood of the Richardson Lakes, in Maine. There, in some of the tangled, boggy, almost im- 
penetrable swamps, these birds have several heronries, which they have inhabited for years. When their haunts are approached, the birds rise with a guttural note, like the syllable quăk, and alight in some tall tree, from which they silently watch the intruder.

The eggs are usually four in number. Their form is generally ovoidal, and their color a rich drab, with sometimes an olive tinge. I know of no species that exhibits so little variation in the size of its eggs as this; for in a large number of specimens in my collection from half a dozen different States, east and west, the only variety of dimensions is from 1.92 by 1.50 inch to 1.88 by 1.48 inch.

In the mating season, and during the first part of the period of incubation, the male has a peculiar love-note, that almost exactly resembles the stroke of a mallet on a stake; something like the syllables 'chunk-a-lunk-chunk, quankchunk-a-lunk-chunk. I have often, when in the forests of Northern Maine, been deceived by this note into believing that some woodman or settler was in my neighborhood, and discovered my mistake only after toiling through swamp and morass for perhaps half a mile. But one brood is reared in the season by this bird in New England; and, by the first week in August, the young are able to shift for themselves.

\section{BUTORIDES, BLYTH.}

Butorides, Burтi (1849), Horsf. (Type Ardea Javanica.)

Bill acute, rather longer than the head, gently curved from the base above; gonys slightly ascending; legs very short; tarsi scarcely longer than the middle toe; broadly scutellate anteriorly; lateral toes nearly equal; head with elongated feathers above and behind; these are well defined, lanceolate, as are the interscapulars and scapulars; the latter not exceeding the tertials; neck short; bare behind inferiorly; tibia feathered nearly throughout; tail of twelve feathers.

\section{BUTORIDES VIRESCENS. - Bonaparte.}

The Green Heron; Fly-up-the-Creek.

Ardea virescens, Linnæus. Syst. Nat., I. (1766) 238. Wils. Am. Orn., VU. 11813) 97. Aud. Orn. Biog., IV. (1838) 274.

Ardea (botaurus) virescens. Nutt., II. (1834) 63.

Butorides virescens, Bonaparte. Consp. Av., II. (1855) 128. 
DESCRIPTION.

"The Green Bittern is eighteen inches long, and twenty-five inches in extent; bill black, lighter below, and yellow at the base; chin, and narrow streak down the throat, yellowish-white; neck dark vinaceous-red; back covered with very long, tapering, pointed feathers, of a hoary green, shafted with white, on a dark-green ground; the hind part of the neck is destitute of plumage, that it may be the more conveniently drawn in over the breast, but is covered with the long feathers of the throat and sides of the neck that enclose it behind; wings and tail dark glossy green, tipped and bordered with yellowish-white; legs and feet yellow, tinged before with green, the skin of these thick and movable; belly ashy-brown; irides brightorange.

"The crested head very dark glossy green. The female, as I have particularly observed in numerous instances, differs in nothing, as to color, from the male; neither of them receive the long feathers on the back during the first season." Wuson.

The above description of this beautiful bird is so comprehensive and accurate, that I cannot do better than to present it in this volume; and the account of this bird's habits, by the same author, is so interesting and full, that, being unable to add to it any thing of value, I give it as below :-

"The Green Bittern makes its first appearance in Pennsylvania early in April, soon after the marshes are completely thawed. There, among the stagnant ditches with which they are intersected, and amidst the bogs and quagmires, he hunts with great cunning and dexterity. Frogs and small fish are his principal game, whose caution and facility of escape requiré nice address and rapidity of attack. When on the lookout for small fish, he stands in the water, by the side of the ditch, silent and motionless as a statute; his neck drawn in over his breast, ready for action. The instant a fry or minnow comes within the range of his bill, by a stroke, quick and sure as that of the rattlesnake, he seizes his prey, and swallows it in an instant. He searches for small crabs, and for the various worms and larvæ, particularly those of the dragon-fly, which lurk in the mud, with equal adroitness. But the capturing of frogs requires much nicer management. These wary reptiles shrink into the mire on the least alarm, and do not raise up their heads again to the surface without the most cautious circumspection. The Bittern, fixing his penetrating eye on the spot where they disappeared, approaches with slow, stealing step, laying his feet so gently and silently on the ground as not to be heard or felt; and, when arrived within reach, stands fixed, and bending forwards, until the first 
glimpse of the frog's head makes its appearance, when, with a stroke instantaneous as lightning, he seizes it in his bill, beats it to death, and feasts on it at his leisure.

"When alarmed, the Green Bittern rises with a hollow, guttural scream; does not fly far, but usually alights on some old stump, tree, or fence adjoining, and looks about with extended neck; though, sometimes, this is drawn in so that his head seems to rest on his breast. As he walks along the fence, or stands gazing at you with outstretched neck, he has the frequent habit of jetting the tail. He sometimes flies high, with doubled neck, and legs extended behind, flapping the wings smartly, and travelling with great expedition. He is the least shy of all our Herons, and perhaps the most numerous and generally dispersed; being found far in the interior, as well as along our salt marshes, and everywhere about the muddy shores of our mill-ponds, creeks, and large rivers.

"The Green Bittern begins to build about the 20th of April: sometimes in single pairs, in swampy woods; often in companies; and not unfrequently in a kind of association with the Qua-birds, or Night Herons. The nest is fixed among the branches of the trees; is constructed wholly of small sticks, lined with finer twigs; and is of considerable size, though loosely put together. The female lays four eggs, of the common oblong form, and of a pale light-blue color. The young do not leave the nest until able to fly; and, for the first season at least, are destitute of the long-pointed plumage on the back: the lower parts are also lighter, and the white on the throat broader. During the whole summer, and until late in autumn, these birds are seen in our meadows and marshes, but never remain during winter in any part of the United States."

A large number of this bird's eggs, lying before me, exhibit a variation: of only from 1.56 by 1.20 inch to 1.49 by 1.15 inch in dimensions. But one brood is reared in the season; and, by the 20th of September, the old and young leave New England for the South.

NYCTIARDEA, SWAINSON. Linn.)

Nyctiardea, Swainsox, Class. Birds, II. (1837) 354. (Type Ardea nycticorax,

Nycticorax, Sternews, Shaw's Gen. Zool., XI. (1819) 608. Same type. 
Bill very stout; culmen curved from base; the lower outline straight, or a little concave; end of upper mandible gently decurved; tarsi short, equal to the middle toe; the scales more than usually hexagonal inferiorly; outer lateral toe rather longer; no unusual development of feathers, excepting a long, straight occipital plume of three feathers, rolled together; neck short, moderately feathered behind.

The Night Herons, with a certain resemblance to the Bittern, differ in the much stouter and more curved bill, the lower edge of which is straight, instead of rising at the end; the tarsus is equal to the middle toe, not shorter, and is covered anteriorly below by small hexagonal scales, instead of large transverse scutellæ; the claws are much shorter and more curved; the tail has twelve feathers instead of ten.

\section{NYCTIARDEA GARDENI, - Baird.}

\section{The Night Heron; Qua-bird.}

Ardea nycticorax, Wilson. Am. Orn., VII. (1813) 101. Aud. Orn. Biog., III. (1835) 275 ; V. 600 .

Ardea (botaurus) discors, Nuttall. Man., II. (1834) 54.

\section{Description.}

Head above and middle of back steel-green; wings and tail ashy-blue; under parts, forehead, and long occipital feathers white; sides tinged with lilac.

Bill very thick at the base, and tapering all the way to the tip. Culmen nearly straight for half its length, then considerably curved; lower outline of bill nearly straight; gonys proper slightly concave; legs short, but stout; the tarsus equal to the middle toe; covered throughout with hexagonal scales, the anterior largest, but those on the upper portion much larger, and going entirely across; tibia bare for about one-fifth; lateral toes nearly equal; the outer rather longest; claws small; considerably curved; tail short, of twelve broad, rather stiff feathers.

Head with the occipital feathers elongated, and with two or three very long, straight feathers (as long as the bill and head) springing from the occiput. These are rolled up so as to appear like a single cylindrical feather; back of the neck covered with down, but not provided with long feathers; interscapular feathers and scapulars elongated and lanceolate, the webs scarcely decomposed.

The upper part of the head, including the upper eyelids, the occipital crest, and the interscapular region and scapulars, dark lustrous steel-green; the wings and tail are ashy-blue; the under parts, the forehead, and the long occipital feathers, are white, passing into pale ashy-lilac on the sides and on the neck above; this color, in fact, tingeing nearly the whole under parts. The region along the base of the bill, however, is nearly pure, as are the tibia. The bill is black; the loral space green: the iris red; the feet yellow; the claws brown.

Length, about twenty-five inches; wing, twelve and fifty one-hundredths; talsus, three and fifteen one-hundredths; bill, above, three and ten one-hundredths inches.

Hab. - United States generally.

The Night Heron is pretty generally distributed throughout New England as a summer resident. It seems to prefer the neighborhood of the seacoast, but is found in many 
sections quite abundant in the interior; as, for instance, Dr. Wood says, "I know of a swamp some fourteen miles from here (East Windsor Hill, Conn.) where thousands breed." "I have counted eight nests on one maple-tree," \&c. This species is most commonly found during the daytime perching in high trees in swamps and thick woods, and seems to feed almost entirely by night. As soon as it begins to grow dark, it begins its flight; and if we stand in a large meadow, or by a pond or other sheet of water, we may sometimes hear the notes of several, as they are engaged in their search for prey. The call of this bird resembles the syllable quăck, which gives the bird the name of Squawk in many localities. The nest of this species is placed in a fork of a tree in a swamp: it is constructed of coarse twigs and leaves, and is very loosely put together. As above remarked, several of these structures may be found on one tree; and, after the young are hatched, their noise, as they scream for food, is almost deafening. I once visited a heronry of this species in Dedham, Mass. As many as a hundred pairs were breeding in the area of an acre; and, as Wilson truly says, "The noise of the old and young would almost induce one to suppose that two or three hundred Indians were choking or throttling each other."

Another larger heronry that I visited last season in company with my friends, F. G. Sanborn and H. A. Purdie, occupied an area of several acres. The locality was a swamp, in which were growing cedar-trees. These were rarely over thirty feet in height; but their dense and twining branches were occupied often by the nests of two or three pairs in a single tree. The reader may judge as to the multitude of parent-birds that were flying in wild confusion over our heads, and may fancy the effect of all their guttural cries. We ascended to a number of the nests, and found them occupied by eggs, both freshly laid and others, far advanced in incubation, and chicks from one day old to some half grown. As the work of ascending to the filthy 
nests was not of the pleasantest, we limited our investigations to the securing of a few of the most recently laid eggs.

The eggs of the Night Heron are laid about the 20th of May. They are usually four in number, and their general form is an elongated ovoidal. In a great number of specimens, the color is generally bluish-green, sometimes a light pea-green or greenish-yellow. Their dimensions vary from 2.15 by 1.50 inch to 2.05 by 1.40 inch. About the latter part of August, the young birds are found in deep woods, and by many are esteemed as excellent eating, as they are plump and fat. They leave for the South early in October.

Mr. William Endicott, who visited the same heronry, gives the following description of it: "The first thing which called the attention of the explorer was the whiteness of the ground, owing to the excrements of the birds; the air hot and close was loaded with its keen, penetrating odor; the fine particles of it, floating in the air and coming in contact with the perspiring body, made one smart all over. There was also a smell of the decaying fish which lay around; some dropped by accident by the old birds (who, I believe, never stoop to pick them up again), and much more disgorged when their tree was assailed. These fish were mostly such as could not be obtained in the ponds and rivers. I once saw a piece of a pout, and once a fragment of a pickerel, but most of the remains were those of herrings. The light-green eggs were usually four in number; but I have seen five and six repeatedly, and once seven, in a nest. The young are downy, soft, helpless things at first, but soon gain strength enough to climb to the upper branches, where they hang on with bill and claws, and are fed by their parents till nearly full-grown." 


\section{SUB-ORDER GRALLE. WADERS.}

Feathers of the head and neck extending over the entire cheeks to the bill; bill, when much longer than head, slender at the base; sometimes thick and shorter than the head; young running about and feeding themselves as soon as hatched.

The preceding characteristics indicate, in a general way, the characteristics of the Gralle as distinguished from the Herodiones: they are usually much smaller birds, and more especially inhabitants of the open sandy shore. Few or none of the species nest on trees or bushes, the eggs being generally laid in a cavity scooped out in the sand.

The sub-order is divided by Bonaparte into two tribes, Cursores and Alectorides (by Burmeister into Limicolce and Paludicoloe): the first having the hind toe elevated, small, or wanting; the second having it lengthened, and inserted on a level with the rest. Additional characters are as follows:-

LmiroL.2. - Species living on the shore, and generally probing the ground or mud in search of food; bill and legs generally lengthened and slender; bill hard at tip, softer and more contracted at base; anterior toes connected at base more or less by membranes, and with very short claws; hind toe very short, elevated, or wanting; wings long, pointed; outer primaries longest, and reaching to or beyond the tip of tail, which is stiff.

Paludicol. - Species living in marshy places among the grass, feeding from the surface of the ground; bill hard to its base, where it is not contracted; toes cleft to the base, lengthened, with very long claws; hind toe lengthened, and on same level with the rest; wing short, rounded, not reaching the tip of the soft tail; outer primaries graduated.

\section{Tribe Limicoræ.}

Birds living on the shore or in open places, usually small species, with rounded or depressed bodies, and slender bills of variable length, having a more or less distinct horny terminal portion, the remainder covered with soft skin, in which are situated the elongated, narrow, open, and distinct nostrils; the feathers of the head are small, and extend compactly to the base of the bill; they are similar in character to those of the neck and body; the wings are long, acute, and, when folded, reaching to or beyond the tip of the tail; the posterior or inner secondaries are generally as long as the outer primaries; the primaries are ten in number; the three outer longest and about equal; the tail is stiff, short, broad, and rounded or graduated; the feathers usually twelve, sometimes more; the legs are slender and delicate, but corresponding with the bill in proportions; a large portion of the tibia below is bare of feathers; the covering of the legs is parchment-like, not horny, generally divided anteriorly and behind into small half rings, laterally more in hexagons; the claws are delicate, sharp, and gently curved; the hind toe is very small, scarcely touching the ground; sometimes wanting; there is usually (except in Calidris, Tringa, \&c.) a rather broad basal membrane between the outer and middle toes, sometimes between the inner and middle; this web occasionally extends toward the ends of the toes. - Burmeister. 1 


\section{Family CHARADRID无. THe Plovers.}

Bill rather cylindrical, as long as the head, or shorter; the culmen much indented opposite the nostrils, the vaulted apex more or less swollen and rising, quite distinct from the membranous portion; legs elevated; hind toe rarely present, and then rudimentary; the outer and middle toes more or less united by membrane.

\section{CHARADRIUS, LiNxжUS.}

Charadrius, Lixiseus, Syst. Nat. (1735).

Plumage yellowish-gray, spotted; tail transversely banded; no collar on neck; tarsi and lower thighs uniformly reticulated.

\section{CHARADRIUS VIRGINICUS, - Borckausen.}

\section{The Golden Plover; Bull-head.}

Charadrius pluvialis, Wilson. Am. Orn., VII. (1813) 71. Nutt. Man., II. (1834) 16. Aud. Orn. Biog., III. (1835) 623.

Charadrius Virginicus, "Borckausen and Bechstein." Licht. Verz. Doubl. (1823).

Charadrius marmoratus, Audubon. Orn. Biog., V. (1839) 575.

\section{DESCRIPTION.}

Bill rather short; legs moderate; wings long; no hind toe; tarsus covered before and behind with small circular or hexagonal scales; upper parts brownish-black, with numerous small circular and irregular spots of golden-yellow, most numerous on the back and rump, and on the upper tail coverts, assuming the form of transverse bands generally; also with some spots of ashy-white; entire under parts black, with a brownish or bronzed lustre, under tail coverts mixed or barred with white; forehead, border of the black of the neck, under tail coverts, and tibiæ, white; axillary feathers cinereous; quills, dark-brown; middle portion of the shafts white, frequently extending slightly to the webs, and forming longitudinal stripes on the shorter quills; tail dark-brown, with numerous irregular bands of ashy-white, and frequently tinged with golden-yellow; bill black; legs dark bluish-brown.

Younger. - Under parts dull-ashy, spotted with brownish on the neck and breast, frequently more or less mixed with black; many spots of the upper parts dull ashy-white; other spots, especially on the rump, golden-yellow.

Total length, about nine and a half inches; wing, seven inches; tail, two and a half inches.

Hab. - All of North America, South America, Northern Asia, Europe.

THIS beautiful and well-known bird passes through New 1 England in the spring and fall migrations, but does not pause here, in either, longer than two or three days. It arrives from the South about the 25th of April or 1st of May, in small flocks of fifteen or twenty, and frequents the 
beach on the seashore and marshes in its neighborhood, where it feeds on small shell-fish and animalcules, and such seeds as it may find at that early season. It is, at this period, thin in flesh, but its plumage is perfect; and it is more desirable for cabinet preservation then than in the fall. It is irregular in its visits in the spring migrations; being quite plenty in some seasons, and in others quite rare. It passes to the most northern portions of the continent to breed; none being found in the season of incubation in the limits of the United States. The flocks separate into pairs; but they breed in small communities, two or three pairs being found in the area of an acre. The nest is nothing but a hollow in the grass or moss, on the open plain, scratched by the female: in this she deposits four eggs, which are oblong-pyriform in shape, of a creamy-buff color, sometimes with an olive tint; and are marked irregularly, chiefly at their larger end, with spots and confluent blotches of umber and obscure spots of lilac. In dimensions, they arerage about 2.10 by $1.40 \mathrm{inch}$. It is in the fall migrations that these birds are most actively pursued by sportsmen. The great flight arrives about the 25th of August, sometimes a little earlier or later, if we have a driving north-east storm. The gunners make it a point to be on the plover grounds the last week in August and first week in September: if they get no plovers then, they usually abandon the hunt for the season. In the fall of 1865, these birds did not alight in New England in any numbers, but were seen seven or eight miles out at sea, flying. at a great height, in immense flocks, towards the South, and not a dozen birds were killed in localities where thousands are usually taken. When the flights are conducted during a storm, the birds fly low; and the gunners, concealed in pits dug in the earth in the pastures and hills over which the flocks pass, with decoys made to imitate the birds, placed within gunshot of their hiding-places, decoy the passing flocks down within reach of their fowling-pieces, by imitat- 
ing their peculiar whistle, and kill great numbers of them. I have known two sportsmen to bag sixty dozen in two days' shooting; and instances are on record of still greater numbers being secured. The flesh of this bird is very delicate and fine-flavored; and the birds are in great demand in all our markets, bringing equally high prices with the favorite Woodeock. The Golden Plover feeds on grasshoppers, varions insects, and berries, but is seldom found in the interior of New England; the pastures, fields, sandy hills, and dry islands near the seacoast, being its favorite resorts.

\section{EGIALITIS, BoIE.}

Agialitis, BoIE, Isis (1822), 558. (Type Charadrius hiaticula, L.)

Plumage more or less uniform, without spots; neck and head generally with dark bands; front of the legs with plates arranged vertically, of which there are two or three in a transverse series.

This genus, as far as North America is concerned, is distinguished from Charam drius by the generally lighter color and greater uniformity of the plumage, by the absence of continuous black on the belly, and by the presence of dusky bands on the neck or head; the size is smaller; the tarsi, in most species, have the front plates larger, and conspicuously different in this respect from the posterior ones.

EGGIALITIS VOCIFERUS. - Cassin.

\section{The Kill-deer Plover.}

Charadrius vociferus, Linnæus. Syst. Nat., I. (1766) 253. Wils. Am. Orn., VII (1813) 78. Nutt. Man., II. 22. Aud. Orn. Biog., III. (1835) 191; V. 577. 1b., Syn., 222. 1b., Birds Am., V. (1842) 207.

Egialtes vociferus, Bonaparte. List (1838).

\section{Description.}

Wings long, reaching to the end of the tail, which is also rather long; head above and upper parts of body light-brown with a greenish tinge; rump and upper tail coverts rufous, lighter on the latter; front and lines over and under the eye white; another band of black in front above the white band; stripe from the base of the bill towards the occiput brownish-black; ring encircling the neck and wide band on the breast black; throat white, which color extends upwards around the neck; other under parts white; quills brownish-black with about half of their inner webs white, shorter primaries with a large spot of white on their outer webs, secondaries widely tipped or edged with white; tail feathers pale-rufous at base; the four middle light olive-brown tipped with white, and with a wide subterminal band of black; lateral feathers widely tipped with white; entire upper plumage frequently edged 
and tipped with rufous; very young have upper parts light-gray, with a longitudinal band on the head and back, black; under parts white.

Total length, about nine and a half inohes; wing, six and a half inches; tail, three and a half inches.

Hab. - North America to the Arctic regions, Mexico, South America.

This species is pretty generally distributed throughout New England as a summer resident. It is not common in any localities, but seems to be found in pairs all along our seacoast; and, although occasionally breeding in the interior of these States, in the neighborhood of large tracts of water, it is almost exclusively found, during the greater part of the year, in moist fields and meadows and sandy pastures, within a few miles of the sea. Wilson describes its habits as follows:-

"This restless and noisy bird is known to almost every inhabitant of the United States, being a common and pretty constant resident. During the severity of the winter, when snow covers the ground, it retreats to the seashore, where it is found at all seasons; but no sooner have the rivers opened, than its shrill note is again heard, either roaming about high in air, tracing the shore of the river, or running amidst the watery flats and meadows. As spring advances, it resorts to the newly ploughed fields, or level plains bare of grass, interspersed with shallow pools; or, in the vicinity of the sea, dry, bare, sandy fields. In some such situation it generally chooses to breed, about the beginning of May. The nest is usually slight, a mere hollow, with such materials drawn in around it as happen to be near, such as bits of sticks, straw, pebbles, or earth. In one instance, I found the nest of the bird paved with fragments of clam and oyster shells, and very neatly surrounded with a mound, or border, of the same, placed in a very close and curious manner. In some cases, there is no vestige whatever of a nest. The eggs are usually four, of a bright rich cream or yellowish-clay color, thickly marked with blotches of black. They are large for the size of the bird, measuring more than an inch and a half in length, and a full inch in width, tapering to a narrow point at the great end.

"Nothing can exceed the alarm and anxiety of these birds during the breeding season. Their cries of kill-deer, kill-deer, as 
they winnow the air overhead, dive and course around you, or run along the ground counterfeiting lameness, are shrill and incessant. The moment they see a person approach, they fly or run to attack him with their harassing clamor, continuing it over so wide an extent of ground, that they puzzle the pursuer as to the particular spot where the nest or young are concealed; very much resembling, in this respect, the Lapwing of Europe. During the evening, and long after dusk, particularly in moonlight, their cries are frequently heard with equal violence, both in the spring and fall. From this circumstance, and their flying about both after dusk and before dawn, it appears probable that they see better at such times than most of their tribe. They are known to feed much on worms, and many of these rise to the surface during the night. The prowling of Owls may also alarm their fears for their young at those hours; but, whatever may be the cause, the facts are so.

"The Kill-deer is more abundant in the Southern States in winter than in summer. Among the rice-fields, and even around the planters' yards, in South Carolina, I observed them very numerous in the months of February and March. There the negro boys frequently practise the barbarous mode of catching them with a line, at the extremity of which is a crooked pin, with a worm on it. Their flight is something like that of the Tern, but more vigorous; and they sometimes rise to a great height in the air. They are fond of wading in pools of water, and frequently bathe themselves during the summer. They usually stand erect on their legs, and run or walk with the body in a stiff, horizontal position: they run with great swiftness, and are also strong and vigorous in the wings. Their flesh is eaten by some, but is not in general esteem; though others say, that, in the fall, when they become very fat, it is excellent.

"During the extreme droughts of summer, these birds resort to the gravelly channel of brooks and shallow streams, where they can wade about in search of aquatic insects: at the close of summer, they generally descend to the seashore in small flocks, seldom more than ten or twelve being seen together. They are then more serene and silent, as well as difficult to be approached.

- The eggs of this species are four in number. They are oblong-pyriform in shape, creamy-buff in color, with numer 
ous spots and blotches of dark-brown, chiefly at their greater end. They vary in dimensions from 1.65 by 1.10 inch to 1.50 by 1.08 inch; but one brood is reared in the season.

\section{EGIALITIS WILSONIUS.-(Ord.) Cassin.}

Wilson's Plover; Ring-neck.

Charadrius Wilsonius, Ord. Ed. Wils. Orn., IV. (1825) 77. Nutt. Man., II. (1834) 21. Aud. Orn. Biog., III. (1835) 73; V. (1839) 577. Ib., Birds Am., V. (1842) 214.

\section{Description.}

Smaller than the preceding; bill rather long and robust.

Male. - Front, and stripe over the eye, and entire under parts, white; front with a second band of black above the white band; stripe from the base of the bill to the eye and wide transverse band on the breast, brownish-black; upper parts of head and body light ashy-brown, with the feathers frequently edged and tipped with paleashy; back of the neck encircled with a ring of white, edged above with fine lightreddish; quills brown, with white shafts; shorter coverts tipped with white; outer feathers of the tail white, middle feathers dark-brown; bill black; legs yellow.

Female. - Without the band of black in front, and with the pectoral band dullreddish and light ashy-brown; iris reddish-brown.

Total length, seven and three quarter inches; wing, four and a half inches; tail, two inches.

Hab. - Middle and Southern States on the Atlantic, and the same coast of South America.

This species is found in New England only as a somewhat rare visitor in the autumn, after it has reared its young in a more southern locality. I think that it seldom passes north of the southern coast of Cape Cod; but it is there occasionally seen in the early part of September, gleaning its food of animalculæ and small shell-fish and insects on the sandy beach of the ocean.

The Wilson's Plover is more southern in its habits than either of the succeeding species; but it breeds abundantly on the seacoast of New Jersey. The nest is nothing but a hollow scratched in the sand, above high-water mark, with a few bits of seaweed or grass for its lining. The eggs are laid about the first week in June. They are, like those of the other Waders, pyriform in shape; and, when placed in the nest, their small ends are together in the middle of the nest. They almost exactly resemble the eggs of the 
Kill-deer Plover, but are some little smaller; varying in dimensions from 1.40 by 1.05 to 1.34 by 1.02 inch. The spots and markings are similar to those of the other, but are less thickly distributed: some specimens have obscure spots of purple and lilac, and the brown spots vary from quite blackish to the color of raw-umber.

\section{EEGIALITIS SEMIPALMATUS. - (Bon.) Cabanis.}

\section{The Semipalmated Plover; Ring-neck.}

Charadrius semipalmatus, Nuttall. Man., II. 24. Aud. Orn. Biog., IV. (1838)

256; V. 579. 1b., Birds Am., V. (1842) 218.

Egialtes semipalmata, Bonaparte. List (1838).

Egialitis semipalmatus, Cabanis. Cab. Journ. (1856), 425.

Tringa hiaticula, Wilson. Am. Orn., VII. (1813) 65.

\section{DESCRIPTION.}

Small; wings long; toes connected at base, especially the outer to the middle toe; front, throat, ring around the neck, and entire under parts, white; a band of deep-black across the breast, extending around the back of the neck below the white ring; band from the base of the bill, under the eye, and wide frontal band above the white band, black; upper parts light ashy-brown, with a tinge of olive; quills brownish-black, with their shafts white in a middle portion, and occasionally a lanceolate white spot along the shafts of the shorter primaries; shorter tertiaries edged with white; lesser coverts tipped with white; middle feathers of the tail ashy olivebrown, with a wide subterminal band of brownish-black, and narrowly tipped with white; two outer tail feathers white, others intermediate, like the middle, but widely tipped with white; bill orange-yellow, tipped with black; legs yellow. Female similar, but rather lighter-colored. Young without the black band in front, and with the band across the breast ashy-brown; iris, dark-hazel.

Total length, about seven inches; wing, four and three-quarters inches; tail, two and a quarter inches.

Hab. - The whole of temperate North America; common on the Atlantic.

This pretty and well-known species is abundant in New England in the spring and fall migrations. It arrives from the South by the latter part of April, in small flocks of eight or ten individuals; some following the course of large rivers, like the Connecticut; others haunting the shores of large ponds and meadows; but the greater number following the seacoast, where they feed, like the others of this genus, on small crustaceans, shell-fish, and the eggs of fish and other marine animals. 
Althcugh I found a single pair with their nest on the island of Muskegeet, Mass., in June, 1866, this bird generally breeds in the most northern parts of the continent. Audubon, in describing its breeding habits, says, -

"As soon as one of us was noticed by a Ring Plover, it would at once stand still, and become silent. If we did the same, it continued, and seldom failed to wear out our patience. If we advanced, it would lower itself, and squat on the moss or bare rock until approached, when it would suddenly rise on its feet, droop its wings, depress its head, and run with great speed to a considerable distance; uttering, all the while, a low rolling and querulous cry, very pleasing to the ear. On being surprised when in charge of their young, they would open their wings to the full extent, and beat the ground with their extremities, as if unable to rise. If pursued, they allowed us to come within a few feet, then took flight, and attempted to decoy us away from their young, which lay so close that we very seldom discovered them; but which, on being traced, ran swiftly off, uttering a plaintive peep, often repeated, that never failed to bring their parents to their aid. At Labrador, the Ring Plover begins to breed in the beginning of June. Like the Piping Plover, it forms no nest; but, whilst the latter scoops a place in the sand for its eggs, the Ring Plover forms a similar cavity in the moss, in a place sheltered from the north winds, and exposed to the full rays of the sun, usually near the margins of small ponds formed by the melting of the snow, and surrounded by short grass. The eggs, like those of all the family, are four, and placed with the small ends together. They are broad at the larger end, rather sharp at the other; measure $1 \frac{1}{4}$ inch in length, $1 \frac{1}{8}$ inches in their greatest breadth; are of a dull-yellowish color, irregularly blotched and spotted all orer with dark-brown of different tints."

Early in September, sometimes by the 20th of August, small flocks of these birds appear in New England, and they remain here as late as the first week in October: they are now fat and delicate, and are esteemed excellent for the table. 


\title{
EGIALITIS MELODUS. - (Ord.) Cabanis.
}

\section{The Piping Plover.}

Charadrius melodus, Nuttall. Man., II. 18. Aud. Orn. Biog,, III. (1835) 154; V. 578 .

\author{
Egialtes melodus, Bonaparte. List (1838). \\ Egialitis melodus, Cabanis. Jour. (1856), 424. \\ Charadrius hiaticula. Wils. Am. Orn., V. (1812) 30.
}

Description.

About the size of the preceding; bill short, strong.

Adult. - Forehead, ring around the back of the neck, and entire under parts, white, a band of black in front above the band of white; band encircling the neck before and behind black, immediately below the ring of white on the neck behind; head above, and upper parts of body, light brownish-cinereous; rump and upper tail coverts lighter, and often nearly white; quills dark-brown, with a large portion of their inner webs and şlafts white; shorter primaries with a large portion of their outer webs white; tail at base white, and with the outer feathers white; middle feathers with a wide subterminal band of brownish-black, and tipped with white; bill orange at base, tipped with black; legs orange-yellow.

Female. - Similar to the male, but with the dark colors lighter and less in extent. Foung. - No black band in front; collar around the back of the neck ashybrown; iris brown.

Total length, about seren inches; wing, four and a half inches; tril, two inches.

Hab.-Eastern coast of North America; Nebraska (Lieut. Warren); Louisiana (Mr. G. Wurdemann).

This pretty and well-known species is pretty abundantly distributed along the coast of New England as a summer resident. It arrives from the South about the 20th of April in small flocks, and soon selects its breeding-residence on some tract of ocean beach ; dividing, early in May, into pairs, which, howerer, associate somewhat together through the whole season. It occasionally penetrates into the interior, and has been known to breed on the borders of a pond twents miles from the seaboard; but generally, in New England, it seldom wanders far from the shore, where it is one of the most beautiful and interesting of our Waders.

It seems to prefer sandy islands a short distance from the main land for its breeding-place. I have found numbers breeding on the island of Muskegeet, off the southern coast of Massachusetts, and hare found it on many others of our islands of similar character. 
The nest is nothing but a hollow in the sand scraped by the female bird: it sometimes has a slight lining of pieces of grass or seameed; but usually the egges are deposited on the bare sand. These are four in number, abruptly pyriform in shape, and a beautiful light ereams-buff in color, with thinly scattered spots of black and brown, and sometimes a few obscure spots of lilac. They arerage smaller in size than either of the preceding. rarying from 1.30 by 1 inch to 1.20 by .95 inch in dimensions. They do not resemble the others, being much more finely marked; and their small ends are more rounded.

The breeding habits and general characteristics of this so much resemble those of the preeeding species that the same remarks will apply to both.

\section{SQUATAROLA, CUTIER.}

Squatarola, Corzer, Règne Anim., I. (1517). (Type Tringa squatarola, Linn.)

A rudimentary hind toe; legs reticulated, with elongated hexagons anteriorly, of which there are five or six in a transverse row; fewer behind; tirst primary longest; tail slightly rounded.

\section{SQDATAROLA HELVETICA. - Curier.}

\section{The Black-bellied Plorer.}

Tringe helvetica, Linnæus. Syst. Nat., I. (1766) 250.

Squatarola heletica. Curier, R. A., (181T).

Charadrius helretious, Audubon. Orn. Biog., IV. (15ss) 2S0. Ib., Birds Amer., V. (17 12$) 199$.

Charadrius apricarius, Tilson. Am. Orn., VII. (1813) 41 .

\section{DESCRIPTION.}

Bill and legs strong; wings long; a very small mdimentary hind toe; around the base of the bill to the eyes, neck before and under parts of body, black; upper white, nearly pure and unspotted on the forehead; sides of the neck and rump tinged with ashy, and having irregular transrerse bars of bromnish-black on the back, scapular, and wing corerts; the brownish-black frequently pretominating on those parts, and the rump also frequently with transrerse bars of the same; lower part of the abdomen, tibia, and under tail corerts, white; quills brownish-black, lighter on their inner webs, with a middle portion of their shatts white, and a narrow longitudinal stripe of white frequently on the shorter primaries and secondaries; tail white, with transverse imperfect narrow bands of black; bill and legs black; the black color of the under parts generally with a bronzed or coppery lustre, and pre- 
senting a scale-like appearance; the brownish-black of the upper parts with a greenish lustre.

Founger and trinter plumage. - Entire upper parts dark-brown, with circular and irregular small spots of white, and frequently of yellow, most numerous on the wing corerts; upper tail corerts white; under parts white, with short longitudinal lines and spots dark brownish-cinereous on the neck and breast; quills brownish-black, with large longitudinal spots of white on their inner webs, and also on the outer webs of the shorter primaries.

Foung. - Upper parts lighter, and with the white spots more irregular or scarcely assuming a circular shape; narrow lines on the neck and breast more numerous; iris black.

Total length, about eleven and a half inches; wings, seren and a half inches; tail, three inches.

Hab. - All of Forth Americs. The seacoasts of nearly all countries of the พorld.

This beautiful bird is almost of the same habits and characteristics as the Golden Plorer described on a preceding page. It arrires and departs at nearly the same time in spring, and. like that speeies, breeds in the most northern sections of the continent. Wilson, in speaking of its breeding in Pennsylrania, says, -

"This bird is known in some parts of the country by the name of the Large Whistling Field Plover. It generally makes its first appearance in Peunsrlrania late in April; frequents the countries towards the mountains; seems particularly attached to newly ploughed fields, where it forms its nest of a few slight materials, as slightly put together. The female lays four eggs, large for the size of the bird, of a light-olive color, dashed with black, and has frequently trro broods in the same season. It is an extremely shy and watchful bird, though clamorous during breeding-time."

About the 10th or 15th of September, or a fortnight later than the Golden Plorer, it returns on its sonthern migration; and the same means are employed for its destruction as for that bird: these birds are called by the gunners by the name of Beetle-heads, and are esteemed as being nearly as palatable and delicate as the other species. 


\section{Family HematOPODID无。 The Oxster-Catchers.}

Bill as long as the head, or trice as long, compressed; culmen but little indented, and the bill not vaulted beyond the nostrils, which are quite basal.

\section{HAMATOPUS, LINNEUS.}

\section{Homatopus, Livw zeUs, Syct. Nat. (1735). (Type H. Ostralegus, L.)}

Bill longer than the leg, twice as long as the head; mandibles much compressed, sharp-edged, and truncate at end; hind toe wanting; legs reticulated, with five or six elongated plates in a transverse series; meshes larger anteriorly; a basal membrane between middle and outer toes; toes enlarged laterally by a thickened membrane; tail even; first primary longest.

\section{HEMATOPUS PALLIATUS. - Temm.}

\section{The Oyster-catcher.}

Hamatopus palliatus, Temm. Man., II. (1820) 532. Aud. Orn. Biog., III. (1885) 181; V. 580. Ib., Birds Am., V. (1842) 236.

Hcematopus ostralegus, Wilson. Am. Orn., VIII. (1814) 15.

\section{DEscription.}

Bill long, straight, flattened vertically; wing long; tail short; legs moderate, rather robust; toes margined; outer and middle united at base; head and neck brownish-black, with a slight ashy tinge in very mature specimens; upper parts of body light ashy-brown, rather darker on the rump; upper tail coverts and wide diagonal band across the wing white; quills brownish-black; tail feathers at base white, with their terminating half brownish-black; under parts of body and under wing coverts white; bill and edge of eyelids bright orange-red; legs pale-reddish; iris bright-yellow.

Total length, about seventeen and a half inches; wing, ten; tail, four and a half; bill to gape, three and a half; tarsus, two and a quarter inches.

\section{THIS bird is of rare occurrence on the seacoast of New} England as a summer visitor. I am not aware that it breeds here; but it may, as it is said to be found all along our coast from Maine to Florida. Wilson, in describing its habits, says, -

"'The Oyster-catcher frequents the sandy sea-beach of New Jersey, and other parts of our Atlantic coast, in summer, in small parties of two or three pairs together. They are extremely shy; 
and, except about the season of breeding, will seldom permit a person to approach within gunshot. They walk along the shore in a watchful, stately manner; at times probing it with their long, wedge-like bills, in search of small shell-fish. This appears evident, on examining the hard sands where they usually resort which are found thickly perforated with oblong holes, two or three inches in depth. The small crabs, called fiddlers, that burrow in the mud at the bottom of inlets, are frequently the prey of the Oyster-catcher; as are muscles, spout-fish, and a variety of other shell-fish and sea insects with which those shores abound.

"The Oyster-catcher will not only take to the water when wounded, but can also swim and dive well. This fact I can assert from my own observation, the exploits of one of them in this way having nearly cost me my life. On the sea-beach of Cape May, not far from a deep and rapid inlet, $\mathrm{I}$ broke the wing of one of these birds, and, being without a dog, instantly pursued it towards the inlet, which it made for with great rapidity. We both plunged in nearly at the same instant; but the bird eluded my grasp, and I sunk beyond my depth : it was not until this moment that I recollected having carried in my gun along with me. On rising to the surface, I found the bird had dived, and a strong ebb current was carrying me fast towards the ocean, encumbered with a gun and all my shooting apparatus. I was compelled to relinquish my bird, and to make for the shore with considerable mortification, and the total destruction of the contents of my powder-horn. The wounded bird afterwards rose, and swam with great buoyancy."

The eggs of this bird are most generally a creamy-drab color, with numerous blotches and spots of blackish-brown. Their form is ovoidal ; and their dimensions vary from 2.30 to 2.12 inch in length by from 1.62 to 1.50 in breadth.

\section{STREPSILAS, ILLIGER.}

Strepsilas, Illiger, Prodromus (1811). (Type Tringa interpres, L.)

Upper jaw with the culmen straight from the nasal groove to near the slightly upward bent tip; the bill tapering to a rather blunt point; no membrane between the anterior toes; hind toe lengthened, touching the ground; legs transversely scutellate anteriorly; reticulated laterally and behind; tail rounded. 
The nasal groove is very broad and shallow, obtuse anteriorly, and not extending beyond the middle of the bill; the lower edge of upper jaw ascends slightly from the middle to near the tip.

\section{STREPSILAS INTERPRES. - Iliger.}

The Turnstone.

Tringa interpres, Linnæus. Syst. Nat., I. (1766) 248. Wils. Am. Orn., VII. (1813) 32.

Strepsilas interpres, Illiger. Prod. (1811), 263. Nutt., II. 30. Aud. Orn. Biog., IV. (1838) 31. 16., Birds Am., V. (1842) 231.

\section{DESCRIPTION.}

Upper parts rather irregularly variegated with black, dark-rufous, and white; head and neck above generally white, with numerous spots and stripes of brownishblack on the crown and occiput; space in front of the eye white, usually surrounded with black; throat white, on each side of which is a stripe of black running from the base of the bill downwards and joining a large space of the same color (black) on the neck before and breast; abdomen, under wing coverts, under tail coverts, back, and rump, white; quills brownish-black, with their shafts white; tail white at base, with its terminal half brownish-black, and tipped with white; greater wing coverts widely tipped with white, forming a conspicuous oblique bar across the wing; bill black; legs orange; in winter, the black of the upper parts is more apparent, and the rufous is of less extent and of lighter shade; iris hazel.

Total length, about nine inches; wing, six; tail, two and a half inches.

Hab. - Shores of the Atlantic and Pacific, throughout North America. One of the most widely diffused of birds, being found in nearly all parts of the world.

It is only on the seacoast, and in very small numbers even, that this bird is found in New England as a spring and summer visitor. It occasionally is found in company with some of the Sandpipers and other beach-birds; but usually appears alone, or in parties of two or three, on the beach, or on the shores of sandy rivers that empty into the ocean, near their outlets. It is almost always actively employed in turning over the pebbles and small stones with its strong, sharp bill, beneath which it finds small marine animals and eggs, on which it principally feeds. It also eats greedily, according to Wilson, on the eggs of the Horse-shoe, or King Crab, and small shell-fish, and occasionally wades into the water for a shrimp or other small animal that is left in a shallow pool by the retiring waves. It breeds on the most northern sections of the continent, 
building its nest in the Hudson's Bay country, early in June: this nest is nothing but a slight hollow scratched in the earth, and lined with a few pieces of grass or seaweed. The eggs are four in number: they are of an olive color, sometimes a drab; and are marked with spots and blotches of reddish and black, chiefly at the greater end, where they are confluent, and nearly cover and conceal the ground-color. Their form is abruptly pyriform; and their dimensions average about 1.55 by $1.15 \mathrm{inch}$.

It is rarely that we find two specimens of this bird in the full plumage, or marked alike : they exhibit all the varieties, from almost entirely gray on their upper parts, to the plumage described above. 


\section{Family RECURVIROSTRIDA. The Avosets.}

Legs covered with hexagonal plates, becoming smaller behind; anterior toes all connected more or less by membrane; bill much lengthened and attenuated; the groove along the side of the upper mandible not extending beyond the middle; gums denticulated only at the base.

In addition to the features above mentioned, these birds are essentially characterized by the excessive length of the legs, with a very long, slender neck and slender elongated bill. Of the several genera assigned the family, but two belong to the United States, with the following features:-

Recurvirostrd.-Hind toe present; toes webbed to the claws; bill recurred at tip.

Hrmaxtopus. - Hind toe wanting; a short web between middle and outer toes at base; bill straight.

\section{RECURVIROSTRA, LINNEUS.}

Recurvirostra, Linn.eus, Syst. Nat. (1744). Gray. (Type R. avocetta, L.)

Hind toe rudimentary; anterior toes united to the claws by a much emarginated membrane; bill depressed, extended into a fine point, which is recurved; tail covered by the wings.

\section{RECURVIROSTRA AMERICANA, - Gmelin.}

\section{The American Avoset.}

Recurvirostra Americana, Ǵmelin. Syst. Nat., I. (1788) 693. Wils. Am. Orn., VII. (1813) 126. Nutt. Man., II. 78. Aud. Orn. Biog, IV. (1838) 168. Ib., Birds Am., VI. (1843) 247.

\section{DESCRITTION.}

Bill rather long, depressed; wings long; legs long; tarsi compressed; tail short.

Adull. - Head and neck pale reddish-brown, darker on the head, and fading gradually into white; back, wing coverts, and quills, black; scapulars, tips of greater wing coverts, rump and tail, and entire under parts, white, the last frequently tinged with reddish; bill brownish-black; legs bluish.

Young. - Very similar to the adult, but with the head and neck white, frequently tinged with ashy on the head and neck behind; iris carmine.

Total length, about seventeen inches; wing, eight and a half to nine; tail, three and a half; bill to gape, three and three-quarters; tarsus, three and a half inches.

\section{THIS bird is a rare summer visitor in New England 1 I am unacquainted with its habits, having never met with one alive; and I must avail myself of the observations of others. Wilson says, -}


"In describing the Long-legged Avoset, the similarity between that and the present was taken notice of. This resemblance extends to every thing but their color. I found both these birds associated together on the salt marshes of New Jersey, on the 20th of May. They were then breeding. Individuals of the present species were few in respect to the other. They flew around the shallow pools exactly in the manner of the Long-legs; uttering the like sharp note of click, click, click; alighting on the marsh or in the water indiscriminately; fluttering their loose wings, and shaking their half-bent legs, as if ready to tumble over; keeping up a continual yelping note. They were, however, rather more shy, and kept at a greater distance. One which I wounded attempted repeatedly to dive; but the water was too shallow to permit him to do this with facility. The nest was built among the thick tufts of grass, at a small distance from one of these pools. It was composed of small twigs of a seaside shrub, dry grass, seaweed, \&c., raised to the height of several inches. The eggs were four, of a dull-olive color, marked with large, irregular blotches of black, and with others of a fainter tint.

Audubon, who found it breeding in the neighborhood of Vincennes, in the State of Indiana, describes the nest and eggs as follows:-

"The nests were placed among the tallest grasses, and were entirely composed of the same materials, but dried, and apparently of a former year's growth. There was not a twig of any kind about them. The inner nest was about five inches in diameter, and lined with fine prairie grass, different from that found on the islets of the pond, and about two inches in depth, over a bed having a thickness of an inch and a half. The islets did not seem to be liable to inundation; and none of the nests exhibited any appearance of having been increased in elevation since the commencement of incubation, as was the case with those described by Wilson. Like those of most Waders, the eggs were four in number, and placed with the small ends together. They measured two inches in length, one inch and three-eighths in their greatest breadth, and were exactly, as Wilson tells us, ' of a dull-olive color,' \&c. To this I have to add that they are pear-shaped and smooth." 


\section{Fanily Phalaropodid e. The Phalaropes.}

Feathers of breast compact, duck-like; legs with transverse scutellæ before and behind; toes to the tips with a lateral margin, more or less indented at the joints, the hinder with a feeble lobe; bill equal to or longer than the head, the lateral groove extending nearly to the tip.

\section{PHALAROPUS, BRISSON.}

Membrane of toes scolloped at the joints.

\section{PHALAROPUS HYPERBOREUS, - Temm.}

\section{The Northern Phalarope.}

Tringa hyperborea, Linnæus. Syst. Nat., I. (1766) 249.

Phalaropus hyperboreus, Temm. Man., II. (1820) 709. Aud. Orn. Biog., III. (1835) $118 ;$ V. 595.

\section{Description.}

Bill short, straight, pointed; wings long; tail short; legs short.

Adult. - Neck encircled with a ring of bright-ferruginous, and a stripe of the same on each side; head above and neck behind sooty-ash; back, wings, and tail, brownish-black, paler on the rump, mixed with bright-ferruginous on the back; tips of greater wing coverts white; sides and flanks ashy, frequently mixed with reddish; throat, breast, and abdomen white; bill and legs dark; iris dark-brown.

Young. - Entire upper parts brownish-black; many feathers edged and tipped with dull yellow and ashy: under parts white; tips of greater wing coverts white.

Total length, about seven inches; wing, four and half; tail, two and a quarter; bill, one; tarsus, three-fourths of an inch.

THE Northern Phalarope is rarely found on the seacoast 1 of New England in the spring and autumn migrations; appearing in the former about the 10th of May, and in the latter about the 25th of August. The migrations are performed by the birds in small flocks out at sea; and it is only when they are driven into shore by heavy winds and storms that they are found here, and then scarcely more than two or three birds are taken in a season. This species is equally a swimmer and wader. When on the water, it has the appearance of a small Gull or Tern, swimming with great elegance 


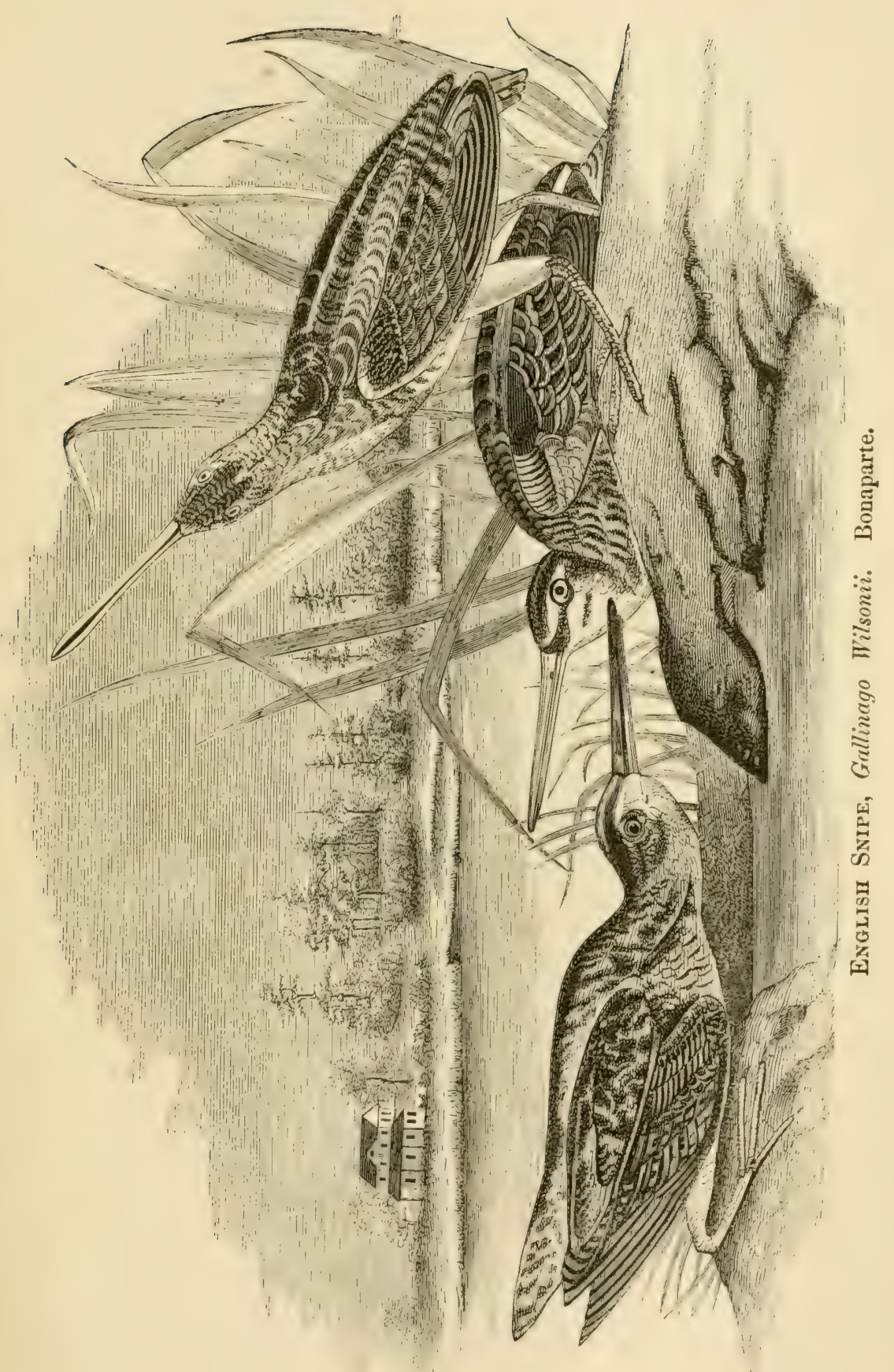



and ease, frequently dipping its bill into the water to secure a small marine animal or fly. Its motions are so graceful when thus employed, that the bird has been compared to a swan ; and all writers agree that it is one of the most beautiful of our aquatic birds.

On the shore, it frequents small pools or ponds of water, near the coast, in which it wades and swims with equal facility ; frequently uttering a shrill cry similar to the syllables creet crêe teet. It is said that tlie same pairs are faithful to each other for successive seasons. I know not how true this may be; but it seems not improbable, from the fact, that, in their winter homes on the shores of the Gulf of Mexico, they are most often seen in small parties of three or four, often by pairs. This species breeds in the most northern sections of the continent. It builds its nest about the first week in June, in the Hudson's Bay country: this is constructed of a few pieces of grass and moss, put loosely together, and placed in a tussock of grass or moss. The eggs are usually four in number. They vary in color from a brownish-drab to light-olive, and are thickly covered with large blotches and spots of dark umber : their form is abruptly pyriform, and their dimensions vary from 1.12 by 1.02 to 1.06 by .98 inch. 


\section{Famixy SCOLOPACID无. The Snipes.}

Legs with transverse scutellæ before and behind; toes not margined broadly to the tips, with or without basal membrane; hind toe generally present; bill generally longer than the head, the groove extending beyond the middle.

\section{Sub-Family Scolopacinæ.}

Bill swollen at the end, and covered almost to the tip with a soft skin, the edges only of the rather vaulted tip horny; the end of the upper bill generally bent a little over the tip of lower; the jaw-bone in typical genera finely porous, and perforated by vessels and nerves, imparting a high degree of sensibility to the bill, enabling it to find food in the mud; after death, the end of bill is usually pitted; legs rather stout; the naked portion of the tibia much abbreviated; the hind toe well developed and generally present; the toes usually without basal membrane (except in Macrorhamphus, \&c.).

\section{PHILOHELA, G. R. GraY.}

Philohela, Grax, List of Genera (1841). Gmelin. (Type Scolopax minor.)

Body very full, and head, bill, and eyes very large; tibia short, feathered to the joint; toes cleft to base; wings short, rounded; first three primaries very narrow, and much attenuated; the fourth and fifth equal and longest; tarsi stout, shorter than the middle toe; hind nail very short, conical, not extending beyond the toe; tail of twelve feathers.

The present genus, embracing a single species, the American Woodcock, is much like Scolopax, with the European Woodcock as type, in color and external appearance. The most striking difference is seen in the wings, which are short, rounded, the fourth and fifth primaries longest, and the outer three attenuated; while in Scolopax the wings are long, the first primary longest and more attenuated.

\section{PHILOHELA MINOR. - Gray.}

The American Woodcock. 474.

Rusticola minor, Nuttall. Man., II. (1834) 194.

Scolopax (microptera) minor, Nuttall. Man., II. (1834) 194.

Philohela minor, Gray. $\quad$ List Genera (1841).

\section{DESCRIPTION.}

Bill long, compressed, punctulated and corrugated near the end; upper mandiole longer than the under, and fitted to it at the tip; wings moderate, three first quills very narrow; tail short; legs moderate; eyes inserted unusually distant from the 
bill; occiput with three transverse bands of black, alternating with three others of pale yellowish-rufous; upper parts of body variegated with pale-ashy, rufous, or yellowish-red of various shades, and black; large space in front, and throat, reddishashy; line from the eye to the bill, and another on the neck below the eye, brownishblack; entire under parts pale-rufous, brighter on the sides and under wing coverts: quills ashy-brown; tail feathers brownish-black, tipped with ashy, darker on the upper surface, paler and frequently white on the under; bill light-brown, paler and yellowish at base; legs pale-reddish; iris brown.

Total length, about eleven inches; wing, five and a quarter; tail, two and a quarter; bill, two and a quarter; tarsus, one and a quarter inches.

Hab. - Eastern North America.

THE Woodcock is a common summer inhabitant of the 1 three southern New-England States, and is not rare in most sections of the others. It is one of the earliest of our spring arrivals ; appearing by the 10th of March, and sometimes much earlier, even before the 25th of February. When it first arrives, it is partially gregarious; being found in small companies of four or five, in the area of a few rods. It frequents low swampy woods and thickets at this season, where, during the day, it remains concealed, only moving about, in its search for food, in the night.

It begins its nocturnal rambles by early twilight, and only retires to its swamp at daybreak. If we stand, in the evening, in the neighborhood of a swamp, or low tract of woods, we sometimes hear two or three individuals moving about in the undergrowth, uttering their note, chip-per, chip-per chip, sometimes varying it to bleat or bleat ta bleät ta; or see them, against the evening sky, flying rapidly from one swamp to another. About the first week in April, after separating into pairs, the Woodcocks begin their duties of fncubation: the female scratches together a few leaves, on a slight elevation in some meadow or swamp, and this forms the nest. I have noticed that the locality most often selected is in a small bunch of bushes, or small birches or alders, in the midst of a meadow. The eggs are three or four in number : their ground-color is usually a rich creamy-drab, sometimes with a slightly olive tint; and they are marked, more or less thickly, with coarse and fine spots and blotches 
of two shades of brown, and obscure spots of lilac. They are less pyriform than the eggs of any other birds in this group, being often almost exactly ovoidal. They exhibit great variations in size, some specimens from Bristol County, Massachusetts, averaging 1.80 by 1.25 ; and others, from the south and west, averaging only 1.45 by 1.15 ; others from Western Massachusetts average about 1.50 by 1.20 , being nearly rounded; and one from J. P. Norris, found in Chester County, Pennsylvania, is abruptly pyriform, being in dimensions 1.45 by 1.20 inch.

Both birds assist in incubation; and they are so unwilling to leave the nest at this time, that I have known of an oxteam being driven within a foot of a bird, without starting her from the nest. The food of the Woodcock consists of worms and animalculæ, which it secures by thrusting its bill into the soft earth, and beneath the dead leaves and grass in swamps and other wet places.

The tongue of the bird is coated with a thick saliva; and the worms sticking to it are drawn out and devoured. The holes where the bill is thus thrust in the earth are called, by gunners, "borings;" and the presence of the bird is detected by them, as none of our wood-birds make any similar. The old bird, if shot in the summer, when she has young, often has her mouth full of small worms; and this proves that she feeds her chicks until they are nearly full grown. The flight of the Woodeock is rapid, and always is accompanied by a sharp twitter. When the bird is flushed, it ascends quickly to the height of the trees; and, after hovering a few seconds, it alights on the ground, within a few rods of the point from which it first flew.

In the latter part of July, and during the month of August, while the birds are moulting, they retire to the most secluded localities; and it is difficult to find them at that season. In September, during the continuance of dry weather, they frequent cornfields and ditches; and I have seen them searching for worms in the mud in a sink 
spout, within a few yards of a house. At the latter part of September, and during October, they are in their prime; and $I$ know of no more exciting sport, and one that is so generally satisfactory, than fall Woodcock hunting. By the 10th of November, none of these birds are to be found in New England.

\section{GALLINAGO, LEACH.}

Gallinago, "LeAcr, Catal. British Birds (1816)." Gray. (Type Scolopax major, L.)

Lower portion of the tibia bare of feathers, scutellate before and behind, reticulated laterally like the tarsi; nail of hind toe slender, extending beyond the toe; bill depressed at the tip; middle toe longer than tarsus; tail with twelve to sixteen feathers.

The more slender body, longer legs, partly naked tibia, and other features, distinguish this genus from Scolopax or Philohela.

\section{GALLINAGO WILSONII. - Bonaparte.}

'The Snipe; Wilson's Snipe; English Snipe.

Scolopax Wilsonii, Nuttall. Man., II. 185. Aud. Orn. Biog., III. (1835) 322;

V. (1839) 583. 1b., Birds Amer., V. (1842) 339.

Gallinago Wilsonii, Bonaparte. List (1838).

Scolopax gallinago, Wilson. Am. Orn., VI. (1812) 18. Not of Linnæus.

DESCRIPTION.

Bill long, compressed, flattened, and slightly expanded towards the tip, pustulated in its terminal half; wings rather long; legs moderate; tail short; entire upper parts brownish-black; every feather spotted and widely edged with light-rufous, yellowish-brown, or ashy-white; back and rump trarsversely barred and spotted with the same; a line from the base of the bill over the top of the head; throat and neck before, dull reddish-ashy; wing feather marked with dull brownish-black; other under parts white, with transverse bars of brownish-black on the sides, axillary feathers and under wing coverts and under tail coverts; quills brownish-black; outer edge of first primary white; tail glossy brownish-black, widely tipped with bright-rufous, paler at the tip, and with a subterminal narrow band of black; outer feathers of tail paler, frequently nearly. white, and barred with black throughout their length; bill brown, yellowish at base, and darker towards the end; legs darkbrown; iris hazel.

Total length, about ten and a half inches; wing, five; tail, two and a quarter; bill, two and a half; tarsus, one and a quarter inch.

Hab.-Entire temperate regions of North America; California (Mr. Szabo).

The Snipe is equally well known, and as great a favorite with sportsmen, as the preceding species. It arrives from 
the South at about the same time, and has many of the habits and characteristics of the other bird. It is found in New England only as a spring and autumn visitor, very rarely breeding here, but passing the season of incubation in higher latitudes. It frequents the fresh-water meadows, where it usually lies concealed during the day, only moving about in dark weather and in the night. In the spring, while with us, it appears to be pairing; and, although associating in small detached flocks, they are most often found in pairs by themselves. It is during this season that the male performs his well-known gyrations in the air: he ascends to a considerable height, early in the evening, and, almost in the manner of the Night-hawk, described on a preceding page, dives towards the earth, uttering his bleating cry, and peculiar rumbling sound. This species breeds sometimes in the northern portions of New England. It forms a loose nest of grass and a few leaves, on the ground, in a bog or wet swampy thicket; - and, about the first week in May, the female lays three or four eggs. These are more pyriform in shape than the preceding, and average about 1.44 by 1.15 inch in dimensions. Their color is an olivaceous-drab, marked with spots of brown, which are, at the greater end, confluent into blotches, which almost entirely hide the ground-color.

The Snipe has been known to breed in Massachusetts; but the occurrence is very rare, and can be regarded only as accidental. By the 25th of August, it returns to the meadows of New England in small parties of three or four; but it is not abundant much before the 10th or 15th of September, and then is not found in great numbers, unless we have had two or three sharp frosts. The time when sportsmen most expect to find them in numbers is after a north-easterly storm, when the wind veers around to the south-westward. Then the meadows are hunted diligently, and generally with success. I have bagged twenty-four birds in an afternoon's shooting, within ten miles of Boston, 
and have known that number to be exceeded in farorable weather. The Snipe lies close to the ground when approached; and, being a bird of strong scent, as the expression is, is winded to a considerable distance by a good dog. It is easy to imagine the excitement the sportsman experiences, when, with a good dog, he enters a large meadow, and sees him suddenly come to a point; when, walking up to the Snipe, and flushing it, the report of his gun, as he shoots the bird, startles from their lurking-places perhaps a dozen others, who fly but a short distance, uttering their peculiar squeak or scaip, and then alight in the grass, promising him an abundance of shooting for the day.

The Snipe, when first flushed, rapidly doubles and twists in a quick, zigzag flight, which it continues for several rods, when it takes a more direct course, almost always against the wind. The sportsman, knowing this habit of the bird, reserves his fire until it has stopped twisting, when his aim is generally successful. Sometimes two birds rise at the same time, when it requires considerable coolness and experience to secure both. I once got three double shots in succession, securing all six birds: but such an occurrence and good luck are rare; and we must be satisfied, in most shooting, to get but single birds.

The Snipe, like the Woodcock, probes in the soft earth for worms and animalcules, which it feeds upon: it also eats the larvæ of water-insects, and leeches, and occasionally captures grasshoppers and other insects in the wet grass in which it almost entirely resides. It is very difficult of approach in cloudy and windy weather; but, in warm, bright days in the fall, it is quiet, and lies until approached quite near. It remains with us until the ground is frozen in the meadow, when it moves to the Southern States, where it passes the winter. 


\section{MACRORHAMPHUS, LEACH.}

Macrorhamphus, "LEAcH, Catal. Brit. Birds, 1816." Gray. (Scolopax grisea.) Gmelin.

General appearance of Gallinago. Tarsi longer than middle toe; a short web between the base of outer and middle toe.

The membrane at the base of the toes will at once distinguish this genus from Gallinago, though there are other characters involved.

\section{MACRORHAMPHUS GRISEUS. - $(G m$.$) Leach.$}

The Red-breasted Snipe; Gray Snipe.

Scolopax grisea, Gmelin. Syst. Nat., I. (1788) 658, No. 27.

Scolopax Noveboracensis, Wilson. Am. Orn., VII. (1813) 45. Aud. Orn. Biog., IV. (1838) 285. Ib., Birds Amer., VI. (1843) 10.

\section{DESCRIPTION.}

Bill long, compressed, flattened, and expanded towards the end, and, in the same space, punctulated and corrugated; wing rather long; shaft of first primary strong; tail short; legs rather long.

Adult. - Upper parts variegated with dark-ashy, pale-reddish, and black, the latter predominating on the back; rump and upper tail coverts white, the latter spotted and barred transversely with black; under parts pale ferruginous-red, with numerous points and circular spots of brownish-black on the neck before, and transverse bands of the same on the sides and under tail coverts; axillary feathers and under wing.coverts white, spotted and transversely barred with black; quills brownish-black; shaft of first primary white; tail brownish-black, with numerous transverse bands of ashy-white, and frequently tinged with ferruginous, especially on the two middle feathers: bill greenish-black; legs dark greenish-brown.

Younger. - Entire under parts dull-white, strongly marked with dull-ashy on the neck in front, and transverse bands of the same on the sides; axillary feathers and under wing coverts white, spotted with brownish-black; upper parts lighter than in the adult.

Total length, about ten inches; wing, five and three-quarters; tail, two and a quarter; bill, two and a quarter; tarsus, one and a quarter inch.

Hab. - Entire temperate regions of North America.

This handsome bird is found in small numbers in the marshes along our coast, in the spring and autumn migrations. It seldom penetrates into the inland waters of New England, but prefers the salt marshes. I think that it is much more of a beach bird than the Common Snipe; for it is often found on the beach of the seashore, while the other is never seen there, so far as my experience goes. It 
is never found in such numbers here as Wilson speaks of in the following description, but is seen in small bunches of six or eight:-

"The Red-breasted Snipe arrives on the seacoast of New Jersey early in April, is seldom or never seen inland: early in May, it proceeds to the North to breed, and returns by the latter part of July or beginning of August. During its stay here, it flies in flocks, sometimes very high, and has then a loud and shrill whistle; making many evolutions over the marshes; forming, dividing, and re-uniting. They sometimes settle in such numbers, and so close together, that eighty-five have been shot at one discharge of a musket. They spring from the marshes with a loud, twirling whistle, generally rising high, and making several circuitous manouvres in the air before they descend. They frequent the sand-bars and mud flats, at low water, in search of food; and, being less suspicious of a boat than of a person on shore, are easily approached by this medium, and shot down in great numbers. They usually keep by themselves, being very numerous; are in excellent order for the table in September; and, on the approach of winter, retire to the South.

"I have frequently amused myself with the various action of these birds. They fly very rapidly, sometimes wheeling, coursing, and doubling along the surface of the marshes; then shooting high in air, there separating and forming in various bodies, uttering a kind of quivering whistle. Among many which I opened in May, were several females that had very little rufous below; and the backs were also much lighter, and less marbled with ferruginous. The eggs contained in their ovaries were some of them as large as garden peas. Their stomachs contained masses of those small snail shells that lie in millions on the salt marshes. The wrinkles at the base of the bill, and the red breast, are strong characters of this species, as also the membrane which unites the outer and middle toes together." 


\section{Sub-Family Tringinæ. - The Sandpipers.}

Bill shorter than the naked leg, widened or rather spoon-shaped at the end, with the edges not bent over; roof of mouth excavated to the tip; no groove along the culmen; ear behind the eye; tail without bands?

\section{TRINGA, LINNAUS.}

Tringa, LrNnæus. Syst. Nat., (1735). (Type T. canutus, L.)

\section{DESCRIPTION.}

Size moderate or small; general form adapted to dwelling on the shores of both salt and fresh waters, and subsisting on minute or small animals, in pursuit of which they carefully examine and probe with their bills sandy or muddy deposits and growths of aquatic plants, rocks, or other localities; flight rather rapid, but not very strong nor long continued; bill moderate, or rather long, straight or slightly curved towards the end, which is generally somewhat expanded and flat; longitudinal grooves, in both mandibles, distinct, and nearly the whole length of the bill; wings long, pointed; the first primary longest; tertiaries long; secondaries short, with their tips obliquely incised; tail short; legs moderate, or rather long, slender; the lower portion of the tibia naked, and with the tarsus covered in front and behind with transverse scales; hind toe very small; fore toes rather slender, with a membranous margin, scaly and flattened underneath, free at base.

This genus comprises a large number of species of all parts of the world, some of which are very extensively diffused, especially during the season of their southern or autumnal migration. Generally, these birds are met with in flocks, frequenting every description of locality near water, and industriously searching for the minute animals on which they feed. The species of the United States are migratory, rearing their young in the north, and, in autumn and winter, extending to the confines of the Republic and into South America. The colors of the spring and autumnal plumage are different in nearly all species, though that of the two sexes is very similar.

\section{TRINGA CANUTUS. - Linnous.}

The Graj-back; Robin Snipe.

rringa canutus, Linnæus. Syst. Nat., I. (1766) 251.

Tringa cinerea, Gmelin. Syst. Nat., I. (1788) 673. Wils. Am. Orn., VII. (1813) 36.

Tringa islandica, Audubon. Orn. Biog., IV. (1838) 130. Ib., Birds Am., V. (1842) 254.

Tringa rufa, Wilson. Am. Orn., VII. (1813) 57. 


\section{Description.}

Large; bill straight, rather longer than the head, compressed, slightly enlarged at the tip; upper mandible with the nasal groove extending to near the tip; legs moderate; tibia with its lower third part naked; neck moderate; wing long; tail short; toes free at base, flattened beneath, widely margined; hind toe slender, small; entire upper parts light-gray, with lanceolate, linear, and irregular spots of black, and others of pale-reddish; rump and upper tail coverts white, with transverse narrow bands and crescent-shaped spots of black; under parts light brownish-red, paler in the middle of the abdomen; under tail coverts, tibial feathers, flanks, axillary feathers, and under wing coverts white, generally with spots and transverse bars of brownish-black; quills brownish-black, with their shafts white; tail light brownish-cinereous (without spots or bars); all the feathers edged with white, and frequently with a second sub-edging of dark-brown; bill brownish-black; legs greenish-black.

Young and Winter Plumage.-Upper parts brownish-ashy, darker on the back, every feather having a sub-terminal edging of brownish-black, and tipped with dull ashy-white; rump white, with crescents of black; under parts dull ashy-white, nearly pure on the abdomen, but with numerous longitudinal lines, and small spots of dark-brown on the breast and neck; sides with crescent-shaped and irregular spots of brownish-black; an obscure line of dull-white over and behind the eye.

Total length (from tip of bill to end of tail), about ten inches; wing, six and a half; tail, two and a half; bill from gape, one and a half; tarsus, one and a quarter inches. Female larger?

This is the largest of the Sandpipers of the United States, and appears to be restricted to the shores of the Atlantic in this division of the continent of America. We have never seen it from the Pacific Coast.

In the United States, this bird is known as the Red-breasted Snipe, or sometimes as the Gray-backed Snipe, though we have never heard the name "Knot" applied to it, which appears to be a common appellation of the same species in Europe, and is given by American authors. This is one of the few species of birds which appears to be absolutely identical with a species of Europe, and is of very extensive diffusion over the world, especially in the season of southern migration.

The bird has received a variety of names, of which the very first appears to be that adopted at the head of this article.

\section{This species appears in New England only in the migra} tions in spring and autumn. It is only seen on the shore, and with us only in small flocks of eight or ten. I have had no opportunities of observing its habits, and will give the description by Wilson:-

"In activity it is superior to the preceding, and traces the flowing and recession of the waves along the sandy beach with great nimbleness, wading and searching among the loosened particles for its favorite food, which is a small, thin, oval, bivalve shell-fish, of a white or pearl color, and not larger than the seed of an apple. 
These usually lie at a short depth below the surface; but, in some places, are seen at low water in heaps, like masses of wet grain, in quantities of more than a bushel together. During the latter part of summer and autumn, these minute shell-fish constitute the food of almost all those busy flocks that run with such activity along the sands, among the flowing and retreating waves. They are universally swallowed whole; but the action of the bird's stomach, assisted by the shells themselves, soon reduces them to a pulp. If we may judge from their effects, they must be extremely nutritious ; for almost all those tribes that feed on them are at this season mere lumps of fat. Digging for these in the hard sand would be a work of considerable labor; whereas, when the particles are loosened by the flowing of the sea, the birds collect them with great ease and dexterity. It is amusing to observe with what adroitness they follow and elude the tumbling surf, while, at the same time, they seem wholly intent on collecting their food.

"The Ash-colored Sandpiper, the subject of our present account, inhabits both Europe and America. It has been seen in great numbers on the Seal Islands, near Chatteaux Bay; is said to continue the whole summer in Hudson's Bay, and breeds there. Mr. Pennant suspects that it also breeds in Denmark, and says that they appear in vast flocks on the Flintshire shore during the winter season. With us they are also migratory, being only seen in spring and autumn. They are plump birds; and, by those accustomed to the sedgy taste of this tribe, are esteemed excellent eating."

ARQUATELLA, BAIRD.

TRINGA MARITIMA, - Brunnich.

The Purple Sandpiper.

Tringa maritima, Brunnich. Orn. Bor. (1764), 54. Nutt. Man., II. 115. Aud. Orn. Biog., III. (1835) 558. Ib., Birds Am., V. (1842) 261.

Description.

Bill rather longer than the head, straight, compressed; nasal groove long; wings long; tail short, rounded; legs moderate; toes free at base, flattened underneath and slightly margined; hind toe small; entire head and upper parts dark smoky-brown, 
with a purple and violet tinge, strongest on the back and scapulars; under parts from the breast white, generally with longitudinal spot of dark-ashy; wing coverts more or less edged and tipped with white; quills brownish-black, edged with white; middle tail feathers brownish-black, outer feathers lighter, with their shafts white; axillaries and under wing coverts white; bill yellow at base, dark at tip; legs yellow.

Total length, about eight to nine inches; wing, five; tail, two and a half; bill from gape, one and a quarter; tarsus, one inch; iris orange.

Hab. - Eastern North America; Europe.

This species is not uncommon on our shores during the spring and autumn migrations, where they are active and busy in their search for small shell-fish, and crustaceans, which constitute their principal food. They have all the characteristics of the Spotted Sandpiper while with us, and, from their preference to rocky beaches and shores, are often called Rock Snipes. They proceed to the most northern portions of the continent to breed, where, according to Dr. Richardson, they lay four eggs, which are "pyriform, sixteen and a half lines long, and an inch across at their greatest breadth. Their color is yellowish-gray, interspersed with small irregular spots of pale brown, crowded at the obtuse end, and rare at the other."

\section{TRINGA SUBARQUATA. - Temm.}

\section{The Curlew Sandpiper.}

Tringa subarquata, Temm. Man., II. (1820) 609. Nutt. Man., II. 104. Aud. Orn. Biog., III. (1835) 444. Ib., Birds Am., V. (1842) 269.

\section{DESCRIPTION.}

Bill rather longer than the head, slender, compressed, slightly curved towards the tip, which is somewhat expanded; both mandibles grooved; wing long, pointed; tail short; legs long, slender; toes moderate, marginated and flattened underneath. Upper parts brownish-black, nearly every feather edged and spotted with bright yellowish-red, rump ashy-brown, upper coverts of the tail white, with transverse bands of brownish-black; wings ashy-brown, shafts of primaries white; under parts fine dark-yellowish rufous; sides, axillaries, and under tail coverts, white; under surface of wing white; tail pale brownish-ashy, with a greenish gloss; bill and legs greenish-brown.

Young. - Upper parts much more ashy, and with little of the red of the preceding; under parts entirely dull-white, tinged with yellowish on the breast and sides; an obscure line over the eye ashy-white; outer feathers of the tail nearly white. 
Total length, about eight and a half to nine inches; wing, five; tail, two and a quarter; bill, from gape, one and a quarter to one and a half; tarsus, one to one and a quarter inches; iris hazel.

Hab. - Atlantic coast of the United States, rare; Europe; Asia; Africa.

This is undoubtedly the most rare of all our shore birds. I found a single specimen in a bunch of Sandpipers shot on Cape Ann, in the autumn of 1865 , for sale in the principal market in Boston. This is the only instance that has come to my own knowledge of its being found here. Audubon speaks of two; and other writers, of a few more in different years.

\section{TRINGA ALPINA var. AMERICANA. - Cassin.}

The Red-backed Sandpiper; Grass-bird.

Tringa alpina, Linnæus. Syst. Nat., I. (1766) 249. Wils. Am. Orn., VII. (1813) 25. Nutt. Man., II. 106. Aud. Orn. Biog., III. (1835) 580. Ib., Birds Am., V. (1842) 266.

\section{DESCRIPTION.}

Bill longer than the head, wide at base, curved, slightly widened and flattened towards the end; nasal groove and another groove in the under mandible long and very distinct; wings long; tail short, with the two middle feathers longest and pointed; legs rather long and slender, lower half of the tibia naked; toes moderate, free at base, flattened underneath and slightly marginated; claws much compressed, hind toe small; upper parts yellowish-red, mixed with ashy, and every feather having a lanceolate, ovate, or narrow spot in the centre, most numerous on the back and rump; front, sides of the head, and entire under parts, ashy-white; nearly pure-white on the abdomen and under tail coverts; a wide tranverse band of black across the lower part of the breast; neck before and upper part of the breast with narrow longitudinal spots of brownish-black; under wing coverts and axillary feathers white; quills light ashy-brown, darker on their outer edges, with their shafts white; tail feathers light ashy-brown; middle feathers darker, outer nearly white; bill and legs brownish-black; sexes alike; iris dark-hazel.

Winter Plumage. - Entire upper parts dark-ashy, nearly black on the rump, and upper tail coverts; throat, abdomen, axillaries and under wing coverts, white; breast pale-ashy, with longitudinal lines of dark-brown.

Total length, eight to eight and a half inches; wing, five; tail, two and a quarter, bill, from gape, one and a half; tarsus, one inch.

Hab. - Entire temperate regions of North America.

This is a rather abundant species on our shores in the spring and autumn migrations. It appears here about the last week in April or first week in May, and frequents 
the beach, where it has all the habits and activity of the other Sandpipers, running along the edge of the surf, and gleaning in the waves and on the sands its food of small marine animals. It mixes with the other species, but is readily distinguished from them by the brightness of its plumage. It is in best condition for cabinet preservation in the vernal migration. It passes leisurely to the most northern sections of the continent, where it passes the breeding season. Maggillivray describes the breeding habits as follows :-

"The nest is a slight hollow in a dry place, having a few bits of withered heath and grass irregularly placed in it. The eggs, four in number, are ovato-pyriform, an inch and four-twelfths in length, eleven-twelfths in breadth, oil-green or light greenish-yellow, irregularly spotted and blotched with deep-brown; the spots becoming more numerous toward the larger end, where they are confluent. The young, like those of the Golden Plover and Lapwing, leave the nest immediately after exclusion, run about, and, when alarmed, conceal themselves by sitting close to the ground and remaining motionless."

This species, when it returns in the autumn, late in September, is very fat, and is considered delicate and palatable as food.

ACTODROMAS, KAUP.

TRINGA MACULATA. - Vieillot.

The Pectoral Sandpiper.

Tringa maculata, Vieillot. Nouv. Dict., XXXIV. (1819) 465.

Tringa pectoralis, Nuttall. Man., II. 111. Aud. Orn. Biog., III. (1835) 601; V. 582. Ib., Birds Am., V. (1842), 259.

Description.

Bill rather longer than the head, compressed, slightly depressed and expanded at the tip; nasal groove long; wings long; legs rather long; tibia with nearly its lower half naked; toes free at base, flattened underneath and slightly margined; tail rather short; middle feathers pointed; entire upper parts brownish-black; all the feathers edged and tipped with ashy and brownish-red; rump and upper tail coverts black, some of the outer feathers of the latter edged with white; line from the bill over 
the eye ashy-white; throat, abdomen, under wing coverts, axillary feathers, and under tail coverts, white; breast and neck before ashy-white; all the feathers darker at base, and with partially concealed lanceolate or pointed spots of brownish-black; quills brownish-black; shaft of first primary white, of others brown; secondaries tipped and edged with white; tertiaries edged with dull reddish-yellow; bill and feet dark greenish-black; iris dark-hazel.

Total length, about nine inches; wing, five and a quarter; tail, two and a half; bill to gape, one and one-eighth; tarsus, one inch.

Hab. - The entire coasts of North America; South America; Europe.

This well-known species is pretty abundantly distributed along our coast in the spring and autumn migrations, when it appears in small flocks, in May, in the former seasons, and in August and September in the latter. It has all the habits of the other Sandpipers, but is more often seen in the marshes and meadows, particularly in the autumn, than the others, where it eagerly pursues the various insects which are found there, particularly the grasshoppers and crickets, that furnish food for so many of our passing birds. This species is best known to our gunners by the name of the Grass-bird. It is a favorite with them because of its fine flavor on the table; and it is found in considerable abundance in our markets, where it meets a ready sale at a very remunerative price.

\section{TRINGA BONAPARTII. - Schlegel.}

\section{Bonaparte's Sandpiper.}

Tringa Schinzii, Nuttall. Man., II: 109. Aud. Orn. Biog., III. (1835) 529. 16., Birds Amer., V. (1842) 275.

Tringa Bonapartii, Schlegel. Rev. Crit. Ois. Eur., (1844) 89.

\section{DESCRIPTION.}

Smaller; bill slightly arched towards the tip, which is somewhat enlarged and flattened, about the length of the head; grooves in both mandibles long and narrow; wings long; secondary quills obliquely incised at the ends; tail rather longer than usual in this group, with the feathers broad; legs rather long and slender; toes free at base; hind toe very small; upper parts light ashy-brown; darker on the rump; nearly all the feathers with ovate or wide lanceolate central spots of brownishblack, and many of them edged with bright yellowish-red; upper tail coverts white; under parts white, with numerous small spots of dark-brown on the neck before, breast, and sides, somewhat disposed to form transverse bands on the last; quills brownish-black, darker at the tips; shaft of outer primary white, of others lightbrown; middle feathers of tail brownish-black; outer feathers lighter, and edged 
with ashy-white; under wing coverts and axillaries white; bill and feet greenishblack; iris hazel.

Total length, about seven inches; wing, four and three-quarters; tail, two and a quarter; bill, one; tarsus, rather less than an inch.

Hab. - North America, east of the Rocky Mountains.

This bird also is often known to sportsmen by the comprehensive name "Grass-bird." It is less abundant than the preceding, but has all its habits. It appears in small flocks of eight or ten, and frequents the marshes and marshy shores in preference to the sandy beach. In such localities, it feeds upon various insects and aquatic animals, and larvæ of aquatic insects; and is often seen in fresh-water meadows, at a considerable distance from the shore, busy in search of this variety of food. Nuttall says it lays four eggs, smaller than those of the T. alpina, of a yellowishgray color, spotted with olive or chestnut-brown.

\section{TRINGA WILSONII. - Nuttall.}

\section{The Least Sandpiper; Peep.}

Tringa pusilla, Wilson. Am. Orn., V. (1812) 32. Aud. Orn. Biog., IV. (1838) 180. 1b., Birds Am., V. (1842) 280.

Tringa Wilsonii, Nuttall. Man., II. (1834) 121.

\section{DESCRIPTION.}

The smallest of all known species of this group found in North America; bill about as long as the head, slightly curved towards the end, which is very slightly expanded; grooves in both mandibles to near the tip; wing long; tertiaries nearly as long as the primaries; tail short; middle feathers longest; outer feathers frequently longer than the intermediate; legs long; lower third of the tibia naked; toes long, slender, margined, and flattened beneath; hind toe small; upper parts with nearly every feather having a large central spot of brownish-black, and widely margined with ashy and bright brownish-red; rump and middle of the upper tail coverts black; outer coverts white, spotted with black; stripe over the eye, throat, and breast, pale ashy-white, with numerous small longitudinal spots of ashy-brown; abdomen and under tail coverts white; quills dark-brown, with the shafts of the primaries white; tertiaries edged with reddish; middle feathers of the tail brownishblack; outer feathers light ashy-white; under surface of wing light brownish-ashy, with a large spot of white near the shoulder; axillary feathers white; bill and legs greenish-brown, the latter frequently yellowish-green.

Total length, from tip of bill to end of tail, about five and a half to six inches; wing, three and a half to three and three-quarters; tail, one and three-quarters; bill to gape, three-quarters; tarsus, three-quarters of an inch.

Hab. - Entire temperate North America. 
The Least Sandpiper or "Peep" is so well known on our shores that any description is almost superfluous. It makes its appearance early in May, in small parties of five or six, and quickly proceeds to the most northern sections of the continent, where it breeds, and then immediately returns to our shores, where it remains until early in October, when it passes on to the South. Audubon, in describing its breeding habits, says, "That this species is naturally disposed to seek alpine sections of the country for the purpose of reproduction, I obtained abundant proof whilst in Labrador, where I found it plentiful, and breeding on the moss-clad crests of the highest rocks, within short distances of the sea." On finding the nest, he says, -

"Four beautiful eggs, larger than I had expected to see produced by birds of so small a size, lay fairly beneath my eye, as I knelt over them for several minutes in perfect ecstasy. The nest had been formed first, apparently, by the patting of the little creatures' feet on the crisp moss, and in the slight hollow thus produced were laid a few blades of slender, dry grass, bent in a circular manner; the internal diameter of the nest being two inches and a half, and its depth an inch and a quarter. The eggs, which were in shape just like those of the Spotted Sandpiper, $T$. macularius, measured seven and a half eighths of an inch in length, and three-fourths of an inch in breadth. Their ground-color was a rich cream-yellow tint, blotched and dotted with very dark umber, the markings larger and more numerous toward the broad end. They were placed with their broad ends together, and were quite fresh. The nest lay under the lee of a small rock, exposed to all the heat the sun can afford in that country."

It is during the latter part of August and the greater part of September that this species is most abundant in New England, where it generally confines itself to the seacoast, but sometimes penetrates to the large tracts of water in the interior, gleaning there its food of small shell-fish, crustaceans, and insects in the pools of water and on the 


\section{sands and flats. It associates in large flocks at that season, and often with other birds.}

\section{CALIDRIS, CUvier.}

Calidris, Cuvier, Anat. Comp., V. in chart (1805). (Type Tringa arenaria, L.)

General characters of Tringa, but without hind toe; bill straight, rather longer than the head and tarsus, widened somewhat or spoon-shaped at the end; tail doubly emarginate; toes short; middle one scarcely two-thirds the tarsus.

\section{CALIDRIS ARENARIA, - Illiger.}

\section{The Sanderling.}

Tringa arenaria, Linnæus. Syst. Nat, I. (1766) 251. Aud. Orn. Biog. 16., Birds Am., V. (1842) 287.

Calidris arenaria, Illiger. Prod. (1811), 249. Nutt. Man., II. (1834) 4.

Charadrius calidris, Linnæus. Syst. Nat., I. (1766) 255. Wils. Am. Orn., VII. (1813) 68 .

Charadrius rubidus. Gm., I. (1788) 688. Wils. Am. Orn., VIX. (1813) 129.

\section{Description.}

No hind toe; front toes moderate or rather long, flattened underneath; distinctly margined with a membrane; bill, rather longer than the head, straight, rather thick; ridge of upper mandible flattened; nasal groove deep, and nearly as long as the upper mandible, not so distinct in the lower; both mandibles widened and flattened at the tip; aperture of the nostril large, and covered with a membrane; wing long; tail short, with the middle feathers longest; under coverts long as the tail; legs moderate; lower third of the tibia naked; upper parts light-ashy, with lanceolate, hastate, and ovate spots of brownish-black on the top of the head, on the back, scapulars, and shorter quills; rump and upper tail coverts with fine transverse lines of black; under parts pure-white; shoulders brownish-black, without spots; quills brownish-black, with their shafts white, and much paler on their inner webs; greater wing coverts widely tipped with white; middle feathers of the tail ashy-brown, edged with white; outer feathers paler; bill and legs greenish-black; sexes alike; iris brown.

In spring plumage, the head, neck, and breast are tinged with pale yellowish-red, and spotted with dark-brown; back and scapulars edged and tipped with yellowish-red; rump and under tail coverts ashy-brown; under parts of the body pure-white.

Total length, seven and three-quarters to eight inches; wing, five; tail, two; bill. about one inch; tarsus, about one inch.

$H a b$. - Entire temperate regions of North America, South America, Europe.

An abundant species on both the Atlantic and Pacific coasts of the Republic, and extending its range, in winter, into South America. We can find no reliable distinction between the American and the European bird, though specimens differ quite materially in size and length of bill. 
The Sanderling, most often called the "Beach-bird" by gunners, is pretty abundant on our shores in the autumn migrations. It is rarely seen in spring, but seems to move by us in passing to its northern breeding-grounds. According to Mr. Hutchins, it breeds on the coast of Hudson's Bay, where it constructs, on the marshes, a rude nest of grass, laying four dusky eggs, spotted with black, on which it begins to sit about the middle of June. Early in September, sometimes by the 20th of August, it returns to our shores, where it associates with the Sandpipers in small flocks. It has all the habits and characteristies of these birds, busily seeking in the retreating waves, and in the pools on the beach, its food of small shells and crustaceans. It is quite fat in the autumn, and is esteemed by many, a fine-flavored bird for the table.

\section{EREUNETES, ILLIGER.}

Ereunetes, Ilciger. Prod. (1811), 262.

The bill of our species of Ereunetes is quite stout, and considerably expanded, by which it is readily distinguished from Actodromas Wilsonii, independently of the semipalmated feet; the tarsus and middle toe are about equal; the tibia denuded anteriorly for about two-thirds the length of tarsus; the basal membrane of toes is more scolloped out interiorly than exteriorly; the notch externally not quite as deep as to the first joint, although the membrane extends beyond the second. There is a tendency to hexagonal subdivision in the bare portion of tibia anteriorly. The tail is doubly emarginate.

\section{EREUNETES PETRIFICATUS. - Illiger.}

\section{The Semipalmated Sandpiper; Peep.}

Ereunetes petrificatus, Illiger. Prod. (1811), 262. (Proved identical with Tringr semipalmata, Wils., by Cabanis.)

Tringa semipalmata, Wilson. Am. Orn., VII. (1813) 131. Aud. Orn. Biog., V. (1839) 111. Ib., Birds Am., V. (1842) 277.

Tringa (heteropoda) semipalmata, Nuttall. Man., II. (1834) 136.

DESCRIPTION.

Bill about the length of the head, rather thicker than usual in this group; both mandibles somewhat expanded and flattened at the tip, and minutely punctulated, is in the genera Scolopax and Gallinago; wings long; legs moderate, rather slender; toes united at base by a membrane, which is large, between the outer and middle toes, extending to the first joint; hind toe small; tail short, with the middle 
feathers longest; outer feathers frequently longer than the third, presenting a doubly emarginate character to the tail; under coverts nearly as long as the tail; upper parts light brownish-ashy, with lanceolate or ovate spots of brownish-black in the middle of the feathers; rump and upper tail coverts black; front, band of the eye, and entire under parts, ashy-white, with small spots on the breast of ashy-brown; quills brownish-black, lighter on their inner webs, and with their shafts white; middle feathers of the tail brownish-black; outer feathers pale brownish-ashy; under wing coverts and axillaries white; bill greenish-black; feet dark, the lower part of the tarsus and toes frequently tinged with yellow; upper parts, in summer, mixed with light-reddish; iris brown.

Total length, about six and a half inches; wing, three and three-quarters; tail, one and three-quarters; bill, from gape, three-quarters; tarsus, three-quarters to one inch.

This abundant little species is singularly variable in the length of the bill, so much so, in fact, that a student with two specimens representing extremes in this particular would deem it quite impossible that they could be identical specifically.

$H a b_{0}$ - Entire temperate regions of North America; South America.

The Semipalmated Sandpiper is so similar in its general appearance and habits with the common "Peep," that it is usually confounded with that bird by all our sportsmen. It appears at the same time, associates with it, and altogether might easily be mistaken for it, were it not for the semipalmation of this species. It breeds in the most northern localities.

Mr. Hutchins says that it arrives at Severn River, in the fur countries, in great numbers, about the middle of May, where it builds a loose nest of withered grass in a slight hollow in the ground, early in June, and lays four white eggs, spotted with black or dusky-brown. Like the "Common Peep," the flight of this bird is rapid and wavering, almost exactly resembling that of the Snipe. It also has the same soft call-note, 'tweet 'tweet, that the other has, which it utters frequently, both while on the strand and when flying.

\section{Sub-Family Totaninæ. - The Stilts.}

Bill as long as the head, or longer; the basal portion covered with soft skin; the terminal portion (generally at least half) horny, and more or less attenuated and pointed in Totanec; the lateral grooves of bill extending to the horny terminal portion; the gape of mouth extending behind the base of culmen toes generallv 
connected by a basal membrane; the tail always with distinct transverse bars in North-American species, except in Heteroscelus.

This sub-family appears to differ from most Scolopacince in the less degree of sensitiveness in the tip of the bill, which is more horny, and not covered by soft skin well supplied with nerves. The toes are almost always connected at the base by a membrane; this being the rule and not the exception, as in Scolopacinoe.

\section{SyMiPHEMIA, RAFinesque.}

Symphemia, RAFInesque, Jour. de Phys. (1819). (Type Scolopax semipalmata, Gmelin.)

Bill compressed, very thick, the culmen rounded; the lower mandible scarcely grooved; the upper grooved to about the middle; culmen slightly convex; gonys ascending; bill cleft but little beyond base of culmen; feathers of sides of both mandibles falling short of the nostrils; the lower rather farther forward; chin feathers reaching to beginning of nostrils; bill longer than head, about equal to tarsus, which is more than one and a half times the middle toe; both toes webbed, the emargination of inner web as far forward as the middle of basal joint of middle toe, the outer reaching nearly to the end; bare portion of tibia rather less than middle toe without claw; tail nearly even, or little rounded, not half the wings.

SYMPHEMIA SEMIPALMATA. - Hartlaub.

The Willet.

Scolopax semipalmatus, Gmelin. Syst. Nat., I. (1788) 659. Wils. Am. Orn., VII. (1813) 27 .

Totanus semipalmatus, Audubon. Orn. Biog., III. (1835) 510; V. 585. Birds Am., V. (1842) 324.

Totanus (catoptrophonus) semipalmatus, Bonaparte. Syn. (1828), 328. Nutt. Man., II. (1834) 144.

Symphemia semipalmata, Hartlaub. Rev. Zool. (1845), 342.

\section{DESCRIPTION.}

The largest American species of this genus; bill longer than the head, straight, rather thick and strong; groove in the upper mandible extending about half its length, in the lower mandible nearly obsolete; wings long; legs long, strong; toes moderate, united at base by membranes, the larger of which unites the outer and middle toe; hind toe small; tail short.

Adult. - Entire upper parts dark-ash color (without spots); the shafts of the feathers brownish-black; rump and upper tail coverts white; under parts white, tinged with ashy on the neck and sides; axillaries and under wing coverts brownssh-black; primary quills white at base, and tipped with brownish-black; secondaries white, spotted with brownish-black; tail ashy-white, the two middle feathers strongly tinged with ashy; others spotted with dark ashy-brown; bill dark bluishbrown, lighter at base; legs light-blue.

Younger. - Entire plumage spotted, and transversely banded with brownishblack; iris brown.

Total length, about fifteen inches; wing, eight and a quarter; tail, three and $s$ quarter; bill, about two and a half; tarsus, about two and a balf inches. 
This large and handsome species is easily recognized, and is abundant on both the Atlantic and Pacific coasts of the Republic. There is very considerable difference of color between the adult and young birds; but the white space on the wings is a character always present and easily distinguished. It is the largest bird of this group inhabiting the United States.

$H a b$. - Entire temperate regions of North America; South America.

This bird is not very abundant on the shores of New England as a summer visitor and resident; but it is taken in considerable numbers in the autumn. It occasionally breeds within our limits, usually preferring a sandy island to the main shore; but it sometimes selects a locality in a marsh for its nest, and has been known to breed in a ryefield twenty-miles from the seashore.

The nest is built about the last week in May. It is placed in a slight hollow in the sand or in a tussock of grass, and is composed of grasses and weeds, arranged in a heap, sometimes three or four inches in depth. It is hollowed an inch and a half or more, and is sometimes lined with softer pieces of grass or weeds. The eggs are four in number: they are pyriform in shape, and are abruptly pointed from the larger end. They are of a pale-olive color, sometimes greenish-drab; and are marked with blotches of two or three shades of brown, which are confluent at the larger end, and sometimes almost entirely hide the ground color.

They vary in dimensions from 2.15 by 1.58 inch to 1.98 by 1.45 inch. When its breeding-place is approached, the Willet flies to meet the intruder, and, coursing around over his head, utters its shrill eries, like the syllables, 'pill-willet'tit pill willet, vociferously; and sometimes darting down at him, or alighting before him, it endeavors to lead him from its nest by pretending lameness.

When the young are able to fly, the whole brood associate with the parents in a flock, and frequent the pools and ditches near the beach, where they busily wade about in the water, searching for small shell-fish, aquatic insects, mollusks, \&c., on which they feed. When wounded, they take 
to the water, and swim off with great activity. They all leave New England in October, when they are exceedingly fat and well-flavored.

\section{GAMBETTA, KAUP.} Gray.)

Gambetta, Kaup, Entw. Europ. Thierw. (1829). (Type Scolopax calidris, L.

Bill much attenuated towards and tapering to the end, the extreme tip decurved; both culmen and gonys, however, bent upwards from the middle; the lateral grooves of upper bill broad, shallow, and not extending to the middle; that of lower reaching about as far; feathers on side of both mandibles extend to about the same point, but fall short of nostrils; those on chin extend as far as middle of nostril; bill nearly as long as the tarsus, which is one and a half times the length of middle toe; outer toe webbed to first joint; the inner web very short; bare portion of the tibia equal to the toes; tip of tail about opposite the middle of outstretched tarsi; legs yellow.

\section{GAMBETTA MELANOLEUCA. - Bonaparte.}

\section{The Telltale; Stone Snipe; Greater Yellow-legs.}

Scolopax melanoleucus, Gmelin. Syst. Nat., I. (1788) 659.

Totanus melanoleucus Audubon. Orn. Biog., IV. (1838) 68.

Gambetta melanoleuca, Bonaparte. Comptes Rendus (Sept., 1856).

Scolopax vociferus, Wilson. Am. Orn., VII. (1813) 57.

\section{DESCRIPTION.}

Bill longer than the head, rather slender, curved towards the tip; wings rather long, first quill longest; tail short; neck and legs long; toes moderate, margined and flattened underneath, connected at base by membranes, the larger of which unites the outer and middle toe; hind toe small; claws short, blunt; grooves in both mandibles extending about half their length; entire upper parts cinereous of various shades, dark in many specimens in full plumage, generally light with white lines on the head and neck, and with spots and edgings of dull-white on the other upper parts; lower back brownish-black; rump and upper tail coverts white, generally with more or less imperfect transverse narrow bands of brownish-black; under parts white, with longitudinal narrow stripes on the neck, and transverse crescent lanceolate and sagittate spots and stripes on the breast and sides; abdomen pure-white; quills brownish-black with a purplish lustre, shaft of first primary white; secondaries and tertiaries tipped and with tranșerse bars and spots of ashywhite; tail white, with transverse narrow bands of brownish-black, wider and darker on the two middle feathers; bill brownish-black, lighter at the base; legs vellow; iris dark-brown.

Total length, about fourteen inches; wing, seven and a half to eight; tail, three and a quarter to three and a half; bill, two and a quarter; tarsus, two and a half inches.

Hab. - Entire temperate regions of North America; Mexico. 
The Greater Yellow-legs is not common in New England ; a few being taken annually.

Nuttall, in describing its habits, \&c., says, -

"The Greater Yellow-shanks, or Telltale, so remarkable for its noise and vigilance, arrives on the coast of the Middle States early in April, and, proceeding principally by an inland route, is seen in abundance as far north as the plains of the Saskatchewan, where, no doubt, in those desolate and secluded marshes, far from the prying eye and persecuting hand of man, the principal part of the species pass the period of reproduction, re-appearing in the cooler parts of the Union towards the close of August: yet so extensive is the breeding range of the Telltale, that many continue to occupy the marshes of the Middle States until the approach of cold weather, in the month of November, breeding in their favorite resorts, on the borders of bogs; securing the nest in a tuft of rank grass or sedge; and laying four eggs, of a dingy-white, irregularly marked with spots of dark-brown or black."

The vociferous vigilance of the Telltale has justly stigmatized him with the present name; for no sooner does the gumer appear than his loud and shrill whistle of about four rapidly repeated notes is instantly heard, as he mounts on wing, and proves generally so good a warning to all the rest of his feathered neighbors, and particularly the vigilant ducks, that the whole, to the frequent disappointment of the fowler, at once accompany their faithful and officious sentinel.

The food of the Telltale is similar to that of our other shore birds. This it obtains by wading in the pools and ditches, which it is almost constantly doing; it being seldom seen in the grass or running on the beach like the Sandpipers.

\section{GAMBETTA FLAVIPES. - Bonaparte.}

The Yellow-legs.

Scolopax flavipes, Gmelin. Syst. Nat, I. (1788) 659. Wils. Am. Orn., VII. 1813) 55.

Totanus flavipes, Audubon. Orn. Biog., III. (1835) 573; V. 586. Ib., Birds Am., V. (1842) 313.

Gambetta flavipes, Bonaparte. Comptes Rendus (Sept., 1856). 
DESCRIPTION.

Bill rather longer than the head, straight, slender, compressed; wing long pointed; tail short; legs long, lower half of the tibia naked; toes moderate, slender, margined, the outer and middle united at base; rump and upper tail coverts white, the latter transversely barred with ashy-brown; other upper parts ashy, many feathers having large arrowheads and irregular spots of brownish-black, and edged with ashy-white; under parts white, with numerous longitudinal lines on the neck before, and arrowheads on the sides, of dark ashy-brown; axillaries and under wing coverts white, with bands of ashy-brown, very indistinct in many specimens, but generally well defined; quills brownish-black; tail ashy-white with transverse bands of dark-brown, middle feathers darker; bill greenish-black; legs yellow; iris dark-brown.

Young. - Entire upper plumage tinged with reddish-brown; neck before with lines much less distinct and pale-ashy.

Total length, about ten to ten and a half inches; wing, six to six and a half; tail, two and a half; bill, one and a half; tarsus, two inches.

Hab. - Eastern North America; western?

The Common Yellow-legs is well known on our coast as a spring and autumn visitor. It does not pause here in its northern migration, but passes at once to its breeding-home: This is generally in high latitudes: there, early in June, its nest is built and its young are reared. I am unacquainted with its breeding habits and eggs, and can find no description of them in any book that I have access to.

Early in September, it returns to New England, where it frequents the muddy flats and marshes on the seacoast, and penetrates into the interior. It is also sometimes quite abundant in the fresh-water meadows and on the shores of large ponds. I have killed numbers while Snipe-shooting: and they are almost equally well-flavored with that bird. They congregate in small flocks, fly rapidly, uttering a loud, shrill whistle, which being imitated by the experienced sportsmen, the whole flock is decoyed within shot; and, as they fly compactly, quite a number often fall at a single discharge of the gun.

Like the preceding, this bird is fond of wading about in pools of water, where it secures for its food larvæ of insects and small crustaceans. With one or two of our other Waders, it has the peculiarity of keeping its wings open and elevated after alighting, as if it were uncertain of the 
firmness of its resting-place. I have sometimes thought that it might be a habit caused by the bird frequenting flats on which the mud was soft and yielding. This is one of the handsomest of our Waders. In the autumn, it is fat, and in poor plumage ; but in the spring it is in good condition for cabinet preservation.

\section{RHYACOPHILUS, KAUP.} Gray.

Rhyacophilus, KAUP, Sk. Entw. Europ. Th. (1829). (Type Tringa glareola, L.,

Bill slender, but widening a little towards the end; lateral gronves of both mandibles extending to the middle of bill; nostril short; feathers on side of bill extending to about the same point and as far as beginning of nostrils; those of chin as far as their end; both mandibles curved upwards slightly from middle; legs short; bill about the length of tarsus, which is equal to middle toe; bare portion of tibia about two-thirds the toes; tail about opposite the middle of toes when outstretched.

\section{RHYACOPHILUS SOLITARIUS. - Bonaparte.}

The Solitary Sandpiper.

Tringa solitaria, Wilson. Am. Orn., VII. (1813) 58.

Totanus solitarius, Audubon. Birds Am., V. (1842) 309.

Totanus chloropygius. Nutt., II. 159. Aud. Orn. Biog., III. (1835) 576; V. 583.

\section{DEsCRIPTION.}

Bill rather longer than the head, straight, slender, compressed; both mandibles with narrow grooves; wing long, pointed; tail medium or rather short, rounded; legs rather long, slender; lower half of the tibia naked; toes long, the outer united to the middle by a small membrane, flattened underneath, marginated; upper parts greenish-brown, with numerous small circular and irregular spots of ashy-white; upper tail coverts darker; under parts white; breast and neck before with numerous longitudinal lines of greenish-brown; sides, axillaries, and under wing coverts white, with numerous transverse narrow bands of dark greenish-brown; under tail coverts white, with a few transverse bands of dark-brown; quills brownish-black, with a slight bronzed or reddish lustre on the primaries; two middle feathers of the tail greenish-brown; other feathers of the tail pure-white, with about fire transverse bands of brownish-black; bill and legs dark greenish-brown; iris hazel.

Total length, about eight to eight and a half inches; wing, five; tail, two and a juarter; bill, one and a quarter; tarsus, one and a quarter inches.

Hab. - Entire temperate regions of North America; Mexico.

The Solitary Sandpiper is not very common in any part of New England. It arrives from the South early in May in pairs, and frequents the shores of our fresh-water ponds 
and streams in preference to those of the seacoast, where, running about with great activity, it busies itself in searching for the larvæ of various aquatic insects, of which its food principally consists. Like the succeeding species, it has the habit of nodding its head, and tipping up its body and tail, which has given it the name of "Wagtail," or "Teetler." Nuttall says that it is seen in Massachusetts only at the commencement of cold weather. I have frequently met with it, both on our seashores and in the meadows around our fresh-water ponds, through the whole summer. Several pairs reside through the season on the borders of Punkapoag Pond, in Canton, Mass.; and they undoubtedly breed there, although I have been unable to find their nest. This species remains with us until late in September. When flushed, it rises with a short, sharp whistle, different from that of the Spotted Sandpiper, which it resembles in almost every other respect.

\section{TRINGOIDES, BONAPARTE.}

Tringoides, Bonaparte, Saggio di una dist., etc. (1831). (Type Tringa hypoleucus, L., Gray.)

Actitis, Bore, Isis (1822), 560. Not of Illiger, Prodromus (1811).

Upper mandible grooved to the terminal fourth; the bill tapering and rather acute; cleft of mouth only moderate; the culmen about five-sixths the commissure; feathers extending rather further on side of lower jaw than upper, the former reaching as far as the beginning of the nostrils; those of the chin to about their middle; bill shorter than the head, straight, equal to the tarsus, which is of the length of middle toe and claw; bare part of tibia half the tarsus; outer toe webbed to first joint; inner cleft about to the base; tail much rounded; more than half the wing.

TRINGOIDES MACULARIUS. - Gray.

\section{The Spotted Sandpiper.}

Tringa macularia, Linnxus. Syst. Nat., I. (1766) 249. Wils. Am. Orn., VII. (1s13) 60.

Totanus macularius, Nuttall. MFan., II. (1834) 162. Aud. Orn. Biog., IV. (1838) 81. Ib., Birds Am., V. (1842) 303.

Tringoides macularius, Gray, genera.

\section{Description.}

Small; bill rather longer than the head, straight, slender; long grooves in both mandibles; wing rather long, pointed; tail medium, rounded; legs rather long; 
lower third of the tibia naked; toes long, margined, and flattened underneath: outer connected with the middle toe by a large membrane; inner very slightly connected to the middle toe; upper parts brownish olive-green, with a somewhat metallic or bronzed lustre, and with numerous longitudinal lines, and sagittate, lanceolate, and irregular spots of brownish-black, having the same lustre; line over the eye, and entire under parts white, with numerous circular and oval spots of brownish-black, smaller on the throat, largest on the abdomen; quills brown, with a green lustre; primaries slightly tipped with white, and having a white spot on their inner edges; secondaries white at their bases, and tipped with white; middle feathers of the tail same green as other upper parts; outer tipped with white, and with irregular bars of brownish-black; bill yellowish-green, tipped with brown; feet reddish-yellow; iris hazel.

Young less bronzed above, and under parts white, without spots.

Total length, seven and a half to eight inches; wing, four and a half; tail, two; bill, one; tarsus, rather less than one inch.

Hab. - Entire temperate North America; Oregon; Europe.

Perhaps none of our summer residents are distributed so generally and so abundantly throughout New England as the species now before us. Every pond and stream of water has two or three pairs breeding on its shores; and it is as abundant in the most thickly settled as in the more retired and secluded localities. It arrives from the South about the first week in April ; and, separating into pairs, it soon commences the duties of incubation. It manifests no preference for a location near the seacoast to one in the interior; and I have found it breeding as abundantly in the depths of the Maine forests as on the low sandy islands, or in the marshes by our seacoast. The female, about the third week in April, scratches a hollow in the sandy earth by some pond, or sometimes in a grain-field or garden; and, lining it with a few pieces of straw or moss, lays four eggs, which she adjusts with their small ends together in the middle of the nest. These eggs are usually abruptly pyriform, sometimes a little more lengthened; and are of a yellowish-buff color, marked with blotches and spots of umber and sienna, thickest at their greater end, where they are sometimes confluent. Occasionally, the primary color is of a yellowish-drab tint, when the spots are much darker than on the other shade. A great number of specimens in my collection from many different localities exhibit a varia- 
tion of size from 1.40 by 1 inch to 1.26 by .95 inch. I can see $n o$ marked peculiarity in any series of specimens, excepting that those collected in the interior of Maine average a little larger than those from the seacoast.

The flight of the Spotted Sandpiper is generally low, its wings being kept bent at an angle beneath its bodý. It has a peculiar note, like peet-weet, peet-weet, easily recognized.

\section{ACTITURUS, Bonaparte.} son.)

Actiturus, Boxapante, Saggio, etc., (1831). (Type Tringa Bartramia, Wilon.)

Upper mandible grooved laterally to within the terminal fourth, the lower not quite so far; culmen concave to near the tip, where it is slightly decurved; gonys straight; mouth deeply cleft, almost as far back as the anterior canthus; the culmen only about two-thirds the commissure, shorter than the head or tarsus, and about equal to middle toe without claw; feathers extending much further forward on the upper jaw than on the lower, although those of chin reach nearly to end of nostrils; "tarsus one and a half times middle toe and claw; the bare part of tibia not quite equal to the middle toe above; outer toe united at base as far as first joint; web of inner toe very basal; tail long, graduated, more than half the wings.

ACTITURUS BARTRAMIUS.-Bonaparte.

\section{The Upland Plover; Bartram's Sandpiper; Field Plover.}

Tringa Bartramia, Wilson. Am. Orn., VII. (1813) 63. Aud. Birds Amer., V. (1842) 248.

Totanus Bartramius, Audubon. Orn. Biog., IV. (1838) 24.

Tringa (Euliga) Bartramia, Nuttall. Man., II. (1834) 168.

\section{DESCRIPTION.}

Bill about as long as the head, rather wide and flattened at base, curved at the tip; nostril with a large membrane; nasal groove long; wing long; tail long for this group; legs moderate or rather long; lower half of the tibia naked; toes moderate, the outer and middle toe united by a membrane, inner and middle free to the base, hind toe small; general color of the upper parts brownish-black, with a greenish lustre, and with the feathers edged with ashy-white and yellowish, the latter especially on the wing coverts; lower part of the back, rump, and upper tail coverts, brownishblack; lateral coverts of the tail yellowish-white, with arrow-heads and irregular spots of black; wide stripe over the eye, and entire under parts very pale yellowishwhite, nearly pure-white on the abdomen; neck before with numerous longitudinal lines of brownish-black; breast and sides with waved and pointed transverse narrow bands of the same; axillary feathers and under wing coverts pure-white, with numerous nearly regular transverse narrow bands of black; quills brownish-black, with numerous transverse bands of white on their inner webs, very conspicuous or the under surface of the wing; shaft of first primary white; middle feathers of the tail 
Plate III.

1
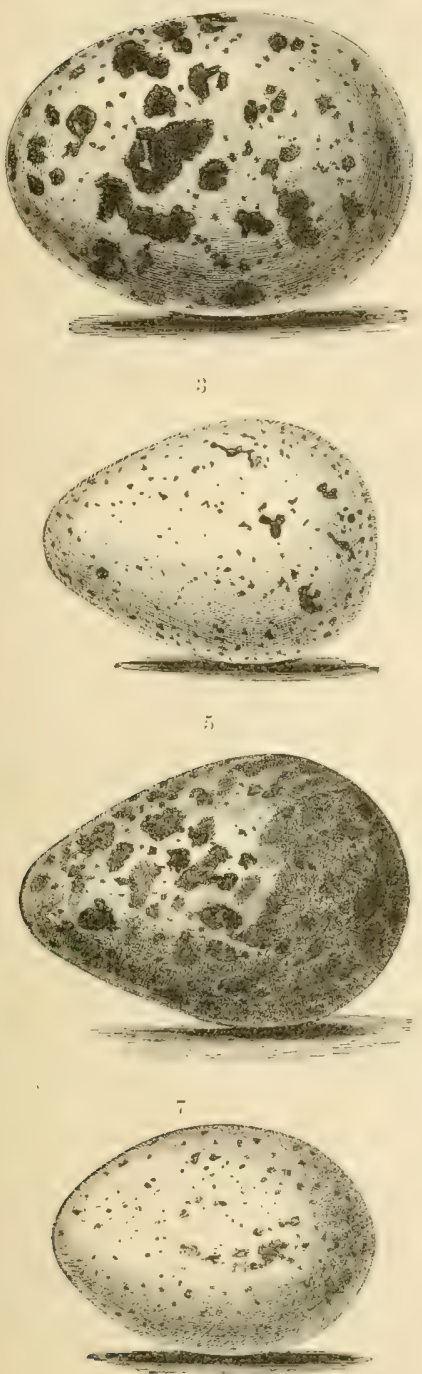

2

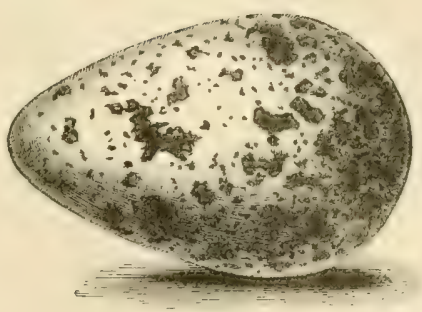

1

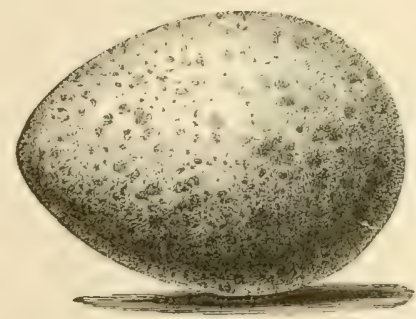

ii

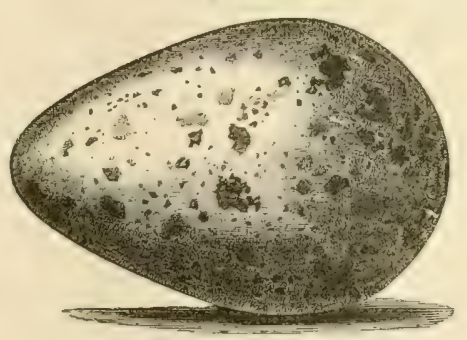

8

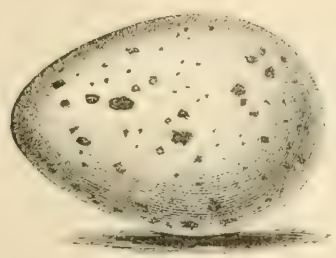

liig. 1. Canada Grouse, Tetrao Canadensis. Linnaus.

, 2. Kïlldeer Plover, Aegialitis vocifenes. Cassin.

, 3. Semipalmated Plorer, Aegialitis semipalmatus. Cabanis.

. 4. American Woodeock, Philohela minor. Gray.

". 5. Wilson's Snipe, Gallinago Wilsonii. Bonaparte.

, 6. Upland or Field Plover, Actiturus Bartramius. Bonaparte.

". T. Virginia Rail, Rallus Virginianus. Linnæus.

" 8. Carolina Rail, Porzana Carolina. Vieillot. 

same greenish-brown as the back, with irregular and imperfect transverse bands of black; outer feathers pale reddish-yellow, edged and tipped with white, and with several irregular transverse bands and a large subterminal arrow-head of black; bill greenish-yellow, with the under mandible more clear yellow towards its base, tip brownish-black; legs light-yellow; toes darker; iris hazel.

'Total length, about twelve inches; wing, six and a half; tail, three and a half.

$H a b$. - Eastern North America, South America, Europe.

Everywhere in the interior of the States on the Atlantic, this is the most abundant and best-known species of this group. Unlike nearly all others, this bird prefers plains and cultivated fields, and is one of the species which has not decreased in numbers on account of the extension of cultivation and the settlement of the country. On the contrary, it appears to be quite at home in the farm lands, and rears its young in the fields of grass and grain in the most populous rural districts of the country.

This bird, commonly known as the "Upland Plover," is not abundant in New England as a summer resident. It breeds sparingly in all these States, arriving in pairs about the 10th of April. It is less aquatic than most of the other species in this order, and frequents old pastures, stubble-fields, and cornfields, in preference to meadows and flats. It begins to nest about the last week in May. It is quite shy at all times, and difficult of approach, and I have spent half a day in one pasture before I could find the nest; both old birds keeping up their shrill whistle, and flying about me always out of gunshot. The nest is placed in a slight hollow in the ground, and is constructed of a few loose straws and leaves, arranged in a circular manner. The eggs are four in number, sometimes three. They are more ovoidal in form than most of our other Waders' eggs, and almost exactly resemble those of the Woodcock, but average considerably larger; varying from 1.92 by 1.31 inch (from Wisconsin) to 1.70 by 1.25 (from Massachusetts). The primary color of some specimens is a buff, while others are of a creamy-drab: they are marked with spots of two shades of brown, and obscure spots of lilac.

By the middle of August, and from then until late in September, these Plovers assemble in small flocks of eight or ten individuals. They then frequent hilly pastures, both on the seacoast and in the interior, where they feed on 
grasshoppers, crickets, grains, and seeds. They are then in good condition, and of delicate flavor on the table, and are much pursued by sportsmen; but, as they are swift-flying birds, and very shy, it requires a more than ordinary shot to bag many of them.

\section{TRYNGITES, CABANIS.}

Tringites, Cabanis, Jour. für Orn. (1856), 418. (Type Tringa rufescens. Vieillot.)

Upper mandible grooved to about the terminal fourth; the lower not quite so far; culmen and gonys about straight; mouth deeply cleft more than half-way to the eye; the culmen about two-thirds the commissure; culmen much shorter than the head, and about equal to middle toe without claw; tarsus about one and one-sixth as long as middle toe and claw; bare part of tibia decidedly shorter than middle toe without claw; toes cleft to the base, with only a very rudimentary web; upper jaw feathered to the nostrils; the side of the lower and beneath feathered much further, or to the end of the nostrils; the interspace of the rami entirely filled; tail somewhat graduated, not half the wing.

\section{TRYNGITES RUFESCENS. - Cabanis.}

\section{The Buff-breasted Sandpiper.}

Tringa rufescens, Nuttall. Man., II. (1834) 113. Aud. Orn. Biog,, III. (1835) 451. Ib., Birds Am., V. (1842) 264.

\section{DESCRIPTION.}

Bill about the length of the head, straight, compressed, narrow at the point; nasal groove long; wings very long; first quill Iongest; tertiaries rather shorter; tail moderate or longer than usual in this group; legs rather long; lower third of the tibia naked; toes free at base, flattened underneath, and slightly margined; hind toe small; upper parts pale and dull ashy-brown with a Jellowish tinge; every feather with a large central, lanceolate, crescent-shaped, or oblong spot of black, frequently with a glossy-green tinge, especially on the back and shorter tertiaries; under parts light yellowish-red, or pale-fawn color; many feathers tipped with white, and paler on the flanks and abdomen, on the breast with partially concealed small spots of black; axillary feathers white; quills with their outer webs light-brown, inner webs ashy-white, marbled with black and narrowly tipped with white; middle tail feathers brownish-black; outer feathers lighter, with transverse waved lines of black, and tipped with white; bill black; legs greenish-yellow; iris hazel.

Total length, seven and a half to eight inches; wings, five and a half; tail, three; bill, from gape, one; tarsus, one and a quarter inches.

Hab. - All of North America, South America, Europe.

This is a little bird of rather peculiar style of form, and of remarkable and handsome plumage. Its relationship appears to be to the preceding well-known species. Both this and the preceting bird more habitually frequent plains and other dry localities than any of the true Sandpipers. 
The Buff-breasted Sandpiper, although not abundant on the shores of New England, is by no means rare, in the months of August and September, when it is returning from its northern breeding-places. It is seldom seen here in spring; but it seems to pass over New England in its northern flight. Of its breeding habits, nest, eggs, \&c., we are ignorant. Audubon was of the opinion that it breeds about the arctic seas, as he had, seen a wing of this bird that came from there; but he knew nothing of its breeding habits whatever.

In the autumn, while with us, it does not frequent the beach as much as it does the marshes and flats in its vicinity, where it is known as one of the "Grass-birds" to our gunners. It feeds upon grasshoppers and other insects, and becomes very fat; so much so, that skinning it for cabinet preservation, at that season, is almost an impossibility.

\section{Section Limosex.}

Bill longer than the tarsus, curving slightly upwards towards the end, where it is thickened; both mandibles grooved for nearly the whole length; gape of mouth very short, not extending beyond the base of culmen.

\section{LIMOSA, Brisson.}

Limosa, Brisson, Orn. (1760). (Type Scolopax limosa, L.)

Bill lengthened, exceeding the tarsus, slender, and curving gently upwards; grooved to near the tip; the tip not attenuated, but pointed; the lower almost as long as the upper; culmen without any furrow; tarsus with transiverse scutello before and behind, reticulated laterally; a short basal membrane between the middla and outer toes; tail short, even.

LIMOSA FEDOA. - (Linn.) Ord.

The Marbled Godwit.

Scolopax fedoa, Wilson. Am. Orn., VII. (1813) 30. V. 590 .

Limosa fedoa, Nuttall. Man., II. (1834) 173. Aud. Orn. Biog., III. (1885) 287; 
Description.

Bill long, curved upwards; both mandibles grooved; wings long; tail short; legs long; tibia with its lower half naked; toes rather short, margined and flattened underneath; the outer and middle toes united by a rather large membrane; entire upper parts variegated with brownish-black and pale-reddish, the former disposed in irregular and confluent bands, and the latter in spots and imperfect bands; in many specimens the black color predominating on the back, and the pale-red on the rump and upper tail coverts; under parts pale-rufous, with transverse lines of brownish-black on the breast and sides; under wing coverts and axillaries darker rufous; outer webs of primaries dark-brown, inner webs light-rufous; secondaries light-rufous; tail light-rufous, with transverse bars of brownish-black; bill pale-yellowish, red at base, brownish-black at the end; legs ashy-black.

Total length, about eighteen inches; wing, nine; tail, three and a half; bill, four to five; tarsus, three inches; iris, brown.

Hab. - Entire temperate regions of North America; South America.

A large and handsome shore bird, well known to sportsmen as the Godwit, and a great favorite for shooting. From the collections of the surveying expeditions, it appears to be equally abundant in the interior and on the Pacific as on the eastern coast of the United States.

It is only in the spring and autumn migrations that the Great Marbled Godwit is found in New England; and at those times it makes only a short stay, particularly in the spring.

They arrive from the south early in May, and pass to the most northern countries, where they pass the season of incubation.

Of their breeding habits I am ignorant, and I have no eggs in my collection to give a description here.

In the autumn, even as early as the middle of August, flocks of ten or a dozen birds appear in the marshes on the seacoast of Massachusetts; and, these flocks uniting their numbers, sometimes as many as a hundred birds are found together. They are called by our sportsmen "Dough" or "Doe" Birds; and, as they are in good condition and well flavored, they are in great repute, and are hunted with great activity. The gunners, using decoys, conceal themselves in the manner described in the account of the Golden Plover on a preceding page, and secure great numbers. They meet with a ready sale in our markets, at very remunerative prices; and I have known of two gunners realizing sixty dollars as the proceeds of one day's shooting. 
At this season, these birds associate with other species; and it is a common occurrence to bring to the ground, at one discharge of the gun into one of these flocks, two or three different species.

By the 20th of September, they have left our shores. They are most abundant about the first week in that month.

LIMOSA HUDSONICA. - Swainson.

The Hudsonian Godwit.

Scolopax Hudsonica, Latham. Ind. Orn., II. (1790) 720.

Limosa Hudsonica. Sw. F. B. A., II. (1831) 396. Nutt. Man., II. (1834) 176

Aud. Orn. Biog., III. (1835) 426; V. 592. Ib., Birds Am., V. (1842) 335

\section{DESCRIPTION.}

Smaller than the preceding; bill longer than the head; both mandibles grooved, slightly recurved; wings long; legs moderate; membrane uniting the outer and middle toe large.

Adult. - Upper parts brownish-black, with spots and transverse bars of palereddish on the back; rump brownish-black; upper tail coverts white; wing coverts and shorter quills dark-cinereous; primaries brownish-black; under parts yellowishred, with transverse bars of brownish-black on the breast and sides and under tail coverts, and frequently with the feathers on the abdomen widely tipped with white; tail black, with the base white, and narrowly tipped with white; under wing coverts and axillary feathers black; shafts of primaries white; bill pale-yellowish at base; tip brownish-black; legs bluish-brown.

Younger. - Head and upper parts cinereous, irregularly marked on the top of the head, and on the back, with brownish-black; stripe before, and over the eye, white; under parts dull yellowish-white; under wing coverts and axillaries black; rump black; upper tail coverts white; tail black; base and tip white; bill yellow, tipped with brownish-black; legs dark-brown; iris brown.

Total length, about fifteen inches; wing, eight; tail, three; bill, two and threequarters to three and a half; tarsus, two and a half inches.

This species is less abundant than the preceding, seldom more than a half-dozen specimens being taken in a season on our coast. It associates with the other, and has all its habits and characteristics. It is called, by the gumners, the "Smaller Doe-bird."

Like the Greater Godwit, it breeds in the most northern sections of the country. I have no specimen of its egg by me, and can give no description of its breeding habits here. 


\section{NUMENIUS, LINNAUS.}

Numenius, Linn xus. Syst. Nat. (1746). (Type Scolopax arquata, L.)

Legs covered anteriorly with transverse scutellæ, laterally and behind with small hexagonal scales; bill very long, exceeding the tibia, and curved downwards for the terminal half; the culmen rounded; tip of bill expanded laterally, and clubshaped; grooves of bill not reaching beyond the middle; tertials as long as primaries.

\section{NUMENIUS LONGIROSTRIS. - Wilson.}

The Long-billed Curlew; Sickle-bill Curlew.

Numenius longirostris, Wilson. Am. Orn., VIII. (1814) 24. Nutt. Man., II. (1834) 88. Aud. Orn. Biog., III. (1835) 240; V. 587. Ib., Birds Am., VI. (1843) 35.

\section{DESCRIPTION.}

The largest American species of this genus; bill very long, much curved; upper mandible longer than the under, somewhat knobbed at the tip; wing rather long; legs moderate; toes united at base; entire upper parts pale-rufous, tinged with ashy; every feather with transverse and confluent bands of brownish-black, most numerous and predominating on the back and scapulars; secondary quills, under wing coverts, and axillaries, bright-rufous; primaries with their outer webs brownishblack, and their inner webs rufous, with transverse bands of black; under parts pale-rufous, with longitudinal lines of black on the neck and sides; tail rufous, tinged with ashy; transversely barred with brownish-black; bill brownish-black; base of under mandible reddish-yellow; legs bluish-brown; specimens vary to some extent in the shade of the rufous color of the plumage, and very much in the length of the bill; the rufous color is probably more distinct in the young; iris hazel.

Total length, about twenty-five inches; wing, ten to eleven; tail, four; bill, five to eight; tarsus, two and a quarter inches.

$H a b$. - The entire temperate regions of North America.

This species is not very abundant on our coast in the spring and autumn. Wilson, in describing its habits, says, -

"Like the preceding, this bird is an inhabitant of marshes in the vicinity of the sea. It is also found in the interior, where, from its long bill, and loud, whistling note, it is generally known.

"The Curlews appear in the salt marshes of New Jersey about the middle of May, on their way to the north; and in September, on their return from their breeding-places. Their food consists chiefly of small crabs, which they are very dexterous at probing for, and pulling out of the holes with their long bills; they also feed on those small sea-snails so abundant in the marshes, and on 
various worms and insects. They are likewise fond of brambleberries, frequenting the fields and uplands in search of this fruit, on which they get very fat, and are then tender and good eating, altogether free from the sedgy taste with which their flesh is usually tainted while they feed in the salt marshes.

"The Curlews fly high, generally in a wedge-like form, somewhat resembling certain Ducks, occasionally uttering their loud, whistling note, by a dexterous imitation of which a whole flock may sometimes be enticed within gunshot, while the cries of the wounded are sure to detain them until the gunner has made repeated shots and great havoe among them."

The eggs of the Long-billed Curlew are four in num ber. They are pyriform in shape, and almost exactly resemble the eggs of the Willet, but are considerably larger; their dimensions being 2.75 inch in length by 1.96 in breadth.

Along the shores of the northern side of Cape Cod, this species is most abundant in the autumnal flight, where it appears in flocks of fifteen or twenty. Like many others of our shore-birds, it is taken, with the aid of decoys, by persons concealed in pits; and, being a delicate and well-conditioned bird, it is in high esteem, and much sought for in the markets where it is exposed for sale.

\section{NUMENIUS HUDSONICUS. - Latham.}

The Short-billed or Hudsonian Curlew.

Scolopax borealns, Wilson. Am. Orn., VII. (1813) 22.

Numenius Hudsonicus, Nuttall. Man., II. (1834) 97. Aud. Orn. Biog., III. (1835) 283; V. 589. Ib., Birds Am., VI. (1843) 42.

\section{DESCRIPTION.}

Smaller than the preceding; bill about twice the length of the head; wings long; tail short; legs moderate; head above brownish-black, with a longitudinal band: other upper parts brownish-black, tinged with ashy, spotted with dull yellowishwhite, and lighter on the rump; under parts dull yellowish-white, with longitudinal narrow stripes of blackish-brown on the neck and breast; under wing coverts and axillaries pale ashy-rufous, transversely barred with black; quills brownish-black, with transverse bars of pale-rufous on the inner webs; tail brownish-black, with 
transverse bars of pale ashy-brown; bill brownish-black; base of lower mandible reddish-yellow; legs greenish-brown; specimens vary in the shade of the lighter colors of the plumage and in the length of the bill; iris brown.

Smaller, and with the colors different from the preceding. This bird is represented as abundant in the northern regions of this continent, but is much less frequent in the United States than the preceding.

Total length, about eighteen inches; wing, nine; tail, four; bill, three to four; tarsus, two and a quarter inches.

Hab. - Atlantic and Pacific coasts of North America; California (MIr. Cassidy).

This species is rare in New England. I have never met with it alive, and will have to depend upon the observations of others. Wilson says, -

"The Short-billed Curlew arrives in large flocks on the seacoast of New Jersey early in May, from the South; frequents the salt marshes, muddy shores, and inlets, feeding on small worms and minute shell-fish. They are most commonly seen on mud-flats at low water, in company with various other Waders; and, at high water, roam along the marshes. They fly high, and with great rapidity. A few are seen in Jume, and as late as the beginning of July, when they generally move off toward the North. Their appearance on these occasions is very interesting: they collect together from the marshes, as if by premeditated design, rise to a great height in the air, usually an hour before sunset; and, forming in one vast line, keep up a constant whistling on their way to the north, as if conversing with one another to render the journey more agreeable."

\section{Nuttall says, -}

"From the middle of August to the beginning of September, they arrive in the vicinity of Massachusetts Bay and other parts of New England, frequenting the pastures as well as marshes, and fatten on grasshoppers and berries till the time of their departure, about the close of September." 
NUMENIUS BOREALIS. - Latham.

The Esquimaux Curlew.

Numenius boreahs, Nuttall: Man., II. (1834) 100. Aud. Orn. Biog., III. (1835) 59; V. 590. Ib., Birds Am., VI. (1843) 45.

\section{DESCRIPTION.}

Much smaller than either of the preceding, but resembling $N$. Hudsonicus in color; bill rather longer than the head, slender; wings long; tail short; legs moderate; entire upper parts brownish-black, spotted with dull yellowish-rufous; quills brownish-black, uniform on both webs, without bars on either; under wing coverts and axillaries light-rufous, with transverse stripes of brownish-black; under parts dull. white, tinged with rufous, with longitudinal narrow stripes of brownish-black on the neck and breast, and transverse stripes of the same on the sides and under tail coverts; tail ashy-brown, with transverse bands of brownish-black; bill brownishblack; base of under mandible yellow; legs greenish-brown; iris dark-brown.

Total length, about thirteen and a half inches; wing, eight and a quarter; tail, three; bill, two and a quarter to two and a half; tarsus, one and three-quarters inches.

This small and interesting Curlew is merely a bird of passage in the United States, to be met with in the spring and autumn. It is easily distinguished from either of the preceding by its small size and its comparatively short and weak bill. We have never seen it from the western countries of the United States.

It is only in the migrations that this bird visits New England, and then only in small numbers. They make their appearance by the last week in April, and pass to the most northern sections, where they breed, and then return here about the first.week in September.

Says Nuttall, "On the 13th of June, 1822, Dr. Richardson discovered one of these Curlews sitting on three eggs, on the shore of Point Lake. When approached, she ran a short distance from the nest, crouching near to the ground, and then stopped to watch the motions of her encroaching visitor. The eggs, sometimes as many as four, have a pyriform shape, and a siskin-green color, clouded with a few irregular spots of bright umber-brown."

On their return in autumn, this Curlew has all the habits of the two preceding species: like them, "they are remarkably gregarious, each company seeming to follow some temporary leader; and, on starting to fly, a sort of watch-cry is heard, resembling the whistling pronunciation of the 
word bee-bee. On their arrival from the North, they are very fat, plump, and well flavored, and included, like the preceding and the Marbled Godwit, under the general name of Doe-birds : they are sought out by epicures, and enhance the value of a table entertainment." They frequent the marshes and adjoining pastures, where they feed much upon grasshoppers and other insects and earthworms, which they collect principally towards evening, or early in the morning.

\section{Tribe PaLUdicole. ${ }^{1}$}

Species living in marshes, with elevated bodies, much compressed laterally; usually with longer necks than most Snipe, with moderately long, strong, and stout bills, also much compressed, and covered at tip by a horny investment; the remaining portion membranous, with elongated nasal furrow, and narrow, more or less perforate, nostrils; the lores are feathered uniformly as in the Limicolo; the rest of the plumage without the spotting of the Snipes; wings rather short, more rounded than pointed, and when folded do not reach beyond the short, soft, and feeble tail, in fact, seldom to its base; the outer two or three primaries generally abbreviated; the toes are very long, cleft to the base, thin, and generally with very long claws; the same is the case with the hind toe, which is not only much longer than in the Limicola, but is generally inserted more nearly on the same level with the anterior ones, touching the ground for most of its extent.

The species pick up their food on the surface, and do not probe the soft mud in search of it.

The North-American species of this tribe are few in number, though very abundant in individuals. Their habit of close concealment among the reeds and grass of marshy places renders them very difficult of detection, except when their abodes are more or less submerged.

\section{Sub-Family RaLline. - The Rails.}

\section{RALLUS, LINNæUS.}

Rallus, Livsaus, Syst. Nat.

Bill longer than the head, rather slender, compressed; upper mandible slightly curved; nostrils in a long groove, and with a large membrane; wings short; tertiary quills long, frequently longer than the primaries; tail very short; legs moderate; tirsus shorter than the middle toe, and covered on all sides with transverse scales; toes long and rather slender; inner toe rather shorter than the outer; hind toe short and weak.

1 See Introduction. 


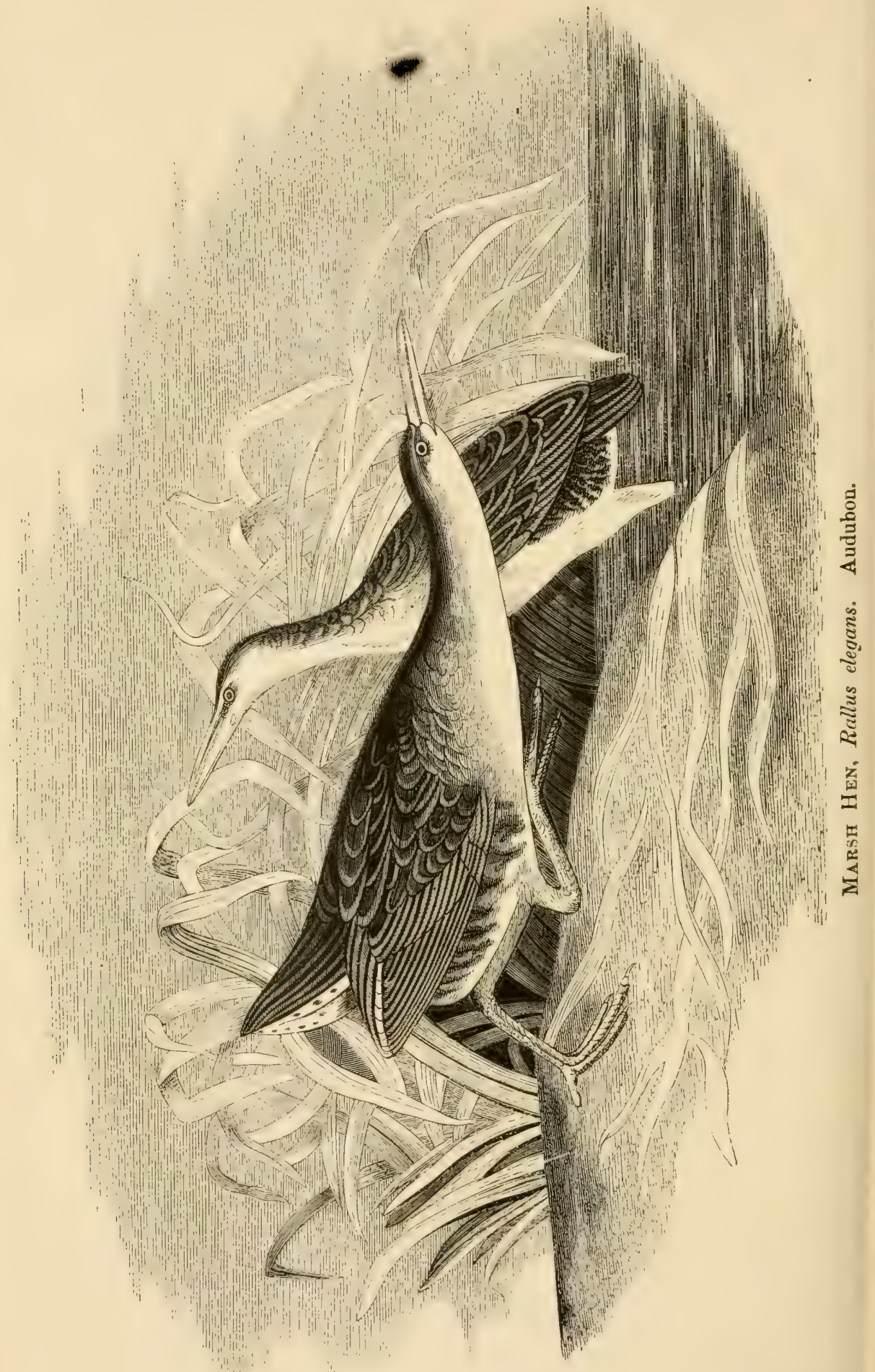


RALLUS ELEGANS, - Audubon.

\section{Marsh Hen.}

Rallus elegans, Audubon. Orn. Biog., III. (1837) 27.

Rallus crepitans, Wilson. Am. Oru., VII. (1813).

\section{DESCRIPTION.}

Upper parts olive-brown, with longitudinal stripes of brownish-black, most numerous on the back; line from the base of the bill over the eye dull orange-yellow; space before and behind the eye brownish-cinereous; throat and lower eyelid white; neck before and breast bright rufous-chestnut; sides and abdomen, and under tail coverts, with transverse bands of brownish-black and white, the dark bands being the wider; tibiæ dull yellowish-white, with spots and transverse bars of ashy. brown; upper wing coverts reddish-chestnut; under wing coverts black, with transverse lines of white. Sexes alike.

Total length (from tip of bill to end of tail), about seventeen inches; wing, six and fifty one-hundredths; tail, three inches.

This beautiful bird is so exceedingly rare in New England, that it can be regarded only as a straggler from its southern home. It has all the habits of the following species; and its eggs exactly resemble those of the Clapper Rail, but average about one-fifth larger.

\section{RALLUS CREPITANS. - Gmelin.}

The Clapper Rail; Mud-hen.

Rallus crepitans, Gmelin. Syst. Nat., I. (1788) 713. IVils. Am. Orn., VII. (1813) 112. Aud. Orn. Biog., III. (1835) 33; V. 570. Ib.; Birds Am., V. (1842) 165.

\section{DESCRIPTION.}

Upper parts light ashy-olive, with longitudinal stripes of brownish-black, most numerous on the back; a line of dull yellowish-white from the base of the bill over the eye; space before and behind the eye ashy; throat and under eyelid white; neck before and breast pale reddish-yellow, or tawny, tinged with bluish-ashy on the breast; sides, abdomen, under tail coverts, and tibix, with transverse bands of brownish-black and white, the former being the wider; upper wing coverts brownish-olive; under wing coverts black, with transverse lines of white; iris pale-yellow.

Total length (to end of tail), about fourteen inches; wing, five and a half; tail. two and a half inches.

This bird, so well known in the Middle and Southern States, is rarely found in New England as a summer risitor. It has been known to breed in. the most southern localities in these States; but the instances are few, and it can be called only an accidental species in New England. 
It begins to build about the 10th of May. The nest is placed on the ground in a marsh, sometimes in a tussock of grass or on a pile of seaweed: it is constructed of a large mass of dried grasses and weeds, and is but little hollowed. The eggs. are from five to seven or eight in number. Their form is usually ovoidal, and their primary color dull creamydrab or dirty-buff. This is marked more or less thickly with spots and blotches of different shades of brown and obscure spots of lilac. The nearest in resemblance to these eggs are those of the Woodcock; but, when a number of each are placed side by side, the eggs of the latter may be readily identified by their generally more pyriform shape. The dimensions of the eggs of the Clapper Rail vary from 1.82 by 1.25 inch to 1.63 by 1.14 inch. The greater number of spots are more of a purplish tint; and they are generally rather sparingly distributed over the entire egg.

The habits of this species are similar to those of the following; but the Clapper Rail seems to prefer for its home the marshes in the neighborhood of salt water.

\section{RALLUS VIRGINIANUS. - Limneus.}

\section{The Virginia Rail.}

Rallus Virginianus, Linnæus. Syst. Nat., I. (1766) 263. Wils. Am. Orn., VII. (1813) 109. Nutt. Man., II. (1834) 205. Aud. Orn. Biog., III. (1835) 41; V. 573. Ib., Birds Am., V. (1842) 174 .

\section{DESCRIPTION.}

Much smaller than either of the preceding, but resembling them in form, and resembling also $R$. elegans in colors; upper parts olive-brown, with longitudinal stripes of brownish-black; line from base of bill over the eye reddish-white; throat white; neck before and breast bright-rufous; abdomen and under tail coverts with transverse bands of black and white, the former being the wider; upper wing coverts bright rufous-chestnut; under wing coverts black, with transverse lines of white; iris bright-red.

Total length (from tip of bill to end of tail), about seven and a half inches; wing, four; tail, one and a half inches.

This handsome species is pretty generally distributed throughout New England as a summer resident. Unlike 
the preceding, it locates itself in the fresh-water meadows, where, in a tussock of grass or in a pile of driftweed, it forms its nest. This is nothing but a pile of weeds or grass, which it arranges in a compact manner, and hollows to the depth of perhaps an inch or an inch and a half.

The eggs are from six to ten in number, usually about seven. They are ovoidal in form, and generally seem to be like a miniature of those of the Clapper Rail: some specimens, collected in Cambridge, Mass., are of a deep-buff color ; but none approach the color of the Carolina Rail sufficiently to be mistaken for them. They are spotted with small marks of reddish and brown, and with a few obscure spots of lilac. They vary in their dimensions from 1.30 by .96 to 1.23 by .90 inch.

This species is undoubtedly more abundant in New England, particularly in its southern portions, than most persons generally believe. It is of very retiring habits; and as it selects the almost inaccessible meadows and boggy swamps for its summer home, and, when approached, quickly retreats into the farthest recesses, I am not surprised that it is in most cases overlooked. I have found it breeding in many localities in Massachusetts, and have no hesitation in calling it one of the commonest of our Grallatores. It feeds only during the twilight and in early dawn, and remains concealed in the grass during the greater part of the day. Its food consists of various insects and worms, such as are abundant in the localities which it frequents. It leaves New England for the South by the 10th of September.

\section{PORZANA, VIEILLOT.}

Porzana, Vieillot, Anal., p. 61 (1816), 61. (Type Rallus porzana, L.)

Bill shorter than the head, compressed, straight; nostrils in a wide groove, with a large membrane; wings moderate; primaries longer than tertiaries; tail short; tarsus about the length of the middle toe; toes long; inner toe slightly shorter than the outer; general form compressed and slender; legs rather robust. 


\section{PORZANA CAROLINA.}

\section{The Carolina Rail; Ortolan.}

Rallus (Crex) Carolinus, Bonaparte. Obs. Wils. (1825), No. 230. Nutt. Man,, II. (1834) 209.

Ortygometra Carolina, Audubon. Birds Am., V. (1842) 145.

\section{DESCRIPTION.}

Space around the base of the bill, extending downwards on the neck before and over the top of the head, black.

Male. - Upper parts greenish-brown, with longitudinal bands of black, and many feathers having narrow stripes of white on their edges; behind the eye, sides of the neck, and the breast, fine bluish-ashy, with circular spots and transverse bands of white on the breast; middle of the abdomen and under tail coverts white; sides and flanks with transverse bands of brownish-black and white; bill greenishyellow; legs dark-green.

Female. - Similar, but duller in colors.

Young. - Without black at the base of the bill or on the neck; throat dull-white; breast dull yellowish-ashy; upper parts tinged with dull-yellow; iris chestnut.

Total length, about eight and a balf inches; wing, four and a quarter; tail, two inches.

This species, like the Virginia Rail, is probably more abundant in our fresh-water meadows than is generally supposed. It arrives in April, about the 16th ; and, separating into pairs, takes up its residence in the inland marshes, where it breeds, and remains until its departure for the South, about the middle of October. Early in May the season of incubation commences. The nest is constructed of pieces of straw and weed, arranged in a large pile, and hollowed to the depth of an inch or more: it is usually placed in a tussock of grass, or beneath a piece of turf. A specimen which $I$ found in Dedham meadows was built beneath some thick cranberry-vines, and I have known of others being placed in small brier patches; but generally the fabric is built in an open meadow, usually on an elevated tussock in a boggy tract of ground. The eggs vary from five to eight or ten in number: their form is almost always an exact ovoidal. Their color is a yellow-drab, with a faintolivaceous tint, different from the color of any of our other Rail's eggs. They vary in dimensions from 1.35 by 1 inch (Quincy, Mass.) to 1.15 by .85 inch (Albion, Wis.). The 
average size is about 1.26 by 1.92 (Cambridge and Needham, Mass.).

After leaving New England and other northern breedingplaces, this species congregates in great numbers on the shores of some of the southern streams and bays, where they furnish much sport to the gumners of those localities.

\section{PORZANA NOVEBORACENSIS.}

The Yellow Rail.

Ortygometra Noveboracensis, Audubon. Birds Am., V. (1842) 152.

Rallus Noveboracensis Audubon. Orn. Biog., IV. (1838) 251.

\section{DESCRIPTION.}

Entire upper parts ochre-yellow, with longitudinal wide stripes of brownish-black and transverse narrow stripes of white; neck and breast reddish ochre-yellow; many feathers tipped with brown; middle of abdomen white; flanks and ventral region with wide transverse bands of dark reddish-brown and narrow bands of white; under tail coverts rufous, with small spots of white; under wing coverts white; iris hazel.

Total length (from tip of bill to end of tail), about six inches; wing, three and a quarter; tail, one and three-quarters inches.

This beautiful bird is an exceedingly rare spring and autumn visitor in New England. I have, in a number of years' shooting, been able to procure but two; and have not heard of more than two or three more being taken here. It has all the characteristics of the other species, but prefers the fresh-water meadows to the salt marshes. ${ }^{1}$ Dr. Richardson, in his "Northern Zoology," says, "This elegant bird is an inhabitant of the marshes on the coast of Hudson's Bay, near the mouth of the Severn River, from the middle of May to the end of September. It never flies above sixty yards at a time, but runs with great rapidity among the long grass near the shores. In the morning and evening, it utters a note which resembles the striking of a flint and steel : at other times, it makes a shrieking noise. It builds no nest, but lays from ten to sixteen white eggs among the grass."

1 The specimens that I procured were found in fresh-water meadows early in September. 
FULICA, LINN גUS.

Fuhca, Lrvweus, Syst. Nat. (1735). (Type Fulica atra, L.)

Bill shorter than the head, straight, strong, compressed, and advancing into the feathers of the forehead, where it frequently forms a wide and somewhat projecting frontal plate; nostrils in a groove, with a large membrane near the middle of the bill; wings rather short, second and third quills usually longest; tail very short; farsus robust, shorter than the middle toe, with very distinct transverse scales; toes long, each toe having semicircular lobes, larger on the inner side of the toe; hind toe rather long, lobed.

\section{FULICA AMERICANA.-Gmelin. \\ The Coot; Poule d'eau; Mud-hen.}

Fulica Americana, Gmelin. Syst. Nat., I. (1788) 704. Aud. Orn. Biog., III. (1835) 291; V. 568. Ib., Birds Am., VI. (1842) 138.

Fulica atra, Wilson. Am. Orn., IX. (1825) 61.

\section{DESCRIPTION.}

Head and neck glossy-black, with a tinge of ashy; under tail coverts white; entire other plumage dark bluish-cinereous or slate-color, with a tinge of olive on the back and darker on the rump; edge of wing at shoulder and edge of first primary white; secondary quills tipped with white; rump frequently tinged with brownish; bill very pale-yellow or nearly white, with a transverse band of brownish-black near the end; tip white; legs dull grayish-green. Female similar, but with the tints lighter. Young like the adult, but with the under parts lighter; abdomen frequently ashy-white; back and rump dark olive-brown; head and neck lighter; iris reddish-hazel.

Total length, about fourteen inches; wing, seven; tail, two inches.

This species probably breeds in all the Nęw-England States, but not abundantly. It prefers the neighborhood of some small muddy pond for its habitation; and its nest is usually built in an almost inaccessible bog. Of the character of the nest, I am ignorant, but judge that it resembles that of the other members of this family.

The eggs are from eight to twelve in number. Their form is an elongated ovoid. Their color is a pale yellowishbuff, or dirty-cream tint; and they are marked with fine dots and spots of dark-umber and obscure fine dots of lilac. In all the specimens that I have examined, these dots are pretty thickly distributed or sprinkled, but are in no case confluent into blotches. Their dimensions vary from 2.10 by 1.35 to 2 by 1.28 inch. 
This species is more abundant in the early spring and autumn than in the rest of the season; and $I$ infer from this, that it breeds principally in the northern countries.

Wilson describes its general habits in the following language :-

"This species makes its appearance in Pennsylvania about the first of October. Among the muddy flats and islands of the river Delaware, which are periodically overflowed, and which are overgrown with the reed, or wild oats and rushes, the Coots are found. They are not numerous, and are seldom seen, except their places of resort be covered with water: in that case, they are generally found sitting on the fallen reed, waiting for the ebb of the tide, which will enable them to feed. Their food consists of various aquatic plants, seeds, insects, and, it is said, small fish. The Coot has an aversion to take wing, and can seldom be sprung in its retreat at low water: for, although it walks rather awkwardly, yet it contrives to skulk through the grass and reeds with great speed; the compressed form of its body, like that of the Rail genus, being well adapted to the purpose. It swims remarkably well; and, when wounded, will dive like a duck. When closely pursued in the water, it generally takes to the shore, rising with apparent reluctance, like a wounded duck, and fluttering along the surface, with its feet pattering on the water. It is known in Pennsylvania by the name of the Mud-hen."

\section{NOTES.}

I continue Mr. Couper's valuable notes, made at Quebec, Lower Canada:-

ARDEA HERODIAS. - The adult is never seen in this latitude. However, in the fall, the young pass this way to the Atlantic States. They breed near Rice Lake, in Upper Canada.

BOTAURUS LENTIGINOSUS. - The Bittern breeds here, and appears to be common. It prefers savannas to lakes; and, as plenty of food is found on the latter, probably this species may visit higher latitudes.

NYCTIARDEA GARDENI. - Common. Breeds on the island of Orleans, east of Quebec, and in the woods adjoining the St. Lawrence. This bird 
suits its own convenience in building in this neighborhood; for the majority of nests on the latter island are the architecture of our Common Crow.

CHARADRIUS VIRGINICUS. - Common during the fall. Breeds further north. This species came on board a steamship, on the Atlantic, six hundred miles out from Europe.

EGIALITIS SEMIPALMATUS. - Uncommon. Occurs in the spring, on its way north to breed.

SQUATAROLA HELVETICA. - Uncommon. Occurs in spring only.

STREPSILAS INTERPRES. - Uncommon. Only in spring.

PHALAROPUS HYPERBOREUS, - Occasional. Common in Labrador.

PHILOHELA MINOR. - Not commion. A few breed.

GALLINAGO WILSONII. - Abundant in the spring and fall. None breed in this district: they go further north.

MACRORHAMPHUS GRISEUS. - Occasional. None breed.

TRINGA CANUTUS. - Occasional. None breed.

T. MARITIMA. - Accidental at Quebec.

T. MaCULATA. - Common. None breed.

T. WILSONII. - Occurs in spring. None breed.

CALIDRIS ARENARIA. - Occurs in spring. Goes far north to breed.

EREUNETES PETRIFICATUS, - Occurs in spring only. None breed.

GAMBETTA MELANOLEUCA. - Occurs in immature plumage in the fall.

GAMBETTA FLAVIPES. - Occurs in the fall.

RHYACOPHILUS SOLITARIUS. - Uncommon. Only noticed in the spring, when on their way north to breed.

TRINGOIDES MACULARIUS. - Common. Breeds.

ACTITURUS BARTRAMIUS. - Rare. Occurs in the spring.

IIMOSA HUDSONICA. - Occurs in spring and fall.

NUMENIUS HUDSONICUS. - Occurs in the fall.

N. BOREALIS, - Visits Quebec in the fall.

RALLUS VIRGINIANUS. - Uncommon.

PORZANA CAROLINA. - UnCommon.

P. NOVEBORACENSIS. - This little Rail is found here in the fall, at which season it is found in Snipe-grounds. There is no doubt that it breeds further north than Quebec.

FULICA AMERICANA, - Uncommon. 


\section{ORDER VI. - NATATORES. SwIMMERS.}

Toes connected by membrane to the claws; the feet fitted for swimming; lower part of the tibia usually feathered to near the joint, which is bare; hind toe, however, usually elevated, and rather . small, except in Pelecanida; fitted for an aquatic life, swimming and diving freely; rump with well-developed oil glands.

The order Natatores, as characterized above, embraces a large number of species of very varied forms, all more or less aquatic in their habits. A character common to all consists in the presence of a membrane between the toes, usually extending to the claws. This membrane, when found in the Grallatores, is confined more or less to the basal joint, unless Phonicopterus be an exception. This genus has been variously placed in both orders, and it is still a question where it really belongs. The internal anatomy resembles that of the Natatores, as well as the lamellated bill and fully webbed toes; the external form however, as well as habits, bring it nearer the Grallatores.

The order Natatores of most authors has been divided by Bonaparte into two, - the Gavice and the Anseres: the former embracing species which rear their young in nests, and belong to the sub-class Altrices; while the latter are Pracoces, the young procuring food for themselves almost from birth.

Gavis. - Bill without lamellæ; and more or less entire; feet with the toes all connected by one continuouis membrane; or the hind toe free, with the anterior continuously webbed.

Anseres. - Bill with transverse lamellæ along the edges; hind toe free. 


\section{SUB-ORDER ANSERES.}

\section{FAMILY ANATIDAE.}

The two jaws with transverse lamellæ, alternating and fitting in each other; upper mandible ending in an obtuse rounded nail; a groove running along both jaws to the nail; the feathers of the forehead extend forward on the culmen in a rounded or acute outline; those on the side of lower jaw and on the chin extend forward in a similar manner; commissure straight; legs short.

\section{Sub-Family Crgninæ. - The Swans. \\ CYGNUS, LINNæUS.}

Cygnus, Linn wus, Syst. Nat. (1835). (Type Anas olor, Gra.) Gray.

Neck very long; bill longer than the head (commissure longer than the tarsus), the basal portion covered by a soft skin extending to the anterior half of the eye; the plane of the upper outline from eye to eye horizontal; the lateral outline extending nearly straight to the commissure, or even sometimes widening slightly; not half the width of the bill at tip; nostrils situated in the middle portion of the bill; lower portion of tibia bare; the tarsus much shorter than the foot, much compressed, covered with hexagonal scales, which become smaller on the sides and behind; hind toe small, much elevated; the lobe narrow; tail of twenty or more feathers, rounded or wedge-shaped; sexes similarly colored.

\section{CYGNUS AMERICANUS. - Sharpless.}

\section{The American Swan.}

Cygnus Americanus, Sharpless. Doughty's Cab. N. H., I. (1830) 185. Aud. Orn. Biog., V. (1839) 133. Ib., Birds Am., VI. (1843) 226.

Cygnus ferus, Nuttall. Man., II. (1834) 368.

\section{DESCRIPTION.}

Bill as long as the head, broad, high at the base; the feathers ending on the forehead in a semicircular outline; nostrils far forward, the anterior extremity considerably more forward than half the commissure; tail of twenty feathers.

Adult pure-white; bill and legs black; the former with an orange or yellowish spot in front of the eye; less mature specimens with the head above tinged with reddish-brown; iris brown.

Length, fifty-five inches; wing, twenty-two; tarsus, four and twenty-five onehundredths; bill, above, four and twenty one-hundredths inches.

$\mathrm{H} a \mathrm{~b}$. - Continent of North America. 
The Common American Swan is equally abundant on both sides of the continent, as well as throughout the interior; the young bird is brown instead of white; the adult seldom, if ever, is without the yellow or orange space at the base of the bill, which is otherwise black.

7 HIS beautiful bird is so extremely rare in New England 1 that it cannot properly be considered as belonging to our fauna. Within a few years, perhaps three or four specimens have been taken in the waters of Lake Champlain; and I believe a small flock is recorded to have been seen in Lake Memphremagog. These are the only instances known to me of its occurrence in these

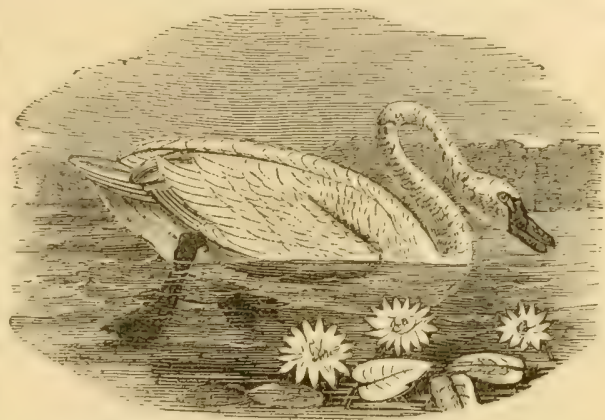
States. It retires to the most northern countries to pass the season of reproduction. It nests on the ground, on the islands and plains in the Hudson's Bay country. 'The nest is constructed of a small collection of weeds and dried grasses, loosely adjusted by the female. The eggs are from six to eight or ten in number. They are broadly ovoidal in shape, and of a pale olivaceous-green in color. They vary in dimensions from 4.65 by 3 inches to 3.98 by 2.85 inch.

\section{Sub-Family Anserinæ.-The Geese.}

ANSER, LINNAUS.

Bill as long as the head, mostly red or orange-colored; the lamellx of upper mandible project below the edge as conical points; nostrils opening behind the middle of the commissure, the anterior edge only reaching to this point; tip of hind too reaching to the ground. 


\section{ANSER HYPERBOREUS.-Pallas.}

\section{The Snow Goose.}

Anser hyperboreus, Pallas. Spic. Zool., VI. (1767) 25. Nutt. Man., II. 344. Aud. Orn. Biog., IV. (1838) 562. 1b., Birds Am., VI. (1843) 212.

Anas hyperborea. Gm., I. 504. Wils. Am. Orn., VIII. (1814) 76.

\section{DESCRIPTION.}

Adult. - Bill and legs red; color pure-white; primary quills black towards the end, silvery-bluish gray towards the base, where the shafts are white; the spurious quills are also bluish; inside of wings, except primary quills, white; immature birds have the head washed with rusty.

Young. - Head and upper part of neck white; lower part of neck to the wings dark-brown, passing on the sides of body into a more ashy shade; rest of under parts, concealed portions of the back, rump, and upper coverts, white; the entire scapular and scapular region is ashy-brown, each feather with faint reddish-brown margin; the upper surface of the wing is of a clear silvery-ash, but passing into darkbrown on the ends of the quills; the coverts, secondaries, tertials, and scapulars, edged with white; iris light-brown.

Length, about thirty inches; wing, sixteen and forty one-hundredths; tarsus, three and twelve one-hundredths; commissure, two and ten one-hundredths inches.

This is another rare species on our New-England sea coast. As a general thing, it is only seen during the winter; but we have, in the Massachusetts State Cabinet, a fine specimen that was taken in Boston Harbor, in July, 1863. It is strictly a noithern species, and hardly belongs to our fauna.

Dr. Richardson, in describing its breeding habits, says, "It breeds in the barren grounds of Arctic America, in great numbers. The eggs, of a yellowish-white color and regularly ovate form, are a little larger than those of the Eider Duck; their length being three inches, and their greatest breadth two. The young fly in August; and, by the middle of September, all have departed to the southward. The Snow Goose feeds on rushes, insects, and in autumn on berries, particularly those of the Empetrum nigrum."

\section{BERNICLA, STEPHENS.}

Bernicla, Stephews, Shaw's Gen. Zool., XII. (1824) 45. (Type Anas bernicla, L.)

Bill about as long as head or shorter; the commissure nearly straight; the teeth of upper mandible concealed, except perhaps at the base; bill and legs black. 
The American geese, with black bill and legs, exhibit very great variations in size; so much so, indeed, as to render it very difficult to distinguish them by this sharacter alone: the variation in the shade of plumage in the same species is likewise considerable.

\section{BERNICLA CANADENSIS, - Boie.}

The Canada Goose.

Ancs Canadensis, Linnæus. Syst. Nat., I. (1766) 198. Wils. Am. Orn., VII. (1814) 52.

Anser Canadensis, Nuttall. MIan., II. 349. Aud. Orn. Biog., III. (1835) 1; V. 607. Ib., Birds Am., VI. (1843) 178.

Bernicla Canadensis, Boie. Isis (1826) 921.

\section{DESCRIPTION.}

Tail of eighteen feathers; head, neck, bill, and feet, deep-black; a large triangular patch of white on the cheeks behind the eye; the two of opposite sides broadly confluent beneath, but not extending to the rami of lower jaw; a few whitish feathers on lower eyelid; upper parts brown, edged with paler; under parts light, with a tinge of purple-gray, sometimes a shade of smoky-brown; the edges of the feathers paler; the color of the body of the feathers, though similar, becoming deeper on the sides, tibia, axillars, and inside of wings; the gray of the belly passes gradually into white on the anal region and under coverts; the upper tail coverts are pure-white; the primary quills and rump are very dark blackishbrown; the tail feathers are black; iris chestnut-brown.

Length, thirty-five inches; wing, eighteen; tarsus, three and ten one-hundredths; commissure, two and ten one-hundredths inches.

This well-known bird passes through or over New England in the spring and autumn migrations, appearing in the former about the first week in April, and passing in flocks until the 10th of that month. In the autumn, it returns as early as the last week in September; and from then until the first of December, and even later, it passes in flocks in its southern migrations. The Wild Goose, as the rule, breeds in the most northern portions of the continent: it sometimes passes the season of incubation in the limits of the United States; but the occurrences are very few of its having been found to remain in New England. I understand that it has bred on Martha's Vineyard, south of Massachusetts, several times; and I have been told of other instances, but do not consider them to be well authentizated. The nest is located in some retired place not far from the water, generally among the thickest grass, and not 
unfrequently under a bush. It is carelessly formed of dry plants of various kinds, and is of a large size, flat, and raised to the height of several inches. The eggs are usually

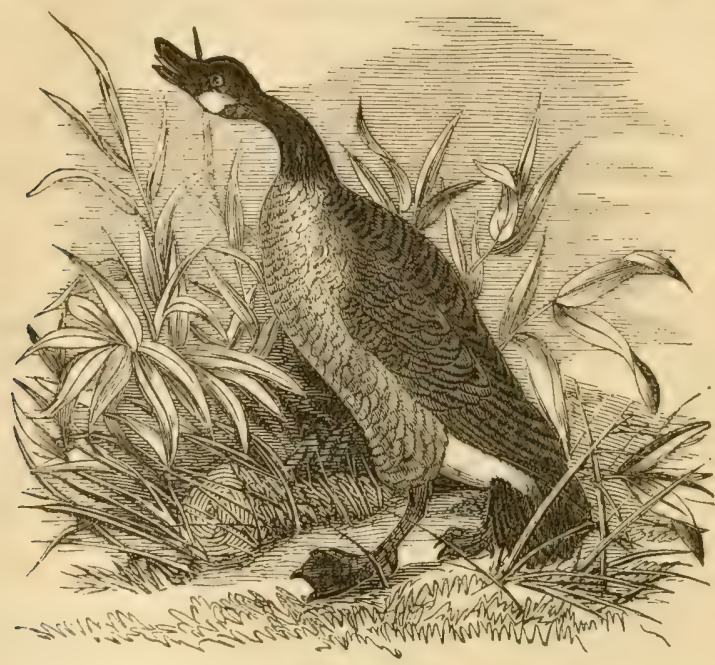

about six in number: they average three and a half inches by two and a half, are thick-shelled, rather smooth, and of a very dull yellowish-green color. The period of incubation is twenty-eight days. Wilson says of this bird:-

"Their first arrival on the coast of New Jersey is early in October; and their first numerous appearance is the sure prognostic of severe weather. Those which continue all winter frequent the shallow bays and marsh islands : their principal food being the broad, tender, green leaves of a marine plant which grows on stones and shells, and is usually called sea-cabbage; and also the roots of the sedge, which they are frequently observed in the act of tearing up. Every few days, they make an excursion to the inlets on the beach for gravel. They cross, indiscriminately, over land or water, generally taking the nearest course to their object; differing, in this respect, from the Brant, which will often go a great way round by water, rather than cross over the land. They swim well; and, if wing-broken, dive, and go a long way under water, causing the 
sportsman a great deal of fatigue before he can kill them. Except in very calm weather, they rarely sleep on the water, but roost all night in the marshes. When the shallow bays are frozen, they seek the mouths of inlets near the sea, occasionally visiting the air-holes in the ice; but these bays are seldom so completely frozen as to prevent them from feeding on the bars.

"The flight of the Wild Geese is heavy and laborious, generally in a straight line, or in two lines, approximating to a point thus, $>$ : in both cases, the van is led by an old gander, who, every now and then, pipes his well-known honk, as if to ask how they come on; and the honk of 'All's well' is generally returned by some of the party. Their course is in a straight line, with the exception of the undulations of their flight. When bewildered in foggy weather, they appear sometimes to be in great distress, flying about in an irregular manner, and for a considerable time over the same quarter, making a great clamor. On these occasions, should they approach the earth, and alight, - which they sometimes do, to rest and recollect themselves, - the only hospitality they meet with is death and destruction from a whole neighborhood already in arms for their ruin."

BERNICLA BRENTA. - Stephens.

The Brant.

Anas bernicla, Linnæus. Syst. Nat., I. (1766) 198. Wils. Am. Orn., VIII. (1814) 131.

Anser bernicla, Nuttall. Man., II. 359. Aud. Orn. Biog., V. (1831) 24, 610. 1b., Birds Am., VI. (1843) 203.

Bernicla brenta, Stephens. Shaw's Zool., XII. (1824) 46.

\section{Description.}

Bill and feet, head, neck, and body anterior to the wings, primary quills, and tail, black; the secondary quills nearly black; on each side of the middle of the neck is a small white crescent, streaked with black; the lower eyelids with a very faint trace of white feathers; the black of the jugulum is abruptly defined against the bluish silvery-gray of the remaining under parts, the feathers of which have the basal portions bluish-gray; the axillars and insides of the wings showing a darker tint of the same; the gray of the belly passes gradually into white behind, the tail being encircled all round and concealed by this color; the back and wing coverts are grayish-blue, with slightly paler edges; the rump is of a similar, but darker and more uniform blue; the secondaries have some concealed whitish on the inner webs towards the base; iris dark-hazel.

Length, twenty-three and fifty one-hundredths inches; wing, twelve and seventyfive one-hundredths; tarsus, two and twenty-six one hundredths; commissure, one and forty one-hundredths inches. 
The Brant is found on our coast pretty abundantly at the same seasons as the Canada Goose, which it resembles very much in its general habits.

Having had but few opportunities of observing this species in its wild state, I give the description, by Wilson, of its general habits: "The Brant is expected at Egg Harbor, on the coast of New Jersey, about the first of October, and has been sometimes seen as early as the 20th of September. The first flocks generally remain in the bay a few days, and then pass on to the South. On recommencing their journey, they collect in one large body, and, making an extensive spiral course, some miles in diameter, rise to a great height in the air, and then steer for the sea, over which they uniformly travel, often making wide circuits to avoid passing over a projecting point of land. In these aërial rontes, they have been met with, many leagues from shore, travelling the whole night. Their line of march very much resembles that of the Canada Goose, with this exception, that frequently three or four are crowded together in the front, as if striving for precedency. Flocks continue to arrive from the North; and many remain in the bay till December, or until the weather becomes very severe, when these also move off southwardly. During their stay, they feed on the bars at low water, seldom or never in the marshes; their principal food being a remarkably long and broad-leaved marine plant, of a bright-green color, which adheres to stones, and is called by the country people, seacabbage: the leaves of this are sometimes eight or ten inches broad, by two or three feet in length. They also eat small shell-fish. They never dive, but wade about, feeding at low water. During the time of high water, they float in the bay in long lines, particularly in calm weather. Their voice is hoarse and honking, and, when some hundreds are screaming together, reminds one of a pack of hounds in full cry. They often quarrel among themselves, and with the Ducks, driving the latter off their feeding-ground. 
Though it never dives in search of food, yet, when wingbroken, the Brant will go one hundred yards at a stretch under water, and is considered, in such circumstances, one of the most difficult birds to kill. About the 15th or 20th of May, they re-appear on their way north, but seldom stop long, unless driven in by tempestuous weather."

This bird nests in the most northern portions of the continent. The nest is similar to that of the Canada Goose. The eggs are from five to eight in number: they are ovate in form, sometimes nearly oval; and of a yellowish-white color, sometimes darkened into a creamy-buff. Their dimensions vary from 2.90 by 1.92 to 2.78 by 1.84 inch. They are very smooth to the touch, and the shell is thin and brittle.

\section{Sub-Family Anatine. - The River Ducks.}

The Anatina, or River Ducks, are easily known by their having the tarsi transversely scutellate anteriorly, and the membrane or lobe of the hind toe narrow and much restricted. The legs are longer than in Fuligulina, but shorter than in the geese.

All the North-American River Ducks agree in having the crissum black. In all, excepting Querquedula, there is a tendency to waved lines on the feathers of the flanks, most conspicuous in the Mallard, Gadwall, and Green-winged Teal.

\section{ANAS, LINNXUS.}

Anas, Livwaus, Syst. Nat. (1735). (Type Anas boschas, I., Gray.)

Bill longer than the head or the foot, broad, depressed; the edges parallel to near the end, which is somewhat acute; nail less than one-third the width of the bill; nostrils reaching to end of the basal two-fifths of the commissure; feathers of farehead, chin, and cheeks, reaching about the same point; upper angle of bill about in line with the lower; tail pointed, about two-fifths the wing.

\section{ANAS BOSCHAS. - Linnaus.}

The Mallard; Green-head.

Anas boschas, Linnæus. Syst. Nat., I. (1766) 205. Wils. Am. Orn., VIIL. i1814) 112. Aud. Orn. Biog., III. (1835) 164. Ib., Birds Am., VI. (1843) 236. 


\section{DESCRIPTION.}

Male. - Head and neck bright grass-green, with violet gloss, the top of the head duller; a white ring round the middle of the neck, below which and on the forepart and sides of the breast the color is dark brownish-chestnut; under parts and sides, with the scapulars, pale-gray, very finely undulated with dusky; the outer scapulars with a brownish tinge; forepart of back reddish-brown; posterior more olivaceous; crissum and upper tail coverts black, the latter with a blue gloss; tail externally white; wing coverts brownish-gray, the greater coverts tipped first with white, and then more narrowly with black; speculum purplish-violet, terminated with black; a recurved tuft of feathers on the rump; iris dark-brown.

Female. - With the wing exactly as on the male; the under parts plain whitishochrey, each feather obscurely blotched with dusky; head and neck similar, spotted and streaked with dusky; the chin and throat above unspotted; upper parts darkbrown, the feathers broadly edged and banded with reddish-brown, parallel with the circumference.

Length of male, twenty-three inches; wing, eleven; tarsus, one and seventy onehundredths; commissure of bill, two and fifty one-hundredths inches.

The Mallard is found in New England only as a wanderer, and then only in the western sections in the spring and autumn seasons; a few are seen in the waters of Lake

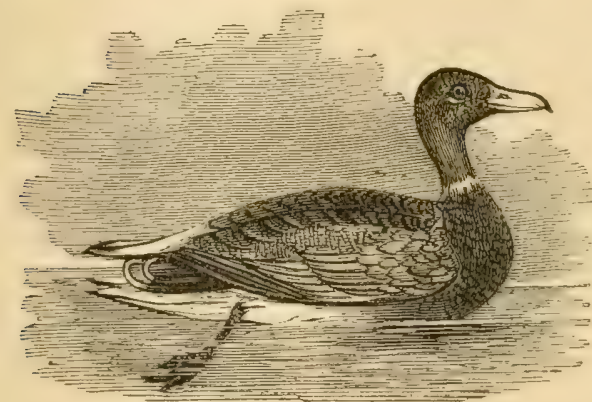

Champlain, and occasionally a small flock is found in the Connecticut River. This is the original of the Common Domestic Mallard ; and its habits are so well known that I will give no description here.

This bird breeds in all sections of the United States, more abundantly, of course, in the northern than in the southern; and less often in the eastern than in the interior and western. In most of the Western States, it is one of the most abundant of water-fowls; and it breeds in all the meadows and by the ponds and streams throughout those sections. The nest is built in a tussock of high grass, or in a thick clump of weeds. It is composed of pieces of grass and weeds, and is lined to the depth of half an inch 
with down and other soft material. The eggs are from ten to fourteen in number: they are usually ovoidal in shape, and vary in color from dirty yellowish-white to an obscure olivaceous-green. Their dimensions vary from 2.42 by 1.75 (Albion, Wis.) to 2.26 by 1.68 (Nova Scotia).

\section{ANAS OBSCURA. - Gmelin.}

The Dusky Duck; Black Duck.

Anas obscura, Gmelin. Syst. Nat., I. (1788) 541. Wils. Am. Orn., VIII. (1814) 141. Aud. Orn. Biog., IV. (1838) 15. Ib., Birds Am., VI. (1843) 244.

Anas (boschas) obscura, Nuttall. Man., II. (1834) 392.

\section{Description.}

Bill greenish; feet red; body generally blackish-brown; the feathers obscurely margined with reddish-brown; those anteriorly with a concealed V-shaped mark, more or less visible on the sides of the breast; head and neck brownish-yellow, spotted with black; the top of head and nape dark-brown, with a green gloss on the sides behind; wings dull-blackish, with a dull-greenish gloss; speculum violet, terminated with black; inner tertials hoary gray towards tip; axillars and inside of wing white; tail of eighteen feathers; iris dark-brown.

Female similar, but rather duller; the light edges to the under feathers more conspicuous; the sides of head without the greenish-gloss; the speculum bluish, with less violet.

Length of male, twenty-two inches; wing nearly twelve; tarsus, one and eighty one-hundredths; commissure, two and fifty-six one-hundredths inches.

Hab.-Atlantic region of North America; not yet detected on the Pacific, nor in Europe.

This is the most plainly marked, as well as perhaps the largest, of our river ducks, and excelled by none in the excellence of its flesh.

This species, generally but improperly known as the Black Duck, is the most abundant of all our fresh-water ducks. It breeds in all the New-England States, but is found in the greatest abundance in the more northern portions of them. The country around Lake Umbagog, Me., seems to be a favorite breeding-ground with this species; almost every paitch of meadow having one or more of its nests.

The nest is built about the last week in April or the first in May. It is placed in a secluded locality in a tussock of grass, or beneath a thicket of briers or weeds; usually in a 
meadow, near a pond or stream, but sometimes in a swamp in which a small brook is the only water for miles around. This species sometimes follows these small brooks up to their sources; and I once found one with a nest on a low stump that overhung a small spring on the side of a hill, a mile from any other water. The nest of this species is constructed of pieces of grass and weeds, which are neatly arranged into a structure eighteen inches in diameter on the outside, and three or four in depth. This is hollowed for perhaps an inch and a half or two inches, and lined with the down and feathers from the breast of the parentbird. The eggs are from seven to ten in number: their form is usually ovoidal; and their color varies from an olivaceous-yellow to a dirty yellowish-white. If a dozen of these, and an equal number of the eggs of the Mallard, are placed side by side, it is almost impossible to identify them, so closely do they resemble each other. The eggs of the present species vary from 2.50 by 1.72 inch (Lake Umbagog) to 2.26 by 1.65 (Weston, Mass.). They average about 2.34 by 1.74 (Nova Scotia). Early in September, the Dusky Duck gathers in flocks of fifteen or twenty. It is now so difficult of approach, that the experienced gumner seldom attempts to secure it by stalking it. The method by which the greater number are killed is as follows: The sportsman, knowing the localities most frequented by these flocks, - generally meadows in which streams of water or small ponds are abundant, - builds a bower near the water, about six feet square, and five or six high, of the limbs of pines and other dense foliaged trees, in which he secretes himself at daybreak, armed with one or two heary double-barrelled guns, and provided with three or four tame ducks. One of these ducks he anchors or moors out in the water, half a gunshot from the bower. The duck, soon becoming lonesome, begins to call, when, if there are any wild ducks in the neighborhood, they answer the call in an almost exactly similar note, and soon fly to 
meet the caller. The sportsman, watching the approaching flock, holds one of the other tame ducks ready to throw; and, as soon as the wild ones approach near enough to see the others, he throws towards the anchored duck the one held in his hand, which is secured from flying off, by a strong line fastened to its legs. The bird moored in the water, seeing her mate flying towards her, immediately redoubles her cries, when the Dusky Ducks, after flying back and forth, alight beside her. As soon as they alight, they gather together in a flock away from the decoy; and it is then that the sportsman pours in his first shot: he fires when the birds are rising from the water, and is often enabled to get four shots at the flock before it gets out of gunshot. The excitement attending this shooting is better appreciated when known. I have passed many days in bowars of this description, and have had my share of the excitement. It is only early in the morning and late in the afternoon that these birds can be shot in this manner; and, if they are much hunted, they will hardly approach one of these bowers without great caution. This duck remains with us through nearly the whole year, and moves southward only in very severe winters. When the fresh ponds are not frozen, it prefers them to the salt water; but in winter it is most abundant in our bays and small creeks, where it feeds on small shell-fish and other marine animals. In autumn it is one of the best flavored of our waterfowl, but in winter is not so good, having much of the fishy taste of the sea-ducks.

\section{DAFILA, LEACH.}

Dafila, "LEAch," Stephens, Shaw's Gen. Zool., XII. (1824) 226. (Type Anas acuta.)

Bill long, narrow; considerably longer than the foot; nearly linear, but widen. ing a little to the end, which is truncate, rounded; nail small; nostrils small, in the basal third of bill; tail pointed; the two middle feathers lengthened, so as nearly to equal the wings. 


\section{DAFILA ACUTA, - Jenyns.}

The Pintail; Sprigtail.

Anas acuta, Linnæus. Syst. Nat., I. (1766) 202. Wils. Am. Orn., VIII. (1814). Aud. Orn. Biog., III. (1835) 214; V. 615. Ib., Birds Am., VI. (1843) 266.

Dafila acuta, Bonaparte. List (1838).

Anas (boschas) acuta, Nuttall. MIan., II. (1834) 386.

\section{DEsCRIPTION.}

Tail of sixteen feathers; bill black above and laterally at the base; the sides and beneath blue; head and upper part of neck uniform dark-brown, glossed with green and purple behind; inferior part of neck, breast, and under parts white; the white of neck passes up to the nape, separating the brown, and itself is divided dorsally by black, which, below, passes into the gray of the back; the back anteriorly and the sides are finely lined transversely with black and white; the wings are plain and bluish-gray; the greater coverts with a terminal bar of purplish-buff, below which is a greenish-purple speculum, margined behind by black, and tipped with white; longest tertials striped with silvery and greenish-black; scapulars black, edged with silvery; crissum and elongated tail feathers black; the former edged with white.

Female with only a trace of the markings of the wing; the green of the specuIum brownish, with a few green spots; the feathers of the back are brown, with a broad U or V-shaped brownish-yellow bar on each feather anteriorly; sometimes those bars appear in the shape of broad transverse lines.

Length, thirty inches; wing, eleven; tail, eight and sixty one-hundredths; tarsus, one and seventy-five one-hundredths; commissure, two and thirty-six one hundredths inches.

Hab. - Whole of North America, and Europe.

This beautiful bird is pretty common on our shores; and it is much pursued, both for the beauty of its plumage and for the excellence of its flesh. It breeds in the most northeru portions of the continent, where, Nuttall says, "it lays eight or nine eggs of a greenish-blue color." It is seen in most abundance in the autumn on our coast, where it appears by the 10th of September, and remains until the last week in October. Wilson says it is a shy and cautious bird, feeds in the mud flats, and shallow fresh-water marshes; but rarely resides on the seacoast. It seldom dives, is very noisy, and has a kind of chattering note. When wounded, they will sometimes dive, and, coming up, conceal themselves under the bow of the boat, moving round as it moves; are vigilant in giving the alarm on the approach 
of the gunner, who often curses the watchfulness of the Sprigtail. Some Ducks, when aroused, disperse in different directions; but the Sprigtails, when alarmed, cluster confusedly together as they mount, and thereby afford the sportsman a fair opportunity of raking them with advantage. They generally leave the Delaware about the middle of March, on the way to their native regions, the North, where they are most numerous.

\section{NETTION, KAUP.}

Nettion, KAUP, Entwick (1829)。 Gray. (Type Anas crecca, L.)

Bill unusually narrow, longer than the foot; the sides parallel; the upper lateral angle not extending back as far as the lower edge; nail very narrow, linear, and about one-fifth as wide as the bill.

\section{NETTION CAROLINENSIS, - Baird.}

The Green-winged Teal.

Anas Carolinensis, Gmelin. Syst. Nat., I. (1788) 533. Aud. Birds Am., VI. (1843) 281.

Anas crecca, Wilson. Am. Orn., VIII. (1814) 101. Aud. Orn. Biog., III. (1853) $219 ;$ V. 616.

Anas (boschas) crecca, Swainson. F. Bor. Am., II. (1831) 400. Nutt. Man., II. (1834) 400.

\section{DESCRIPTION.}

Head and neck all round chestnut; chin black; forehead dusky; region round the eye, continued along the side of the head as a broad stripe, rich-green, passing into a bluish-black patch across the nape; under parts white, the feathers of the jugulum with rounded black spots; lower portion of neck all round, sides of breast and body, long feathers of flanks and scapulars, beautifully and finely banded closely with black and grayish-white; outer webs of some scapulars, and of outer secondaries black, the Iatter tipped with white; speculum broad and rich-green; wing coverts plain grayish-brown, the greater coverts tipped with buff; a white crescent in front of the bend of the wing; crissum black, with a triangular patch of buffy-white on each side; lower portion of the green stripe on each side of the head blackish, with a dull edge of whitish below; iris brown.

Males vary in having the under parts sometimes strongly tinged with ferruginous-brown.

Female with the wings as in the male; the under parts white, with hidden spots on the jugulum and lower neck; above dark-brown, the feathers edged with gray.

Length, fourteen inches; wing, seven and forty one-hundredths; tarsus, one and fourteen one-hundredths; commissure, one and sixty-eight one-hundredths inches.

$H a b$. - Whole of North America; accidental in Europe.

This beautiful little fowl is quite abundant in the spring and autumn migrations in New England; arriving in the 
former about the 10th of May, and in the latter about the second week in September, and remaining until the middle of October. It frequents fresh-water ponds and streams in small flocks, where it feeds on various water insects, their larvæ, the seeds of aquatic plants, and the tadpoles of the different frogs. Its flesh is well flavored, and, with the next species, is one of the most popular in all our markets. I have often seen individuals of this species associate with the ducks in a farmer's yard or duck-pond, and have known them to come to the barn-yard with the tame fowls, and eat with them the corn thrown out for their food. In the water, it is a graceful bird, moving about with great activity. Its flight is rapid; and accompanied with a whistling murmur different from that of most of our other ducks.

This bird probably breeds in the secluded lake districts of the northern portions of New England, as it is found in considerable abundance in localities in Nova Scotia and Canada in the same latitude. It nests early in June, sometimes by the 20th of May.

The nest is placed on the ground, in a thick patch or tussock of grass, usually in meadows within a few feet of a small pond or stream. It is constructed of, first, a thick layer of soft pieces of grass and weeds, on which is placed a thin covering of the down and feathers from the breast of the bird. The eggs are from five to eight in number: they are usually ovoidal in form, sometimes nearly oval, and vary in dimensions from 1.90 by 1.32 inch (Nova Scotia) to 1.73 by 1.22 inch. Their color is a dirty-white, with a slight greenish tint.

\section{QUERQUEDULA, STEPHENS.}

Querquedula, StePhexs, Shaw's Gen. Zool., XII. (1824). (Type Anas querque$d u l a, \mathrm{~L}$.

Bill narrow, lengthened, a little longer than the foot, widening a little to the end, which is obtusely rounded; the tail occupying about one-third the width; the lamellæ visible in the lateral profile; the upper lateral angle at the base of bill extending rather further back than the lower edge. 


\section{QUERQUEDULA DISCORS. - Stephens.}

\section{The Blue-winged Teal.}

Anas discors, Wilson. Am. Orn., VIII. (1814) 74. Aud. Orn. Biog., IV. (1838)

111. 1b., Birds Am., VI. (1843) 287.

Querquedula discors, Stephens. Shaw's Gen. Zool., XII. (1824) 149.

Anas (Boschas) discors, Swainson. F. Bor. Am., II. (1831) 444. Nutt. MIan., II. (1834) 397.

\section{Description.}

Male. - Head and neck above plumbeous-gray; top of head black; a white crescent in front of the eye; under parts from middle of the neck purplish-gray, each feather with spots of black, which become more obsolete behind; forepart of back with the feathers brown, with two undulating narrow bands of purplish-gray; feathers on the flanks banded with dark-brown and purplish-gray; back behind and tail greenish-brown; crissum black; wing coverts and some of the outer webs of scapulars blue; other scapulars velvet-black or green, streaked with pale reddishbuff; speculum glossy-green; the outer greater wing coverts white, as are the axillars, the middle of under surface of the wing, and a patch on each side of the base of the tail; bill black; feet flesh-colored; iris dark-hazel.

Female. - With the top of head brown, and the wing coverts blue and white, as in the male; base of bill, except above, chin, and upper part of the throat, dirty yellowish-white; back brown, the feathers margined with paler; under parts whitish, with rounded obscure brown spots; the jugulum darker.

Length of male, sixteen inches; wing, seven and ten one-hundredths; tarsus, one and twenty one-hundredths; commissure, one and eighty-five one-hundredths inches.

Hab. - Eastern North America to Rocky Mountains. Not yet found on the Pacific coast nor in Europe.

This species is more often found in small creeks near the seashore than the Green-winged Teal; but it prefers the small fresh-water ponds and streams to the salt water, and is most abundant in mill-ponds, where the water varies in depth in different days; there it searches in the little nooks and pools, among the half-submerged rocks and bushes, for its favorite food of aquatic insects and the seeds of aquatic plants. It arrives from the South in spring, by the latter part of April, sometimes earlier, and remains lingering in its favorite haunts until the first week in May. It proceeds slowly to the North, where it breeds; and it then returns through New England, by the middle of September, to the Southern States, where it passes the winter. It sometimes breeds in New England. George A. Boardman, Esq., has 
found it with young at Milltown, Me.; and Giraud, in his "Birds of Long Island," says that it breeds in that locality. The greater number, however, pass to the more northern countries, where they begin to lay early in June. The nests are similar to those of the Green-winged Teal, and are placed in similar localities. The eggs are from six to ten in number. They vary in form from ovate to ovoidal, and are sometimes nearly oval in shape : they are of a dirty yellowish-white color, paler than that of the eggs of the Green-winged Teal. They vary in dimensions from 1.95 by 1.35 inch (Wisconsin) to 1.74 by 1.30 inch (Labrador). The surface of both these eggs, and those of the preceding species, is covered with stains of a darker tint than the primary color; probably caused by the feet of the bird, or by the decaying vegetation which forms the nests of both species.

\section{SPATULA, BoIE.}

Spatula, BoIE, Isis (1822), 564. (Type Anas clypeata, L.)

Bill much longer than the head and spatulate, widening to the end, where it is twice as broad as at the base; nail long and narrow; lamelle of the upper mandible very close, delicate, and lengthened, projecting far below the lower edge; tail acute, less than half the wing.

\section{SPATULA CLYPEATA. - Boie.}

The Shoveller; Spoonbill.

Anas clypeata, Linnæus. Syst. Nat., I. (1766) 200. Wils. Am. Orn., VIII. (1814). Aud. Orn. Biog., IV. (1838) 241. Ib., Birds Am.; VI. (1843) 293.

Spatula clypeata, Boie. Isis (1822), 564 .

Anas (Spathulea) clypeata, Nuttall. Man., II. (1834) 375.

\section{Description.}

Head and neck green; forepart and sides of the breast, with greater portion of scapulars, and the sides of the base of the tail, white; rest of under parts dull purplish-chestnut; crissum, rump, and upper tail coverts black, the latter glossed with green; wing coverts blue, the posterior row brown in the concealed portion, and tipped with white; longest tertials blue, streaked internally with white; others velvet-green, streaked centrally with white; speculum grass-green, edged very narrowly behind with black, and then with white.

Female with the wing similar, but with the blue of coverts and scapulars less 
distinct; head and neck brownish-yellow, spotted with dusky; the belly with a decided chestnut tinge; iris reddish-orange.

Length, twenty inches; wing, nine and fifty one-hundredths; tarsus, one and thirty-eight one-hundredths; commissure, three and two one-hundredths inches.

The Shoveller is a rare species on the coast of New England; but two or three are taken in a season, and it is rarely that one is found here in the mature plumage. It is as often found in fresh-water ponds and streams as in the creeks and bays near the shore. It breeds in the most northern portions of the eastern coast; but, according to Mr. Audubon, it passes the season of incubation "from Texas westward to the Columbia River, thence to the fur countries." Says Nuttall, "Soon after March, according to Baillou, they disperse through the fens in France to breed, and select the same places with the Summer Teal; choosing with them large tufts of rushes, making a nest of withered grass in the most boggy and difficult places of access, near waters. The eggs are twelve to fourteen, of a very pale greenish-yellow: the female sits twentyfour or twenty-five days."

The Spoonbill feeds, like the other fresh-water ducks, on various aquatic insects and tadpoles; but, unlike the Teals, eats but few seeds of aquatic plants. A specimen that I examined, killed in Plymouth County, Mass., had its stomach filled with small pieces of some aquatic roots, and one or two tadpoles: there were also fragments of small crustaceans, but so small that it was impossible to identify them.

\section{CHAULELASMUUS, Gray.}

Chaulelasmus, G. R. Gray (1838). (Type Anas strepera, L.)

Bill as long as the head; the lower edge about as long as the outer toe, and longer than the tarsus; the lamellæ distinctly visible below the edge of the bill.

ChadLelasmus STREPERUS. - Gray.

The Gadwall; Gray Duck.

Anas strepera, Linnæus, Wilson, and others. 


\section{DESCRIPTION.}

Male. - Head and neck brownish-white, each feather spotted with dusky; the top of head tinged with reddish; lower part of neck, with forepart of breast and back, blackish, with concentric narrow bars of white, giving a scaled appearance to the feathers; interscapular region, outermost scapulars, and sides of the body, finely waved transversely with black and white; middle wing coverts chestnut, the greater velvet-black, succeeded by a pure-white speculum, bordered externally by hoary-gray, succeeded by black; crissum and upper tail coverts black; longest tertials hoary plumbeous-gray; innermost scapulars with a reddish tinge; inside of wing and axillars pure-white; bill black; iris hazel.

Femals. - With the bill dusky, edged with reddish; wing somewhat like that of the male, but with the chestnut-red more restricted.

Length, twenty-two inches; wing, ten and fifty one-hundredths; tarsus, one and sixty-four one-hundredths; commissure, two and four one-hundredths inches.

The Gadwall is a rare autumnal visitor in New England, and is seldom seen in the spring as it is passing to its northern breeding-places. Audubon, in describing its habits, says, -

"This species dives well on occasion, especially on being wounded. At the appearance of danger, it rises on wing - whether from the ground or from the water - at a single spring, in the manner of the Mallard; and, like it also, ascends almost perpendicularly for several yards, after which it moves off in a direct course with great celerity. I have never seen it dive on the flash of the gun ; but, when approached, it always swims to the opposite part of the pond, and, when the danger increases, flies off. On being wounded, it sometimes, by diving, makes its escape among the grass, where it squats, and remains concealed. It walks with ease, and prettily, often making incursions upon the land, when the ponds are not surrounded by trees, for the purpose of searching for food. It nibbles the tender shoots and blades of grasses with apparent pleasure; and will feed on beech-nuts, acorns, and seeds of all kinds of gramineæ, as well as on tadpoles, small fishes, and leeches. After rain, it alights in cornfields, like the Mallard, and picks up the scattered grains of maize."

The eggs of this species are from eight to twelve in number. Their color is a pale-drab, with a slight olivaceous tint: 


\section{their form is a long ovoid; and their dimensions average about 2.15 inch in length by 1.50 inch in breadth.}

\section{MARECA, StepHeNS}

Mareca, Sternens, Shaw's Gen. Zool., XII. (1824) 130. (Type Anas Penelope, I.)

Bill shorter than the head, and equal to the inner toe claw; the sides parallel to near the end, which is rather obtusely pointed, the nail occupying the tip, and about one-third as broad as the bill; bill rather high; the upper lateral angle at the base not prominent, nor extending as far back as the lower edge; tail pointed, not lialf the wings.

The North-American and European species of MFareca have the upper parts finely waved transversely with black and gray or reddish-brown; the under parts, with the usual exceptions, snowy-white. The top of the head is uniform white or cream-color; the neck more or less spotted; the middle and greater coverts are white, the latter tipped with black; the speculum is green, encircled by black; the tertials are black on the outer web, edged with hoary-white; the entire outer web of one of them hoary.

\section{MARECA AMERICANA.-Slephens.}

\section{The American Widgeon; Baldpate.}

Anas Americana, Gmelin. Syst. Nat., I. (1788) 526. Wils. Am. Orn., VII. (1814) 86. Aud. Orn. Biog., IV. (1838) 337. Ib., Birds Am., VI. (1843) 259.

Mareca Americana, Stephens. Shaw's Gen. Zool., XII. (1824) 135.

Anas (Boschas) Americana, Nuttall. Man., II. (1834) 389.

\section{DESCRIPTION.}

Male. - Tail of fourteen feathers; bill blue, the extreme base and tip black; head and neck pale-buff, or faint reddish-yellow, each feather banded narrowly with blackish, so as to give the appearance of spots; the top of the head from the bill is pale unspotted creamy-white; the sides of the head from around the eye to the nape, glossy-green, the feathers, however, with hidden spots, as described; chin uniform dusky; forepart of breast and sides of body light-brownish or chocolate-red, each feather with obsolete grayish edge; rest of under parts pure-white; the crissum abruptly black; the back, scapulars, and rump, finely waved transversely anteriorly with reddish and gray, posteriorly with purer gray, on a brown ground; a little of the same waving also on the sides; the lesser wing coverts are plain gray; the middle and greater are conspicuously white, the latter terminated by black, succeeded by a speculum, which is grass-green at the base, and then velvet-black; the tertials gre black on the outer web, bordered narrowly by black, the outermost one hoarygray; externally edged with black; the tail is hoary-brown; the upper coverts are black externally; the axillars are white; iris hazel.

The blackish chin appears to be found only in very highly plumaged birds. The top of the head is sometimes pure-white.

The female has the head and neck somewhat similar, but spotted to the bill; wings as in the male; the black of tertials replaced by brown; the gray of the lesser coverts extending slightly over the middle ones; back and scapulars with rather 
broad and distant transverse bars of reddish-white, each feather with two or three interrupted along the shafts; these are much wider and more distant than in the male.

Length, twenty-one and seventy-five one-hundredths inches; wing, eleven; tarsus, one and forty-two one-hundredths; commissure, one and eighty one-hundredths inches.

Hab. - Continent of Northamerica. Accidental in Europe.

This beautiful bird is found in small flocks of four or five individuals in the spring and fall migrations, and is more often found in the fresh-water ponds and streams in the interior than in the salt water on the coast.

It breeds in the Hudson's Bay Country, early in June. The nest is placed on the ground, as I am informed, in the marshes and sterile plains of that country, and resembles very much the nest of the common Black or Dusky Duck. The eggs are from eight to twelve in number. They resemble those of the Blue-winged Teal in form and color, being a dirty yellowish-white. They average in dimensions about 2.05 by 1.50 inch.

The food of this bird consists principally of the tender leaves and roots of aquatic plants, which it obtains, when in company with the Canvas-back, by stealing from that bird; the latter diving, and bringing it up from the bottom of the water, and the Widgeon seizing it when he appears at the surface.

\section{AIX, BoIE.}

Aix, Bore, Isis (1828), 329. (Type Anas galericulata, L.)

Bill very high at the base, where the upper lateral angle runs back much behind the lower edge of the bill; nostrils very large, and scarcely enveloped by membrane; the feathers of the forehead reaching to their posterior edge; nail very large, and much hooked, occupying the entire tip of bill; lamellæ depressed, broad, and distant; bill, from feathers of forehead, shorter than the head, and equal to the tarsus; head crested; claws short, much curved, and very sharp; tail, about half the wings, vaulted, cuneate, but truncate at the tip; the coverts nearly as long as the feathers.

\section{AIX SPONSA. - Boie.}

The Summer Duck; Wood Duck.

Anas sponsa, Linnæus. Syst. Nat., I. (1766) 207. Wils. Am. Orn., VIII. (1814)

97. Aud. Orn. Biog., III. (1835) 52; V. 618. Ib., Birds Am., VI. (1843) 271.

Aix sponsa, Boie. Isis (1828), 329.

Anas (Boschas) sponsa, Nuttall Man., II. (1834) 394. 


\section{DESCRIPTION.}

Head and crest metallic-green to below the eyes; the cheeks, and a stripe from sehind the eye, purplish; a narrow short line from the upper angle of the bill along the side of the crown and through the crest, another on the upper eyelid, a stripe starting below and behind the eye, and running into the crest paralle. with the one first mentioned, the chin and upper part of the throat sending a well-defined branch up towards the eye, and another towards the nape, snowy-white; lower neck and jugulum, and sides of the base of tail, rich-purple; the jugulum with triangular spots of white and a chestnut shade; remaining under parts white, as is a crescent in front of the wing bordered behind by black; sides yellowish-gray, finely lined with black; the long feathers of the flanks broadly black at the end, with a subterminal bar, and sometimes a tip of white; back and neck above nearly uniform bronzed-green and purple; scapulars and innermost tertials velvet-black, glossed on the inner webs with violet; the latter with a white bar at the end; greater coverts violet, succeeded by a greenish speculum, tipped with white; primaries silvery-white externally towards the end; the tips internally violet and purple; iris bright-red.

Female with the wings quite similar; the back more purplish; the sides of the head and neck ashy; the region round the base of the bill, a patch through the eyes, and the chin, white; the purple of the jugulum replaced by brownish; the waved feathers on the sides wanting.

Length, nineteen inches; wing, nine and fifty one-hundredths; tarsus, one and forty one-hundredths: commissure, one and fifty-four one-hundredths inches.

$H a b$. - Continent of North America.

This, the most beautiful of all our Ducks, is pretty abundantly distributed through New England in the breeding season. Wilson's description of its habits is so much better than I can give, that I make a liberal extract from it. He says, -

"The Summer Duck is equally well known in Mexico and many of the West India Islands. During the whole of our winters, they are occasionally seen in the States south of the Potomac. On the 10th of January, I met with two on a creek near Peterssurg, in Virginia. In the more northern dis-

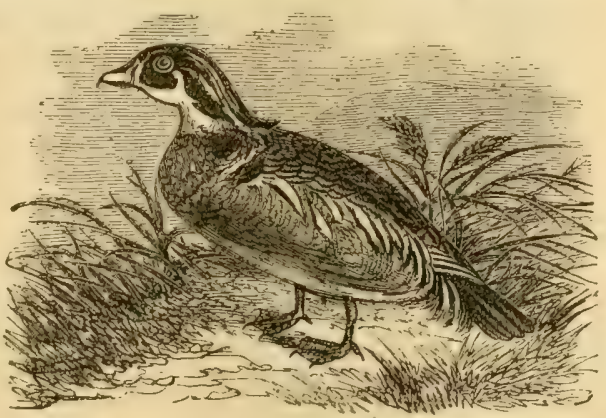
tricts, however, they are migratory. In Pennsylvania, the female usually begins to lay late in April, or early in May. Instances 
have been known where the nest was constructed of a few sticks laid in a fork of the branches: usually, however, the inside of a hollow tree is selected for this purpose. On the 18th of May, I visited a tree containing the nest of a Summer Duck, on the banks of Tuckahoe River, New Jersey. It was an old, grotesque white oak, whose top had been torn off by a storm. It stood on the declivity of the bank, about twenty yards from the water. In this hollow and broken top, and about six feet down, on the soft, decayed wood, lay thirteen eggs, snugly covered with down, doubtless taken from the breast of the bird. These eggs were of an exact oval shape, less than those of a Hen; the surface exceedingly fine-grained, and of the highest polish, and slightly yellowish, greatly resembling old, polished ivory. The egg measured two inches and an eighth by one inch and a half. On breaking one of them, the young bird was found to be nearly hatched, but dead, as neither of the parents had been observed about the tree during the three or four days preceding, and were conjectured to have been shot.

"This tree had been occupied, probably by the same pair, for four successive years, in breeding-time: the person who gave me the information, and whose house was within twenty or thirty yards of the tree, said that he had seen the female, the spring preceding, carry down thirteen young, one by one, in less than ten minutes. She caught them in her bill by the wing or back of the neck, and landed them safely at the foot of the tree, whence she afterwards led them to the water. Under this same tree, at the time I visited it, a large sloop lay on the stocks, nearly finished: the deck was not more than twelve feet distant from the nest; yet, notwithstanding the presence and noise of the workmen, the Ducks would not abandon their old breeding-place, but continued to pass out and in, as if no person had been near. The male usually perched on an adjoining limb, and kept watch while the female was laying, and also often while she was sitting. A tame Goose had chosen a hollow space, at the root of the same tree, to lay and hatch her young in.

"The Summer Duck seldom flies in flocks of more than three or four individuals together, and most commonly in pairs or singly. The common note of the Drake is peet, peet; but when, standing sentinel, he sees danger, he makes a noise not unlike the crowing 
of a young cock, oe eek! oe eek! Their food consists principally of acorns, seeds of the wild oats, and insects. Their flesh is little inferior to that of the Blue-winged Teal. They are frequent in the markets of Philadelphia."

The eggs of the Summer Duck are of a dirty yellowishwhite color. Their form varies from ovate to nearly oval; and their dimensions vary from 2.20 by 1.55 (Wisconsin), to 2.10 by 1.55 (Maine), and 1.98 by 1.45 (Massachusetts).

This species is easily domesticated, and soon becomes very tame. It breeds in confinement, and soon acquires all the habits of the domestic Mallard, but prefers a hollow tree or stump for its resting-place.

Mr. O. Brewer, editor of the "Boston Cultivator," has, at his residence in West Roxbury, Mass., a large flock of these birds, which he has raised himself; and they are certainly the most beautiful and interesting pets that $I$ have seen.

\section{Sub-Family Fuligulinæ. - The Sea Ducks.}

The chief character of the Fuligulina, as compared with the Anatince, consists in the greatly developed lobe or membranous flap attached to or suspended from the inferior surface of the hind toe; the feet are usually enormously large, the tarsi short, the legs set far back, and the whole organization well fitted for swimming and diving: many of the species live on or near the seacoast, although most of them straggle more or less through the interior of the countries they inhabit.

\section{FULIX, SUNdeVAlL.}

Fulix, Sunderald, Kong. Vet. Ak. Hand. (1835). (As restricted.)

Bill longer than the tarsus, and about equal to the head, and to the middle toe without the nail; feathers of cheeks, chin, and forehead advancing but slightly, and to about the same distance; nostrils open, situated in the anterior portion of the basal two-fifths of the bill, not reaching the middle; edges of bill about parallel, or widening to the tip; profile gently concave to the nail, which is decurved; nail not one-third the width of the bill, and forming only the central portion of its tip; tarsus about half the middle toe and claw; bill as long as the feet; tail short, rounded, of fourteen feathers; head and neck black. 


\section{FULIX MARILA, - Baird.}

The Scaup Duck; Big Black Head; Blue Bill.

Anas marila, Linnæus. Syst. Nat., I. (1766) 196. Wils. Am. Orn., VIII. (1814) 84.

Fuligula marila, Audubon. Birds Am., VII. (1843) 355. Gir. Birds L. Island, (1844) 321.

\section{DESCRIPTION}

Hedd and neck all round, jugulum and shoulders, lower part of back, tail, and coverts, black; the head with a gloss of dark-green on the sides; rest of under parts white; feathers on the lower parts of belly and on the sides, the long feathers of the flanks, the interscapulum, and the scapulars, white, waved in zigzag transversely with black; greater and middle wing coverts similarly marked, but more finely and obscurely; greater coverts towards the tip and the tertials greenish-black; the speculum is white, bordered behind by greenish-black; the white extending across the whole central portion of the secondaries; outer primaries and tips of all, brownish-black; inner ones pale-gray; the central line dusky; axillars and middle of the inferior surface of the wing white; bill blue; the nail black; legs plumbeous; iris yellow.

Female with the head brown; the region all round the base of the bill white; the undulations of black and white on the feathers wanting, or but faintly indicated above.

Length, twenty inches; wing, nine; tarsus, one and fifty-eight one-hundredths inches; commissure, two and sixteen one-hundredths inches.

Hab. - Whole of North America and Europe.

This species is, although not abundant, generally met with on our coast in spring and fall. It seldom penetrates far inland, but prefers the bays and mouths of creeks on the shore, where it has all the habits of the sea Ducks. I have known of its being taken in small numbers on Punkapoag Pond, Massachusetts, where it associated with the common Dusky Duck. Giraud, in his "Birds of Long Island," speaks of it as being very abundant on our coasts; arriving from the North from the 10th to the 20th of October in large flocks. My experience has been, that it is far from being an abundant species; and that it is more often seen in flocks of not more than eight or ten birds than in larger parties. Its habits, however, may vary in different localities ; and it may be abundant, like many other species, in some sections, when it is comparatively scarce in others.

It passes to the most northern countries to spend the 
season of incubation on our coast; but, in the interior, it is an abundant breeder, - in the lake country, in Wisconsin, and other localities in similar latitudes. It nests on the ground ; forming, as I am told, a nest of grass and weeds in a marshy swamp, very similar to the nest of the Mallard that breeds in the same localities.

The eggs are from six to ten in number: they are of an ovate form, sometimes nearly oval; and are of a dirty paledrab color, with a slight tint of olivaceous.

They vary in dimensions from 2.32 by 1.60 to 2.26 by 1.52 inch (both sizes from Wisconsin).

FULIX AFFINIS. - Baird.

The Little Black-head; Blue Bill.

Fuligula marila, Audubon. Orn. Biog., III. (1835) 226; V. (1839) 614. Ib., Birds Am., VI. (1843) 316.

Fuligula minor, Giraud. Birds L. Island (1844), 323.

\section{DESCRIPTION.}

Bill blue; the nail black; head, neck, forepart of breast, and back anterior to the shoulder, lower part of back, tail and its coverts, black; the head with violet purple reflections, changing occasionally to green; the belly and sides, with axillars, and central portion of inner surfaces of wings pure-white; the lower part of the belly, near the anus, undulated finely with black spots; the interscapular region and scapulars white, with transverse zigzag bands or lines of black, these lines much further apart in the scapulars, which consequently are whiter; wings blackish; the lesser and middle coverts sprinkled with grayish; the speculum is white, edged behind by greenish-black, the color also of the tertials; the white of the speculum goes across the middle of the secondaries; iris yellow.

The female has the wing nearly similar; the black replaced by brownish; the region round the base of the bill whitish; the marbling or mottling almost entirely wanting.

Length, sixteen and fifty one-hundredths inches; wing, eight; tarsus, one and thirty-four one-hundredths; commissure, one and ninety-four one-hundredths inch.

This species resembles the former in its general habits, but is more abundant on our coast, where it is generally known to our gunners by the name of "Blue-bill Coot." It appears in our creeks and bays early in October, and remains with us until late in November, and even later, if the season is mild and open. 
"The food of the Scaup Duck I have found to consist of small fry, cray-fishes, and a mixture of such grasses as here and there grow along the beds of our rivers." - АШDUBON. It is an expert diver, and can remain a considerable time under water. When wounded, it often dives, and, clinging to the weeds or rocks at the bottom of the water, remains there until dead; and often the bird does not rise to the surface until the whole warmth of it has left its body, when the muscles, losing their contraction, permit the bird to float off. Very often it does not come to the surface at all, when thus wounded and dying, but remains like a stone on the bottom until its parts become separated by the waves, or by crabs or other crustaceans. Of the breeding habits and nest of this bird I am ignorant. I have but a single egg in my collection, from Youkon. This is ovoidal in form, of a dirty pale-drab color, and is 2.25 inch in length, and 1.60 at its greatest breadth.

\section{AYTHYA, Bore.}

Aythya, Boie, Isis (1822). (Type Anas ferina, L.)

Very similar to Fuligula in general characters of shape; the bill elongated, longer than the head, and about equal to the middle toe with the claw; the bill more slender in one species, the nail smaller and less decurved; the bill higher at base, and the upper outline nearly straight to beyond the end of the nostrils, which do not quite reach the middle of the bill; colors similar to those of Fuligula; the head and neck red; tail of fourteen feathers.

\section{AYTHYA AMERICANA. - Bonaparte.}

\section{The Red Head.}

Anas ferina, Wilson. Am. Orn., VIII. (1814) 84.

Fuligula ferina, Nuttall. Man., II. (1834) 434. Aud. Orn. Biog., IV. (1835) 198. Ib., Birds Am., VI. (1843) 311.

Description.

Bill as long as the head, broad, blue, the end black; the region anterior to the nostrils dusky; head, and neck for more than half its length, brownish-red, glossed above and behind with violaceous-red; rest of neck and body anterior to the shoulders, lower part of back and tail coverts, black; beneath white, sprinkled with gray and black anterior to the crissum; the sides, interscapulars, and scapulars finely lined with undulating black and white in nearly equal proportions, imparting a 
general gray tint; wing coverts bluish-gray, finely sprinkled with whitish; the speculum, consisting of the ends of the secondaries, hoary grayish-blue, lightest externally, and the innermost narrowly edged externally with black; basal portion of inner primaries somewhat similar to the speculum; tail of fourteen feathers; iris orange-yellow.

This species, with a strong resemblance to the Canvas-back, is readily distinguished by the shorter, broader bill, absence of brown on the head, and a greater predominance of black in the waved lines; this being equal in amount to the white, instead of much less.

Female with the head, neck; and forepart of body, brownish; the region round the base of the bill whitish.

Length of male, twenty and fifty one-hundredths inches; wing, nine and fifty one-hundredths; tarsus, one and sixty one-hundredths; commissure, two and thirty one-hundredths inches.

Hab. - Whole of North America.

This handsome bird is pretty abundant on our shores, where it usually prefers the small bays and estuaries of creeks : it is also found in many of our large tracts of fresh water, where it feeds on the tender leaves and roots of the rarious aquatic plants, and small fish, and larvæ of aquatic insects. I found several specimens of both sexes in the Umbagug Lakes in June; and I think it not impossible, that, if it does not breed there, it will be found to breed in some of the lake regions of northern New England. For it is observed, in various localities, as late as the first week in June; and it can be hardly possible that all the birds thus observed are barren.

The habits of this species so much resemble those of the succeeding species, that the same remarks will apply to both.

\section{AYTHYA VALLISNERIA. - Bonaparte.}

The Canvas-back Duck.

Anas vallisneria, Wilson. Am. Orn., VIII. (1814) 103.

Fuligula vallisneria, Nuttall. Man., II. 430.

Aythya vallisneria, Bonaparte. List (1838).

Fuligula vallisneriana, Audubon. Orn. Biog., IV. (1838) 1. Ib., Birds Am., VI. (1843) 299. 


\section{Description.}

Bill long, slender, and tapering; head all round and neck chestnut; the top of the head and region around the base of the bill dusky-brown; rest of neck, body anterior to the shoulders, back behind, rump and tail coverts, black; under parts white; the region anterior to the anus, the sides, the interscapulars and scapulars, white, finely dotted, in transverse line, with black, the white greatly predominating; speculum bluish-gray, lighter externally; the innermost secondaries of the speculum edged externally with black; iris carmine.

Female with the black and chestnut replaced by brown, the cheeks and chin lighter, and some tinged with dull-rufous.

Length, twenty and ten one-hundredths; wing, nine and thirty one-hundredths; tarsus, one and seventy one-hundredths; commissure, two and sixty-five inches.

The Canvas-back is rarely taken in New England. I have seen a few that were killed in Punkapoag Pond, Canton, Mass. J. A. Allen speaks of its being occasionally found at the western part of the State; and I once killed one in Lake Umbagog, Me. It generally passes to its northern breeding-grounds, and back to its winter home, through the interior of the country, seldom by the seaboard, at least north of Pennsylvania; and, when found in New England, is only a wanderer from the great flight.

Wilson, in describing its habits, says, -

"The Canvas-back Duck arrives in the United States from the north about the middle of October : a few descend to the Hudson and Delaware; but the great body of these birds resort to the numerous rivers belonging to and in the neighborhood of the Chesapeake Bay, particularly the Susquehanna, the Patapsco, Potomac, and James Rivers, which appear to be their general winter rendezvous. Beyond this, to the south, I can find no certain accounts of them. At the Susquehanna, they are called Canvas-backs; on the Potomac, White-backs; and on James River, Sheldrakes. They are seldom found at a great distance up any of these rivers, or even in the salt-water bay, but in that particular part of tide-water where a certain grass-like plant grows, on the roots of which they feed. This plant, which is said to be a species of vallisneria, grows on fresh-water shoals of from seven to nine feet (but never where these are occasionally dry), in long, narrow, grass-like blades, of four or five feet in length: the root is white, and has some resemblance to small celery. This grass is in 
many places so thick that a boat can with difficulty be rowed through it, it so impedes the oars. The shores are lined with large quantities of it, torn up by the Ducks, and drifted up by the winds, lying; like hay, in windrows. Wherever this plant grows in abundance, the Canvas-backs may be expected, either to pay occasional visits, or to make it their regular residence during the winter. It occurs in some parts of the Hudson; in the Delaware, near Gloucester, a few miles below Philadelphia; and in most of the rivers that fall into the Chesapeake, - to each of which particular places these Ducks resort; while, in waters unprovided with this nutritive plant, they are altogether unknown.

"On the first arrival of these birds in the Susquehanna, near Havre-de-Grace, they are generally lean; but such is the abundance of their favorite food, that, towards the beginning of November, they are in pretty good order. They are excellent divers, and swim with great speed and agility. They sometimes assemble in such multitudes as to cover several acres of the river, and, when they rise suddenly, produce a noise resembling thunder. They float about these shoals, diving, and tearing up the grass by the roots, which is the only part they eat. They are extremely shy, and can rarely be approached, unless by stratagem. When wounded in the wing, they dive to such prodigious distances, and with such rapidity, continuing it so perseveringly, and with such cunning and active vigor, as almost always to render the pursuit hopeless. From the great demand for these Ducks, and the high price they uniformly bring in market, various modes are practised to get within gunshot of them. The most successful way is said to be decoying them to the shore by means of a dog, while the gunner lies closely concealed in a proper situation. The dog, if properly trained, plays backwards and forwards along the margin of the water; and the Ducks, observing his manœurres, enticed perhaps by curiosity, gradually approach the shore, until they are sometimes within twenty or thirty yards of the spot where the gunner lies concealed, and from which he rakes them, first on the water, and then as they rise. This method is called tolling them in. If the Ducks seem difficult to decoy, any glaring object, such as a red handkerchief, is fixed round the dog's middle or to his tail; and this rarely fails to attract them. Sometimes, by moonlight, the sports- 
man directs his skiff towards a flock whose position he had previously ascertained, keeping within the projecting shadow of some wood, bank, or headland, and paddles along so silently and imperceptibly as often to approach within fifteen or twenty yards of a flock of many thousands, among whom he generally makes great slaughter.

"Many other stratagems are practised, and, indeed, every plan that the ingenuity of the experienced sportsman can suggest, to approach within gunshot of these birds : but, of all the modes pursued, none intimidate them so much as shooting them by night; and they soon abaudon the place where they have been thus repeatedly shot at. During the day, they are dispersed about, but, towards evening, collect in large flocks, and come into the mouths of creeks, where they often ride as at anchor, with their head under their wing, asleep; there being always sentinels awake, ready to raise an alarm on the least appearance of danger. Even when feeding and diving in small parties, the whole never go down at one time, but some are still left above on the lookout.

"When the winter sets in severely, and the river is frozen, the Canvas-backs retreat to its confluence with the bay; occasionally frequenting air-holes in the ice, which are sometimes made for the purpose, immediately above their favorite grass, to entice them within gunshot of the hut or bush, which is usually fixed at a proper distance, and where the gunner lies concealed, ready to take advantage of their distress. A Mr. Hill, who lives near James River, at a place called Herring Creek, informs me, that, one severe winter, he and another person broke a hole in the ice, about twenty by forty feet, immediately over a shoal of grass, and took their stand on the shore in a hut of brush, each having three guns well loaded with large shot. The Ducks, which were flying up and down the river, in great extremity, soon crowded to this place, so that the whole open space was not only covered with them, but vast numbers stood on the ice around it. They had three rounds, firing both at once, and picked up eighty-eight Canvas-backs, and might have collected more, had they been able to get to the extremity of the ice after the wounded ones. In the severe winter of 1779-80, the grass, on the roots of which these birds feed, was almost wholly destroyed in James River. In the month of January, the wind 
continued to blow from W.N.W. for twenty-one days, which caused such low tides in the river, that the grass froze to the ice everywhere; and, a thaw coming on suddenly, the whole was raised by the roots, and carried off by the fresh. The next winter, a few of these Ducks were seen; but they soon went away again: and, for many years after, they continued to be scarce; and, even to the present day, in the opinion of my informant, have never been so plenty as before."

The delicacy of the flesh of this bird for food is so well known that any remarks here seem superfluous; but I will say that it does not greatly excel that of the Red Head, and in my own opinion is not at all superior to that of the Teals or Widgeon.

The Canvas-back breeds in the most northern portions of the continent. I am ignorant of its habits in the season of incubation, and have but one egg in my collection to describe from. This is of an ovate form, nearly oval, of a pale-blue color with an olivaceous tinge, quite smooth to the touch, and quite thin and brittle. Its dimensions are 2.54 by 1.78 inch.

\section{BUCEPHALA, BAIRD.}

Clangula, Flemixg, Philos. Zool. (1828). (Type Anas clangula, L.) Not of 1822, which has Anas glacialis for type, according to G. R. Gray.

Bill, from feathers of forehead, about equal to the tarsus, and shorter than the head; high at the base; lateral outlines tapering to the tip, where the nail forms only the central portion, though rather large; nostrils situated near the middle of the bill; feathers of chin and forehead extending only moderately forward, a littlo further than those of the cheeks; tarsus rather more than half the foot; tail moderately long, about half the wing, and somewhat pointed; of sixteen feathers.

BUCEPHALA ISLANDICA. - Baird.

Barrow's Golden Eje.

Fuligula (Clangula) Barrowii, Nuttall. Man., II. 444.

Fuligula clangula, Audubon. Orn. Biog., V. (1839) 105. Ib., Birds Am., VI. (1843). 


\section{DescritTION.}

Head and neck all round bluish-violet, occasionally with green or purplish reflection; a large white patch anterior to the eye, occupying the entire side of the bill, and running up in a point on the forehead; lower neck and under parts generally white; a narrow white patch on the middle wing coverts; the greater coverts black, tipped with white, which is continuous with the white secondaries, but separated from that on the middle coverts; anterior seapulars white, edged externally with black; the posterior ones black, with white central streak; rest of upper parts black, as are the sides behind, and including the tibia; long feathers of the flank white, tipped and edged above with black.

Length, twenty-two and tifty one-liundredths inches; wing, nine and fifty onehundredths; tarsus, one and fifty-eight one-hundredths inches; commissure, one and eighty one-hundredths inches.

IIab. - Iceland, and northern parts of America. In winter, not rare on the St. Lawrence.

This species is found in considerable numbers on our north-eastern coast, in the winter months. It breeds in the aretic portions of the continent, but has all the other habits of the succeeding species.

\section{BUCEPHALA AMERICANA. - Baird.}

\section{The Golden Eyo; Whistle Wing.}

Anas clangula, Wilson. Am. Orn., VIII. (1814) 62.

Fuligula (Clangula) clangula, Bonaparte. Syn., (1828) 393. Nutt. Man., II. 441.

Fuligula clangula, Audubon. Orn. Biog., IV. (1838) 318. Ib., Birds Am., VI. (1843) 362. 167.

Clangula Americana, Bonaparte. Comp. List (1838). Eyt. Mon. Anat. (1838)

\section{Descimtion.}

Bill black; head and upper part of neck glossy-green; the under surface opaque velvety purplish-black; an elliptical patch along the base of upper mandible anterior to the eye, lower part of neck, under parts generally, and sides, middle and greater wing coverts, the innermost secondaries (and tertials, except the innermost three or four), white; the white on the wing is in a continuous patch, although there is a concealed black bar on the bases of the greater coverts; the inner scapulars are white, margined externally with black; posteriorly, however, they are black, streaked centrally with white; the inner scapulars and tertials, and the whole back, rump, and lesser wing coverts, are black; the primaries and tail black, with a hoary gloss; the under side of quills and lower greater coverts are plumbeous-gray; the rest of the under wing and the axillars are sooty-brown; the long white feathers of the flanks are edged superiorly with black; iris golden yellow.

Female with the head and neck above snuff-brown, without white patch; white of wing less extended; the middle coverts only touched with white; there is a ten- 
dency to a black bar across the tips of the greater coverts; the white of the wing sometimes well defined.

Length, eighteer and seventy-five one-hundredths inches; wing, eight and fiftyonc-hundredths; tarsus, one and fifty one-hundredths; commissure, two inches.

IIab. - Whole of North America.

This handsome species is a common spring and autumn resident in New England; and in mild winters is often seen, bath in the bays and rivers on the coast, and in the lakes and ponds in the interior, when they are open. It breeds in the northern portions of New England, particularly in the lake country of Northern Maine. I have found it, in the breeding season, in Lake Umbagrog, and in the Magalloway River; but, although I searched carefully for its nest, I could not find it. This might have been, and probably was, owing to the nature of the nesting-place; for I saw several pairs, and the localities were those which this bird selects for the purpose of incubation.

The nest of this species is built in a hole, in a tall dead tree, or in the top of a tall stub, which is hollowed sufficiently for its reception. The pines and hemlocks often die; and, standing for years, the bark drops off, then the limbs; until the body is at last left, a single straight, smooth, white shaft, often from forty to fifty feet high, and two or three feet thick at its base. At last, in a fierce storm or gale, the shaft either breaks off close to the ground, or at sometimes the height of twenty or more feet; leaving, in the top that remains standing, a huge rent, sometimes a foot or even more in depth. In this the Golden Eye nests; building of grass, leaves, moss, and down from its own breast, a warm structure, in which she lays from six to ten eggs. These are generally very rounded in form, of a greenish-blue color, and average from 2.40 by 1.75 inch to 2.36 by 1.78 inch in dimensions. The loud whistling of the wings of this species, as it passes through the air, has given it the name of the "Whistler." The bird feeds on small fish and various aquatic plants, and, when living in the interior, is 
a fine-flavored fowl for the table; but, when killed on the coast, its flesh is fishy and strong. It is a bird of very rapid flight, and is rather shy and difficult of approach.

\section{BOCEPHALA ALBEOLA. - Baird.}

The Bufle-head; Dipper; Butter-ball.

Anas albeola, Linnæus. Syst. Nat., I. (1766) 199. Wils. Am. Orn., VIII (1814) 51.

Fuligula (Clangula) albeola, Bonaparte. Syn. (1828) 394. Nutt. Man., II. 445.

Fuligula albeola, Audubon. Orn. Biog., IV. (1838) 217. Ib., Birds Am., VI. (1843) 369.

\section{DESCRIPTION.}

Male. - Bill blue; head and neck anteriorly, dark-colored; the region in front of the eye and on the sides of the collar behind, rich-green, this color shading into purplish on the upper and under surfaces of the head; a broad patch on each side of the head from the posterior border of the eye, and meeting its fellow on the nape, the lower neck all round, under parts generally, wing coverts (except the lesser) and most of the secoldaries, and the scapulars, white; the latter narrowly edged externally with black; rest of upper parts, except as described, black; passing gradually on the upper tail coverts into pale-gray; axillars and undor wing coverts sooty-brown, more or less tipped with white; iris hazel.

Female. - With the entire head, neck, and upper parts almost black; an elongated patch behind and below the eye (not reaching it); the outer webs of some secondaries, and the under parts, white; the jugulum, sides, and anal region, plumbeousgray.

Length, fifteen inches; wing, six and sixty-five one-hundredths; tarsus, one and twenty-five one-hundredths; commissure, one and forty-four one-handredths inch.

Thiis very common and well-known bird is abundant on our coast in the spring and autumn. It associates with most of the other Sea Ducks in our bays and creeks, but, in the interior, is seen only in pairs, or in small flocks of three or four individuals. It is an expert diver; and one finds difficulty in shooting it when there are two or three individuals together, from its habit of diving at the flash of the gun. I have seen it at times, particularly after a severe storm, in small fresh-water ponds, in the interior; and, at such times, it is quite tame and unsuspicious, or possibly fatigued from its efforts in the. storm. It feeds on small fish and crustaceans, which it is very expert at catching. When several birds are together, one always remains on the 
surface while the others are below in search of food, and, if alarmed, it utters a short quack, when the others rise to the surface; and, on ascertaining the cause of the alarm, all dive and swim off rapidly to the distance of several hundred feet. The Buffle-head breeds in the northern portions of the continent. It nests in the holes of dead trees, like the preceding. The eggs are from five to eight in number.

\section{HISTRIONICUS, LESSON.}

Mistrionicus, Lesson, Man. d'Ornith., II. (1828) 415. (Type Anas histrionica, L.)

Bill very small; the culmen shorter than tarsus, tapering rapidly to the rounded tip, which is entirely occupied by the nail; nostrils small, in the anterior portion of posterior half of bill; the centre about opposite the middle of commissure; a wellmarked angle at the postero-superior corner of the bill; the lateral outline concave behind, the feathers on forehead extending a little beyond it; those of chin not reaching further than those of the sides, and much posterior to the nostrils; lateral outline of edge of bill nearly straight; a membranous lobe at the base of the bill; tertials bent outward, so as to cross the edge of the wing; tail more than half the wing, considerably pointed, of fourteen feathers.

\section{HISTRIONICUS TORQUATUS, - Bonaparte.}

The Harlequin Duck.

Ancs histrionica, Linnæus. Sy'st. Nat., I. (1758) 127. Wils. Am. Orn., VIII. (1514) 139.

Fuligula (Clangula) histrionica, Bonaparte. Syn. (1828), 394. Nutt. Man., II. 448.

Fuligula histrionica, Audubon. Orn. Biog., III. (1835) 612; V. (1839) 617. Ib., Birds Am., VI. (1843) 374.

\section{DESCRIPTION.}

Male. - Head and neck all round dark-blue; jugulum, sides of breast, and upper parts, lighter blue, becoming bluish-black again on the tail coverts; the blue of breast passes insensibly into dark bluish-brown behind; a broad stripe along the top of head from the bill to the nape, and the tail feathers, black; a white patch along the entire side of the base of bill anterior to the eye, and passing upwards and backwards so as to border the black of the crown, but replaced from above the eye to the nape by chestnut; a round spot on the side of the occiput; an elongated one on the side of the neck; a collar round the lower part of the neck, interrupted before and behind, and margined behind, by dark-blue; a transversely elongated patch on each side the breast, and similarly margined; a round spot on the middle wing coverts, a transverse patch on the end of the greater coverts, the scapulars in part, a broad streak on the outer web of tertials, and a spot on each side the rest of the tail, white; sides of body behind chestnut-brown; secondaries with a metallic speculum of purplish or violet-blue; inside of wing, and axillars, dark-brown; iris reddish-brown. 
Female. - With the head and body above, dark-brown; the chin more plumbeous; the lower part of neck, breast, and under parts generally, except the central region (which is white), duller and lighter brown; a whitish patch in front of the eye, and a rounded spot just behind the ear.

Length, seventeen and fifty one-hundredths inches; wing, seven and seventy one-hundredths; tarsus, one and forty-eight one-hundredths; commissure, one and fifty-four one-hundredths inches.

Hab. - Northern seacoast of northern hemisphere.

The Harlequin Duck is very rare in Southern New England, and is seldom met with here south of the most northern portions on its coast. There it is pretty abundantly seen as a winter visitor. It greatly resembles the following in its general characteristics. Its nest and eggs are thus described:

"The nest is composed of dry plants of various kinds, arranged in a circular manner to the height of three or four inches, and lined with finer grasses. The eggs are five or six, rarely more, measure two inches and one-sixteenth by one inch and four and a half eighths, and are of a plain greenish-yellow color. After the eggs are laid, the female plucks the down from the lower parts of her body, and places it beneath and around them."

\section{HARELDA, LEACH.}

"Harelda, LeAch (1816)," Gray. (Type Anas glacialis, L.)

Bill shorter than the head and tarsus, tapering laterally to the end; the nail very broad, occupying the entire tip; lateral profile of lower edge of upper mandible straight to near the end, then rising suddenly to the prominent decurved nail; nostrils large, in the posterior half of the bill, their centre about opposite the middle of the commissure; tertials long, lanceolate, and straight; tail pointed, of fourteen feathers, the central feathers very long, equal to the wings; bill with almost no posterior lateral upper angle; the feathers of the sides advancing obliquely forwards; feathers of chin reaching beyond the middle of the commissure, or almost to the anterior extremity of nostrils; tail of fourteen feathers.

HARELDA GLACIALIS. - Leach.

The South Southerly; 0ld Wife; Long-tail.

Anas glacialis, Wilson. Am. Orn., VIII. (1814) 93, 96.

Fuligula (Harelda) glacialis, Nuttall. Man., II. (1834) 453.

Fuligula glacialis, Audubon. Orn. Biog., IV. (1838) 103. Ib., Birds Am., VI. (1843) 379 


\section{DESCRIPTION.}

If ale in summer. - Bill black, orange-yellow towards the tip; head, neck, and breast, very dark blackish-brown; the head above, back, rump, and middle tail feathers, black; the whole side of the head from the bill and to behind the eyes and the sides of the body, pale bluish-gray; the portion of the cheek patch immediately around and behind the eye with a longitudinal streak each side the occiput; the under parts generally, and the more external tail feathers, white; feathers on the fore part of the back, with the scapulars, broadly edged with light reddish-brown; under wing coverts and axillars brownish-chocolate; no white whatever on the wing.

Male in winter.-Differs from summer dress in having the head and neck white to the jugulum and interscapular region; the gray of the cheeks persistent, and a broad patch of black on the sides of the neck behind this; the scapulars are pale pearl-gray; iris white.

Female. - Lacks the long points to the tail and scapulars; the head and neck dusky, with a whitish patch around the eye and on the sides of the neck behind.

Length, twenty and seventy-five one-hundredtbs inches; wing, eight and ninety one-hundredths; tail, eight; tarsus, one and thirty-eight one-hundredths; commissure, one and sixty-two one-hundredths inches.

The Long-tailed Duck, so common in Massachusetts Bay in the fall and spring migrations, breeds in the most northern portions of the continent.

Audubon, in describing the nest and eggs, says, -

"The nest was placed under an alder-bush, among rank weeds, not more than eight or nine feet from the edge of the water, and was formed of rather coarse grass, with an upper layer of finer weeds, which were neatly arranged, while the down filled the bottom of the cavity. [ [This was on the 28th of July, 1833. The young birds had left this nest.] The number of young broods in sight induced me to search for more nests; and in about an hour I discovered six more, in one of which I was delighted to find two unhatched eggs. They measured two inches and one-eighth long, by one and four and a half eighths broad; were of a uniform pale yellowish-green, and quite smooth."

In the months of September and October, this bird is most abundant in New England. It gathers in immense flocks, and frequents the bays and inlets on the shore, where, keeping up its peculiar cry or chatter, the noise of the flock is sometimes to be heard at the distance of a mile. It is in this season, that the gunner, with his 
sail-boat or float, pursues these birds with great activity. On approaching one of these large flocks, it is customary to steer the boat to the windward of it; for they, like most other fowls, always rise to the windward. When, therefore, the gunner arrives within gunshot, he fires into the flock while it is in the water; and when it rises, and flies to the windward, often directly over his boat, he pours into it sometimes three or four other charges before it gets out of shot. It is a difficult bird to kill; and, when wounded, it always dives and clings to the bottom, where it dies. I once brought down seven birds out of a flock at one discharge, when they dove, and I did not secure one. Its flesh is oily and strong, and is in no repute for the table.

\section{MELANETTA, BoIE.}

Feathers extending nearly as far forward on the sides of the bill as the nostril, leaving the edges only free from the base; bill very broad; nail broad and almost truncate.

\section{MELANETTA VELVETINA. - Baird.}

\section{The Velvet Duck; White-winged Coot.}

Anas fusca, Wilson. Am. Orn., VIII. (1814) 137.

Fuligula (Oidemia) fusca, Bonaparte. Syn. (1828), 390. Nutt. Man., II. (1834) 419.

Fuligula fusca, Audubon. Orn. Biog., III. (1835) 354. Ib., Birds Am., VI. (1843) 332.

\section{DESCRIPTION.}

Male. - Bill very broad, wider towards the tip than at the base; feathers extending far along the side of the bill, and on the forehead, for nearly half the commissure, running in an obtuse point about as far forward as the lower corner of the outline of feathers on the side, both reaching nearly to the posterior border of the large, open, nearly rounded nostrils; culmen horizontal a little beyond the frontal feathers, then abruptly bent downwards, nearly perpendicularly, to the much-depressed, nearly horizontal portion; a sharp indented ridge along the base of culmen, ending in a trihedral tubercle; color black; a white elongated patch around and a little behind the eye, and a large white speculum on the wing, composed of white secondaries and tips of greater coverts; bill black at base and lateral edges; red elsewhere; iris bright-yellow.

Female. - Somewhat similar, but lighter beneath; a large whitish patch on the side of the head behind the eye, but none around it; wings with white speculum, somewhat as in the male; bill also similar, but less swollen and elevated at base. 
Length, twenty-one and fifty one-hundredths inches; wing, eleven and thirty one-hundredths; tarsus, two and eight one-hundredths; commissure two and eighty-two one-hundredths inches.

Hab. - Along both coasts of North America to the north.

The Velvet Duck, or "White-winged Coot," as it is com. monly called on our coast, is a very abundant species, in the autumn and through the greater part of the winter, in the bays and inlets along our whole shores. It is one of the Sea Ducks ; and, although occasionally found in small numbers in the large bodies of water in the interior, it is seldom seen in large flocks in any other localities than the salt waters of the seacoast. There it is taken in abundance from the first week in October until the middle of December. The sportsmen, with decoys made of wood, painted to resemble these fowls, anchor their small boats in localities where the Coots are known to pass; and, from early dawn until late in the forenoon, and from late in the afternoon until night, keep up a constant fusillade on the swiftly moving flocks. I have known two gumners to secure, in one day's shooting, thirty pairs of these birds; and this large number is often exceeded.

The "Coots" are hunted more for the excitement" of the thing than for the sake of their flesh; for, living as they do, entirely on fish and a few mollusks, their flesh is strong and oily, and far from pleasant. This species breeds in Labrador and other northern localities. "The nests are placed within a few feet of the borders of small lakes, a mile or two distant from the sea, under the low boughs of the bushes of the twigs of which, with mosses and various plants matted together, they are formed. They are large, and almost flat, several inches thick, with some feathers of the female, but no down, under the eggs, which are usually six in number, $2 \frac{3}{4}$ inches in length by $1 \frac{7}{8}$ in breadth, and of a uniform pale-cream color tinged with green." 


\section{PLLIONETTA, KAUP.}

Feathers not extending on sides of the bill ; nail pointed anteriorly; colors black, with a triangular white patch on the top of head and another on nape; bill red, with a rounded black lateral spot at base.

\section{PELIONETTA PERSPICILLATA, - Kaup.}

The Surf Duck; Sea Coot; Butter-bill Coot.

Anas perspicillata, Wilson. Am. Orn., VIII. (1814) 49.

Fuligula (Oidemia) perspicillata, Bonaparte. Syn. (1828), 389. Nutt. Man., II. 416 .

Fuligula perspicillata, Audubon. Orn. Biog., IV. (1838) 161. Ib., Birds Am., VI. (1843) 337.

\section{Description.}

Male. - Tail of fourteen feathers; bill but little longer than the head, the feathers extending forward half-way from the base to the tip, and opposite the posterior border of the nostril; the bill abruptly decurved or gibbous anterior to the end of the feathers; nostrils open, nearly semicircular or stirrup-shaped, the straight portion of the outline antero-inferior; sides of bill swollen at the base so as to be further apart above than below; color, entirely black throughout, with a greenish lustre above, duller beneath; a triangular white patch on the top of head, the base extending between the posterior outline of the eye and reaching forward to a point a little beyond the posterior line of the bill, the outlines rounded laterally and anteriorly; the patch is separated from the eye by a narrow superciliary black space; there is a second triangular white patch beginning on the nape as a straight line the width of the other patch, and running backwards for more than two inches; these triangular spaces are thus base to base; iris yellowish-white.

Female. - Bill as long as that of the male, but not swollen at the base, where the sides approach each other above; the feathers of forehead do not extend one-third the distance from base to tip of bill; the middle of nostril not quite as far as the middle of the bill; nostrils linear, acutely pointed anteriorly; color brown; lighter on the neck; sides and beneath the under surface of the body whitish; an obscure whitish patch at the base of the bill, and another on the side of the head behind the eyes.

Length of male, nineteen inches; wing, nine and forty one-hundredths; tarsus, one and sixty-three one-hundredths; commissure, two and thirty-seven one-hundredths inches.

$H a b .-O n$ and near seacoast of North America, quite far south in winter; accidental in Europe.

The Surf Duck, or "Butter-bill Coot," as it is usually called on the coast, is equally abundant with the preceding. Like all the Sea Ducks, this bird is an expert diver. I have followed a flock of Sea Coots for hours in a small yacht, with a good breeze, and have been unable to get within 
gunshot of them, and without their taking wing even at that. As soon as I arrived within two or three gunshots' distance, the whole flock sank, beneath the surface like so many stones; and, swimming under water for almost a quarter of a mile, appeared at the surface in a locality where I least expected to see them: sometimes immediately astern of my boat; at others, in a direction at right angles to the course which I supposed they had taken.

Audubon, in describing a nest that he found in a boggy marsh near the Gulf of St. Lawrence, says, -

"The nest was snugly placed amid the tall leaves of a bunch of grass, and raised fully four inches above its roots. It was entirely composed of withered and rotten weeds, the former being circularly arranged over the latter; producing a well-rounded cavity, the borders of which were lined with the down of the bird, in the same manner as the Eider Duck's nest; and in it lay five eggs, which were two inches and two and a half eighths in length, by one inch and five-eighths in their greatest breadth. They were more equally rounded at both ends than usual, the shell perfectly smooth, and of a uniform pale-yellowish or cream color."

\section{OIDEMIA, FLEMING.}

Oidemia, Fremixa, "Philos. Zool. (1822)." (Type Anas nigra, L.)

Bill much swollen at base, the terminal portion much depressed and very broad; nail broad, occupying the terminal portion of the bill; nostrils situated anterior to the middle of the commissure; feathers of the chin running forwards as far as the nostrils; color black with or without small patches of white.

\section{OIDEMIA AMERICANA. - Swainson.}

The Scoter.

Anas nigra, Wilson. Am. Orn., VIII. (1814) 135.

Fuligula Americana, Audubon. Orn. Biog., V. (1839) 117. Ib., Birds Am., V1. :1843) 343.

\section{DESCRIPTION.}

Male. - Tail of sixteen feathers; bill much swollen on the basal third; the basal portion of culmen convex, and rapidly descending; the terminal portion of bill much depressed; the anterior extremity of nostrils half-way from the lateral or upper feathers at the base of bill to the tip; the swelling at base of bill divided by a furrow along the median line; the frontal feathers extend slightly forward in an obtuse 
point; bill of female not very dissimilar, lacking the swelling at the base; color entirely black all over, without any white; bill black along the edges and tip; the swollen basal portion red to beyond the nostrils.

Female. - Brown: lighter on sides of head, throat, and under surface of body, where the feathers have each an obscure dusky spot.

Length, twenty-three and eighty one-hundredths inches; wing, nine and twenty one-hundredths; tarsus, one and seventy-eight one-hundredths; commissure, two and fourteen one-hundredths inches.

This species is also known on the coast by the name of Coot. It is far less abundant than the other, but has all the habits of that bird. It also associates with it, and is a very expert diver; sinking beneath the surface of the water, at the flash of a gun, before the shot reaches it. I know nothing of its breeding habits, and have no eggs by me for description.

\section{SOMATERIA, LEACI.}

isomateria, LeAcri, in Fleming's Philos. Zool. (1822). (Type Anas mollissima, L.)

Bill much compressed, tapering to the tip; the nail enormously large, and forming the terminal portion of the bill, and much decurved; the feathers of forehead advancing forward in an acute long point, separating on each side a frontal extension or linear process, or the feathers of the cheek may be said to extend a considerable distance along the commissural edge of the bill; nostrils situated anterior to the middle of the commissure; tail rather pointed, but short, of fourteen feathers.

\section{SOMATERIA MOLLISSIMA. - Leach.}

\section{The Eider Duck.}

Anas mollissima, Wilson. Am. Orn., VIII. (1814) 122.

Fuligula (Somateria) mollissima, Bonaparte. Syn. (1828), 388. Nutt. Man., II. (1834) 407.

Fuligula mollissima, Audubon. Orn. Biog., III. (1835) 344; V. 611. Ib., Birds Am., VI. (1843) 349.

\section{DESCRIPTION.}

Tail of fourteen feathers; prevailing color white; the under surface and sides of body, hinder part of back, rump, and tail, black; wings white on both surfaces, except the quills, which are black; narrow margin inferiorly of the frontal process of bill and the forehead violet-black, this color bifurcating opposite the middle of the eye, and continued broadly on each side the head to the nape, the color extending a little below the eye; the white below and behind the black glossed with transparent emerald-green; the interopace white; iris brown.

Length, twenty-six inches; wing, eleven and twenty-four one-hundredths; tarsus, one and eighty-two one-hundredths; commissure, two and fifty-three one-hundredths inches. 
This is another of our Sea Ducks that is very abundant in the bays and inlets of our coast during the fall and winter months, and until April in the spring.

The history of its habits and distribution is so well known, that any account here is hardly needed.

It breeds in abundance in Labrador and other northern portions of the con-

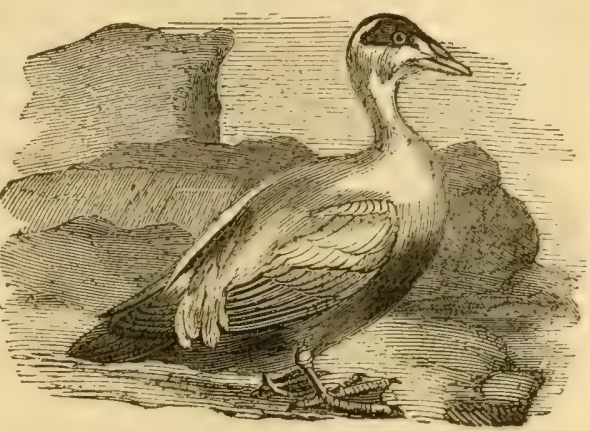
tinent, and a few pass the season of incubation on the islands in the Bay of Fundy; this being the nearest point to our coast that it breeds in at present, although it is said to have formerly reared its young on the islands off Cape Ann in Massachusetts, and off the coast of Maine.

The nest is placed on the ground beneath the shelter of a low bush or thick bunch of weeds or grass. It is constructed, first, of a thin layer of grasses and weeds, on which the female deposits a thick layer of down, which she pulls from her breast. This is deeply hollowed; and in this warm receptacle, the eggs, from six to eight or ten in number, are deposited. These are of a dirty pale-green color, and their form is varied from ovate to a sharply pointed ovoidal. Their dimensions vary from 3.22 by 2.10 inches to 2.82 by 1.98 inch.

\section{SOMATERIA SPECTABILIS, - Leach.}

The King Eider.

Anas spectabilis, Linnæus. Syst. Nat., I. (1766) 195. Gm., I. 567.

- Fuligula (Somateria) spectabilis, Bonaparte. Syn. (1828), 389. Nutt. Man., II. 1834) 414.

Fuligula spectabilis, Audubon. Orn。 Biog., III. (1835) 523。 Ib., Birds Am., VI. i1843) 347. 


\section{DESCRIPTION.}

Body and wings black; the portion anterior to the shoulder joint, interscapular region in part, most of neck and throat, white; the jugulum with a creamy tinge; a narrow border to the frontal processes of the bill and their interspace; small space round the eye and a V-shaped mark on the chin black; top of head and nape bluish-ash, slightly spotted with black; middle wing coverts, tips of secondaries, axillars, and most of under surface of wing, with a patch on each side of the rump, white; sides of head glossed with transparent emerald-green; the scapulars have the black tinged with slate.

Length, twenty-one and fifty one-hundredths inches; wing, ten and seventy onehundredths; tarsus, one and eighty-six one-hundredths; commissure, two and fifty-three one-hundredths inches.

The King Eider is a rare species on our coast in the winter months. It is a more northern species than the preceding, and seldom reaches as far south as the coast of Massachusetts. It is of similar habits with the other Sea Ducks, and breeds in the most northern sections of the country. The eggs found by Captain James Clark Ross, R.N., measure $2 \frac{5}{8}$ inches by $1 \frac{3}{4}$, have a smooth shell, and are of a uniform dull-greenish color.

\section{Sub-Family Erismaturine.}

The most prominent character of the Erismaturince is found in the very rigid tail feathers with the much abbreviated coverts, which leave the greater portion of the tail exposed. There are peculiarities in the nail at the end of the bill in Erismatura not found in the other sub-families.

\section{ERISMATURA, BONAPARTE.}

Erismatura, Bonaparte, Saggio, etc. (1832).

Bill broad, rather high at the base, much depressed, and bent upwards; upper lateral angle of bill running back on the forehead some distance, farther than the lower edge of the bill; nostrils reaching to the middle of the bill, rather small; portion of nail seen from above very narrow and linear; bent abruptly downwards and backwards at the tip, so as to be invisible from the upper surface; tarsi very short, scarcely more than one-third the long feet; tail very stiff, of eighteen feathers; the coverts above and below very much abbreviated, so as to expose the greater part of the tail; the feathers narrow, linear; the shafts very large, and channelled on the under surface near the base; wings very short, and incurved at the end. 
ERISMATURA RUBIDA.-Bonaparte.

\section{The Ruddy Duck; Dipper Duck.}

Anas rubida, Wilson. Am. Orn., VIII. (1814) 128, 130.

Anas (Fuligula) rubida, Bonaparte. Obs. Wils. (1825), 268.

Fuligula (Gymnura) rubida, Nuttall. Man., II. (1834) 426.

Fuligula rubida, Swainson. F. Bor. Am., II. (1831) 455. Aud. Orn. Biog., IV. (1838) 326. Ib., Birds Am., VI. (1843) 324.

Erismatura rubida, Bonaparte. List (1838).

\section{DESCRIPTION.}

Bill grayish-blue; top of head and nape black; sides of head below the eyes. with the chin, pure opaque-white; lower part of neck all round, and the entire upper parts, with upper portion of sides, chestnut-red ; under parts generally lustrous grayish-white, with an occasional brownish tinge; crissum pure-white; wings brown, without speculum, finely and almost inappreciably sprinkled with gray; tail nearly black; iris hazel.

Female with the entire upper parts dark-brown; the back and wing coverts finely sprinkled with grayish; the under parts brownish-white, tinged with greenish-brown across the lower part of neck; the brown of the head comes down below the level of the eye, and there is an obscure dusky stripe parallel with its lower outline, from the commissure.

The continuity of the white of the under parts is interrupted by the occasional appearance of the basal brown of the feathers, owing to the shortness of the white tip, which thus gives rise to the appearance of dusky transverse bands.

Length, sixteen inches; wing, five and eighty one-hundredths; tarsus, one and twenty-six one-hundredths; commissure, one and eighty one-hundredths inches.

$H a b$. - Whole of North America; abundant throughout the interior.

This pretty little Sea Duck is not very common on our coast. It visits us only late in the autumn, and remains until early spring, frequenting the bays and inlets along the shore, where it feeds on small fish and mollusks, which it obtains by diving. It is so expert a diver that sportsmen recognize it by the name of "Ruddy Diver" and "Dipper ;" and all attest to the difficulty with which it is shot.

\section{Sub-Family Mergine. - The Sheldrakes.}

Bill very slender, narrow, compressed, terminated by a conspicuous nail; edges much serrated, the serrations projecting; tarsi much compressed; the scales anteriorly large and transverse, becoming smaller and smaller on the sides and behind; tail feathers eighteen in North-American species. 
The Mergince, or Fishing Ducks, are represented in the United States by three well-established species, placed by modern systematists in as many genera. Two of these, however, are so nearly alike that I prefer to consider them as the same: the third is sufficiently distinct.

\section{MERGUS, LINN EUS.}

Mergus, Linndeus, Syst. Nat. (1735). (Type M. castor, L.)

Bill longer than the head, mostly red; serrations conical, acute, recurved; crest occipital, pointed, or depressed; tarsus about two-thirds the middle toe; tail about half the length of wings.

\section{MERGUS SERRATOR.-Linnous.}

The Red-breasted Merganser.

Mergus serrator, Linnæus. Syst. Nat., I. (1766) 208. Wils. Am. Orn., VIII. (1814) 81. Nutt. Man., II. (1834) 463. Aud. Orn. Biog., V. (1839) 92. Ib., Birds Am., VI. (1843) 395.

\section{Description.}

Feathers of the forehead extending on the bill in a short obtuse angle, and falling far short of the end of those on the sides; the outline of the latter sloping rapidly forwards, and reaching half-way from the posterior end of the lower edge of bill to the nostrils, and far beyond those on the side of lower jaw; nostrils narrow, posterior; their posterior outline opposite the end of basal third of commissure.

Male. - Head with conspicuous pointed occipital crest; head and upper part of neck, all around, dark-green; under parts reddish-white; jugulum reddish-brown, streaked with black; sides conspicuously barred transversely with fine lines of black; feathers anterior to wing white, margined with black; white of wing crossed by two bars of black; iris red.

Female. - Head with compressed occipital crest; chestnut-brown; body above ash; beneath reddish-white; the black at base of secondaries exposed; outer tertials white, edged with black.

Length, twenty-three and twenty-five one-hundredths inches; wing, eight and sixty one-hundredths; tarsus, one and eighty one-hundredths; commissure, two and seventy-six one-hundredths inches.

Hab. - Whole of North America and Europe.

This species is quite abundant on our coast in the autumn and winter months. It does not appear to be gregarious to a great extent; for seldom more than three or four individuals are observed together. It is an expert diver, swimming to a great distance beneath the water at the least alárm, and, when appearing at tho surface, usually only thrusting its head out to reconnoitre. I have seen it swimming, with only the bill and upper part of its head above water, in the 
wake of a boat from which it had been wounded: and it actually followed for a considerable distance before it was discovered. I have noticed, in other Sea Ducks, this trait of following behind a boat, and conclude that it is done for concealment.

I am not aware that this species breeds in New England. It breeds in localities in the same latitude with the most northern sections of these States; but I am inclined to think that it is less of a southern species than the succeeding.

It is described as selecting for its nesting-place a small island, usually in the neighborhood of the sea, sometimes in the interior. "The nest is very large; at times raised seven or eight inches on the top of a bed of all the dead weeds which the bird can gather in the neighborhood. Properly speaking, the real nest, however, is not larger than that of the Dusky Duck, and is rather neatly formed externally of fibrous roots, and lined round the edges with the down of the bird." There are usually about eleven eggs. These are generally nearly oval in shape, sometimes ovoidal. They are of a pale yellowish-drab color, much darker than those of the Sheldrake. They vary in dimensions from 2.63 by 1.82 inch to 2.48 by 1.75 inch.

\section{MERGUS AMERICANUS, - Cassin.}

The Goosander; Sheldrake; Fish Duck.

Mergus merganser, Wilson. Am. Orn., VIII. (1814) 68. Nutt. Man., II. (1834) 469. Aud. Orn. Biog., IV. (1838) 261. Ib., Birds Am., VI. (1843) 387.

Mergus Americanus, Cassin. Pr. A. N. Sc. (1853), 187.

DEscription.

Feathers of the forehead extending on the bill in an acute angle for half the distance between those on the sides and the nostril; outline of those on the sides nearly vertical, and reaching only a little beyond the beginning of lower edge of bill, but as far as those on the side of lower jaw; nostril large, far forward, its middleropposite the middle of the commissure.

Jiale. - Head without conspicuous crest; head and neck green; forepart of back black; beneath salmon-color; wings mostly white, crossed by one band of black: sides scarcely barred transversely; iris carmine. 
Female. - Head with a compressed occipital crest; head and neck chestnut, above ashy; beneath salmon-colored; white of greater coverts with a terminal bar of ashy (sometimes wanting); the black of base of secondaries entirely concealed; outer tertials ash.

Head without conspicuous crest, though one is visible in life. Head and most of neck all round very dark green; rest of neck and the body generally, except the upper part, creamy-white, deepening to salmon-red beneath. Lower part of back, rump, and tail feathers, plumbeous; forepart of back, interscapular region, and inner scapulars, black.

Length, twenty-six and fify one-hundredths inches; wing, eleven; tarsus, one and eighty-four one-hundredths; commissure, two and ninety one-hundredths inches.

Although this species is found on our coast through the autumn and winter months, where it has all the habits of the other Sea Ducks, it breeds in the neighborhood of freshwater lakes and streams far in the interior. It is one of the most abundant summer residents in the lake region of Northern Maine, and about the Umbagog Lakes and Richardson Lakes it is the most common Duck.

There, in the top of some tall stump, or in a high forked branch of a dead pine, it builds its nest. In many localities on the borders of these lakes, the spring inundations or some other causes have destroyed whole acres of gigantic hemlocks, which, standing for years, become, in consequence of the bark falling off, perfectly smooth and difficult of ascent. When such trees are broken at the height of thirty or forty feet from the ground, leaving a jagged top, no better nesting-place can be found; because it not only secires the bird and eggs from the attacks of predaceous animals, but it guarantees to the nest a perfect security from any inundations that may arise. This nest is built of leaves, moss, and pieces of grass, which are arranged in a deep layer, on which a thin covering of down from the breast of the bird is placed. This is hollowed to the depth of two or three inches, and it is ready for the eggs. These are from seven to twelve in number. Their form is almost always exactly oval. Their color is a pale creamy-white; sometimes a little darker, almost a very pale buff. They vary in dimensions from 2.80 by 1.80 inch (Milltown, Me.) to 2.50 by 1.70 inch. 


\section{LOPHODYTES, REICHART.}

Lophodytes, Reichart, Syst. Av. (1852).

Bill shorter than the head, black; serrations compressed, low, short, inserted obliquely on the edge of bill; the point truncated, and not recurved nor acute; tail more than half the wings; tarsi short, half the feet; head with a much compressed, vertical, circular, and erect crest.

But a single species of this genus is known to naturalists.

\section{LOPHODYTES CUCULLATUS. - Reichart.}

The Hooded Merganser.

Mfergus cucullatus, Linnæus. Syst. Nat., I. (1r66) 207. Wijls. Am. Orn., VIII. 79. Nutt. Man., II. 465. Aud. Orn. Biog., III. (1835) 246; V. 619. Ib., Birds Am., VI. (1843) 402.

Lophodytes cucullatus, Reichart. Syst. Av. (1852).

\section{DESCRIPTION.}

Head with an elongated, compressed, semicircular crest; anterior extremity of nostril reaching not quite as far as the middle of commissure; frontal feathers extending nearly as far as half the distance from lateral feathers to nostril; the latter much beyond the feathers on side of lower mandible; bill shorter than head.

Male. - Bill black; head, neck, and back, black; under parts and centre of crest white; - sides chestnut-brown, barred with black; white anterior to the wing, crossed by two black crescents; lesser coverts gray; white speculum with a basal and median black bar; black tertials streaked centrally with white; iris yellow.

Female. - With a shorter and more pointed crest; the head and neck reddish brown; the back without pure-black; the sides without transverse bars; the white of wings less extended.

Length, seventeen and fifty one-hundredths inches; wing, seven and ninety onehundredths; tarsus, one and twenty one-hundredtbs; commissure, one and ninetv. eight one-hundredths inches.

Hab. - Whole of North America.

This beautiful bird is less common than either of the other Mergansers on our coast and in our bays and inlets, in autumn, winter, and early spring. In the summer, it resides in the interior, where it breeds by the lakes and other bodies of fresh water; building its nest in holes in high dead trees, or on the tops of stubs, thirty or forty feet from the ground, exactly like the Sheldrake. The eggs are from nine to twelve or fourteen in number, usually about ten. They are of a clear-white color, although their surface is, in some specimens, stained by the moisture from the 
feet of the bird. They are very thick-shelled, and, when struck together, sound almost like balls of ivory. They are more spherical in form than the eggs of any other duck that I have seen, and are but little more pointed at one end than at the other. Their dimensions vary from 2.30 by 1.75 inches (the longest and narrowest specimen in a large number in my collection) to 2.10 by 1.80 inches (the shortest and broadest specimen in the same): the usual size is, on the average, about 2.13 by 1.70 inches. I am not aware that any nest of this bird has been found south of Lake Umbagog.

When the nest of this species is approached, the female remains quiet, and flies off only when alarmed by blows on the trunk of the tree on which her nest is built. She then flies silently, and alights in the lake, near which the nest is usually built, and watehes the intruder from a safe distance, without making any outcries or disturbance. If the tree is surrounded by undergrowth so thick that she cannot see the intruder from the water, she flies silently over and around him, always at a safe distance. The male never shows himself on such occasions; and I think it likely that he separates from his mate at the commencement of the period of incubation, and remains by himself until the young are able to provide for themselves.

When living in the neighborhood of fresh water, this bird has many of the habits of the other Mergansers, and then feeds on aquatic insects and their larva, and is an expert fisher and diver.

When the female is suddenly surprised, while with her young in a stream or pond, she gives a guttural, chattering cry, when the whole brood dives and swims off under water to the shore, where they conceal themselves in the aquatic herbage. While they are thus retreating, the mother simulating lameness, almost exactly like some of the shore-birds on the beach, flutters before the intruder, using every artifice to decoy him from the neighborhood of her young, 
when she takes wing, and flies off. If, however, she have sufficient notice of the approach of a person before he reaches gunshot she swims rapidly off, with her whole brood paddling behind her, until she turns a point or neck in the pond or stream where she happens to be, when, silently creeping into shore, she, with her brood, hides herself in the herbage on the land until the danger is

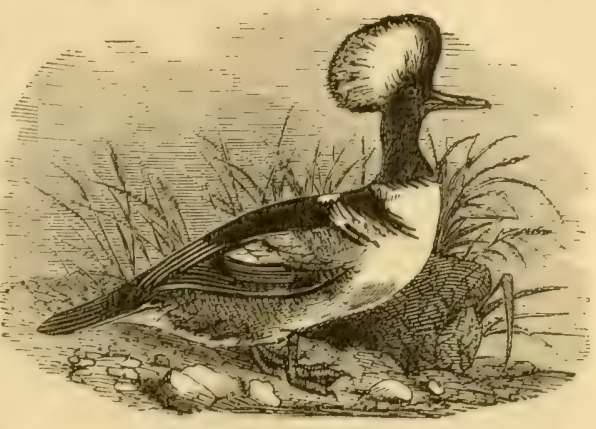
past. When about two-thirds grown, these young Mergansers, like the young of most of the other fowls, are excellent eating. They are called "Flappers," because of their habit of flapping their wings on the water to aid their escape from pursuers.

This species, in passing with its young from one body of water to another, often, while flying, carries them singly in its mouth; and I have been told, that even after it has been shot and has fallen to the ground, it not unfrequently holds the chick. Mr. George A. Boardman informs me that the female of the Summer Duck often encroaches on the nest of this Merganser; and he once witnessed an attempt of the latter to drive the other from her domicile, of which she had taken possession, and in which she was engaged in the duties of incubation. He watched them, and noticed, that, when the Wood-duck left the nest, the Merganser took possession of it; and, when she left it, the other did the same. 


\section{SUB-ORDER GAVIA.}

\section{Famity SULID E. The Gannets.}

Bill rather long, straight, sides compressed, very strong, tapering to the point, which is a little decurved; nostrils hardly observable; wings very long; tail long and cuneate; toes long, and all joined by full webs; gular sac moderate.

\section{SULA, BRIssoN.}

Sula, Brisson, Ornith. (1760). (Type Pelecanus bassanus.)

Bill rather longer than the head, straight, stout at the base, with the sides compressed, grooved near the tip, which is a little curved, the cutting edges serrated irregularly; nostrils basal and scarcely perceptible; wings lengthened; tail rather long and much graduated; tarsi short and stout; toes long, and joined together by full webs; claws moderate, the middle one serrated; gular sac rather moderate.

These birds usually frequent almost inaccessible rocky islands, where they congregate in great numbers during the season of reproduction, at other times migrating along the coast. 'Their flight is rapid, powerful, and long-continued.

SULA BASSANA. - Brisson.

\section{The Common Gannet; Solan Goose.}

Pelecanus bassanus, Linnxus. Syst. Nat. (1766), 217.

Sula bassana, Nuttall. Man., II. (1834) 495. Aud. Orn. Biog., IV. (1838) 222. Ib., Birds Am., VII. (1844) 44.

\section{DESCRIPTIOX.}

General color of the plumage white; bill bluish-gray; bare space around the eye and on the throat blackish-blue; primaries brownish-black, first longest.

Adult. - The color of the plumage generally is white, the head and hind neck being of a fine buff-yellow; alula and primaries brownish-black; shafts white for about two-thirds their length from the base, thence gradually becoming dark-brown; bill pale bluish-gray, greenish at the base, the lines on the upper mandible blackishblue; bare space in the region of the eye, and down the centre of the throat blackish-blue; iris white; tarsi, toes, and their webs, blackish-brown; the lines of scutellx on the tarsi and toes green; claws bluish-white. The female resembles the male, but is rather smaller. The young have the head, neck, and upper plumage dark-brown, each feather terminating with a triangular white spot; under plumage grayish-white, the feathers broadly margined with grayish-brown. 
Length, thirty-eight inches; wing, nineteen and fifty one-hundredths; tarsi, two, and twenty-five one-hundredths; tail, ten inches.

$I I a b$. - Atlantic coast, from Labrador to the Gulf of Mexico.

The Gannet breeds in almost incredible numbers on some of the rocky islands near the coast of Labrador. When the breeding season is over, it wanders as far south as the Gulf of Mexico. Its mode of flight is powerful, and at times graceful. Its food consists of fish, principally herrings; these are obtained by plunging from on high, often remaining under water for a minute or more at a time.

$\mathrm{T}$

HIS species is quite common on our coast in the autumn and spring, and through the greater part of the winter. Audubon, in describing its breeding habits, says:-

"The newly finished nest of this bird is fully two feet high, and quite as broad externally. It is composed of seaweeds and maritime grasses, the former being at times brought from considerable distances. Thus, the Gannets breeding on the rocks in the Gulf of St. Lawrence carry weeds from the Magdalene Islands, which are about thirty miles distant. The grasses are pulled or dug up from the surface of the breeding-place itself, often in great clods, consisting of roots and earth, and leaving holes not unlike the entrances to the burrows of the Puffin. 'The nests, like those of Cormorants, are enlarged or repaired annually. The single egg, of a rather elongated oval form, averages $3 \frac{1}{12}$ inches in length, by 2 inches in its greatest breadth; and is covered with an irregular roughish coating of white calcareous matter, which, on being scraped off, leaves exposed the pale greenish-blue tint of the under surface." 


\section{Family GRaCulid 在. The Cormorants.}

Bill rather moderate, culmen concave, tip much hooked and acute; nostrils not perceptible; wings moderate and pointed; tail rather short and rounded; tarsi short; toes long and all joined by full webs; gular sac capable of considerable expansion.

\section{GRACULUS, LINNÆUS.}

Graculus, Linndeus, Syst. Nat. (1735). (Type Pelecanus carbo, L.)

Bill rather slender, of moderate length, with the culmen concave, hooked at the tip, the sides compressed and grooved; nostrils not visible in the adult; wings moderately long and pointed, second and third primaries longest; tail moderate and graduated at the end; tarsi short and much compressed; toes long and full-webbed; a leathery pouch at the base of the lower mandible, which can be much distended.

These birds exist abundantly in all parts of the globe. They are mostly found on the seacoast, breeding on rocky ledges difficult of access, and also on trees. They are exceedingly expert in catching fish; being very active in the water, and capable of remaining under its surface for a great length of time.

\section{GRACULUS CARBO. - Gray.}

\section{The Common Cormorant.}

Phalacrocorax carbo, Nuttall. Man., II. (1834) 479. Aud. Orn. Biog., III. (1835) 458. Ib., Birds Am., VI. (1843) 412.

Graculus carbo, Gray. Gen. of Birds (1845).

\section{Description.}

Bluish-black; feathers on middle of occiput and hind neck elongated; gular sac yellow, at the base of which is a broad band of white; linear feathers on the head, and neck white; a patch of white on the sides; third primary longest; tail of fourteen feathers.

Adult. - Plumage in general black, glossed with greenish-blue; the feathers of the upper part and sides of the back and wing coverts are dark-ash, with bronzed reflections, and bordered with greenish-black; primaries and tail feathers grayish-black, secondaries grayish-brown; bare space around the eye dull-olive, under the eye red; the gular sac yellow, encircling the lower part of which is a broad band of white; numerous linear filamentous white feathers are distributed over the head and neck; on the side, over the thigh, is a patch of elongated linear white feathers; upper mandible grayish-black, with the edges yellowish-white, lower dusky yellowish-white at the base; iris bluish-green; eyelids with dusky margins; tarsi, feet, and claws grayish-black.

The bill is strong and powerful, the ridge is smooth, but the sides of both mandibles are rugose.

Length, thirty-seven inches; wing, fourteen; bill, three and fifty one-hundredths; tail, six and fifty one-hundredths inches. 
The female resembles the male, but is smaller.

$H a b$. - Labrador, and along the coast as far south as New Jersey in winter.

These birds are abundant on the coast of Labrador, where large numbers assemble for the purpose of reproduction, forming their nests upon the inaccessible ledges of rocky cliffs.

Their mode of flight is swift and strong. Their food is obtained by diving and pursuing it beneath the surface, where they make rapid progress by the aid of their wings.

7 HIS species is pretty common on our coast in the latter 1 part of autumn and during the winter. It is not gregarious, but is seen singly or, at most, in pairs. It is shy, and difficult of approach, and seems ever on the alert for danger. The Grand Menan is the most southern breedingplace of this bird in our neighborhood. There it builds a large nest of seaweeds on shelves of steep cliffs or in crev ices of the rocks. The eggs are usually three in number. They are of a bluish-green color which is covered, over nearly their whole surface, with a calcareous deposit. They are of an elongated ovate form, and average in dimensions about 2.90 by 1.75 inch. They are, in their various sizes, impossible of identification from the succeeding species.

\section{GRACULUS DILOPHUS, - Gray.}

\section{The Double-crested Cormorant.}

Phalacrocorax dilophus, Nuttall. Man., II. (1834) 483. Aud. Orn. Biog., III. (1835) 420; V. (1839) 628. Ib., Birds Am., VI. (1843) 423.

Graculus dilophus, Gray. Gen. of Birds (1845).

\section{DESCRIPTION.}

Greenish-black; behind each eye a recurved crest of loose feathers; gular sac orange; second quill longest; tail of twelve feathers.

Adult. - The plumage of the head, neck, lower part of the back and entire under surface is greenish-black, the feathers of the upper part of the back, the wingcoverts, the scapularies and tertiaries, grayish-brown or dark-ash, the margins of which are greenish-black; primaries blackish-brown, lighter on the inner webs; the secondaries dark grayish-brown; tail black, as are also the shafts; running from the bill over the eye is a line of white filamentous feathers, - there are also a few of the same character sparsely distributed over the neck; behind each eye is a tuft of rather long slender feathers, erect and curving forwards; bare space in the region of the eye, and gular sac, orange; upper mandible blackish-brown, with the edges yellowish; lower yellow, marked irregularly with dusky; iris bright-green: legs, feet, and claws black, claw of the middle toe pectinated. 
Length, thirty-three inches; wing, thirteen; tail, six and seventy-five one-hundredths inches.

Bab. - Atlantic coast from Labrador to Carolina; fur countries; Pacific coast from Washington Territory to California.

This species resorts in large numbers to the low islands off the coast of Labrador, which are their breeding stations: they construct their nests on the surface of the rocks, not on the shelves of precipices.

I once witnessed a large migrating flight of these birds to the South, along our seacoast. They passed in great flocks, which succeeded each other frequently during the entire day: each flock formed a widely extended front, the individuals being side by side. Their mode of flight was by alternate flapping of the wings, and their sailing for a short distance, the effect of which was peculiar and striking. - GEorGE W. LAWRENCE.

I think that this species is more northern in its habits than the preceding, as it is seldom seen on the coast of New England except in the winter months, and then only in small numbers. Unlike the preceding, it does not breed south of the coast of Labrador; and, in nesting, does not frequent high precipices, but prefers low rocky islands. The nest is similar to that of the other : and the eggs, although averaging smaller, are hardly recognizable from those of the Common Cormorant; an ordinary large one of the present being of similar form and size with the other. 


\section{Famry LARID E. The Gulls.}

Bill generally shorter than the head, straight at the base, and more or less curved at the end; nostrils linear; head ovate; neck short; body rather full and compact; wings long and pointed; legs of moderate length, strong, and covered anteriorly" with transverse scales; feet fully webbed, the hind toe small and elevated.

Birds of this family frequent the shores of the ocean, but often wander to great distances from land; they are incapable of diving, but swim buoyantly. Their food consists principally of fish and crustacea; but some of the larger species feed occasionally on the flesh of cetaceous animals, and devour the young and eggs of some species of sea-birds.

The family of Laridoe is divisible into four sub-families, with the following characters :-

LESTRIDIN - Basal half of upper jaw with a horny covering, distinct from the tip, and under which the nostrils open considerably beyond the middle of the bill; bill abruptly and much decurved at the tip; tail cuneate; body full, stout.

LARINA- - Covering of the bill continuous; anterior extremity of nostrils generally reaching to the middle of the bill; culmen considerably decurved towards the tip; body robust; tail generally even.

STERNINA. - Covering of bill continuous; nostrils opening in the basal third of the bill; culmen gently curved to the tip of the lengthened and attenuated bill; body rather slender; wing lengthened; tail usually deeply forked.

RHynchopinæ. - Bill excessively compressed, like the blade of a knife; lower jaw much longer than the upper; the point obtuse; body slender; tail forked.

\section{Sub-Family Lestridinz. - The Skua-Gulls ; the Jagers.}

Bill strong and much curved at the end, the base covered with a membranous cere; wings lengthened; tail cuneate, with the two central feathers projecting.

These hardy birds inhabit the high latitudes of both hemispheres. There are four Arctic species found both in Europe and North America. They are piratical in their habits, appearing to derive their subsistence mainly from the labors of others. They chase and harass various species of Gulls, compelling them to disgorge a portion of their food, which they dart after, and seize before it reaches the water.

\section{STERCORARIUS, BRISSON.}

Stercorarius, Brisson. Ornithologie (1760).

Bill rather strong; the culmen straight, and covered at the base with a smooth cere, the end curved; nostrils linear, and more open anteriorly; wings pointed; first quill longest; tail of moderate length; the two middle feathers elongated; tarsi strong, and covered with prominent scales; claws sharp and much curved; feet fully webbed; hind toe short, and but little elevated. 
STERCORARIUS POMARINUS. - Temminck.

The Pomarine Skua.

Lestris pomarinus, Nuttall. Man., II. (1834) 315. Aud. Birds Am., VIr. (1844) 186.

Description.

Adult. - Front, crown of the head, back, wings, and tail, blackish-brown; sides and back part of the neck bright-yellow; throat and entire under plumage white, with a band of brown spots extending across the upper part of the breast; sides and lower tail coverts barred with brown; shafts of quills and tail feathers white; bill greenish-olive, black at the tip; legs and feet black; the middle tail feathers extend beyond the others for about two inches; they are rounded at the end, and of a uniform breadth throughout.

Young birds have the plumage of the upper parts blackish-brown; of the lower, grayish-brown, with the feathers of the abdomen and lower tail coverts margined with dull-ferruginous; tarsi and base of the toes and webs yellow.

Length, twenty inches; wing, fourteen; tail, eight to nine; bill, one and three quarters; tarsus, two inches.

THIS species is not uncommon on our north-east coast in 1 the autumn and winter months. "It subsists on putrid and other animal substances thrown up by the sea, and also on fish and other matters which the Gulls disgorge when pursued by it. It also devours the eggs of sea-birds." It breeds in the Hudson's Bay country and other northern localities; nesting "in elevated spots in the marshes, or upon rocks; making a coarsely interlaced nest of the surrounding moss and herbage; laying two or three very pointed eggs, of a grayish-olive, marked with a small number of blackish spots." - NuttalL.

\section{STERCORARIUS PARASITICUS, - Temminck.}

\section{The Arctic Skua.}

Lamus parasiticus, Linnæus. Syst. Nat., I. (1756) 226.

Stercorarius parasiticus, Temminck. Man. d'Orn., II. (1820) 796.

Lestris Richardsonii, Nuttall. Man., II. (1834) 319. Aud. Birds Am., VIl. (1844) 190 .

Description.

Adult. - Upper part of the head blackish-brown; nape and sides of the neck yellowish-white; remainder of upper plumage blackish-brown; wings and tail darker; shafts of the primaries white; under plumage white; bill bluish at the base, black at the point; tarsi and feet black; the central tail feathers extend beyond the 
others about three inches; they taper slightly, varying but little in breadth until near the end, where they are abruptly acuminated, differing in this particular from all tho other species.

Length, twenty to twenty-two inches; wing, thirteen and a half; tail, eight and a half; bill, one and four-twelfths; tarsi, one and three-quarter inches.

Hab. - Arctic America; breeds in the Barren Grounds; coast of the United States from New York northward.

This species is much more common on our coast in winter than the other. Its habits are the same, and its breeding-place is also in the far north. Its eggs are three in number. They are broadly ovoidal in form, and much resemble the eggs of the Laughing Gull. Their primary color varies from a greenish-drab to the predominating olivaceous-green. This is marked with spots and blotches of various shades of brown, thickest at the greater end, and some spots of obscure-purple. The dimensions vary from 2.25 by 1.60 inch to 2.18 by 1.54 .

\section{Sub-Family Larine. - The Gulls.}

Bill differing considerably in strength and form; generally straight, with the sides compressed; the culmen straight at the base, with the end curved; nostrils lateral and oblong; wings long and pointed; tail usually even, in two or three cases pointed or forked; tarsi rather strong; fore-toes united by a web; hind toe short and elevated.

These birds vary much in size, some being quite small, while others rank among the largest of marine birds. They are not peculiar to any region, but are found abundantly over the world. They congregate in great numbers on the sand-bars at the entrance of inlets and large bays. In winter they migrate in search of food, frequenting harbors and ascending rivers.

The above general descriptions of the habits of our Gulls are so comprehensive and terse that I will add nothing at length to them here. They feed on fish (which they often seize in their bills in the water), various aquatic animals, and dead animal matter thrown up on the shores or floating on the waves. They attack and kill wounded birds, and eat them, and also drive aquatic birds from their eggs and 
young, which they eat. They are, in the water, almost precisely what the Crows and Jays are on the land.

\section{LARUS MARINUS. - Linnous.}

\section{The Great Black-backed Gull.}

Larus marinus, Linnæus. Syst. Nat., I. (1766) 225. Nutt. Man., II. (1834) 308. Aud. Birds Am., VII. (1844) 172.

\section{Description.}

Adult. - The head, neck, entire under plumage, upper tail coverts, and tail are pure-white; the back and wings are of a dark-slate color; the primaries are deep black, largely tipped with white, as are the extremities of most of the quills; the bill is gamboge-yellow, with an orange-red spot near the end of the lower mandible; legs and feet pale-yellow; iris white.

Young. - Head, rump, and under plumage grayish-white, with streaks of lightbrown; back and wings mottled with brownish-ash and grayish-white; primaries blackish-brown, having the tips edged with white; tail white, spotted with brown, and having a broad subterminal band of the same color; bill brownish-black, yellowish at the base; legs and feet yellow.

Length, about thirty inches; wing, twenty; tail, nine; bill, two and ten-twelfths ; tarsus, two-twelfths of an inch.

Hab. - North Atlantic, Labrador; as far south as Florida in winter.

The Black-backed Gull is of frequent occurrence on our coast in the autumn and winter months; and, according to Mr. George A. Boardman, a few breed as far south as the islands in the Bay of Fundy. Audubon describes its breeding habits as follows:-

"The nest of this species is usually placed on the bare rock of some low island, sometimes beneath a projecting shelf, sometimes in a wide fissure. In Labrador, it is formed of moss and seaweeds carefully arranged, and has a diameter of about two feet; being raised on the edges to the height of five or six inches, but seldom more than two inches thick in the centre, where feathers, dry grass, and other materials, are added. The eggs are three, and in no instance have I found more. They are two inches and seveneighths in length by two inches and one-eighth in breadth; broadly ovate; rough, but not granulated; of a pale earthy greenish-gray color, irregularly blotched and spotted with brownish-black, darkumber, and dull-purple." 


\section{IARUS ARGENTATUS. - Brïnnch.}

The Herring Gull; the Silvery Gull.

Larus argentatus, Brïnnich. Orn. Bor. (1764), 44. Nutt. Man., II. (1834) 304. Aud. Birds Am., VII. (1844) 163.

\section{DESCRIPTION.}

Adull. - Head, neck, under parts, rump, and tail, pure-white; back and wings light pearl-blue; the first six primaries are marked towards their ends with black, which begins on the first at about half its length from the end, and is rapidly lessened on the others until it becomes only a subterminal bar on the sixth; the primaries all tipped with white; on the first quill it is about an inch and a half in extent, crossed near the end with a black bar, on the second quill there is a round white spot on the inner web near the end; secondaries and tertiaries broadly ending with white; bill bright-yellow, with an orange-red spot near the end of the lower mandible; legs and feet flesh-colored; iris white.

Young. - Mottled with light grayish-brown and dull-white; primaries blackishbrown; bill brownish-black, yellowish at the base.

Length of male, twenty-three inches; wing, eighteen; tail, seven and a half; bill, along ridge, two and a half; depth at angle, thirteen-sixteenths; tarsus, two and a half. Female a little smaller than the male, but similar in plumage.

Hab. - Atlantic coast from Texas to Newfoundland; Western States; Ohio and Mississippi Rivers.

This species is abundant on our coast in the autumn, winter, and until late in spring, and many individuals are seen through the whole summer. I found several apparently breeding about the Umbagog Lakes, in Maine; and have no doubt that it incubates in various localities in New England, both on the coast and in the interior. It breeds in the greatest abundance in Labrador and other northern countries, where it nests like the preceding, and sometimes in trees. The birds which I saw about Lake Umbagog probably had nests in trees, as they frequented a tract of dead pines and hemlocks inaccessible to me on account of inundation, and they frequently alighted in their tops. The eggs of the Herring Gull are so different in form, color, and markings, that hardly any description can be intelligible. A great number of specimens in my collection vary in form from abruptly ovate to a lengthened ovoidal. Their color varies from a pale-cinereous to an olivaceous-drab; and their markings from thickly spattered blotches of 
black to different browns and obscure-purples. Their dimensions vary from 2.85 by 2.05 inch to 2.65 by 1.85 inch. Large specimens of this species cannot be distinguished from small ones of the preceding.

\section{CHROICOCEPHALUS, ExtoN.}

Chroicocephalus, Eyton, Cat. Brit. Birds (1836).

Bill moderate, rather slender, much compressed; upper mandible straight at base, more or less curved at the end; nostrils lateral and longitudinal; wings long, narrow, and pointed; tail moderate, usually even; tarsi rather slender; feet webbed; hind toe small and elevated.

These Gulls are of medium or small size: in their spring attire, the head is clothed with a dark-colored hood; but in the winter it becomes white, with a dusky spot behind the ear. These birds are very handsome, the dark and light colors of their plumage forming a beautiful contrast.

\section{CHROICOCEPHALUS ATRICILLA. - Laurence.}

\section{The Laughing Gull.}

Larus atricilla, Linnæus. Syst. Nat., I. (1766) 225. Bon. Syn. (1828), No. 294. Nutt. Man., II. (1834) 291. Aud. Birds Am., VII. (1844) 136.

Larus ridibundus. Wils., IX. (1824) 89.

\section{DESCRIPTION.}

Adult.-Head and upper part of neck blackish lead-gray, extending lower in front; upper and lower eyelids white posteriorly; lower part of neck, entire under plumage, rump, and tail, pure-white; in spring, a beautiful roseate tint exists on the breast and abdomen; back and wings grayish-lead color; the first six primaries are black, beginning on the first at about two-thirds of its length from the point, and regularly becoming less on the others, until, on the sixth, it is reduced to two spots near the end; tips in some specimens white, and in others black to their points; bill and inside of the mouth dark-carmine; iris bluish-black; legs and feet deep-red; in winter the head becomes white, intermixed on the crown and hind neck with brownish-gray.

Length, seventeen inches; wing, thirteen; tail, five; bill, one and three-fourths; tarsus, two inches.

Hab. - Texas to Massachusetts.

This handsome bird is a resident on our coasts through the summer, but is not at all abundant. It nests in the marshes, making only a loose structure of a few pieces of seaweeds or grasses, which it places in a sandy, elevated spot, where the tides do not reach. The eggs are three in number. Their form is usually ovoidal, sometimes ovate. 


\section{PLITE IV.}
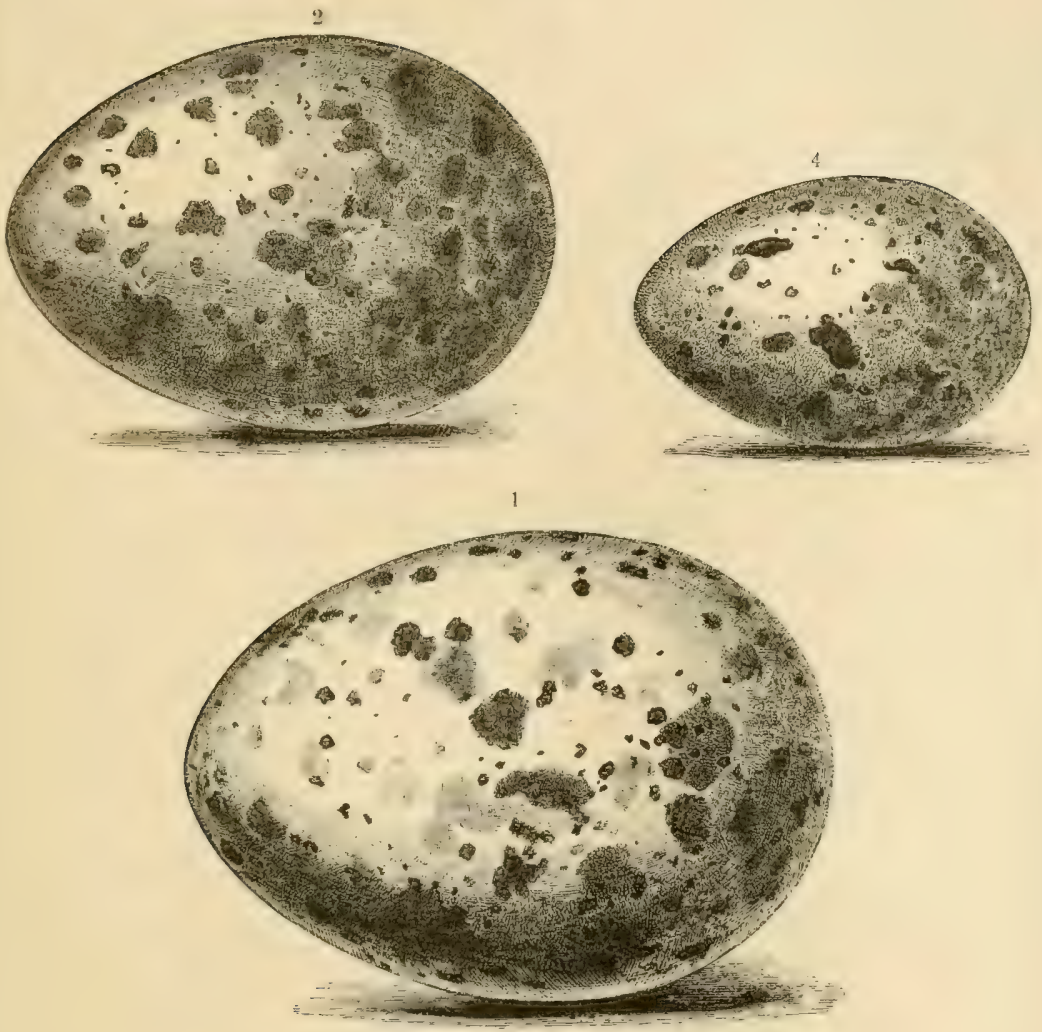

3
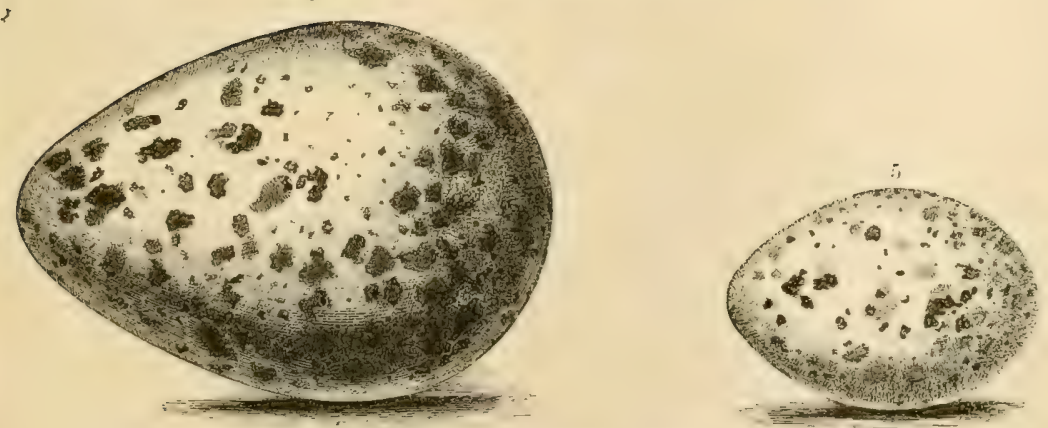

Fig 1 Iferring Gull, Lrrus argentatus, Brunnich.

.. 2. Iaughing Gull, Chroicocephalus atricilla. Linnau.

"3 Kittisake Gull, Rissa tridactyla. Bonaparte.

"4. Wilson's Tern, Sterna Wilsonii. Bonaparte.

" 5. Least Tern, Sterna frenata. Gambel. 

Their color is an olivaceous-drab, sometimes a grayishgreen. This is covered, more or less thickly, with blotches and spots of different shades of brown and purple, and obscure markings of the same.

Their dimensions vary from 2.28 by 1.65 inch to 2 by 1.50 inch. Some specimens have numerous irregular streaks of umber-brown over the surface at the greater end, and others have large confluent blotches of the same color.

\section{CHROICOCEPHALUS PHILADELPHIA. - Lawrence.}

\section{Bonaparte's Gull.}

Larus Bonapartei, Nuttall. Man., II. (1834) 294. Aud. Birds Am., VII. (1844) 131.

\section{DESCRIPTION.}

Adult. - Head and upper part of neck grayish-black, this color extending rather lower on the throat than on the neck behind; lower part of neck, under plumage, rump, and tail, white; back and wings clear bluish-gray; first primary black on the outer web; inner web of the first primary, both webs of the second, and the outer web of the third, white; the inner web of the third, and all the other primaries, are of the same color as the back; the six outer primaries have their ends black for the extent of about an inch on the central ones, but less on the first and sixth, - they are all slightly tipped with white; shoulders, anterior borders of the wings, and outer webs of the primary coverts white; bill deep black; inside of mouth carmine; iris hazel; legs and feet orange, with a reddish tinge.

The young have the head white, intermixed on the occiput and hind neck with dark-gray; a round spot of dark-plumbeous behind the eye; the smaller wing coverts brown; the outer webs of several of the primaries, and a subterminal band on the tail, black.

Length, fourteen and a half inches; wing, ten and a half; tail, four and a quarter; bill, one and one-eighth; tarsus, one and five-sixteenths inch.

Mab. - Texas to Nova Scotia, Mississippi River, fur countries, Pacific coast of North America.

This species is pretty common on our coast, and is often found in the neighborhood of large tracts of water in the interior.

\section{RISSA, LEACH.}

Rissa, Leacr, Steph. Gen. Zool., XIII. (1825) 180. (Type Laras tridactylus, L.)

Bill rather long, strong, and much compressed; culmen straight at base, curved from the nostrils to the tip; nostrils lateral and longitudinal; wings long and pointed; tail even; tarsi rather short; toes slender and united by a full web; hind toe rudimentary or very small. 


\section{RISSA TRIDACTYLA, - Bonaparte.}

The Kittiwake Gull.

Larus tridactylus, Linnæus. Syst. Nat., I. (1766) 224. Nutt. Man., II. (1834) 298. Aud. Birds Am., VII. (1844) 146.

\section{DESCRIPTION.}

Adult.-Head, neck, entire under plumage, rump, and tail, white; back and wings light bluish-gray; the ends of the five outer primaries, and the outer web of the first, black; the fourth and fifth have small white tips; bill greenish yellow; iris reddish-brown; legs and feet brownish-black, with a green tinge.

Young. - The head is white, marked on the hind head and neck with bluishgray; a spot of the same color over the ears; a narrow crescent of black in front of the eye; wings and shoulders marked with black; primaries black; tail white, with a subterminal black band; bill black; rest of the plumage same as in the adult.

Length, about seventeen inches; wing, twelve; tail, five and three-quarters, bill, one and a half; tarsus, one and three-eighths inches.

Hab. - Fur countries; Labrador; southern coast in winter.

This species is not common on our coasts through the summer months. Audubon says it breeds as far south as the island of Grand Menan, off the entrance of the Bay of Fundy; and it probably also incubates on other islands off the coast of Maine. The nest is composed of seaweeds, which are arranged in a large pile, and placed on a ledge of rock in a crevice, or on a jutting shelf. This nest is occupied for successive years; and it receives additions in every season. The eggs are three in number. Their form is usually ovoidal: their color varies from a creamy-drab, with a very slight olivaceous tint, to a delicate gray. On this are scattered blotches of different shades of brown, and obscure spots and blotches of lilac. Of these eggs as of all the eggs of Gulls and Terms - it is difficult to give descriptions by which specimens could be identified. The above description, however, answers for all the eggs of this species in my collection. The dimensions vary from 2.20 by 1.60 inch to 2.04 by 1.55 . 


\section{Sub-Family Sterninæ. - The Terns.}

Bill rather long, usually slender, straight, sometimes with the upper mandible curved at the tip, which is acutely pointed; nostrils linear and pervious; wings elongated; primaries long and pointed, secondaries of moderate length; tail rather long and in most species forked; tarsi slender; anterior toes have their webs emarginate, hind toe small; claws moderate, curved and acute.

These birds are mostly found on the seacoast and neighboring bays, occasionally on rivers and lakes: they assemble in large numbers on the sand bars and points at the mouth of inlets, are much on the wing, and are remarkable for their buoyant and easy flight. Their food consists of small fishes and crustacea, which they obtain by hovering over and suddenly darting down upon: although they thus seize their prey while in the water, they only occasionally swim or rest upon its surface.

\section{STERNA, LINNXUS.}

Sterna, Lins.eus, Syst. Nat. (1748).

Bill more or less strong, about the length of the head; the upper mandible slightly curved to the tip, which is narrow and acute, the lower straight, with the junction of the crura about the middle; the nostrils lateral and linear, with the frontal feathers extending to the opening; wings long, primaries narrow and tapering, the outer quill longest; tail rather long and more or less forked; tarsi short; toes small and slender, with the webs emarginate; hind toe short; claws slightly arched and acute.

\section{STERNA ARANEA, - Wilson.}

\section{The Marsh Tern.}

Sterna aranea, Wilson. Am. Orn., VIII. (1814) 143.

Sterna Anglica, Nuttall. Man., II. (1834) 269. Aud. Orn. Biog., V. (1839) 127. Ib., Birds Am., VII. (1844) 81.

\section{DESCRIPTION.}

Adult. - Upper part of the head, occiput, and sides of the head upon a line with the lower eyelid, black; back and wings light bluish-gray; primaries hoary on the outer webs and ashy-gray on the inner, becoming lighter towards the base; tail same color as the back, but paler, and with the outer feather nearly white; a line at the base of the upper mandible, neck in front and entire under plumage, pure-white; bill deep-black; iris brown; legs and feet black.

Length, thirteen and three-quarters inches; wings in extent thirty-four, from flexure ten and a half; tail, four; bill, one and three-eighths; tarsus, one inch.

Hab. - Coast of the United States as far north as Connecticut.

\section{I include this species in our New-England Terns on the} above authority. I have not met with it myself, and know nothing of its habits. Wilson says, - 
"This species I first met on the shores of Cape May, particularly over the salt marshes, where it was darting down after a kind of large black spider, plenty in such places. This spider can travel under water, as well as above, and, during summer at least, seems to constitute the principal food of the present Tern. In several which I opened, the stomach was crammed with a mass of these spiders alone: these they frequently pick up from the pools, as well as from the grass, dashing down on them in the manner of their tribe. Their voice is sharper and stronger than that of the Common Tern; the bill is differently formed, being shorter, more rounded above, and thicker; the tail is also much shorter, and less forked. 'They do not associate with others, but keep in small parties by themselves.

"This species breeds in the salt marshes. The female drops her eggs, generally three or four in number, on the dry drift grass, without the slightest appearance of a nest: they are of a greenisholive, spotted with brown."

\section{STERNA CASPIA, - Pallas.}

The Caspian Tern.

Sterna Caspia, Pallas. Nov. Com. Petr., XIV. 582. Lawr. Ann. Lyc. N.Y., V. (1851) 37.

\section{DESCRIPTION.}

Adult. - Forehead, crown, sides of the head, and occiput, black, glossed with green; this color extends below the eye, under which is a narrow white line; back and wings light bluish-ash; the six outer primaries dark slate-gray on their inner webs; quill shafts strong and white; tail and its upper coverts grayish-white; neck and entire under plumage pure white; bill and inside of mouth bright vermilion; legs and feet black; bill very stout; tail not deeply forked.

In the young, the back, wing coverts, and tail, are mottled and barred with blackish-brown.

Length, twenty-one and a half inches; extent of wings, fifty-one; from flexure, sixteen and three-quarters; bill, from base, two and seven-eighths; tail, six inches.

$H a b$. - Coast of New Jersey northward.

I include this species on the above authority. Its habits are unknown to me.

\section{STERNA WILSONII, - Bonaparie.}

Wilson's Tern.

Sterna himundo, Wilson. Am. Orn., VII. (1813) 76. Nutt. Man., II. (1834) 271. Aud. Orn. Biog., IV. (1838) 74. Ib., Birds Am., VII. (1844) 97. 


\section{DESCRTPTION.}

Adult. - Upper part of the head and hind neck deep-black, tinged with brown on the front part of the head; back and wings light grayish-blue; first primary with the outer web black, on the inner web grayish-black next the shaft, this color increasing in extent towards the end, where it covers the entire web for about one inch, rest of inner web white; the next five primaries are hoary on their outer webs, and blackish-gray on the inner next the shaft, occupying the entire web at the end; margin of the inner webs white; central tail feathers very pale bluish-gray, the others white on the inner webs and dusky-gray on the outer webs, deepening in color from the central feathers until it becomes blackish-gray on the lateral ones; sides of the head, throat, rump, and under tail coverts, white; breast and abdomen clear pearlgray; bill coral-red, black near the end with the tip yellow; iris hazel; legs and feet coral-red, not so dark as the bill; claws brownish-black.

Length, fourteen and three-quarters inches; wing, ten and three-quarters; tail, five and three-quarters; bill, one and three-eighths; tarsus, three-quarters of an inch.

Hab. - Texas to Labrador.

This is by far the most common species we have in New England. It breeds in great abundance all along our coast, both on the beach, on the mainland, and on the rocky and sandy islands off our shores. In some localities, it is so abundant that I have collected in the space of two hours, in the area of about thirty acres, a half-bushel of eggs. In most localities, it forms no nest, but drops its eggs on the sand or on the bare rock. On the island of Muskegeet, I found that it invariably scooped out a hollow of two or three inches in the sand, in which it laid three or four eggs, arranged them with their small ends together in the middle, and built around them a loose nest of seaweeds and grass. These eggs are so varied in color and markings, that no description of them can be given by which they may be recognized. In a great number in my collection, the predominating color is a reddish-drab, which is marked with numerous spots and confluent blotches of different shades of brown, and obscure blotches of cinereous. Many specimens are an olivaceous-gray, with the same markings; and others are a creamy-buff. Their form is usually exactly ovoidal, and their dimensions average about 1.55 by 1.25 inch.

This species is very irregular in its period of depositing its eggs. I have found them as early as the last week in 
May, and as late as the 12th of July. I have seen, in the space of a square rod, eggs, in which the chicks were about ready to break the shell, and others that were apparently but just laid; and, close beside them both, were squatting young birds almost fully grown and feathered.

About the 15th of June is the period when the eggs of this species are in the best condition in New England for cabinet preservation; the young then being, as a general thing, scarcely formed.

Early in October, these birds begin to be scarce in our latitude, and they spend the winter on the shores of the southern gulf.

STERNA MACROURA.-Naumann.

\section{The Arctic Tern.}

Sierna macroura, Naumann. Isis $(1819,1847)$.

Sterna Arctica, Temm. Man. d'Orn., II. (1820) 742. Bon. Syn. (1828), No. 287. Sw. and Rich. F. B. A., II. (1831) 414. Nutt. Man., II. (1834) 275. Aud. Orn. Biog., III. (1835) 366. Ib., Birds Am., VII. (1844) 107.

\section{Description.}

Adult.-Upper part of the head and hind neck black; back and wings light grayish-blue; first primary deep-black on the outer web, dusky-gray on the inner next the shaft, and over the entire web at the end, inner margin of inner web white; the next five primaries are bluish-gray on the outer web and on the inner web next the shaft, this color extending over the entire web at the end, where it is blackishgray on the inner margin, the remaining part of inner web white; central tail feathers and inner webs of the others white, the outer web of the outer tail feather blackish-gray, the outer webs of the two next pale bluish-gray; rump, sides of the head, and under tail coverts, white; under plumage bluish-gray, of a lighter shade than the back; bill deep-carmine; iris brown; legs and feet dark-crimson.

Length, fourteen and a half inches; wing, ten and a half; tail, six and a half inches.

Hab. - Coast of the New-England States to Arctic seas; fur countries.

This species is almost, if not equally, as abundant on our shores in summer as the preceding. It breeds, in our latitude, in the same localities and at the same time as the other; and its eggs are so exactly similar, that any description of either is impossible, by which they can be identified. The only method that I know of to obtain authentic specimens of each is, either to visit localities in which either 
species is found by itself, or to wait until late in the season, and, after finding a nest, observe carefully the bird that hovers over it, and shoot her. It is a well-known habit of these species to hover over their eggs after being driven from them: but this is generally confined to the close of the season of incubation, or very dark or wet weather; and the student, to avail himself of it, must be on the spot at the proper time. The moment a person approaches one of their breeding places, the whole colony leave their eggs or young, and fly to meet the intruder. I have been on an island of not more than thirty acres area, where thousands of

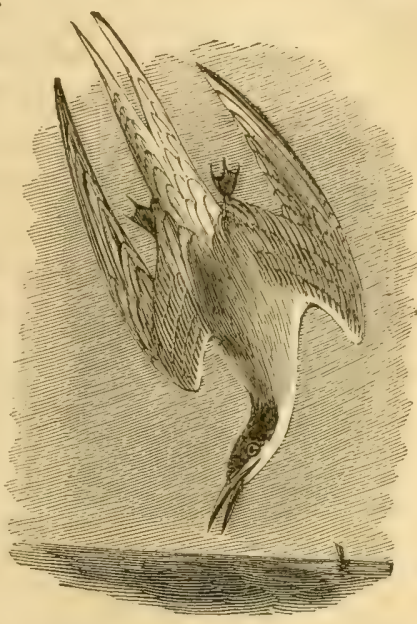
these birds of both species, and also the following, were breeding; and their cries, 'kree 'kree 'kree, were so loud that my companions within twenty feet of me had to shout at their loudest to make their words intelligible.

The Arctic Tern, like all the others, leaves its eggs in warm sunny days for several hours, depending on the sun to assist in incubation. When one bird is shot, the others, instead of flying off, only redouble their outcries, darting down at the intruder within a few feet of his head; and the noise and confusion are so great, that one is almost bewildered, and can hardly keep his wits about him sufficiently to secure and properly identify his specimens.

\section{STERNA FRENATA. - Gambel.}

The Least Tern.

Sterna minuta, Wilson. Am. Orn., VII. (1813) 80. Aud. Orn. Biog., IV. (1838)

175. Ib., Birds Am., VII. (1844) 119.

Sterna argentea, Nuttall. Man., II. (1834) 280. 


\section{DESCRIPTION.}

Adult. - On the forehead is a triangular white spot extending to the eye; crown, occiput, and a line from the eye to the upper mandible, deep-black; entire upper plumage and wings clear bluish-gray; first two primaries with the outer web and half the inner next the shaft, grayish-black, ends of the same color, inner margins white, the shafts of these two quills are black; the other primaries same color as the back, with the inner margins white; tail same color as the back, except the outer margin of the exterior feather, and the inner webs of the others at the base, where they are white; entire under plumage silvery-white; bill pale orange-yellow; iris hazel; legs and feet light orange-red.

Length, eight and three-quarters inches; wing, six and three-quarters; tail, three and a half inches.

$H a b$. - Texas to Labrador; western rivers.

This handsome little bird is of similar habits, and is almost as abundant as the preceding. It breeds in the same localities, and, like the others, nests on the beach or bare rocks. The eggs are three in number. They are a rounded ovoidal in form, and a grayish-cream tint in color: they are marked with spots and confluent blotches of different shades of brown and obscure-lilac, and vary in dimensions from 1.25 by .90 inch to 1.15 by .91 inch. A large number of specimens from both the Southern and Northern States exhibit no appreciable difference either in size or markings.

\section{HYDROCHELIDON, BoIE.}

Hydrochelidon, Bore, Isis (1822), 563.

Bill rather short, strong, the upper mandible curving slightly to the tip; nostrils basal, lateral, and longitudinal, the frontal feathers reaching nearly to the opening; wings very long and pointed; tail moderate and emarginate; legs short; the anterior toes slender, with the webs deeply indented; hind toe small; claws slender and acute.

\section{HYDROCHELIDON PLUMBEA. - Wilson.}

The Short-tailed Tern.

Sterna plumbea, Wilson. Am. Orn., VII. (1813) 83.

Sterna nigra, Nuttall. Man., II. (1834) 282. Aud. Orn. Biog., III. (1835) 535; V. (1839) 642. Ib., Birds Am., VII. (1844) 116.

\section{DESCRIPTION.}

Adult.-Head, neck, breast, sides, and abdomen, black; lower tail coverts white; under covering of wings ashy-gray; back and wings dark plumbeous-gray; the 
first four primaries grayish-black, with their shafts white; bend of the wing edged with white; tail same color as the back; bill brownish-black; iris brown; legs and feet reddish-brown.

Young. - Back, wings, and tail, light-plumbeous, with the feathers of the back margined with brown; top of the head and around the eve brownish-black; front and under plumage white; tail short, and but slightly forked.

Length, nine and a half inches; wing, eight and a half; tail, three and a half inches.

Hab. - Texas to the New-England States, Mississippi River, and tributaries; fur countries.

This species is included on the above authority. Wilson describes its habits as follows:-

"I examined upwards of thirty individuals of this species by dissection, and found both sexes alike in color. 'Their stomachs contained grasshoppers, crickets, spiders, \&c., but no fish. The people on the seacoast inform me, that this bird comes to them only in the fall, or towards the end of summer, and is more frequently seen about the mill-ponds and fresh-water marshes than in the bays; and add, that it feeds on grasshoppers and other insects, which it finds on the meadows and marshes, picking them from the grass, as well as from the surface of the water. They have never known it to associate with the Lesser Tern; and consider it altogether a different bird. This opinion seems confirmed by the above circumstances, and by the fact of its greater extent of wing, being full three inches wider than the Lesser Tern, and also making its appearance after the others have gone off."

Audubon describes the bird as placing its nest on the top of a broken tussock of the rankest grasses, of which the fabric is itself composed; it is of a flattish form, and about two inches thick. It is enlarged or renewed every year, some nests being found to be from four to six inches in height. The eggs, laid early in June, are four in number, $1 \frac{8}{8}$ by 1 inch in dimensions, and are of nearly an elliptical form, being but slightly pointed at one end: their ground-color is greenish-buff, spotted and dashed with reddish-umber and black, more abundantly towards the middle. 


\section{Fanily Procellarid}

Bill more or less lengthened, compressed, and deeply grooved, appearing to be formed of several distinct parts; the tip is strong, much hooked, and acute; the nostrils open from distinct tubes, either single or double, and are situated at the base of the upper mandible.

All the birds embraced in this family are strictly oceanic, some of the smaller species only being observed in bays near the ocean during or after a storm. They vary greatly in size, some being quite diminutive, while others are equal in dimensions to the largest known birds of flight.

Two sub-families, namely, Diomedeina and Procellarina, constitute this family, the distinguishing characters of which are as follows :-

DIOMEDEnd. - Bill very strong, curved, and acute at the end; nostrils short, tubular, and situated on the sides of the upper mandible near the base.

Procellarind.-Bill more or less strong, curred at the end, and pointed; nostrils tubular, situated on the culmen, near the base, and opening forwards.

\section{Sub-Family Proceldarinas. The True Petrels.}

The bill more or less strong, compressed, tip much hooked and pointed; the nostrils tubular, to a greater or less extent, and situated on the basal part of the culmen; generally of medium or small size, wandering in their habits, and capable of sustaining themselves on wing for a great length of time.

\section{THALASSIDROMA, VIGORS.}

Thalassidroma, Vigors, Zool. Jour. (1825).

Bill shorter than the head, slender and weak, the tip curved and acute, the sides compressed and moderately grooved; nostrils at the base of the culmen tubular and prominent; wings long and narrow, the second quill longest; tail forked or emarginate; legs slender and very long; tibia bare for a considerable space; anterior toes rather short and slender, united by an indented web; a short spur in place of the hind toe.

THALASSIDROMA LEACHII, - Bonaparte.

\section{Leach's Petrel.}

Procellaria Leachii, Temm. Man., II. (1820) 812.

Thalassidroma Leachii, Nuttall. Man., II. (1834) 326. Aud. Orn. Biog., III. (1835) 434. Ib., Birds Am., VII. (1844) 219. 
DESCRIPTION.

The plumage generally is sooty-brown, darker on the crown; primaries and tail brownish-black; wing coverts and inner secondaries ashy-gray; rump, feathers of the sides adjoining it, and outer lower tail coverts, white ; bill black; iris dark-brown; tarsi and feet black.

The female differs only in being rather smaller.

This is larger than Wilson's Petrel, and has a much stronger bill: it may be readily known from it by its forked tail, and the interdigital webs being entirely black.

Length, eight inches; wing, six and a half; tail, three; bill, two-thirds of an inch; tarsus, one inch.

TrHIS species is the most abundant of our Petrels. It is, 1 in fact, the only one that breeds here; and all others may be regarded as wanderers. About the first week in June, in the latitude of the islands on the north-eastern coast of Maine, it pairs. Breeding in communities, it soon begins its nest. This is composed of weeds, short grasses, and small pebbles, which are arranged in a flat structure, at the end of a burrow constructed by the birds, or in the fissures and crevices of rocks on the islands off our northern coast. In this a single egg is deposited, which is of a pure-white color, with an obscure lilac ring around one end, consisting of fine confluent dots. It is nearly oval in form, and averages in dimensions about 1.30 inch in length and .96 inch in breadth. A large number of specimens in my collection exhibit a variation of from 1.35 to 1.24 inch in length, and from 1 inch to .80 inch in breadth. These eggs soon become discolored and dirty, from the nature of the nest and the habits of the bird; but originally they are purewhite. Their shell is exceedingly fragile, and a little rough to the touch, like that of the eggs of all birds of this class.

\section{THALASSIDROMA WILSONII. - Bonaparte.}

Wilson's Stormy Petrel.

Procellara pelagica, Wilson. Am. Orn., VII. (1808) 90.

Thalassidroma Wilsonii, Bonaparte. Syn. (1828), No. 308. Nutt. Man., II. (1834) 324. Aud. Orn. Biog., III. (1835) 486; V. (1839) 645. Ib., Birds Am., VII. (1844) 223.

Oceanites Wilsonii, Bonaparte. Cons. Av. II. (1855) 199. 


\section{DESCRIPTION.}

The general color of the piumage is dark sooty-brown; primaries and tail blackish-brown, the latter white at the base; some of the outer secondaries and the secondary coverts grayish-ash, ending with grayish-white; rump, sides of the abdomen and exterior lower tail coverts, white; bill black; iris dark-brown; tarsi and feet black, with the webs yellow except at the margin.

This species is somewhat smaller than T. Leachii, and more delicate in form; the bill is much weaker: it may readily be distinguished by the greater proportion of white on the under tail coverts and on the sides at the base of the tail, together with its much longer tarsi and yellow webs; tail nearly even.

Length, seven and one-fourth inches; wing, six; tail, three-quarters; bill, seventwelfths inch; tarsus, one and three-eighths iuch.

Hab. - Off the Atlantic coast from the Gulf of Mexico to Baffin's Bay.

This species is rare on our coast, and, to my knowledge, does not breed within the limits of New-England shores. Audubon says, -

"Wilson's Petrel breeds on some small islands situated off the southern 'extremity of Nova Scotia, called 'Mud Islands,' but which are formed of sand and light earth, scantily covered with grass.

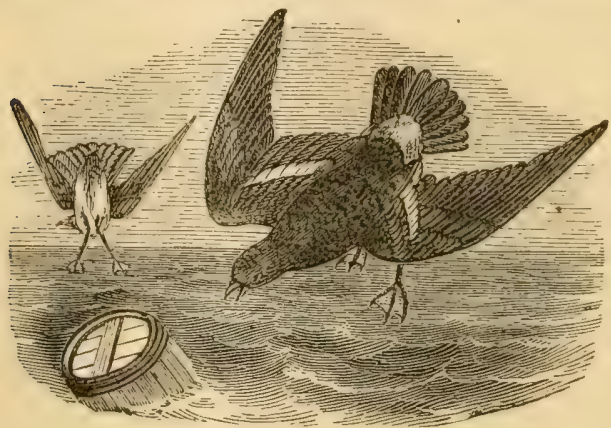
Thither the birds resort in great numbers about the beginning of June, and form burrows of the depth of two or two and a half feet, in the bottom of which is laid a single white egg; a few bits of dry grass, scarcely deserving the name of inch and a half in length by seven-eighths of an inch in breadth; is almost equally rounded at both ends. ... On wing, this species is more lively than the Forked-tailed, but less so than the common Stormy Petrel. Its notes are different from that of the Forked-tailed Petrel, and resemble the syllables kee-re-kee-kee. They are more frequently emitted at night than by day." 


\section{Family COLYMbid瓜. The Divers.}

Bill more or less long and compressed; the nostrils are linear or rounded, and situated in a lateral groove; tail rudimentary or short; tarsi much compressed; anterior toes Iong, with the interdigital membrane more or less full, the outer longest; hind toe short, free, with a hanging lobe; claws broad, depressed, buried in the body.

The species are remarkable for their powers of swimming and diving: their ease and gracefulness on the water is in strong contrast with their awkwardness on land,

The following are the characters of the two sub-families, Colymbince and Podicipina; -

CoLymbix - Bill long, rather strong, much compressed, with the point acute; nostrils basal, linear; tarsi much compressed; toes long and webs full; tail short; lores feathered.

Podicipras. - Bill generally long and tather slender, compressed and pointed; nostrils situated in a groove, oblong and narrow; tarsi compressed; toes long and broadly lobed; tail wanting, or very rudimentary; lores naked.

\section{Sub-Family Colymbinæ. - The Loons.}

Bill about the length of the head, rather stout, much compressed, and acute; nostrils basal, linear, and pervious; wings of medium size, narrow and pointed, first quill the longest, reaching far beyond the scapulars; tail short and rounded; tarsi very much compressed; entire tarsi and base of toes reticulated; toes long, the anterior ones united by regular webs, the claw of the middle twice as long as broad; hind toe short, edged with a narrow membrane.

These birds excel all others in their rapidity of diving, and the great progress they are able to make under water. Only one genus in this sub-family is recognized by authors.

\section{COLYMBUS, LINNXUS.}

Colymbus, Linseus, Syst. Nat. (1735). (Type C. articus.)

As the characters of the sub-family include those of the single genus Colymbus, it is not necessary to repeat them.

They are abundant during summer in the high northern latitudes, both on the seacoast and on inland lakes; in winter, they migrate to the South. They are solitary in their habits, keen-sighted, and very difficult of approach: their flight is strong, rapid, and direct.

\section{COLYMBUS TORQUATUS, - Brünnich.}

\section{The Great Northern Diver; the Loon.}

Colymbus glacialis, Linnæus. Syst. Nat., I. (1766) 221. Wils. Am. Orn., IX. (1824) 84. Nutt. Man., II. (1834) 513. Aud. Jm. Biog., IV. (1838) 43. Ib., Birds Am., VII. (1844) 282. 


\section{DESCRIPTION.}

Bill compressed, strong and tapering, outline of upper mandible nearly straight, very slightly curved; the lower mandible has a groove underneath, running frone the junction of the erura towards the point; the tail consists of twenty feathers.

Adult. - The head and neck are dark bluish-green, the upper part and sides of the head glossed with purple; there is a small transverse mark on the throat, composed of white feathers of a quill-like form, distinct from each other, and placed longitudinally on each side of the neck; lower down are larger patches of white, of the same peculiar form, and running in the same direction; these almost meet behind, and in front are about one inch apart; the effect of these pure-white feathers, relieved by the dark color of the neck, is very beautiful; the upper plumage and wing coverts are deep glossy-black, beautifully marked with pure-white spots, placed in regular transverse rows, slightly curving downwards; these spots, on the upper part of the back, are small and nearly round, but, as they descend lower on the back, increase in size, and become quadrangular in form, being largest on the scapularies; on the lower part of the back, upper tail coverts, and sides (which are black), the spots are small and round; the sides of the neck, near the shoulder, are beautifully lineated with black and white; the primaries, secondaries, and tail, brownish-black; the under surface glossy-white, with a narrow band of dusky feathers crossing the lower part of the abdomen, and marked with small white spots; lower tail coverts blackish-brown, tipped with white; bill black; iris deep bright-red; tarsi and feet grayish-blue externally, tinged on the inside with pale-yellowish red; webs brownishblack; claws black.

Young. - The plumage above is grayish-black, the feathers of the back margined with grayish-white, the under plumage pure-white; bill yellowish, with the ridge of the upper mandible dusky.

Leugth, thirty-one inches; wing, fourteen; tarsus, three and a quarter; bill, three; height at base, one inch.

$H a b .-$ Very generally distributed; it is abundant on the Atlantic coast; in the lakes of the interior, and the fur countries.

7 THE Great Loon is a rather common species on our coast in the autumn and winter. It passes the season of reproduction in the neighborhood of large tracts and ponds of fresh water in the interior, where it nests, about the middle of June, on some low island, or in meadows, bordering the lakes where it collects a large pile of grasses, sods, and weeds; in which it forms a hollow of from fourteen to sixteen inches in diameter, and four or five in depth; lining it with a few softer grasses and pieces of moss, if such are obtainable. The eggs are two or three in number. They vary in shape from almost exactly oval, usually about ovate and occasionally very much lengthened, as will be seen by the following dimensions of four specimens from different 
localities in Maine: 3.67 by $2.35,3.85$ by $2.15,3.50$ by $2.25,3.50$ by 2.25 inches. Their color is an olivaceousbrown, sometimes an olivaceous-drab; and one specimen is of a reddish-brown, with but a slight olivaceous tint. This primary color is sparingly marked with small spots and a few larger blotches of blackish or very dark-brown. The Umbagog Lakes, in Maine, are a favorite breeding locality of this species; and sometimes several pairs may be found, within a hundred rods of each other, engaged in the duties of incubation. When the nest is approached, the sitting bird silently leaves it; and, gliding through the grass, drops into the water; and, diving, swims below the surface to a considerable distance from the shore, where, appearing above it, she attentively watches the intruder.

The nest is built only a short distance from the water, and is approached in different directions by paths through the grass, beaten by the birds, or sometimes by muskrats in their approaches to their winter homes. I once heard of one of these Loons forming its nest in the top of an abandoned muskrat's nest, and of another that placed it in the top of a low stump of a pine. Usually, it is laid on the mud or earth, in thick grass or weeds.

\section{COLYMBUS SEPTENTRIONALIS. - Linnous.}

The Red-throated Diver.

Colymbus Septentrionalis, Nuttall. Man., II. (1834) 519. Aud. Orn. Biog., IIf. (1838) 20; V. (1839) 625. Ib., Birds Am., VII. (1844) 299.

\section{DESCRIPTION.}

Adult. - Front, sides of the head, upper part of the throat, and sides of the neck, clear bluish-gray; upper part of the head of the same color, intermixed with blackish spots; the hind neck streaked longitudinally with white on a greenish-black ground, the white feathers being raised above the others; on the forepart of the neck is a large longitudinal patch of deep reddish-brown; upper plumage brownishblack, slightly tinged with green, and on the upper part of the back and lower part and sides of the neck streaked and mottled with white; wings and tail brownishblack; under plumage pure-white, with a band across the hind-part of the abdomen, and the lower tail coverts, brownish-gray; bill bluish-black; iris bright-red; tarsi and feet brownish-black externally, on the inside pale flesh-color; claws yellowish at the base, dusky at the end. 
Young. - Upper part of the head and hind-neck dull-gray, streaked with grayishwhite; back and wings blackish-gray, profusely marked with oval-shaped white spots, there being two on each feather, smallest on the upper part of the back and largest on the tertiaries; quill feathers and tail blackish-brown, the latter edged with white; sides of the neck white, speckled minutely with gray; under plumage silky-white, crossed on the lower part of the abdomen by a dusky band; bill bluishgray, dusky on the ridge and flesh-colored at the base.

Length, twenty-seven inches; wing, eleven and a half; tail, two and a half; bill, two and a quarter; tarsus, two and three-quarters inches.

Hab. - During the winters as far south as Maryland; inhabits as far north as the arctic seas; found also on the Pacific coast.

This bird, although pretty common on our coast during the winter, is much more northern in its breeding habits than the Loon; seldom passing the season of incubation south of Labrador, where it begins to lay early in June. The nests are placed on small islands in fresh-water ponds, a short distance from the sea. "These nests consist merely of a few blades of rank grasses loosely put together, and are quite flat, without any down to warm or conceal the eggs at any period of incubation." They are placed within a few feet of the water, and are approached by well-beaten paths, like those of the preceding. 'The eggs are usually three in number. They exactly resemble those of the Loon in form, color, and markings, but are much smaller; varying from 3 to 2.65 inches in length, and from 1.90 to 1.75 inch in breadth.

\section{Sub-Family Podicipine. - The Grebes.}

Bill gennerally long, compressed on the sides, and pointed; lores usually naked; nostrils placed in a groove, oblong and narrow. Wings short, the second quill longest, shorter than the scapulars; the tail is represented by a tuft of downy feathers; tarsi much compressed and rather short; toes long, the outer longest, broadly and evenly lobed, most so on the inner side; claws short, broad, and obtuse; tarsi with plates on the sides, in front with a single, behind with a double, longitudinal series of projecting scales; toes and their lobes plated above.

The plumage is very soft, and on the under surface silky: they are remarkably active on the water, and when alarmed remain below the surface, exposing only the bill. 


\section{PODICEPS, LATHAXY.}

Podiceps, Lathax, Ind. Ornith. (1790), 780. (Type Colymbus cristatus, L.)

Bill long, slender, tapering, and pointed; nostrils situated in a groove, small, linear, and pervious; wings.short and narrow, second primary a little the longest, emarginate near the ends; tail a tuft of loose feathers; tarsi short, much compressed, the edges covered with small scutellæ, and the sides with broad transverse scutellæ; toes long, the outer longest, flattened, with the sides lobed, the most on the inner side, and at the base united by webs; hind toe short and broadly lobed, claws small, depressed, and obtuse.

These birds mostly frequent the fresh-water rivers and interior lakes; but they are also found near the seacoast. They are very expert swimmers, but make progress with great difficulty on land; their flight is rapid and direct. In the breeding season, the head is ornamented with ruffs and elongated tufts, which disappear when they assume their winter garb.

\section{PODICEPS GRISEIGENA. - Gray.}

\section{The Red-necked Grebe.}

Podiceps rubricollis, Nuttall. Man., II. (1834) 253. Aud. Orn. Biog., III. (1835) 617; V. (1839) 520. Ib., Birds Am., VII. (1844) 312.

\section{DEŚCRIPTION.}

Adult. - Upper plumage blackish-brown, with the upper part of the head and hind-neck black; primaries ashy-brown, secondaries mostly white, a ferw of the inner ones dark-ash; cheeks and throat ash-gray; a white line extends from the lower mandible under and beyond the eye; forepart and sides of the neck rich brownishred; lower parts silvery-white, with the sides dusky; bill black, paler at the end, and bright-yellow at the base; iris carmine; tarsi and feet externally greenish-black, internally yellow.

Young. - The upper plumage is blackish-brown, darker on the head; throat and abdomen white; sides of the head and forepart of neck brownish-ash; abdomen silky-white; sides dark brownish-ash; bill bright-yellow.

Length about eighteen inches; wing, seven; bill, one and three-quarters; tarsi, two inches.

Hab. - Fur countries and in the Atlantic States, as far south as Pennsylvania, in winter.

The Red-necked Grebe is common on our coast in winter, where it is commonly called "The Diver," from its habit of diving at the flash of a gun. It feers, like all other birds of this family, on small fishes and marine animals, which it obtains by diving; and such is its expertness and powers of endurance in this respect, that I have known it to remain certainly a minute beneath the surface, if not longer. It is 
shy, and difficult of approach; and, when apprehending danger, it immerses its body, and swims with nothing but its head above the surface. This trick I have noticed in other allied species; and it is, I think, common in all birds of this class. It breeds in the most northern portions of the continent, where it forms the same kind of nest "as that of the Crested Grebe, and lays three or four eggs." Audubon describes an egg in his possession as being two inches in length by one and a quarter inch in breadth, and of a uniform pale greenish-white.

\section{PODICEPS CRISTATUS. - Latham.}

\section{The Crested Grobo.}

Podiceps cristatis, Nuttall. Man., II. (1834) 250. Aud. Orn. Biog., III. (1835) 595. Ib., Birds Am., VII. (1844) 308.

\section{DESCRIPTION.}

Adult.-Front, upper part of the head, and long occipital tufts dark umberbrown, the base of the tufts brownish-red; the ruff is bright brownish-red on the upper portion immediately under the tufts and anteriorly, on the hind-part brownishblack; upper plumage dark umber-brown; humeral feathers white; primaries umberbrown; secondaries mostly white; throat and sides of the head white; forepart and sides of the neck adjoining the ruff brownish-red; under plumage silvery-white; sides dusky, tinged with reddish-brown; bill blackish-brown, tinged with carmine; bare loral space dusky-green; iris bright-carmine; tarsi and feet greenish-black externally, greenish-yellow internally; webs grayish-blue.

Young.- Upper part of head dark-brown; hind-neck brownish-gray; back and wings brownish-black; humeral feathers white; primaries dark umber-brown on the outer webs, paler on the inner; lower parts silvery-white, sides brown; upper mandible brownish-black, pale at the end, and yellow on the sides at the base; lower mandible yellow, with the sides dusky.

Length, twenty-three and one-half inches; wing, seven and three-quarters; bill, two and one-sixteenth; tarsus, two and a half inches.

This is not uncommon as a summer resident in northern New England; and, according to Mr. George A. Boardman, it breeds about the lakes in the neighborhood of Calais, Me. The nest is placed in a retired spot, in a swamp or marsh, near the water; and is constructed, according to Dr. Richardson, of "a large quantity of grass, placed among the reeds and carices." The eggs are generally four in 
number. They are, when first laid, of a white color; but they quickly become dirty and stained by the habits of the bird and the nature of the nest. They are of an ovoidal form, and average about 2.16 by 1.48 inch in dimensions.

\section{PODICEPS CORNUTUS. - Latham.}

\section{The Horned Grebe.}

Podiceps cornutus, Nuttall. Man., II. (1834) 254. A Aud. Orn. Biog., III. (1835) 429; V. (1839) 623. Ib., Birds Am., VII. (1844) 316.

\section{DESCRIPTION.}

Adult. - Upper part of the head, cheeks, throat, and ruff, glossy-black; a broad band running from the bill over the eyes, the elongated occipital tufts behind them, yellowish-red, deepest in color adjoining the bill; upper surface brownish-black; the feathers margined with gray; primaries brownish-ash; secondaries mostly white, some of the outer one dark-ash; the fore-neck and upper part of the breast bright chestnut-red, sides of the same color, intermixed with dusky; abdomen silky-white; bill bluish-black, yellow at the tip; loral space bright-carmine; iris carmine, with an inner circle of white; tarsi and feet dusky-gray externally, dull-yellow internally, and on both edges of the tarsus.

Young. - The whole upper plumage grayish-black, darkest on the head, feathers of the back with gray margins; throat, sides of the head, a broad space on the sides of the neck, nearly meeting behind, breast, and abdomen, silvery-white; sides and lower part of abdomen dusky.

Length, about fourteen inches; wing, five and three-quarters; bill, one; tarsi, one and three-quarters inch.

Hab. - Generally distributed from the Atlantic to the Pacific coast.

The Horned Grebe is not uncommon in our lakes and rivers, and in the waters on our coast, in the spring and autumn. It breeds in more northern localities than New England, but is not invariably an arctic breeder. Audubon says, -

"Although the greater number of these birds go far northward to breed, some remain within the limits of the United States during the whole year; rearing their young on the borders of ponds, particularly in the northern parts of the State of Ohio, in the vicinity of Lake Erie. Two nests which I found were placed at a distance of about four yards from the water's edge, on the top of broken-down tussocks 
of rank weeds; the materials of which they were composed of the same nature, and rudely interwoven to a height of upwards of seven inches. They were rather more than a foot in diameter at the base; the cavity only four inches across, shallow, but more finished with finer plants, of which a quantity lay on the borders, and was probably used by the bird to cover the eggs when about to leave them. There were five eggs in one nest, seven in the other. They measured one inch and three-quarters in length by one inch and two and a half eighths. Their shell was smooth, and of a uniform yellowish-cream color, without spots or marks of any kind."

A single egg in my collection, from Wisconsin, is of an ovoidal form; measures 1.85 by 1.20 inch in dimensions. It is of a dirty-white color, the shell being covered by a calcareous deposit. On scraping this, the shell is of a bluish-white tint.

\section{PODILYMBUS; Lesson.}

Podilymbus, Lesson, Traite d'Ornith. (1831), 595. (Type Colymbus podiceps, L.)

Bill shorter than the head, snout much compressed; the culmen much curved to the tip, which is acute; nostrils situated in the anterior part of a broad groove, oval and pervious; wings short, second quill longest, the outer quills emarginate at the end; tail a tuft of downy feathers; tarsi short, and very much compressed; anterior toes long, flattened, the outer longest, and broadly margined, the inner sides the most, hind toe short and moderately lobed; claws small, depressed, oblong, and obtuse

PODILYMBUS PODICEPS. - Lawrence.

\section{The Pied-bill Grebe.}

Colymbus podiceps, Linnæus. S. N. (1766), 223.

Podiceps Carolinensis, Nuttall. Man., II. (1834) 259. Aud. Orn. Biog., III. (1835) 359; V. (1839) 624. Ib., Birds Am., VII. (1844) 324.

\section{Description.}

Adult.-Upper plumage very dark brown; primaries dark-ash; secondaries ash on the outer webs, and white on the inner; bill pale-blue, dusky on the ridge of the upper mandible, both mandibles crossed with a broad black band, including the nostrils; chin and throat marked with a conspicuous black patch nearly two inches in extent; cheeks and sides of the neck brownish-gray; lower part of the neck, upper 
part of the breast, and the sides, dull rusty-brown, spotted and rather indistinctly barred with brownish-black; lower part of breast and abdomen grayishwhite, mottled with dusky spots; iris brown; tarsi and feet grayish-black.

Young. - The throat is white and the bill without the transverse black band, the under plumage more silvery-white; in other respects the same as the adult; some specimens, probably the birds of the year, have whitish lines on the sides of the head.

Length, fourteen inches; wing, five and a quarter; bill, seven-eighths; tarsus, one and a half inch.

Hab.-Atlantic States generally; Texas and New Mexico; California and Oregon.

This is the most common Grebe in New England, where it is a summer resident. It undoubtedly breeds in all these States, as it is frequently taken in the breeding season; but its nest, owing to the secluded habits of the bird, is very rarely found. It. is described as being similar to that of the preceding species. The eggs, five in number, are covered with a calcareous deposit, which gives them a dirty yellowish-white color: on scraping this off, the shell beneath has a bluish-white tint. The form of the egg is exactly ovoidal. Specimens in my collection, from Illinois, measure about 2.17 inches in length by 1.45 inch in their greatest breadth. Another, from Wisconsin, is only 1.95 inch in length, and 1.18 inch at its greatest breadth. 


\section{FAMily ALCID无.}

Bill without lamellæ along the edges; usually shorter than the head, compressed, and pointed; anterior toes connected fully by a continuous membrane; hind tne often entirely wanting; the outer as large as the middle; the claws higher than broad; legs inserted far back; wings short, concave.

The Alcidae are readily distinguished from the Colymbidas by the absence of hind toe, the continuous webbing of the toes, the compressed claws, and other characters. The species are all exclusively marine, usually arctic, only coming southward in winter. Owing to their boreal residence, they are little known; and several species doubtless yet remain to be discovered.

\section{Sub-Family Alcine.-The Auks.}

\section{ALCA, LinNeUs.}

Alca, Linn жus, Syst. Nat. (1758).

General form short, broad, and strong; wings short; tail short; bill about as long as the head, feathered at base, much flattened laterally, wider, and somewhat hooked at the end; upper mandible with oblique transverse grooves; wings short and feeble; tail short, pointed; legs and feet short and strong; toes fully webbed.

\section{ALCA TORDA, - Linnœus.}

The Razor-billed Auk.

Alca torda, Linnæus. Syst. Nat., I. (1758) 130. Aud. Orn. Biog., III. (1835) 112 ; V. 428.

\section{Description.}

Much smaller than the preceding; general form short and heavy; bill rather long, densely feathered at base, flattened laterally; upper mandible with three to five curved transverse grooves; under mandible with three or four transverse grooves; feathers on side of upper jaw reaching far beyond the middle of the commissure, and nearly as far as those of the lower jaw; wing moderate, pointed; tail short, graduated, with the middle feathers longest and pointed; legs short, strong; a narrow but very distinct line of white on each side from the base of the upper mandible to the eye; head and entire upper parts brownish-black, more clearly brown on the throat and neck in front, and darker on the back; secondary quills narrowly tipped with white; entire under parts white; bill black, with a single transverse band of white on both mandibles; feet black.

Total length, about seventeen inches; wing, eight to eight and a half; tail, three and a half; bill to gape, two and a half inches.

Hab. - North-eastern coast of America; Newfoundland, Labrador, and south in winter to New Jersey; also, arctic regions of Old World. 
This well-known species is very abundant on the north-eastern coasts of North America, and appears to be quite identical with the bird of the northern regions of the Old World. It wanders southwardly in the winter, and is occasionally noticed on the coasts of the Middle States on the Atlantic. This bird may always be recognized by the conspicuous white line in front of the eye, which is present in all ages and stages of plumage.

THIS species visits our coasts, in small numbers only, in the winter months. It breeds in the most northern portions of the continent, the nearest breeding-place to New England being the islands in the Bay of Fundy. Audubon, in describing the breeding habits of this bird, says, -

"When the Auks deposit their eggs along with the Guillemots, which they sometimes do, they drop them in spots from which the water can escape without injuring them: but when they breed in deep fissures, which is more frequently the case, many of them lie close together; and the eggs are deposited on small beds of pebbles or broken stones, raised a couple of inches or more to let the water pass beneath them. When they lay their eggs in such a horizontal cavern, you find them scattered at the distance of a few inches from each other: and there, as well as in the fissures, they sit flat upon them, - like Ducks, for example; whereas, on an exposed rock, each bird stands almost upright upon its egg. Another thing, quite as curious, which I observed, is that, while in exposed situations, the Auk seldom lays more than one egg; yet, in places of greater security, I have, in many instances, found two under a sin gle bird. The eggs measure at an average $3 \frac{1}{8}$ by $2 \frac{1}{8}$ inches, and are generally pure-white, greatly blotched with dark-brown or black; the spots generally forming a circle towards the larger end. They differ considerably from those of the Common and Thickbilled Guillemots, being less blunted at the smaller end."

It is a matter of great difficulty to distinguish the eggs of this species from those of the Murre and Foolish Guillemot. In a large number of each in my collection, I can discover no characteristic peculiar to either so persistent as to distinguish it. The exception noted by Audubon, of the small end being less sharpened than the others, is 
the principal; yet this is not invariable, and it cannot be depended upon as a sure means of identification.

\section{MORMON, IlLiger.}

Mormon, Illiger, Prod. (1811), 283.

General form short and heavy, and adapted to swimming and diving with great facility, and to limited power of flight; bill short, entirely horny, much flattened laterally, and nearly as high as long; measured on the side obliquely rugose and laminated; a portion at the base punctulated; nostril in the edge of and in the second lamina of the upper mandible; wing moderate or rather weak, first quill usually longest; tail short; legs short; toes, three only, directed forwards, rather long; fully webbed; claws large, curved; plumage very compact.

\section{MORMON ARCTICA.-1lliger.}

The Puffin.

Alca arctica, Linnæus. Syst. Nat., I. (1766) 211.

Mormon arctica, Illiger. Prod. (1811). Aud. Orn. Biog., III. 105.

\section{DESCRIPTION.}

Smaller than either of the preceding, but much resembling the two last species in form and color; a short, blunt process over each eye, and a narrow transverse process under it; bill much flattened laterally, horny; upper mandible composed of two parts, that at the base narrow, and covered with minute spots or granulations, terminal part with about four curved ridges at its base, and two or three curved descending grooves near the end; under mandible smooth at base, and with about three grooves near its end; wing rather short and weak; tail short; legs and feet strong; throat black, uniting with the same color of the upper parts of the body; large space on each side of the head and entire under parts, from the throat, white, frequently tinged with ashy about the eyes; entire upper parts (and throat) brownish-black, darker, and frequently clear black on the back; head above frequently dark-ashy, separated by a well-defined line from the black of the other upper parts; bill and feet orange-yellow; sides, under the wings, ashy-black; iris light-blue.

Total length, about twelve and a half inches; wing, seven and a half; tail, two and three-quarters inches.

This bird is not uncommon on the coast of northern New England as a winter visitor, and a few breed on the islands about Grand Menan. The nest is placed in a burrow in the earth, dug by the birds. "In all the burrows that communicate with each other, a round place is scooped out on one side of the arenue in the form of an oven; while, in those which are single, this ovenlike place is found at the end. All the passages are flattish above and rounded beneath, as 
well as on the sides. In many instances, tro birds are found sitting each on its egg in the same hole. Both birds work in diggings the hole, using their bills and feet: they also sit alternately on their egg, although the female engages more industriously in this occupation, while the male labors harder at the burrow. But one egg is laid: this is at first pure-white; but it soon becomes soiled and stained, and appears to be a dirty yellowish-white. Its form is a pure ovoidal. A number of specimens in my collection are from 2.48 to 2.30 inches in length, and from 1.70 to 1.65 inch in their greatest breadth. Some specimens are marked with spots and blotches of brownish-red, - the proportion of marked ones being about two in five.

\section{Sub-Family URINж. - The Guillemots.}

URIA, MOEHRING.

Uria, Moerning, Av. Gen. (1752). (Type Colymbus grylle, L.)

General form short and robust; head moderate; bill rather long, straight, somewhat compressed, pointed, angle of the under mandible distinct; nostrils in a groove at base of upper mandible, the membrane of which is covered with short velvet-like feathers; wings short, pointed; tail short; legs short and robust; tarsus shorter than the middle toe, compressed; toes rather long, fully webbed; claws rather strong, curved.

\section{URIA GRYLLE, - Latham.}

\section{The Guillemot.}

Alca grylle, Linnæus. Syst. Nat., I. (1758) 130.

Uria grylle, Audubon. Orn. Biog., III. (1835) 148; V. 627.

\section{DESCRIPTION.}

Bill straight, pointed; wing rather short, weak; first quill longest; tail short; a large oval transverse space on the wing white, which is also the color of the under wing coverts and axillary feathers, outer edge of the wing and shoulder brownishblack; all other parts of the plumage brownish-black, with a greenish tinge, and darker on the back; bill black; feet red.

Younger. - Under parts, neck, and rump, white; head above and back darkbrown; large space of white on the wing.

Total length, about thirteen inches; wing, six and half; tail, two inches. 
This species is pretty abundant on our coasts; and it is said to breed on rocky islands, from Mount Desert eastward. It can therefore be considered as a resident of north-eastern New England through the year. It is found all along our shores in the winter, but not in any great abundance; and it is less common on the shores of Massachusetts, than on those of Maine. Like the other Auks and Guillemots, it is an expert diver; and it obtains its food by diving and swimming beneath the surface of the water: this food, as with the others, consists principally of fish, which it seizes in its bill, and swallows whole. It also eats various small marine animals and their eggs; and, like the other's, picks up such floating garbage as may come in its way.

The eggs, three in number, are placed on the bare rock or earth, usually in fissures of cliffs or almost inaccessible ledges. These are exactly ovoidal in form, and vary in color from a pale greenish-white to a pure pearl-white. This is covered irregularly with spots and blotches of different shades of brown and black, thickest at the great end, where they are usually almost confluent into a ring around the whole egg. Besides these spots, there are others of an obscure-purple scattered over the egg, that appear as if they were beneath the outside of the shell. The dimensions of the eggs of this species vary from 2.40 by 1.60 inch to 2.25 by 1.50 inch.

URIA LOMVIA. - Brünich.

The Foolish Guillemot; the Murre.

Uria lomvia, Brünnich. Orn. Bor. (1764), 27.

Colymbus troile, Linnæus. Syst. Nat., I. (1766) 220.

\section{Description.}

Bill rather long, pointed, compressed; from the lateral feathers longer than the tarsus, or than the inner toe and claw; a narrow line under and behind the eye dark-brown; head above, and entire other upper parts, brownish-black; sides of the head, and entire under parts, white; sides of the body under the wing with transverse stripes of ashy-brown; under wing coverts white, secondary quills tipped with white; bill blackish-brown, paler at base; tarsi and feet dark greenish-brown; sum- 
mer plumage, with the entire hind and upper parts of body, dark sooty-brown; under parts white; head and orbital region dusky, without white stripes.

Total length, about fifteen inches; wing, seven and a half; tail, two inches.

Hab. - Northern coasts of America; Northern Europe and Asia.

This bird is rather common on our coast in the winter months, and is said to breed in small numbers about the Bay of Fundy. As a general thing, however, it passes the season of incubation in more northern localities, and is very abundant on the coast of Labrador, where, on the low islands, it breeds, laying a single egg, like the Razor-billed Auk, on the bare rock or gravel. It is impossible to describe the egg of this species in a manner that will lead to its being distinguished from that of the Murre or Razorbilled Auk.

Audubon makes the following observations, which are, of course, of more value to the collector than to the student, who has no opportunities of visiting the breeding-grounds of these birds. He says :-

"The Foolish Guillemot lays only a single egg, which is the case with the Thick-billed Guillemot also. The Razor-billed Auk lays two, and the Black Guillemot usually three. This is confirmed by the fact, that the Foolish Guillemot, which lays only one egg, plucks the feathers from its abdomen, which is thus left bare over a roundish space, just large enough to cover its single egg. The Thick-billed Guillemot does the same. The Auk, on the contrary, forms two bare spots, separated by a ridge of feathers. The Black Guillemot, to cover her three eggs, and to warm them all at once, plucks a space bare quite across her belly."

One peculiarity which I notice in the eggs of this species and those of the Murre is, that they are generally somewhat pyriform in shape: but this is not persistent; and the same rock may contain a deep-green egg with brown spots and blotches, a light-blue one with hardly any marks, and cream-colored ones, drab, reddish-white, and bluish-white, some with only a few spots and blotches, and others thickly marked. It may also have pyriform eggs, ovoidal, ovate, 
and almost oval ones. The only means of perfect identification of either of these species is to visit their breedingplaces, and secure the parent birds on their nests.

The dimensions vary from 3.50 by 2.15 inches to 2.95 by by 1.78 inch.

URIA RINGVIA. — Brünnich.

The Murre.

Uria ringvia, Brünnich. Orn. Bor. (1764) 28.

Uria troile, Audubon. Orn. Bor., III. (1835) 142.

\section{DESCRIPTION.}

About the size of, or rather larger than, the preceding; bill rather long, pointed, compressed; from the lateral feathers, longer than the tarsus, or than the inner toe and claw; wings rather short: tail very short; a narrow line of white encircling and running backwards behind the eye and over the ear; head and entire upper parts darkbrown, with a tinge of ashy; under parts white; sides with transverse stripes of ashy-brown; under wing coverts white; bill black; feet greenish-black; winter plumage, with the throat and all other under parts, white; the white line behind the eye frequently wanting, and different in length in specimens.

Total length, about seventeen inches; wing, seven and a half to eight inches; tail, two inches.

Hab. - Northern America, Northern Europe, and Asia.

The same remarks are applicable to this as to the Foolish Guillemot. It is northern in its habits, and is more abundant on the coast of Maine than farther south.

\section{MERGULUS, RAY.}

Mergulus, RAY, Syn. Av. (1713), 125.

Small; general form short and heavy; head rather large; bill short, thick; upper mandible curved, slightly lobed on its edge; membrane of the rounded nostril large; wings moderate or rather short, pointed; first quill longest; tail short; feet rather short.

\section{MERGULUS ALLE. - Linnoers.}

The Little Auk; the Sea Dove; Dovekie.

Alca alle, Linnæus. Syst. Nat., I. (1766) 211.

Uria alle, Audubon. Orn. Bor., IV. (1838) 304.

\section{DESCRIPTION.}

Small; head, breast, and entire upper parts, brownish-black, inclining to fuliginous on the head and breast; under parts from the breast white; a narrow line of white over the eye; secondaries tipped with white; scapulars edged with white; 
under wing coverts dark-ashy; flanks with longitudinal stripes of brownish-black; bill black; feet pale-reddish; webs of toes dark; winter plumage and young, with the throat and other under parts, white, extending somewhat on the sides of the neck.

Total length, about seven and a half inches; wing, four and a half; tail, one and a. quarter inch.

One of the most abundant of the sea-birds of northern America and Europe, straying south in the winter occasionally to the coasts of the Middle States.

This curious little bird is not uncommon on our coast in winter. In severe storms, it is occasionally blown far inland; and it has been killed in the Umbagog Lakes, in the north-western part of Maine. I know but little of its habits. Wilson says:-

"The Little Auk is said to be but a rare visitant of the British Isles. It is met with in various parts of the North, even as far as Spitzbergen; is common in Greenland, in company with the Black-billed Auk, and feeds upon the same kind of food. The Greenlanders call it the Ice-bird, from the circumstance of its being the harbinger of ice. It lays two bluish-white eggs, larger than those of the Pigeon. It flies quick, and dives well, and is always dipping its bill into the water while swimming or at rest on that element; walks better on the land than others of the genus. It grows fat in the stormy season, from the waves bringing plenty of crabs and small fish within its reach. It is not a very crafty bird, and may be easily taken."

\section{NOTES.}

I conclude herewith Mr. Couper's notes on the foregoing species, made at Quebec, Lower Canada:-

ANSER HYPERBOREUS. - Common on the St. Lawrence in the fall.

BERNICLA CANADENSIS, - This is our most common species. It goes north and west to breed. They breed abundantly in the swamps of Illinois. A few breed in Anticosti; and I believe they are to be found breeding in Labrador. 
ANAS BOSCHAS, - Uncommon.

A. OBSCURA. - This duck is very common here. It is truly a northern species. It breeds in the swamps adjacent to this city.

DAFILA ACUTA. - Common in spring: a few visit us in the fall.

NETTION CAROLINENSIS. - Common. Breeds.

QUERQUEDULA DISCORS. - Uncommon.

SPATULA CLYPEATA. - Uncommon.

MARECA AMERICANA. - The adult bird is seldom seen in this latitude.

AIX SPONSA. - Sometimes common. Breeds.

FULIX MARILA. - The young are abundant on the St. Lawrence during autumn. They breed north-west of Quebec.

F. AFFINIS. - Occasional specimens are shot at Sorel and Three Rivers. It is more abundant in Western Canada.

F. COLLARIS. - Occasional.

AYTHYA AMERICANA. - Occasional.

BUCEPHALA AMERICANA. - Very common in spring and fall. Breeds in Canada.

B. ISLANDICA. - Adult birds are occasionally shot on the lakes. The young are abundant on the St. Lawrence during the early part of winter. I have seen the adult on Lac à la Philip in July.

B. ALBEOLA, - Common in spring and fall.

HISTRIONICUS TORQUATUS. - Common on the north shore of the St. Lawrence. A beautiful adult male was shot in the spring, on the Montmorenci River, near Quebec.

HARELDA GLACIALIS. - Occasional near Quebec. Common on the upper lakes in spring and fall.

PELIONETTA PERSPICILLATA. - Very common in the fall at Mille Vaches, lower St. Lawrence.

SOMATERIA MOLLISSIMA. - Common on the north shore of the St. Lawrence. Breeds on islands in the river below the Saguenay.

MERGUS AMERICANUS. - Common. Breeds.

M. SERRATOR. - Common in spring and fall.

LOPHODYTES CUCULLATUS. - Adult is occasionally seen. Young visit the St. Lawrence in the fall. Breeds on the margins of northern lakes.

LARUS ARGENTATUS. - Common on the St. Lawrence in spring and fall. Breeds on our mountain lakes. 
LARUS DELAWARENSIS. - The young are occasionally seen hovering over the river, opposite the city, in autumn. Breeds in Labrador.

CHROICOCEPHALUS PHILADELPHIA. - The young of this Gull are common in the St. Lawrence during autumn. Adult rare. They are supposed to breed on the islands of the St. Lawrence.

STERNA WILSONII. - The young are common in the autumn. Adult birds are occasionally seen on their way to the upper lakes.

COLYMBUS TORQUATDS, - Common on all our northern lakes. Breeds.

URIA LOMVIA. - This species makes an occasional foolish visit to the fresh waters of the St. Lawrence. In the fall of 1866, hundreds were destroyed by the inhabitants, who sold them to hucksters to exhibit on the market as an article of food. 



\section{A P P E N D I X.}

I HERE append the following list of additional species, which occur or have occurred within the limits of New England. As will be perceived, the greater number can be regarded only as occasional or accidental visitors; and, indeed, some of the species are deemed by ornithologists as of doubtful existence, - as, for instance, Smallheaded Flycatcher, Wood Wren, \&c.

I am under special obligations to Mr. Henry A. Purdie for many valuable suggestions and facts in relation to the times of arrival, distribution, breeding habits, \&c., of many of the species described in the body of the work, and mentioned in the Appendix. Reference has been made to the following works:-

Birds of Massachusetts. By W. B. O. Peabody. 1839.

Birds of Long Island. By J. P. Giraud. 1841.

Birds of VermoNt. By Zadock Thompson. 1853.

Catalogue of Brrds of Essex County, Mass. By F. W. Putnam. Published in Proceedings of Essex Institute. Vol. I. 1856.

Catalogue of Birds found at Norway, Me. By A. E. Verrill. Published in Proceedings of Essex Institute. Vol. III. 1862.

Catalogue of Birds found at Calais, Me., and about the Islands in the Bay of Fundy. By George A. Boardman. Published in Proceedings of Boston Society of Natural History. Vol. IX. 1862.

Catalogue of Birds found at Springfield, Mass. By J. A. Allen. Published in Proceedings of Essex Institute. Vol. IV. 1864.

Catalogue of Birds of Massachusetts. By E. A. Samuels. 1864.

Catalogue of the Birds found in the vicinity of Waterville, ME. By Professor C. E. Hamlin, in Report of Maine Board of Agriculture. 1865.

Catalogue of Birds of New England. By Elliott Coues, M.D. Published in Proceedings of Essex Institute. Vol. V. 1867.

Notes on some of the Rarer Birdos of Massachusetrs. By J. A. Allen. Published in American Naturalist. Vol. III. 1869. Article by John Burroughs in Atlantic Monthly. June, 1869. 
CATHARTES AURA. Turkey Buzzard. - Accidental. One taken at Calais, Me.,-George A. Boardman; two in Massachusetts, 1863.

Cathartes atratus. Black Vulturo, - Accidental. One taken at Swampscott, Mass, in November, 1850, by S. Jillson; one at Gloucester, Mass., on Sept. 28, 1863, by William Huntsford; one in Hudson, Mass. ; others seen, - S. Jillson; one near Calais, Me., - G. A. Boardman.

FALCO SACER. Jer Falcon. Iceland Falcon, - Rare winter visitor, almost accidental in southern portions. One killed at Seekonk Plains, Mass., about 1840, by Jillson; one taken in the winter of $1864-5$, near Providence, R.I., by Mr. Newton Dexter. 'The two species heretofore considered distinct - viz., Falco Candicans and F. Islandicus - are now considered as belonging to the present species.

ARCHIBUTEO SANCTIJOHANNIS, Black Hawk; and ARCHIBUTEO LAGOPUS, Rough-legged Hawk. -J. A. Allen gives, in his article on the "Rarer Birds of Massachusetts," the following extract, from a letter written by Dr. William Wood, in relation to these species, to prove that they are identical :-

"I have," he says, "all shades of color, from the light to the black, and I am unable to find the dividing line; both have the same measurements, the same claws and bill, the same habits, come and leave at the same time, and hunt together. I have them almost black, with the faint markings of the lighter bird, showing, to my mind, that the lighter markings become extinct as the black increases, or as the bird increases in age. Those who claim that they are distinct say, that in some localities the Rough-legs are common, and no Black Hawks are to be seen. This proves nothing. The young of the Red-throated Diver are very common in Long-Island Sound, yet the adult is never seen there. So it is with the Crested Grebe: the young are found here in winter, never the adult."

In another letter, Dr. Wood says: "The Rough-legged Falcon and Black Hawk are the same. I have taken and examined, I presume, forty specimens. They are the same bird, but not of the same age. The black is the adult. So gradually do they become more black till jet-blick is reached, that I will defy any one to draw the separating line."

STRIX PRATINCOLA. Barn 0wl. - Given by Thompson, on authority of Dr. Brewer, as being not only found in Vermont, but also breeding there. This is, of course, ineorrect. Accidental visitor from the South. One taken in Lynn, Mass., about 1863, by Mr. James Teal; one taken at "Sachem's Head," Conn., Oct. 28, 1865,--Dr. William Wood; one at Springfield, Mass., May, 1868, - J. A. Allen. 
NYCTALE ACADICA, Saw-Whet 0wl. - The following account of the breeding habits of this little owl is kindly furnished me by Richard Christ, of Nazareth, Pa.:-

"This, the smallest of all our owls, is also the most rare, but a single specimen being seen in a period of several years. It is very tame when found, permitting one to approach very close to it before flying away. I am inclined to think that it sees less in the daytime than any other species of our owls, for one can touch it without being noticed, the bird taking flight more from alarm to its sense of hearing than any other cause.

It generally frequents stone quarries or piles of rocks, beneath which it takes shelter; and it is from this habit that the bird here is known by the name of "stone owl." On the 25th of April, 1867, I was so fortunate as to find the nest of one of these birds. It was placed or located in the hollow of a tree, about twenty feet from the ground; the entrance to the hole was very small, scarcely two inches in diameter. On climbing the tree and looking into the hollow, I discovered sitting on the bottom what I supposed might be a small owl. Uncertain as to the truth, I introduced a small stick into the hole, and turned the bird over upon her side, she making no struggle whatever, but remaining perfectly still as if dead. I discovered that she was sitting upon a single egg. Supposing that she had but just commenced laying. I left her, and did not molest her again for several days; on the fifth day after, I again examined the nest, and found the bird on her egg, none other having been laid. I enlarged the hole, and took the egg, leaving the owl quietly sitting on the rotten chips which formed the bottom of the nest.

The egg was white, with a bluish tint, like many of the other owls' eggs, nearly globular in form, and considerably smaller than the egg of the Red or Mottled owl."

CENTURUS CAROLINUS. Red-bellied Woodpecker. - Given in Allen's list as accidental. He "saw one, May 13, 1863; and it has been taken several times in Connecticut, but occurs in New England only as a straggler." Accidental summer visitor, and only in more southern portions.

ARGITRIA MacUlata. - A South American Humming Bird, a single individual of which was captured in Cambridge, Mass., August, 1865, by Mr. William Brewster. Entirely accidental.

TYRANNOS DOMINICENSIS. Gray King Bird. - Entirely accidental; from the South. One shot in Lynn, Mass., October, 1869, by Charles I. Goodale.

EMPIDONAX FLAVIVENTRIS, Yellow-bellied Flycatcher, - A not common spring and autumn migrant in southern, and summer resident in 
northern sections. Is generally found in thick undergrowth in swampy localities. It is said to have a more musical note than other species of this genus; and, according to William Brewster, of Cambridge, its song somewhat resembles that of the Wood Pewee, but it is not so prolonged, and much more subdued.

TURDUS NEIIUS. Varied Thrush. - But one instance on record of its capture in New England; at Ipswich, Mass., December, 1864. Accidental; from the West.

SAXICOLA ENANTHE. Stone Chat. - Not as yet, I believe, actually obtained within the limits of New England; but as it has, according to Coues, been found in Nova Scotia, Labrador, and on Long Island, it may occur. The species is a straggler from Europe, and entirely accidental.

POLIOPTILA CERULEA. Blue-Gray Gnatcatcher. - An accidental summer visitor to southern portions of New England. No recent instance of its occurrence on record.

LOPHOPHANES BICOLOR. Crestéd Titmouso.-An accidental species, same as the preceding.

TROGLODYTES AMERICANUS. Wood Wren.-I have never met with this species; but was induced to include it in my list of Massachusetts birds, published in 1864 , because several collectors and others had informed me that it was occasionally found here. Thompson and others include it in their catalogues, and its egg is even said to have been found by Dr. Brewer. I doubt that the species is well established, and have no knowledge of an authentic specimen in any collection.

GEOTHLYPIS PHILADELPHIA. Mourning Warbler.-Chiefly a rare spring and autumn migrant; but it breeds in northern and elevated portions of New England. A nest said to belong to this species, found by Mr. John Burroughs about the head-waters of Delaware River, in the Catskill Mountains, N.Y., is thus described by him in the "Atlantic" for June, 1869 :-

"It was placed in a bunch of ferns, and about six inches from the ground. It was quite a massive nest; composed entirely of the stalks and leaves of dried grass, with an inner lining of fine, dark brown roots. The eggs, three in number, were of light flesh-color, uniformly specked with fine brown specks. The cavity of the nest was so deep that the back of the sitting bird sank below the edge."

According to this writer, the song of this bird resembles that of the Maryland Yellow Throat. Like that species, it gives a preference to damp places. 
PROTONOTARIA CITREA. Prothonotary Warbler. - But one occurrence in New England, - male bird, obtained in October, at Calais, Me., by G. A. Boardman. Accidental. A southern species.

HELMINTHOPHAGA CHRYSOPTERA. Golden-winged Warbler. - As stated by Mr. H. A. Purdie, in the "American Naturalist," Vol. III. p. 497, Massachusetts is probably about the northern limit of this species, and it is a not uncommon summer visitor in that State, instead of a spring and autumn migrant. He also mentions the discovery of the nest in West Newton, by. Mr. C. J. Maynard, thus confirming his belief that this warbler nidified with us.

In the same volume of the above magazine, pp. 575-6, Mr. J. A. Allen thus deseribes the nest found by Mr. Maynard:-

The nest was placed " on the ground, in a tract of coarse weeds and ferns, near a swampy thicket, and but a few rods from a public highway. It was placed entirely above the surface of the ground, and the birds seem to have made no special effort to conceal it. It was composed externally of dried oak-leaves and the bark of the grape-vine, and rather roughly lined with fine grass and a few horse-hairs. He says it is large for the size of the bird, and somewhat reminds one of the nest of the Maryland Yellow Throat. It is a little smaller at the top, where the internal diameter is less than two inches, while in the middle it is two and a quarter. The eggs were five in number, including a Cow Bunting's egg that these watchful parasites had introduced."

These eggs are described as varying from 66.100 th inch in length by 55.100 th inch in breadth to 66.100 th inch by 53.100 th inch, and being more or less spotted and blotched with brown, over a white ground color.

HELMINTHOPHAGA CELATA. Orange Crowned Warbler. - Accidental. One obtained at Springfield, Mass. ; others seen, May, 1863, by J. A. Allen. A western species.

SEIURUS LUDOVICIANUS. Large-billed Water Thrush.- Very rare, if not accidental, summer visitor. One taken at Norway, Me., May, 1865, by Irving Frost; one at Waterville, Me., 1865, - Professor C. E. Hamlin; one on Mount Tom, Mass., April 28, 1869, by J. A. Allen.

DENDROICA CERULEA. Blue Warbler. - Perhaps an accidental summer visitor to extreme southern portions of New England. No recent instances on record of its occurrence.

DENDROICA MACULOSA. Black and Yellow Warbler. - The following description of a nest and eggs of this species is kindly furnished me by 
Mr. R. Deane, of Cambridge, Mass. The specimens were found at Upton, Maine, June 10, 1870 :-

"The nest was placed in a forked branch of a low spruce about three feet from the ground, on a rising piece of land leading from a wood path. The nest, which contained four eggs, was constructed of dry grass, spruce twigs, roots, \&c., and was lined with fine black roots, the whole being quite a coarse structure for so dainty a looking Warbler.

"The eggs were more spherical than any Warbler's $I$ have seen, the ground being a creamy white, and blotched sparsely over with large spots of lilac and umber.

"The dimensions are as follows: .62 by .52 inch; .61 by .52 inch; .62 by .50 inch; .63 by .52 inch."

MrIodioctes MINUTUS. "Small-headed Flycatcher." - Although Dr. Brewer informed Mr. Peabody that " it has been found in Ipswich, Mass., and that he picked up a specimen, evidently just dead, on the step of his door in Brookline, Mass.," I think that its oceurrence in New England must be regarded as very doubtful, even if the species exists, which many naturalists deny. Some one of the species of Empidonax, as Dr. Coues remarks, was probably mistaken for it.

MYIODIOCTES CANADENSIS. Canada Flycatcher.-This species probably more often nests on the ground and in damp situations than elsewhere. A nest found in Lynn, Mass., some years since, by George Wells, is thus described, Vol. VI. Proc. Boston Soc. Nat. Hist.: "The nest was found in low swampy ground, and was built at the foot of a tussock of thick grass, on the ground. It was constructed almost entirely of leaves of the white pine, so loosely arranged that it was found necessary to sew them together, in order to preserve it. The eggs, five in number, in shape are an oblong ovoid, 3.4ths of an inch in length by 9.16ths in breadth; their ground color is a bluish-white, irregularly marked with dots and small blotches of reddish-brown."

PYRANGA ESTIVA. Summer Red Bird.-Accidental summer visitor to southern portions. Two taken in Lynn, Mass., April 21, 1852, by S. Jillson; one taken in Framingham, Mass., May; one in Amherst, Mass., August, 1867.

COLLYRIO EXCUBITOROIDES. White-rumped Shrike. - Said by Nuttall to have been seen in Massachusetts in winter. Doubtful.

VIREO PHILADELPHICUS. Philadelphia Vireo. - Very rare summer visitor; only one instance of its occurrence on record. Waterville, Me., - Professor C. E. Hamlin. 
CHONDESTES GRAMMACA. Lark Finch. - Entirely accidental; but one instance of its occurrence recorded, - S. Jillson, Gloucester, Mass., 1845. A western species.

CENTRONYX BAIRDII. Baird's Sparrow. - Accidental. One specimen obtained at Ipswich, Mass., by C. J. Maynard, Dec. 4, 1868. A northwestern species.

MELOSPIZA LINCOLNII. Lincoln's Sparrow. - Accidental; but five instances of its capture on record. Three at Springfield, Mass., by Mr. J. A. Allen, May, 1860, 1863, 186t; two at Hudson, Mass., by S. Jillson, May, $1867,1868$.

PASSER DOMESTICA. European Hö̈se Sparrow. - Introduced from Europe, and will probably become generally distributed, at least in the more southern portions of New England.

GUIRACA CERULEA. Blue Grosbeak. - Accidental visitor from the South; but one instance of its occurrence on record, - George A. Boardman, Calais, Me., 1S61, when several were seen.

CARDINALIS VIRginianus. Cardinal Grosbeak. Red Bird.-Accidental visitor from the South; but three recent instances of its occurrence. Four specimens taken near Springfield, Mass., in October, 1866. Seen by Mr. W. H. Niles, at Belchertown, Mass., October, 1868; and at Southampton, Mass., May 5, 1869.

XANTHOCEPHALUS ICTEROCEPHALUS. Yellow-headed Blackbird.-Accidental visitor from the West. One taken in Watertown, Mass., in October, 1869.

LAGOPUS ALBUS. White Ptarmigan. - Rare winter visitor in northern New England.

HERODIAS EGRETTA. Great White Heron. - Accidental visitor from the South. Several instances of its capture in southern portions of New England.

FLORIDA CEROLEA. Little Blue Heron, - Of rare occurrence. Specimen taken in Barnstable, Mass., in spring of 1861. Accidental; from the South.

NYCTHERODIUS VIOLACEUS. Yellow-crowned Night Heron. - Accidental visitor from the South. One taken in Lynn, Mass., by Mr. N. Vickary, October, 1862.

IBIS ORDII. Glossy Ibis. - Accidental visitor from the South. Two recent instances of its occurrence recorded, - Nantucket, September, 1869, one specimen; New Hampshire, in October, 1858, by Dr Palmer. 
HIMANTOPUS NIGRICOLLIS. Black-necked Stilt.-But one or two occurrences, in our limits, on record. A southern species.

PHALAROPUS WILSONII. Wilson's Phalarope.-Given in Dr. Coues' list as "Very rare, perhaps only accidental, and chiefly during its migrations."

PHalaropus FUlicarius. Red Phalarope.-Oceurs rarely, along the coast, during its migrations.

Micropalama himantopus. Stilt Sandpiper. - Exceedingly rare summer visitor. Two specimens obtained at Rye Beach, N.H., by Mr. William Brewster, late in Augusts of 1868-69.

PHILOMACHUS PUGNAX. Ruff- - One or two instances given by Boardman. Accidental visitor from Europe.

Gallinula Galeata, Common Gallinule; and G. MaRTiniCa, Purple Gallinule. - Are both rare visitors from the South.

ANSER GAMBELLII. American White-fronted Goose.-Given in Dr. Coues' list as "Very rare, and perhaps accidental, in winter."

BERNICLA HUTCHINSIr. Hutchinson's Goose. - Given in Dr. Coues' list as "Chiefly spring and autumn migrant. Not abundant."

NETTION CRECCA. English Teal. - A wanderer from Europe. But one or two instances of its occurrence on record.

FULIX COLLARIS. Ring-necked Duck. - Spring and autumn. Not common.

CAMPTOL无MUS LABRADORIUS. Labrador Duck. - Rare winter visitor.

MERGeldus ALbellus. Smew. - Very rare. Have seen a specimen that was killed in Massachusetts Bay, as I was informed; and Mr. Chas. W. Lovett, Jr., of Boston, assures me that he once met with one at Point Shirley, Mass. A straggler from the northern parts of the Old World.

SULA FIBER. Booby. - Entirely accidental; but two instances of its occurrence, and those not recent. A southern species.

PElecanus Fuscus. Brown Pelican.-Accidental; from the South. Only one specimen obtained, Brant Point, Nantucket; others seen, J. A. Allen.

PELECANUS ERTTHRORYNCHUS. American Pelican. - Has been taken in New England. "One or two instances." Calais, Me., - G. A. Boardman. Accidental.

STERCORARIUS CEPPHUS. Buffon's Skua, Long-tailed Jager. $-\mathbf{A}$ not uncommon fall and winter visitor. 
LARUS GLAUCDS. Glaucous Gull, Burgomaster Gull, - A very rare winter visitor.

LARUS LEUCOPTERUS. White-winged Gull. - A rare winter visitor.

LARUS DELAWARENSIS, Ring-billed Gull. - Not uncommon in winter. Breeds on the coast of Maine rarely.

STERNA ACUFLAVIDA. Cabot's Tern. - Accidental; from the South. One obtained at Chatham, Mass., August, 1865, by Mr. Nathaniel Vickary.

SterNa FULIGINosa. Sooty Tern. - Has been met with on Muskegeet Island, Mass., in the breeding season. A southern species.

STERNA PARADISEA. Roseate Tern. - Summer visitor to southern portions of New England.

PROCELlarius Glacialis. Fulmar Petrel, - Given by Coues as "A rare winter visitant along the coast."

THALASIDROMA PELAGICA. Stormy Petrel.-Rare in winter off the coast.

PUFFINOS MAJOR. Greater Shearwater. - Not uncommon in winter off the coast.

PUFFINUS ANGLORUM, Mank's Shearwater; and P. FULIGINOSUS, Sooty Shearwater. - Are occasionally met with in winter off the coast.

MORMON CIRRHATA. Tufted Puffin. - Very rare, and probably accidental; in winter, on south-eastern coast of Maine. A north Pacific species.

COLPMBUS ARCTICUS. Black-throated Diver. - Is given in several lists as occurring in winter. Given in Putnam's list as "common in young plumage in winter, rare in adult plumage." I have never met with an undoubted specimen. Its occurrence in New England must be considered rare.

URIA ARRA. Thick-billed Guillemot. - Not uncommon in winter. 



\section{INDEX OF COMMON NAMES.}

A.

American Avoset, 428.

Bittern, 405 .

Creeper, 190

Goldfinch, 288.

Osprey, 55.

Raven, 355.

Swan, 480.

Widgeon, 499 .

Woodcock, 432 .

Auk, Little, 570.

Razor-billed, 564.

Aroset, American, 428.

B.

Bald Eagle, 51.

Baldpate Duck, 499.

Baltimore Oriole, 348 .

Barrow's Golden-eye Duck, 511.

Belted Kingfisher, 125.

Bittern, American, 405.

$$
\text { Least, } 403 .
$$

Blackbird, Cow, 339.

Crow, 352.

Red-winged, 341.

Rusty, 350 .

Bluebird, 175 .

Blue Jay, 364 .

$$
\text { Snowbird, } 314 .
$$

Bobolink, 335 .

Brant, 485.

Bull-head Plover, 413.

Bunting, Black-throated, 327.

Bunting, Cow, 339 .

Henslow's, 306.

Snow, 296.

Butcher-bird, 268.

Buzzard Hawks, 34 .

C.

\section{Canada Flycatcher, 247.}

Goose, 483.

Grouse, 378 .

Jay, 366, 372 .
Canvas-back Duck, 507.

Carolina Dove, 375 .

Cat-bird, 172.

Cedar-bird, 265.

Chat, Yellow-breasted, 209.

Chatterer, Bohemian, 264.

Chewink, 332

Chick-a-dee, 182.

Chimney Swallow, 116.

Coot, American, 476.

Butter-billed, 520.

White-winged, 518.

Cormorant, Common, 534 . Double-crested, 535.

Cow Blackbird, 339.

Creeper, American, 190. Black and White, 201.

Crossbill, Red, 291.

White-winged, 293.

Crow Blackbird, 352.

Crow, Common, 357.

$$
\text { Fish, } 363 \text {. }
$$

Cuckoo, Black-billed, 85.

Yellow-billed, 83.

Cuckoos, 82.

Curlew, Esquimaux, 469.

Hudsonian, 467.

Long-billed, 466.

Short-billed, 467.

Curlew Sandpiper, 443.

\section{D.}

Dipper, 525.

Diver, Great Northern, 555.

Red-throated, 557.

Dove, Carolina, 375.

Dovekie, 570.

Ducks, River, 487. Sea, 503.

Duck, Baldpate, 499. Barrow's Golden-eye, 511. Big Black-head, 504.

Black, 28, 489.

Buffle-head, 514.

Butter-ball, 514.

Canvas-back, 507 . 
Duck, Dipper, 514, 525. Dusky, 28, 489.

Eider, 522 .

Gadwall, 497.

Golden-eye, 512.

Harlequin, 515.

King Eider, 523.

Little Black-head, 505 .

Long-tailed, 516 .

Mallard, 487.

old Wife, 516 .

Pintail, 492.

Red Head, 506.

liuddy, 525.

Scaup, 504.

Scoter, 521.

South Southerly, 516.

Spoonbill, 496.

Sprigtail, 492.

Summer, 500 .

Surf, 520.

Velvet, 518

Whistle-wing, 512.

Wood, 500.

E.

Eagles, 49.

Eagle, Bald, 51.

Golden, 49, 81

Gray, 51.

White-headed, 51.

F.

Falcons, 7.

Finches, 283.

Finch, Bay-winged, 303.

Grass, 303.

Pine, 290.

Purple, 285.

Sea-side, 308.

Sharp-tailed, 307.

Flicker, 105 .

Flycatcher, Acadian, 143.

Canada, 247.

Great-crested, 131

Green-crested, 143.

Least, 141.

Olive-sided, 135

Pewee, 133.

Traill's, 140.

Wilson's Black-cap, 246.

Wood Pewee, 137.

\section{G.}

Gannet, Common, 532.

Godwit, Hudsonian, 465 .

$$
\text { Marbled, } 463 .
$$

Goldfinch, American, 288.

Goosander, 527 .

foose, Canada, 483.
Goose, Snow, 482.

Solan, 532

Goshawk, 22.

Grebe, Carolina, 562.

Crested, 560.

Horned, 561.

Pied-billed, 562.

Red-necked, 559 .

Greenlets, 270.

Grosbeak, Pine, 283.

Rose-breasted, 328.

Ground Robin, 332.

Grouse, Canada, 378.

Pinnated, 380.

Ruffed, 388.

Spruce, 378.

Guillemot, Common, 567 .

Foolish, 568 .

Gull, Bonaparte's, 543.

Great Black-backed, 540 .

Herring, 541.

Kittiwake, 544 .

Laughing, 542.

\section{H.}

Harrier, 46, 81.

Hawk, Black, 45 .

Broad-winged, 40, 81.

Cooper's, 27.

Duck, 7, 16.

Fish, 55, 81 .

Gos, 22, 81.

Great-footed, 7, 16.

Marsh, 46, 81.

Night, 122.

Pigeon, 16, 80.

Red-shouldered, 37 .

Red-tailed, 35.

Rough-legged, 43, 81.

Sharp-shinned, 31, 81 .

Sparrow, 19, 80 .

Heron, Great Blue, 401.

Green, 406.

Night, 409.

Snowy, 398.

Hooded Merganser, 529.

Humming-bird, Ruby-throated, 111.

I.

Indigo-bird, 330.

J.

Jay, Blue, 364.

Canada, 366.

K.

King-bird, 128.

Kingfisher, Belted, 125.

Kites, 46. 
L.

Lapland Longspur, 300 .

Lark, Meadow, 343. Tit, 200.

Lesser Redpoli, 294.

Loon, Great Northern, 555. Red-throated, 557.

M.

Mallard Duck, 487 .

Marsh Hen, 471.

Martin, Purple, 260.

Maryland Yellow-throat, 205.

Meadow Lark, 343.

Mealy Redpoll, 295.

Merganser, Red-breasted, 526.

Mocking-bird, 167.

Mlurre, 568, 570 .

\section{N.}

Night Hawk, 122.

Notes, by William Couper, 80, 368, 396, $477,571$.

Nuthatch, Red-bellied, 188.

White-bellied, 187

O.

Oriole, Baltimore, 348. Orchard, 346.

Osprey. 55.

Oven-bird, 218.

Owls, 60 .

Owl, Acadian, 75, 81 .

Barred, 73, 81 .

Great Gray, 72, 81.

Great Horned, 60, 81.

Hawk, 79,81 .

Long-eared, 68, 81.

Mottled, 64 .

Red, 64 .

Saw-whet, 75, 81.

Screech, 64.

Short-eared, 70, 81.

Snowy, 77, 81 .

Oyster-catcher, American, 424.

\section{P.}

Partridges, 393.

Passenger Pigeon, 373.

Peep, 447, 450 .

Petrel, Leach's, 553.

Pewee, 133

$$
\text { Wilson's, } 553 .
$$

Pewee, Wood, 137.

Phalarope, Northern, 430.

l'igeon, Wild, 373.
Pine Finch, 290.

Grosbeak, 283.

Plover, Bartram's, 460.

Black-bellied, 422.

Field, 460 .

Golden, 413.

Kill-deer, 415 .

Piping, 421.

Semipalmated, 419.

Wilson's, 418 .

Upland, 460.

Puffin, Arctic, 566.

Purple Finch, 285.

Qua-bird, 409.

Q.

Quail, Virginia, 393.

R.

Rail, Carolina, 474.

Clapper, 471.

Marsh, 471.

Virginia, 472.

Yellow, 475.

Raven, American, 355.

lied Start, 249

Redpoll, Lesser, 294.

Mealy, 295.

Ring-neck, 419 .

liobin, 154.

S.

Sanderling, 449.

Sandpiper, Bartram's, 460.

Bonaparte's, 446.

Buff-breasted, 462.

Curlew, 443.

Gray-back, 440 .

Least, 447,478 .

Pectoral, 445.

Purple, 442.

lied-backed, 444.

Semipalmated, 450 .

Solitary, 457.

Spotted, 458 .

Scarlet Tanager, 251.

Sea Dove, 570 .

Seed-eaters, 283.

Sheldrake, American, 527.

Shore Lark, 280.

Shoveller Duck, 496.

Shrike, Great Northern, 268.

Skua-gulls, 537.

Skua, Arctic, 538. Pomarine, 538.

Skylarks, 280.

Snipe, English, 435.

Red-breasted, 438.

Robin, 440.

Wilson's, 435 .

Snowbird, 314. 
Snow Bunting, 296.

Sparrow, Chipping, 320, 372.

Field, 319.

Fox-colored, 325 .

Savannah, 301.

Snow, 314

Song, 321.

Swamp, 32

Tree, 317.

White-crowned, 309

White-throated, 311

Yellow-winged, 305.

Stake-driver, 405.

Starlings, 335.

Summer Duck, 500.

Swallow, Bank, 258.

Barn, 254.

Chimney, 116.

Clift', 256.

Eave, 256.

White-bellied, 257.

Swan, American, 480.

\section{T.}

'Tanager, Scarlet, 251.

Teal, Blue-winged, 495. Green-winged, 493.

Tell-tale, 454.

Tern, Arctic, 548.

Caspian, 546.

Least, 549 .

Marsh, 545

Short-tailed, 550 .

Wilson's, 546 .

Thistle-bird, 288.

Thrasher, Brown, 163.

Thrush, Brown, 163

Golden-crowned, 218.

Hermit, 148.

Olive-backed, 152.

Song, 146.

Swainson's, 152.

Tawny, 150 .

Water, 220.

Wilson's, 150

Titlark, 200.

Titmice, 182

Titmouse, Blackeap, 182. Hudson's Bay, 185.

Towhee Bunting, 332.

Turnstone, 426.

Tyrant Flycatchers, 128.

\section{V.}

Virginian Partridge, 393.

Vireo, Blue-headed, 277.

Red-eyed, 270 .

Solitary, 277.
Vireo, Warbling, 273.

White-eyed, 275.

Yellow-throated, 278.

\section{W.}

Warblers, 199.

Warblers, Wood, 201.

Warbler, Bay-breasted, 228.

Blackburnian, 227.

Blackpoll, 233.

Black-throated Blue, 224.

Black-throated Green, 222.

Black and Yellow, 238.

Blue Yellow-backed, 203.

Blue-winged Yellow, 212.

Cape May, 240.

Chestnut-sided, 231.

Connecticut, 208.

Golden-winged, 214.

Hooded, 245.

Magnolia, 238.

Maryland Yellow-throat, 205.

Mourning, 207.

Nashville, 215.

Oven, 218.

Pine-creeping, 229.

Prairie, 241.

Tennessee, 217.

Worm-eating, 211.

Yellow, 237.

Yellow Redpoll, 240.

Yellow-rumped, 226.

Whippoorwill, 119.

Widgeon, American, 499.

Willet, 452 .

Woodcock, American, 432.

Wood Pewee, 137.

Woodpecker, Banded Three-toed, 95. Black-backed Three-toed, 94.

Downy, 89.

Golden-winged, 105.

Hairy, 87.

Pileated, 99

Red-headed, 102.

Yellow-bellied, 96 .

Wren, Golden-crested, 179

House, 195.

Long-billed Marsh, 192.

Ruby-crowned, 178 .

Short-billed Marsh, 194.

Winter, 177.

Y.

Yellow-bird, 288.

Yellow-breasted Chat, 209.

Yellow-throat, Maryland, 205.

Yellow-legs, Common, 455 .

Yellow-legs, Greater, 454. 


\section{INDEX OF SCIENTIFIC NAMES.}

A.

Accipiter Cooperii, 27. fuscus, 31, 81.

Actiturus Bartramius, 460, 478. Egialites melodus, 421. semipalmatus, 419,478 . vociferus, 415 . Wilsonius, 418 .

Egiothus canescens, 295 linaria, 294, 371.

Agelaius Phøniceus, 341, 372. Aix sponsa, 500,572 .

Alaudidar, 280.

Alca torda, 564.

Ammodromus caudacutus, 307. maritimus, 308

Ampelis cedrorum, 265, 371. garrulus, 264, 370 .

Anas boschas, 487,572 . obscura, $28,489,572$.

Anseres, 479, 480 .

Anser hyperboreus, 482, 571.

Anthus Ludovicianus, 200, 369.

Antrostomus vociferus, 119,368 .

Aquila Canadensis, 49, 81 .

Archibuteo lagopus, 43, 81 . Sancti Johannis, 45.

Ardea herodias, $400,477$.

Ardetta exilis, 403.

Astur atricapillus, 22, 81.

Aythya Americana, 506, 572. vallisneria, 507 .

B.

Bernicla Canadensis, 483, 571. brenta, 485 .

Bonasa umbellus, $388,396$.

Botaurus lentiginosus, $405,477$.

Brachyotus Cassinii, 70.

Bubo Virginianus, 60,81 .

Bucephala albeola, 514, 572 . Americana, 512, 572.

Buteo borealis, 35 . islandica, 511,572 .

lineatus, 37.

Pennsylvanicus, 40,81 .

Butorides virescens, 406 .
C.

Calidris arenaria, 449,478 .

Carpodacus purpureus, 285, 371 .

Certhia Americana, 190, 371.

Ceryle alcyon, 125, 369.

Chætura pelasgia, 116, 368 .

Charadrius Virginicus, $413,478$.

Chaulelasmus streperus, 497.

Chordeiles popetue, 122,368 .

Chroicocephalus atricilla, 542. Philadelphia, 543, 573

Chrysomitris pinus, 290, 371. tristis, 290, 371

Circus Hudsonius, 46, 81 .

Cistothorus palustris, 192 . stellaris, 194.

Clamatores, 5, 125.

Coccygus Americanus, 83. erythrophthalmus, 85 .

Colaptes auratus, 105.

Collyrio borealis, 268,371 .

Colymbus septentrionalis, 557 . torquatus, 555,573 .

Contopus borealis, 135. virens, 137, 369.

Corvus Americanus, 357, 372. carnivorus, $355,372$. ossifragus, 363.

Coturniculus Henslowi, 306. passerinus, 305.

Cotyle riparia, 258, 370 .

Cupidonia Cupido, 380.

Curvirostra Americana, 291, 371. leucoptera, 293,371

Cyanospiza cyanea, 330,372 . Cyanurus cristatus, 364,372 . Cygnus Americanus, 480.

D.

Dafila acuta, 492, 5r2.

Dendroica restiva, 237, 370 .

Blackburnix, 227, 369 .

Canadensis, 224, 369. castanea, 228,370 . coronata, 226, 369 . discolor, 241 . maculosa, 238,370 .

[589] 
Dendroica palınarum, 240.

Pennsylvanica, 231, 370. pinus, 229,370 .

striata, 233, 370 .

tigrina, 240.

virens, 222,369 .

E.

Ectopistes migratoria, 373, 396.

Empidonax Acadicus, 143. minimus, 141

Traillii, 140.

Eremophila cornuta, 280, 371 .

Ereunetes petrificatus, 450,478 .

Erismatura rubida, 525.

Euspiza Americana, 327.

\section{F.}

Falco anatum, 7.

Fulica Americana, 476, 478.

Fulix affinis, 505, 572. marila, 504, 572 .

\section{G.}

Galeoscoptes Carolinensis, 172.

Gallinago Wilsonii, 435, 478 .

Gambetta flavipes, 455,478 . melanoleuca, 454,478 .

Garzetta candidissima, 398.

Geothlypis Philadelphia, 207.

Grallatores, 5,397

$$
\text { trichas, 205, } 369 .
$$

Graculus carbo, 534 dilophus, 535.

Guiraca Ludoviciana, 328, 372.

\section{$\mathrm{H}$.}

Hæmatopus palliatus, 424.

Haliztus leucocephalus, 51.

Harelda glacialis, 516,572 .

Harporhynchus rufus, 163.

Helminthophaga chrysoptera, 214. peregrina, $21 \%$. pinus, 212. ruficapilla, 215 .

Helmitherus vermivorus, 211.

Hirundo bicolor, 257, 370 .

horreorum, 254, 370 .

lunifrons, 254,370 .

Histrionicus torquatus, $515,572$.

Hydrochelidon plumbea, 550 .

Hylatomus pileatus, 99 .

Hypotriorchis columbarius, 16, 80.

\section{I.}

Icteria viridis, 209.

Icterus Baltimore, 348 .
Icterius spurius, 346 .

Insessores, 108.

\section{J.}

Junco hyemalis, 314,371 .

\section{L.}

Larus argentatus, 541, 572.

$$
\text { marinus, } 540 .
$$

Limosa fedoa, 463.

Hudsonica, 465.

Lophodytes cucullatus, 529, 572 .

\section{M.}

Macrorhamphus griseus, $438,478$.

Mareca Americana, 499, 572.

Melanerpes erythrocephalus, 102.

Melanetta velvetina, 518 .

Melospiza melodia, 321, 372. palustris, 323,372

Mergus Americanus, 527, 572. serrator, 526,572 .

Mergulus alle, 570 .

Mimus polyglottus, 167 .

Mniotilta varia, 201, 369.

Molothrus pecoris, 339.

Iormon arctica, 566 .

Myiarchus crinitus, 131.

Myiodioctes Canadensis, 247. mitratus, 245. pusillus, 246.

\section{N.}

Natatores, 5, 479.

Nettion Carolinensis, 493, $\mathbf{5 7 2}$.

Numenius borealis, 469,478 . Hudsonius, 467, 478 . longirostris, 466 .

Nyctale Acadica, 75,81 .

Richardsonii, 75, 81.

Nyctea nivea, 77,81 .

Nyctiardea gardeni, 409, 477.

\section{O.}

Oidemia Americana, 521.

Oporornis agilis, 208.

Ortyx Virginianus, 393.

Oscines, 5, 145.

Otus Wilsonianus, 68,81 .

P.

Pandion Carolinensis, 55, 81 .

Parula Americana, 203.

Parus atricapillus, 182, 371.

Hudsonicus, 185, 371 .

Passerculus Savanna, 301.

Passerella iliaca, 323, 372. 
Pelionetta perspicillata, 520, 572 . Perisoreus Canadensis, 366371.

Phalaropus hyperboreus, $\mathbf{4 3 0}, \mathbf{4 7 8}$.

Philohela minor, 432, 478.

Picoides arcticus, 94. hirsutus, 95 .

Picus pubescens, 89 . villosus, 87 .

Pinicola Canadensis, 283, 371.

Pipilo erythrophthalmus, 332.

Plectrophanes lapponicus, 300. nivalis, 296,371 .

Podiceps cornutus, 561 . cristatus, 560 . griseigena, 559 .

Podilymbus podiceps, 562 .

Poocætes gramineus, $303,371$.

Porzana Carolina, 474, 478. Noveboracensis, 475,478 .

Progne purpurea, 260, 370.

Pyranga rubra, 251, 370.

\section{Q.}

Querquedula discors, 495 .

Quiscalus versicolor, 352, 372 .

R.

Rallus crepitans, 471 . elegans, 471.

Virginianus, 472, 478 .

Raptores, 4, 6.

Rasores, 5, 378 .

Recurvirostra Americana, 428.

Regulus calendula, 178, 369 . satrapa, 179,363 .

Rhyacophilus solitarius, 457, 478. Rissa tridactyla, 544 .

\section{S.}

Sayornis fuscus, 133.

Scansores, 4, 82 .

Scolecophagus ferrugineus, 350,372 .

Scops asio, 64.

Seiurus aurocapillus, 218, 369

Noveboracensis, 220.

Setophaga ruticilla, 249,370 .

Sialia sialis, 175, 369 .

Sitta Canadensis, 188, 371. Carolinensis, 187.

Somateria mollissima, $522,572$. spectabilis, 523 .

Spatula clypeata, 496,572 .

Sphyrapicus varius, 96 .

Spizella monticola, 317,371 . pusilla, 319,371 . socialis, 320,371

Squatarola Helvetica, $422,478$.
Stercorarius parasiticus, 538. pomarinus, 538.

Sterna aranea, 545 .

Caspia, 549 .

frenata, 549 .

macroura, 548.

Wilsonii, 546, 573

Strepsilas interpres, $426,478$.

Strisores, 4, 110.

Sturnella magna, 343.

Sula bassana, 532 .

Surnia ulula, 79,81 .

Symphemia semipalmata, 452.

Symium cinereum, 72, 81. nebulosum, 73, 81 .

\section{T.}

Tetrao Canadensis, 378, 396.

Thalassidroma Leachii, 552.

Wilsonii, 553.

Tinnunculus sparverius, 19,80 .

Tringa Alpina, var. Americana, 444. Bonapartii, 446 .

canutus, 440,478 .

maculata, 478 .

maritima, 442,478 .

subarquata, 443.

W'ilsonii, 447,478 .

Tringoides macularius, 458,478 .

Trochilus colubris, 111,368 .

Troglodytes ædon, 196 . hyemalis, 197, 371.

Tryngites rufescens, 462 .

Turdus fuscescens, 150,369 .

migratorius, 154

mustelinus, 146.

Pallasii, 148, 369.

Swainsonii, 152.

Tyrannus Carolinensis, 128, 369.

\section{U.}

Uria grylle, 567 .

lomvia, 568,573 .

ringvia, 570 .

\section{V.}

Vireo flavifrons, 278.

gilvus, 273.

Noveboracensis, 275 .

olivaceus, 270,371 .

solitarius, 277.

\section{Z.}

Zenaidura Carolinensis, 375, 396.

Zonotrichia albicollis, 311,371 .

leucophrys, $309,371$. 







SMITHSONIAN INSTITUTION LIBRARIES 